

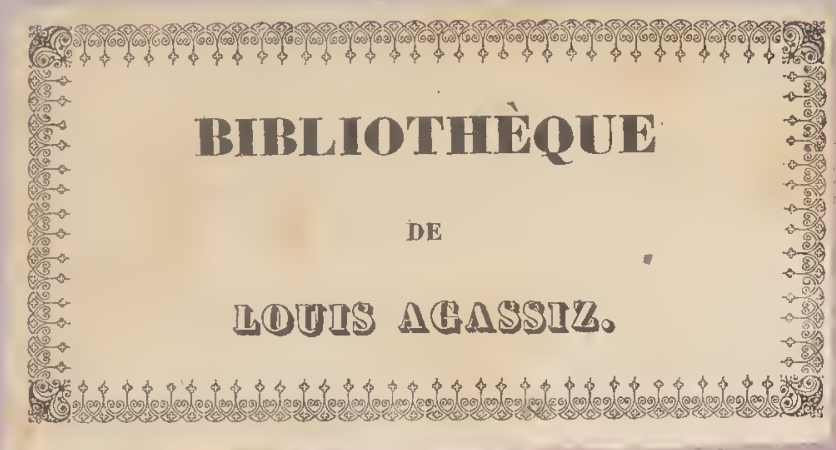

This Copy has been struck off previously to the final Revision of the Book, for the purpose of being laid before the BritisH Association, on its meeting in Dublin.

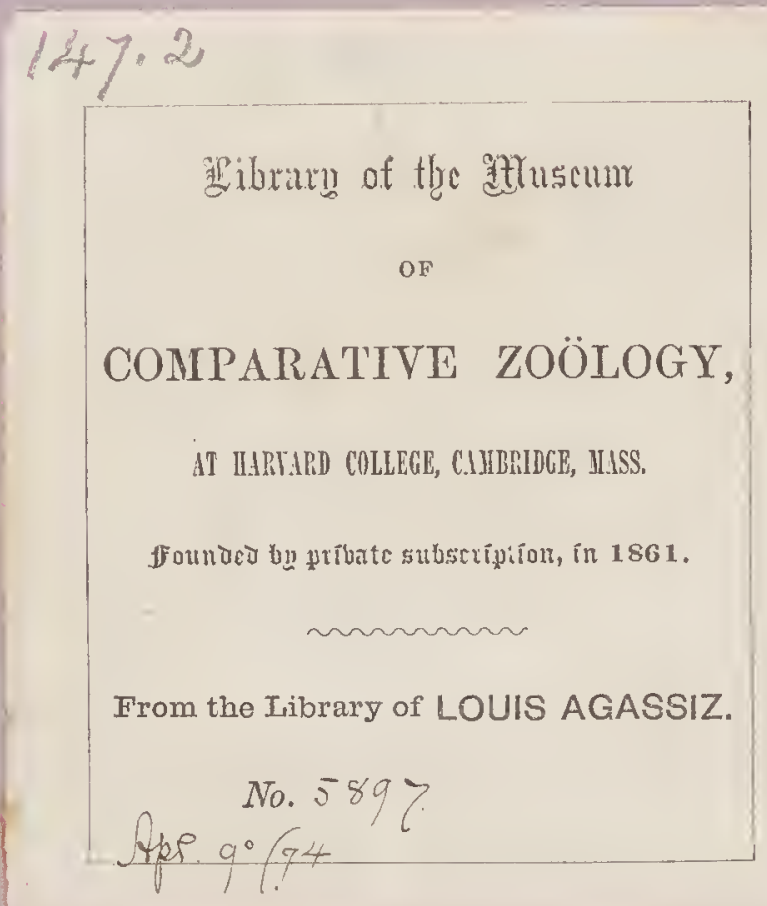




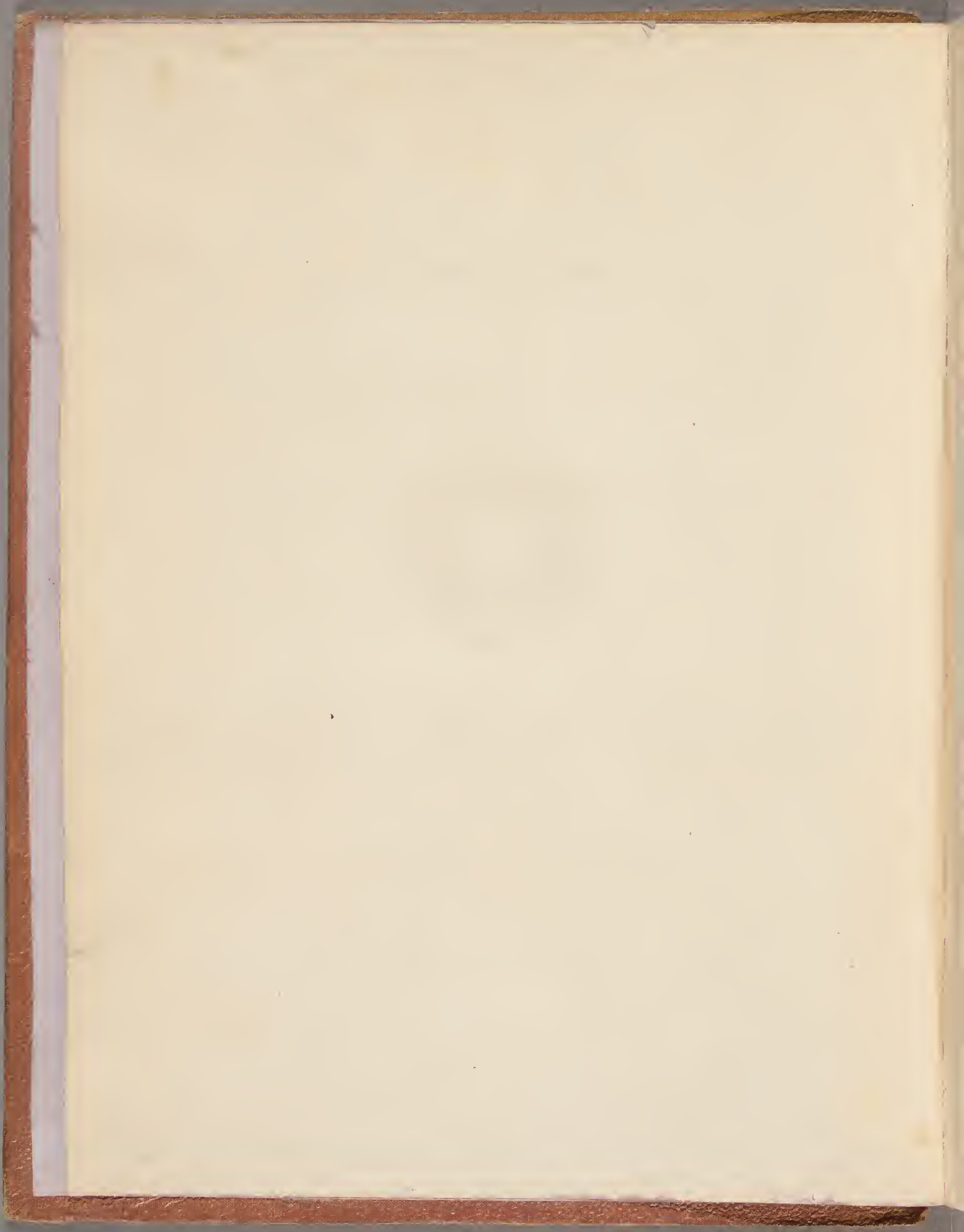




\section{ORDNANCE SURVEY}

OF

\section{THE COUNTY OF LONDONDERRY.}

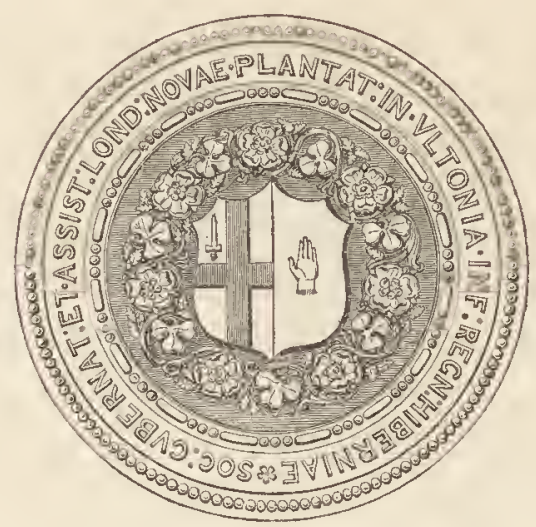

LIEUTENANT COLONEL COLBY, OF THE ROYAL ENGINERRS,

F.R.S. L. AND E., M.R.I.A., ETC. ETC., SUPERINTENDENT.

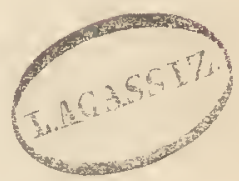

DUBLIN :

PUBLISHED FOR IIIS MAJESTY'S GOVERNMEX',

BY HODGES AND SMITH, 21, COLLEGE-GREEN.

$$
\text { in } \overline{\text { M.DCCC.XXXV. }}
$$


MCZ LIBRARY

HARVARD UNIVERSITY

CAMBRIDGE. MA USA

Printed by R. Graismerry. 


\section{NTRODUCTION.}

In preparing this branch of the Survey for publieation various sourees of information have been requisite, and I have been permitted to engage the services of thosc whose rescarches have qualified them to write partieular parts with advantage. Mr. Georgc Petrie, whose abilities have rendered his name eminent among artists, has long devoted a large portion of his time to the examination and study of the history and antiquitics of his eountry. In the present work the value of his services has been greatly enhaneed by a eombination of his knowledge and talent with the critical knowledgc possessed by Mr. John O'Donovan of the aneient Irish languagc. By this combination cvery ancient Irish authority or manuscript within our reach has been scarehed for information, with the previous knowledge necessary for its elucidation. And the continuance of researches thus judieiously directed eannot fail to throw new light on Irish history and antiquitics.

The Natural History and Productive Economy which is so dependent on it, and intimatcly eonnceted with it, have been drawn up by Captain Portloek from observations made by himself, and under his direction, in the parish of Templemore. In that parish he dcrivcd but little assistance from the previous rescarchcs of the surveying officcrs, in eonsequenee of its linear survey having been exeeuted at the eommeneement of the survey before the offieers had acquircd expcrience in the general nature of the work.

Lieutenant Dawson, who directs the delincation of hills for the maps, has, both by himself and his assistants, contributed valuable information in every branch. 


\section{INTRODUCTION.}

The general arrangement and preparation of the work has been eonfided to Lieutenant Lareom, and I eannot speak too highly of the indefatigable cxertions he has made to render it as eorrect and as perfeet as possible; at his request I also acknowledge the assistanee he has derived from $\mathrm{Mr}$. George Downes. And in closing these introduetory observations, I have to express my approbation of the zealous exertions whieh all those employed have made in their various departments to eontribute their aid wherever it has been requisite.

\section{THOMAS COLBY,}




\title{
CONTENTS.
}

\author{
NAME AND LOCALITY. \\ SECTION I. \\ NATURAL STA'TE. \\ DIVIDED INTO
}
NATURAL FEATURES AND NATURAL HISTORY.
HILLS.
LAKES.
RIVERS, ETC.
GEOLOGY.
BOTANY.
ZOOLOGY.

SECTION II.

ARTIFICIAL STATE.

DIVIDED INTO

MODERN.

TOWNS.

GENTLEMEN'S SEATS.

MANUFACTORIES.

COMMUNICATIONS.
ANCIENT.

TOWNLAND HISTORY.

PAGAN.

ECCLESIASTICAL.

MILITARY.

In this Section of the PARISh of TEMPLesiore the important CITY OF LONDONDERRY

is included-and its Description-divided into NAME-LOCALITY-HISTORY-STATE as to BUILDINGS, and STATE as to PEOPLE.

The Classification observed in the latter being MUNICIPALITY-EDVCATION-BENEVOLENCE-JUSTICE-COMMERCE, and a Summary of the population.

\section{SECTION III.}

GENERAL STATE.

DIVIDED INTO

SOCIAL ECONOMY.

of which the matter is embodied in the correspond-

ing Heads of the City.
PRODUCTIVE ECONOMY.

RURAL.

MANUFACTURING, AND FISHERIES.

with a Series of TOWNLAND TABLES. 


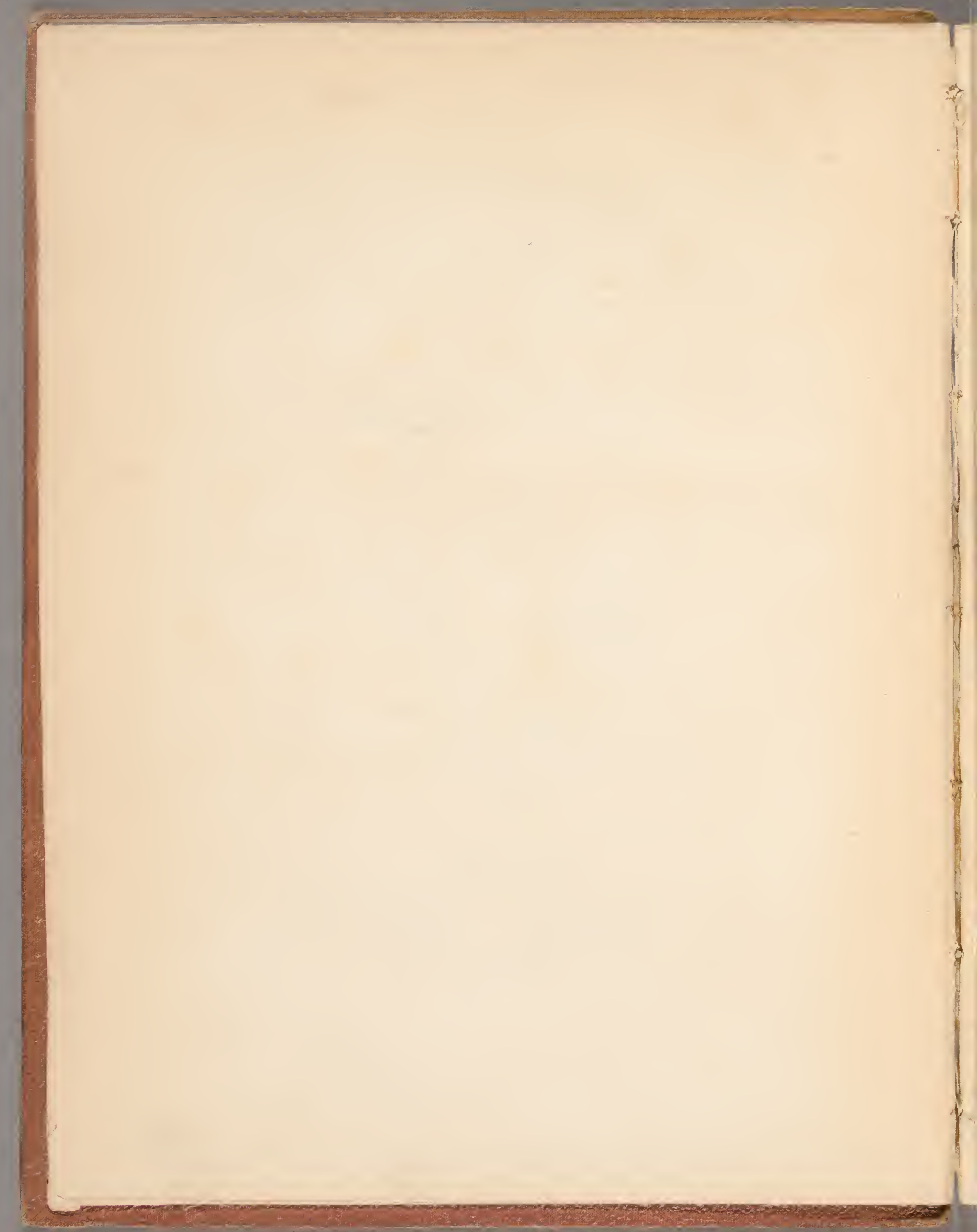


$\alpha^{\prime}$ 


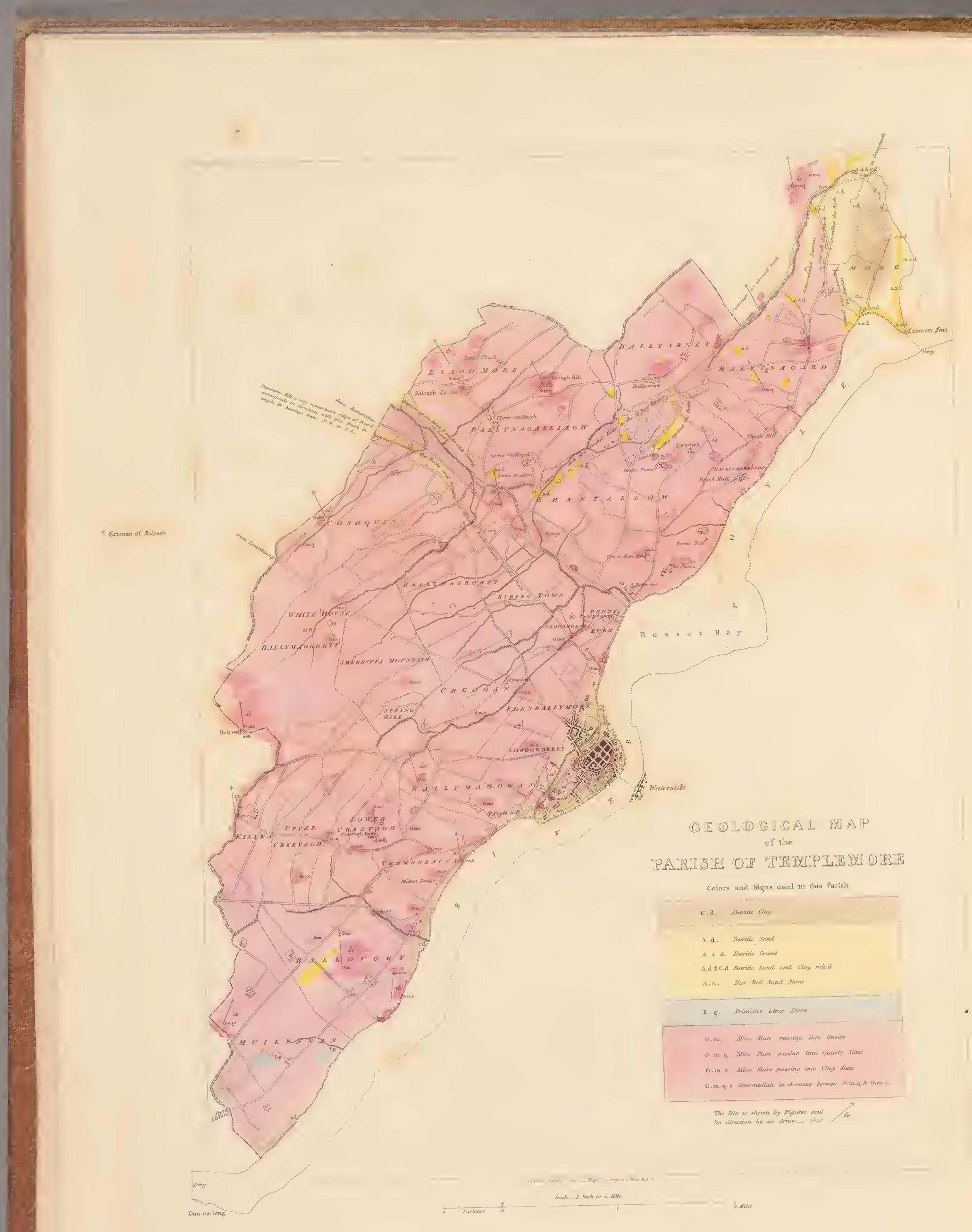




\section{PARISH OF TEMPLEMORE.}

NAME.-The parish of Templemore, sometimes called Temple Derry, (Ceampull Ohoipe) and more anciently (Ooine) Derry, or Derry Columbricle (Ooipe Cholum Cille), derives its first and most usual name-TEMPLEMORE-from the Irish Ceampull móp or "great church,"-- Eeampull (templum) being derived from the Latin, like most other Irish words expressive of Christian edifices, offices, rites, and ceremonies. This name was originally applied, in a popular sense, to the cathedral, or great church, of Derry, in contradistinction to the smaller churches in its immediate vicinity, and, after the cathedral had become the parish Church, its popular name of Templemore was in a similar manner transferred to the parish. There is every reason, however, to believe that the use of this name is not of very ancient standing; for it appears from the Irish annals, that the cathedral, or Templemore, was not erected until 1164, and it is probable that it was not used as a parish church for some centuries later. Its more ancient appellation of Derry would, therefore, still be the more correct one, and it is generally so called in ecclesiastical records down to recent times.

LoCALITY.-A division only of the parish, considered ecclesiastically, is in this county; the other, which is in that of Donegal, is subdivided into the dependent perpetual curacies of Muff, Burt, and Inch. Of the former division, a portion was included in the very ancient district called Moy-lha ( $\mathrm{ma \dot { \delta }} \mathrm{l} \dot{\mathrm{c} e}$ ), and the whole of it, subsequently, in the territory, or cantred, of Tir-Enda (Cin $\epsilon_{n o \alpha}$ ), of which the ancient chiefs were the Mac Duans (Mac Oubón), and O'Lappans, (O'Gapáin) both of whom were of the Kinel-owen (Cineul Eożain), or descendants of Owen, the son of Niall, monarch of Ireland in the 4th century:- This division, to which alone the designation Templemore is here applied, occupies the most westerly part of the county of Londonderry, and includes merely the city of that name, with its N. W. Liberties. It is bounded by the county of Donegal on every side, except the E., where it is washed by the river Foyle, (which separates it from CLONDERMOT), and for a small extent by Lough Foyle. Its extreme length is nearly 10 miles, and its extreme breadth about $3 \frac{1}{2}$. Its content is $12611 \AA .2 \mathrm{R} .21 \mathrm{P}$., including $3 \mathrm{~A} .3 \mathrm{R} .27 \mathrm{p}$. of water. The quantity of ground uncultivated is $2228 \mathrm{~A}$. $1 \mathrm{R}$. $32 \mathrm{P}$. It is divided into twenty-five townlands.

\section{SECTION I.}

\section{NATURAL STA TE.}

\section{NATURAL FEATURES.}

HILLS.-The surface of this parish is beautifully undulating, and presents a succession of hills, generally cultivated or under pasture. A wide valley, extending from the river Foyle at Pennyburn in a north-westerly direction, separates the hills of the parish into two leading masses, or 


\section{PARISH OF TEMPLEMORE.}

groups. Of these the southern is the more prominent, rising at its western extremity into Holywell Hill, which is the highest land of the parish, being 860 feet above the sea. This group is again intersected by the remarkable valley, which, as it were, isolates the Hill of Derry; and its surface is further undulated by ravines, which, like that valley, conform in direction to the valley of the Foyle.

The nolthern group, of which the highest point-in Elaghmore-is only 354 feet above the sea, is subdivided into low but distinct ridges by valleys parallel to the Foyle. Of these valleys that of Ballyarnet assumes, in some positions, an importance little inferior to that of the valley of Pennyburn. A general view of this tract, when seen from the road to Culmore, combines the characters derived from its moderate height, and frequent subdivision: it then appears a wide and undulating plain, bounded on the S. by the higher ground of the parish, and on the N.W. by the sorthern hills of Ennishowen.

LAKES.-The lake of Ballyarnet, the only one in the parish, occupies portions of three townlands-Ballyarnet, Ballynashallog, and Ballynagard. It is small, containing only $3 \mathrm{~A}$. $3 \mathrm{R} .27 \mathrm{P}$, and fills a shallow basin in the surrounding bog. Its height above the sea is about 100 feet.

RIVERs. - The Foyle is formed by the junction of the Mourne and the Finn at Lifford-the former having also received, in the county of Tyrone, the waters of the Derg from that of Donegal it also receives the Deel, from Donegal, below Lifford, and empties itself into Lough Foyle at Culmore. The ancient Irish, however, appear to have applied the name Lough Foyle to the river, up to Lifford, as well as to the present lough; but, in the accounts of the early settlement by the English, they are distinguished as the "harbour of Lough Foyle" (the present lough), and the "river of Lough Foyle," by which name the river is called in the Down Survey, as well as in some later documents.

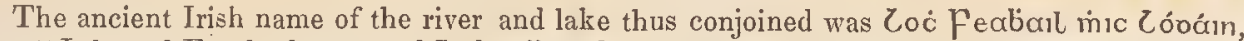
or the "Lake of Feval, the son of Lodan," and it is always so written in the Annals of the Four Masters, and other authorities. The origin of this name is explained in the Dinnseanchusa MS. work anterior to the 12th century - by a legend of the Tuatha-de-Dananns, who are stated to liave been a Greek colony,-importing that, at the time when the lake was formed, Feval, the son of Lodan, was drowned, and that its waves cast his body on the shore, and rolled a stone over it, which formed his sepulchral monument. The similarity of this legend to that of Selim in Byron's "Bride of Abydos," will hardly fail of striking the reader.

The river flows from S. W. to N. E. in a deep and tranquil bed, within the tideway. Its greatest breadth above Derry is at New Building:s, in CLONDERMOT, where it measures nearly $\frac{1}{2}$ a mile. Below Derry is an expansion of it, called Rosses' Bay, which is $1 \frac{1}{4}$ mile broad. At the city itself it is narrowest, being only 1068 feet wide at the bridge. Its depth at high water is 22 feet, opposite Carrigan, where it enters the county of Londonderry: opposite Prehen it is 24, and it gradually increases to about 43 , its depth at the bridge of Derry. The point where it enters the county is about $4 \frac{1}{2}$ miles above the city. Its banks in this parish are bold, excepting at Pennyburn, where it is met by a transverse valley, and their beauty is heightened by ornamental woods, which spread in many places to the water's edge.

Of the rivulets, which are insignificant, the greater number either flow into the river Foyle, or Lough Foyle; one, which passes by Coshquin, flows into Lough Swilly, in the county of Donegal.

The springss are numerous. Within a tract of not more than twenty acres, in Springhill and Creggan, no fewer than eight occur. These springs, percolating through the detritus of rocks, which abound in oxide of iron, become frequently charged with oclireous particles, and are sometimes slightly chalybeate.

BoGs.-The bogs are scattered through the parish in insulated patches.-[See Geology.].

WooDs.- In Ballynagalliagh alone there is a small patch of wood, apparently natural. It is possible, however, that some natural wood may have been preserved in the demesnes along the Foyle, which are all rich in ornamental planting.

CoAst.-The shore of Lough Foyle, where it borders the parish, is low and flat.

Chimate.- In an able essay by Dr. Patterson, the mean temperature of the city is stated to be 49 , which is nearly that of the earth, as indicated by the niean of six wells in different parts of the city, the extremes being 17 and 71. The range of the barometer is from 28.6 to 30.6 , and on an average of twelve years the medium number of fair days is 126 . The hygrometer of De Luc varies from $26 \frac{1}{2}$ to $52 \frac{4}{5}$, and the mean annual depth of rain is 34.2 inches the latter has, however, been stated by Mr. Sampson at 31 . The ratio of winds during nine years was N. 295-S. 398-E. 283-W. 1005-N. W. 737-N. E. 265-S. W. 599S. E. 454 . 


\section{NATURAL HISTORY.}

To estimate with certainty the variations, if any, of this climate, long continued and carefully conducted observations would be necessary. In defect of such it may be mentioned that the farmers believe, and assert, that a marked amelioration has taken place-the times of seeding and harvest being both considerably advanced. In support of this opinion may be adduced the extending and successful cultivation of wheat, and the increased number of quails, a bird now comparatively abundant. However, though the circumstance of a recent improvement in this respect may be probable, it would be rash to pronounce it, on the present evidence, permanent.

In the Annals of Derry, by Mr. Gillespie, two remarkable frosts are recorded. The first was in 1740, when the river was frozen over, and an ox roasted on the ice, opposite to the Ship Quay. The other was in 1814 , when the ice on the river was so strong that carriages were driven over it in several places, and-on the 6th of February-a part of the bridge was carried away by masses of ice, floated down the river by the ebb tides and a very high wind. And, when it is recollected that such unusual and impressive events are more likely to dwell on the memory than the more simple and unobtrusive fact of a peculiarly mild and genial season, it may be reasonably doubted whether the change alluded to is more than a periodical return of warm seasons alternating with those of severe and rigorous cold.

There are similar instances of hard frost, and other variations of weather, recorded in the earlier annals of the district, which, however, are not so immediately connected with the parish as to claim notice here. The most remarkable circumstance bearing on the subject was a meteoric appearance, which accompanied the death of bishop Murry O'Coffy, in 1173. [See Local History.]

\section{NATURAL HISTORY.}

GEologY.-A geological description, founded on the principles of practical utility, naturally divides itself into two sections :-1st Rocks (including clays, sands, \&c.), as regards their mutual relations in geological science; 2nd Rocks, \&c., as regards their application to practical purposes.

And the first of these sections may again be divided into two sub-sections, namely:-

1st. Rocks in situ (including stratified clays and sands)-Being a consideration of the order of their geological position, and of the accidents which have affected or modified their arrangement.

2nd. Detritus-Being a consideration of those accumulated fragments, which now form beds of clay, sand, or gravel, and have proceeded from the disintegration, removal, and rearrangement of those pre-existing rocks, which are now recognized as part of the visible crust of the Earth.

Section 1.-Sub-section 1.-Rocks, \&c., in situ.

The geological structure of the parish is simple, and it may be observed that it has no exact geological boundary - the same rocks occurring on the opposite side of the Foyle, and on the W. and N. of the parish, in the county of Donegal. The great mass of the prinary schistose rocks, which occupies so much of the western part of the county, spreads over its whole surface, with the exception of a considerable detritic patch at Culmore, in the N. E. of the parish, which probably conceals a part of the new red sandstone - that rock being visible at the extreme northern end of the parisl, - and of several very limited deposits of mud and clay, which on the S. E. skirt the river Foyle. Within this space the rocks exhibit a considerable variety of texture, passing through several steps of progression from a rough and knotty psendo-gneiss into a smooth, even, and apparently homogeneous slate. That these varieties have a definite and regular order of arrangement is improbable, although it does appear that some of them recur frequently with the same characters, and are sufficiently persistent over a large extent of country to be admitted as types of the following subdivisions :-

1st. Mica slate, passing into gneiss. G.m.

2nd. Mica slate, passing into clay slate. G. m.c.

3rd. Mica slate, passing into quartz slate. G. m. q.

The dip varies in direction from N. to N.W., and in amount from $30^{\circ}$ to $55^{\circ}$; but here, as in all the primary slates, much donbt and difficulty must attend the determination of the dip, and the very fact of distinct stratification is sometimes questionable. The lamince of these 


\section{PARISH OF TEMPLEMORE.}

schists are usually (but not alrvays) co-incident with the principal cleavage, or plane of stratification, and they occasionally project in sharp cdges peyond the face of the secondary cleavages, which, were it not for these interruptions of their continuity, might from their general snoothness be considered planes of stratification. It is difficult to state any exact proportion in quantity as existing between these Rocks, but an approximate estimate may bc given as follows:-

1st. Mica Slate, passing into Gneiss. - This is of small extent, protruding amidst the mere schistose strata, and exhibiting a rugged aspect, and almost massire structure. In texture also this slate is remarkable—small isolated lumps of bluish quartz, of the size of, or less than, a pea, being arranged in layers parallel to the lamince of the schist, and giving to the cross fracture a granular, or even a conglomerate appearance. The paste in which they are set is common quartz, mixed occasionally with felspar, the crystals of which become frequently prominent. In this, as in all the other rocks, the mica can only be discerned on the face of the lamince, and is almost evanescent. The hill of Ballougry may bc cited as a good example of this rock. It there alternates with the common variety in beds 30 feet thick, and terminates abruptly on the summit of the hill.

2nd. Mica Slate, passing into Clay Slate.-The distinction of the mineral substances is here almost, or entirely lost. This principally occurs towards the $S$. of the parish. Judging by the position of the localities, where this variety is visible on the surface, it occupies a strip a mile widc, extending across the parish. It is succeeded by

3rd. Mica Slate, passing into Quartz Slate.-The quartz, in thin layers, is the most conspicuous material, and the mica a mere evanescent parting, which from its frequent recurrence renders the Rock highly lamellar. This is the prevailing rock of the parish, occurring on the S. as wcll as N., and occupying at least two-thirds of its surface. In structure it is variable, and also in composition, the mica being replaced by talc, and probably by chlorite, though, from the extremc thinness of the partings, it is difficult to distinguish between them. The undulations of surface, so frequent in mica slate, may be noticed in the two last varieties, the lamince being twisted in a very curious manner. Sometimes indeed a break occur's in the middle of one of these minute bends, the general direction of the lamince being preserved above and below it.

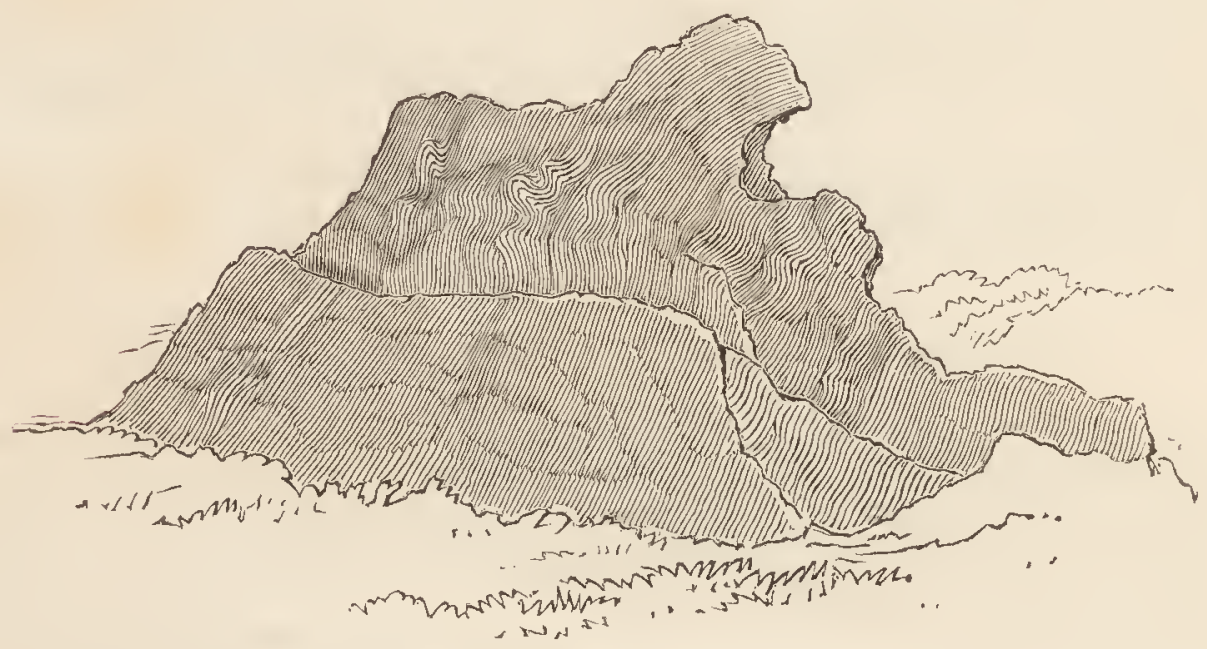

And it is remarkable that such contortions, accompanied by a tendency to break into small angular fragments, are more frequent at the surface than below it-the continuity of the lamince extending, and the quality of the stone for building improving, at the depth of about 10 feet.

Quartz veins are common in the first, or gneiss varicty, rare in the second, and not very common in the third. A uniform character prevails to a considerable extent in all, namely, that small specks of oxide of iron are visible on the cross fracture. None of these rocks attain any great elevation-the highest point in the parish, Holywell Hill, which is composed of the second variety, being only 860 feet above the sea.

Subordinate to the preceding formation are occasional beds of limestone and oreenstone. The limestone appears only on the E. of Mullennan, in a small excavation at the base of the little lime-lsiln on the S. of the old mill, and close to the river. It is dark in colour, finely 


\section{NATURAL HISTORY.}

granular in texture, and analogous in structure to the schist-thin, white, crystalline stripes being visible on the cross fractmle, though they are not sufficiently continuous to affect the cleavage. The greenstone is dense, close-grained, and homogeneous, and is met with only at Conn's Hill quarry, which (strictly speaking) is without the parish. The mode of its arrangement in respect to the schist cannot be seen in this quarry, but will be described in other parishes. It is traversed by several veins of quartz, which have much of the character of metalliferous veins, though they are thin, and do not exhibit any important metallic ore.

New red sandstone is seen to a small extent on the little stream, which bounds the parish and the county on the N. It is too much concealed by the detritus to be traced to its junction with the grcat mass of schist on the W. of it: but, when its appearance in a similarly confined space is considered-in CLONDERNOT on the S. E. of the parish, and beyond Muff, in the county of Donegal, on the N., as well as on the slore on the N. E. - there can be little doubt that it either does extend along the whole face of the schist range, though now concealed in detritus, or did so formerly. Near the spot pointed out the slate has a loose, shaly structure, very similar to that which it possesses in places where it is decidedly in contact with the sandstone, as will be shown in subsequent parishes.

\section{Section 1.-Sub-seetion 2.-Detritus.}

Detritus. - The consideration of the varied deposits, which come under this head, is always replete with interest. In this parish they occupy only a small space-the principal locality being a patch at the north-eastern angle of the Liberties, including Culmore Point. It is bounded on one side by Louglh Foyle, and extends into the county of Donegal on the other, its edge being defined by the rise of the schist range, the termination of which is concealed by an accumulation of gravel. The inner portion of this spacious flat is bog, rcsting on clay, the surface of which has been to a considerable extent reclaimed. The cdge at Lough Foyle is an elevated bank, composed of sand and pebbles, which often exhibits a very striking regularity of arrangement, horizontal layers of sand being interposed between others of pebbles-the latter varying in size from 1 to 8 or 9 inches. They are of two kinds:-1st. Rocks not immediately found in the parish, such as granite; gneiss; primitive greenstone, approaching to hornblende rock; and quartz rock. 2nd. Rocks common in the vicinity, such as the several varieties of schist. These constitute by far the greater proportion of the whole. The pebbles are rounded, but usually have flat bases, on which they rest, such being a natural consequence in rocks of schistose strncture. Approaching. Muff (in the county of Donegal) the pebbles are observed to overlie the clay substratum of the bog, while the resemblance they bear to the pebbles now on the beach is striking, though, to a certain extent, it might have been expected-the wearing-down of the banks having, without doubt, supplied many of the latter.

The central portion of this detritic flat is principally clay of a reddish hue, and so strongly resembling some of the beds, which in FAUGHANVALE alternate with the red sandstone, as further to corroborate the opinion already stated - that rocks of that formation either extended once over the whole space, or still underlie it. On the surface of this clay water accumulates, which, percolating the girdle of sands and gravels, that in part surrounds it, supplies the springs, which either trickle from the bank, or appear in shallow holes made by the country people in the sand on the shore of the lough, a little above high-water mark.

The only other deposits of this kind are small patches of clay, which here and there border the Foyle. These have resulted from the decomposition of the slate rocks, and gradual washingdown of the finer particles: they are of very recent origin, and still augmenting. $A$ drain, cut through one portion, exposes horizontal logs of oak-while in others, near the surface, there are numerous small tubular bodies of a conical form, apparently the encrusted roots of plants, - and the rubble of an old brick-yard, abandoned only about thirty years ago, which was thrown on the shore, is now covered with 8 inches of soil. However, as might have been anticipated, what is formed at one period is destroyed at another, according to the direction of the current, which, while the banks of the river are subject to wear, must be ever varying; and embankments are, in consequence, fornd absolutely necessary to secure from destruction the now projecting points.

But, though in other parts of the parish the detritus has not assumed that definite arrangement, which would entitle it to be considered as a distinct formation, it deserves attention, as having an evident bearing on the general phenomena of the district. It may be noticed as gravel and sand, heaped on the sides of the principal valleys - or as clay spread orer the greater portion of the plains and hollows, which either were formerly or are now covered with bog. The union of these two forms of detritus impresses strongly on the present surface the character of ancient water-courses, either lakes or rivers. The detritus of gravel narrows and defines the boundaries, while the level clay base contributes to give the boggy covering that uniformity of surface, which characterizes the tranquil waters of a lake. Along the valley, which now contains the bog 


\section{PARISH OF TEMPLEMORE.}

of Shantallow, and the bog and lake of Ballyarnet, a chain of isolated sand-hills may be traced, ap. pearing above the bog, while, opposite to one of them, a remarkable pinnacle of rock also rises above its surface, and another, at no great distance, is seen just level with it. Up the sides of these sandhills the bog is seen to have crept, and, as within the memory of the existing generation it has covered the summits of some of them, no doubt can exist that the sand-hills were prior in origin to the bog. In the still more marked depression, which, constituting the valley of Pennyburn, proceeds with little variation of level towards Lough Swilly, the appearances are equally illustrative for, in advancing towards the W., the valley is narrowed between two beds, or islands, of rocks, and exhibits a channel so natural and well-defined that it is impossible to resist the feeling of being in a river, or strait-an effect which is greatly heightened by the level, smooth, and now grassy bog, which lines the bottom. The channel again swells into an open basin, and is again for a short distance contracted, as it winds lound some projecting rocks, which, like those previously described, seem to attest by their isolated position, limited extent, and low level, that some powerful agent, such as water, had long exercised on them its abrading influence.

The curious sand-hill in the county of Donegal, called Dunberry Hill, is in the prolongation of this valley, and bears the same relation to it, which those described in the preceding paragraph bear to the valley of Ballyarnet. Similar appearances are observable in the bog of Mullennan, which occupies the south-eastern corner of the parish, and extends beyond it-for there also the edge of the bog is marked by heaps or banks of sand, whilst Conn's Hill rises like an island from its surface.

As yet no shells, either fresh-water or marine, have been found in the detritic gravel, or clay, of this parish. In other parts of Ireland marl, abounding in fresh-water shells, is frequently the substratum of the smaller bogs, establishing fully their former lacustrine state, which is further supported by the occasional discovery of ancient canoes within them. Under the larger bogs clay, or gravel, without shells, is more commonly found; but, before the full bearing of this deficiency on the question of formation can be estimated, the bottoms of existing lakes should be carefully examined in all positions, and under all circumstances, and the abundance, scarcity, or total absence, of shells in the shingle of the present sea or lake shores, carefully ascertained at various points, and under varying conditions. Indeed, as regards this immediate parish, the insulated valley of Derry, or Mary Blue's Burn, seems a stepping-stone in the inquily, as it can be nearly proved from history to have been a channel of the river; and yet it still exhibits a bottom of gravel and clay, without shells-a circumstance in some measure to have been expected, as the current running through it was probably strong enough to render it an unfavourable habitation for molluscous animals. At present, therefore, the subject must be considered strong in the evidence of external characters, though, as yet, only partially supported by that of existing organic remains.

That this valley has probably been a water-course, may be judged from the following excavations :-

F. I.

1st. Excavation, 2 6-Surface loam, with pebbles of mica slate, and quartz.

2nd. Excavation, 2 8-The same result as in the 1st; then bluish tenacious clay, with thin gravel.

3rd. Excavation, 2 12-The same result as in the 1 st and 2nd, then coarse gravel.

Underneath there was a finer gravel mixed with sand.

Boulders of primitive greenstone, and of granite, are occasionally found in the parish : they are of considerable size, and sometimes rest on other more minute detritus, as may be seen at a bluff, facing the valley which extends from Pennyburn to Lough Swilly. There are several on the shore of the Foyle, and at Culmore there is also a single boulder of basalt.

\section{SPECIFIC GRAVITIES.}

Variety 1. Mica slate, passing into gneiss ..

Variety 2. Mica slate, passing into clay slate ..

Variety 3. Mica slate, passing into quartz slate

Greenstone $\quad$. $\quad \ldots \quad$. .

$\begin{array}{lll}\ldots & \ldots & 2.65 \\ \ldots & \ldots & 2.84 \\ \ldots & \ldots & 2.69\end{array}$

It is usual to introduce geological descriptions by some notice of the physical features of the country, but such is more naturally placed at the close.

The direction of the successive ridges of schist is nearly $E$. and $W$. These, as will have been seen from the preceding notice of "Hills," have disposed the country in a series of longitudinal valleys, which, from the tendency of slate rocks to break down on the outcropping side into slopes similar to that of the strata, are bounded on both sides by planes of nearly equal 


\section{NATURAL HISTORY.}

inclination. The valley of the Foyle,-another which nearly insulates the city of Londonderry,- and a third in the bishop's garden (beyond the walls), are good examples. The transverse valleys, resulting from broken and rugged edges of the strata, are of comparatively small extent, and form the upper surface into gentle undulations.

\section{Section 2.-Rocks, \&c., as applied to practical Purposes.}

In this section there is not much to remark upon: it may be noticed under the following heads:-

1. Building Stones.-The schistose rocks are in the harder varieties too coarse, and in the softer not sufficiently coherent for roofing slates; but no deep excavations have yet been made. They are, however, used extensively as common building stones, and, when selected from a hard variety, are well fitted for the purpose.

2. Limestone.-This is probably a very limited deposit, and the limekiln in Mullennan, as well as the quarry, has been abandoned. The limestone, used at the liilns in the city, is brought down the river from beyond the limits of the parish.

3. Greenstone. - This is quarried extensively for the roads, and, being carried to the river, is transported to Derry, where it is broken up at the gaol by the prisoners. It is raised for $7 d$. per ton, and costs $2 s .9 d$. at the gaol, carriage included. Being exceedingly hard, the people imagine that it is purchased for the mere purpose of increasing the labour of the prisoners.

4. New Red Sandstone.-This is used occasionally for grindstones, though rather soft for the purpose.

5. Clays.-The brick-yards on the Foyle were given up about thirty years ago, in consequence of the growing scarcity of fuel. It is desirable that steps should be taken to supply coals to the farmers on the river, as there can be no doubt that the manufacture would then be resumed, and much valuable time saved, which is now applied to the cutting and making of turf.

6. Soils. - The soils in this parish, resulting from the decomposition of the same class of rocks, have much uniformity of appearance and composition. In the higher grounds they contain more of the silex of the rocks, - and are occasionally, though rarely, stony, sandy, and meagre. In by far the greater portion of the parish they are light productive clays, or loams, which in the very low grounds become stiffer, though never to an injurious extent.

7. Bogs.-Though only relics of a much more extensive tract, the bogs are of great local importance. In several townlands they supply fuel to the inhabitants, as well as an important ingredient in the composts used for manures. Portions are still occasionally reclaimed, and when the turf has been totally cut away the sub-soil is readily brought into cultivation.

Bogs have been already incidentally cited, to illustrate some of the appearances exhibited by detritic accumulations. They merit, however, a distinct geological notice, as being one of the most recent effects of those modifying agencies, which still con tinue to operate on the Earth's surface. The vast mass of vegetable matter, spread over so large a portion of Ireland, has at all times attracted attention from its magnitude; and even in this parish, were it possible to restore all that has been cut away, and to remove the now verdant surface from the parts reclaimed, about $\frac{1}{10}$ th would be bog. It is natural that a formation so remarkable should be attributed to other causes than those now operating by persons, who, beholding merely the accumulated result of ages, do not perceive the steps by which that result has arisen; but careful investigation will induce more correct views, by showing that what was once done might be done again - the causes which then acted being equally efficient now, or, if comparatively inactive, only so in having arrived at natural limits, which arrested the further progress of their efforts. In the "Bog Reports" Mr. Griffith states, from his own observation during twenty years, an example of bog having grown at the rate of 2 inches every year-an instance probably of excessive growth under peculiarly favourable circumstances, yet valıable in its direct testimony to the fact tliat bog, fitly circumstanced, still continues to grow with undiminished vigour.

In the production of bog sphagnum is allowed on all hands to have been a principal agent, and superabundant moisture the inducing cause. To account for such moisture, various opinions have been advanced, more especially that of the destruction of large forests, which, by obstructing in their fall the usual channels of drainage, were supposed to have caused an accumulation of water. That opinion, however, cannot be supported,-for, as Mr. Aher remarks in the "Bog Reports," "such trees as are found have generally six or seven feet of compact peat under their roots, which are found standing as they grew, evidently proving the formation of peat to have been previous to the growth of the trees"--a fact, which, in relation to firs, may be verified in probably every bog in this parish, turf from 3 to 5 feet thick underlying the lowest layer of such trees. It is, indeed, so strongly marked in the bog, which on the Donegal side bounds the road to Muff, that the turf-cutters, having arrived at the last depth of turf, find timber no longer, 


\section{PARISH OF TEMPLEMORE.}

though formerly it was abundant, as is proved by their own testimony from experience, and by the few scattered stumps whicl still remain resting on the present surface. Not so, however, with oaks, as their stumps are commonly found resting on the gravel at the base, or on the sides of the small hillocks of gravel and sand, which so often stud the surfaces of bogs, and have by Mr. Aher been aptly called "islands." He further adds that in the counties of Tipperary, Kilkenny, \&c., they are popularly called "derries" - a name deserving attention, whether viewed as expressive of the existing fact, or as resulting from a lingering traditionary remembrance of their former condition, when, crowned with oaks, they were distinguishable from the dense forest of firs, skirting the marshy plains around them. The strong resemblance to ancient water-conrses, of the valleys and basins which now contain bog, and the occurrence of marl and shells at the bottoms of many, naturally suggest the idea of shallow lakes - a view of the subject adopted in the "Bog Reports," by Messrs. Nimmo and Griffith. Such lakes may have originated in the natural inequalities of the ground, - or been formed by the choking-up of channels of drainage by heaps of clay and gravel,-or they may have been reduced to the necessary state of shallowness by the gradual wearing-away of obstacles, which had dammed up and retained their waters at a higher level. Mr. Nimmo describes the mode in which the basin of a bog has been banked in by the alluvial deposits of a river (during freshets), and, in a similar manner, numerous examples might be adduced of bogs separated by banks of clay and gravel, owing to rivers running at their base,
and below their level.

In some cases also clay, which is so frequently found spread over gravel at the bottom of bogs, has produced a kind of puddle, which, by retaining the waters of floods or springs, has
facilitated the formation of muddy pools.

In all such cases the process may be thus stated:-A shallow pool induced and faroured the vegetation of aquatic plants, which gradually crept in from the borders towards the deeper centre. Mud accumulated round their roots and stalks, and a spongy semi-fluid mass was thus formed, well fitted for the growth of moss, which now, especially sphagnum, began to luxuriate. This, absorbing a large quantity of water, and continuing to shoot out new plants above, while the old were decaying, rotting, and compressing in to a solid substance below, gradually replaced the water by a mass of vegetable matter. In this manner the marsh might be flled up, while the central, or moister portion, continuing to excite a more rapid growth of the moss, it would be gradually raised above the edges, until the whole surface had attained an elevation, sufficient to discharge the surface water by existing channels of drainage, and calculated by its slope to facilitate their passage, when a limit would be in some degree set to its further increase. Springs existing under the bog, or in its immediate vicinity, might indeed still favour its growth, though in a decreasing ratio; and hereif the water proceeding from them were so obstructed as to accumulate at its base, and to keep it in a rotten, fluid state-the surface of the bog might be ultimately so raised, and its continuity below so totally destroyed, as to cause it to flow over the retaining obstacle, and flood the adjacent
country.

In mountain districts the progress of the phenomenon is similar. Pools, indeed, cannot in so many instances be formed, the steep slopes facilitating drainag'e,_-but the clouds and mists, resting on the summits and sides of mountains, amply supply their surface with moisture, which comes too in the most favourable form for vegetation-not in a sudden torrent, but unceasingly and gently, drop by drop. The extent of such bogs is also affected by the nature of the rock below gently, On quartz they are shallow and small; on any rock, yielding by its decomposition a clayey coating, they are considerable-the thickness of the bog, for example, on Knocklaid, in the county of Antrim, which is 1685 high, being near 12 feet. The summit bogs of high mountains are distinguishable from those of lower levels, by the total absence of large trees.

The general phenomena of the growth of bog having been explained, as clearly as the subject at present admits, it is necessary to describe in detail the remarkable fact, that successive layers of trees (or stumps) in the erect position, and furnished with all their roots, are found at distinctly different levels, and at a small vertical distance from each other-a fact which has been noticed by Mr. Aher, and may be verified in the bogs of Mullennan, Shantallow, and Ballymagrorty. On entering into this inquiry it is necessary to premise - that the firs found in bogs are Scotch firs, which, from numerous experiments, are now known to grow and flourish when planted in bogs. Walworth Wood, near Ballylelly, is an example-the trees having there grown for many years, and attained a large size under similar circumstances.

Reverting now to the preceding remarks, it appears that the consolidation of the lower portion of the turf was a necessary preparation for the first growth of timber, and-considering the huge size of the roots thrown out by these trees, and the extent of space over which they spread-the mode is readily perceived, by which they obtained a basis of support sufficiently firm and extensive to uphold their rising and increasing stems. The first layer of turf was now matted by the roots, and covered by the trunks of the first growth of timber, but, as the bog still continued to vegetate, and to accumulate round the growing stem, a new layer of turf was 


\section{NATURAL HISTORY.}

created, to support a second growth of timber, the roots of which passed over those of the preceding, and so on with a third, or more-until at length the singular spectacle was exhibited of seveal stages of trees growing at the same time. Such seems a natural way of viewing the subject-but it is often stated that one stump is found actually on the top of another, which would imply that the lower tree had been destroyed before the turf had ascended to the level of the broken stump. In such an instance, using Mr. Griffith's example of the rate of increase of recent bog, and supposing it compressed by growth into $\frac{1}{5}$ th of its original bulk, little more than one hundred years would have elapsed between the two periods. However, as but one decided example has come under actual observation in this parish, though many are spoken of by the country people, it is more probable that the evident superposition of roots, and the difference of level, have in many cases led to the idea of one tree being actually over the other-a phenomenon, which, even when it does occur, is easily explained by the decay of some of the older trees in the progress of successive growth already explained. This effect is to be naturally expected as the consequence of age, and equally so of the accumulation of turf over the roots and stumps, tending to facilitate the separation of the trunk, by forwarding its decay at the point of junction with the stump. It is indeed remarkable that, in the lower and larger stumps, this separation of the trunk appears to have taken place close to the stump, which exhibits a jagged edge around its circumference, whilst in the trees of the higher stratum there is usually a considerable portion of trunk attached to the stump, the tops of the trunks frequently rising above the surface. The example of tree existing above tree, already referred to, is singular, inasmuch as the lower one is a prostrate stem; but it is necessary to bear in mind, that as the progress of the growth of bog commences at the edges of the pools, or marshes, trees might have there grown, fallen, and sunk, before the internal parts had been filled and consolidated; and, also, that the great weight of some of these trees may have sunk them deeper in the bog than they had stood when first beginning to grow. A very interesting experiment, by Professor Lindley, is detailed in the 17th Part of the "Fossil Flora," from which it appears that the Coniferce are amongst the very few dicotyledonous plants, which, when dead, resist the action of water: the experiment, however, was continued only through two years, and it may be doubted whether, as a rule, it would apply to the living tree.

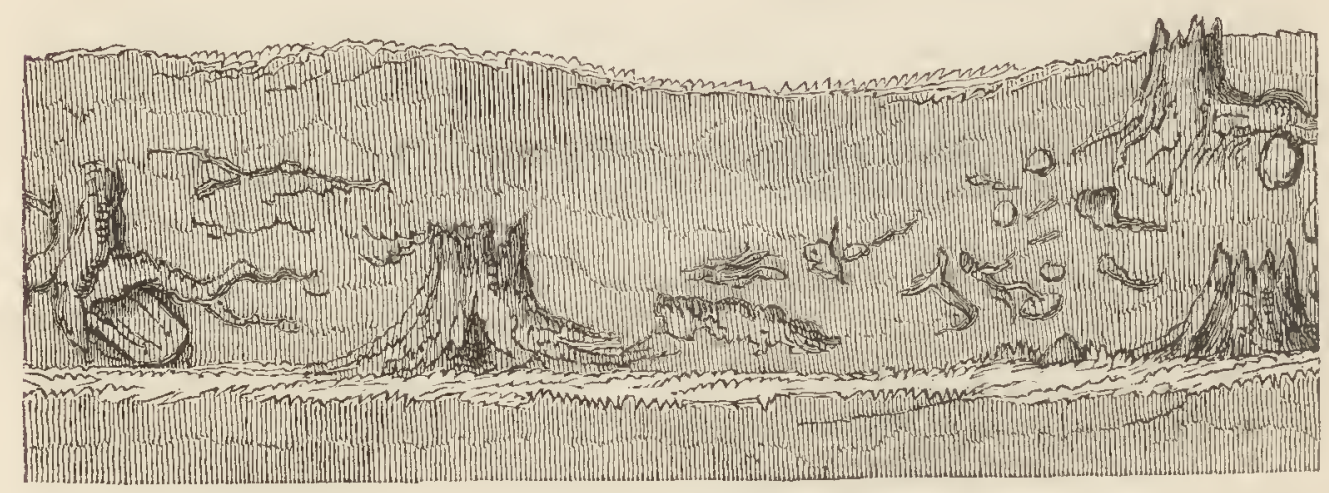

In this parish the bog has been so much cut down that it is difficult to estimate its depth From 10 to 15 feet may, however, be taken as a close approximation in the deeper parts, from which it gradually shallows towards the sides of the basins, or troughs, containing it. The trees have been of large size. In Ballymagrorty bog one may be observed, having six principal roots, each of which is $1 \mathrm{r}$. 6r. deep, from $10 \mathrm{I}$. to $1 \mathrm{~F}$. 4.r. broad, and extends 4F. from the stump, without any marked diminution, at which distance it bifurcates.

In Shantallow bog a principal root measured $1 \mathrm{~F}$. 10r. square-its form approaching that figure,-and these were by no means exceptions, nor examples of great size. The largest Scotch fir at present growing in the parisls is at Brook Hall: at the height of IF. 3r. from the ground it is $10 \mathrm{~F} .81$. in circumference. To estimate the actual size of the bog trunks is difficult, owing to the decay and wearing-away of the external surface; but the size of the roots supports the deduction that many must have greatly exceeded this tree in size, and still more equalled it.

Combining all these phenomena together, the mind is irresistibly led to contemplate that ancient condition of the parish, when its hills looked over an extent of marsh and morass, where waved a noble forest of lofty firs, the deep green foliage of which was only here and there broken and enlivened by clustering oaks. 


\section{PARISH OF TEMPLEMORE.}

BOTANY.-The natural vegetation throughout the parish is variable, and presents no peculiarly marked features, excepting the marine vegetation along the side of the river Foyle, where, on the muddy shore from Culmore Point to Derry, the more common plants are Eleocharis palutris, Creeping Spike Rush; Juncus compressus (var. $\beta$, ) - the J.conosus of Bicrieno-Roundfruited Rush; Glaux maritima, Sea Milkwort; Statice Armeria, Common Thrift, or Sea Gilliflower; Cochlearia officinalis, Common Scurvy Grass; C. Anglica, English Scurvy Grass; and Zostera marina, Common Grass Wrack. Near the bridge of Derry, where the last plant becomes scarce, large patches of Scirpus maritimus, or Salt Marsh Club Rush occur, which, with the others, spreads to the extremity of the county. Along the dry banks in Termonbacca the Lithospermum officinale, or Common Gromwell (which is not general in this county), is very abundant, together with a flesh-coloured variety of the Convolvulus sepium, or Common Bindweed - a variety of that genus, which does not seem to have been hitherto noticed in Britain, and only in one place in Ireland, viz. the Island of Baffin (Inishbofin), in the county of Galway.

In some of the glens near the county boundary, and by the side of the Foyle near Culmore, a fer stunted natural hazels occur, - but, in general, the interior is bare and uninteresting.

The old walls of Derry are in many places literally covered with the common Parietaria officinalis, or Pellitory of the Wall; the Acer Pseudo-platanus, or Common Plane Tree, also grows naturally on them.

This parish possesses no plants peculiar to it, nor even any which can be considered very rare, although the Rubus rhamnifolius, and Rubus Kochleri, have hitherto been so considered. Those most worthy of notice are the following :-

MONOCOTYLEDONOUS.

1. Alisma Ranunculoides, Lesser Water Plaintain.

Habitat. Abundant in boggy ground beside the Foyle.

2. Sparganium simplcx, Unbranched Bur-reed.

3. S. natans, Floating Bur-reed.

$H a b$. Both in Ballyarnet Lough.

4. Blysmus rufus; LiNK.-Schœenus rufus; Eng. Bot.-Narrow-leaved Blysmus. Hab. Side of the Foyle, near Brook Hall.

5. Rynchospora alba; VAIL. White Beak Rush. Hab. Bog at Cnlmore Point.

6. Iris fotidissima, Stinking Iris, or Roast Beef Plant. Hab. Banks at Culmore Point.

\section{DICOTYLEDONOUS.}

7. Circcea lutetiana, Common Enchanter's Nightshade.

$H a b$. Bushy places beside the Foyle.

8. Utricularia vulgaris, Greater Bladderwort.

9. U. minor, Lesser Bladderwort. Hab. Abundant in holes on the Race-course Bog.

10. Pinguicula vulgaris, Common Butterwort. Hab. Moist banks on the side of the Foyle.

11. Erythrcea Centaurium, Common Centaury. Hab. Side of the Foyle.

12. Samolus Valerandi, Brookweed, or Water Pimpernel. $H a b$. Side of the Foyle.

13. Drosera rotundifolia, Round-leaved Sundew.

14. D. longifolia, Long-leaved do.

15. D. Anglica, great do. $H a b$. All three in the bog at Culmore.

16. Solanum Dulcamara, Woody Nightshade. Hab. Walls of Derry.

17. Enanthe crocata, Hemlock Water Dropwort. Hab. Side of the Foyle: abundant from Culmore to Pennyburn.

18. Sium latifolium, Broad-leaved Water Parsnip. Hab. Marsh near Culmore Point. 


\section{NATURAL HISTORY.}

19. Rosa tomentosa, Downy-leaved Rose.

$H a b$. Common in many places.

20. Rubus casius, Dewberry.

21. R. Kochleri; WE11E and NEES-R. glandulosus; E. Flora-Kochler's Bramble.

$H a b$. Both on banks at the side of the Foyle, above Derry.

22. R. rhamnifolius (W. and N.), Buckthorn-leared Bramble.

23. Nuphar lutea, Yellow Water Lily.

24. Nymphaa alba, Great White Water Lily.

$H a b$. Both in Ballyarnet Lough.

25. Galeopsis versicolor, Large-flowered Hemp Nettle.

Hab. In Killea.

26. Cnicus pratensis, Meadow Plume Thistle.

Hab. Meadows in Killea.

27. Ceratophyllum demersum, Common Hornwort.

$H a b$. In a marsh by the side of the Foyle, above Derry.

The natural meadows in this parish are moderately extensive, principally on the sides of the boggy ground in Ballyarnet, Shantallow, and Ballynagalliagh. The grasses and other plants, of which they are chiefly composed, are:-the Agrostis alba, Fiorin, or Marsh Bent, Grass; Cynosurus cristatus, Crested Dog's-tail Grass; Holcus mollis, Soft Grass; Aira caspitosa, Turfy Hair Grass ; and, on wet ground, the Juncus effusus, Soft Rush; J. conglomeratus, Common Rush; and $J$. acutiflorus, Sharp-flowered Jointed Rush. The average produce of these meadows is generally rated at $2 \frac{1}{2}$ tons per Cunningham acre.

The Alopecurus pratcnsis, or Meadow Fox-tail Grass, and the Bromus Mollis, or Soft Brome Grass, are also very common in the neiglibourhood of Derry.

The mountain pasture is generally poor. The most abundant plant on the top of Sheriff's Mountain (552 feet in height) is the Calluna vulgaris, Ling, or Common Heath. The pasture grasses are:- the Festuca ovina, Sheep's Fescue Grass; Agrostis vulgaris, Fine Bent Grass; Anthoxanthum odoratum, Sweet-scented Vernal Grass; Nardus Stricta, Mat Grass. The following plants likewise are abundant:- the Eleocharis Caspitosa, or Scaly-stalked Spike Rush; and the Juncus squarrosus, or Heath Rush. The productions of Creevagh Hill, and all the mossy ground in that neighbourhood, are similar, witls the addition of the Mclica corulea, or Purple Melic Grass, on the low ground.

In most of the corn fields throughout the parish the Sinapis arvcnsis, or Wild Mustard, or Charlock - generally known here by the name of Prashach -is very common, and is, in many instances accompanied by that still more troublesome weed the Chrysanthemum segetum, or Corn Marigold-known here by the name of Guil, or Guilgowans. The Spergula arvensis, or Corn Spurrey, known here by the name of Yare, is also very abundant : of boggy ground lately reclaimed, it often takes almost exclusive possession. In some places the tall oat-like grass, here lnnown by the name of Pearl-the Avena elatior -is but too frequent in the corn-fields, - as are also the Rumex obtusifolius, or Broad-leaved Dock; and the Cnicus arvensis, or Creeping Plume Thistle.

ZooLOGY.-It is probable that a first view of this parish would lead an observer, totally unacquainted with its localities, to auticipate a full harvest of rich and interesting facts in zoological science-and such, assuredly, must have been the result of research in those remote times, when the surface of the land was covered with forests, its inmost recesses occupied by swamps or lakes, and the waters of the expanded Foyle still silent and undisturbed. The scene is changed: the small lake of Ballyarnet affords no shelter for water fowl; the plantations on the sides of the Foyle are narrow stripes, which abound in small birds, but produce few of large size, amongst which are probably two species of owls.

The bare and exposed sufface of the interior of the parish is even less favourable; and the hills, though rocky, are too low to tempt the larger predaceous birds to linger among them, when the mountains of Ennishowen,- the lofty summits and heathery sídes of Sawel, Dairt and Menard, - and the wild and gloomy precipices of Benyevenagh (beyond the Foyle) -invite them to more sequestered and fitting positions for nidification and repose. Nor have the lough and river of the Foyle been unaffected by the influence of advancing civilization, and extending commerce,though in more retired parts, beyond the ordinary track of vessels, they are still resorted to in winter by numerous flocks of water fowl, for some of which the lough has long been celebrated. Among these are the Bernicle Goose (Anser Bernicla); the Brent Goose (A. Brenta) - a species which is probably often sold as Bernicle in the Derry market; the common Teal (Anas Crecca; Lins.); and the common Wigeon (A. Penelope; LinN.)

On reviewing these circumstances it is evident that this branch of the Natural History of the Parish requires only a brief notice of some leading faets, and may, in the more general details, be allowed to merge in the description of the Zoology of the county at large. 


\title{
PARISH OF TEMPLEMORE.
}

\author{
MAMMALIA. \\ Cheiroptera.
}

Plecotus auritus (Vespertilio auritus; LrNs.); Eared Bat.

A colony of these interesting little animals was discovered in June last (1835), under the slates of Foyle House, above the city. More than ten were secured; and the specimen examined, having escaped from its confinement in the room, was seen for a few minutes, hanging by its hind legs to the cornice, when, insinuating itself into a hole, it disappeared.

\section{Fera.}

Lutra vulgaris; Common Otter. Occasionally met with in the Foyle.

\section{Aves (Birds.) \\ Insessores (Perchers.)}

Alcedo Ispida ; Common King's-fisher. Occasionally met with on the banks of the river. Muscicapa (?) Grisola; Spotted Flycatcher. Shot in the demesne of Brook Hall. It has been but little noticed by the country people, who, however, speak of its regular return in May. The specimen obtained is less distinctly marked than is usual with this bird.

Merula viscivora (Turdus viscivorus; LINN.); Missel-Thrush. This bird, until within the last few years, was rare : it is now more common, and is on the increase.

Saxicola Rubetra (Notacilla rubetra; LrNo.); Whinchat. Rarely seen before May. The inhabitants think of this, as of many other migratory birds, that it sleeps during the winter.

Sylvia Hippolais (Motacilla hippolais; LrNs.); Lesser Pettychaps, or Chiff-chaff. Not very common. mon.

Regulus auricapillus, (Motacilla regulus; LrNo.); Golden-crested Wren. Not uncom-

Parus corruleus; Tom-tit. Not uncommon; and here, as in other places, driven to the houses by the frosts of winter.

Sturnus (?) vulgaris, or Turdus solitarius; Brown Starling, or Solitary Thrush.-The uncertainty which hangs over the history of this bird is well described by Professor ReNNIE in his edition of Montagu's Dictionary. SELBY speaks of it as the young bird of the Common Starling, prior to its first moult. Mr. KNAPP, quoted by RENNIE, considers it in every respect distinct from the Common Starling, his concluding words being:- "I scarcely know any bird less conspicuous for beauty than the Solitary Thrush; it seems like a bleached way-worn traveller, even in its youth." The specimen under consideration affords a good example of this weather-beaten aspect. It was killed on the 16th of July last (1835), whilst feeding in company with the Ringed Plover on the shore of Lough Foyle, and has every appearance of an old bird-its claws being worn and blunted. The legs are of a dark red-brown, as described by Mr. KNAPP, and the bill black, but faintly edged with white.

\section{Rasores (Scratchers.)}

Perdix coturnix (Tetrao coturnix; Linn.); Common Quail. This bird has now become tolerably abundant, though hitherto considered rare in the parish.

\section{Grallatores (Waders.)}

Numenius arquata (Scolopax arquata; LrNv.); Curlew. Abundant.

Totanus calidris (Scolopax Calidris; Linn.); Redshank. Frequent.

Crex pratensis; Meadow-crake, or Corn-crake.-Very common. SELBY observes of the peculiar note of this bird:- " it is continued until a mate be found, and incubation commenced, after which it ceases:" such also is the opinion of MoNTAGU. It was heard, however, during the present season, on the 15th of July last (1835); and in a corn field opposite Boom Hall its note was, prior to that period, frequently repeated, especially in the evening before sunset. 


\section{NATURAL HISTORY.}

BEwICK, therefore, is probably correct in his assertion-that it is heard till the grass is cut, or, in other words, till the bird is deprived of shelter.

Squatarola cinerea (Tringa cinerea; Lin .); Grey Plover-LLarge flocks are sometimes seen in the latter end of September. Foyle.

Charadrius Hiatacula ; Ringed Plover.-Common; frequenting the pebbly shores of Lough

Pisces (Fishes.)

Being arrived at the next great class of the Animal Kingdom, the peculiar position of the parish in reference to the waters of the Foyle, both lough and river, should arrest attention. It is in such situations (estuaries, - -and here especially, where river, lake, and sea combinethat fishes, varying in their ordinary habits and places of abode, may be expected to congregate together, either drawn by the impulse of nature to a more quiet region for the deposition of their eggs, or spawn, or led by a similar instinct to the common rendezvous - that they may prey upon others of less size and strength. To facilitate inquiry into a subject of such curious speculation, a list will here be given of those fishes alone, which are taken in or above the salmon nets of Culmore, on Lough Foyle - that is to say within 5 miles of Derry - a little below the junction of the river and lake, and about 20 miles from the main ocean. The time of experiment also has been short-not exceeding a month-and the list itself will be continued, on the same principle, in the next parish. To facilitate comparison, the arrangement of FLEMING is in this class adopted-the work containing it being easy of access, and in popular use.

\section{Cartilaginous.}

Scyllium stellare (Squalus stellaris, Linn. and Penn.); Spotted Dog-fish.-In the application of the synonymes and history of this fish, there is much confusion. PENNant describes two species-the Spotted, Squalus canicula, (Lins.), and the Lesser Spotted, Squalus catulus, (Linn.), -considering tle Catulus maximus of WiLlovgнву (Squalus stellaris, LiNr.), or "Le Squale Rochier" of LACEPEDE, a mere variety of S. canicula of larger size. It is singular that in this arrangement ho makes no allusion to the reasoning of LACEPEDE, who has totally reversed the order of separation. That writer (Hist. Nat. des Poissons-Tome 1.223), after remarking on the supposed analogy between sharks and birds of prey, exhibited in the superior size of the female, thus expresses himself:-_" C'est principalement dans l'espèce du squale roussette que se montre cette inegalité de dimensions entre le male et la femelle. Elle $y$ est même assez grande pour que plusieurs auteurs anciens et plusieurs naturalistes modernes les aient considerés comme formant deux espèces distinctes, dont on a nommé une le grand chat de mer ou chien marin (canicula vel catulus major), et l'autre le petit chat de mer ou petit chien marin (canicula vel catulus minor)." He therefore advocates the union of $S$. canicula and $S$. catulus, and in his next article recognizes Catulus maximus (S. stellaris), as a distinct species, under the name "Le Squale Rochier."-Again, Cuvier (Règne Animal, Tome 2.) admits two species, but places the line of separation in a still different position, making $S$. canicula a synonyme of his "Grande Roussette," and S. catulus, and S. stellaris, synonymes of "La Petite Roussette" - to which he also adds LacePede's name "Le Rochier,"-thus uniting the species in size supposed to be the smallest, with that considered by PENNANT and LACEPEDE to be the largest. He also cites the plate given by LACEPEDE for "Le Rochier" as "La Grande Roussette," and vice versd.

Fieming also desoribes two species, but, overlooking LACEPEDE's description of "Le Squale Rochier," quotes him as authority for uniting these two species into one. Such, however, was not the mcaning of LACEPEDE, who contended against three, and not against two species: his words, in describing "Le Rochier," are:- "Ce squale a été souvent confondu avec le male ou la femelle de la roussette, que l'on a pris pour le malle ou la femelle du rochier." This curious confusion in terms will be rendered intelligible by the following summary :-

PENNANT.

1st Species.

Catulus major.

Squalus Canicula.

Le Squale Roussette.

Catulus maximus.

Squalus stellaris.

Le Squale Rochier. 2nd Species.

$\{$ Catulus minor.

$\left\{\begin{array}{l}\text { Squalus Catulus. } \\ \text { Le Squale Roussette. }\end{array}\right.$ 


\section{PARISH OF TEMPLEMORE.}

LACEPEDE.

$\left.\begin{array}{l}\quad 1 \text { st Species. } \\ \text { Catulus maximus. } \\ \text { Squalus stellaris. } \\ \text { Le Squale Rochier. }\end{array}\right\}$

\}

2nd Species.

Catulus major.

$\left\{\begin{array}{l}\text { Catulus minor. } \\ \text {. }\end{array}\right.$

Le Squale Roussette.

CUVier.

\author{
1 st Species. \\ Squalus canicula. \\ La grande Roussette.
}

\author{
2nd Species. \\ Squalus stellaris. \\ $\int$ Squalus catulus. \\ Le petite Rochier. \\ Le Squale Rochier.
}

FLEMING.

1 st Species.

Catulus maximus.

Squalus stellaris.

\author{
2nd Species.
}

s Catulus major.

¿ Squalus catulus.

The confusion is one of terms only, as regards the three first writers, though it has doubtless been in part the cause of FLEMING'S mistake, in his quotation of LACEPEDE'S opinion.

In placing the specimen under consideration in the species Scyllium stellare, or Spotted Dog-fish, the position of the fins, as compared with the plates of LACEPEDE, has been the leading guide. It was a female : and, when its small size is considered, the impossibility of forming any specific determination on a character so uncertain, in the present limited state of knowledge either of growth or maturity in fishes, must be admitted. In form it agrees entirely with the plate given by LACEPEDE of "Le Squale Rochier." Its ventral fins are disjoined, and the spots are small and numerous--agreeing in that point with Cuvien's description of the Great, " $d$ petites taches nombreuses,") and with FLEMING's of the Small Scyllium. On the whole-it may be fairly stated that a new consideration of this genus is necessary, and that, in such consideration, size should be entirely left out of view. It may be added that FLemING's description of the position, in his great Spotted Dogfish, of the first dorsal nearly over the ventrals, corresponds with the plate of LACEPEDE, cited by CUVIER under "La petite Roussette."

Dimensions, \&c. :-Extreme length 2F. 4r.; between root of pectoral fins and root of anal fin $1 \mathrm{~F}$; ; ventral fins half-way between pectoral and anal, reckoning from the root, or beginning, of each; anal fin half-way between ventral and caudal ; 1 st dorsal half-way between ventral and anal ; $2 \mathrm{~d}$ dorsal half-way between anal and caudal; from lip to snout 1 inch; nostrils ${ }_{3}^{1} \mathrm{rd}$ of an inch from lips, with each a valvular lobe; under the nose 4 regular rows of pores; colour dusky grey; belly white; form slender. The tendrils of one of its purses, or eggs, were seen protruding from the belly; and, when pulled, two of these singular bodies were extracted, having between them a length of tendril equal at least to 1F. 6I., and the same quantity attached to the opposite end of the inner one. Eggs of various sizes, but without their horny covering, were found within the animal, and a small portion also of unattached tendril, perhaps broken from that extracted. The stomach contained fragments of crustacea, and valves of shells. The eggs, commonly called "Sailors' Purses," have in Ireland the poetic name of "Mermaids' Purses."

2. Raia rubus, Rough Ray. The stomach contained numerous fragments of crustacea.

\section{Osseous.}

3. Syngnathus, Pipe-fish. Syngnathus acus, Sea Adder of Cornwall.

\section{Malacopterygeous.}

4. Salmo Salar; Common Salmon. Mr. DAN IELLs, long employed as a clerk on the Foyle Fishery, has collected much valuable information on the habits of this fish. From numerous experiments he ascertained that the male salmon was the sole labourer in the arduous operation of forming the spawning trough. Of many taken for trial the males were found with snouts scratched 


\section{NATURAL HISTORY.}

almost to bleeding, and with bellies and sides nearly denuded of scales by the violent rubbing they had undergone, while the females bore no mark of injury. The sharpened form of the snout in the male salmon, as well as in the male of the sea trout, is consistent with this theory; and the peculiar condition of the female, laden with spawn, affords a satisfactory reason why such should be the law of nature. It excuses, likewise, the apparent apathy, with which in some sheltered pool she awaits the return of the male, whom she then accompanies to the prepared furrow, that they may together deposit their milt and rne. The great disproportion in number between the males and females, taken in the nets, has also been noticed by Mr. DANIELLS-the males perhaps not exceeding in number $\frac{1}{3} \mathrm{rd}$ of the females - but it is probable that this arises from a partial separation of the sexes in the ascent of the river, the males keeping the central, and more rapid part of the stream.

5. Salmo Trutta; Sea Trout. These accompany the salmon in considerable numbers, and are probably very conformable to them in habits.

6. Salmo Fario ; Common, or River, Trout. Two specimens were taken on the 2nd of July last (1835), in the first nets below Derry: it is therefore an example of a fresh-water fish, existing by choice in salt water.

7. Clupea Alosa; Shad. By no means uncommon. It attains a considerable size, 一the extreme length of the specimen examined being $2 \mathrm{~F} .2 \mathrm{r}$.

8. Esox Lucius; Common Pike. Taken between Derry and Culmore. Another interesting example of a fish, whose usual habits are fluviatile and lacustrine, found in salt water: length, 2F. 10I.

9. Belone vulgaris; Common Gar. Numerous after the middle of June.

10. Molva vulgaris; Common Ling. A specimen, 4 feet long, was taken in July (?) 1835. Dark oblique streaks along the dorsal fin.

11. Merlangus vulgaris; Whiting. A specimen was taken on the 9 th of July (?) 1835. The first dorsal fin has only 13 rays.

12. Pleuronectes Rhombus; Brill.

13. Pleuronectes, species nearly allied to Megastoma, but without tubercles on the lateral line. The retral portion of the dorsal fin is widest. Body translucent.

14. Platessa vulgaris; Plaice. Very common.

15. Platessa Flesus; Flounder. The sinistral variety very frequently met with.

16. Anguilla vulgaris; Common Eel. Caught with hook and line at the quays of Derry, as early as the 9 th of June last (1835).

\section{Acanthopterygious.}

17. Gunnellus vulgaris (Murcenoides guttata-LACEPEDE and YARRELL); Spotted Gunnel, or Butter Fish. Well described by $\mathrm{YARRELL}_{\mathrm{A}}$ in the 5 th part of his British Fishes, though the spots should be on the back rather than on the dorsal fin.

18. Lophius Piscatorius; Angler, or Frog-fish. Many of this species are met with in Lough Foyle, and are called Herring Hogs. A specimen of this unsightly fish was stranded near Derry, having been previously wounded: it was still alive. The extreme length of the specimen examined was 3F. 9I., and the expanded jaws measured 12I. by 10 .

19. Trigla Gurnardus; Grey Gurnard. Taken on the 15th of July last (1835).

20. Cataphractus Schoneveldii; Common Pogge. Several specimens obtained-the largest 6 inches long. The angular form is preserved in the upper surface of the tail, though it is rounded below. The number of rays in the pectoral fins is 16-FLEMING says 18.

21. Mugil Capito-Cuvier and Yarrell; $M$. Cephalus-Fleming; Common Mullet. It is frequently of considerable size : one taken on the 30th of June last (1835) measured 2F. II.

22. Zeus Faber; Doree. This was taken on the 9 th of July last. In the Ist dorsal fin were 9 rays, -in the pectoral 13 -both numbers agreeing with those of YARRELL.

\section{Mollusca.}

\section{Cephalopoda.}

Loligo vulgaris; Calamary: the Great Cuttle of PennAnT. Taken in the Culmore net. The fins were in this specimen narrower than is usual, and much thickened at the edges. The spots were principally on the right half of the animal - an arrangement traceable even on the arms and feet. 


\section{NATURAL HISTORY.}

\section{Siphonida.}

Mya arenaria; Abundant-buried in the sand, near low-water mark at Culmore Point. This is sometimes called Brallion, but the same name seems to be applied to other shell-fish.

From the position of the parish little variety could be expected in shells-and few, indeed, there are. The above-mentioned, together with the Turbo littoreus, or Periwinkle, and small specimens of the Mytilus edulis, or Common Muscle, constituting by far the greater proportion.

Here then may cease this slight sketch of some of the leading features of the Zoology of the parish, which will be filled up in its details, and completed in the zoological description of the county. 



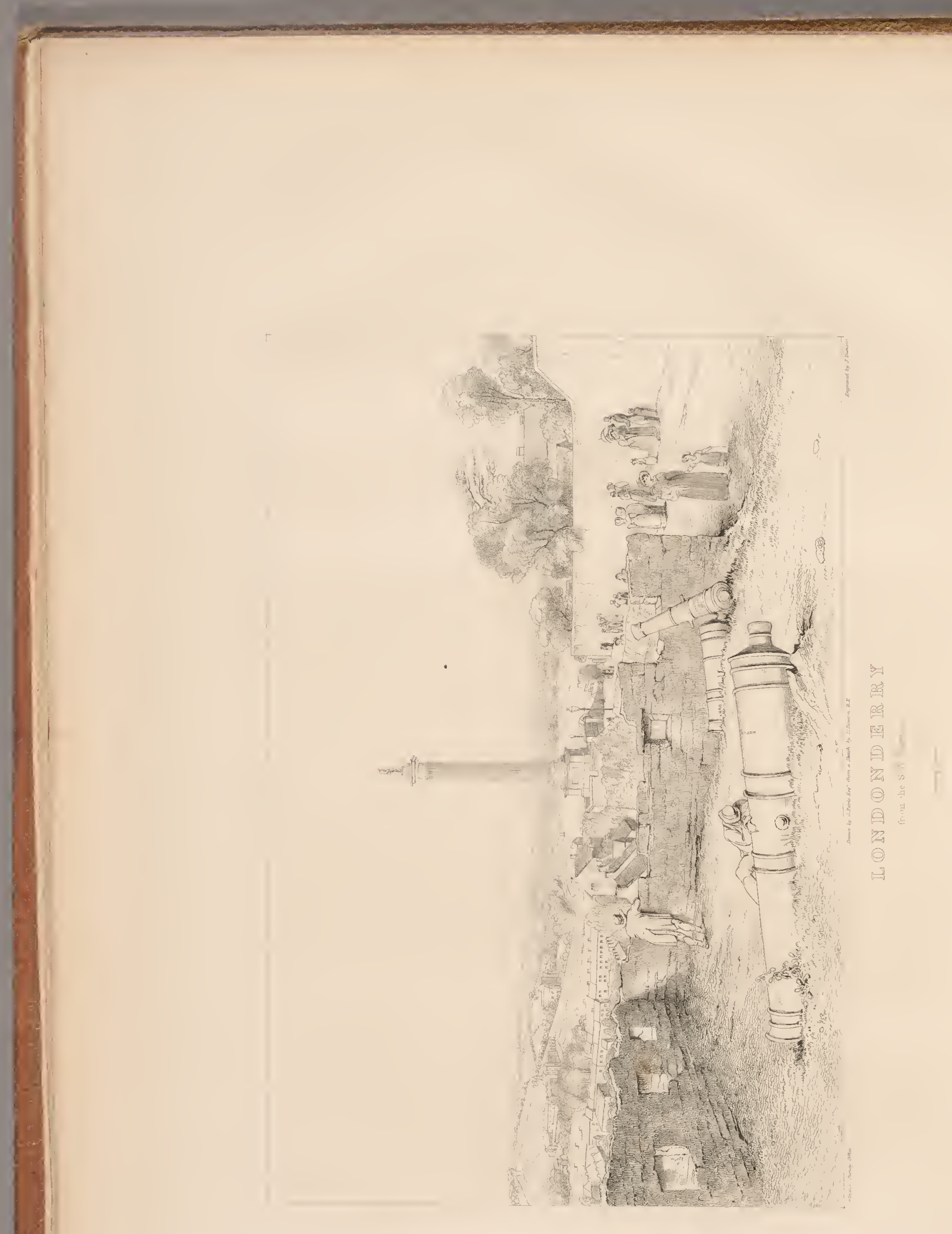




\section{SECTION II.}

\section{A RTIFICIAL STA TE.}

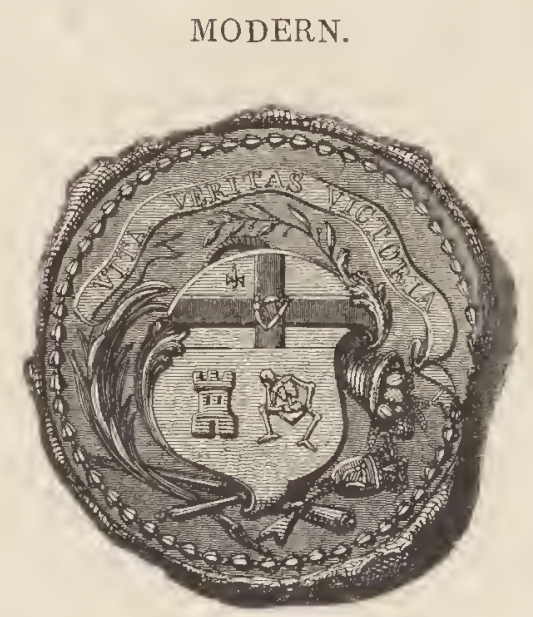

Towns. - The CITY of LONDONDERRY is included within this parish.

NAME.-DERRY, in Irish Oo ipe-the popular name of the place-means literally a "place of oaks," but is also used to express a "thick wood." It is so explained by CoLGAN (1645) - an Irish topographer of the lighest authority-in his Acta Sanctorum, p. 566 [recte 562]. This word, however, was not topographically used by the ancient Irish without the addition of somc intinctive Ooriginal Pagan appellation of this place was Ooine Calzaic, or Derry Calgach-the "oak wood of Calgach,"-CaIgach, which sionifies " a fierce warrior," being the proper name of a man in pagan times, and rendered illustrious as Galgacus in the pages of TACiTus. In support of this etymology may be adduced the high authority of ADAlNAN - abbot of Iona, in the 7th ccntury-who, in the Life of his predecessor, St. Columbkille, invariably calls this placc Roboretum Calgagi, his custom being to give the Latin equivalents for Irish topographical names. For a long period subsequent to the 6rive prevailed; but, towards the latter end of the 10 th century, this appellation seems to have yielded to that of Derry-Columbkille-no other appearing in the Irish annals after that period. In subsequent ages, when the place had risen in importance above every other Derry, the distinctive epithet Columbkille was dropped as no longer neccssary; and such is the effect of long cstablished usage that the English rof - andon-which was imperatively imposed by the original charter of James I., and preserved with pride by the colonists for a long time after, has likewise fallen into popular disuse. Indeed this mode of abbreviation is usual in Ireland, whenever the name of a place is compounded of two distinct and easily separable words: thus, in the counties of Antrim and Down Carrickfergus is shortened into Carrick, Downpatrick into Down, Iniscourcy into Inch, \&c.

The name LoN DONDERRY, al though a hybrid compound, is, even in its modern part, traceablc to a Celtic origin; and, it will be seen that by a curious coincidence, the word LoNDON is as graphically descriptive of the modern locality, as DERRY was of its ancient. By LLUYD, and other British etymologists, it is interpreted "the town of ships," from long in British, and in Irish, "ship" - and dinas in British, or oun in Irish, "fortress,"-(the dunum of the Romans), which is the root of the word "town." This derivation is, however, merely conjectural; and the Celtic compound Conn-oun, signifying a "strong fortress," is as likely to have been the original signification of London. Either explanation is, however, curiously applicable to Lon- 


\section{CITY OF LONDONDERRY.}

donderry, or Comnoun-oone, which would mean in Irish what the English have really made the city - the "ship town," or "fortified town, of Derry;" and it may be worthy of remark that the name of an ancient fortress, a few miles higher up the river, was Oun na long, "town of ships," as it has been preserved to this day.

Locality.- The city of Derry, or Londonderry, is situated I50 miles from Dublin, in latitude $54^{\circ} 59^{\prime} \mathrm{N}$, and longitude $7^{\circ} 19^{\prime} \mathrm{W}$. It is in the diocese of Derry and Raphoe, and the N.W. circuit of assize.

The city is placed on the western or Donegal side of the river Foyle, about 5 miles above the junction of that river with Lough Foyle, and 14 miles below the town of Lifford. This situation is equally remarkable for its distinguished local advantag'es and picturesque features, being on a hill stretching out into a broad and navigable river, by which it is nearly insulated, and commanding on every side views of a country, which is rich in natural and cultivated beauty. This hill, which in troubled times was selected as the natural Acropolis of the North, comprised till lately within its limits the whole of the city and suburbs; but Londonderry, in its days of prosperity and peace, has expanded itself beyond its natural military boundary, and is now rapidly extending northerly towards the lough, along the champaign shore of the river. The "Hill," or "Island of Derry," as it is still usually called, is of an oval form, ascends to an eleration of 119 feet, and contains 199 acres, 3 roods, 30 perches.

\section{HISTORY.}

BEFORE THE REIGN OF ELIZABETH.

\section{Section 1.-General.}

Trie history of Derry, anterior to the close of the reign of Elizabeth, is almost wholly ecclesiastical; and in relation to its state in Pagan times, nothing is recorded with certainty, except its name-Derry Calgach-and the fact of its being a pleasant eminence covered with oaks. The erection of a monastery here by the celebrated Irish Thaumaturgus and apostle of Scotland-Columbkille-is assigned by the best anthorities to the year 546 , at which period that distinguished person was in or about his twenty-ffth year; and it is said that this was the first of the saint's ecclesiastical foundations, from the great number of which he received the cognomen Cille, i. $e$. "of the cells," or "churches"- usually appended to his name. The exact era of this foundation, as well as the various circumstances connected with that event, are, however, involved in deep obscurity. Accordino to O'Donnell, Prince of Tirconnell, who wrote the life of St. Columb in 1520 , the locality of Derry was bestowed upon the saint by Aid, the son of Ainmirach, at that time a very young prince, who had there his residence. This Aid and the saint were of the same Connellian stock--the former being descended in the fifth, and the latter in the fourth degree from Connell Gulban (a son of Niall the Great), from whom the country of Tirconnell received its name. But it appears certain that Aid, if he were in existence, could hardly have been a powerful prince at the period assigned to this donation, as it appears from authentic sources that his father Ainmirach, who was cousin-orerman to the saint, did not ascend the Irish throne till 568 that is, twenty-two years after, and he was himself slain in battle in 598-9, two years after the death of Columb at the age of 77. The foundation of the monastery at Derry must, therefore, as Colgran acknowledges, have been at a much later period, or the story told by O'Donnell must be regarded as a groundless legend. Waving this objection, however, which has been already made by Colgan and Lanigan, there is another of greater weiglit, which has not hitherto occurred to investigators of Irish history, namely - that it is contradictory to all our authentic authorities to allow that Aid, or any other "Tirconnellian prince, possessed the power to make any gift of Derry, or the lands adjacent, which, as is shown in the country history, were then, and for nearly a thousand years after, within the territory of the Kinel-Owen, or descendants of Eogan, another son of Niall; and-as not even a shadow of ancient authority has been found to support O'Donnell's statement-there is reason to believe that it was fabricated by that biographer, or some of the bards of his house, to support those claims to the possession of Derry and Inishowen, which had been fiercely contested by the Kinel-Connel with the O'Neills or Kinel-Ow'en, for upwards of a century previously.

Of the history of the saint himself, as connected with Derry, but little is recorded. The village of Gartan, in Donegal, has, according to O'Donnell, the honour of being his birth-place In 563 he sailed to Iona from Derry, to which place he returned in 590, when he assisted at the great national council of Drum-keat; whence, after visiting some neighbouring monasteries of his foundation, he returned to Iona, where he died on the morning of Sunday, the 9th of June, 597 . 


\section{HISTORY.}

The ancient records of the Irish churches, as preserved in the brief notices of the annalists, present but little to interest the general reader. They are merely records of tleir misfortunes, and obituaries of the most distinguished men, connected with them. Unfortunately even such notices are, in respect to the church of Derry, unusually barren, in consequence of the destruction of its local chronicle-the Zeabon Ooine-as well as all the other chronicles connected with the county; but, meagre as they confessedly are, they are yet valuable to the serious investigator, as evidences of the progress of society, and the origin of the family names still commonly found in the district; and, as tributary to these legitimate objects of statistical inquiry, snch uses shall be made of them in the present memoir. It may be proper to state that in all instances, when the authority is not cited, the notices are to be considered as taken from the Annals of the Four Masters.

A. D. 783. "Derry Calgach was burned."

832. "Niall Caille [king of Ireland], and Murchadh, defeated the Danes at Derry-Calgach, with great slaughter."

989. "Derry-Calgach was plundered by the Danes."

997. "Derry-Calgach was plundered by the Danes."

1095. "The abbey was consumed by fire."-Annals of Munster.

1100. "A large fieet of foreigners was brought by Murtagh O'Brien to Derry; but they did not plunder any place, being opposed by the son of Mac Loughlin [Prince of Aileach,] who defeated them with great slaughter, both by killing and drowning."

1121. "Donnell, the son of Ardgar Mac Loughlin, monarch of Ireland, the most distinguished of the Irish for personal form, nobility of birth, wisdom, feats of arms, wealth, and prosperity, for bestowing riches and food, died in Derry-Columbkille, in the 38th year of his reign, and 76th of his age, on Wednesday night, the 4th of the ides of February, on the festival of Mochuarog."

1124. "Ardgar, the son of Hugh, heir apparent to the throne of Aileach, was killed by the people [that is the monks] of Derry, in defence of [the church of] Columbkille."-See also Gelasii vita apud Colgan, cap. 5.

1135. "Derry Collumbkille with its churches, was burned on the 30th of March." Colgan, in respect to this fire, states that "as some conjecture, it was caused by a person desiring" to revenge the deatl of the cliief [Ardgar], who had been lately slain there."-Citata vita S. Gelasii: cap. 6.

1146. "A violent tempest liappened on the 3rd of December, which prostrated much timber throughout Ireland. It threw down sixTy oAks in the Derry Columbkille, by which many persons were killed and disabled in the church." This record is interesting, as furnishing evidence of the existence to so late a period of the oak wood, from which the place had originally received its name.

1149. "Derry-CoIumbkille was burned."

1150. "The visitation of Kinel Owen was made by Flahertach O'Brolchain, coarb [successor'] of Columbkille, and he received a horse from every zaorpeac [nobleman], a cow from every two biazaiচ [xictuallers, officers similar to the Roman parochus], a cow from exery three freemen, and one from every four of the common people. He received from Maurice Mac Loughlin, king of Ireland, 20 cows, a gold ring weighing 5 ounces, and his own horse and dress."

1151. "Flahertach O'Brolchain, coarb of Colımbkille, made a visitation throughout Siol Cathasaigh [O'Casey's country], and received a horse from every nobleman, and a sheep from every dwelling house. He also received from Cu-uladh [Cooley] O'Flynn, the lord of the territory, his own horse and a gold ring weighing two ounces."

1153. " Flahertach O'Brolchain, coarb of Columbkille, nxade a visitation throughout Ireagh [in the county of Down], and receixed a horse from every nobleman, a sheep from every dwelling house, a rcpeapall [scruple] and five cows from O'Donslevy [Donlevy] lord of the territory, and an ounce of gold from his wife."

The preceding notices present some curious particulars relating to the constitution and state of society in Ireland at this early period, as well as to the mode sometimes resorted to by the clergy for procuring funds to raise any expensive sacred edifice - a purpose which, as will presently appear, was the chief, if not sole cause of these remarkable visitations. It is evident from the term raop$\dot{\tau} \alpha \dot{c}$, or "freemen" (translated by Colgan "liberis personis"), which is applied by the annalists to distinguish the persons of property from the olomome ic - the "plebeians,"or "common people"that the latter were still no better than serfs or slaves, as among the Saxons in Britain, and as they continue in Russia to this day. To establish this fact much additional evidence might be adduced. It is also evident that minted money was as yet unknown as a circulating medium, at least in the north of Ireland, and that the valne of the precious metals was estimated only by weight. Gold as well as silver rings, of the kind mentioned above, are frequently found : they are sometimes of elegant, but frequently of the rudest workmanship.

Thus far these brief notices relate exclusively to the abbey of Derry, and its dependent town, or village. In those which follow the cathedral and bishopric will be included, concerning the 


\section{CITY OF LONDONDERRY.}

foundation of which it will be proper to give some account in this place. That there were any fixed episcopal sees, or uninterrupted successions of bishops in Ireland, previously to about the year I118-when at the council of Rath-Breasail, by the infuence of the power of Rome, the island was regularly partitioned into dioceses, and their boundaries fixed-may be, perhaps, doubted,-though something approaching to a regular snccession may be found in the successors of Saint Patrick, at $A$ rmagh, and notwithstanding that the general fact of the existence of more ancient fixed bishoprics has not been hitherto questioned. 'This, however, is not the proper place for entering" on the evidences of a question of so much importance and magnitude. It is enough for the present purpose to state, that the greater part, if not the whole, of the church property in the present county of Derry appears from the cliarter, and the several inquisitions relative to cliurch property, first taken by the English in the county, to have been anciently of the nature of termon or erenach lands, enjoyed by the several septs in course of gavelhind, without being subject to any episcopal jurisdiction, or control. Thus in the inquisition taken in the city of Londonderry, on the 1st of September, 1609, the jurors find that "touchinge the severall names of herenagh, termon, and corbe, the said jurors doe uppon their oathes finde and present that all termon and herenagh land within the said countie was att the first given by Collumkill, and the succeeding abbotts, unto the severall septs, before any busshopps were knowne to be in this countrie; and that the said land was free and had the priviledges of sanctuarie and other liberties, and was enjoyed by the sept in course of gavelkynde." This is further corroborated by the inquisition taken at Limavaddy, on the 30th of A ugust, in the same year, by a jury composed of fifteen Irishmen of the principal septs of the country, viz., "and further, touchinge the originall and difference of corbes and herenaghs, and of the termon lands of the said countie of Colrane, the said jurors doe, uppon their oathes, finde and say, that Donell Mc. Hugh O'Neale, kinge of Ireland, [anno 635], did, longe before any bushopps were made in the said kingdome of Ireland, give unto certaine holy men, whom they call Sancti Patres, severall portions of land and a third parte of all the tiethes, to thend they should say praiers, and beare a third parte of the chardge of repairinge and mainteyning the parishe church, thother twoe third parts beinge borne by the parson and viccar, to whom the rest of the tiethes is yerrly paied, and alsoe for their owne honor and sustentation; and that afterwards the said holy men did give unto severall septs, severall proportions of the said lands, and placed one or more of them in everie parishe, and withall gave unto him a third parte of the tiethes of that parishe, to hould both the said land and the third parte of the tiethes, for ever, accordinge to the course of tanistrie, free from all exactions, and that for that cause the land was called termon or free, and the tennant thereof some tymes called corbe and sometymes herenagh, and tbat the said corbe or herenagh was to beare a third parte of the chardge in repairinge and maynteyning the parishe church, and that the said portion of land, and the thirde part of the tiethes soe contynued free unto the corbe or herenagh, for many yeares, untill the church of Rome established busshopps in this kingdome, and decreed that everie corbe or herenagh should give unto the bushopp (within whose dioces he lived) a yerely pension, more or less, accordinge to his proportion out of his entire erenarchie, consistinge of the said land and the said third parte of the tiethes, and that thereunto the said corbes and herenaghes submitted hemselves, but held their herenaghie free for ever, and could not be removed by any of the temporale or spirituale lords, oy [or] other person whatsoever."

As these inquisitions, then, clearly refer to a period anterior to the existence of any fixed episcopal jurisdiction in this county, as well as to the suhsequent time in which the bishopric was established, and its revenues settled and defined, there is solid ground for the conclusion, that this important ilnovation was an immediate result of the decree of the Rath-Breasail council already spoken of. At that synod-over which, in corroboration of the inquisitions, it may be well to state that Gelasius, the first papal legate in Ireland, presided-it was fixed that the bishopric of Raphoe, or Derry, as it is sometimes improperly called, should extend from Ear Ruao (now Ballyshanion) to Spuim bnóm, and from Cápn zlał to Snumb bnóı. The bishopric of Ardstraw or Rathlury from Slıab lanza to Cápm zlar, and (northwards) from Coc Cpur to beann Fhorbine, now Benerena in Magilligan). The diocese of Connor (eastwards) from ठeann Fholbine to $\boldsymbol{C}_{\text {op }}$ buipz, (now Tor-point in Antrim); southward from Múpbiolz, (now Murlough bay), to the harbour of Snám $\alpha_{i \delta}$ neać, '(now Belfast Lough), and from Zlean Rize-the vale of the Newry river-to Col,ba Jeanmuinn. It is not easy now to ascertain the modern names of all these ancient places-but for our present purpose there is enorgh of them known to shew that the portion of the present diocese of Derry, situated to the west of the river Foyle, belonged to the bishopric of Raphoe or Tirconnell, and the portion east of the Foyle had been divided between the bishoprics of Ardstraw or Rathlury, and Connor-the former, as nearly as can be ascertained, comprising the district west, and the latter, the district east of the river Roe. Shortly after this settlement, the seat of the bishopric of Tyrone, which comprised the greater portion of the present county of Derry, appears to have 


\section{HISTORY.}

been removed from Ardstraw to Rathlury, the present Maghera, but the exact time of this change has not been ascertained.

The subsequent establishment of a distinct episcopal see in Derry, as now constituted, is sup. posed by all our modern ecclesiastical historians to have taken place in the year 1158 , when Flahertagh O'Brolchain, the then abbot of the monastery, was undoubtedly raised to the episcopal dignity by a decree of the council held at Brigh-mac-Taidhg, in the north of Meath. The circumstances relative to this event are thus related by the Four Masters:-

"An asscmbly was held by the Irish clergy at Brigh-mac-Taidhg, in the territory of $\mathbf{H y}$-Laoghaire, at which were present 25 bishops, together with the apostolic legate, for the purpose of establishing ecclesiastical discipline and the improvement of morals. In this assembly the coarb of St. Patrick, or archbishop of Armagh, and the clergy of 1reland, decreed by common consent, that

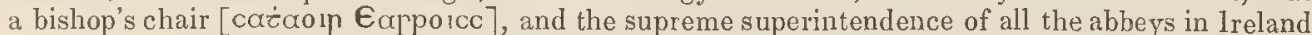
[that is, of the Columbian order,] should be given to the coarb of Saint Columbkille. The bishops of Connaught set out on their way to this synod, but they were robbed and beaten, and two of their people killed, by the soldiers of Dermot O'Melaghlin, king of Meath, at the wooden bridge at Clonmacnoise, after they had passed through the town. They then returned home."

The promotion of O'Brolchain to the episcopal dignity was the result of the friendship of the celebrated primate, Gelasius, or Gilla-mac-liag, who was distinguished not less for abilities and virtues than for the zealous assistance, which he gave, in establishing the discipline and influence of the church of Rome in Ireland. Gelasius was himself of a Derry sept, as it appears that he had been coarb, or erenagh, of the monastery of Derry, previnusly to his promotion to the archiepiscopal chair of Armagh. These facts are ascertained from the Life of Gelasius, as quoted by Colgan, (Tr. Th. page 504):-

"Blessed Gelasius, an indefatigable undertaker of pious labours, presided over an assembly convened in the territory of Meath, in which, after enacting many sacred and wholesome institutes concerning morals, and the discipline of the clergy and people, he caused Flahertach O'Brolchain, a student of Derry, and formerly his disciple whilst he presided over that community, and the brother (as I suppose,) of blessed Maolbrigid O'Brolchain, [suffragan] bishop of Armagh, not only to be promoted to the episcopal dignity, but also to be placed as chief director over all the abbeys in Ireland."-Life of Gelasius : cap. 31.

But though the authorities now quoted leave no doubt as to the fact of O'Brolchain having. been raised to "the episcopal dignity," they are far from being so conclusive as generally deemed in respect to the establishment of a new see in Derry; and there is much, if not satisfactory, evidence to shew, that this event did not take place for a century later. In the first place, it is no where stated (as it most probably would if it had been the fact, ) that a bishopric was fixed here with its limits or boundaries defined, at this period; and, if the elevation of the abbot be held sufficicnt to imply the establishment of a bishopric, there would be equal reason to conclude that there had been one two centuries earlier, as several of O'Brolchain's predecessors in the abbacy had been of the episcopal order. Next it is certain that O'Brolchain did not resign his abbacy on his promotion in rank, but retained it till his death. And, lastly, no successors of that abbot in the bishopric can be found for an entire century-the supposed successors being, as will be proved in the notices of the prelates, not bishops of Derry, but of Tyrone or Ratlilury.

Be this for the present, however, as it may, we find from the Annals that the new bishop lost no time after his elevation in collecting funds, and making other preparations to erect a church in Derry, morc worthy of his rank and power than that already in existence.

1]61. "O'Loughlin led an army into Meath, to hold a conference with the men of Ireland, both clergy and laity, at Ath-na-dairbrighe, and he received hostages from them all. It was on this occasion that the churches of Columbkille in Meath and Leinster were liberated by Flahertach O'Brolchain, coarb of Saint Columblille, and their tributes and government given up to him. These churches were under slavery till then."

"The visitation of Ossory was made by Flahertach O'Brolchain, and his due was 140 oxen, but in their place he chosc to receive 420 ounces of pure silver."

1162. "Flahertach O'Brolchain, coarb of Columbkille, and Nuirchertach O'Loughlin, king of Ireland, removed the houses from the Abbey church of Derry. On this occasion 80 houses, or more, were removed from their places, and the coarb of Columbkille erected Carreal an Unlápi, [the enclosure of the level], and he left a curse on him that should ever come over it." This caiseal, or cashel, was the circular wall, or fort, which surrounded the abbey, \&c.

1163. "A lime-kiln, seventy feet every way, was built by Flahertach O'Brolchain, coarb of Columbkille, and by the congregation of Derry." Colgan erroneously states that this kiln was erected to burn lime for the repairs of the abbey, which was destroyed by fire in 1149, but its true purpose will be seen in the following account of the erection of the Temple More. 


\section{CITY OF LONDONDERRY.}

1164. "The Tenple More, or Great Church of Derry, 80F. [or paces, as Colgan properly adds], was erected by Flahertach O'Brolchain, coarb of Columbkille, and by the family of Derry, assisted by Muirchertach O'Loughlin, king of Ireland, and they completed it in 40 days" - or, as Colgan witl more accuracy states, 80 days.

Henceforward the original abbey church of Saint Columbappears in the Annals distinguished from the Temple More, or cathedral, by the appellation of Ouib Rezler, or Duv-Regles, i.e. Black Church.

1166. "Derry-Columbkille was burned as far as the church called Duv-Regles," by Rory Mackanny Macgilmory O'Morna.-Annals of Munster.

1168. "The chiefs of Kinel Owen [Tironians], and the coarb of Derry, went to the house of Rory O'Conor, king of Ireland, to Athlone [that is, to make submission], and brought home with them gold and clothes, and many kine."

1177. "Niall O'Gormly, lord of Moy Tha and Kinel Enda, was slain by Donogh O'Caireallain, and the clan Dermot, in the middle of Derry-Columbkille. They first burned the house in which he was, and Niall, in endeavouring to escape, was killed in the door-way of the house. Donogh $\mathrm{O}^{\circ}$ Caireallain then made his perfect peace with God, with Saint Columbkille, and witl the cleroy of Derry, for himself and his posterity, and he promised his own maincine [gifts], and those of his sons and posterity for ever, to Saint Columbkille and the clergy of Derry. He also made over to them a townland in the parish of Donaghmore, and delivered up to them the most valuable goblet at that time in Ireland [which goblet was called Mac Riabici], as a pledge for a gift of sixty cows. There was also a house erected for the clerk in lieu of that of O'Gornily, which had been burned, and he [O'Caireallain] made reparation for all damage caused by the burning. The clan Dermot also gave full satisfaction for their part of the danıage."

1178. " A violent storm occurred in this year, to the great destruction of trees. It tore tp large oaks by the roots, and among the rest 120 trees were prostrated in Derry-Columblille.'

1180. "Randal O'Caireallain was killed by the Kinel-Noen [O'Gormlys,] in the middle of Derry-Columbkille."

1188. "Donnell O'Canannain wounded his foot with an axe at Derry, as he was cutting a piece of wood, and died of his wound. The accident occurred in consequence of his having received the curse of the clergy of Derry."

“Edaoin, daughter of O'Quin, queen of Munster, died on her pilgrimage at Derry, victorious over the world and the devil."

1192. "The door of the refectory of the church of Saint Columbkille, called Duv-Regles, was made by O'Cażain na Cncoibe [O'Kane of the Creeve], and by the daughter of O'Inneirghe"now O'Hencry, a family name of the Kinel Owen, located about Ballynascrcen.

1195. " Conor Mac Fachtna died in the church of Derry."

1196. "Murtagh, the son of Murtagh O'Loughlin, was interred at Derry with honour and veneration. He was killed by Donogh, the son of Blosgadh O'Kane, at the instigation of the Kinel Owen, or Tironians,"

1197. "John De Courcy, and the English of Ulidia [county of Down], marched witl an army to Eas Craoibhe, [now the Cuts' fishery]: they erected the castle of Kill-Sanctain, and plundered and laid waste the territory of Kianachia. In the castle thcy left Rotsel Pyton [Payton], together with a large body of forces, who, issuing from the castle, commenced plundering and destroying the country and churches. Rotsel Pyton soon after set out upon a predatory excursion, and coming to the harbour of Derry he plundered the churches of Cluain-i, Eanach, and Dearo.bliruach, but he and his party were overtaken by Flahertach O'Maoldoraidh, lord of Tirone and Tirconnell, and some of the northern Hy-Niall. A battle ensued on the shore of Ua Congbhala, [Faughanvale], in which the English and the son of Ardgar Mac Loughlin were dreadfully slaughtered through the miracles of Saints Columbkille, Caineach, and Brecan, whose churclies they had plundered."

1 197. "Mac-Etig, one of the Kianachts, robbed the altar of the Templemore of Derry, carrying. away the four richest goblets in Ireland, viz.: one called Mac Riabac, [see 1177]; a second called Mac Solaıp the goblet of O'Maoldoraidh [O'Muldorry]; and the goblet of O'Dogherty, called Cam copainn [crooked goblet]. He broke them, and took off their jewels. On the third day after this robbery, these jewels and the robber were discovered. He was hanged at Cnor no pı⿱宀 [i. e. the cross of executions, ] for his profanation of the altar of St. Columbkille."

"Eachmarcach O'Dooherty, surnamed " 10 lla prón maoll [the youth with the flat nose] immediately after O'Muldorry's death, assumed the government of Tirconnell. A fortnight after his election, John De Courcy at the head of a great army crossed the ferry of Tuaim [now Toome bridge, ] into Tirone, thence proceeded to Ardstraw, and afterwards marched round to the town of Derry, where he and his troops remained five nights."

1198. - "Jnhn De Courcy made an incursion into Tirone to plunder the churches. Ardstraw and Raphoe were plundered and destroyed by him. He afterwards arrived at Derry, where he remained a week and two days, plundering Inishowen and all the adjacent country. While 


\section{HISTORY.}

John De Courcy was thus engaged IIugh Boy O'Neill sailed with five ships to Kill-Latharna, [Larne], burned a part of the town, and killed eighteen of the English. The English of Moylinny and Dalaradia mustered three luundred men who marched against Hugh. Hugh had no intimation of their approach, until they surrounded him, while in the act of burning the town [Larne,] and a battle ensued in which the English were defeated. The English were routed five times before they took to their ships. Hugh lost only five of his people. As soon as John De Courcy had received intelligence of this, he left Dcrry."

1203. "Derry was burned from the burial ground of Saint Martin to the well of Saint Adamnan."

1211. "Thomas Mac Uchtry, [now Oughterson,] with the sons of Randal, who was son of Samhairle [Mac Donnell,] came to Derry with a fleet of seventy-six ships; and, after having plundered and destroyed the town, passed thence into Inishowen, and destroyed the whole peninsula."

1212. "Donnell O'Davine [now Devine], was slain by the sons of Mac Loughlin, in the porch of the church of Derry."

I213. "Thomas Mac Uchtry, and Rory Mac Ranal, plundered Derry, and from the middle of the church of Derry carried off with them to Cuil-raithen [Coleraine] all the jewellery of the people of Derry, and of the north of Ireland."

This Thomas [Mac Uchtry, Mac Uchtred, or Gothred,] who was the brother of Allan de Galloway, got a grant from king John in the following year of O'Neill's country of 'Tirone [which then included Derry], excepting the cantred of Tullaghog, retained by the king. In the charter he is styled Thomas de Galloway, earl of Athol.--Roll. ex. Joltn xv. 1214; see County History.

"O'Kane, and Fin wa Craorbe [men of the Creeve], came to Derry to storm the house of the sons of Mac Loughlin. The vicar of the church of Derry, who interposed to make peace between them, was killed. God and Saint Columbkille wrought a miracle upon this occasion, for Mahon Magaithne, the person who collected the army, was killed in the porch of the church, called Duv-Reg.les, in defence of Columbkille."

" 1215. Donogh O'Duibhdhiorma, chief of Breadach, died at Derry, in the church called Duv-Regles."

I222. "Niall O'Neill plundered Derry, and the daughter of O'Kane; God and Saint Columbkille took revenge for this crime, for O'Neill did not live long after the perpetration of it."

1250. "The upper end of the great church fell to the ground on the 8th of February."

1259. "Hugh O'Conor went to Derry to espouse the daughter of Dubhgall [Dugald], the son of Somhairle [Mac Donnell]."

1261. "Sixteen of the most distinguished of the clergy of Tirone were slain at Derry by Conor O'Neill and the Kinel Owen, together with Conor O'Firgil. Conor O'Neill was slain soon afterwards by Donn O'Breslen, chief of Fanad [Fannet,] through the miracles of God and Saint Columbkille."

1281. “Donnell Oge O'Donnell, lord of Tirconnell, Fermanagh, Oriel, and the greater part of the Irish of all Ulster, and nearly all Connaught, and the entire of Breifny-the most illustrious man of the Irish for hospitality, feats of arms, pre-eminence, and nobility in his time, and the most distinguished warrior of western Europe, was slain in the battle of Orpeapz oú ćpioc [Desertcreat, in Tyrone, ] in the 41 st year of his age, and interred in the monastery of Derry, after gaining victory in goodness until that time."

1310-11. The king [ [ $\mathrm{dw}$. II.] appoints the bishop of Connor to inquire on the oaths of proper men of the vicinage of Derry, Bothmen, Moybyle [Moxille], and Fathun-murra [Fahan], and the crosses of Ulster, whether or not the king or any other person would be prejudiced if he should grant to Richard de Burgo, Earl of Ulster, that he might retain to himself and his heirs for ever the city of Derry, 2 townlands in Bothmean in Inchetum [Inch Island], 2 messuages, and 8 carucats of land in Moybyle and Fathun-murra, and the advowson of the moiety of the church of lnchetum [Inch], which are held of the King, in capite, as aforesaid, and which the said earl has obtained in fee from Gofridns [Mac Loughlin], bishop of Derry, with the consent of his chapter, but without the license of Edw. I. 8th Feb."-Rot. Pat. de anno 3 et 4 Edw. II.

1311. The king grrants the towns of Derrecolumkille and Loughlappan [in Inishowen,] to Richard de Burgo, Earl of Ulster.-R. Pat. 4. Edw. II.

These two last notices indicate that, previously to the revolt of O'Neill, in 1333, Derry, as well as Antrim, was under tolerable government. (See County History).

1318. "John, the son of Donnell O'Neill, was slain by O'Donnell, [Hugh, the son of Donnel] Oge,] at Derry; and Mac Donnell, and many others, were slain and drowned."

I 537. "The son of O'Dogherty, [Niall Caoch, the son of Gerald, who was son of Donne'l, who was son of Felim, ] was slain in a nocturnal aggression, by Rory, the son of Felim O'Dogherty, at baile na $\delta$-canámac [the town of the canons], in the termon of Derry."

Churches, \&c.-The Irish annals of Derry, preceding its occupation by the English, terminate bere. Meagre, as already acknowledged, these notices are, but they afford striking exidences of the 


\section{CITY OF LONDONDERRY.}

continuation in this part of the island, to so recent a period, of the original institutions of the conztry, and saddening illustrations of the insecurity of life and property, and the amount of misery anc confusion, which were the inevitable results of such a social system. The town, if such it might be called, was entirely ecclesiastical, and consisted, almost exclusively, of churches and the habitations of the clergy and monks. The former were evidently structures of stone, and the latter of wood, or mud; for in those days a stone-house was called a castle, and the only structure of tliat kind recorded to have been erected in Derry was a small square tower, built by O'Dogherty, in the 15 th or 16 th century, for O'Donnell, on a spot of ground purchased for the purpose from the erenagh Mac Loughlin. Of this castle some remains are supposed to exist still-but of all the ancient ecclesiastical buildings not a vestige is to be found. They have shared the fate of that renerable oak grove in the midst of which they were originally erected, and which, as has been shewn, had been preserved through so many successive ages with an equally religious veneration.

St. Columb's Church, or Duv-Regles.-A passage in the life of Saint Columb, written in the 16th century by O'Donnell, prince of Tirconnell, makes us acquainted with the position and form of the original churcl of Derry, and shews that the conservation of those trees was considered by the clergy as a sacred duty, imposed upon them by the order of the patron saint himself. He writes thus :- " many other signs and miracles were wrought by this servant of Christ in the same place, in which he himself dwelt for a long time, and which he loved above every other; and particularly that beautiful grove very near the Monastery of Derry, which he wished should be alwrays left standing. And he gave orders that, should any one of its trees be prostrated by a storn, it should not be remored until after the expiration of nine days, after which onetenth part should be given to the poor, one-third be reserved for the hearth of the guests, and the remainder be distributed among the people. From this veneration for the grove, when the holy man was about erecting the church, commonly known by the name Duibh Regles, he had rather that the foundation of the building should be laid in a transverse position, leaving the grove untouched, which by its density and contiguity l'endered the place narrow, than that the building should, according to the usual custom, look to the east, the grove being in part destroyed. But, that he might not appear to deviate entirely from the usage of the church, he ordered that the sacred altar, upon which he himself offered sacrifice, should be erected at the eastern side of the building. The ruins of that church, remaining at this day [1520], demonstrate that such was its situation."-(Tr. Th. O'Donnell's Life of Columbkille. Book lst; chapter 57 thi).

Temple More, or Cathedral and Round Tower. - The peculiarity of position alluded to by O'Donnell, was, it is probable, the only feature which distinguished the Duv-Regles from the cotemporaneous churches of the country, many of which still remain, and are remarkable for the simplicity of their form and architecture. Not so, however, the Temple More, or cathedral church, erected in 1164, which was evidently one of the most distinguished ecclesiastical structures built in Ireland, previously to the settlement of the Anglo-Normans, and which, as Colgan accurately states, was 80 paces or 240 feet in length.

These churclies, with their accompanying building's, were situated adjacent to each other outside the present city wall, on the ground now chiefly occupied by the Roman Catholic chapel and cemeteries; and with the exception of the round-tower belfry, were totally destroyed by Docwra, in $\mathbf{1 6 0 0 ,}$, to use their materials in the new works which he erected. This tower survived till after the siege, being maiked on the maps, or plans, of that time as the "Long Tower or Temple More," and its site is still indicated by the name of a lane called the "Long Tower." In the charter of Derry it is called "Columb-lille's Tower." In Raven's plan of the city, in 1621, it is represented as a very high and slender belfry; but it is incorrectly drawn as square, a common error in the plans made by English artists in Ireland in that and earlier times, as appears from many old maps among the MSS, in Trinity College library. In the popular traditions of Derry and its vicinity, this torer is to this day invariably spoken of as a lofty round tower, built by St. Columb himself, and many legends are current of its miracle-working silver bell. It has been erroneously supposed by Mr. Sampson that "the old windmill," so memorable during the sieg*e, and still existing as a pigeon-house at the Cassino, was the remains of this tower.

Nunnery.-Of the other churches of Delry but very slender accounts exist. The registry of the Honor of Richmond, according to Harris, states that an abbey for nuns of the Cistercian order was founded at Derry in the year 1218, and Allemande says that the founder was Turlogh Luinag O'Neill. There was, however, no O'Neill of that name but the celebrated chief of the 16 th century - and it would appear that the foundation of a nunnery must have been earlier than that assigned, from a notice in the Annals of the Four Masters, which records the death of Bcbinn, the daughter of $\mathrm{M}$ 'Conchaille, female erenagh of Derry, who died on the 23rd of March, 1135 . It is possible that the nuns adopted the Cistercian rule in 1218 , but the evidence is scarcely strong enorgh to warrant the conclusion; nor is it quite certain that there were any nunneries in Ireland 


\section{HISTORY.}

of that order. This nunnery was situated on the south side of the city, and its property is described in the inquisitions.

The Dominican Abbey was founded in the year 1274; but Archdall makes a strange error in supposing that it was founded by O'Donnell, prince of Tirconnell, at the request of Saint Dominick himself, whereas it is certain that this saint, who established his order in 1216, died in 1221. De Burgo very properly treats this statement of Saint Dominick's request, which rests solely on the authority of Allemande, as a silly fable; and it is by no means certain that the O'Donnells had any claim to the honour of this foundation.

Nicholas, the Lochlynnach, or Mac Loughlin, was prior in 1397. The number of friars in this house, previously to the suppression, was generally 150 . It had the honour of supplying two bishops to the see of Derry, and of scnding forth five martyrs. A convent of the order was preserved in Derry till a late period. In 1750 it contained nine brothers.

The Church and Monastery of the Dominicans appear to have shared the fate of the other ecclesiastical buildings of Derry, which were destroyed either by an accidental explosion of a powder magazine in 1565, or by Sir Henry Docwra in 1600, and even their site is not now accurately known. It is certain, howcrer, that they were on the north side of the city, outside the present walls.

The Church of Saint Augustine appears to have been the only religious house preserved on the erection of the new city. It was repaired and used by the Londoners, previously to the erection of the present cathedral, after which it was known as "the little church." This church was situated within the walls, on the spot now occupied by the bishop's garden at the rear of the palace; and, though bishop Downham complains in his account of the estate of Derry in 1620, that it was not capable of containing half the auditory, it appcars from the plans of the time to have been a large and not inelegant structure of its kind. The erection of this church is not noticed in the annals, from which it may be concluded that its date was not earlier than the 14th, or the close of the 13th century, for some time previously to which the records of Derry are minute and accurate.

Franciscan Friary. De Burgo, or Burke, states that there was a monastery of the Franciscan order here, but gives neither the name of its founder, nor the date of its erection. It appears from the inquisition of 1609 that this monastery belonged to the order of begging friars, or friars mendicant, and was situated on the north side of the bog near the island of Derry, "and had attached to it a churchyard containing thrce acres or tlereabouts." The site is now occupied by Abbey-street, William-street, and Rosville-street, and the foundations of the church were discovered a few years ago by workmen employed by Mr. Horner.

St. Columb's Wells. As connected with the ancient history of Derry, the sacred springs, called St. Columb's Wells, claim some notice in this place. They are, or rather were, thrce in number - for one has been dried up or diverted from its original locality, - and situated near the Roman Catholic chapel outside the wall. It appears from the Irish annals that each of these wells had its peculiar name, one being called Cobap Aóamnáin, another Cobap Maprain, and the third Cobap Colurm, but the two former names are now quite forgotten, and the wells are popularly called St. Columb's. They are regarded with much superstitious veneration by the Roman Catholic peasantry, but no celebration of St. Columb's festival is now held at them.

St. Columb's Stone. In the centre of St. Columb's Lane, adjacent to the wells, there is a remarkable stone, called St. Columb's Stone, which is popularly regarded with a still higher veneration by the aboriginal Irish of the district. It is of a shapeless form, about 3 feet long, and 10 inches wide; the height above ground is one foot and a half, and it has two oval hollows on each side,
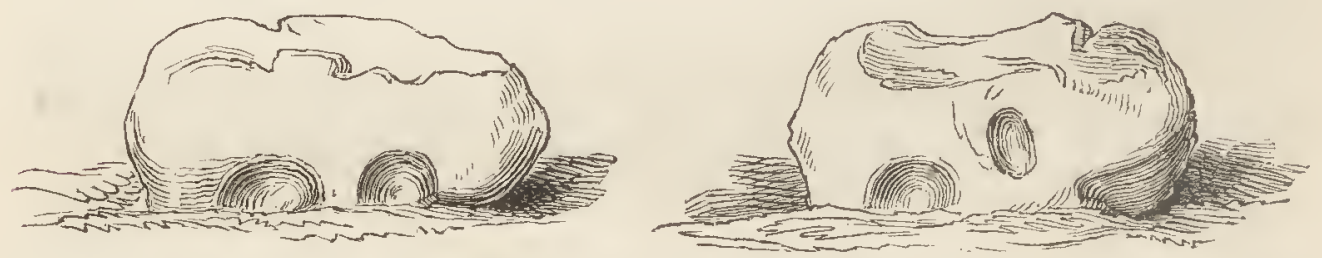

artificially formed. Many foolish legends are current among the peasantry respecting the origin of these hollows, which, it is supposed, are the impressions made by the saint's knees "when he leaped from the wall of the city." It may be worth observing, however, that stones of this description are found in the vicinity of most of the ancient Irisl churches, and usually bear the name of their founders, or patron saints. They are always held sacred, and the water, deposited by rain in their hollows, is believed to possess a miraculous power in curing various diseases. 


\section{CITY OF LONDONDERRY.}

\section{Section 2.-Biographical.}

Abbots, and other distinguished Persons, connected with the Churches of Derry.

THE annalists have preserved no account of the successors of Columbkille in the abbacy of Derry, for more than two centuries. This silence, as Colgan remarks, can only be accounted for by the fact that its ancient chronicle has been lost, as well as those of the several religious houses in its vicinity, in which notices of the distinguished men connected with it would have probably been preserved. The Annals of Ulster and of the Four Masters record, at the year 704, the death of Saint Mochonna, abbot of Derry - a very distinguished man of his age, who, at a synod held in the year 695, by Flann, archbishop of Armagh, and Saint Adamnan, subscribed to the acts thereof under the signature of Antistes Dorensis. But though Colgan, Doctor O'Conor, Doctor Lanigan, under the granted that Mochonna was abbot of Derry-Columblille, it is manifestly an error. As has been already remarked, there were many other places in Ireland, in the names of which the word Derry formed a part, and among others was one called Oo me Moconna, or Derry of Mochonna, evidently from this saint, who was the founder of a religious house there, and who is consequently called in the genealogy of the saints in the Book of Lecan, "Patron of Derry" - an appellation only applied to the founder of a religious house-and we know that he was not the founder of the abbey at Derry-Columbkille. Thus he is properly called by the annalists simply abbot of Derry, because it would have been superfluous, and contrary to custom, to have repeated his name in connexion with the place, and it is also certain that the Derry of Saint Columbkille was invariably called Derry-Calgach for many centuries later than the age in which Mochonna flourished.

Colgan had better evidence for connecting with Derry, either as monk or abbot, a still more distinguished man of this period - the celebrated Adamnan, abbot of Iona, who died in 596. It is certain that his memory was venerated here, and, what is more conclusive, that his name was con-

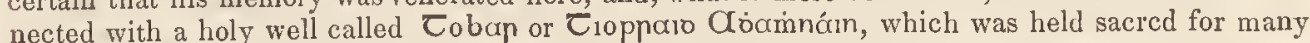
ages. In those which follow therc is, however, no roum for doubt.

724. "Caochscuile, scribe of Derry-Calgach, died."

852. "Indreachtach O'Finachtan, coarb of Columbkille, an eminent sage, suffercd martyrdom from the Saxons on the 12th of March."

879. "Muirchertach, the son of Niall, abbot of Derry-Calgach, and other churches, died."

903. (908) "Dermot, abbot of Derry-Calgach, died."-Annals of Munster.

919. (921) "Kinaeth, the son of Donnell, abbot of Derry-Calgach and Drumhome, the head of the religious of Kinel-Connell, died."-Annals of Munster. For Drumhome, in the county of Donegal, Colgan has inaccurately written Drumcliffe, in the county of Sligo.

925. "Maolbrighde, the son of Tornan [now Dornan], coarb of Patrick, Columbkille, and Adamnan, "abbot of Armagh, Derry, and Raphoe, head of the piety of all Ireland, and of the greater part of Europe, died on the 22nd of February, at a venerable old age." Colgan gives a notice of this cminent man in his Acta Sanctorum, from which it appears that he was of the same royal stock as Columbkille himself, being the twelfth in descent from Connell Gulban, son of Niall of the nine hostages, monarch of Ircland. The family of Tornan, or, as it is now called, Dornan, still exists.

927. "Caoncomhrac, son of Maoluidhir, abbot and bishop of Derry-Calgach, and keeper of the canons of Saint Adamnan, died."

936. "Dublhthach, [Duffy], coarb of Columbkille and Adamnan, in Ireland and Scotland [that is at Derry and Raphoe], died."

937. "Firachtach, the son of Kellach, coarb of Derry, a bishop and a sage, skilled in the old language of Ireland, died."

948. "Maolfnnen [now Mulfinnen], the learned bishop of Derry-Calgach, died."

949. "Clericen, the son of Conallan, erenach of Derry-Calgach, rested in peace."-Annals of Ulster.

950. Adhland, the son of Egneach, who was the son of Dalach, coarb of Columbkille, the Juaine Cirne of the Irish clergy, died." This Adland, as appears from the grenealogy of the O'Donnells, was of the royal family of Tirconnell, being the brother of Donnell, from whom the name O'Donnell originated. By the proverbial phrase Guaire Aidhne of the Irish clergy is to be

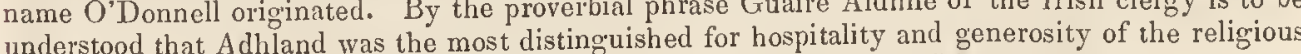
order in Ireland in his time. Guaire was king of Connaught in the 7 th century.

952. "Robhartach [Rafferty] O'Steaphain, coarb of Columbkille and Adamnan, died."

962. "Dubhscuile Mac Cionadha [Mc Kenna], coarb of Columbkille, died." 


\section{HISTORY.}

967. "Aengus O'Robhartaich [O'Rafferty], anchorite of Derry-Calgach, and Kinaeth O'Cathmhaoil [now anglicized Camphill, Campbell, and Caulfield], erenach of Derry-Calgach, died within the same month." Both these families exist in the county.

973. "Fogartach, abbot of Derry-Calgach, died."

983. "Uissine [Ossian] O'Lapain, erenach of Derry-Calgach, died."

985. "Maolkiaran O'Maighne, coarb of Columblille, suffered martyrdom from the Danes of Dublin."

988. "Dunchadh O'Robhacain, coarb of Columbkille and of Adamnan, died. The name of Rogan, which is still found in Derry, is probably modernized from this."

"Dubdaleth, coarb of Saint Patrick, assumed the coarbship of Columbkille by the suffrage of the Irish and Scots, that is, as Colgan explains it, supreme moderator of the monasteries of the congregation of Columbkille in Ireland and Scotland."

998. "Dubdaleth, the son of Kellach, coarb of Saint Patrick and Columbkille, died on the 2nd of June, in the 83 rd year of his age."

1006. "Muireadhach Mac Criochain [now Creighan and Cregan] resigned the coarbship of Columbkille, to apply himself more sedulously to devotion."

1010. "Muireadhach Mac Criochain, coart of Columbkille and Adamnan, a learned doctor and bishop-a son of purity-lecturer of divinity at Armagh, and intended coarb of Patrick, died in the 84th year of his age, on the 5th of the kalends of January, on Saturday night, and was intcrred with honor and veneration in the cathedral church of Armagh, before the high altar."

1022. "The coarb of Columbkille [Malone O'Dornan] was present at the death of Malachy the Great, the son of Donnell, king of Ireland, at Cro-inis an Island, in Lough Ainin [now Longh Ennel]."

1025. "Malone O'Toran, or 'Tornan [Dornan], coarb of Derry-Columbkille, died. This is the first notice in the annals in which the name of Derry appears as Derry-Columbkille."

1040. "Maolmurry ()'Ochtain, coarb of Columbkille and Adamnan, died."

1057. "Robhartach, the son of Ferdomhnach, coarb of Columbkille and Adamnan, died."

1061. "Muireadhach O'Maolcolum [now O'Malcolm], erenach of Derry, died."

1062. "Gilcreest O'Muldorry, coarb of Columbkille, both in Ireland and Scotland, died. This name is still found in Derry and Donegal. They were princes of Tirconnell preceding the O'Donnells."

1066. "Dunchadh O'Daimhin [now Devine], coarb of Derry, died." The family of O'Daimhin, or Devine, was one of the tribes of the Kinel-Owen, and is still numerous in Derry and Tyrone.

1096. "Owen O'Cearnaigh [Kearney], erenach of Derry, died on the 18th of the kalends of January [15th of December]."

1098. "Donnell O'Robhartaich [Rafferty], coarb of Columbkille, died."

1112. "Congalach, grandson of Cucaille, erenach of Derry, died after great penance in the 94 th year of his age."

1120. The celebrated Gilla Mac-Liag, the son of Rory, better known by the latinized name of Gelasius, became, at the age of 33, erenach, or, as Colgan and others suppose, coarb or abbot, having been previously erenach. But it has been already shewn that these terms were frequently synonimous, and in all the ancient lrish authorities Gelasius is invariably called erenach, though it appears certain that he exercised the authority of abbot: hence Dr. Lanigan had no authority to state that erenach meant archdeacon, and that Derry was consequently then considered as an episcopal see. 1t may not be improper also in this place to correct another erroneous assertion of this usually accurate and learned writer, namely, that Colgan was mistaken in stating that Niell, or Nigel, had again obtruded himself into the abbacy, or, as Dr. Lanigan has it, archbishopric of Armagh, on the retirement of Malachy, and previously to the elevation of Gelasius to that dignity. Had Dr. Lanigan carefully consulted the Annals of the Four Masters he would have found that Colgan had authority for his statement, viz. :-

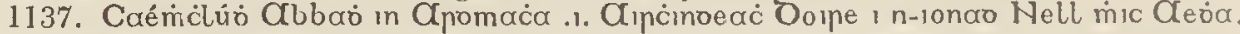

"A change of abbots at Armagh, viz.: the erenach of Derry, in the place of Niall, the son of Hugh."

"Gelasius filled the episcopal chair of Armagh 38 years, and died in the 87 th year of his age, on the 27th of March, 1174."

1126. "Fionn O'Conaingen, erenach of Derry for a time, died." He was probably the predecessor of Gelasius."

1129. "Gilla Colmain O'Kellaigh, a principal presbyter of Derry, died."

1134. "Bebinn, daughter of Cuchaille, abbess of Derry, died on the 23rd of December."

1150. "Maoliosa O'Branain [Brannon], erenach of Derry-Columbkille, who was the most prosperous and munificent man in the north of Ireland, died." 


\section{CITY OF LONDONDERRY.}

1162. "Cathusach, the son of Comaltan, reader of divinity in Derry-Columbkille, died. He was a distinguished sage."

1175. The Annals of the Four Masters at this year record the death of the celebrated Flahertach O'Brolchain, for whom the bishopric of Derry was instituted, viz.: -

"Flahertach O'Brolchain, coarb of Columbkille, tower of wisdom and hospitality, to whom, for his wisdom and great virtues, the clergy of Ireland had given a bishop's chair [see], and offered the superintendence of the monastery of Iona, after having borne the pains of a long. infirmity with patience, died most piously in the monastery of Derry. Gelasius O'Branain succeeded him in the government of the monastery."

Colgan says of the family of O'Brolchain, which supplied so many eminent ecclesiastics to the abbey of Derry - that they were of ancient nobility, and formerly of distinguished name, but now nearly extinct. They are still, however, one of the most numerous families in the neighbourhood of Derry, and, though they call themselves O'Brollaghan in speaking Irish, they generally adopt the name of Bradley in English. The Irish provincial allusion to their fallen state- " He is a gentleman of the Brollaghans"-commonly applied to persons poor and proud, has probably influenced them in this change of their name to that of an English family.

1180. "Macrath O'Doighre [Deery], erenach of Derry, died." This family was also very noble. They still exist, and are called Deery.

1185. "Maoliosa O'Muireadhaich [Murry], lecturer of divinity at Derry-columbkille, died at a venerable old age."

1189. "Maolcainnigh O'Fearcomais, professor" of divinity at Derry, was drowned between Aird [Ardmagilligan], and Inishowen."

1195. "Conor Mac Fachtna died in the church of Derry."

1198. "The abbot, Gilla-Mac-Liag, or GelasiusO'Branan, resigned the abbacy, and Gilcreest O'Cearnaich was elected abbot by the consent of the clergy. He was afterwards advanced to the see of Connor, and died in 1210."

1202. "Moyle Finnan M'Colman was elected arch-prior, but died the same year, and, on the 27 th of April following, O'Brolchain, the prior and great senior, died. He was in high estimation for his many virtues and extensive learning." - (Archdall.)

O'Brolchain appears to have been succeeded in the abbacy by Amhalgaidh [Awley] O'Ferrall, who was abbot in 1203, as appears from the list given by the annalists of the clergy assembled in that year to pass over into Iona. Ainmire $O^{\prime}$ Coffey was also a distinguished ecclesiastic of Derry at this time.

1206. "Donnell O'Muireadhaich [Murry], chief professor of divinity at Derry, died."

1213. "Ainmire O'Coffey [the successor of Anhalgaidh O'Ferrall], abbot of the church of Derry, a clergyman of noble birth, and distinguished for his piety, meekness, charity, and every other good quality, died."

1215. "Donogh O'Duibhdhiorma, chief of Breadach, near Derry, died in the church of DuvRegles."

1218. "Maoiliosa O'Doighre [O'Deery], erenach of Derry, died on the 8th of December, after having been erenach of Derry for 40 years, and having done all the good in his power both for church and state." place."

1219. "Fanactan O'Broin, abbot of Derry, died, and Flan O'Brolchain was elevated to his

1229. "The canon, Gerard O'Cahane, esteemed the most learned of the whole order, died."

1233. "Geoffry O'Doighre, erenach of this abbey, died."

1397. "Reginald O'Hegarty resioned the abbacy, and Odo [Hugh] Mac Gillibride O'Dogherty was chosen in his place."-Ware, MS. note.

1475. "Donogh, the son of Hugh M'Sweeny, prior of Derry, died."

1531. "Cuconnaght O'Fraghill was abbot, for Sir Odo O'Donnell, lord of Tirconnell, being prevented by sickness from personally renewing his oath of allegiance, did appoint the said abbot aud Richard O'Grayhan, of Tredagh [Drogheda], to perform his bounden fidelity to the king, which they accordingly did on the 5th of May this year, before the lord deputy Skeffington, at Tredagh."-(Archdall, from Ware.)

\section{Bishops.}

Flahertach O'Brolchain, elected 1158 ; died 1175.

"A sufficient notice of Flahertach O'Brolchain, the first bisbop of Derry, has heen already given among the abbots in the preceding section. His successor, according to Ware and Harris, was Muireadhach [Murry] O'Cobthaich [Coffey], whose death is thus recorded in the Annals of the Four Masters.

"1173. Muireadhach O'Coffey, bishop of Derry and Raphoe, a son of purity, a precious stone 


\section{HISTORY.}

a transparent gem, a brilliant star, a treasury of wisdom, and conservator of the canons of the church, after having bestowed food and raiment upon the poor and the needy ; after having ordained priests and deacons, and men of every ecclesiastical degree; after having repaired many churches, consecrated many temples and burial places, and performed every ecclesiastical duty; after having gained the palm of piety, pilgrimages and penances, resigned his spirit to lieaven, in the DuvRegles, of Columbkille, in Derry, on the 10 th day of February. A great miracle was performed on the night of his death : from twilight to day-break the firmament was illuminated, and all the neighbours beheld the light; and a large globe of fire arose over the town, and moved in a southeasterly direction; all arose from their beds, imagining it to be day. This light was in motion, and was perceived as far as the sea, at the east of Ireland."

In the preceding passage, this distinguished ecclesiastic is called bishop of Derry and Raphoe. Harris, however, shews from satisfactory evidences, tlat Muireadbach could not have been bishop of Raphoe, and there is equal reason to doubt of his having been bishop of Derry. For in the first place, as O'Brolchain survived him two years, he could only have succeeded by the abdication of the former, for which supposition there is not the slightest evidence. Next it is to be observed, that O'Coffey is called bishop of Derry by the Four Masters only; in all the earlier annals he is either called bishop of Ardstraw, or Rathlury, or more generally-as in the very original, in the Annals of Connaught, of the passage given by the Four Masters-mishop of Kinel Owen, or Tirone, which was but another name of the same see. O'Coffey held this bishopric at the council convened by cardinal Paparo, in 1152, six years before Derry is supposed to have been raised to the rank of an episcopal see, and his name is signed as a witness to the foundation charter of Newry about 1160 , as "bishop of Tir-Eogain," Tirowen, or Tirone. A gainst such evidences the unsupported authority of the Four Masters must be considered as of no weight, or, if not, a mistake of the transcriber must, at most, be understood as applying in a loose way to the bishopric of Rathlury, which originally, as already shewn, comprised the greater part of the present county of Derry. It must, indeed, be confessed, that the early history of this bishopric is, as already stated, involved in much obscurity ; and it is extremely difficult to fix with any precision the time when the ancient bishopric of Rathlury, or Tirone, was thoroughly incorporated with the new see of Derry. Our ancient authorities appear to be wholly opposed to the conclusions of Ware, and others, who suppose a succession of bishops to have been preserved at Derry from the death of Flahertach O'Brolchain, whereas there is no record to be found in our annals of a bishop of Derry, that of Murry O'Coffey, now noticed, expected till Fogartach, or' Florence O'Carellain, who died in 1293. The four bishops who are placed by Ware and Harris in succession between $O^{\prime}$ Brolchain and him, are always called bishops of Kinel Owen, or Tirone, the seat of which was at that time Rathlury, the present Maghera. The fact appears to be that O'Brolchain had only episcopal jurisdiction over the monasteries of the Columbian order, and that, on his death, Derry leverted to the bishopric of Raphoe, or Tirconnel, in which it was situated, and remained annexed to it for nearly a century, till the increasing power of the O'Cairellans, chiefs of the clan Dermot, aided by the Kinel Owen, or Tironians, enabled Gervase or Gilla an Coimhdhe O'Cairellan, the bishop of Tirone, to annex it to his own bishopric, and constitute it the seat of his see. Harris states, from the Registry of Clogher, that this bishop took many things by a high hand from David O'Brogan, bishop of Clogher, and annexed them to his own see, particularly the church of Ardstraw, and many other churches of O'Fiachra. He is said also to have taken away from Carbry O'Scopa, bishop of Raphoe, some parts of the diocese of Raphoe, and to have united them to his own bishopric. This union took place about the year 1274 , as we find that the bishop of Raphoe, who took a journey to Rome to solicit the interference of the church in this matter, died there in the year 1275 , exactly a century after O'Brolchain's death. This augmentation of the diocese remains unchanged to this day; yet it is worthy of remark that, so late as the close of the last century, Doctor Coyle, titular bishop of Raphoe, protested against the right of the titular bishop of Derry, in the barony of Inishowen. After this period the bishops of Kinel Owen cease to be so called by the annalists, and a regular succession of bishops of Derry follows. 'The other supposed successors of O'Brolchain, prior to this period, as given by Ware, are-

2d. Amlave, or Awley O'Coffey, died 1 I85. This bishop, who is usually called by the annalists bishop of Kinel Owen, or Tirone, but never bishop of Derry, died at Dun-cruithne, now DunCrun, in Magilligan, whence his body was conveyed to Derry, where it was buried in the DuvRegles, or Saint Columb's abbey church, at the feet of his predecessor, Murry O'Coffey, near the wall. The notices of this prelate in the annals fully corroborate the remarks already made on the early history of this bishopric. In the Annals of the Four Masters his death is thus recorded:-

A. D. 1185.- "Amlave O'Murry, bishop of Armagh, and of Kinel-Feradaigh, a brilliant lamp that had enlightened clergy and laity, died, and Fogartach $\mathrm{O}^{\prime} \mathrm{Ca}$ (reallain was consecrated his successor."

That the person here called Amlave O'Murry was the same as the Amlave O'Coffey of the 


\section{CITY OF LONDONDERRY.}

other annalists cannot be doubted, though it did not occur to either Ware or Harris, who have him among the archbishops of Armagh under the former name, for all the circumstances, related of the one, are also ascribed to the other. The title of bishop of Kinel-Feradaigh, given him by the Four Masters, more distinctly points to his bishopric of Rathlury, or Maghera, which was comprised in the territory of Kinel-Feradaigh, though Derry was by no means so; and the notice by the same annalists relative to the consecration of his successor, Florence O'Caireallan, must, unquestionably, be understood as applying solely to that bishopric, which we have undoubted evidences that he filled, and not to the see of Armagh, to which it is equally certain he never succeeded.

3rd. Fogartach, or Florence O'Cerbhallain [properly Caireallan], succeeded 1185, died 1230. The death of this bishop, whose Christian name is generally written Fogartach by the annalists, is thus recorded by the Four Masters:-_" Florence O'Caireallan bishop of Tirone, a noble select senior, died in the 86 th year of his age."

4th. German, or Gervase O'Caireallan, succeeded 1230, died 1279. Some account of this bishop, who was a Dominican friar, has been already given. His death is thus recorded in the Annals of the Four Masters. Jilla an Chomóe, [servant of God] O'Carolan, bishop of Tirone, died. In him terminates the succession of the bishops of Tirone, or Rathlury, distinct f rom Derry.

Fogartach, or Florence O'Caireallan, succeeded 1279, died 1293. This was the third and last bishop of the same surname and family, who held the bishopric of Tirone in succession, after the manner usual among the powerful Irish families. The establishment of the episcopal chair in Derry seems to have been fixed during his time, as the annalists, who record his death, expressly call him bishop of Derry. He died in July, 1293, and on the 25th of October following, the king issued a Conge de Estier, to proceed to the election of his successol.

Of the powerful family to which these bishops belonged, some historical notices have been given in the preceding Annals of Derry, and still more will be found in the account of the parish of Clondermot. After this period the power of the British crown appears to have had, for a time, a dominant influence in this, as well as in the other Irish ecclesiastical sees, and the election of its bishops to have proceeded in a more orthodox manner. It is certain that henceforward we find but slight traces of that exercise of power in the local aristocracy, which previously constitutes so remarkable a feature in the history of the Irish church.

Henry of Ardagh succeeded 1295, died 1297. This bishop, who was " a Cistercian monk, was lawfully elected by the dean and chapter of Derry, and obtained the royal assent on the 3rd of March, 1294, reckoning the year to begin from the lst of January; but he had not restitution of the temporalities until the 16 th of June following." - Ware. His proper name was Mac-Oireaghtaigh, or, as it is now called, Geraghty, a distinguished family in Annaly, the present county of Longford. He was the first person elected to the bishopric of Derry, who did not belong to any of the powerful families of the district; and it may, perhaps, be doubtful that he was ever permitted to exercise ecclesiastical jurisdiction within the diocese, as in the records of his death, given by the annalists, he is not called bishop of Derry, but bishop of Connor.- Thus in the Annals of the Four Masters :-

1297. "Henry Mac-Oireaghty, bishop of Connor, died, and was buried in the monastery of Droglieda. He was a monk."

And in the Annals of Connaught:-

1297. "Henry Mac-Oireaghty, bishop of Connor, and a grey friar of the Cistercian order, quiescit.'

Ware and Harris have also placed him among the bishops of Achonry, but erroneously, while they have omitted him among the bishops of Connor.

Godfrid, or Jeffry Mac-Loughlin, succeeded 1297, died 1315. He was consecrated bishop of Derry, and had his writ of restitution to the temporalities, on the 26th of June, 1297. He governed this see about 17 years. The family of Mac-Loughlin as well as the O'Neills, were of the blood-royal of Ireland, and were long seated in the neighbourhood of Derry.--(See Grianan of Aileach).

Odo, or Hugh O'Neill, succeeeded 1316, died 1319. He was a secular priest of the diocese of Derry, was elected in the year 1316, and died in June, 1319. On the 19th of August following the king's license issued to the dean and chapter of Derry, to go to the election of a successor.

Michael Mac Loughlin succeeded 1319, died 1324. This bishop was elected in August, 1319, and about the beginning of October following was confirmed by Denis, dean of Armagh, in the absence of primate Roland, who then lived beyond the seas. He sat in this see in the year 1324, but I do not find how long after.-Ware.

Simon-" One Simon, a friar, (but I do not know of what order), governed this see in the year 1367 , and 1369. I have not yet discovered either when he was consecrated, or when he died."-Ware. 


\section{HISTORY,}

John Dongan, a Benedictine friar, was translated by the provision of pope Boniface the 9th from this see to that of Down in 1395 [in which see he died in 1412]. The see continued afterwards vacant six years. - Ware.

John succeeded 1401. John, abbot of Magh-coscain or de Claro Fonte, was promoted to the see of Derry by the provision of pope Boniface the 9 th, on the 4 th of the calends of September, and died in 1419.-Ware's Manuscripts; vol. 75

William Quaplod, an English Carmelite friar, succecded. He had his education at Oxford, and was the Mæcenas of Bertran Fitz Allan, who was also a Carmelite, and a man of profound learning, as Leland says.-Ware.

Donald, or Donat (as some call him), sat in this see in 1423, and died ten years after; but it is uncertain how long he held the bishopric, as he was called to task in 1426 , by archbishop Swain, in his visitation, for incontinence and other crimes, which being proved against him, he was obliged to do penance: and in another visitation, in 1429, he was obliged to submit to further ecclesiastical rigour, in consequence of which, Harris, with much appearance of probability, conjectures that he resigned in that year, as the bishopric was vacant in 1430 . It was not filled up in 1433 . -(Ware's Manuscripts, vol. 75, page 179. See Ware's Bishops).

John, succeeded, and died in 1456 . It appears in the registry of John Prim, archbishop of Armagh, that a citation was issued against this John, bishop of Derry, dated the 17 th of October, 1441 , for homicide and other crimcs : but no further proceedings are there mentioncd against him.-(Harris's Ware).

Bartholomew O'Flanagan, a Cistercian monk, was promoted to the bishopric of Derry, by the provision of Pope Celestus the 3rd on the 27th of May, 1458. He sat not full five ycars, for the see was vacant on the 14th of April, 1463, as appears in the registry of John Bole, archbishop of Armagh, who was on that day guardian of the spiritualities and temporalities during the vacancy of the see. It seems it was not filled for three years afterwards.-(Harris's Ware).

Neither Ware nor Harris were able to ascertain the year in which this bishop died, and indeed our annalists are wholly silent respecting any bishop of Derry of the name. But at the year 1462, they record the death at Lough-Dearg, of Bartholomew (the son of Hugh) O'Flanagan, the prior of Devenish, who, there is every reason to believe, was the same person, and if so, it may perhaps be conjectured that he never had restitution of the temporalities, or was allowed to excrcise pontifical jurisdiction in this bishopric. This Bartholomew was the founder of the abbey church in Devenish, as appears from the inscription on it, which still remains: he was distinguished also for illustrious birth, his father, Hugh, having been chief of his name, and lord of Clan Chathail in Fermanagh.

Nicholas Weston succeeded 1466, died 1484. Nicholas Weston, bachelor of the Canon Law, and canon of Armagh, was consecrated in 1466. He assisted at a provincial synod convened at Drogheda, in Saint Peter's church, in July, 1480, by Octavian, archbishop of Armagh.—Ware. His death is recorded by the annalists, as bishop of Derry, in 1484. Of this bishop, who was, as his name indicates, an Englishman, O'Donnell, prince of Tirconnell, in his life of St. Columbkille, relates a circumstance, which equally shews how little he understood the peculiar prejudices of the Irish, over whom he was appointed, as well as their dislike to reccive an Englishman among: them. O'Donnell, after stating that Columblille, when erecting the church of Cluain-i [now Saint Columb's, in Clooney], near Derry, prophesied that it should be destroyed by the English in future times, proceeds to relate that the prophecy was realized, not long before [1520] by Nicholas Boston, an English bisliop, who pulled down this church for the purpose of using the materials in the erection of a palace in its neighbourhood, but that God and Saint Columbkille did not permit him to carry his sacrilegious project into effect.

Donald O'Fallon succeeded 1485, died 1500. This bishop was advanced to this see by the provision of Pope Innocent the 8th, on the 17 th May, 1485, and consecrated in the following year.-Ware's Manuscripts, volume 75th, page 179. His death is thus recorded by the Four Masters:-

1500. "Donnell O'Fallon, bishop of Derry, a friar minor, "de observantice," who had been for the space of thirty years before industriously teaching and preaching throughout Ireland, died of an inward disease, and was interred at Trim."

In the archives of Christ Church there is a letter of indulgence and plenary pardon of all sins, however enormous, granted by this Donald O'Fallon to Richard Skylret, then canon, but afterwards prior of that cathedral, for contributing to the crusade. He entitles himself deputy of the order of minors, and on the seal is called the guardian of Youghill, dated A. D. 1482. The see was vacant on the 30 th of May, 1502.-(Ware's Manuscripts, vol. 75, page 179).

James Mac Mahon succeeded 1507 , died 1519. He was consecrated in 1507, and died a little before Christmas in 1519. He was commendatory prior of the abbey of Saint Peter and Saint Paul, of Knock, in the county of Louth.-(Ware's Manuscripts; vol. 75th, page 179). 


\section{CITY OF LONDONDERRY.}

William Hogeson, bachelor of divinity and a Dominican friar, was advanced to this see by the bull of pope Leo the 10th, dated the 8th of August, 1520. Of this bishop, who has been omitted by Ware and Harris, nothing more has been preserved: he held the bishopric but a few years, as we find another in his place in 1529.-(See De Burgo; page 484).

Rory O'Donnell succeeded 1529, died 1551. But little is known of this prelate more than that he was sometime dean of Raphoe, and that he filled this see in September, 1529, as appears from the registry of George Cromer, archbishop of Armagh. According to Ware he died on the 8th of October, 1551, bnt the Annals of the Four. Masters place his death in 1550, adding, that he took on him the habit of a friar, and was interred in the Franciscan monastery of Donegal. He was the son of Donogh, the son of Hugh Roe O'Donnell, prince of Tirconnell.

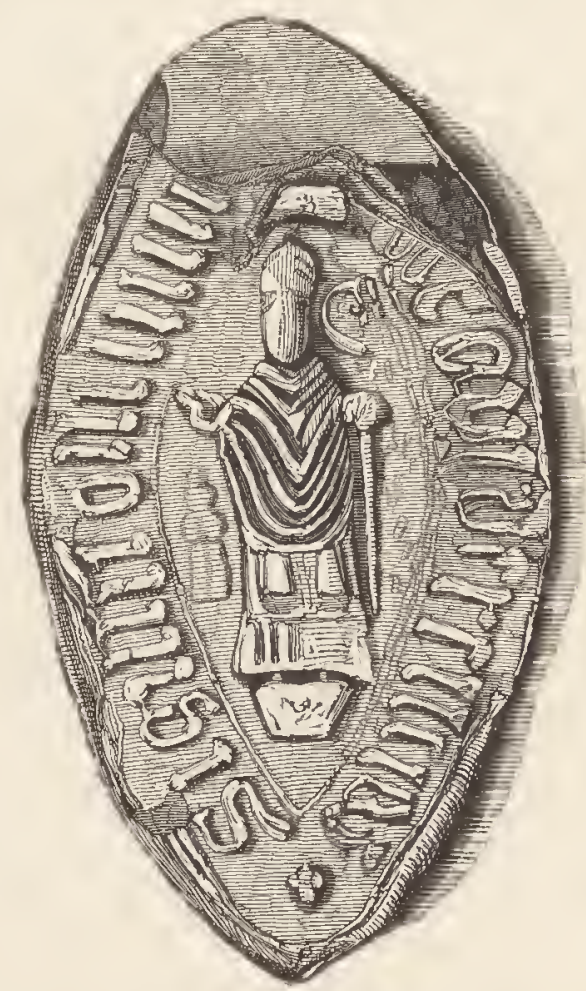

Eugene Mac Genis, is placed next in succession by Ware, but without quoting his authority, and he adds, that he was not able to discover either when he was consecrated, or when he died. If appointed to the bishopric, it is probable, that he was never restored to the temporalities, or If appould scarcely be wanting further notice of him in connexion with Derry. There can be little, if any, doubt that he was the same person who was appointed to the see of Down and Connor by provision from pope Paul the 3rd, in 1541, and who continued in possession of those sees in 1559 . The year of his death is not known.

Redmond O'Galchor, or Gallachar, died 1601. Of this bishop, who appears to have been the last Roman Catholic prelate in possession of the see, but little is known, except the unhappy circumstances relating to his death. De Burgo states that after the death of Elizabeth, O'Galchor at about the age of seventy (or according to some accounts eighty), being taken by a heretic band of the governor's soldiers (Prcesidariis Excursoribus hareticis), he received from them many mortal wounds, of which he died in the year 1604. But this account appears to be erroneous in two important circumstances, which for the sake of humanity should not be left uncorrected; namely, the reign of the monarch, and the year in which the unhappy event occurrea-circumnamely, the reign of the monaction than it deserves, as the period thus assigned to it was one of peace and law in the country, and which could offer no plition for an the hewerer, seems to be that this unfortunate man met his end three years earlier, during the period of the Tyrone rebellion at the close of the reign of Elizabeth, and that his death was one of those unhappy occurrences so characteristic of the horrors of a desolating civil war. In the accurate annals of the Four Masters, compiled in the
adjacent county of Donegal but a few years after the event, his death is recorded as follows at 


\section{HISTORY.}

the year'1601 : "Redmond O'Gallagher, bishop of Derry, was killed by the English, [not the heretics] in Orpeać U, Choćám, i. e. in O'Kane's country, on the 15th of March,"- -and this date seems to be verified by a letter written by Sir Henry Docwra, the governor of Derry, to the lord deputy on the 7 th of April, in the same year, in which, among other things, he states that Sir John Bolles, (the second in command in that garrison), " in a journey recently made upon O'Kane, had killed 50 of his people, and burned many houses and much corn."

In this prelate terminates the legal succession of the bishops of Derry, of the Roman Catholic church ; for there appears to liave been previously no substitution or appointment of a bishop of the reformed church to this see, and it is probable that government had not as yet acquired sufficient power to effect this object in this great strong hold of the Irish.

\section{AFTER THE REIGN OF ELIZABETH.}

\section{Section 1.-General.}

The preceding portion of these annals shews that, down to the middle of the 16 th century, the city, as well as the district now forming the county of Londonderry, was still in the hands of the native Irish, and governed by their cliefs, with at best but an occasional and doubtful acknowledgment of subjection to British power. In the subsequent period, now to be treated of, the city of Derry became the theatre in which many of the most inportant events connected with the history of Ireland were acted; but these events are so inseparably interwoven with the general history of the county as to render their incorporation with this local history impracticable, without either destroying the clearness of both, or repeating that which has been necessarily told already. It has therefore been thought most proper to confine the minute notices of Derry, in this place, to matters altogether peculiar to the city, and give merely an abstract of the more important events which the reader will find fully detailed in the County history.

1565. The rebellion of the celebrated Shane, or Jolın O'Neill, earl of Tyrone, as detailed in the County history, gave the first occasion for the presence of an English garrison in Derly. "To check the increasing boldness of this man," says Camden, "Lord Deputy Sydney advanced with an army against him, having prudently sent Edward Randolph, an experienced officer, with seven companies of foot, and a troop of horse, by sea, to the north coast of Ireland, where they encamped at Derry, upon Lough Foyle, in order to fall on the enemy in the rear. Shane, fearing this, had drawn all his forces that way, to dislodge him; but Randolph immediately gave him battle, and though he lost his life honourably in the cause of his country, he gave him such a defeat that he was never after able to make any resistance." This action, according to Cox, took place in October, 1565. Colonel Edward St. Low, or Lo, succeeded Randolph in the command of the garrison, but in consequence of the accidental explosion of the powder magazine, on the 24 th of April, 1566, by which the town and fort were blown up, the provisions destroyed, and a great number of lives lost, the place was found to be untenable, and the foot embarked for Dublin, whither also the horse returned, passing through Tirconnell and Connaught to avoid O'Neill.The importance of securing Derry, though for a time defeated by this accident, was not abandoned by the queen's government. During the deputyship of Adam Loftus, archbishop of Dublin, and Sir Robert Gardiner, Lord chief justice, 2000 foot, and 100 horse, under the command of Sir Samuel Bagnall, were designed to effect this purpose, but were remanded on the defeat of Marshall Bagnall by the Earl of 'Tyrone, and sent into Lecale to strengthen the queen's forces; and one of the chief articles of complaint against the earl of Essex, was his neglect of fulfilling the instructions given him to plant a garrison here. "How often," the queen writes to him in 1599, "have you resolved us that until Loughfoyle and Ballyshannon were planted there could be no hope of doing service upon the capital rebels."

1600. This important object was at length effected early in this year, under the government of lord Mountjoy. Un the 16th of April, Sir H. Docwra, with a British force of 4,000 foot and 200 horse entered the harbour of Lough Foyle, effected a landing at Culmore, and in six days afterwards took Derry without opposition. The circumstances connected with this most important event are thus told by Sir Henry Docwra himself, in the "Narrative of the Services done by the Army employed to Lough Foyle," under his command.-M. S.

"The army consisting in list of 4000 foote and 200 horse, whereof 3000 of the foote, and all the horse were levied in England, the other 1000 foote were taken of the old company's about Dublin, and all assigned to meete at Knockfergus [Carrickfergus] the first of May: that part levyed in England was slipt at Helbree, neere $11 n$ to Westchester on the of 24 th Aprill, 1600. And of these a regiament of 1000 foote and 50 horse were to be taken out imediatelie upon our landing, and assigned to $\mathrm{Sr}$ Mathew Morgan to make a plantation with att Ballishannon. 


\section{CITY OF LONDONDERRY.}

"The provisions wee carried w th us at first were a quantetie of deale boards, and sparrs of firr timber, a 100 flock bedds, wth other necessaries to furnish an hospitall wthall, one peece of demycannon of brass, two culverins of iron, a master gunner, two master masons, and two master carpenters allowed in pay, with a greate number of tooles and other utensiles, and wth all victuell and munition requisite.

"Soe wth those men from England and these provisions aforesaide on the 25th day of Aprill wee sett saile, and on the 28 th in the evening, put in at Knockfergus, where wee staide the space of 8 days before the companyes from Dublin came all unto us.

"The last of them coming in by the 6 th of May, on the 7 th we sett saile againe, and the windes often fayling, and sometimes full against us it was the 14 th before wee could putt into the mouth of the bay, at Lough-Foyle, and noe sooner were wee entered but, wee fell on grounde, and soe stucke till the next day, then at a full tide we waighed our anchors, sayled a litle way, and rune on ground againe.

"On the 16 th in the morning wee gott loose, and about 10 of the clocke $(100$ men lying on shoare, and giving us a volie of shott and soe retyring) wee landed att Culmore, and wth the first of our horse and foote that wee could unshipp, made np towards a troupe of horse and foote, that wee sawe standing before 115 on the top of a hill, but by ignorance of the wayes onr horses were presentlie boggt, and soe of that day wee made none other use, but onelie to land our men. The next day, the place seaming to my judgement fitt to build, wee beganne about the butt end of the old broken castle, to caste up a forte, such as might be capable to lodge 200 men in.

"Sixe dayes wee spent in labour about it in wch meane space, makeing upp into the countrie wth some troupes (onely wth intent to discover) wee came to Ellogh a castle of O Doghartyes, wch he had newlie abandoned and beginne to pulle down, But, seeing it yet tennable, and of good use to be held, I put Captaine Ellis Floudd into it and his companie of 150 men.

"On the 22th May weeput the army in order to marche, and leaving Captaine Lancellott Atford at Culmore wth 600 men to make up the workes, wee went to the Derry 4 myles of upon the river side, a place in manner of an iland, comprehending wthin it 40 acres of ground, wherein were the ruines of an old abbay, of a bishopps house, of two churches, and at one of the ends of it an old castle, the river called Loughfoyle encompassing it all on one side, and a bogg most comonlie wett, and not easilie passable except in two or three places dividing it from the maine land.

"This peece of ground we possest ourselves of whout resistance, and iudging it a fitt place to make our main plantation in, being somewhat hie, and therefore dry and healthie to dwell upon, att that end where the old castle stood, being close to the water side, I presentlie resolved to raise a forte to keep our stoore of munition and victuells in, and in the other a little above, where the walls of an old catledral church were yet standing, to erect annother for our future safetie and retreate unto upon all accasions.

"Soe then I unloaded and discharged the shipping that brought us, all but those reserved for Sr Math: Morgan, and two men of warre under comaund of Captaine George Thornton, and Captaine Thomas Fleminge, wch were purposlie assigned to attend us all that sommer, and the first bussiness I setled myselfe unto was to lay out the forme of the said two intended fortes, and to assign to every companye, his severall taske how and where to worke.

"I know there were some that presentlie beganne to censure mee, for not starring abroade, and makeing iourneyes up into the countrye, alleadging wee were strong enough and able to doe it. I deny not but wee were, but that was not the scope and drift of our coming, wee were to sitt it out all winter, prayes [preyes] would not be sett whout many hazards and a great consumption of our men, the countrie was yet unknown unto us, and those wee had to deale with were [such?] as I was sure, wrould chuse or refuse to fieght wth us as they sawe theire orne advantage; these considerations moved me to resolve to hould an other course, and before I attempted any thinge else, to setle and make sure the fonting wee had gayned.

"The two shipps of warre therefore (the countrie all about us being wast and burned) I sent wth souldiers in them to coast all along the shoare for the space of 20 or 30 myles, and willed wheresoever they found any howses, they should bring away the timber and other materialls to build wthall, such as they could, And O'Cane hauing a woode lying right over against us (on the other side of the river) wherein was plentie of old grown birch, l daylie sent workemen with a guard of souldiers to cutt it downe-and there was not a sticke of it brought home, but was first well fought for. A quarrie of stone and slatt wee found hard at hand, cockle-shells to make lyme, wee discouered infinite plentie of in a litle iland in the mouth of the harbour as wee came in, and with these helpes, togeather wth the provisions ree brought, and the stones and rubbilge of the old buildings wee found, wee sett ourselves wholie, and wth all the dilligence wee conk possible to fortefying and framing and setting upp of howses, such as wee might be able to live in, and defend our selves when winter shonld come, and our men be decayed as it was apparant it would be: And whether this was the right course to take or noe, let them that save the after events be the judges of. 


\section{HISTORY.}

"My lord deputie, att the time wee should land, (to make our discent the more easie) was Arawne downe to the Blackwater and gaue out that hee would enter the countrey that way, whereupon Tyrone and ODonell had assembled theire cheifest strength to oppose against him: but his lordship now knowing wee were safe on shore, and possest of the ground wee ment to inhabite, wthdrew his campe and retourned to Dublin, and then being delivered of that feare, those forces they had brought togeather for that purpose, being now encreased by the addition of more, and estimated (by common fame) to be about 5000 in all, they came downe wth upon us, and placing themselues in the night wthin litle more then a mile from where wee lay, earelie in the morning at the breaking upp of the watch, gave on upon our corps de gaurd of horse, chased them home to our foote sentynells, and made a countenance as if they came to make but that one dayes worke of it, but the alarume taken, and our men in armes, they contented themselues to attempe noe further, but seeking to draw us fortl into the countrey where they hoped to take us at some aduantages, and finding wee stoode upon our defensive onelie, after the greatest pte of the day spent in skrimish a litle wthout our campe, they depted towards the evening whither did wee thinke it [not] fitt to pursue them.

"And now did $\mathrm{Sr}$ Mathew Morgan demaund his regiament of 1000 foote, and 50 horse, wch at first (as I saide before) were designed him for a plantation att Ballyshannon, but upon consultation held how he should proceed, and with what probabilitie, he might be able to effect that intended bussiness, there appeared soe many wants and difficulties unthought on, or unprouided, for before that it, was euident those forces should be exposed to manifest ruine, if at that time, and in the state as things then stoode, hee should goe forward, the truth whereof being certified both by himselfe and mee, to the lords of the councell in England as also to the lord deputie and councell of Ireland, wee received present directions from them both to suspend the proceeding in that action till another time, and soe I discharged the rest of the shipping reserved for that journey, and not long after the companys growing weake, and the list of the foote reduced to the number of 3000 , that regiament was wholie dissolued, and made as a part onslie of our army."

"On the second of July I put 800 men into boates and landed them att Dunalong: Tyrone (as wee were tould) lying in campe within two myles of the place, where I presentlie fell to raiseing a forte, his men came downe and skirmisht with us all that day, but perceiving the next, wee were tilted and out of hope to be able to remoue us, they rise up and left us quietly to doe what we would where after I had made it reasonable defensible, I left Sr John Bowles in garrison with 6 companyes of foote, and afterwards sent him 50 horse."

It will not, perhaps, be uninteresting to the rcader to see the contemporaneous Irish accoun of Docwra's transactions, as given in the Annals of the Four Masters, particularly as they throw some additional light on the character of the works, erected by the English on this occasion.

A. D. 1600." The English fleet, that was ordered by the queen and the English parliament to be sent to Ireland against the province of Ulster, when Lord Mountjoy was lord justice of Ireland, which was about the festival of St. Patrick, as we have already mentioned, was preparing in England, and all necessary apparatus procuring with the greatest possible expedition; because it was great vexation of mind to the queen, and her councils in England and Ireland, that the Kinel-Connell, Kinel-Owen, and all Ulster, besides those chiefs who were confederated with them, had made so long and successful a defence against them. They also remembered, yea, it privately preyed like a consumptive disease upon their hearts, that so many of their people had been lost, and so mucl of their money and wealth consumed in carrying on the Irish war until this period; wherefore they were determined to send the aforesaid fleet to Ireland.

"They put into the harbour of Dublin in the month of April this year, whence they sailed in the beginning of summer, by the advice of Clanricard and Thomond, by whom they were ordered to oo to the lake of Feval, the son of Lodan [Lough Foyle]. They sailed, keeping Ireland to the left, until they landed at the place they were ordered. After they had landed they erected on both sides of the harbour three fortresses of trenches, as they had been instructed in England,_-ne of these fortresses, namely Dun-na-long, and two in the country of O'Donnell; of these, one in Culmore, in the country of O'Dogherty in the cantred of Inishowen; the other in Derry, to the S. W. of the former.

"The English immediately commenced sinking fosses around them, and erecting a strong wall of earth, [mún cniáo], and a rampart, [oúnćl.á̉], so that they were able to hold out a defence against their enemies. There were many other fortifications and preparations of defence, and also courts [large houses] of lime and stone, and a city, on the erection of which much time and labour were bestowed. They immediately tore down the monastery and cathedrall, [oamliaz, ] and destroyed all the ecclesiastical buildings of the town, and with the materials thus obtained erected houses and apartments. Henry Docwra was the name of their general: he was an illustrious knight of wisdom and prudence, a pillar of valour and prowess. Six thousand was the number that came to that place. Whan they arrived at Derry they made little account of Culmore and Dunnalong." 


\section{CITY OF LONDONDERRY.}

These accounts, it will be seen, agree substantially ; the only discrepancies worth notice are in respect to the number of men that came to Lougl Foyle, and the destruction of the cathedral and other religious houses. 'The first is of little importance, as the Four Masters probably included in their amount the followers of the army, and the seamen, who must have been very numerous, as Peter Lombard states that the number of ships enuployed on the expedition was sixty-seven. At all events the annalists could only have given their estimate from common report, and their error, if it were such, was more excusable than that of Moryson, the secretary to the lord deputy, who states officially that the number of horse was one hundred, though we find from Docwra himself that it was two.

The statement of the Four Masters, relative to the destruction of the cathedral, \&c. appears to be a greater error, unless by destruction, or tearing down, they merely meant the ruins left by the explosion in 1566; and it is certain that the clo'z-taec, or round tower belfry, escaped on both occasions, as already shewn, and that Docwra preserved one of the churches for a place of worship.

Of the forts erected by Sir H. Docwra at Derry, Culmore, and Dunnalong, the original plans will be found in connexion with their history in succeeding portions of this memoir.

1601. The subsequent operations of the garrisons of Lough Foyle are fully detailed in the County history. It may be proper, however, in this place, to correct an error of Ware and Cox, who state that the castlc of Derry was regained in this year by Sir Henry Docwra, having: been betrayed by some of his Irish soldiers to the rebels. The concurrent silence of Docwra himself, and the Irish annalists, is a sufficient refutation of the statement.

1603. The termination of the war at the commencement of this year rendering the presence of a large body of troops at Derry no longer necessary, the garrison was reduced to 100 horse, and 150 foot, under the governor, Sir Henry Docwra, and 200 foot, under Captain Richard Hansard. There were also left at Culmore 20 men, under Captain Hart. The origin of the present city may, perhaps, be properly dated from this period. 'The vigorous mind of the governor, which was equally fitted for distinction in the arts of war or peace, lost no time in laying the foundation and promoting the prosperity of a commercial town, which has since risen to a rank so considerable, and which, from its local advantages, may yet assume a high rank among the cities of the empire.

For these services the name of Docwra has not received its just meed of celebrity, even on the spot which is reaping the benefit of them; but that he is well entitled to be revered, as the true founder of "the Derrie," will abundantly appear by the following abstract of charters, from the patent rolls of James I.

September 12. A grant was made to Sir Henry Docwra, knt., governor of Lough Foyle, and privy councillor, to hold two markets on Wednesday and Saturday, and a fair for six days, (viz. on the vigil, day, and morrow of St. Lawrence, 9th, 10 th, and 11 th of $A$ ugust), and for three days following, at Derrie every ycar, with horse races, there to be held during the same markets and fairs, togcther with the issues, profits, and emoluments belonging and appertaining to the said markets and fairs. Rent $2 s .6 d$. English at Michaelmas.-(1. Jac. I. 2 pars. f. 33.)

1604 , July 11. The town or borough of Derrie is by reason of the natural seat and situation thereof, a place very convenient and fit to be made both a town of war and a town of merchandize, and so might many ways prove serviceable for the crown and profitable for the subject, if the same were not only walled, entrenched and inhabited, but also incorporated and endowed with convenient liberties, privileges, and immunities; and Sir Henry Docwra, lsnight, during the reigns of Queen Elizabeth and King James, having, by his extraordinary valour, industry, and charge, repossessed, repaired, and repeopled that town; being utterly ruinated and laid waste by the late rebellion in those parts, and having begun and laid a good foundation there for the planting of a colony of civil and obedient people in that place, the king (for the better progress therein, and more fully establishing of the same in perpetuity, and for a memorial and recompence of the good service and charge which Sir H. Docwra had employed and bestowed as aforesaid), did pursuant to letters dated at Wesminster, 22d March, 1603-4, inrolled, (anno $2^{\circ}$, $3^{\mathrm{a}}$, pars. $d$. memb. 7.) give, grant, and confirm unto him, and the inhabitants of the Derrie, all the circuit and extent of land and water within the compass of three miles, to be measured from the circumference of the old cliurch walls, directly forth in a riglit line, every way round about, every mile containing 1,000 geometrical paces, and every pace five feet in length, shall be for ever, a free, entire, and perfect city and county of itself, to be called the city and county of Derrie, and shall be a corporation and body politic, made and created of the inhabitants of the same, consisting of one provost, twelve aldermen, two sheriffs, twenty-four burgesses, and as many freemen as the said Sir H. Dockwa, during his life, and as the provost, aldermen, sheriffs, and burgesses, should think good to admit, Sir Henry to be provost for life, as fully as the Lord Mayor of London had in the city of London, and to appoint a vice provost. The sheriffs to hold a county court from three weels to three weeks, and another court called the sheriff's Turne, at the two usual times of the year, according to statute; to build a hall or town 


\section{HISTORY.}

house, to be called the council house of Derrie, to assemble in to nominate a recorder during behavioul; the provost or vice provost, recorder, and two senior aldermen to be justices of the peace, oyer and terminer, and gaol delivery. A gaol to be built at the expense of the inhabitants; two coroners, a town clerls, a chamberlain or treasurer, a water-bailiff, a sword-bearer, a competent number of serjeants of the mace, and other inferior officers. The several trades to distinguish themselves into several companies or guilds, each to erect a common hall, and to make bye laws. The provost to be clerk of the market, escheator, and the king's admiral and mayor of the staple. The corporation every Tuesday to keep courts, and to hold plea of all actions, and to have all the fines and amerciaments of the said courts, all waifs and estrays, felons' goods, deodands, wrecks of the sea, all kind of tolls, (not formerly granted to any other by the crown), at the fee-farm rent of $6 s$. $8 d$., licence to purchase lands to the amount of $£ 300$ a-year.(2 Jac. I. $2^{\sharp}$. pars. f. R. 9.)

About this period Sir Henry received still further marks of his sovereign's favour, in reward of his services.

"Having received from Queen Elizabeth and King. James a pension of 10 s. a day, as colonel of the army in Ireland, and in augmentation thereof, 3s. $4 \mathrm{~d}$. a day, as governor of Lough Foyle, during pleasure the king, [by letter of privy seal, March 22nd, 1603-4, and by patent, June 14th, 1604], increased the same to 20s. a day, during life." - (2 Jac. I. $2^{\text {a }}$.pars. $f . R .39$.)

1604. The connexion of Sir Henry Docwra with Derry, which, it might be supposed, was thus destined to terminate only with his life, was however, unfortunately, of but short duration. From a variety of causes, which are detailed in his narrative, and quoted in the county history, he was induced in this year " to conclude a bargain with $\mathrm{Mr}$. George Pawlett, a gentleman of Hampshire, selling him his house whicl he had built, with ten quarters of land he had bought and laid to it, all with his own money, and his company of foot, altogether for less, a great deal, than the very house alone had stood him in," and after conferring upon him the vice-provostship of the town from the time of his absence, returned to England, and never after resumed the government of Derry.

1608. The connexion with Derry of the vice-provost, Sir George Pawlett, was of still shorter duration, and had a far more disastrous close. Having, by insulting language and personal chastisement, exasperated Sir Cahir O'Dogherty, who at that time considered himself badly treated by the government, the young chief of Inishowen madly rushed into rebellion, and, after taking the fort of Culmore by treachery, and Derry by surprise, he put the governor, Pawlett, with his lieutenant Corbie and the garrison, to the sword, plundered the town, and reduced it to ashes. This event occurred on the morning of the 1st of May, and on the 18th of July following the career of Sir Cahir and his followers was closed by his death in the field. This daring revolt, together with the flight of " the Earls," in the preceding year, smoothed the way for the general confiscation of the six northern counties, and their plantation with British and Scottish subjects, professing the reformed faith - an object which the king had long had at heart. The general history of that plantation, as applicable to the county of Londonderry, having been already given in the County history, it is only necessary here to pursue such of its details as are more immediately connected with the city.

1609. By the agreement concluded on the 28 th of January, between the lords of the privy council and the committee appointed by the corporation of London, it was determined, among other things, that 200 houses should be built at Derry, and roon left for 300 more; and that 4000 acres, lying on the Derry sicle, next adjacent to the Derry, should be laid thereunto, bog and barren mountain to be no part thereof, but to go as waste for the city; the same to be done by indifferent commissioners. That the bishop and dean of the Derry should have convenient plots of ground for the site of their houses at the Derry. That the lands of the city should be holden of the king in free burgage; that the liberty of the city should extend three miles every way; and lastly, that 60 houses should be built in Derry by the 1 st November, 1611 .

1612-13. On the 29th of January this year the Irish Society was formed, who received their charter of incorporation on the 29th of March, under the name of the Governors and Assistants of the new Plantation of Ulster, the preceding charter having been surrendered.

By this charter it is granted that the city or town of Derry, and all the castles, lordships, manors, lands, and hereditaments, and all others lying within the precinct or circuit of the same, are hereby united, consolidated, and for ever made and created an entire county of itself, distinct and separate. It is granted that the city or town of Derry should be called the city of Londonderry, and all lands within the circuit of three Irish miles, to be measured from the middle of the city, to be within the liberties and jurisdictions thereof. That the citizens be incorporated by the name of mayor, commonalty, and citizens, consisting of a mayor, 12 aldermen, 2 sheriffs, a chamberlain, and 24 chief burgesses. The mayor and sheriffs to be elected on the 2 nd of January, and sworn in on the 2nd of February before the preceding mayor; to appoint a sword-bearer, serjeants at mace, and other inferior officers during pleasure. The king by this charter grants to the said London Society and their successors the entire island of Derry, and all the lands next 
adjacent to the city, on the west side of the river of Lough Foyle, containing by estimation 4,000 acres, besides bog and barren mountain, to be used by them as waste acres belonging to the said city. The society, within one year, to assign to the bishop and dean of Derry, and their successors, 2 acres of land a-piece next adjoining to Columbkille's tower, to build houses for their residence. The Society for ever at their own charge to find and maintain a ward in Culmore castle, of so many men well armed and officers, as shall be necessary for the defence thereof, and to acquit and exonerate the crown from the same for ever. Provided that the city be enclosed and fortified with stone walls, except that part next the river of Lough Foyle, within ten years, to hold weekly markets on Monday, Wednesday, Friday, and Saturday, and a fair on the feast of saint Bartholomew, and for eight days next following. The city to exercise the office of packer and gauger, and to return two members to parliament.

6th July. The Society sent over two of their assistants, Mr. Alderman Smithes and Mr. Mathias Springham, to take an exact survey and account of the various operations and concerns of the plantation. They brouglit with them the ncw charter of Londonderry, and had the old charter surrendered to them. On the 8 th of November, on their return, they reported to the common council, that among other things, they had presented a silver-gilt conmunion-cup to the church of Derry. They also reported that as to the city of Derry, and town at Coleraine, with the territories, ferries, and fishings belonging to the same, they were of opinion that a division could not be fully made of them, but that the rents and profts of them might be divided amongst the several companies. Agreeable to recommendation, they were retained by the society, who received the rents and profits, and accounted for them to the twelve chief companies.

1615. An additional sum of $£ 5,000$ ordered, towards finishing the walls of Derry.

9 th November. Directions given by the Irish Society, in order that Derry might not in future be pcopled with Irish; that 12 Christ's Hospital and other poor children should be sent there as apprentices and servants, and the inhabitants were prohibited from taking Irish ap-
prentices.

1616. Mr. Alderman Proby and Mr. Mathias Springham were sent over to Derry to take a survey of the plantation. On the 27 th of July they reported that the 12 children sent from Christ's Hospital to be apprenticed had arrived safe at Derry, and they had caused ten to be apprenticed in Derry, and two in Coleraine. They considered it would be proper, in future, a market-house and town-honse should be erected in Derry, by which the city of London would gain the rent of 3 houses then used for a town-honse there. They continued Thomas Raven as surveyor for two years, holding his service necessary for measuring and setting out the fortifications at Derry and Culmore. They stated the allowances made to the burgesses of Derry and Coleraine by the city of London, for their attendance in parliament. The commissioners grantcd 500 acres of land, which had formerly belonged to Rory O'Kane, (who had incurred the forfeiture of his land by a criminal conviction), to $M$ r. Carey, recorder of Derry, during his life, paying the usual rent of $£ 5.6 s .8 d$., he having no salary, which they conceived to be the best way of giving him satisfaction without charge to the city. They caused Mr. Goodwin, town clerk of Derry, to be reinstated in his office, he having been suspended therefrom. Tley examined the fortifications of Derry, and found that the ditch round the fortification was a dry ditch, 8 feet deep and 30 broad, and extended from the Prince's Bulwark, being at the west end of the city, along the S. side of that fortification, unto the water side, being more than half the circuit of the wall, as would appear by the plan they had made. They found that the quay at Derry was sufficient for the trade of the place, and they thought that when the fortifications were finished, the city might either enlarge the same or make a new one. They dischargerl one Humphrey Wetherly from his employment as water bailiff and searcher, for misconduct. They granted leases of most of the houses at Derry for 31 years, and allotted to evcry loouse a portion of land according to the $r c n t$, and distributed the island (except the bog) for gardens and orchards, as belonging to every housc, in ease of the rent; and the bog they leased out to sundry persons for small rent, in hope that the same might be made firm and rood meadow in time to come. And they stated that, whereas the city had nothing for the bog before, thcy had procured a profit of $£ 7$ yearly for the same. They delivered swords as presents from the city to the several mayors of Londonderry and Coleraine. The commissioners also allotted 300 acres for a free school, when it should be finished, which Mr. Springham promised to erect at his own expense, the next year. They made estimates of repairing the churches and fortifications. They represented that out of the 4,000 acres of land to be laid to Derry, 3,217 acres had been granted to the mayor, or otherwise laid to houses.

1621 , July 31 . The city received a charter of incorporation of a mayor, two constables and merchants of the staple, with the like immunities and privileges as are expressed in the charter of the staple at Youghal-(19 Jac. $1,4^{\mathrm{a}}$ pars. d. 34 .)

1622. During this year, the crown being dissatisfied with the city of London, by reason of various representations which had been made, suggesting that the city lial not performed the original conditions of plantation, appointed commissioners in Treland to inquirc into the affairs of 


\section{HISTORY.}

the plantation, to whom the mayor and corporation presented a petition, complaining of many grievances, which they suffered by the conduct of the society.

1625. The rents of the company of Londoners sequestered by order of the privy council, but not carried into execution.

1626. A commission for a court of justice to be held in the city, directed to, and authorizing. the mayor, vice mayor, recorder or his deputy, and all such aldermen as, according to the tenor of the commission of King James the 1st., under the great seal of England, dated 2d July, 1613. $11^{\circ}$, are, or shall be made justices of the peace within the city, to hold the said court of justice, according to such instructions as in certain schedules were annexed to the said commission, and were thereby limited and appointed, and according to the tenor of his now Majesty's letters, dated in March, 1625, for the granting of new letters patent of all officers of public justice, whose commissions were determined by the decease of James the 1st.- $\left(2 \mathrm{Car} .1,3^{\mathrm{a}}\right.$, pars. d. 39.)

1627. The sequestration, by order of the privy council in 1625 , taken off.

1628, 3d May. By the king's letter, the city and county of Londonderry was sequestrated, and the rents levied for the king's use. This sequestration was revoked and taken off by the lords in England on the 28th of July following.

August 22. Sequestered again by letter of King Charles the 1st., and the rents ordered by grant to Sir R. Phillips.

1629. The following return was made of the total disbursements by the Londoners in Londonderry from the 2nd of January, 1609, to this year:-

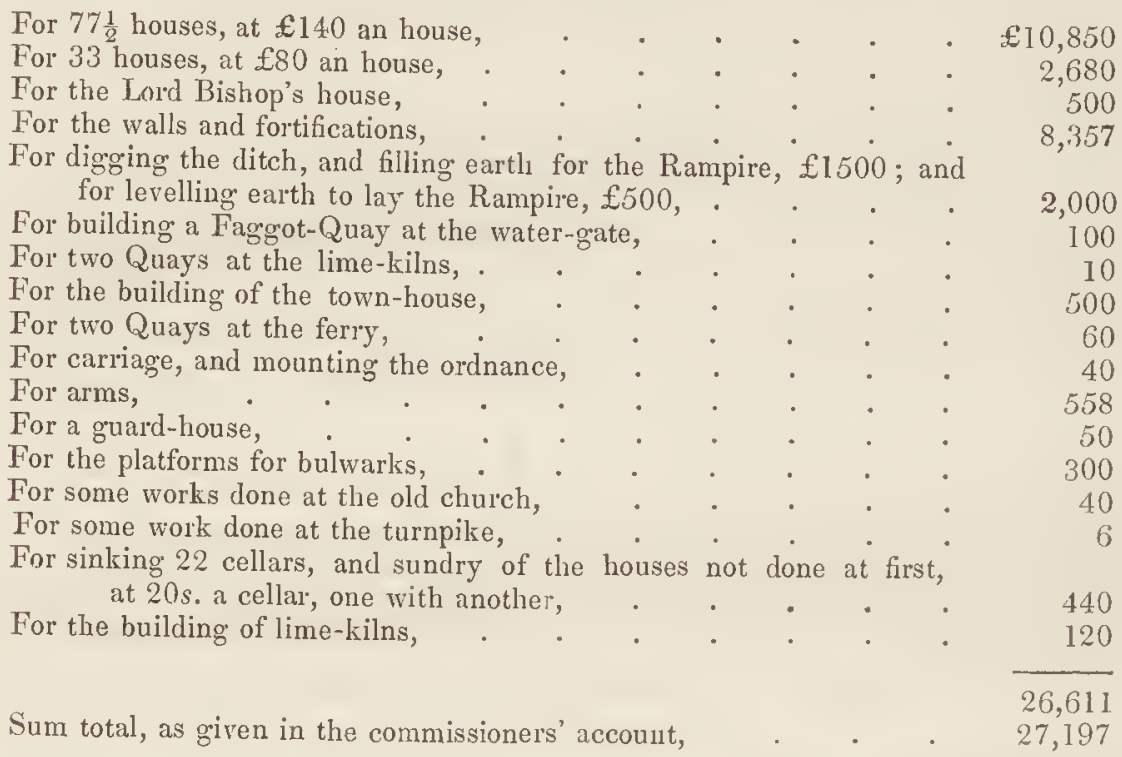

1632. The whole county and city of Londonderry again sequestrated, and the rents levied for the king's use. Bishop Bramhall was appointed chief receiver.--(Hist. of the Irish Soc.)

1635. At Michaelmas this year, by sentence of the court of star-chamber, it was adjudged that the letters patent of king James the 1st. should be surrendered, and brought into court to be cancelled. (See Carte, vol. 1, p. 83.)

1637. The lord chancellor, with the advice of the judges, king's counsel, \&c., gave judgment that the letters passed to the society of Londoners, and the enrolment thereof, should be revoked, cancelled, and made roid, and the said city and county seized unto the king's hands. In conformity with this judgment, the city was accordingly seized into the king's hands.-(See Parliamentary Register at this year).

1638. The king, at a dinner given him by the corporation of London, publicly expresses his regret for the judgment given for taking away his father's grant to the Society, and promises a restoration to the corporation, but the rebellion breaking out afterwards, his Majesty's intentions were not fulfilled.

1641. 20th August. The sentence of the star-chamber was annulled by rote of parliament, and a resolution entered that the Society should be restored to the same estate as previous to that sentence, but this resolution was not carried into effect till 165 .

At the breaking out of the rebellion, on the 22 nd of October, in this year, the surprise of 


\section{CITY OF LONDONDERRY.}

Derry was an object of vital importance to the insurgents, but their plot in this instance miscarried, and Derry became one of the chief places of refuge in the north, for the despoiled English, many of whom took shipping there for England. Shortly after, the city of London sent four ships to Londonderry, with all kinds of provisions, clothing and accoutrements, for several companies of foot, and abundance of ammunition. The twelve companies also sent, each, 2 pieces of ordnance, and these are still preserved as memorials of the warlike achievements of the city. There were at that time 20 pieces of artillery in Londonderry, which the Society had many years before provided for its safety, and it was considered that the assistance which was then so given by the city of London, was the principal means of preserving the city of Londonderry from the fury of the rebels.-(Hist. of the Irish Soc.)

In September, 1642, during tlie illness of Lord Ormond, the lords justices made an alteration in the command of the troops in Derry, which at that period consisted of six companics, under the command of the mayor and Sir J. Vaughan. Sir William Stewart was appointed Commander-inChief of the Laggan forces, but the command was superseded on the 15 th December, and the original officers restored.

In 1643 the city of Londonderry and Coleraine sent letters to the lords justices, expressing their lamentable condition, and praying for relief.--(Carte, p. 420.)

On the death of Sir John Vaughan in this year, Sir Robert Stewart was made governor of Derry by the king. Five companies of the garrison had the honor of contributing to Sir Robert's oreat defeat of Oren O'Neill, at Clones, on the 13th of June, which was the most disastrous the rebels had hitherto suffered in the province of Ulster.

Towards the close of the year the parliament having taken the Covenant, the London adventurers sent over an agent with letters desiring it to be taken within their plantation.

1644. April 15th. The mayor of Derry was ordered by the lord lieutenant and council, to publish a proclamation against the covenant.

Colonel Audley Mervin, was made governor of Derry by the marquess of Ormonde. He was obliged for expedience or safety sake to take the Covenant, which was generally received by the people.-(Carte, p. 492).

1645. Colonel Mervin became obnoxious to the parliament through the representations of Sir Frederick Hamilton, who desired the guvernorship of Derry himself, was displaced, and lord Folliott appointed in his place.

Sir R. King, and Mr. Annesley as a committee of parliament, and Colonel Beale, from the committee of adrenturers, came into Ulster in the latter end of October, with considerable supplies of money and provisions. They turned Colonel Mervin out of the gorernment of Derry, and every thing lowered before their power.

1648. Sir C. Coote treacherously seized Sir Robert Hamilton's person, forced him to orde his castle of Culmore to be delivered up, and then sent him prisoner to London. By this means the independents were not only entire masters of Great Britain; but of all the north of Ireland, and all the forts of Ulster, except Charlemont.

The marquess of Ormond endeavours by every means to draw over Sir C. Coote to his majesty's interest, but in vain, and the king's troops were necessitated, in the last week of March, to block him up in Derry.

1649. Derry and Culmore were besieged by Sir Robert Stewart. The garrison consisted of 800 foot, and 180 horse, under the command of Sir C. Coote. Neither of them could have held out any time, if any ships had been sent to guard the coast, and lie in the mouth of the river to interrupt the supplies of men, money, ammunition and victuals, which Sir C. expected soon Mar, with a good party to strenothen the army before Derry, and the lord Montgomery joined his forces to the besiegers soon after. These officers were all devoted to the service of Charles the II., and had commissions under him, and that monarch was proclaimed with great solemnity in the camp before Derry. The execution of the late king had at this time caused such a general feeling of disgust among the presbyterians as well as protestants of the north, that they rose in arms, declared against the English rebels, and made themselves masters of all the towns and places of strength in those parts, except the forts of Derry and Culmore.

After a siege of four months, and when it was reduced to the grreatest extremities, Derry was relieved by Owen Roe O'Neill, who was promised by Coote $£ 5,000$ for this service, and in the following year, Coote, by the defeat of Ever Mac Mahon, the Roman Catholic general at Skirfolas in Donegal, reduced all Ulster under the power of the parliamentary army.

1656. The services of the citizens of Derry in the cause of the rebellion were not forgotten by the usiurper. The original charter of James the lst having been condemned and cancelled by two warrants of king Charles the Ist, it was regranted by Cromwell, 24th March, 1656, with additional liberties and privileges. [In the History of the Irish Society, it is stated that it does not appear that this charter was ever enrolled in the office of rolls in Ireland. But this is an 


\section{HISTORY.}

error. It was enrolled in 1658 , and is yet preserved in the rolls office]. In this year a great number of marriages were solemnized before John Hansford, mayor of Derry.

1662. April 10. Upon the restoration, the city of London petitioned the crown for a reversal of tle judgment given against their first letters patent; but as the proceedings necessary to be adopted in this respect, it was considered, would be tedious, the king proposed to grant a new charter, to embrace all the possessions and rights the city originally possessed. Accordingly, (the grant of Cromwell being deemed insufficient), on the 10th of A pril, 1662, letters patent were made out, which contained, with very little alteration, all the clauses of the first charter of James the 1st, which charter is that under which the Irish Society and corporation of Londonderry now act.-(Hist. of the Irish Soc.)

1668. A great part of the city was destroyed by fire.-(Ib.)

15 th September. The society required from the corporation of Londonderry a certificate under seal, of their by-laws, for confirmation of the society, agreeably to the provisions of the charter, and expressed their unwillingness to receive any communications purporting to be the acts of the common council of Londonderry, unless they were under the seal of that corporation.- $(I b$.

1684. June 13. The corporation of Londonderry, by letter to the Irish Society, offered to hold a correspondence with them, and to render a faithful account of their concerns when desired. $-(I b$.

September 4 th. King Charles the 2nd being informed that in the several charters granted by King James the 1 st and limself, incorporating the city, there was no power given to take the acknowledgment of statute staples, which had been granted to many cities and towns not so considerable as the city of Londonderry for trade, and in the said charters one fair being only granted, to be held 24th August, and several days then next following; also that the sessions of the city are to be held by the said charter's before three Justices of the Peace of the city, at least, of whom the mayor and recorder are always to be two, which had been the occasion of some inconvenience, by the recorder's being often absent at the terms when the said sessions should be held; his Majesty (at the suit of the city, and pursuant to letters from Windsor, 14th June, 1684) granted and constituted a guild of the staple, consisting of a mayor and two constables, and such a number of merchants of the city as to said mayor and constables, for the time being, should seem meet; the mayor and constables to be chosen yearly, and to execute all things thereto belonging, as fully as the city of Dublin or any other city or town, had used or accustomed; to hold two fairs more in the city or franchises on the 6 th June and 6 th October (unless on Sundays), and three days next following each; rent 20s. sterling: any three justices of peace, whereof either the mayor or the recorder to be always one, to keep and hold the sessions of the city in the same manner, as by the former charters the mayor and recorder, with any other justice or justices of the city, might or could hold the same: provided always, that the said justices shall not proceed in any capital cause at any of their sessions, unless the mayor and recorder shall be both personally present.-(36 Car. $2,2^{\mathrm{a}}$. pars $d .46$.)

1685. During this year there was a great decay of trade in the city. The corporation complained that the government of the place was too expensive for the magistrates to sustain, and they supplicated the society for an abatement of rent, and the society promised them assistance.(Hist. Irish Soc.)

1687. The bishop of Derry laid claim to the quarter lands, which became the subject of a long and expensive litigation, which, as will appear hereafter, terminated in the rejection of his claim.- $-(I b$.

A guo warranto was brought against the corporation, by king James's government, and tley were shortly after deprived of their charter by judgment of the court of Exchequer.-(King.)

1688-9. The siege of Derry, which commenced on the 7 th of December, by the closing of the gates against lord Antrim's regiments, was raised on the 30th of July following.-(See County history.) The city was found to be reduced to a very sad and deplorable state, but active measures were speedily taken to restore it. By the representations of its heroic defender, Mr. Walker, to the Irish Society, the 12 chief companies of London were induced to advance $£ 100$ a-piece; wood was supplied hy the society for the public buildings, and abatements were made in the rents, and the terms of leases augmented.- (Hist. of the Irish Soc.)

1692. The corporation endeavoured to negociate with the bishop (King) for a renewal of the lease of the quarter-lands, which was then near expiring; but their terms were refused. The corporation knowing that the bishop's claims to these lands were unsubstantial, and deeming it their interest to make a discovery of the fact to the Irish Society, accordingly did so, and entered into an agreement with the society to establish their right for a consideration of $£ 9010 \mathrm{~s}$. a-year, which sum is still paid to the corporation. On the 18 th of July, 1695 , an ejectment was brought by the society against the bishop for the remainder of the 1500 acres comprised in the society's letters patent, and on the $23 \mathrm{~d}$ of November the society resumed the possession of them. On the Ist of October, 1697, the bishop appealed to the house of lords against the order of the chancel. 


\section{CITY OF LONDONDERRY.}

lor, and obtained an order for re-establishing him in his possession, which being opposed by the sheriffs, and other inhabitants of Derry, they were in consequence taken into custody, and carried to Dublin. On the 23d of November the Irish Society appealed to the English house of lords against the decision of the lords in Ireland, and in 1703 an act of parliament was passed establishing the Society not only in the right to the 1500 acres, but also to the fisheries, which had previously been a source of much litigation. The society, however, were bound to pay a rent charge of 250 per annum, to the bishop and his successors for ever, (which sum is still paid), and to exonerate him from any rents or other demands whatsoever, for the palace and gardens in Derry.(Condensed from the Hist. of the Irish Soc.)

1704. Ten Presbyterian aldermen, and twelve burgesses refuse to qualify according to the act of conformity, and resigned their offices. Robert Rochford, recorder of the city, advised the mayor, \&c. to elect other members in their place; the mayor, therefore, to leave the dissenting members without excuse, caused the sergeants to summon them twice. None, lowever, attended; consequently he proceeded to a new election on the 12th of August, and filled up the vacancies. This circumstance occasioned the necessity of a special act of parliament respecting the qualification of Presbyterians in these respects.-(Gillespie's Annals of Londonderry.)

1721. February $2 \mathrm{~d}$. The military commander of the garrison refused to deliver the keys of the city to the new mayor, which by the charter he was bound to do and surrounded the townhall with troops, and prevented the entrance of the corporation into it. Immediately after the commander was removed.- $(I b$. $)$

1725. Cicily Jackson, servant of the bishop, was burned at a stake outside Bishop's-gate, for the murder of her natural child.-(Ib.)

1769. September 23rd. King Charles the 2nd having, by his charter, granted that the mayor, recorder, and four senior aldermen who had served the office of mayor, should be justices of the peace of the city and liberties, and the corporation having represented, that, from the increase of trade and manufactures, the inhabitants were become very numerous, and that it frequently happened that the four senior aldermen, from their age and infirmities, were incapable of transacting business, or retired into the country at a distance, so that the whole business of the magistry devolved upon the mayor, which he was unable to do, with the other duties of his office, and that it had been found by experience, that for the more speedy administration of justice, a greater number of justices of the peace was requisite; wherefore the king, by this charter, grants that all the aldermen who have, and who hereafter shall serve, the office of mayor, from the time of the expiration of their said office, may be appointed justices of the peace of the said city, during such time as they shall continue in the office of aldermen.-(9 George 3.-Lodge's Parliamentary Reg.)

1779. June 4th. The Londonderry Volunteer Association was established for the defence of the country-Thomas Conolly, Esq., the county member, commandant.

1781. May 23rd. The Irish Society contributed $£ 100$ towards the association.

1788. November 19th. The Irish Society contributed $£ 50$ towards the celebration of the centenary of the 9 th December, 1688, at Londonderry. This commemoration of the shutting of the gates was continued for three days with great vivacity and splendour, and in an uninterrupted spirit of harmony and conviviality, by the citizens of every denomination and class.

\section{Section 2.-Biographical.}

\section{Bishops.}

Before proceeding to that part of this subject, which relates to the bishops, it will be proper to give some account of the ancient and present state and constitution of the chapter of this see, as well as of the extent, subdivisions, \&c., of the diocese.

Chapter.--Owing to the destruction of the ancient records of this see, in the civil war's of Tyrone, nothing is known of the original constitution of the chapter, further than that it consisted of a principal and three inferior or rural deans, an archdeacon, and a certain number of other canons, "who assisted the bishop, and had their houses, and kept their residences about the Cathedral Church, and had lands belonging unto them, which were called the Canons' lands." These lands, which constituted the termon, or free lands of Derry, and lay partly within the island of Derry, and partly beyond it, but adjacent to the canons' houses, being all found by an inquisition taken in 1605 , while the see was vacant, to be abbey lands, and the property of the crown, were granted to the then governor, Sir George Pawlet, and were for some years after his death in the possession of his widow and heirs. These grants were, however, suddenly revoked, and at the plantation in 1609 , a considerable portion of the termon lands were given to the bishop and dean. The origi- 


\section{HISTORY.}

Mal canons were, however, not restored, but in their place a chapter was constituted, consisting only of a dcan, archdeacon, and three prebendaries, namely, those of Cumber, Moville, and Aghadowey.

"The Deanery is endowed with domains, glebes, and with all the tithes and perquisites of three parishes, the cures of which he [the Dean] serves by himself and assistants. The Domain Lands of the Deanery are called Ballyowen, and contain by the old survey about 706 acres. The Parishes belonging to the Deanery are Templemore, alias Temple-Derry, Clondermot, and Faughanvale. These ly round Londonderry, and extend in some places ten miles from the city, which city, with all liberties thereof, ly in these parishes. sterling:

"The King is Patron of the Deanery. The valuation in the King's book is 50 [Pounds]

"The Parish of Dunbo is the living of the Archdeacon.

"The Archdeacon and Prebendaries are merely nominall, having no jurisdiction, nor is there any obligation on them to attend the Cathedral, except when a Chapter is called, or an ordination requires their attendance. They are endowed no otherwise than plain rectors, each having the glebes and tithes of a Parish for his subsistence, and they are obliged to reside and have cure of souls, as much as any other Rectors in the diocese." -(King's MS. Visitation Book).

"It were much to the honour and advantag'e of the Catliedrall that new letters patent should be taken out for settling the chapter, in which mole members may be added, and those obliged to attend the Bp. and Cathedrall at least at ordinations and examinations of clergymen, and at such other solemn acts as require the presence of clergyman by the Canons.

"These following Rectories are all in the Bps. gift, and may be erected into præbends, being" of good value and able to bear it: Clonleigh, Urney, Badoney, Tamlagh Finlagan, Fahan, Tamlagh O'Crily, and Bally na Screen."

"The Dean and Chapter were anciently a Corporation, but lost their records in the Civil Wars of Ulster, on which consideration B. Charles 1st, by his letter, dated November 20, the 7 th year of his reign, [1632], ordered letters pateut to be granted them, the grant for which patent is in the rolls, but the patent, if ever taken ont, is lost."- $-($ King $)$.

"By patent, dated September 17th, 1634, King Charles granted a license to the Society of the Govcrnors and Assistants of London of the new plantation in Ulster, to alien in mortmain to Bishop Bramhall and his successors, the Church, or fabric of a church, lately built in Derry, together with a chancel, a library, a vestry house, and Tower, belonging to the same, and also a church yard and place of burial lying about the same, to the end that they might be consecrated to the service of God, to have and to hold to the Bishop and his successors in frank almoyne, together with a clause for the use of the inhabitants of Derry, alias Templemor." - $(R o l l s, 10$ Char. 1, p. D).

Diocese.-According to bishop Downham's Visitation Book, the diocese consisted originally of 45 parishcs, besides 2 peculiars-Dungiven and Agivey: but these latter have since become parishes. These were divided into 4 rural deaneries :-

1. Derry alias Templemore-containing Templemore, Moyville, Coldagh, [Culdaff] Clonragh, [Cloncha] Clonmanny, Donaghclontagh, Fathan, Diser-tegny.

2. Mohey-containing Donaghkiddy, Leckpatrick, Camus juxta Mourne, Clonloy, Donag:hmore, Urney, Ardstraw, Lamfyll, Termonmungan, Diumragh, Cappy, Badoney.

3. Bynagh-containing Drumachose, Tamlaght-Finlugan, Balteagh, Bovevagh, Banagher, Cumber, Aghlowe, Tamlaght Ard, Faughanvale, Clondermot, Dunbo, Camus juxta Bann cum Macosquin, Aghadowey, Disertoghill, Killowen, Arrcgall.

4. Rathlowry, alias Maghera-containing Maghereragh [Maghera], Inistede of Ballynescullen [Ballyscullion], Ballinascreen, Tamlaght O'Crilly, Killaloughy, [Killelagh], Kilreagh [Kilrea], Disertmartin, Termoneny, Kilcronaghan.

"There is but one parish in the diocese that wants a glebe-Termonamongan: there is no sinecure within it, every rectory being entire with the cure annexed."

Patronage. - "The patronage of the bishop extends at present to all the parishes except the corPs of the deanery, which is in the gift of the crown, and those of Dungiven and Banagher, which are in the gift of the lessee of the Skinners' Company of London. It appears, however, from the 9 th of the original articles of agreement between the corporation of London and the crown, in 1609 , that the city of London " should have the patronage of all the churches, as well within the said city" of Derry and town of Coleraine, as in all lands to be undertaken by them." By the new charter of Charles the $2 \mathrm{~d}$, under which the Irish Society now hold, they were given "the advowsons, donations, free dispositions, and rights of patronage of all and singular, the rectories and churches of Towlaght Finlegran [Tamlaght Finlagan], Tawlaghtare [Tamlaghtard], Anlowe [Aghanloo], Bonacher [Banagher], Boyvanney [Bovevagh], and Boydafeigh [Balteagh], in the barony of Kennaght aforesaid, in our said late county of Coleraine, now Londonderry. And also the adrowsons, donations, free dispositions, and rights of patronage of all and singular, the rectories and 


\section{CITY OH LONDONDEARY.}

churches of Dunboe, Temple Eregle [Eırigal], Temple Desart Itowshill [rectè Temple Dísertoghill], Cames [Camus juxta Bann, cum Macosquinn], and Killowan [Killowen], in the bareny of Coleraine, in the said late county of Coleraine, now Londonderry; and the advowsons, donations, free dispositions, [dispositions] ? and right of patronage, of the rectory and church of Faighen Vale [Faughanvale], in the said barony of Annaght, in the said late county of Coleraine, now Londonderry."

It appears, however, fiom the following passage, that the rights thus clearly defined did not long remain undisputed:-

" 12th November, [1731]. -A letter was sent to Mr. Richardson, which involved matters of very considerable interest, relating to the presentation and right of patronage to advowsons, supposed to belong to the Society under their charter, and it particularly referred to a Report of the Committee of 20th June, 1717, whereby it appeared, that Mr. Davis, the Society's agent, by a letter written on or about the year 1685, supposed the Society were entitled to nine livings, and recommended their maling choice of Coleraine, Tomlatfinlagan, Camos, Bannocher, Deserttoughill, and Talaghtard; and that the Bishop should have the choice of three others, towards effecting the compromise of a dispute on the subject then existing between the Bishop and the Society; and the Committee concluded their Report in the words following, viz. "The troubles in Ireland happening soon after, in the year 1688, and the suit and controversy between the Society and the Lord Bishop of Derry soon following, were the reasons, as we conceive, that nothing further was done towards the intended compromise or agreement, between the see of Derry and the Society, touching the adrowsons, for that nothing appears in the books of the Society from that time, relating thereunto." "-(History of the Irish Society.)

Ecclesiastical Division.-.The following note to the passage just cited is the latest historical notice on this important subject:-

"From this period, the Society, and those deriving title from them, appear to have lost sight of an extensive and important right of patronage and presentation to advowsons, granted by the crown, exceeding the present yearly value of $£ 6,000$; which patronage is now exercised by the Bishop of Derry in right of his see, although it is evident, by the inquisition taken before the Bishop's predecessors and others, in the reign of King James the First, and also by the charter of King Charles the Second, set forth in the Appendix to this Work, that the Society were entitled to such adowsons."

The following account of the ecclesiastical division in 1792, is given by Sampson from Dr. Beaufort's mernoir.

The ceclesiastical boundary of the diocese of Derry is not commensurate with that of the county of Londonderry, but is extremely involved with that of other counties.

The county itself contains thirty-one parishes, of which, five with six churches belong to the primacy of Armagh; the remainder, with twenty-five churches, to the diocese of Dcrry.

The diocese extends into three other counties, viz., Donegal, Tyrone, and for a small space opposite Ballyscullion, into that of Antrim. This last circumstance probably arose from the convent of Ballyscullion having extended its precincts along the shore on the opposite bank of the lake; tle island on which the conventual church anciently stood, being equally near to either shore.

According to Dr. Beaufort, this diocese in its greatest length is 4.7 lrish, or 60 English, and in its greatest breadth 43 Irish, or $54_{2}^{1}$ English miles; containing 659,000 acres, 48 parishes, 43 benefices, 51 churches, 12,921 acres to each church, 33 glebe houses, 12 parishes with glebes, only one benefice without a glebe, and one impropriate rectory.

From the same authority, it is stated that the province of Armagh extends into the county of Londonderry 25,000 acres.

The present state of the diocese, according to the visitation book of 1834, in 52 parishes, 6 perpetual cures, and 4 chapels of ease,- the number of churches 62.

Tithes...." Before the reformation the Bishop had one-third of the Tythes [called tertia epis. copalis] a lay person, who was the Bishop's Furmer, called an Eirenach, had another, and the other third was allowed for the cure. But Bishop Montgomery, who was the first Bishop after the reformation, abolished all these, and gave the whole Tythes to the cure, King James the 1 st supporting and forwarding him in it. The Bishop hath land in every Parish in the Diocese except one."-(Harris's Ware.)

Income. - "The annual income of the Bishop, previously to the late legislative reduction of $£ 5,000$, was estimated at about $£ 12,000$. It is valued in the King's books at $£ 250$ sterling, by an extent returned anno 15 Jac. $1 . "-$ (Harris's Ware. $)$

As there are neither vicars choral, nor provision for choristers, cathedral or choir service is not performed.

By the suppression of the Tyrone rebellion, the power of the English govcrnment being at length established, immediately after, one Denise Campbell, a native of Scotland, and dean 


\section{HISTORY.}

of Limerick, was nominated to the sees of Derry, Clogher, and Raphoe. However, as he died in London without consecration in July, 1603, Ware does not rank him among the bishops. The succession henceforward becomes unbroken in the Protestant line.

George Montoomery succeeded 1605; resigned 1610. This prelate was born at Braidstane, in Scotland, in 1566, and of the illustrious family of the earl of Eglinton, head of the house of the Montgomerys in that country, and was younger brother to Sir James, created viscount Montgomery. He was preferred to the parsonage of Chedchie by queen Elizabeth, and king's chaplain, and dean of Norwich, to which he was installed the 7th of June, 1603; was promoted on the 5th of February, 1604, by privy seal, dated at Westminster, and by patent, dated the 13th of June, 1605, by king James-to the sees of Derry, Raphoe, and Clogher, and, the day following, restored to the temporalities. Sir John Davies, in his letter to the earl of Salisbury, written in 1606, complains that the absence of the bishop of Derry, Raphoe, and Clogher, (which three dioceses comprehended the greatest part of Ulster, though now united for one man's benefit), being two years since he was elected, hath been the chief cause that no course hath been taken to reduce this people to Christianity (vol. 1. page 150.) In 1610, he resigned this see and that of Raphoe, taking on him the administration of that of Meath, which he held together with Clogher till his death, which occurred in London on the 15th January, 1620, whence his body was conveycd into Ireland, and interred in the church of Ardbraccan.

Brutus Babington, (or as he is called in the privy seal, Brute), succeeded 1610, died 1611. This prelate, who was a native of Cheshire, and for some time fellow of Corpus Christi college in Cambridge, was advanced to this see by the letter of king James the 1st, dated the 11 th of August, in the 8 th year of his reign, and was consecrated at Drogheda in the year 1610 . In a writ under the privy seal, it is granted, that under the consideration of the great changes and expenses which he hath, and must sustain in attending the business for the new plantation; the king grants him the meane profits \&c., from the 2nd of May last, and to pay no first fruits. He died in September, in the year following; his death, if we believe the annalist, Francis Porter, being caused by a violent illness with which he was instantly seized on vainly attempting to burn an image of the Virgin Mary, which belonged to the monastery at Colcraine.

John Tanner succeeded 1613, died 1615. He was a native of Cornwall, educated in the university of Cambridge, and by the interest of Arthur lord Chichester, lord deputy, was first nominated bishop of Dromore by king James, in the year 1611, and afterwards advanced to this see by thc king's letter, dated the 13th of May, 1613, and was consecrated the same month in St. Patrick's cathedral. On the $23 \mathrm{~d}$ of November, 1614, he made a surrender to the crown of all the lands of his see; which surrender was confirmed by the dean and chapter on the 10 th of March following; and on the 25th of May, 1615, the same were re-granted by new patents to March following; and on successors for ever, to be holden in free almoyne with a grant of four courts leet, and four courts barron, and felon's goods, with license to his lordship only to make leases for 60 and four courts resing $6 \frac{1}{2}$ quarters of land.-(Rolls $13 i h$ Jae. 1$)$. He died in Derry on the 14th ye

George Downham, D. D., succeeded 1616, died 1634. This prelate was a native of Cheshire, and the son of William Downham, who was for some time bishop of Chester. He was, in 1585, elected a fellow of Christ Church, Cambridge, and professor of logic in that university. elected a fellow of Christ Church, Cambridgc, and professor to king James, by whom he was advanced to this see by letters under the privy seal, dated at Westminster 28th October, and by patent, dated 6 th of December, 1616, and consccrated the 6th of October in that year. He died at Londonderry on the 17th of April, 1634, and was buried there in the Augustinian church. The Londonderry on the 17 the cause of the reformed faith in his diocese, was a prominent feature zeal of this prelate Harris writes that "in the government of the Lord Chancellor Loftus, and the Earl of Cork, he obtained a commission by an intermediate warrant from himself, to arrest, apprehend and attach the bodies of all people within his jurisdiction, who should decline the same, or should refuse to appear upon lawful citation, or appearing, should refuse to obey the sentence given against them, and authority to bind them in recognizances, with sureties or without, to appear at the council table to answer such contempts. The like Commission was renewed to him by the Lord Deputy Wentworth on the $23 \mathrm{~d}$ of October, 1633. Both were obtained upon his information Lord Dith all manner of delinquents, who refused obedience to all spiritual processes." "What success," Harris adds, "this Bishop had in civilizing the Wild Irish, he must proses of the bishop himself, his efforts were far from being attended with the success which he desired. He writes in his visitation of the Diocese, that "For the removing of the Popish Priests" (of whom he says, that while they are suffered to reside amongst the people there was no hope of reformation) "our laws are weak or powerless; neither can I get the assistance of the military men as I desire, and laws are whenended, convicted, and committed, they have been by government set at liberty to follow their former courses; N 


\section{CITY OH LONDONDERRY.}

o1" when I have excommunicated them, and procured by Writ, de excommunicato capiendo, the dungeon houses of the county of Londonderry, Tyrone, and Donegall, cannot be got, to apprehend them and bring them to prison again."

John Bramhall, D. D., succeeded 1634, resigned 1660. This most distinguished prelate was born in 1593 , at Pontefract, in Yorkshire, and was of a respectable and ancient family descended from the Bramhalls, of Bramhall-hall, in Cheshire. He was educated in Sydney college, in Cambridge, where he took his degree of Bachelor of Arts, and soon after married a young and weal thy widow of a clergyman (by whom he got, with other advantages, a good library collected by her deceased husband, which greatly facilitated the literary pursuits in which he was then engaged). Being put into orders, he was presented with the rectory of Elvington, or Ethrington, in Yorkshire, and distingrished himself highly by his controversial ability and learning. He was subsequently promoted by Toby Mathews, archbishop of York, to a prebend of his cathedral, and soon aftcr to a

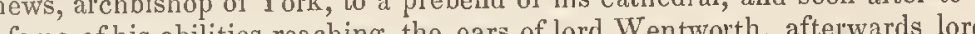
stall in Ripon - and the fame of his abilities reaching the ears of lord Wentworth, afterwards lord Strafford, who was then about to assume the lord deputyship of Ireland, he was induced by promises of preferment, as well as by his zeal for the interests of the church, to throw up his livings and accompany him in the capacity of chaplain. Shortly after his arrival, he was presented by his patron with the archdeaconly of Meath, and was employed as a commissioner in a regal visitation through the country. His services on this occasion were of the greatest benefit to the church, and upon the death of Doctor Downham, he was rewarded, through the interest of the lord deputy, with the bishopric of Derry, and was consecrated to this see in the Castle Chapel, Dublin, on the 26th of May, 1634, by James Ussher, primate of Armagh, and three other prelates. On his arrival in his diocese, he lost no time in taking the same active measures for the promotion of the interests of his cleroy, whom he found in a very impoverished statc, as he had already done in the regal visitation, and such was his success, that he is said to have doubled the revenucs of the bishopric visitation, and such was his success, that he is said to have doubled the revenucs of the bistion. "Many poor Vicars," says Harris, " now eat of the tree which the bishop of Derry planted, and many have their grounds refreshed by his care and labour, who know not the sourcc of the river that makes them fruitful." These exertions could hardly fail of drawing down upon him the hatred of all those who were in any way interested in the perpetuation of such abuses, and in the parliament of 1640, the bishop, with Sil Richard Bolton, lord chancellor, and Sir Gerard Lowther, one of the chief judges, was impeached by Sir Brian O'Neil, and a party of Irish Roman Catholics, backed by some violent and deluded Protestants. He was at Londonderry when he received intelligence of this attack from his friends, who advised him to decline the trial; but lelying on God's providence, and on the consciousness of innocence, he came to town, appeared in the parliament hoise, and was immediately committed prisoner. His enemies, however, were unable to substantiate any charge against him, beyond his undaunted endeavours to retrieve the ancient patrimony of the church, and their malice was orerruled by the king, who wrote to this kingdom at the instance of the Earl of Strafford, and he was restored to liberty without any public acquittal, the charge still lying dormant against him, to be awakened when his enemies should find a fit opportunity.

He had scarcely arrived in Londonderry when the rebellion broke out, when finding himself surrounded by enemies, he took ship privately for England, where he was graciously received by the king, and immediately employed his vigorous mind in various ways conducive to his majesty's service. After the fatal battle of Marston Moor he fled to the continent, where he remained till 1648, when he returned into Ireland, where he passed safely through a succession of dangers, of which the most remarkable was his escape to France, though pursued by two frigates belonging to the parliament. He remained abroad till the restoration, when on his return to England he received a suitable reward for his services and zeal in the royal cause, being on the 18 th of January, 1660, translated from the see of Derry to the archbishopric of Armagh. He died of apoplexy, in Dublin, on the 25th June, 1663, in the 70th year of his age, and was buried in Christ Church. For a more full account of this distinguished man, who is described by Grainger as " one of the most learned, able, and active prelates of the age in which he lixed; an acute disputant, and an excellent preacher;" the reader is referred to his life, written by Doctor John $\checkmark$ esey, bishop of Limerick, prefixed to his works, published in four volumes, folio, in 1676; or to Harris's Ware, among the archbishops of A rmagh, fron which this notice is chiefly taken.

George Wild, or Wield, (succeeded 1660, dicd 1665), Doctor of Laws of the unirersity of Oxford, was the son of Henry Wild, a citizen of London, and born in the county of Middlesex. He was educated in Merchant Taylors' school in London, whence he was elected a scholar of Saint John's college in 1628, of which he was afterwards a fellow. After taking one degree in the faculty of civil law in 1634, he was made chaplain to Doctor Laud, archbishop of Canterbury, who preferred lim to the vicarage of Reading, and intended higher promotions for him, had not the civil wars broken out. He adhered in the rebellion to the royal cause, and suffered much in its service, for which he was, on the restoration, promoted to this see by letters patent, dated the 22 nd of January, 1660 , and on tlic same day had his mandate for consecration and writ of res- 


\section{HISTORY.}

titution to the temporalities, and was consecrated in Dublin, in Saint Patrick's Church on the 27 th of January following, by the primate, assisted by three other prelates.

"He becane," says Harris, " highly valued for his public spirit, religious conversation, exemplary piety, and extensive charity, in which, and hospitality, he, for the most part, spent the revenues of his See. Anthony Wood says, he was, in his younger days, a person of great ingenuity, and in his elder, of singular prudence, a grace to the pulpit; and when in Ireland, as worthy of his function as any there. He died in Dublin on the 29th of December, 1665, and was buried on the 12th of January, in Christ Church, [near the Altar,] his chaplain, George Senior, preaching his funeral sermon."

The virtue, humanity, and amiable cheerfulness of this bishop's character are equally manifest in his will, dated about two months preceeding his death; some particulars of which are given by Harris, but here necessarily omitted for the sake of brevity. It should be stated, however, that in the disposal of the very little which he had to leave after him, the poor of his diocese were not forgotten.

Robert Mossom, D. D., (succeeded 1665, died 1679). The father of this prelate kept a school in London, and was himself a considerable sufferer during the usurpation. After the restoration, he was made dean of Christ Church, Dublin, on the Ist of February, I660; pre. bendary of Knaresborough in the cathedral of York; and thence promoted to this see by privy seal, dated at Oxford, 11 th of January, 1665, and by letters patent, dated the 26th of March, his writs of consecration and restitution the $27 \mathrm{th}$. He was consecrated in Clrist's church on the Ist of April following, by James, archbishop of Armagh, assisted by the archbishop of Dublin, and the bishops of Kildare, Killaloe and Achonry. He died at Londonderry on the 21st of December, 1679, and was buried there in the cathedral.

Michael Ward, succeeded 1679, died 1681. He was a native of England, but had his education in the university of Dublin, where he took the degree of Doctor of Divinity, on the 8th of July, 1672, having been previously elected fellow, in which situation he was distinguished for his more than ordinary pains in the care and instruction of his pupils. He was successively adranced to the deanery of Lismore, the archdeaconry of Armagh, and to the provost-ship of the university, by letters patent, of the 19th of February, 1674, through the interest of the duke of Ormond; he was thence promoted to the see of Ossory, by letters patent, dated the 8th of November, 1678, and was consecrated in Christ's Church by the archbishop, assisted by the archbishop of Tuam, and the bishops of Clogher, Meath, and Clonfert, and was finally translated to Derry, by letters patent, dated the 2 I st of January, 1679, where he died on the 3rd of October, I681, and was interred in his cathedral. He was greatly esteemed for learning and sound judgment, to which qualities he owed his rise to so many preferments within so short a period of time.

Ezekiel Hopkins, D. D. He was born in the parish of Crediton, near Exeter, in Devonshire, and was son to the curate of Sandford, a cliapel of ease belonging to Crediton. He was educated in Magdalen College, whence he was, by the interest of Sir Thomas Viner, made lecturer of the parish of Hackney, and after a long interval of time, promoted to the parish of St. Mary, London.

Being driven by the plague from thence, he returned to Exeter, where he obtained a parish from the bishop, and having the good fortune to give great pleasure, by his preaching, to lord Truro, who was shortly after sent over to Ireland, as lord lieutenant, he brought him with him as chaplain, in 1669, and the same year gave him his daughter in marriage, and rewarded him with the treasurership of Waterford, and the year following, the deanery of Raphoe. On the retirement of lord Truro from the vice-royalty, he was strongly recommended by him to his successor, lord Berkely, of Stratton, who on the 27 th of October, 1671 , promoted him to the bishopric of Raphoe, to which he was consecrated, in Christ's Church, Dublin, by Janes, archbishop of Armagh, assisted by the bishops of Clogher, Waterford, and Derry. Ten years afterwards he was translated to the see of Derry, by privy seal, dated the 6th of September, I681, where he continued until the breaking out of the troubles, when he fled into England with his wife and children, and obtaining a parish there, died on the 22nd of June, 1693, and was interred in the church of St. Mary Aldermanbury. His income as bishop was valued at $£ 2000$.

He was at great expense in beautifying and adorning the cathedral of Derry, and in furnishing it with an organ and massy plate, and is said in this bishopric, and that of Raphoe, to have expended $£ 1000$, in buildings and other improvements.

Harris says, that he was a prelate greatly esteemed for his humility, modesty, and charity, as also, for his great learning and excellent preaching, and was reckoned no inconsiderable poet.

William King, D. D., succeeded 1690; resigned 1702. For a full account of this most distinguished prelate, who was the first born Irishman, as well as the most distinguished prelate for abilities, who had filled the see from the establishment of the reformed religion in the diocese, the reader is referred to his life in Harris's Ware, and the account of the Irish writers in the same work. $\Lambda$ few particulars are all that the nature of this worl will permit here. William King 


\section{CITY OF LONDONDERRY.}

was born at Antrim on the 1st of May, 1650, and was descended of an ancient and respectable family of the house of Burras, in the North of Scotland, whence his father removed in the reign of Charles the Ist, to avoid engaging in the solemn league and covenant, and settled his family and effects in the North of lreland, and had the happiness to live to see his son promoted to the bishopric of Derry. He was sent in 1662 for his education, to the Latin school of Dungannon, and on the 18 th of April, 1667, was admitted into Trinity College, Dublin, where his extraordinary talents and application were soon noticed, and rewarded with a scholarship and native's place. On February 23d, 1670, he took the degree of Bachelor of Arts, and in 1673, that of Master ; and, in the same year was put into deacon's orders, by Dr. Mossom, bishop of Derry. The honour he obtained by a fellowship examination, on a week's preparation, though unsuccessful, obtained lim the notice of John Parker, archbishop of Tuam, who in 1674 took him under his protection, ordained him a priest on the 12 th of April in the same year, and admitted him into his family as a domestic chaplain, on the 10th of January, 1676. The same year he was collated to the prebend of Kilmainmore, in the cathedral of Tuam, and afterwards to the provostship of that church, and, to the rectory and vicarage of Killaseran, Aghicert, and others, united October 26 , 1627 , by the same.

While in the archbishop's family he diligently applied himself to the study of all useful learning, and acquired that store of knowledge which subsequently enabled him to become so eminently serviceable to church and state, and to raise himself to such a distinguished elevation. On the translation of his patron to the see of Dublin, Mr. King was collated to the chancellorship of Saint Patrick, to which the parish of Saint Werburgh's is annexed, and was installed therein on the 29th of October, 1679.

He remained here zealously employed in preaching, writing; and keeping his flock together, till the Irish took up arms in the cause of James the $2 \mathrm{~d}$, and in the disastrous times which followed, continued courageously at his post without any relaxation of his exertions. By this daring exlibition of zeal he made himself very obnoxious to the Roman Catholic party, by whom he was twice imprisoned during the years 1689 and 1690, but released each time without other injury than personal indignities. It was during this period that he wrote his chief work:- "The State of the Protestants in Ireland under King James's Government;" an able but partisan production. The victory of the Boyne put an end to his danger's, and opened the door to his ecclesiastical advancements. The see of Derry having been kept vacant by king James till the revolution, Dr. King was promoted to it by letter's patent of king William and queen Mary, dated the 9 th of $J_{a}$ nuary, 1690, and was consecrated in Christ's Church, Dublin, on the 25th of the same month, by Francis, archbishop of Dublin, assisted by the bishops of Meath, Kildare, Killaloe, and Leighlin and Ferns. He immediately repaired to his diocese, which he found in a miserable and distressed condition, but which, during the three years in which he remained there, he restored to a state of order and security. He built, it is said, a capacious house in Derry-the under rooms to serve for a school-house and conveniences for a master, and the upper rooms for a library. He also bought from the executors of bishop Hopkins the library of that bishop, or a great part of it, which by his will, dated the 6th of May, 1726, he devised to William Nicholson, then bishop of Derry, and his successors in trust, to remain in the said library for the use of the clergy and gentlemen of the said diocese for ever.

The promotion of archbishop Marsh from Dublin to the primacy in 1702, opened the way to the former for bishop King, to which he was translated by letters patent, dated the 11 th of March following, and which he governed with his usual zeal and diligence for upwards of 26 years. He died at his palace of Saint Sepulchre's, Dublin, on the 8 th of May, 1729, having just attained the 80 th year of his age, and was interred on the north side of the church yard of Donnybrook, as he had previously directed.

The character of this prelate, as given by Halris, from whom this sketch of his life is drawn, is enthusiastically laudatory, and assigns him all the qualities of head and heart that should belong to a Christian bishop.

Charles Hickman succeeded 1702, died 1713. The successor of Doctor King was a native of Northamptonshire, and Doctor of Divinity in the university of Oxford. He was rector of Saint Ebbs, in Oxford, for sometime afterwards chaplain to Charles, duke of Southampton, and in 1680 to James lord Chandos, then going as ambassador to Constantinople. In 1680 he was made domestic chaplain to Laurence, earl of Rochester, lord lieutenant of Ireland, and the year following took his degree of Doctor of Divinity. Upon the revolution he was made chaplain in ordinary to king. William and queen Mary, and in July, 1692, lecturer of Saint James' Church, Westminster, and afterwards rector of Hogs-Norton, in Leicestershire, and chaplain in ordinary to queen Anne, by. whom he was promoted to this see by letters patent, dated the 19 th of March, 1702, and was consecrated at Dunboyne, on the 10th of June following, by Narcissus, archbishop of Armagh, assisted by the bishops of Kilmore, Ardagh, Ossory, and Killaloe. He died on the 28 th of Novenber, 1713, and left by his will $£ 20$ to the poor of Derry. There is a small tablet erected to his memory on the left of the chancel-table, in the cathedral. 


\section{HISTORY.}

John Hartstonge succeeded 1713, died 1716. He was the son of Sir Standish Hartstonge, one of the barons of the exchequer in Ireland, was born at Catten, near Norwich in England, 1st of December, 1659, and educated at the schools of Charleville and Kilkenny, from the latter of which he was admitted into Trinity College, Dublin, and thence sent to Gonvill and Caius college, Cambridge. Here he took his degree of Master of Arts in 1680, and was unanimously elected a fellow in 1681. He was soon after made chaplain to James duke of Ormond, then lord lieutenant of Ireland, and after his death in 1686, to his grandson, to whom he was indebted for his promotions. He was raised from the archdeaconly of Limerick to the see of Ossory, at the instance of his patron, by King William, by letters patent dated the 8th of April, 1693, and was consecrated in Christ's Church, Dublin, by Francis, archbishop of Dublin, assisted by the bishops of Meath, Kildare, Elphin, and Waterford and Lismore. From Ossory he was translated, by letters patent dated the $3 \mathrm{~d}$ of March, 1713 , and died in Dublin the 30th of January, 1716.

St. George Ashe succeeded 1716, died 1717. This prelate was born in the county of Roscommon, in the year 1658, and educated at the university of Dublin, of which he became a a fellow in 1679, and provost in 1692. He was successively promoted to the sees of Cloyne 1695, Clogher, 1697, and Derry, by letters patent dated the 25th of February, 1716, and died in Dublin on the 27th of February, 1717, where he was buried in Christ's Church. He was a man of learning and a member of the Royal Society, to the transactions of which he contributed some papers. He bequeathed all his mathematical books to the college of Dublin.

William Nicholson, D.D., (or as he usually wrote it himself, " Nicolson"), succeeded 1718, resigned 1726. This distinguished prelate was born at Orton, in Cumberland, educated in Queen's College, Oxford, and was first vicar of Torpenhoe, 17 th of November, 1681, collated to the first stall in the cathedral of Carlisle, 13th of October, 1682; to the arclideaconry and bishopric of which he succeeded, and was translated to Derry by letters patent, dated the 2nd of May, 1718, and on the 28th of January, to the archbishopric of Cashel, and died suddenly in Derry the month following. Doctor Nicholson was a man of literary and antiquarian taste, and published, among other works, the English, Scotch, and Irish Historical Library, a useful and meritorious performance for its time. He is said to have built an apartment near his garden at Derry, for the preservation of the manuscripts and records relating to the see.

Henry Downs succeeded 1726; died 1734. This prelate, who was first minister of the church of Barrington, in Northamptonshire, was promoted to the bishopric of Killaloe, by letters patent, dated the lst of February, 1716, translated to Elphin, in 1720, from Ephin to Meath, in 1724, and thence to Derry, the 8th of February, 1726. He died on the 14th of January, 1734, and was buried on the 16th, in Saint Mary's Churcl, Dublin. He left by his will $£ 20$ to the poor of Derry.

Thomas Rundle, LL.D., succeeded 1734; died 1742. He was presented 22d "January, 1721 , to the first stall in Durham; 22d November, 1722, removed to the 12 th. He was treasurer of Salisbury, and archdeacon of Wilts. With this stall he was made rector of Sedgfield. He was promoted to the see of Derry by letter's patent, dated the 17th July, 1735, by — Talbot, lord chancellor of England, to whom he had been chaplain, and was consecrated in the church of Dunboyne, on the 3d of August following, by Hugh, archbishop of Armagh, assisted by the bishops of Meath, Kilmore, and Ardagh. He died in Dublin on the 15th of April, 1742, and was buried in St. Peter's church-yard at the north side, where a stately monument has been erected to his memory.

Carew Reynell succeeded 1742 ; died, 1745. This prelate was translated from Down and Connor, by letters patent, dated the 16th of May, 1742, and died the Ist of January, 1744. He had been chancellor of the cathedral of Bristol, and chaplain to the Duke of Devonshire, lord lieutenant of Ireland, by whose interest he was promoted to these sees.

George Stone succeeded 1745; translated 1746. He was first promoted to the see of Ferns, by letters patent, the 5th of June, 1740, and consecrated at Chapelizod, by the archbishop of Dublin. On the $3 \mathrm{~d}$ of August, 1742, he was translated to Kildare, installed dean of Christ's Church, 15th of June, 1743, and translated to Derry by letters patent, dated the $1 \mathrm{Ith}$ of May, 1745. He was thence translated to the primacy of Armagh, by letters patent, the 13 th of March, 1746, died in London the 19th of December, 1764, and was buried in Westminster-Abbey.

William Barnard succeeded 1746, ob. 1768. Doctor Barnard, prebendary of Westminster, was made dean of Rochester in 1743 , and promoted to the see of Raphoe by letters patent, dated the 26th of June, 1744. He was consecrated at Saint Michael's Church, Dublin, August the 19th, and translated to Derry by letters patent, dated the 19th of March, 1746. He died in London, 10th January, 1768, aged 72, and was buried on the 17th, in Saint Peter's Abbey, Westminster. A monument was erected to him in Islips chapel. He was a man of distinguished piety and virtue.

Frederick Hervey succeeded 1768, died 1803. Frederick Hervey, 4th earl of Bristol, was the third son of John lord Hervey, whose father Joln was created baron Hervey of Ickworth, in the 


\section{CITY OF IONDONDERRY.}

county of Suffolk, in 1703, and earl of Bristol in I714. He was born in 1730; educated at Mr. Newcomb's school, at Hackney; admitted of Corpus Christi Collcge, Cambridge, 1747, where he took no degree, but the honorary one of D. D. was conferred on him by mandamus. He was appointed chaplain in ordinary to the king, and principal clerk of the privy seal, which otfice he resigned in February, 1767, on being promoted to the bishopric of Cloyne. This dignity was conferred on him, while his brother George, 2nd earl of Bristol, was viceroy of Ireland, and on the 30th of January, in the year following, he was translated to the see of Derry, and appointed a privy councillor of Ireland. On the death of his brother Augustus John, 3rd earl of Bristol, in 1779, he succeeded to that title. He married Elizabeth, daughter of Sir Jermyn Davers, of Rushbrook, in Suffolk, Bart., who dicd at Ickworth, Suffolk, December 19th, 1800, by whom he had issue two sons-John, who succeeded him in the title, and Augustus John; and two daughters - Nary, married to John Lord Erne, and Elizabeth, married to John Thomas Foster, Esq. The latter years of lord Bristol's life were spent in continental travel, and he died at Albano, near Rome, of a severe attack of gout, in his $73 \mathrm{~d}$ year.

The political character of this very remarkable man belongs to the general history of his time, and it is only necessary to remark here, that in the mcmorable political events connected with the Irish volunteers, in whicl he played so conspicuous a part, the city and county of Dery very strongly felt the influence of his rank and talents. In private life he was no less distinguished for refined taste in literature and art, than for the possession of many Christian virtues, among which those of humanity, charity, and libcrality were not the least conspicuous; and as a bishop, he was a zealous promoter of every thing tending to the good of his see, and the advantage of the city and county in general. To his taste and munificence the city and county owe many of their chief architectural embellishments. He ncarly rebuilt the palace, and contributed largely to the erection of a spire and other improvements to the cathedral, and many of the parish churches are similarly adorned or newly built under his patronage and by his assistance. The gorgeous collections of pictures, statues, books, \&c., with which he filled the princely residences erected by him at Downhill and Ballyscullion, abundantly testified the justness of the character awarded to him as the greatest patron of the arts in Europe in his time. But he left after him a memorial still nobler, less perishable, and morc worthy of a Christian bishop, the memory of his singular humanity and universal benevolence.

William Knox, D. D., sncceeded 1803, died 183I. This very distingished prelate, who was the $3 \mathrm{rd}$ son of the late lord viscount Northland, was born on the 13th of June, 1761. He was educated in , and received holy orders in

His first employment in the church was as curate in the city of Limerick, and having been soon after appointed chaplain to the Irish house of commons, he was recommended by that body to the lord lieutenant for preferment. He accordingly obtained the union of Callan in the county of Kilkenny, where his memory is still cherished, as wcll for his kindness and hospitality, as for his exertions in building and establishing a poor school on a very extended scale, and for other efforts to ameliorate the condition of the poor. He was appointed to the bishopric of Kilfenora in $\mathbf{1 7 9 4}$, and presided over that see for nine year's. It was during this period that a society, consisting of the most distinguished men of that day, was formed "for promoting the comforts of the poor." The bishop was one of its most active members, and a paper written by him, and published among their transactions by the society, on the utility and management of dispensaries, poor schools, and schools of industry, contained most valnable practical details on matters which, though so interesting, were not then very gencrally attended to or understood. His translation to the see of Derry gave him a wider field, and more ample means, to exercise that munificent philanthropy, which was the distinguishing characteristic of his mind. He succeeded a bishop, who, though of princely munificence, did not, in consequence of his absence from Ireland during the latter years of his life, take that active interest in the welfare of the church which might otherwise have been justly expected from him; and thereforc Dr. Knox, on his arrival in Derry, found a neglected diocese, and a "cathedral in ruins." He immediately contribu ted $£ 1000$ towards its repairs, and subsequently added $£ 2000$ more towards its internal adornment, and the erection of the present spire. He also made gifts of $£ 1000$ and $£ 100$ per annum, to the diocesan school, and $\mathfrak{\& 4 0 0}$ and $£ 20$ per annum, to the poor school. His lordship established yet further claims on public gratitude by founding the charitable loan, to which he largely contributed, and for which in the pulpit he most effectually pleaded. The mendicity association also was chicfly indebted to him for its origin, and owes much of the success of its efforts to his fostering care and large pccuniary contributions. Indeed, there is scarely one of the numerous public institutions of Derry of which he might not be called the parent, while his private charities were no less extensive, well-timed, and munificent. As a bishop, Dr. Knox was eminently entitled to respect and admiration, and was generally loved by his clergy, for though he never compromised the duties of his high office, he yet governed with a mild and paternal hand, encouraged zeal, fostered piety, and rewarded talent. The number of churches and glebe-houses built during his presidency 


\section{HISTORY.}

evinces the deep anxiety with which he fulfilled the duties of his station. The free church of Derry, which he built and supported at his own private expense, may be adduced as a proof of his zeal for the interests of religion, and the spiritual welfare of a large portion of the population previously unprovided with accommodation in a place of public worship, while his splendid gift of $£ 1000$ to the clergymen's widows' fund manifested the paternal interest with which he regarded every thing connected with the peace and comfort of the body over which he presided. His mind was at the same time free from prejudice, liberal and enlarged; in proof of which it will be sufficient to state that he cheerfully contributed to the schools and houses of worship of the different religious denominations within his diocese. To this brief sketch it should be added, that by his generous hospitality, as well as by the kindness and affability evinced in his familiar intercourse with the citizens of Derry, he won the affectionate regard of all classes. This distinguished prelate died in London on of July, 1831, and his remains were interred on the 17 th in the vault of North-Audly-st. chapel.

Richard Ponsonby succeeded 1831. A respectful delicacy towards the present estimable occupant of the episcopal chair of Derry, prompts the propriety of leaving his character to the justice of posterity-accompanied, however, with the hope, that it may be long before it shall be called on for its award. But it would be an unworthy omission to close these slight sketches of the bishops of Derry of the established church (the materials are wanting to do equal justice to the Roman Catholic), without the concluding remark, that on the wholo they present a succession of individuals distinguished for learning, or talents, or virtues, and not unfrequently all these united, which would not be disparaged by a comparison with the prelates of any other see in the island.

\section{Deans.}

Of the deans, who are also incumbents of the parishes of Templemore, Clondermot, and Faughanvale, no list is found in the records of the office of first fruits, anterior to the year 1724: those preceding that period have been collected from various sources.

A. D. 1605 . Webb, was the first dean.

1620. Henry Sutton, M. A., was dean during the prelacy of Bishop Downham, by whom he is described as " a man very well qualified, both for his learning and conversation."-(Downham's Visitation Book).

1685. Peter Manby held the deanery previously to the revolution, when he became a convert to the Roman Catholic church, in hopes, as it is said, of procuring a bishopric from James the 2nd. In this, however, he was disappointed, but he was afterwards made an alderman of Derry by that monarch.
1690. ...... Thomas Wallis, M. A.
1695. ........ Coote Ormsby.
1699. ........ John Bolton, D. D.
1724, May 4. George Berkly, S. T. D.
1740, August 9. Robert Downes, D. D.
1769, June 2. Thomas Bernard.
1781, June 21. Edward Emit, M. A.
1783, March 28. John Hume.
1818, June 6. James Saurin.
1820, Feb. 10. Thomas Bunbury Gough.

\section{Roman Catholic Bishops.}

After the death of bishop O'Gallagher, and transfer of the ecclesiastical property in 1601, the see of Derry appears to have been without a Roman Catholic bishop for upwards of a century. This was not, however, the only instance of a vacancy for a considerable time in the Irish sees, though there were but few so long wholly unoccupied; and indeed, it appears, that it was only in the primatial and metropolitan sees, that the Roman court took care to preserve an uninterrupted succession of prelates, some of whom, however, appear never to have visited their bishoprics. In the vacant sees, the episcopal power was usually exercised to a certain extent by vicars-general, by whom priests were appointed to the several parishes, and officials in the rural deaneries.

From bishop Downham's visitation-book of the diocese of Derry (circa 1620, ) we learn, that Bernard Mac Oreaghty, or Geraghty, was the first vicar-general during the vacancy in the see of Derry, and that his successor was Patrick Mac Mahon, both of whom were appointed by Eugenius 


\section{CITY OF LONDONDERRY.}

Mac Mahon "pretended archbishop of Dublin, and Darid Routhe, pretended vice-primate of Ireland." - Of the succeeding vicars-general, no accounts have been found.

The first Roman Catholic bishop after the plantation, of whom any notice has been discovered, was Terence O'Donnelly, [O'Oonn'ंสrle] the brother of Patrick O'Donnelly, titular bishop of Dromore, about the year 1720. Some time previously to this period, however, it appears that an effort was made to have a bishop appointed; for, a petition was drawn up in 1711, by Irish Roman Catholics to the Pretender, praying him to nominate Doctor Brian O'Cahan bishop of Derry. It was found on board a ship bound from Ireland to France; and, consequently, never reached its destination. (Southwell MSS.) Brian O'Cahan was parish priest of Ballynascreen, in the county of Derry.

Neal Conway [Moc Conmui $\delta$ e], a native of the parish of Ballynascreen, was promoted to this see in 1727, and died on the 6th of January, 1738. - He was interred in the old church of Ballynascreen, where a monument to his inemory still remains. He went beyond sea, before 1688 , and was about thirty years of age in 1700.-Original MS.

He was a Franciscan, and reputed guardian of that order intended to be established at Ballynascreen.-Ib.

Michael U'Reilly, Doctor of both Laws, succeeded Neal Conway. He was vicar-general of Kilmore, archdeacon of Armagh, and afterwards vicar-general and official under Hugh and Bernard Mac Mahon archbishops of Armagh, and also for five years a most vigilant rector of the parish church of St. Peter, in Drogheda. He was advanced to the see of Derry about the month of April, 1739, and concecrated in Dublin, on the 23d of September, of the same year, by John FlanaganLinegar, archbishop of Dublin, assisted by the bishops of Meath and Raphoe. $-I b$.

Patrick Brollaughan was a Benedictine monk of the monastery of Coleraine. He commenced his studies at Mountserrat, and finished them at Rome. He came to London in 1730, where he was appointed chaplain to the 'Sardinian ambassador, which office he retained to the year 1751 , when being appointed bishop of Derry, by pope Benedict the 14tll, he was consecrated on the $3 \mathrm{~d}$ of March, in that year, at the royal chapel of Sardinia in London, by James Dunne, Roman Catholic bishop of Ossory, assisted by two prelates in partibus. He immediately after betook himself to his dincese, without resioning his chaplaincy; but plainly seeing the impossibility of performing the duties of both, he voluntarily resigned the episcopal office in the year following, but not the honor, and returned to London, where he died in the month of May, 1760, aged 56 years. (De Burgo.)

- Mac Colgan or O'Colgan, D.D., succeeded, and filled the see for many years; but the year of his death is uncertain, and nothing has been preserved of his history.

Mac Devitt, D. D., succeeded. and died 1797. Of this prelate, who, like his predecessor, was of an ancient family or tribe of the Kinel Owen, very little is known. He was a literary man, and celebrated in his time for his great learning; although he published nothing. He received his education in Paris at the Irish community, ("Seminaire Irlandois Rue de cheval vert",) in which seminary he received orders.

Charles O'Donnell, D. D., consecrated 1798, died 1819. This prelate received his educa tion at the college "des Lombards," in Paris, but was ordained in the diocese of Derry, in which he alvays remained in his ministerial capacity. He was of rery liberal principles, avoiding all party feeling, and in consequence was popularly known in Derry and its vicinity under the name of "olange Charlie". In 1813, political disturbances having been excited in Derry by Mr. O'Mullan, the priest of the parish, Dr. O'Donnell considering his conduct as leader of a political party opposed to the government as improper, prohibited him from officiating as parish priest, this decision gave great offence to Mr. O'Mullan and his adherents, who attacked Dr. O'Donnell in his chapel on the 28th of November, and would perhaps have maltreated him, had he not succeeded in making his escape to the court house, where he was protected by the magistrates several persons who interfered in his favor were severely hurt.

Peter Mac Loughlin, D. D., consecrated to the see of Raphoe in 1802, translated to the see of Derry in 1819. Dr. Mac Loughlin also received his education in Paris, at the "Seminaire Irlandois," where he received orders. He is distinguished for his piety, and very generally esteemed by the various classes for his zealous and unremitting exertions to promote concord and good feeling among all sects within his diocese,-interfering in political matters only so far as to endeavour to prevent the people of his own persuasion from given themselves violently to party.

Previously to the establishment of the reformed church in Derry, the bishops were at the same time rectors of the parish, and the deans, vicars. This practice is still preserved by the Roman Catholic bishop and dean of Derry. 


\section{HISTORY.}

\section{Presbyterian Ministers.}

It is very probable that a seed of Presbyterian dissent was introduced into the city of Londonderry, at the plantation by the London companies. The first bishop, Montgomery, was a Scotchman, "who held the see from 1605 till 1610, during whose time there is little doubt but that the service in the cathedral was conducted in such a manner as to meet the scruples of the dissenters. The succeeding prelates were not so favourable, especially Bramhall, who came to Derry in 1634. He was a tool of Strafford in his severities against the non-conformists, and during the time from his accession to the rebellion of 1641 , the greater part of the Scotch, and other dissenters, fled to Scotland. After that event, however, they returned. In 1644, Derry was visited by Mr. W. Adair, and Mr. John Weir, two Presbyterian ministers fiom Scotland, sent to administer the covenant to the north of Ireland. They came in April, were opposed by Thornton the mayor, but, supported by Sir Frederic Hamilton, they obtained admittance. They then sent for the keys of the church, in order to preach there on the Sabbath, but the mayor refused them, on the ground that the sacrament was to be administered in it on that day, but he offered them 'the little church.' This they found too small, they, therefore, preached in the market place, where the covenant was solemnly taken by great numbers. On Monday they preached in "the great church," or present cathedral, "and spent some time in the city." "Thence, to the restoration, the Presbytarian worship experienced several vicissitudes, according to the opinion of the governor." "At the Restoration in 1662," as might have been naturally expected from the political part which its professors had acted in the preceding troubles, that worship "was thoroughly purged from the city as an intolerable nuisance; as appears by a letter from the curates of the cathedral, to the primate, in July of that year." It is probable that for some time after this there was no Presbytarian minister or worship, in Derry: but in 1670 , however, the congregation "gave an ample call to Mr. Alexander Moncrief, a minister in Fifeshire, in Scotland, to become their minister, but he declined. However, in $1672, \mathrm{Mr}$. Robert Rule was formally ordained their minister. He continued till the troubles, which terminated in the siege, drove him away early in the year 1688." "Mr. Robert Craighead, minister of Donoughmore, was translated to Derry in 1690," during whose ministry " the congregation had a dispute with the congregation of Burt, respecting the boundaries of their respective parishes." "The presbytery of Derry was erected in 1702." "Mr. Craighead died August 27, 1711." " After R. Craighead's death, they applied for the celebrated Abernethy, then minister of Antrim, but without success. They, however, succeeded in obtaining Mr. James Blair, minister of Moira, who was installed in Derry on June 2d, 1713," and "died in January, 1716." "Their next minister was Samuel Ross, who was ordained February 13th, 1718."

The above information has been chiefly furnished in a letter addressed to the Rev. Mr. Hay, of Derry, by the Rev. Dr. Reid, author of a history of Presbyterianism in Ireland.

\section{Governors.}

Sir Henry Docwra, knt., afterwards Lord Docwra, Baron of Culmore, by patent, Westminster, May 15th, 1621, was constituted governor of Lough Foyle, during pleasure, by letter of privy seal, March 22, 1603-4, and by patent, June the 14th, 1604, for life.

Sir George Pawlett, knt., under the title of vice provost, governed the city during the ahsence of Sir Henry Docwra, from 1604 till 1608.

Sir John Vaughan, knt., was governor, as it appears from the plantation in 1611, till his death in 1643.

Sir Robert Stewart was made governor of Derry by the king, on the death of Sir John Vaughan. 1644 .

Colonel Audley Mervin was made governor of Derry by the Marquess of Ormond in

Lord Folliott was appointed in the place of Colonel Mervin, who had become obnoxious to the parliament through the representations of Sir Frederick Hamilton, who desired the governorship for himself.

Sir Charles Coote took the governorship in 1648, and held it till the restoration.

Sir Robert Stewart, knt.-Privy seal, Whitehall, November 20, 1660-patent, February 12, 1660 -pleasure.-13 Charles 2. $1^{\text {a }}$ pars f. R. $24 \& 15-18 . d . R .28,-($ In English.)

He was made governor of the city and county, and of the county at large, in consideration of his many services performed to King Charles the 1 st, and the good affection expressed by him in 


\section{CITY OF LONDONDERRY.}

the late troubles in Ireland, in his arming and maintaining a regiment of foot and a troop of horse, at his own charge, in the service of the said King.-Idem.

Colonel John Gorges - vice Stewart-privy seal, May 7, 1661-patent, September 17, 1661 -pleasure.-13. $4^{2}$ pars d. R. 21.

\section{Parliamentary Representatives.}

1613, April 27.-George Cary, Esq. Thomas Crewe, Esq., Derry.

1634, June 13.-Robert Farrar, Esq', [knt.] Robert Goodwin, Esq.

1639, Feb. 25.-Sir Robert Stewart, knt. r. Culmore.

Sir Francis Butler, knt., r. Dublin, June, 1641. He was dismissed, but $2 d$ of August, 1642 , it was ordered, that he should be continued notwithstanding any former order to the contrary.

1661, April 8.-John Godbold, Esq., Londonderry.

Hugh Edwards, merchant, Londonderry.

1665, October - John Gorges, Esq., Somerset, vice Godbold, deceased.

1692, Sept. 12.- Robert Rochfort, Esq., Dublin. David Cairnes, Esq. burgess, Londonderry.

1692, Oct. 13. - Bartholomew Van Homrigh, Esq. Dublin, vice Rochfort, for Co. Westmeath.

1695, July 25.-David Cairnes, Esq. Derry.

Bartholomew Van Homrigh, Esq., Dublin.

1703, Sept. 2.-James Lennox, Esq., Derry.

Charles Norman, Esq., Derry.

1713, Nov. 14. -Charles Norman, Esq. Derry. John Newton, Esq., Derry.

1715, Oct. 25.-Charles Norman, Esq., Derry. George Tomkins, Esq. Derry.

1727, Oct. 11.-George Tomkins, Esq., Derry.

Thomas Upton, Esq. Dublin, Celbridge, Kildare.

1733, Dec. 6. - Robert Norman, Esq., r. Derry, vice Upton, deceased.

1739, Oct. 31.-William Scott, Esq., Dublin, vice Tomkins, deceased.

1743, Nov. 16.-Frederick Cary Hamilton, Esq., New Grange, Meath, vice Norman, deceased.

1747, Oct. 30.-Henry Hamilton, Esq., Castle Conyngham, Donegal, vice Hamilton, deceased.

1759, Nov. 9.-William Hamilton, merchant (and alderman), Londonderry, vice Scott, J. K. B.

1760, March18.-Alexander Stewart, Esq., Newtown Ards, Down, vice W. Hamilton, mis-elected.

William Hamilton, merchant, r. Londonderry, vice Stewart, mis-elected.

1761, April 28.- Francis Andrews, LL. D., Trinity College.

Henry Hamilton, Esq., Castle Coyngham, Donegal.

1764.

Francis Andrews, LL. D., Trinity College.

Hugh Hill, Esq., Londonderry.

1768, July 6.-Right Honorable Francis Andrews, LL. D., Trinity College. Hugh Hill, Esq., r. Derry.

1773. - Right Honorable Francis Andrews.

Hugh Hill, Esq., Londonderry.

1782. - Sir Hugh Hill, Bart.

James Alexander, Esq.

1790. - Sir Hugh Hill, Bart.

William Lecky, Esq., Londonderry.

1795. - William Lecky, Esq., Londonderry.

Sir George Fitzgerald Hill, Bart., Londonderry.

1799.-Henry Alexander, Esq.

Andrew Ferguson, Esq.

1800.-Right Honorable Sir George Fitzgerald Hill, Bart.

1801. - Right Honcrable Sir Georoe Fitzrerald Hill, Bart.

1806, December.-Right Honorable Sir George Fitzgerald Hill, Bart. 


\section{HISTORY}

180\%. Right Honorable Sir George Fitzgerald Hill, Bart. 1812, Nov. 24._Right Honorable Sir George Fitzgerald Hill, Bart. 1818, July -Right Honorable Sir George Fitzgerald Hill, Bart. 1820, April 21.-Right Honorable Sir George Fitzgerald Hill, Bart. 1826, July 25.-Right Honorable Sir George Fitzgerald Hill, Bart.

1830, July 7.-Sir Robert Alexander Ferguson.

1831, May 14.-Sir Robert Alexander Ferguson.

1832, Dec. 18. - Sir Robert Alexander Ferguson.

1835, Jan. 12.--Sir Robert Alexander Ferguson.

Mayors and Sheriffs after the Restoration.

MAYORS.

1662. William Gardner.

- $\left\{\begin{array}{l}\text { Gervais Squire. } \\ \text { Richard Graham. }\end{array}\right.$

SHERIFFS. no account has been obtained.

1670. Thomas Skipton.

1671. Hugh Edwards. .

1672. Samuel Norman.

1763. Ditto.

1674. Ditto.

1675. Gervais Squire.

1676. Ditto.

1677. Col, William Cecil.

1678. Thomas Moncrieff.

1679. Ditto.

1680. Thomas Moncrieff.

1681. John Campsie. .

1682. Ditto.

1683. Alexander Tomkins.

1684. James Hobson. .

1685. John Campsie. .

1686. Ditto.

1687. Andrew Coningham.
$\{$ William Noble.

$\int$ Edward Edwards.

$\{$ William Miller.

$\{$ William Rogers.

$\{$ Francis Newton.

S Samuel Hobson.

$\{$ Andrew Coningham.

$\{$ Henry Thompson.

John Buchanan.

Robert Houston.

$\{$ Henry Long.

Sames Coningham.

John Ash.

William Squire.

Alexander Lecky.

Charles Newton.

$\{$ James Morrison.

$\{$ Andrew Coningham.

$\{$ Matt. Bridges.

$\{$ John Ewing.

$\{$ Henry Farbasco.

James Gordon.

James Strong.

$\{$ Henry Cochran.

William Hemsworth.

James Sympson.

Andrew Coningham.

Matt. Cocken.

Ditto.

John Campsie, jun.

$\{$ William Newton.

$\{$ William Newton.

$\{$ Henry Ashe.
William Kyle.

$\{$ Robert Shannon.

The mayor died within ten days after he was sworn, and alderman John Campsie was sworn in his place.

1688. John Campsie.

S Horace Kennedy.

$\{$ Edward Brookes.

Mr. Campsie continued mayor till the 12 th of October, when, by appointment of the earl of Tyrconnell and council, he was removed, and Cormick O'Neill, of Broughshane, Esq. a Roman Catholic, succeeded. He came to Derry, was sworn mayor, and staid some days with his new corporation, most of the 
members being also Roman Catholic: when he went away, he made John Buchanan deputy.

From the 2nd of February, 1689, to the month of September, there were neither mayor nor sheriffs.

1690. Gervais Squire. .

( Thomas Moncrieff.

1691. Alexander Lecky.

1692. William Squire.

$\{$ Henry Ash.

Henry Ash.

Samuel Leeson.

\{ William Crookshank.

John Harvey.

Within three days after Mr. Squire was sworn in, he died, when Mr. James Lenox was elected and sworn mayor.--In the month of May, 1693, sheriff Crookshank died, and $\mathrm{Mr}_{\mathrm{r}}$. John Crookshank was chosen in his place.

1694. Henry Long.

$\{$ William Mackie.

1695. Alexander Lecky

\{Thomas Ashe.

1696. Henry Ash.

John Cowan.

Hugh Davey.

$\{$ John Harvey.

1697. James Lennox. .

Alexander Coningham.

$\{$ Joseph Morrison

1698. Horace Kennedy

J John Dixon.

( Albert Hall.

\{ Robert Gamble.

On the $2 \mathrm{~d}$ of November, Mr. Kennedy was again elected, but, not being approved of by government, alderman Brooks was chosen; and he also not being allowed, a third election made choice of Alderman Squire.

1669. Gervais Squire. • . . . SJohn Denning.

1700. Edward Brooks. . . . .

1701. Thomas Moncrieff. • J John Denning.

November 3, Alderman Kennedy was elected mayor, and James Anderson and John Conningham, sheriffs; but not being approved of, the corporation then chose

1702. Robert Shannon.

\{ Archibald Coningham.

\{ Jos. Ewing.

1703. Samuel Leeson.

Thomas Lecky.

James Anderson.

November 2, Alderman Kennedy was elected mayor, and Alexander Skipton and Joseph Davey, sheriffs; Mr. Kenedy not being approved of, Alexander Mackie was chosen; he also being disapproved of, alderman Cowan was elected, and laid aside. Without any election, the present mayor was sworn, 2 d February, 1703.

1704. Samuel Leeson.

Alexander Skipton.

Jos. Davey.

William Edgar.

1705. Henry Ash.

John Riddell.

1706. George Tomkins.

\} George Ash.

John Moore.

1707. Charles Norman.

1708. Thomas Lecky.

1709. Henry Ash.

Robert Norman.

Fred. Coningham. Ditto.

$\int$ Henry M'Manus.

\{ John Duckett.

John Duckett died, and Matthew Squire was chosen in his place.

1710. Samuel Leeson. .

$\{$ Robert Houston

$\{$ Peter Stanley.

1711. Robert Norman.

$\{$ Giles Gifford.

1712. John Wotton.

$\{$ Francis Jennings. Ditto.

1713. Alex. Tomkins: .

$\int$ Fred. Coningham.

Edward Skipton. 


\section{HISTORY.}

A. D. MAYORS.

1714. John Wotton.

1715. Robert Norman.
SIIERIFFS.

S Alexander Squire.

Thomas Moncrieff

$\{$ Robert Taylor.

\{ Frederick Gordon

November 2, the corporation elected alderman Hen'y $\mathbf{M}^{\prime} M$ Manus, to be mayor, and John Darcus and Phillip Sullivan, to be Sheriffs; none of them being approved of, at a second election, alderman Matthew Squire was chosen mayor, and George Gonne and Robert Graham sheriffs. Alderman Squire not being' approved of, alderman Wotton was elected and approved of.

1716. John Wotton.

\{ George Gonne.

$\{$ Robert Graham.

Nov. 2, Alderman M'Manus was elected mayor, and John Darcus and Philip Sullivan, to be sheriffs; Mr. Sullivan not being approved of, Edward Carter was elected and approved of.

171\%. Henry M'Manus.

John Darcus.

Trancis Jennings.

1718. George Tomkins.

1719. Peter Stanley.

$\int$ Phillip Sullivan.

$\{$ Henry Hart.

1720. John Wotton.

Henry M'Manus.

1721. Alexander Tomkins.

1722. George Tomkins.

1723. Charles Norman.

1724. Matthew Squire.

1725. Frederick Coningham

1726. Joseph Bolton.

1727. John Wotton.

1728. Thomas Moncrieff.

$\{$ Edward Carter.

Frederick Coningham.

$\{$ Henry White.

John Darcus.

$\{$ Andrew M'llwaine.

George Ash.

$\{$ Frederick Gordon.

William Stewart.

$\{$ William Ash.

Richard Coninglıam.

Matthew Leeson.

Edward Skipton.

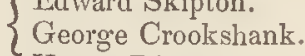

$\{$ Henry Dixon.

$\{$ William Montgomery.

Andrew M'Ilwaine.

$\{$ William Ash.

\{ George Hart.

\{ John Davis.

Robert Houston.

1729. Ditto.

Ulysses Burgh.

Robert Houston died IIth July, and James Evory chosen in his place.

1730. Henry M‘Manus.

Edward Houston.

Ezekiel Coningham.

1731. Peter Stanley.

f Charles $\mathrm{M}^{\prime}$ Manus.

1732. Frederick Coningham

$\{$ Jeremiah Gardner.

1733. Henry Hart.

$\{$ Richard Coningham.

George Ewart.

John Darcus.

1734. Ditto.

Joseph Hill.

$\{$ Andrew $\mathrm{M}$ 'Ilwaine.

$\{$ William Foliott.

1735. Edward Skipton.

f William Gamble.

George Ash.

1736. Hugh Edwards.

1737. Henry M'Manus.

Francis Knox.

Alexander Lecky.

$\{$ Francis Knox.

1738. Ditto.

Henry Darcus.

Ditto.

1739. Ditto.

Ditto. 


\section{CITY OF LONDONDERRY.}

A. D. MAYORS.

1740. Ditto.

1741. Alexander Knox.

1742. Ditto.

1743. Henry Cary.

1744. Ditto.

1745. Charles M'Manus. 1746. Ditto.

1747. Henry Cary.

1748. William Lecky. .

1749. Mossom Gamble.

1750. Geo. Crookshank.

1751. Alexander Knox.

1752. Andrew Knox.

1753. Thomas Monçrieff.

1754. Ditto.

1755. Charles M'Manus.

1756. Ditto.

1757. Ditto.

1758. Wm. Hamilton. .

1759. Ditto.

1760. Willian Hogg.

1761. Ditto.

1762. George Ash.

1763. Thomas Lecky. .

1764. Ditto.

1765. Wm. Kennedy.

1766. Ditto.

1767. Thomas Lecky. .

1768. Robert Alexander.

1769. Robert Fairly.

Alderman Hill was chosen to be mayor for the ensuing year, but declining to serve aldermam Fairly was continued in office.

1770. Robert Fairly.

1771. Adam Schoales.

1772. Hugh Hill.

1773. William Lecky. .

1774. Charles M'Manus.

1775. Ditto,

1776. Thomas Bateson.

1777. John Coningham.
SHERIFFS.

Andrew M'Tlwaine.

$\{$ Mossom Gamble.

Charles Richardson.

$\{$ William Foliott.

$\{$ Charles Richardson.

John Hamilton.

$\int$ John Hamilton.

$\{$ George Gordon.

George Gordon.

William Boyd.

W. Hamilton (So.)

John Fairly.

Ditto.

S John Fairly.

Thomas Lecky.

\} Thomas Lecky.

William Kennedy.

Ditto.

$\{$ William Hamilton

Robert Fairly.

$\{$ William Hamilton.

\{ Hugh Hill.

Ditto.

Ditto.

$\{$ Sam. Montgomery.

J. Mauleverer.

Ditto.

$\{$ William Hamilton.

$\{$ Robert Houston.

$\{$ Frederick Hamilton.

$\{$ James Ramage.

Ditto.

〔 James Ramage.

Thomas James.

Ditto.

Ditto.

JThomas James.

William Reynolds.

$\{$ William Reynolds.

Adam Schoales.

S Stephen Bennett.

¿John Nicolls.

Ditto.

Ditto.

Ditto.

Ditto.

Ditto.

Ditto.

Ditto.

Ditto.

S John Nicolls.

$\{$ James Ramage.

Ditto.

$\{$ John Darcus,

$\{$ Matt. Rutherford.

$\{$ John Coningham.

\{ Hol. Lecky.

$\{$ Squire Lecky.

$\{$ James Patterson. 
1778. John Ferguson.

1779. George Ash.

1780. Thomas Lecky.

1781. Ditto.

1782. Robert Fairly.

1783. John Coningham.

1784. Ditto.

1785. Squire Lecky.

1786. Ditto.

1787. John Coningham.

1788. Ditto.

1789. Squire Lecky.

The mayor died the 20th of March, and alderman mainder of the year.

1790. Eneas Murray.

1791. Ditto.

1792. Stephen Bennett.

1793. Ditto.

1794. Geo. C. Kennedy.

1795. Ditto

1796. And. Ferguson.

1797. Ditto.

1798. John Darcus.

1799. Ditto.

1800. William Walker.

1801. Ditto.

1802. R. G. Hill.

1803. John Darcus.

1804. Roger Murray,

1805. Ditto.

1806. William Walker.
\{ Dan. Patterson.

Samuel Curry.

David Ross.

$\{$ William Swettenham

Eneas Murray.

Mossom Boyd.

$\{$ George Lenox.

Wm. M'Clintock.

$\{$ Mich. Ross.

William Lenox.

S John Hart.

Joseph Curry.

(Dick. Coningham.

G. C. Kennedy.

William Walker.

$\{$ Roger Murray.

Andrew Ferguson, jun.

R. Harrison.

Alexander Lecky.

Alexander Fletcher.

$\{$ David Ross.

H. Mitchell.

$\{$ Adam Schoales, jun.

George Hart.

George Schoales.

\{ James Galbraith.

$\int$ William Alexander.

$\{$ George Curry.

$\int$ William Lenox.

I George Hart.

$\int$ Marcus Hill.

Alexander Young.

$f$ R. Murray.

James Murray.

f R. G. Hill.

$\{$ William Law.

$\int J$. Murray.

William Patterson.

$\{$ J. Murray.

John Bond.

f Thomas Lecky.

W William H. Ash.

$\{$ Thomas Patterson.

John Ferguson.

$\{$ Maurice Knox.

A. Major.

$\int$ Thomas P. Kennedy.

T. Moffett.

$\int$ David Ross.

$\{$ Thomas Murray.

f Thomas Patterson.

William D. Lecky.

f David Ross.

\{ James Gregrg.

$\int$ James Moody.

J. Moffett.

$\{$ Thomas Young

P. M'Donagh. 
180\%. Ditto.

1808. Thomas Lecky. .

1809. Ditto.

1810. Thomas Scott.

1811. Ditto.

1812. John Curry,

1813. Ditto.

1814. M. S. Hill.

1815. Ditto.

1816. William Alexander.

181\%. Ditto.

1818. William Scott.

1819. Ditto.

1820. J. Maginnis.

1821. Ditto.

1822. John Dysart.

1823. Ditto.

1824. John Rea.

1825. Ditto.

1826. Richard Young. .

1827. Ditto.

1828. Conolly Skipton. .

1829. Ditto.

1830. John Dysart.

1831. Richard Young. .

1832. Ditto.

1833. George Hill.

1834. J. Gillespie.

1835. Ditto.
J. Chambers.

$\{$ William Marshall.

H. B. Beresford.

Thomas Woore.

$\int$ Thomas Shepherd.

C. Rea.

J. Dysart.

\{ William Ball.

J. Cuningham.

D. Ross.

$\{$ J. Murray.

Thomas Kennedy.

$\{$ James Gregg.

John Rea.

$\int$ Conolly Skipton.

M. M'Causland.

$\{$ Samuel Curry.

$\{$ Tris. Cary.

$\{$ J. Murray.

TT. P. Kennedy.

S Richard Harvey.

$\{$ James Major.

J J. Thompson.

$\{$ R. Babington.

Thomas Kennedy.

E. Leslie.

D. Knox.

W. M'Clintock.

J. Gillcspie.

IM. Gage.

Thomas Kennedy.

J. S. Gage.

$\int$ Dominick Knox.

A Andrew Bond.

Thomas Kennedy.

\{ Sir William William.

CMarcus M'Causland.

Thomas D. Bateson.

$\{$ Adam Schoales.

$\{$ George Hill.

Sir James R. Bruce.

$\{$ Pitt Skipton.

$\{$ William L. Conyngham.

$\{$ Tristram Kennedy.

John Hart.

George H. Baggs.

f Conolly Gage.

William Gregg.

$\{$ John Murray.

$\{$ Joshua Gillespie.

$\{$ Adam Schoales.

\{ Samuel Crookshank.

$\int$ Henry Darcus.

Anthony Babington.

$\{$ John Murray.

$\{$ Frederick Hamilton

S Stewart C. Bruce.

$\{$ Anthony Babington.

[Extracted chiefly from Gillespie's Annals of Derry.] 
List of the Members of the first Corporation of Londonderry, after the Restoration, in the year 1662.

William Gardner, Esq., Mayor.

John Godbold, Esq., Recorder.

ALDERMEN.

Earl of Montrath.

Ralph King.

John Gorges.

George Cary.

Simon Pitt.

John Handford.
William Gardner.

Thomas Moncrieff.

Henry Finch.

John Elvin.

Henry Osborne.

Hugh Edwards.

Gervais Squire and Richard Graham, Sheriffs.

Henry Osborne, Chamberlain.

CAPITAI BURGESSES.

Robert Lawson.

Tristram Fowler.

Henry Simkins.

Thomas Cole.

Thomas Phillips.

James Sutton.

Alexander Tomkins.

Richard Graham.

Thomas Slipton.

James Hobson.

William Tuckey.

Henry Vaughan.

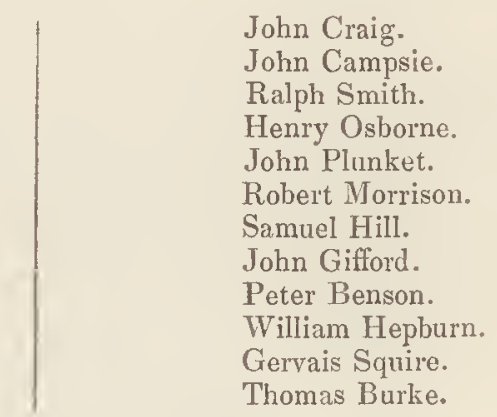

Thomas Burk, Town Clerk.

Corporation appointed by James the 2nd in 1688.

Cormick O'Neile, Mayor.

$\left.\begin{array}{l}\text { Horace Kennedy, and } \\ \text { Edward Brooks, }\end{array}\right\}$ Sheriffs.

A LDERMEN .

Cohanagh Mac Guire.

Gordon O'Neile

Constantine O'Neile.

Constance O'Neile.

Manus O'Donnel.

Peter Manby.

Peter Dobbin.

Antho. Dobbin.

John Campsie.

Daniel O'Doglierty.
William Hamilton. Roger O'Cahan.

Daniel O'Donnel.

Nicho. Burside.

Alexander Lacky.

Constance O'Dogherty.

Daniel O'Sheile.

Roger O'Dogherty.

Brian O'Neile.

John Buchanan.

Daniel O'Sheile, Chamberlain.

BURGESSES.

Francis O'Cahan.

Robert Butler.

Cornelius Callaghan.

Thomas Moncriefe. 


\section{CITY OF LONDONDERRY.}

BURGESSES.

Hugh O'Hogan. John Mackenny.

John Campsie.

Henry Campsie.

James Lenox.

John O'Hogan.

William Stanley.

James Connor.

Hugh Eady.

John Donnogh.

Alexander Gourdon.

John Crookshanks.

Phel. Mac Shaghlin.

John O'Lingshane.

Art. O'Hogan.

Charles O'Sheile.

Johnlius O'Mullan.

John Sheridan.

James Sheridan.
Constance O'Rorke.

Dom. Boy Mac Loghlin.

John Nugent.

William O'Boy.

John O'Boy.

William O'Sullivan.

Dionysius Mac Loghlin.

Manus O'Cahan.

Hugh Mac Loghlin.

Hugh More O'Dogherty.

Ulick O'Hagurty.

Henry Ash.

Thomas Broome.

Pet. Nac Peake.

Henry Dogherty.

Robert Shenan.

Cornelius Magreth.

Art. O'Hogan.

(King's State of the Protestants.)

\section{List of the Corporation in 1704.}

By a late act of parliament, those that did not receive the sacrament according to the usage of the church of Ireland, were rendered incapable of bearing any office or trust under the queen; and because most of the members of the corporation did not qualify themselves, as aforesaid, Robert Rochford, Esq. recorder of the city, advised the mayor, \&cc. to elect other members in their room. The mayor, to leave the dissenting members without excuse, cansed the serjeants to summon them twice; none came; upon which he proceeded to a new election on the 12th of August, 1704. Alderman Alexander Leckey surrendered some time before his aldermanship and justiceship of the peace to Mr. Charles Norman, the mayor. Alderman Ash and Norman, and seven burgesses, with the sheriffs, in all twelve members, chose the undernamed persons in the the room of those that did not qualify, whose names are here set down according to their seniority in the corporation:-

ALDERMEN.

Henry Ash

Samuel Leeson.

Charles Norman.

George Tomkins.

John Newton, Gov.

William Conolly.

J. Denning, Cham. Samuel Hobson. John Campsie. Francis Neville.

William Edgar.

John Riddle.

Edward Lloyd.

Robert Norman.

George Ash.

Robert Houston.

John Moore.

Robert Bonner.
John Crookshank.

Thomas Ash.

Alexander Coningham.

Thomas Leckey.

Robert Dent.

Colin Maxwell.

BURGESSES.

John Graham.
Robert Taylor.
Peter Stanley.
Richard Lowry.
Giles Gifford.
Frederick Coningham.
John Hickman.
Christopher Carleton.
William Baldridge.
Roger Dixon.
Francis Jennings.
William Evory.




\section{HISTORY.}

Corporation of Londonderry, December 18, 1822.

John Dysart, Esq., Mayor.

Right Hon. Sir G. F. Hill, Bart. Recorder.

A LDERMEN.

William Lecky.* William Alexander.*

Roger Murray."

William Scott.*

John Schoales.

John Nicholson.

\author{
Thomas Scott. \\ John Curry.* \\ Marcus Samuel Hill.* \\ Sir J. Maginniss, * knt., (Mayor \\ of the Staple.)
} John Rea.

Thomas Kennedy and J. S. Gage, Sheriffs.

BURGESSES.

Archibald Boyd.
Alexander Lecky.
Sir G. Hill, Bart., Recorder.
Andrew Knox.
Andrew Ferguson.
William Patterson.
William Macky.
Alexander Major.
James Schoales.
John Ferguson.
William Boyd.
Sir R. Ferguson, Bart.

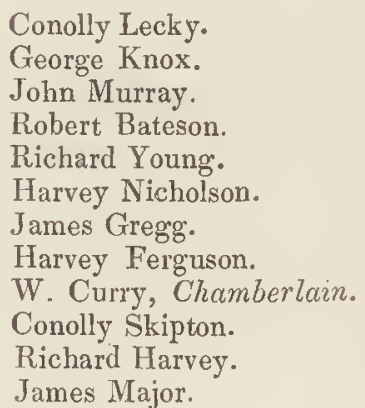

Frederick Hamilton, Swordbearer. Andrew Maginniss, Macebearer.

N.B.-Those marked with $a *$ are magistrates for the city and liberties, having served the office of mayor.

The jurisdiction of the sheriffs extends both to city and county.

List of the present Corporation of Derry.

J. Gillespie, Mayor.

ALDERMEN.

John Nicholson.

John Schoales.

John Dysart.

Richard Young.

William Boyd. Conolly Skipton.
Sir Robert Ferguson.

John Hart.

George Hill.

Thos. P. Kennedy.

1 vacant.

William Boyd, Alderman, Recorder.

James Gregg, Burgess, Chamberlain.

$\left.\begin{array}{l}\text { Stewart Crawford Bruce, } \\ \text { Anthony Babington, }\end{array}\right\}$ Sheriffs. 


\section{CITY OF LONDONDERRY.}

BURGESSES.

Andrew Knox.

Andrew Ferguson.

William Mackey.

Alexander Major.

John Ferguson.

Conolly Lecky.

John Murray.

Sir Robert Bateson, Bart.

Harvey \icholson.

Richard Harvey.

James Major:
William H. Ashe.

Thomas Bateson.

Alexander Curry.

Adam Schoales.

1. T. Macky.

Pitt Skipton.

William Kerr $\mathrm{M}^{\circ}$ Clintock.

Joseph E. Miller.

Samuel John Crookshank.

Frederick Hamilton.

2 vacant.

\section{Miscellaneous.}

George Farquhar, the celebrated dramatist, is on all hands stated to hare been a native of this city, although there is some variation as to the circumstances of his birth. According to one account, he was the son of an otficer, and born while his father was quartered in Derry. Of another', furnished by the Rev. John Gralım of Magilligan, which is more detailed, the following is the substance: After the battle of Worcester, three brothers, who had been employed in the king's eause, fled to the north of Ireland, where they settled in the eounty of Fermanagh. Being compelled to abandon the service, they all took orders. On the Restoration, they were all presented with benefices. One became rector of Cleenish, near Enniskillen, another of Ballyshannon, in the county of Donegal, and the third, of Lissan, in that of Tyrone. The last was the father of the dramatist, who was born in Derry, to which city his mother had removed for the sake of superior medical assistance, as was then usual with the ladies of the neighbouring country on the approacl of their confinement. The eldest of the three brothers possessed a large estate at Gellmelscroft, or Gelmire's Croft, in Ayrshire, which, in 1824, had descended to Colonel Farquhar, of the Ayrshire militia. George Farquhar is said to have been born either in 1674, or 1678. In 1694 he entered Trinity College, Dublin, which, however, he quitted prematurely. He then began a short but inglorious career on the stage. About 1696 he accompanied his friend Wilks, tlıe actor, to London, where he devoted himself to dramatic composition, and with great success, as the libertinism of thought and language which tarnishes the merit of his productions. was but too much in accordance with the taste of that day. About 1698, and shortly after the appearance of his first comedy, he was presented with a lieutenancy in Lord Orrery's regiment. About 1703, he was wheedled into marriage with a pretended heiress, and in 1707 he died, during the run of the last and best of his comedies.

Farquhar is not known to have left any lineal descendants; but a few traces of the posterity of his uncle, the rector of Cleenish, were obtained from the late Mr. James Farquhar of Strabane, attorney, and are thus given by Mr. G. :Murray.

"James Farquhar", son of Thomas Farquhar of Dublin, cabinet-maaker, married Jane

"He was the son of George Farquhar", surveyor of excise at Augher and Clogher. He, this George, was the son of the Rev. Mr. Farquhar, rector of Cleenish, in the county of Fermanagh. During his incumbency some of the parishioners were drowned, going to the place in which the church was situated, which induced him to get a ehurch built at Ballinalack, near Enniskillen."

The Rev. William Hamilton, D.D., the author of "Letters concerning the Northern Coast of the County of Antrim," was descended from an ancient Scotch family, and his grandfather held an honorable station among the defenders of Londonderry, during the siege of that city. His father, Mr. John Hamilton, had the command of a vessel connected with the port, and was inore than once captured by the enemy's cruisers. He afterwards settled at Londonderry, as a merchant, where he died in 1780, in the 55th year of his age. From a notice in the hand-writing of Dr. Hamilton's grandmother, the date of his birth was the 16 th of December 1755 ; but from his epitaph, and other authorities, his natal year was 1757. (See Cathedral.)

Dr. Hamilton was educated by Mr. Torrens, probably at the diocesan school of Londonderry, from which he was sent to the Dublin University, which he entered on the lst of November, 1771. On the 30th of May, 1774, he was elected a scholar; on the 20th of February, 1776, he took the degree of Bachelor of Arts; and on the 31st of May, 1779, he crowned a brilliant collegiate career by the attainment of a fellowship. He now made a transition from his scholastic 


\section{HISTORY.}

studies to the one most eongenial to his taste, that of Natural History, whieh, and in partieular, ehemistry and mineralogy, he assiduously eultivated. In eonjunction with a number of his cotemporaries, he founded a literary and seientifie soeiety, ealled the Palceosophers, which was sueceeded by that of the Neosophers. Among the distinguished names enrolled in one or the other were those of Dr. Hall, afterwards provost of Trinity College, and bishop of Dromore; Dr. Versehoyle, afterwards bishop of Killala; and eounsellor William Ball. From the ineorporation of these two soeieties originated one more distinguished than either-the present Royal Irish Aeademy.

On the 13th of July, 1779, Mr. H. graduated as a Master of Arts, and on the 13th of Mar, 1780, he married Sarah, the youngest daughter of the Rev. — Walker, of Roseonnel, in the Queen's County. This lady was the great grand-daughter of Sir Chamberlain Walker, one of Queen Anne's physieians, and great grand-nieee of Rear-Admiral Sir Hoenden Walker, who, in 1708-9, eommander the disastrous expedition against Quebec. This family is descended from the eelebrated David Gam, distinguished for his bluntness, and for his valour in the field of Créey.

During his intervals of leisure $\mathrm{Mr}$. H. made frequent tours through varions parts of his native eountry, Great Britain, and the eontinent; of these only one reeord remains, but that an important one. A visit to the Giants" Causeway, in 1784, led to the composition of the "Letters eoncerning the Northern Coast of the County of Antrim," which not only secured for their author a deserved celebrity at home, but rendered him an object of interest to the few foreigners, who, at that period, visited Ireland for scientific purposes. These "Lett rs" were the first fruits of the leisure, which Mr. Hamilton enjoyed after his election to a fellowship. His next publieation was "An Aeeount of Experiments for determining the Temperature of the Earth's Surface in Ireland"- - printed in the Transactions of the Royal Irish Academy for 1788. IT is removal to the college living of Clondevadock, in the county of Donegal, shortly after th:s period, placed him amid the new and absorbing duties of a parochial elergyman and a county magistrate. He still, however, found leisure to publish "Letters on the Freneh Revolution." The last of his literary labour's was "A Memoir on the Climate of Ireland," which appeared in a volume of the Transactions of the Royal Irish Academy, published shortly after his decease.

The period at which Mr. H. took the degree of Baehelor of Divinity has not been ascertained, but it appear's from the college registry that he was admitted to that of Doctor of Divinity on the 4th of March, 1794.

The memorable year 1797 had now arrived, and with it a period, in whieh Dr. Hamilton was to engage in the turmoil, whieh should neeessarily attend the diseharge of his magisterial duties. To detail the various dangers and difficulties whieh he and his family had now to eneounter, would be liere irrelevant: the first and the last will be alone adverted to. On the nioht of Christmas-day, 1796, a brig laden with wine, while on its passage from Oporto to Greenoek, was wreeked a few miles from Dr. H.'s residence by the same storm, whieh drove the Freneh into Bantry Bay, and the exertions he made to save the property, first sowed the seeds of animosity between him and his parishioners; these soon ripened into open hostility, while the almost isolated position of his parish-in the peninsula of Fannet-rendered his situation peeuliarly dangerous. He eseaped, however, the dangers that beset himself and his family, until the 2nd of March in this fatal year, when he was assassinated in the Laggan, at Sharon, the glebe of his friend Dr. Waller, in the 40th year of his age. He was buried in the cathedral of Londonderry. - [See Cathedral.]

The above particulars have been extracted from a more detailed notiee given in an edition of the letters eoncerning the northern eoast of the eounty of Antrim, published at Belfast in 1822, which eontain, amid other interesting matter, a beautiful "Address to his Children," penned by Dr. Hamilton.

But the eloud which had so long brooded over the family of Dr. IIamilton did not pass away at his grave. In the early part of the present eentury, his son, Mr. B. W. Hamilton, then of the Dublin University, while on an excursion in Wales, was aecidentally shot by a younger brother, who, in consequence, lost his reason, and, eventually, his life. The former individual was not only very highly distinguished as a student and scholar of the eollege, and a member of the historieal society, then existing within it, but had given in another way sueh promise of future celebrity in the busier walks of life, that onc of the most distinguished characters of the day pronouneed his premature fate to be- "a national loss."

John Gwyn, the founder of the charitable institution called after his name, was the son of a farmer of Drumscallen, near Muff, in Donegal, and born in 1754. While yet a child he lost his father. A few year's after his mother married again, and he accompanied her to his stepfather's house, where he was treated as a eommon drudge, and his edueation entirely neglected, a eircumstance which, in after life, he deeply regretted. To this early acquaintance with adversity may, however, be traced that sympathy with the clildren of misfortune, which cha- 


\section{CITY OF LONDONDERRY.}

racterized his conduct dnring life. On the death of her second husband Mr. Gwyn's mother racterized his cond shop on the slender capital of $£ 50$. In the course, however, of a few years they had realized $£ 500$, by dint of rigid eeonomy. Mr. Gwyn's property continued to increase, and his benefieence kept pace with it. When possessed of much wealth his habits were as frugal as when he was poor, and he was as rigorous sesse saving of a penny was an object to him ; not, how as before in making a bargain. Even the saving of a penny was an ojject to him, not, however, from a penurious motive for accumulation, but from a desire to enlarge the sphere of his benevolence. This is apparent from the circumstance, that, although for many years his great object was to become the founder of a splendid endowment, he never rejected the immediate claims of the poor, but entertained a considerable number of pensioners to the hour of his death. Mr. Gwyn, who was originally a Protestant, beeame a Presbyterian from conviction; but his compassion for what he considered the errors of others, did not interfere with that but his compassion for what he considered the errors of others, did benovolenee. He died on the lst of August, 1829. - (Information communieated by the Rev. Wm. Moore, of Derry).

\section{Section 3.-Progress of the Town-Present State as to Streets, Buildings,} ETC.

The WaLLs. - It will have been seen, from the preceding annals of Derry, that the original English town, erected by Sir Henry Doekwra, was burned and destroyed by Sir Cahir O'Dogherty in 1608 , and that the present may properly be considcred as deriving its origin from the Londoners' plantation, whieh was an immediate result of that catastrophe. It appears certain that of Doekwra's town, within the walls, nothing had survived when the present was commenced but the ruins of the church, which originally belonged to a monastery of Angustinians, and was subsequently repaired for the use of the London colony; and without the walls, on one side, a small castle or fortalice which had originally belonged to O'Donnell, and wh the other, the ancient round tower belfry of Columb's Abbey. All these have long since disappeared. In point of extent Dockwra's town was not more than half of that originally laic out by the nexed copy of the original plan, drawn by Griffen, and preserved in the MS. chamber of Trinity College library, that it appears to have been his intention to have extended the town thards the soutlo in a nearly equal portion; and, in a military point of view, this would undoubtedly have been more judicious than that afterwards adopted, which, by dewould undoubtedly have been more judicious than that afterwards adopted, whis in the new scending to the river, left it expos fortifications did not escape report on the Londoners" plantation in the city and county. "We 1628 , to inquire into and report on the Londoners" plantation in the city and county. "Wh find a stone wall of 20 feet high well rampered within with earth, and 8 bulwarks; but the city itself is so ill situated that both the walls, houses, and streets lie open to the command of any itself is so ill situated that both the walls, houses, and divers hills about the town, and to many other inconvenienees, so that in our judgment it is not a place of defence, nor tenable if any foreigil enemy were to come before it."

Happily, however, the strength of the defensive works of Derry are now of little importance,- and (with their useless artillcry, wisely preserved as memorials of the deeds they have performed or witnessed) in their present appearance, surrounded by inhabited houses, and have performed or withe most grateful picture to the assuming the character of beauty and ornament, they exhibit the most grateful picture

The crown and the eorporation of London in 1609 , it was stipulated that they should be finished on the lst November, in the year following; but, though commenced, they were not entirely completed for several years after. They were laid out and built under the direction of Thomas Raven, an engineer of London, sent over for the purpose, and the total eost of their Thomas Raven, an engineer of London, sent over for the purpose, and the total eost " The erection, "including ports, or gates, with all materials and workmanship, was $£ 8,357$." The original character of these walls will be seen in the annexed plan, copied from the original drawing in the

account as given by Pynnar in 1618-19:-

"The city of Londonderry is now encompassed about made, and neatly wrought; being all of good lime and stone; the circuit whereof is $284 \frac{2}{3}$ perches, at 18 feet to the perch; besides the four gates, which contain 84 feet; and in every place of the wall it is $24 \mathrm{fect}$ high; two of them there is no going up, so that they sridges serve for two of them, and two portcullises for the other two. The bulwarks are very large and good, being in number nine; 


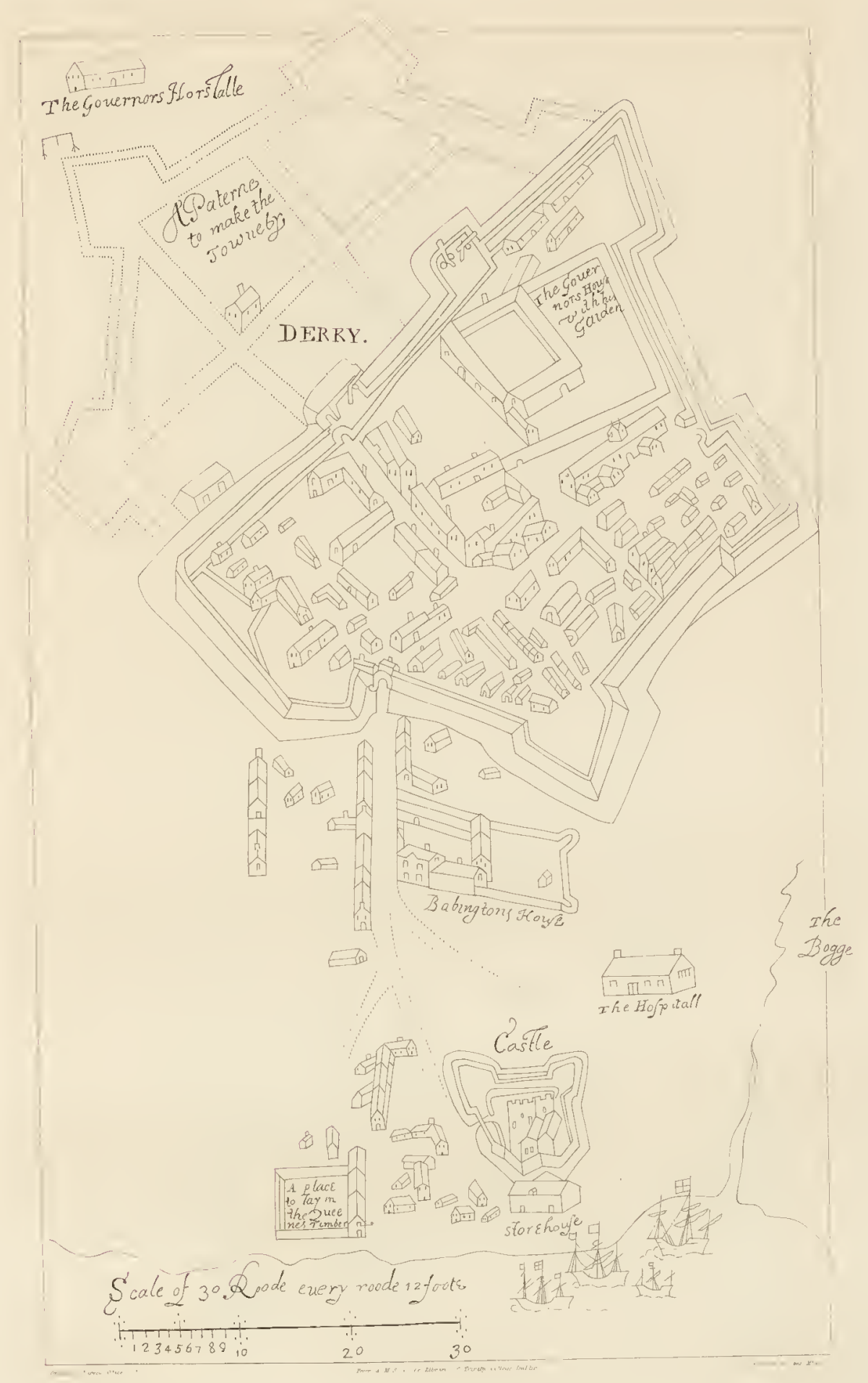




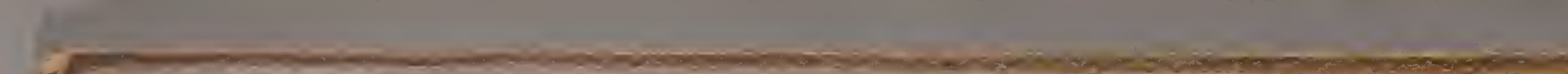




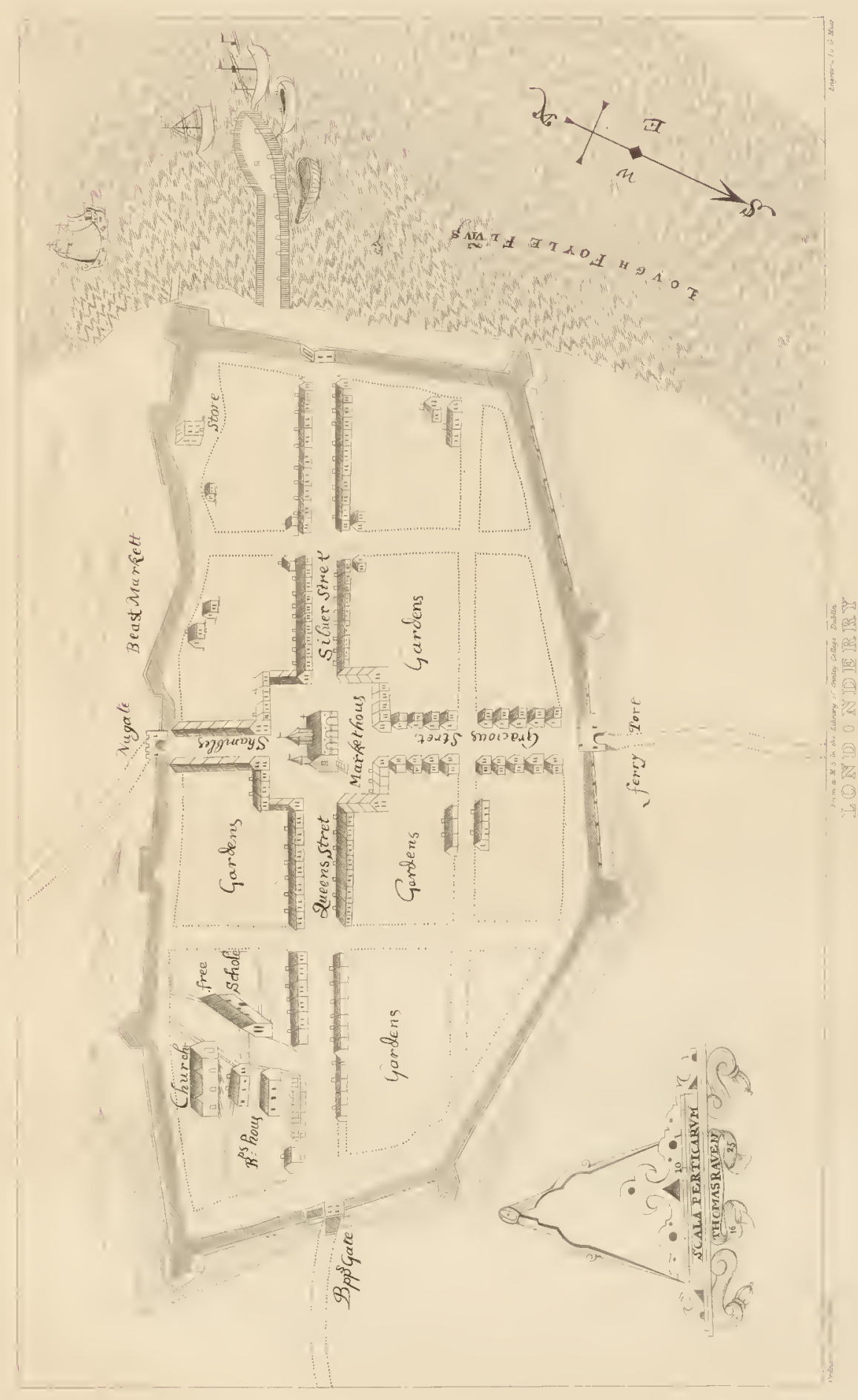




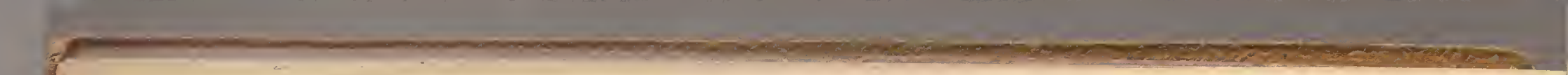




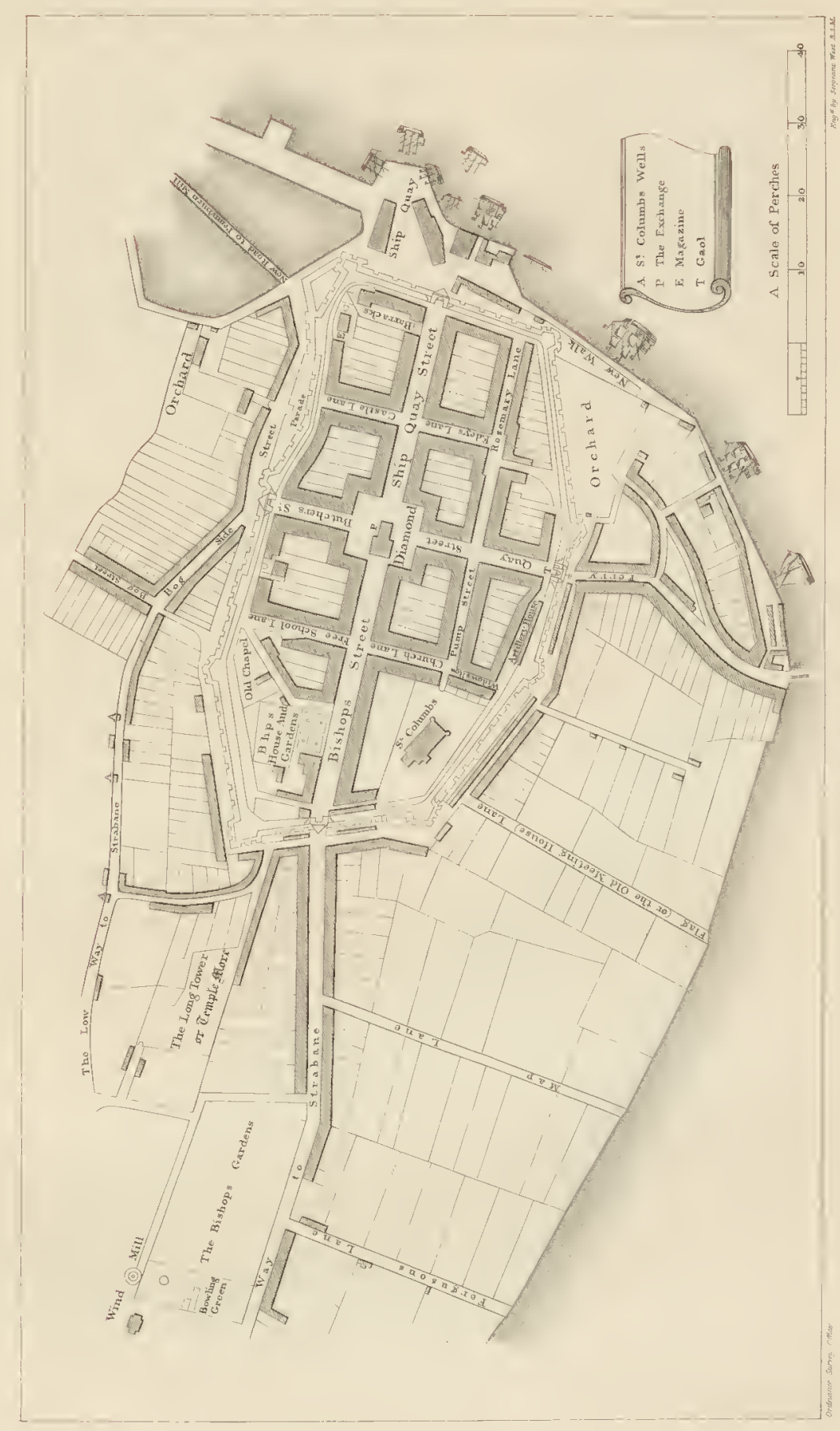




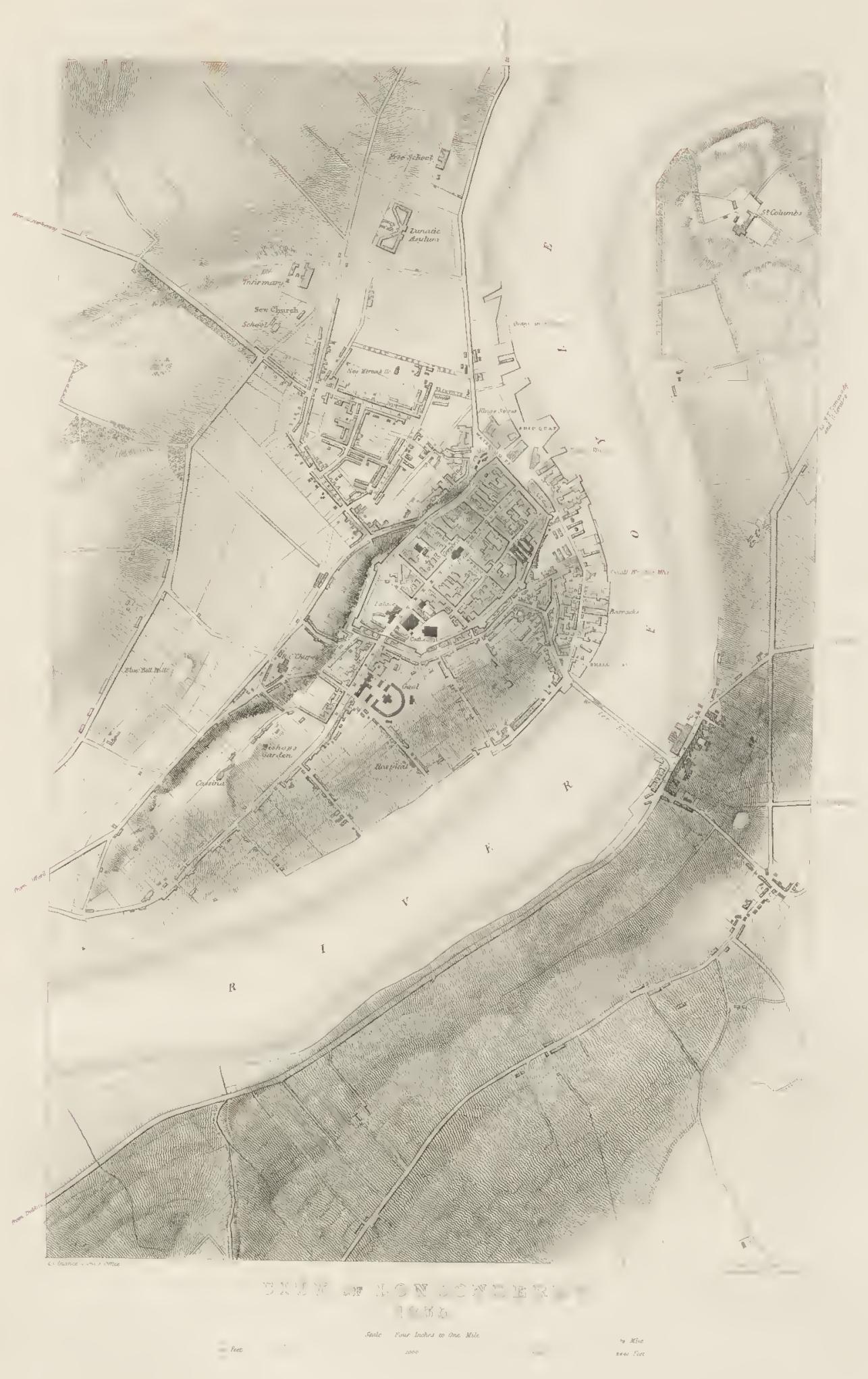




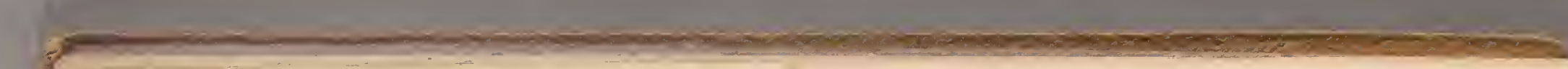


THE WALLS.

besides two half bulwarks; and for four of them there may be four cannons, or other great pieces; the rest are not all out so large, but wanteth very little. The rampart within the city is 12 feet thick of earth; all things are very well and substantially done, saving there wanteth a house for the soldiers to watch in, and a centinel-house for the soldiers to stand in in the night to defend them from the weather, which is most extreme in these parts."

To this description may be added from the report to the Irish Soeiety of the commissioners, Proby and Springham, in 1618, that the walls had around them a dry diteh, 8 feet deep and 30 broad, whieh extended from the Prince's bulwark, at the west end of the eity, along the south to the water side, being more than half the circuit of the wall

The wants complained of by Pynnar were not supplied till after 1628 , when the corporation of London was ordered by his majesty " to build and erect guard houses, centinel houses, stairs and passages, to the bulwarks and ramparts, where they are deficient or defective;" in consequenee of which, they commenced building 3 guard houses and 8 platforms. Two of the guard or centinel houses then erected still remain; they are situated between Bishop's-gate and the $\mathrm{S}$. bastion.

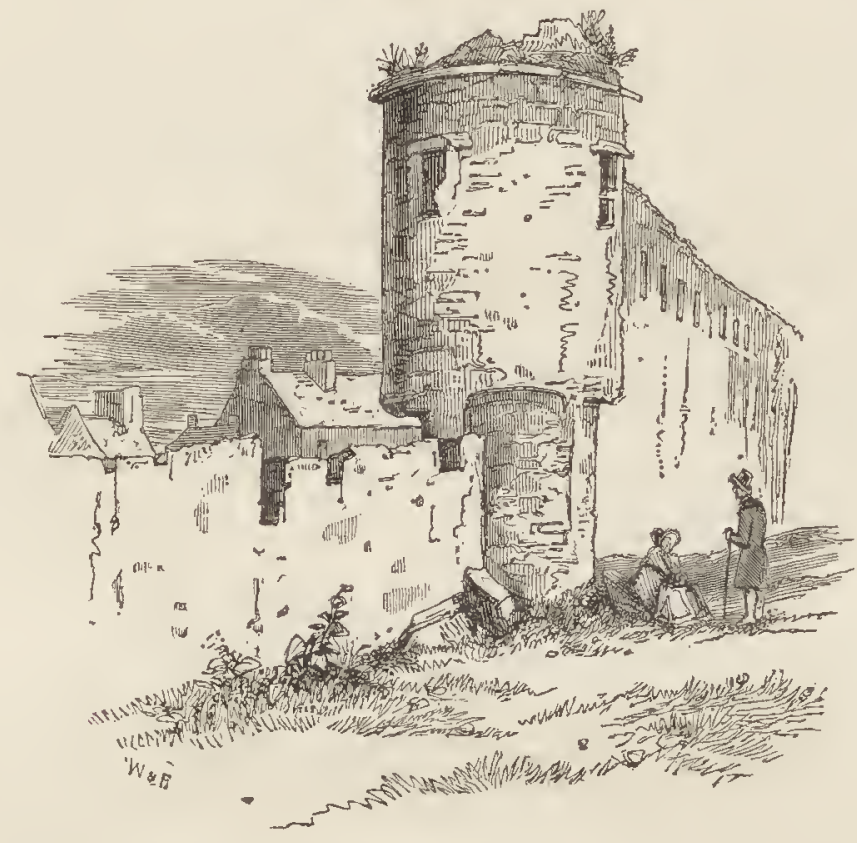

After a lapse of more than two centuries the fortifications of Derry retain, nearly unchanged, theil original form and character. The external diteh, indeed, no longer appears, and is, for the greater part, occupied by the rears of houses; the gates have been rebuilt on a larger scale and in a more elegant style, and two new ones have been added. The N.W. bastion was demolished in 1824 to make room for the erection of a butter market; and in 1826 the central western bastion was appropriated to the reception of Walker's testimorial —a just and appropriate ornamental memorial.

Of the guns which performed such valuable service in by-gone times a few are preserved as memorials in their original localities-the bastions-but the greater number have been converted to the quiet purposes of peace, and serve as posts for fastening cables, protecting the corners of streets, \&c. There are six at the south-western bastion, of which, two are inscribed:-

VINTNERS, LONDON, 1642.

Mercers, LoNDON, 1642.

A third bears the arms of Elizabeth-a rose, surmounted by a crown-with the letters $\mathrm{E}$. R. at each side, and below, the date, 1590. There are four at Walker's testimonial, of which, two are inscribed:-

Merchant Taylors, London, 1642.

Grocers, LoNDON, 1642. 


\section{CITY OF LONDONDERRY.}

Mounted on a carriage at the Court House, and in good condition, stands " Roaring Meg," so called from the loudness of her utterance during the siege. This cannon is inscribed:-

Fismiongers, London, 1642.

The total number of cannon remaining in the city and suburbs is nearly 50.

The Gates. - The four original gates of the city were called Bishop's gate, New gate, (now Butcher's gate), Ferry-port gate, (now Ferry-quay gate), and Ship-quay gate. In ad dition to these gates, two others have been subscquently added, and all of them rebuilt. The only gates which have any embellishment are, the Bishop's gate, and the Ship-quay gate. The former is a triumphal arch, with a latcral passage on each side. The crown of the arch is surmounted, both on the inside and outside, with the head of a warrior in relief on the key stone, and over each passage is a tablet exhibiting military dcvices. The western front of the latter gate is adorncd on each side with a circular frame, onc of which exhibits a cornucopict, the other a caduceus, each combined with othcr devices. On the eastern front there are similar frames, which, however, contain no ornaments. This gate was erceted by public subscription in $1788-9$, to commemorate the centenary of the siege. It is a chaste architectural work, designed by H. A. Baker, Esq. R. H. A, and the sculpture executed by the celebrated Edward Smyth.

STREETS.-From a comparison of Raven's plan with that of the present town it will be seen, that, within the walls, the strects have undergone but little change either in form or name since they were originally laid out. Their plan may be described as that of a central square, called the Diamond, or market place, and occupied by the corporation hall, from which four principal streets radiate at right angles towards the four original gates. These streets give name to the four wards of the city, and are called:-

1. Queen's-street, now popularly Bishop-street, which name is also applied to its continuation outside the wall. This street contains the palace, deancry, court-house, and-outside the gatc-the gaol. The principal approach to the cathedral also is from this strcet through St. Columb's-Place.

2. Silver-street, or now, popularly, Ship-quay-street, which descends from the Diamond to Ship-quay gate, and is so steep as to be scarccly accessible to carriages. Its appearance too, although other wise rather imposing, is mared by the broken line of the roofs, which descend like the steps of a staircasc. It contains the National Bank, the Provincial Bank, Gwyn's Charitable Institution, and several of the chicf private residences. The Public Library and Reading-rooms are also connected with this strcet, though its front opens into Castle-street.

3. Gracious-street, or now more popularly Ferry-quay-street, which is exclusively occupied with shops. The part without the gate is also called Bridge-street.

4. Shambles-street, or Butchcr-strect, which is similarly occupied.

Besides these principal strcets, there are several of a subordinate character, which branch off from them at right angles, the only one worthy' of particular notice is Pumpstreet, which connects Gracious or Ferry-quay-strcet with a second entrance to the cathedral. It contains the King's-Arms Ilotel, and the residences of sereral of the most respectable citizens.

The names of the principal streets have been changed at different periods, as will appear from the various plans of the city. In 1818 and 1819, during the mayoralty of the latc Dr. William Scott, a further alteration was made by the corporation; but after two ycars the former names were restored by the Irish Society. In the interim the new nomcnclature was adopted in leases, and, other documents, wherein, for examplc, the Diamond is termed King William's-Square.

Burldings.-By an article in the original agreement between the crown and the corporation for 300 more): "and that of these 60 houses should be finished by the 1 st November next following, with convenient fortifications, and the rest of the houses with the fortifications should be built and perfected by the lst November, 1611."

The corporation of London neglected, notwithstanding, to fulfil their contract. According to Pynnar, the number of houses in the town in 1618-19, was but 92; and Sir Thomas Phillius states the number built by them up to 1626, to have been but 102 houses of lime and Phille in addition to which there were 26 houses of lime and stonc built at private men's charges, and 12 cabins. The default of the corporation in this particular was one of the chief articles of complaint which led to the several sequestrations of the city and county preceding the year 1628 , and to the appointment of commissioners by the king in that year to inquirc concerning the plantations madc, or intended to have bcen made, in the county of London derry, and the city of Londonderry and town of Colcrainc. In answer to the first article for: inquiry, namely, that 200 houses were to have been built in the city of Londondcrry, and room left for 300 more, - these commissioner's reported, that, "If every single house, that is 


\section{BUILDINGS.}

every bay or building, or every lowest room, with what is about it, is to be esteemed an house, then there are in Derry, abont 200 houses; if the houses are to be esteemed according to the householders or families, then there are 135 houses; if according to the estimation of those whom we employed to view the houses, there are but 101, (that is to say) in Queen-street, Silverstreet, and the market place, 77 houses and a half of 2 stories high, being in length from out to outside 36 feet, and 16 feet wide within the walls; in Gracious-street, Shambles-street, and Pump-street, 33 and a half of one storie in height, in length some 28 feet, and some 24 feet from out to outside, in breadth 16 feet within the walls."

To the second, "that although the houses be reekoned according to the first estimate, that is, a house for every bay, yet there is not room left for 300 more, beeause the schoolhouse and the yard, and the new chureh begun with the intended chureh-yard, take up a good part of the room."

Another sequestration was the result of this commission, whieh, however, was shortly after taken off, and the corporation in 1629 cntered into new articles with the Crown, to complete their original agreement to build 200 houses with the 300 more, at the rate of 50 a year, till all should be finished. The troubles, however, which sueceeded, rendered this impracticable, and the progress of the town advanced at but a slow rate, till very reeent years, as will be seen from the annexed plan of the city in 1788. The rapid progress of the town during the last 30 years will be strikingly apparent from the following private document, written by the late Bishop of Derry in 1826, in which he contrasts its state at that time with that in whieh he found it in $1804:-$

"Provision for the poor-none, but occasional contribution; no relief for siek roomkeepers. Dispensary-none. Repository-none. Mcndicity fund-none. Charitable loannone. Bible Society-none. Library-none. Court-house-no assize but in the Exchange, built in 1692, in which prisoners were tried-building unsafe from decay. Poultry-marketnone. Fish-market near the walls, and in the open air. Flesh-market-none. Potatomarket-in the open air in Bishop-street. Grain market-none. Coffee-room-none. Supply of water-none-but from pumps inside, and a few wells outside the walls, from whenee it was carried in cans. Gaol-small and bad. Pathways with little or no flagging. Lampsnone. City walls in very bad order."

In proeeeding to detail the existing state of the eity, in respeet to its buildings and institutions, the reader may be thus addressed-" Look on this picture and on that!"

It is supposed to be about 60 years since the city began to spread beyond the hill. The most important additions, however, are of recent date. These lie on the N., and mostly along or near the river's bank, which is a very eligible situation for buildings eonnected with the port. Several warehouses, stores, and mcr'chants' residences have been ereeted in this quarter, whieh contribute to the beauty of the city, and attest its prosperity. There are also a few houses in progress near the gaol. This extension of the city evinees the cessation of an old prejudiee, that to reside without the walls was not respectable.

The valley already mentioned, as existing on the W. of the city, forms a considerable suburb. It lies very low, being at low-water only about 24 fcet above the sea. The name Bogside is given to one part of it, which is also called Fahan-street. The names of the Long$B o g$ and Cow-Bog likewise have reference to the original state of the district. Within the last fifteen years some new streets have been built in this suburb, some of which are intended for merehants' stores and residences.

The $W$ aterside, another important suburb, is on the eastern bank of the Foyle.-[See Parish of Clondermot.]

A part of Edenballymore is also eonsidered a suburb.

The Cathedral, whieh is also the parish Church of St. Columb, stands on the summit of the hill of Derry. It consists of a nave, divided into a eentral and lateral aisles, which are separated by pointed arches, resting on stone pillars. On the eastern gable there is a eross, springing from the central battlement; and at the western end is the tower, or belfry, surmounted by a handsome spire. The length of the nave is 114 feet, or, with the tower 150 . Its breadth is 66 feet, of which the nave measures 27. Its height is 46 feet. That of the spire is 178 feet, 6 inches from the ground: of this, the tower measures 89 feet 6 inehes, the battlements bcing omitted, as the spire rises from a platform on a level with the base. The cathedral contains accommodations for above 1000 persons.

The style of this church was originally that known among architeetural antiquaries, as the perpendieular or 'ludor style; but, it has lost much of its original charaeteristic uniformity by the fantastic decorations which have been subsequently added.

For nearly twenty years after the plantation Derry was without a place of worship capable of accommodating even its then seanty population-a part of the old ruined church of St. Augustins, whieh had been repaired, being the only building appropriated to the services of religion. After repeated complaints of the default of the London eorporation in this as well as in other articles, which the king's eommissioners in 1628 were appointed to inquire into, the 


\section{CITY OF LONDONDERRY.}

latter reported, "that although the citizens of London have not hither to built any chureh in the whereof, they have contraw they have begun to build a fair church therc, for the perfecting finished, they have promised that if one Parrott to give him $£ 3,400$; and when the work is dred more to that sum." - (Phillips's MS )

The erection of the (Phillips's MS.

Vaughan ef This event alderman and governor of Derry, at the cost of $£ 4,000$.

Bishop's Court, a small structurc adjoining wheh has been transferred to the tower from the

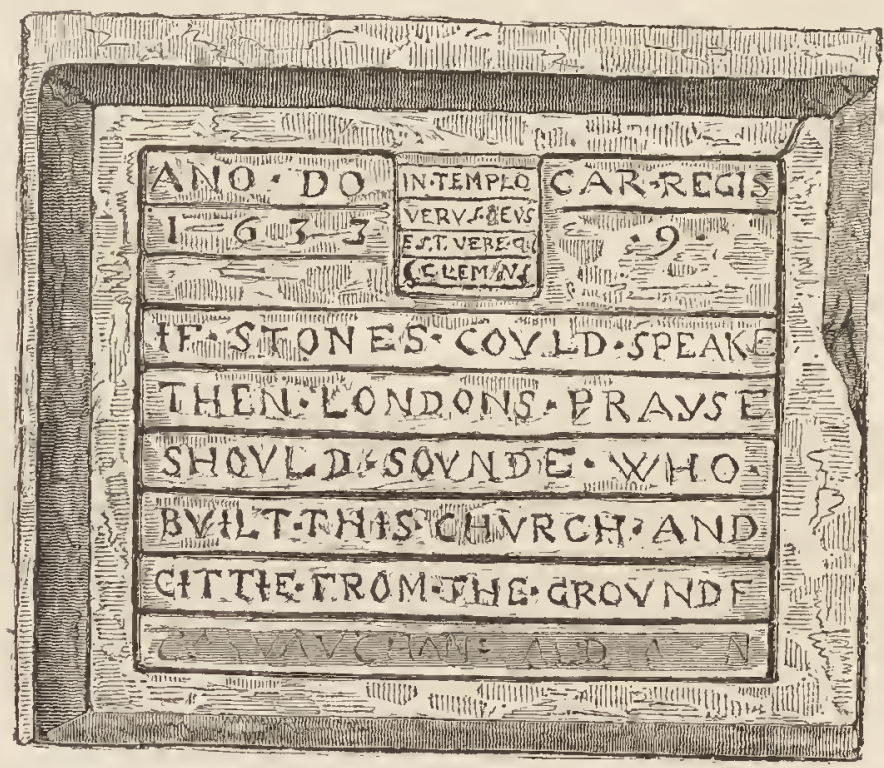

Of the state of the cathedral both before and after the rcvolution, the following account is given by archbishop King in his visitation book of the dioccse in 1690 .

"The cathedral, which is likewise the parish church, is a goodly fabric begun by the Londoners in 1622 [1628]; but was not finished for many years aftcrwards. It has an organ, a square stceplc, and a good ring of six bclls. It had formerly a spire of wood, leaded, but it was dill the late taken down before the troubles. 'The lead was prescrved (in ordcr to build it again) till the late siege, during which it was used for bullets. The church suffered much in the roof from bombs and other aecidents. Their majesties allowed 200 pounds towards repairing it, but 200 more will not finish the necessary repairs of it."

On the night of the 1 st of Deccmbcr, 1740, the eathcdral took fire from the carelessncss of the bcll-ringers; the flames, however, were spcedily extinguished.

A ncw spire, whieh was erceted by the Larl of Bristol, Bishop of Derry, was completed on the 13th of July, 1778. It was of hewn stone, and of an octagonal pyramidal form, with open ornamented windows. The top was erowned with a large gilt coppcr ball, over which was plaeed a handsomc vane, also of copper. The old steeple, originally 66 fect high, was now feet above the stone ball, vanc, and ornamented work, rose 11 228 feet. In 1802 this spire The height, therefore, from the ground of the cntire edificc was 228 feet. In 1802 this spire was taken down, the tower whieh supported it being in a dangerous f of which onc-half was contributed by the Irish Socicty-the other by Bishop Knox and the
citizens. It is surmounted by a eross, which cnds in a vane.

In 1813 eight now bclls were suspended in the steeple: this is recorded on a tablet orcr the entrance of the eathedral :-

"To commemorate the Liberality of The Mayor, Commonalty, and Citizens of Londonderry, who, On the 12th day of August, 1813, in the Fifty-third, year of the of Londonsovereign Lord, Georgc the Third, At their own expensc, completed the erection of eight new Bells in this Catliedral, in plaec of those presented by his Majesty, Charles the First, in the year 1638, which had suffcred by time and accident and become totally useless. This tablet 


\section{BUILDINGS.}

is ereeted by the unanimous vote of the parishioners of Templemore, at a vestry held on the twenty-eighth March, 1815.

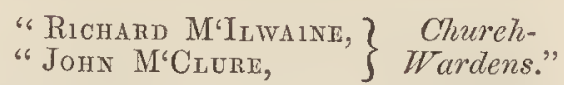

In 1819 the Irish Soeiety eontributed a sum for the embellishment of the eathedral, and in 1822 a slate roof was substituted for the former lead one.

Bishop Stone, who sueceeded to this dioeese in 1745, presented a new organ to the cathedral, which eontinued to be used until 1829. In this year a new organ was ereeted, which was, however, placed within the old case. The expense was defrayed by subscriptions of $£ 100$ from Bishop Knox, and $£ 50$ each from Dean Gough and the corporation, with a few minor ones raised in the eity.

The Communion plate is as follows:-

1. A Silver Dish, thus inseribed underneath:-

"R. D. Mrchaeli Dolleen Decano S. Cruels Memoria Ergo dot Exgelifardus A. Rindtorff Catiedralis Ecclesi.e Hildesiemimensis Canonicus Anno 1605. $30 \frac{1}{4}$ lott.*

This dish is of a peeuliar shape. In the centre is a shield of gold, or silver gilt: on this are six raised medallions, one of whieh appears to represent a warrior in armour; two are female busts; and the remaining three are winged eherubs; these figures are in very strong relief. In the eentrc of the shield is a coat of arms, with the initials-_ " $\mathrm{E}$. R." The dish is $10 \frac{1}{2}$ inehes in diameter, and $1 \frac{3}{4}$ in depth.

2. A Cup, presented by the Irish Soeiety, and thus inseribed:-

"Ecclesia Dei, in Civitate Derriensi Donum Londinensium."

There is no date, but the donation was probably made in 1612. Under the inseription are the eity arms.

3. A Cup, presented by Dean Wandesford, and thus inseribed:" Michail Wandesford Deeanus Derensis obtulit 1637."

Under the inseription is represented a chureh with a spire.

4. Two Chalices, presented by Bishop Hopkins, and thus inseribed :-

"The gift of Zzekiel [qy. Ezekiel ?] $\mathrm{L}^{\mathrm{d}}$. Bpp . of Derry-to the Cath" ${ }^{11}$ Chureh of Derry 1683."

They are each 5 inehes in diameter, and 10 in height.

5. Two Silver Plates, also presented by Bishop Hopkins in 1683, and bearing an inscription similar to that on the Chaliees. They are each one foot in diameter.

6. A Silver Salver, thus inseribed:-

"The gift of the Bishop and Clergy of the Diocese of Derry, to Pcter Stanley Esq $\mathbf{r}$ in testimony of their gratitude for his generous serviees in the management of their foundation for the support of Clergymen's Widows-1742.

"The gift of said Peter Stanley to the Cathedral Chureh of Saint Columb, Derry, 174265 oz. -10 dwts."

It is 16 inehes in diameter.

7. Two Silver Patens. There is no date, but the eity arms are engraved on the bottom of one. They are eaeh $5 \frac{1}{2}$ inches in diametcr.

On the sill of the E. window is the following inseription :-

"This eity was besieged by the Irish army the 18th of April, 1689, and eontinued so till the first of August following, being then relieved with provisions by Major General Kirk. On the 7th of May, about one in the morning, the besiegers foreed $\mathrm{y}^{\mathrm{c}}$ out gards of $\mathrm{y}^{\mathrm{e}}$ garrison, and intrenehed themselves on the Windinill hill, eommanded by Brigadier General Ramsay. At four the same morning $\mathrm{y}^{\mathrm{e}}$ besieged attaeked $\mathrm{y}^{\mathrm{e}}$ Irish in their trenches, and after a sharp engagement $\mathrm{y}^{\mathrm{e}}$ enemy gave ground, and fled. Ramsey, their generall, was killed with others of note, the Lord Netterville, Sir Garrett Aylmer, Lieut ${ }^{t}$. Collon'1. Talbot, Major Butler, son y Lord Mountgarret, and several others taken prisoners, with five eolours, two of which fell into $y^{e}$ hands of Collon'. John Mielielburne, who placed them as they now stand, with the consent and approbation of his Lordship William King, then Lord Bishop of this city, now his Graee Lord Archbishop of Dublin; $y^{\mathrm{e}}$ said Collon ${ }^{1}$ Michelburne being at that time Governor, to perpetuate $\mathrm{y}^{\mathrm{e}}$ memory of whieh seige, when $y^{e}$ eolours shall fail, his Lordship John Harstong, now $L^{d}$ Bishop of Derry, at $\mathrm{y}^{\mathrm{e}}$ request of $\mathrm{y}^{\mathrm{e}}$ said Collon'. Miehelburn, is pleased to give leave that this

* Lott is probably the same as Loth, a German weight, equal to about half an ounce. 


\section{CITY OH' LONDONDERRY.}

inscription be placed under the said colours in remembrance of the eninent and extraordinary
service then performed."

The flags, mentioned in this inscription, stand one on each side of the eastern window. The poles and tassels are genuine: the flags wcre renewed a century after their eapture, but

The most conspict

of the communion table, monument in the eathedral is that of Bishop Knox, on the N. and laity, amounting to $£ 500$. It is of Italian in 1834, from a subscription of both clergy On an elevated plinth is an inscribed tablet marble, and was exeeuted by Behnes, of London. a mitre. On the right of the tor tomb surmounted by that of Charity, with a babe on fomb stands the figure of Religion, at full length; on the left her knees. The principal fioures arm, and two other children of different ages standing at leneies of the departed prelate, and the entive does to personify the spiritual and moral exeelof the artist. The epitaph is as follows:"Sacred to the memory of the Honor

Bishop of Derry. This monument has and Right Reverend William Knox, D. D., Lord minations, of his diocese, to perpetute bected by the elergy and laity of all denospirit which, for twenty-seven years, marke remembranee of that tolerant and Christian and fostered the public institutions of this his episeopate, that munificenee which reared animating and adorning his life, secured the eity; and that unaffected benevolence whieh, of society. He died the I0th of July, 1831, in the 71 st won the affeetions of all classes Of the tablets the most ancient is age."

memory of his father. It was originally overlaided by Edward Edwards, in 1674, to the paste. Another old tablet, erected in 1676 , inscribed:-

"To the memory of John Tomkins and Reber

his wife. And of John Sin and Rebeeea his wife. Alexander Tomkins and Elizabeth dren to the $\mathrm{s}^{\mathrm{d}}$ Alexander 'Tomkins. He died the Elizabeth, Margaret, and Fanny, chilThe gallery covers the remainder. an old tablet, the middle part of which is covered pew allotted to the bishop's family therc is appears above the gallery-and on the part

"And also Margaret formerly on the part below the gallery is the following:-

said Alderman Elvin, Lord 1764 and of her age $y^{\text {e }} 63$.

The following tablets are at the east end of the church, on each side of the com-
munion table. On a plain white marble tablet:sto marble tablet:-

"To the memory of Sir Hugh Hill, Bart. who died

of Hannah his wife, daughter, Bart. who died 11 th Feb. 1695, aged 66 years; and also, gal, Esq. ${ }^{r}$. who died the 6 th day of Jahn M'Clintock of Dunmore in the county of Donesented the eity of Londonderry in parliament from and aged 65 years. Sir Hugh Hill repreOn the same tablet is recorded the in parliament from 1768 till his death."

died in the Isle of Anglesea, on the above, who "To the memory of Mary, second dant July, 1806, aged 39 years. On the same tablet is also, Hill, Esqr ${ }^{r}$, youngest son of Sir Hugh of the Rev. Doet. Henry Barnard, wife of Marcus S. her age." ", youngest son of Sil Hugh Hill, who died at Fahan in 1807, in the 35 th year of

On the same tablet is recorded the death of the Rev. John Beresford Hill, Moville, second son of Sir Hugh Hill, who died in the Beresford Hill, A.M. rector of Upper 1806, aged 40 years. Another white who died in the city of Londonderry on the 4 th Dee. Treasurer of the county of poration of the city. He died Dec. 27th for 36 ycar's, and some time senior burgess of the corthe prematurc death of a citizen $\mathrm{Dec} .27 \mathrm{th}, 1825$; aged 75 years. The following tablet records "Sacred to the memory of

Army; who, with 53 bert Boyd of this eity, Esquire, and sometime Lieut. in the Bengal 1831 , in a bold but successless attempt doted companions, fcll at Malaga on the 11 th Decr. sacred eause of Religion and Liberty in the ovthrow despotism iu Spain, and advance the A plain tablet has been erected by therty in that degraded country. Aged 26."

memory of John Gay Leathem, by the officers of the $33 \mathrm{r}$ d Regiment of the Madrass N. I. to the vember 1830 , aged 25 years. ensign of that Corps, who died at ST. THOME, on the 2nd Nosome years senior alderman of the corporation is to the memory of Adam Sehoales, Esq. for age, on the 6th of May 1803. Also, his wife Flizabeth, small white marble tablet is to Also, his wife Elizabeth, who died 24th August, 1796, aged 69. A 20th May, 1832. On a separate stone is of John Rea, Esq. of St. Columb's, who departed this 


\section{BUILDINGS.}

May, 1815 , aged 22 years. The name of the Rev. William Hamilton, author of the interesting "Letters concerning the Northern Coast of the County of Antrim," recorded on his father"s tomb-stone, recalls the memory of his unhappy fatc. [See History.] The entire epitaph is as follows :-

"The Tomb of John Hamilton, of this city, Merchant, who died on the 9th day of August, 1780, aged 55 years. Likewise, of his son, the Rev. Wm. Hamilton, D. D. Late Rector of Clondevadock, in the county of Donegall, formerly Fellow of Trinity College, Dublin. The cause of Religion Has to lament the Loss of one of its ablest Advocates : Virtue one of its best Supporters; and learning onc of its brightest ornaments. He was assassinated at the House of Dr. Waller, at Sharon, on the $2 \mathrm{~d}$ of March 1797, Where he fell a Victim to the brutal fury of an armed Banditti, In the 40th year of his Age. His acquirements as a scholar, cqually solid and refined, are duly appreciated in the World of Letters; whilst the sacred remembrance of his Virtues is enshrined in the hearts of those who knew him."

There is also a tomb-stone erected to the memory of George Tomkins Esq., cxecutor to Colonel Mitchelburne's will, and a relation by marriagc to Colonel Knox of Prehen.

In the churchyard therc are also a tombstone erected in 1642 , to the memory of

Martin, and the remains of another-a monument of Counsellor Cairns, who signalized himself in 1688 , during the siege.

The Palace was erected during the prelacy of Bishop Barnard, but was almost rebuilt by the Earl of Bristol, when in possession of the see. It suffered some damage in 1798, when it was cmployed as a barrack, but was repaired by Bishop Knox. It stands opposite the courthouse, and in the rear are gardens, which occupy nearly two acres, and extend to the city walls. These, in 1798, scrved for a parade, which designation is still applied to the adjacent part of the walls. It is a substantial and commodious building, but has no pretensions to architectural beauty.

The palace occupies the site of the Augustinian convent, and of the subsequent manse, erected by the corporation of London immediately after the plantation, at a cost of $£ 500$. A memorial from the Bishop of Derry to the primate, proposing that the latter should be rebuilt, was approved on the 9th of March, 1753, and the accounts for building the palace received his sanction on the $23 \mathrm{rd}$ of April, 1761 .

The Deanery, which was erected in 1833 , is a large, but unadorned brick building. The expense, which was paid by the dcan, and is to be reimbursed by his successor, amounted to $£ 3,42116 s$. $8 \frac{1}{2} d$. The last deanery which was built by the Very Rev. Dr. John Boltou, was finished on the 28th of Febluary, 1720.

The Chapel of Ease is a plain rectangular building, adjacent to the city wall, on the W. It contains accommodation for only 200 people. The eastern window is semicircular, and the side-windows nearly so.

This place of worship was built by Bishop Barnard, whose descendant, Sir Andrew Barnard, became patron. The chaplain's original stipend of $£ 50$ annually is now paid from the property of William J. Campbell, a minor, who claims the right of presentation. This is, however, disputed by Sir A. Barnard, on the plea that a document was drawn up on the transfer of the property, by which the presentation was reserved to him. The parties having concurred in the nomination of the present chaplain, the point has not been yet brought to an issue.

The first entry in the registrar's office, relative to the chapel, is a license to the cure of it, granted by the Earl of Bristol, Bishop of Derry, to the Rev. John Blackall- " he having bcen nominated and appointed thereunto by the Right Reverend Father in God Thomas Lord Bishop of Killaloe and Kilfenora, the patron thereof, with a salary of fifty pounds a year." It is dated the 17th of August 1791.

Another entry is the appointment of the Rev. William Henry Murdock as chaplain, in consequence of the resignation of the Rev. James $M^{\prime} G$ Gee. It was made by the patron, the Bishop of Limerick, son to the Bishop of Derry, by whom the chapel was built, and contains a request to the then Bishop of Derry for license to officiate. This document is dated the 25 th of March, 1795, but the license appears not to have been granted until the November following.

In the cemetery is the tomb-stonc of Alderman Stanley, with the following inscription:-

"Hcre Lyc the Bodies of Alderman Peter Stanley and Ann his Wifc, who Lived Together 51 Years in Perfect Harmony and in the Excrcise of Every Private, Social, and Christian Duty: She Died the 17th of March 1750 in the 70th Year of Her Age; He the 6th of November Following in the 73rd. "To FEED THE HUNGRY AND CLOTHE THE NAKED, TO EASE THE HEAVY BURTHENED, AND LET THE OPPRESSET GO FREE', was the Business of their Lives: His Integrity, public Spirit and Zeal in promoting every good work will be transmitted to Posterity by the Gratitude of the present Gcneration. 


\section{CITY OF LONDONDERRY.}

"But it is thought proper to inseribe his last Act upon this Stone, to prevent, if possible, for Ages to eome, any abuse of so exeellent a charity. He bequeathed all his Houses in DERRY, with their Aeres and Perches, to the amount of forty-two Pounds Yearly Profit Rent to the Desn and Curates of Demry [for the time being], and his Exeeutors Alid. George Crookshank and William Kennedy, in trust, to be distributed to thirty poor Inhabitants of the City and Liberties on the Derri side of the River. He also bequeathed twenty Barrels of Shelling, (eaeh Barrel to weigh eighteen Seore, ) to be distributed annually in the Month of MaY, by the Curate and Church-Wardens of the Parish of GLANDERMot, to forty poor Inhabitants of that Parish.

" "Though these frail Monuments may fail to preserve an adequate Memory of his pious Acts ; yet the 'Righteous SRALL BE HAD iN EVERLASTING REMEMBRANCE.'

The Free Church, situated withont the eity, on the N., was built in 1830 , by Bishop Knox, at an expense of $£ 760$. It was intended for the lower elasses alone, but the congregation is no longer confined to them. In 1832, a gallery was ereeted by subseription, the expense of building whieh, and a vestry-room, with that of introdueing susseription, the 145. The profit of letting seats in the gallery belongs to the offieiating minister. During his lifetime the bishop defrayed all the expenses of repairing, \&e., and sinee his death the Sabbath collections have been applied to these purposes. 'The church, ineluding the gallery, has aceommodation for 370 persons.

The Presbyterian Meeting-House, situated in Meetinghouse-row, is supposed to have been built about 1750 , at an expense of nearly $£ 4,000$, but all the documents relating to its earlier history have been destroyed by fire or otherwise. It was repaired in 1828 , at an expense of $£ 700$, and now presents a chaste and handsome front, of whieh the pediment and corniees are of Dugiven saudstone. It contains accommodation for 2000 persons.

The Seeeding Meeting-House, situated without the walls, in Fountain-street, was buil in 1783 , at an expense of $£ 450$. It is a very plain building, has a good gallery, and is well provided with seats. The approael is a narrow passage between two houses, and it cannot be seen from the street. It contains aecommodation for 500 persons.

The Covenanting Meeting-House, situated without the wall, in Fountain-street, was built in 1810 , at an expense of $£ 450$. It has no gallery, but resembles the Seceding Meetinghouse in size and style of building, and, like it, has a very indifferent approach. It eontains seats for only 300 persons.

The Independent Meeting-House, situated in Bridge-street, was built in 1824, at an expense of $£ 500$. It is provided with a gallery, and contains accommodation for 200 persons.

The Primitive Westeyan Methodist Chapel, situated in Meeting-House Row, was originally a store, but was used by Wesley as a place of worship in 1763 , when he visited this city. In 1783 his eongregation built the Wesleyan Methodist Chapel, but, on a schism breaking ont, the Primitive Wesleyans separated from their brethren, and returned to their former place of worship. It was then refitted, and made capable of aceommodating 200 persons. A part of the building is still let for a store, at a rent of $£ 10$ a year. The chapel is used as a Sunday sehool in the interval between morning and evening service, and for this a rent of $£ 20$ a year is paid by the dean.

The Wesleyan Methodist Chapel, situated in Linen-Hall-street, is on a very bad site, adjoining the Shambles and Fish-Market. It was built, as already stated, in 1783 , and is to be vaeated on the opening of the new ehapel. It can accommodate about 130 persons.

The Nen Wesleyan Methodist Chapel, situated at the junction of Linen-Hall-street and the Walls, on the E., is not yet finished. The expense will be $£ 1100$, raised by a subscription, to which the Irish Society eontributed $£ 100$. It will aceommodate 650 persons. The lower story is to be used as a vestry-room, and as a sehool-room for 300 children.

The Roman Catholic Chapel stands without the Walls, on the site of the old monastery of St. Columb in the street ealled the Long Tower. The singular appellation of this street is derived from the lofty round tower, whieh formed the belfry of the original ehurehthe Duv-Regles, erected by St. Columb. [See History.] The building was begun in 1784, and finished in 1786. In the June of the former year the Rev. Dr, Lyneh, the R. C. Clergyman of Templemone, first applied for subseriptions to erect a plaee of worship, and collected 500 guineas within a few hours. Of these 200 were contributed by the Earl of Bristol, Bishop of Derry, and 50 by the eorporation. Between 1810 and 1812 a new aisle was added, and galleries, whieh, with the original building, cost $£ 2,700$. The ground floor not being furnished with seats, the Chapel can with ease accommodate 2000 persons. It possesses a good organ.

The aneient cemetery of the Duv-Regles and Templemore is conneeted with this Chapel, but it eontains no monumental inscriptions anterior to the plantation. The following is the oldest discovered:-

"Here lye buried the bodies of Robert Rigat and John Rigat, Sons to Thomas Rigat of this citie, Burgess, both which dyed in the month of May anno Domini 1618." 


\section{BUILDINGS.}

In the muster roll of the men of Coleraine, taken by Sir Thomas Phillips in 1628, the name of John Reygate oeeurs.

The Diocesan and Free Grammar School, sometimes called Foyle College, is situated without the eity, on the N., and near the river. Its length is 135 feet, and its greatest breadth 66. It is a simple but handsome stone edifice, eonsisting of a eentral pavilion 21 feet long, and two wings, each measuring 24. The height of the former is 47 feet, and of the latter, 40 . 'The first stone was laid in 1814 , by bishop Knox, through whom liberal grants towards the erection were obtained from some of the London eompanies. To these was added one from the eity of London, with the bishop's private donation of $£ 1000$, and the results of a county presentment, and of a sale of stoek. The expense of ereetion was £5255. The Lord Lieutenant is nominally the patron, but the Bishop of Derry virtually.

The Parish School, or Poor School, is now most usually styled the Foundation School. It is situated without the eity. Its length is 54 feet on the north, and its breadth 30 feet.

'The first stone was laid in 1812 by Bishop Knox, who contributed largely towards its ereetion. It has obtained the name of Foundation School, from having been built partly from the funds of Erasmus Smith's foundation. It is two stories high, and contains separate eompartments for males and females.

The Public Library and Ners-Room is a plain building, faeed with cut Dungiven sandstone. It was ereeted by subseription in 1824 , at an expense of nearly $£ 2000$. Its length is 42 feet, its breadth 23 , and its height 35 . It contains the eommittee-room of the elamber of eommeree.

The Lunatic. Asylum is a handsome building, situated on a rising ground without the eity, on the N. It is uniform with those at Armagh and Belfast, and, like them, is a district asylum, being intended for three counties-Londonderry, Donegal, and Tyrone. It stands about 270 feet from the high road to Greeneastle, and presents to the river a façade, consisting of a eentral building with pavilions, from whieh extend wings, with airing-sheds, terminating in angular pavillions. Above the eentre rises a turret, exhibiting the date "1828," and furnished with a cloek. Its upper part forms an oetagonal eupola, with sides of regularly alternating lengths, and surmounted by a vane. In front of the edifiee there is some ornamental planting, and it is surrounded by a good garden. In the rear are several eommodious airing-yards, separated by various ranges of building. The extent of the grounds is 8 aeres.

The plan of the asylum was furnished by the late Francis Johnston, Esq. of Dublin, and carried into effeet by William Murray, Esq. The first stone was laid in June, 1827, by bishop Knox, and in 1829 , patients were admissible. The total expense was $£ 25,67828.4 \%$.

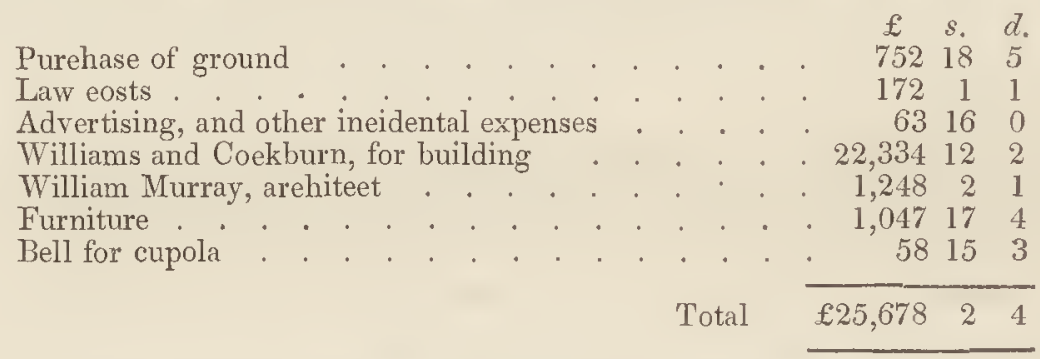

The materials employed were Dungiven sandstone for the front, and brick for the rear. The entire length in front is 364 feet, the depth 190 , ineluding the airing-yards, and the height to the eve 25. The near buildings aeeommodate one-fourth more patients than the front, and inelude kitehens and workshops.

The Asylum, which was built for 100 patients, although enlarged so as to aeeommodate 150 , is still too small. The eells, however, are partly oecupied by patients, who are, strictly speaking, inadmissible, but for whom there is no special retreat: these are the ineurable, the epileptie, and idiots. Sueh eases are also reeeived in the Infirmary, and a subordinate Asylum at Lifford.-(See Infirmary.)

The Infirmary and Fever IIospital, or City and County Infirmary, is situated without the eity on the N. It was ereeted in 1810 , by Mr. Edward Edgar, under the superintendenee of $\mathrm{Mr}_{1}$. Woodgate of Dublin. It is 90 feet long, by 50 broad, and its height is 50 feet, ineluding an underground story, whieh measures 10. 


\section{CITY OF LONDONDERRY.}

The Corporation Hall stands in the centre of the Diamond on the site of the original townhouse, erected by the London corporation in 1622, at the cost of 500 pounds. The military as well as civil character of that building will be seen from the annexed wood-cut, copied from the original drawing in Sir Thomas Phillips's MS.

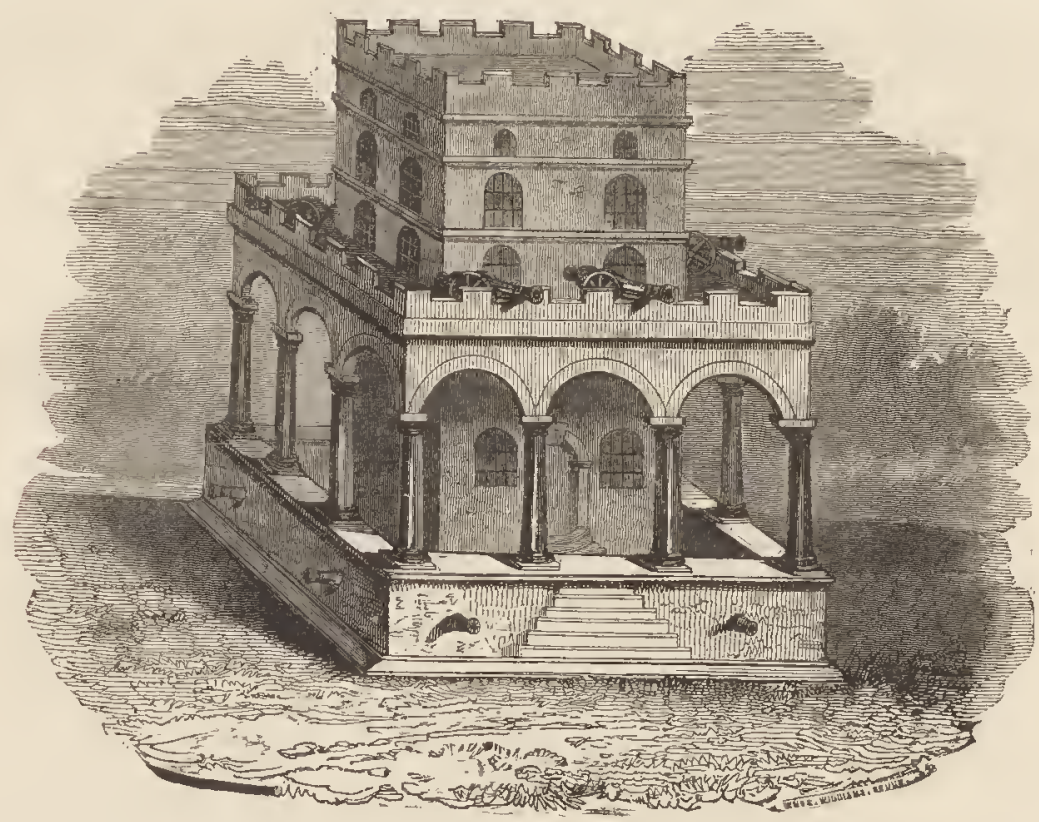

The present town-house was built by the corporation in 1692 , and until 1825 was called the market-house, or Exchange. Up to that period it was open below, and meal and potatoes were sold in it. "Over one of the arches the followmg inscription formerly existed:- "His Majesty's Exchange." It measures 120 feet by 45 . The southcrn part, in which is the principal entrance, is circular.

The upper story contains the common council-room, an assembly-10om, which measures 75 feet by 36 ; and an ante-chamber. The assembly-room is occasionally used for concerts, public exhibitions, and corporation dinners. In the lower story, now closed in, there is a newsroom, established by the corporation in 1825 , and a wcll appointed kitchen; on this new work is inscribed the date:- " 1826 ",

This building formerly comprised the court-house, the exchange, the weigh-house, and a guard-room.

The Court House possesses much architectural beauty. It exhibits a façade, judiciously broken by a tetrastylc portico of the enriched Ionic order, modelled after that of the temple of Erechtheus, at Athens. It measurcs 126 feet by 66 . The tympan of the pediment is embellished with the royal arms in high relief, and the wings are surmounted by statues of justice and peace, executed in Portland stonc by the late eminent Irish sculptor, Edward Smith. AII the ornamental work is of the same, but the principal material is white sandstone, procured chiefly from the neighbourhood of Dungiven.

The foundation was laid on the 18th of December, 1813, by John Curry, Esq. Mayor, and Sir Gcorge F. Hill, Bart.; and in 1817 the building was finished, at an expense of $£ 30,47915 s$., the purchasc of ground and furniture included. The first assizes held in it were those of the summer of 1816 .

The design was furnished by Mr. John Bowden, who died before the work was finished, and the remainder was executed by Messrs. Henry, Mullins, and M'Mahon, pursuant to a commission under the 52 George 3, c. 182 .

The principal apartments are the Crown and Record courts, the Mayor's public and private office, the Record office, the Treasurer's office, those of the clerks of the Crown and Peace, the Judges' room, and the grand jury room.

In the mayor's private office are preserved two swords. One of these, which is inscribed "Andrea Farara," having probably been made by that celebrated sword-cutler, is erroneously 


\section{BUILDINGS.}

reputed to have belongod to Sir Cahir ODoherty: it was, in 1616 , presented to the mayor of Derry by the city of London.

In addition to the assizes, sessions, and mayor's cour't, the county and other meetings are held in the Court House.

\section{Public Institutions.}

The Gaol, which is situated in Bishop-street, without the gate, is very commodious, and at present exceeds the wants of a district in which crime is comparatively rare. The extent of the front is 242 feet, and the entire building, including the yards, is 400 feet in depth. Part of the front is coated with cement, part is built of Dungiven sandstone. It was erected by Messrs. Henry, Mullins, and M'Mahon, between 1819 and 1824, and was first occupied on the 16th of August, in the latter year. The expenses of its erection, which had been estimated at $£ 27,000$, amounted to $£ 33,718$, Irish currency; and thosc of its support are defrayed from grand jury presentments. Working-tools, however, are provided from the profits of the work itself

The front part is occupied by debtors and female prisoners. A little within it is the governor's house, 60 feet by 28 , which is surrounded by a panoptic gallery, and includes the chapel and the committee-room. It stands between two buildings, 60 feet by 20 , which were designed for female prisoners, but, beiug found unsuitable, are now appropriated to culprits sentenced to hard labour; they are called correctional prisons.

The Crown Prison, which is nearly semicircular, is separated from this group by airingyards, at a distance of 84 feet. The entire gaol contains 179 single cells, and has room for 368 prisoners, when more than one sleep in the same cell. There are in the gaol 26 work and day-rooms, and 20 yards. Apart from the main building there is an hospital.

The Custom-House was originally a store. It was built in 1805 , by Mr. John A. Smyth, from whom it has been, since 1809, rented by government, at first as a king's store, but since 1824 as a custom-house. The premises comprise some extensive tobacco and timber yards, laid out at different periods. They now extend in front 450 feet, and are generally 25 deep; but a part of the timber yard extends to the depth of 240 . The annual rent is $£ 14194 \mathrm{~s} .6 d$. and the tenure is for ever.

The Linen-Hall, which was built about sixty years ago, is in an obscure situation. It consists of a court measuring 147 feet by 15 , which is enclosed by small dilapidated houses. In these the cloth is paid for, after being purchased under sheds, and on stands placed in the court. The sealing-room is on the opposite side of the street.

The Barrack, which was built for a regiment of infantry, is inadequate both in extent and accommodation. Its site is damp, the yard being occasionally overflowed by the river. The erection of a new barrack having been long contemplated, ground has been provided in Clooney, a townland of CLONDERMOT.

The Magazine was erected by Sir William Smith, formerly assistant royal engineer in this district, on the site of O'Donnell's Castle, (See History). It is well built, and said to be bomb proof. The magazine was formerly under the carc of the ordnance storekeeper. It came next into the possession of Sir George F. Hill, who obtained from the Irish Society a lease of the plot on which it stood-the government, as is supposed, having about this time resigned their claim on it in his favour. He afterwards disposed of it, and it now belongs to Mr. Robert Young, who has occasionally rented it to the government. There is nothing deposited in it at present, the ammunition of the troops being kept in the barrack.

The Bridgc, although wooden, is the boast of Derry. It was begun in 1789, by Lemuel Cox, of the firm of Cox and Thompson, of Boston, in New England, near which city they had constructed wooden bridges over waters as deep and rapid as the Foylc at Derry, and of greater breadth. In 1790 it was opened for foot passcngers, and in the spring of 1791 for vehicles.

Its length is 1068 feet, and its breadth 40 . The piles of which the piers are composed, are from 14 to 18 inches square, and from 14 to 18 feet long. They are made of oak, and the hcad of each pile is tenoned into a cap piece, 17 inches square, and 40 fect long, supported by three sets of girths and braces. The piers, which are $16 \frac{1}{2}$ feet asunder, are bound together by thirteen string-pieces, equally divided, and transversely boltcd: on the string-pieces is laid the flooring. On each side of the platform there is a railing, $4 \frac{i}{3}$ feet high, and a broad footway, provided with gas-lamps. Between the middle of the bridge and the end next to the city a turning-bridge has been constructed, in place of the original draw-bridge. Some contrivance of this kind is necessary, the inhabitants of Strabane having a right to the free navigation of the Foyle.

The city and its reservoir being at opposite sides of the river, the water has to be conveyed across the bridge by pipes. There is a toll-gate at the end next to the city.

On the 6th of February, 1814, a portion of the bridge, extending to 350 feet, was carried 


\section{CITY OF LONDONDERRY.}

away by large masses of ice, which had been floated down the river by the ebb-tide, and a very
high wind.

column of the Roman Doric order, surmounted by thestern bastion, is a well-proportioned whom, with his gallant companions, it is inted by a statue of the distinguished governor, built of Portland stone. The height, including the to commemorate [See History.] It is measures 9, and the thickness is 1 fot 8 inding the pedestal, is 90 feet, of which the statue staircase of 110 steps, which measures 3 feet 5 inches in ascended on the inside by a spiral The foundation was laid

Richard Young, and in 1828 the work of December, 1826, O. S., by the mayor, Major defrayed by subscription, amounted work was completed. The entire expense, which was

The governor's likeness was procured from that of the statue included, which was $£ 100$. his descendants. He is represented in the possession of one of holds a bible. His left, which points towards the costume of the day, and his right hand held a sword, which has, howevcr, dropped off: the spot wherc the boom was laid, formerly the belt alone remains. The column was erect : the sheath was aftcrwards rcmoved, so that and the statue was carved by John Smith, Esq. of Dublin.'s Henry, Mullins, and M'Mahon,

On the basc there is a tablet intended Lublin.

The Theatre, which was built about for an inscription.

obscure situation. A few years since it forty year's ago, is an insignificant structure, in an better fitted up. mercial.

The principal Hotels arc-the King's Arms', the City Arms', Floyd's, and the ComThe King's Arms' Hotel was built by private subscription for a County Hotel, but has
becn long open to the public.

houses. 'lo make room for building the Corn Markct, well provided with sheds and weighlished, in which were found human bones Corn Markct, the "Coward's Bastion" was demoThese may have been the remains of individuals $\rightarrow$ the bastion was indebted for its opprobrious name. 


\section{MUNICIPALITY.}

\section{STATE AS TO PEOPLE.}

\section{Section 1.--Municipality.}

\section{EXTENT OF THE CITY AND LIBERTIES.}

According to the present charter of Londonderry, granted by Charles the 2nd, in the 14th year of his reign, and enrolled in the 18 th, the extent of the "city and liberties" is defined to be "within, and by the space and circuit of three Irish miles, to be measured and limited from the middle of the said city of Derry, on each and every side of the said city."

The proportion annexed to the city on the west of the Foyle was originally computed at 4000 acres, and divided into the upper and lower liberties, which are separated by the bishop's demesne. The former division is included within a line, stretching from the demesne by the Sheriff's Mountain, and turning eastward by the road to Raphoe, and the hill above Dunmore, and thence to the bank of the Foyle. The latter extends from the demesne towards the west and north.

The jurisdiction of the corporation at present extends over the whole parish; but in Culmore only by sufferance, this townland not forming a property in the county. In CLONDERNoT, on on the east of the Foyle, the limit follows the southern county boundary, and proceeds eastward to Lisdillon, inclusive: it then turns northward, and comprehends Glenkeen, Lismacarol, Gortica, Tirbracken, Managhmore, Managhbeg, Gortree, Gorticross, Carn, Ballyoan, Stradreaghbeg, Maydown, Carrakeel, Culkeeragh, and Lissahawley.

\section{ORIGIN AND PROGRESS.}

Cirarters.-On the conclusion of the warlike operations of Sir Henry Docwra, in 1603, the attention of the English government was particularly turned towards establishing a muncipality in Derry, of which, as has been seen in Civil History that able commander may be considered the "true founder." By an abstract of charter's from the patent rolls of James the 1st, it appears that on the 12th of September, 1603, a grant was made to Sir Henry Docwra to hold two markets, and a fair for six days, with horse-races during such markets and fairs, which horseraces were continued until 1834 , when they were suppressed by the exertions of a number of the resident gentry, who considered that they led to immorality. Pursuant also to letters dated at Westminster on the 22nd of March, 1603, the king did "give, grant, and confirm unto him, and the inhabitants of the Derrie, all the circuit and extent of land and water within the compass of three miles, to be measured from the circumference of the old church walls, directly forth in a right line, every way round about, every mile containing 1000 geometrical paces, and forth in a right feet in length," which "shall be for ever a free, entire and perfect city and county of itself, to be called the city and county of Derrie, and shall be a corporation and body politic, made and created of the inhabitants of the same, consisting of 1 provost, 12 aldermen, 2 sheriffs, 24 made and created of the inhabitants of the same, consisting of 1 provost, aldermen, sheriffs, and burgesses, should think good to admit." By the same letters the sheriffs are empowered to hold various courts, "to nominate a recorder during behaviour - the provost, ar vice-provost, recorder, and two senior aldermen to be justices of the peace, to hold courts of oyer and terminer, and gaoldelivery." The corporation also, in general, was empowered to keep courts, amono other privileges.

In 1609 it was again determined "that the liberty of the city should extend three miles every way."

On the 27 th of January in the year 1612-13, the I rish Society was formed, and on the 29th of March they received their charter of incorporation, under the name of " the governor and assistants of the new plantation in Ulster." By this charter "it is granted that the city or town of Derry should be called the city of Londonderry, and all lands within the circuit of three Irish miles to be measured from the middle of the city, to be within the liberties and jurisdiction thereof."

From the extracts just given it appears that, so far as the extent of mmicipal jurisdiction is concerned, the various charters agree. This agreement prevails pretty generally throughout, and the circumstances which led to their successive abrogation, and the final settlement of the present charter, have been fully detailed in the previous parts of this Memoir, 


\section{CITY OF LONDONDERRY.}

STYLE.-The present style of the corporation is "the mayor and commonalty, and citizens of the city of Londonderry."

OFF1CERS. The corporation, as described in the charter of Charles the 2nd, consisted of the mayor, 12 aldermen, 2 sheriffs, a chamberlain, and 24 burgesses. A recorder is afterwards mentioned, a sword-bearer, and 6 serjeants-at-mace.

The common council were to consist of "the mayor for the time being, and also the aldermen, sheriffs, chamberlain, and chief burgesses." There are at present a sword-bearer, in addition to the mace-bearer, and 4 town serjeants, in place of the 6 serjeants-at-mace: the recorder may serve by deputy.

Annexed to the corporation are also the following officers, who are elected and paid by them:--a prothonotary of the mayor's court, a mace-bearer, 4 serjeants-at-mace, and 2 sheriffs'
bailiffs.

EtECTION OF OFFICERs.-None who reside beyond the liberties are qualified to be members of the corporation: until 1834, however, this rule was not strictly observed.

The sheriffs are choscn by the corporation exclusively, and the proceedings take place in close chamber. The election of the mayor and sheriffs takes place on the 2nd ef February: the other officcrs are chosen at any time, and for a stated period.

Although the military and police form no part of the municipal body, it may not be improper to introduce the mention of them luere, as they are amenable to the control of the mayor and magistrates, in the exercise of the local government.

The city is in the northern military district, and is the head-quarters of a regiment of infantry, which supplies detachments to various places.

The usual force of revenue police is a lieutenant and $12 \mathrm{men}$, of constabulary-a chief con. stable and 12 men.

Admission of FrEemen.-According to the existing charter it would appear that the freedom of the city was to cxtend to the entire community, although the practice is different: " and we will, grant, establish, ordain, appoint, confirm, and create, that all citizens and inhabitants of the city of Londonderry aforesaid, and they who hereafter shall be citizens and inhabitants of the said city and their successors for ever hereafter, be and shall be by force of these presents a new body corporate and politic, in deed, fact, and name." The sons of aldermen and burgesses, and the husbands of their daughters, are of right cntitled to their freedom, as are also such persons as have served their apprenticeship to a freeman. Some obtain it by special favour, among' whom are the clergymen of the cathedral, and thuse attached to the Presbyterian meeting-house.

Jurisdiction and Revenue of tife Corporation.-With or without the recorder, the mayor holds a record court for sums to any amount, which is, however, too expensive to be much frequented. Hc also presides in the court of conscience, from which there is no appeal : here ordinary debts may be recovered, not exceeding $20 l$., Irish currency; or servants wages, not exceeding $6 l$. Courts of petty sessions also arc held at irregular intervals before the mayor, or any other ciric magistrates, for assaults within the liberties. The recorder has likewise a separate court, in which he presides alone.

The jurisdiction of the corporation is also exercised in the enactment and cnforcement of various regulations, and in presiding over various civic institutions. However, as the whole subject of corporate jurisdiction is at present undergoing parliamentary investigation, it would be premature to enter very fully into it; but it will be necessary to advert to such parts of it as form the most legitimate matter for statistical inquiry.

Watciling, Pavrng, Cleansing, and Lighting.-The city is watched, paved, cleansed, and lighted, under a police committee, in whom the necessary powers have been vested by an act, which reccived the royal assent on the $4 \mathrm{th}$ of July, 1832. This committee consists of the mayor, with twelve inhabitants, chosen by ballot. Those only are qualified to be put in nomination as candidates, who are rated at or above $£ 20$, and reside in the city, or suburbs: and those only are qualified to ballot, who are liable to assessment, and whose tax, or cess, is not one year in arrear. The committee has the powcr of appointing watchmen, fixing their salaries, and fining, or dismissing them. The watchmen, when on duty, possess the same powers as constables. The streets are maintained in good order, and remarkably well lighted with gas. Fire-engines are kept ready to be used at a moment's notice. The expenses of this establishment are defraycd by assessments, or rates, levied on the city and suburbs, as directed in the act, by which the committee is empowered to determine the limits of the city and suburbs once a ycar, and to rate accordingly all premises not under the value of $£ 10$ yearly, "provided such assessment shall not exceed one shilling in the pound of a valuation made by the committee."

The city is supplied with water from a tank, or reservoir, on the Quay Brae Head, over the Waterside.-[Sce Parish of Clondermot.]

The corporation were empowered by the 40 th Gcorge $3 \mathrm{rd}$, to supply the city with water, and 


\section{MUNICIPALITY.}

to reimburse themselves by levying a rate. They expended for this object $£ 15,500$, but, on the passing of the 48 th George $3 \mathrm{rd}$, they were allowed interest on no more than $\mathfrak{E} 8,000$. There is an annual assessment of interest on this sum. In addition, there is another sum of about $£ 150$, levied annually for the current expenditure, and within the last four years from $£ 200$ to $£ 300$ more have been levied for laying down metal pipes.

The assessment authorized by the act is as follows:-

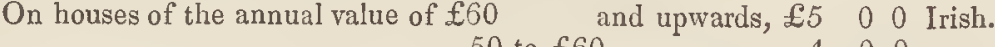

$$
\begin{aligned}
& 50 \text { to } £ 60 \quad 4 \quad 00 \\
& 40 \text { to } 50 \quad 3 \quad 00 \\
& 30 \text { to } 40 \quad 200 \\
& 20 \text { to } 30 \quad 1100 \\
& 5 \text { to } 20 \quad 0 \quad 10 \text { in the } £ \text { l. }
\end{aligned}
$$

The full amount of these rates was originally levied; they have, however, been since considerably lowered. First class houses are now rated at $£ 35 s .8 d$. The whole sum assessed in 1833 was $£ 1000$. Those who require an extra supply of water, such as brewers, \&c., have to pay in proportion.

Fairs and Markets.-Fairs and markets are likewise under the control of the corporation: in estimating their extent it will be necessary to advert specifically to the commodities vended.

There are six annual fairs, only three of which are important. These are held on the 17 th of June, 4th of September, and 17 th of October. The other three are badly attended, and have hitherto proved unprofitable. They are held on the 4th of March, 30th of April, and 20th of September.

Previously to 1826 there was custom charged on every article of merchandize that entered the city. At that period the usage was abolished, except in reference to articles conveyed across

\begin{tabular}{|c|c|c|c|c|c|c|c|}
\hline Name. & Locality. & Market Days. & 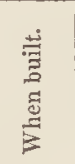 & $\begin{array}{l}\text { By whom } \\
\text { built, \&c. }\end{array}$ & $\begin{array}{l}\text { Principal com- } \\
\text { modities } \\
\text { vended. }\end{array}$ & 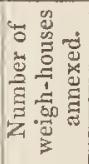 & $\begin{array}{l}\text { Proprietors of } \\
\text { the Tolls. }\end{array}$ \\
\hline Shambles. & $\begin{array}{l}\text { Off Linen- } \\
\text { Hall-street. }\end{array}$ & $\begin{array}{l}\text { Every day. } \\
\text { (Sunday ex- } \\
\text { cepted.) }\end{array}$ & 1760 & $\begin{array}{l}\text { Alderman } \\
\text { Alexander, and } \\
\text { other mem- } \\
\text { bers of the }\end{array}$ & Meat. & 1 & $\begin{array}{l}\text { Sir Robert A. } \\
\text { Ferguson. }\end{array}$ \\
\hline Linen Market. & $\begin{array}{l}\text { Linen-Hall- } \\
\text { street. }\end{array}$ & Wednesday. & 1770 & $\begin{array}{l}\text { The late Fred. } \\
\text { Hamilton, Esq. }\end{array}$ & Linen. & 0 & $\begin{array}{l}\text { Frederick Ha- } \\
\text { milton, Esq. }\end{array}$ \\
\hline Butter Market. & $\begin{array}{l}\text { Waterloo } \\
\text { Place. }\end{array}$ & $\begin{array}{l}\text { Every day. } \\
\text { (Sunday ex- } \\
\text { cepted. }\end{array}$ & 1825 & Corporation. & $\begin{array}{l}\text { Butter and } \\
\text { hides. }\end{array}$ & 3 & Corporation. \\
\hline Fish Market. & $\begin{array}{l}\text { Off Linen- } \\
\text { Hall-street. }\end{array}$ & do. & 1825 & do. & Fish. & 0 & $\begin{array}{l}\text { Sir Robert A. } \\
\text { Ferguson. }\end{array}$ \\
\hline Potatoe Market. & Society-street. & do. & 1825 & do. & $\begin{array}{l}\text { Potatoes and } \\
\text { meal (by re- } \\
\text { tail.) }\end{array}$ & 1 & Corporation. \\
\hline Vegetable Market. & $\begin{array}{l}\text { Off Linen- } \\
\text { Hall-street. }\end{array}$ & do. & 1825 & do. & $\begin{array}{l}\text { Vegetables, } \\
\text { poultry, and } \\
\text { butter, (by re- } \\
\text { tail.) }\end{array}$ & 0 & $\begin{array}{c}\text { Sir Robert A. } \\
\text { Ferguson. }\end{array}$ \\
\hline Corn Market. & Foyle-street. & $\begin{array}{l}\text { Wednesday } \\
\text { and Saturday. }\end{array}$ & 1832 & James $\mathrm{M}^{\circ} \mathrm{Crea}$. & $\begin{array}{l}\text { Oats, meal, } \\
\text { wheat, barley, }\end{array}$ & 3 & James $\mathrm{M}^{\top} \mathrm{Crea}$. \\
\hline Cow Market. & $\begin{array}{l}\text { A field at the } \\
\text { south part of } \\
\text { Bishop-st., } \\
\text { near the river. }\end{array}$ & Wednesday. & 1832 & $\begin{array}{l}\text { Field inclosed } \\
\text { by corporation. }\end{array}$ & $\begin{array}{c}\text { bere, and rye. } \\
\text { Cows, pigs, } \\
\text { sheep, and } \\
\text { goats. }\end{array}$ & 0 & Corporation. \\
\hline Flax Market. & Bishop-street. & Thursday. & - & Open street. & Flax. & 0 & - \\
\hline Yarn Market. & Butcher's-st. & Wednesday. & - & do. & Yarn. & 0 & - \\
\hline
\end{tabular}
the bridge. In place of entrance custom the city authorities then instituted trespass, cranage, storage, \&c. In 1830 the shambles, and the fish and vegetable markets, were purchased from the corporation, by Sir Robert A. Ferguson.

TABLE OF MARKETS. 


\section{CITY OF LONDONDERRY.}

BrIDGE. -The bridge is, likewise, an important source of revenue. Previously to its erection all intercourse with the country at the opposite side of the Foyle was maintained by a ferry, which the corporation held under the Irish Society, at an annual rent of $£ 20$, and sub-let at $£ 300$ annually. In 1789, when thirty years of their tenure were still unexpired, they presented a memorial to the society, stating their intention of building a wooden bridge, but soliciting as a preliminary, a lease renewable for ever, securing to the corporation a right to erect such bridge, and appropriate the tolls of it to their own use, subjcct to the resumption of the society whenever they should cease to maintain it. The society, however, as mere trustees for the twelve London companies, declined full compliance, but granted a lease of the ferry in perpetuity, at the original rent, which was to be secured on the tolls, and to cease if the bridge were not kept in fitting repair.The lease was never executed; but the corporation hold by virtue of the above agreement.

In 1790 the corporation petitioned parliament, and obtained an act ( 30 Geo. III. c. 31 ), empowering them to build a bridge over the Foyle at Derry, and granting tolls for passage, to be applied to "lighting, watching, maintaining, and supporting the bridge, expenses of collecting toll, removing buildings, purchasing interests, making approaches, and payment of $£ 20$ annually to the Irish Society." It likewise authorizes them to advancc or borrow money, and enacts that, after the payment of all debts and expenses, the surplus tolls should be applied, like the other corporation property, to the improvement of the city and suburbs. A wooden bridge was accordingly erected, exclusively from money borrowed on the credit of the tolls. The expense amounted to $£ 16,594$, Trish currency.

In 1800 another act was obtained by the corporation, (40 George 3, c. 41,) which granted an increase of tolls. For repairing the damage, which, as above mentioned, occurred to the bridge in 1814, a third act obtained by the corporation, (54 George 3, c. 230), authorizes them to bolrow, on dcbenture, any sum not exceeding $£ 60,000$, to be secured on the tolls of the bridge, and their other estates, premising that the corporation have already incurred a debt to that amount in erecting and repairing the bridge, ano constructing quays, wharfs, and other public works. It also cmpowers the lord lieutenant to order the treasury to advance $£ 15,000$, Irish currency, for the repair of the bridge, to be refunded by instalments within twenty years; the first instalment to be made on the 1st of January 1817. Lastly, it grants a further increase of tolls; allows of their modification and renewal; enforces their application, as specified in the preceding acts; directs that, in consideration of the additional tolls, the corporation shall always maintain a proper and substantial bridge ; and requires them to fund at least $£ 1000$ a year, adding interest to principal, until the sum of $£ 30,000$ shall have been amassed for repairing or rebuilding the present bridge, and no other purpose; adding that, in case of accident preventing the use of the bridge, the same tolls shall be paid for a ferry, and the money arising therefrom applied and invested like the annual sum of $£ 1000$, but not considered part of it. No money was borrowed on debenture, but the bridge was repaired from the $£ 15,000$ advanced by government, witl the addition of $£ 3,208$ from the tolls, making in all $£ 18,208$.

Of the above $£ 30,000$ there was funded in Febriary, 1830, the sum of $£ 500$, and a second sum of $£ 500$ has since been added.

The corporation having incurred a considerable debt, by constructing quays, markets, and other public works, as already stated, paying salaries and pensions, and subscribing to public establisloments, executions to the amount of $£ 38,000$ were in 1831 issued against them. As no part of the sum lent from the treasury in 1814 had been repaid, the government also procured from the court of chancery a sequestration against the tolls of the bridge. They consented, however, with the approbation of parliament, to accept of twenty equal annual instalments of $£ 81618$ s. $5 d$, , the sum then due being in British money as follows :-

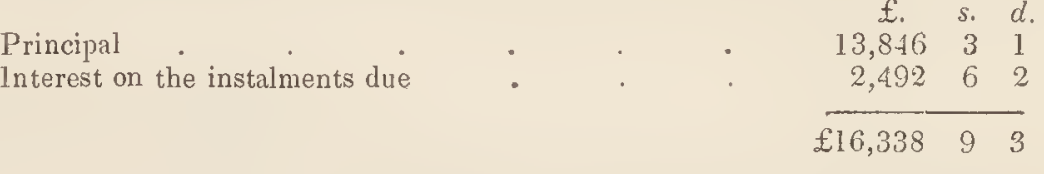

This arrangement was confirmed by two acts, (2nd and 3rd William, 4th, c. 107), under which two instalments have been paid.

On the 2nd of January, 1833, the debts of the bridge were as follows:-

$\left.\begin{array}{l}\text { Original debt incurred in erection, bearing interest at } 5 \\ \text { per cent. }\end{array}\right\}$ British, $£ 15,317$

Re-payment due to Government without interest, . 14,755 


\section{MUNICIPALITY.}

Those general creditors of the corporation, who hold their bonds as a security, have also a claim on the bridge, which in 1833 amounted to $£ 9,500$.

There are therefore three descriptions of creditors on the property of the bridge :-

1st. The original creditors.

2nd. The government.

3 rd. The general creditors of the corporation.

The Irish Society also have a claim on it of $£ 20$ annually.

It is in contemplation to erect a new bridge, nearly 600 feet above the present one, and the corporation are negotiating about the sale of their property in it, and the right of ferry, the government sequestration not having been carried into effect. They have agreed to take $£ 31,000$ for their interest. Plans and estimates have been procured, and soundings of the river taken. According to Sir John Rennie, the cost of a suspension bridge would be $£ 56,960$; of a cast iron bridge with three arches, on stone piers, £81,917; of a stone one, $£ 126,663$. It is, however, thought that a suspension bridge on the most improved plan would not cost more than $£ 50,000$. Without the co-operation of government, however, and of the Irish Society, it is not likely that such an object can ever be effected. Mr. Tite in his last report to the society recommends that the new bridge should be constructed at a point a little below the Gallows Brook, or western end
of a stream called Mary Blue's Burn.

REVENUE. - The following Tables, from recent parliamentary documents, exhibit a condensed view of the present state of the corporation revenue:- 

CITY OF LONDONDERRY.

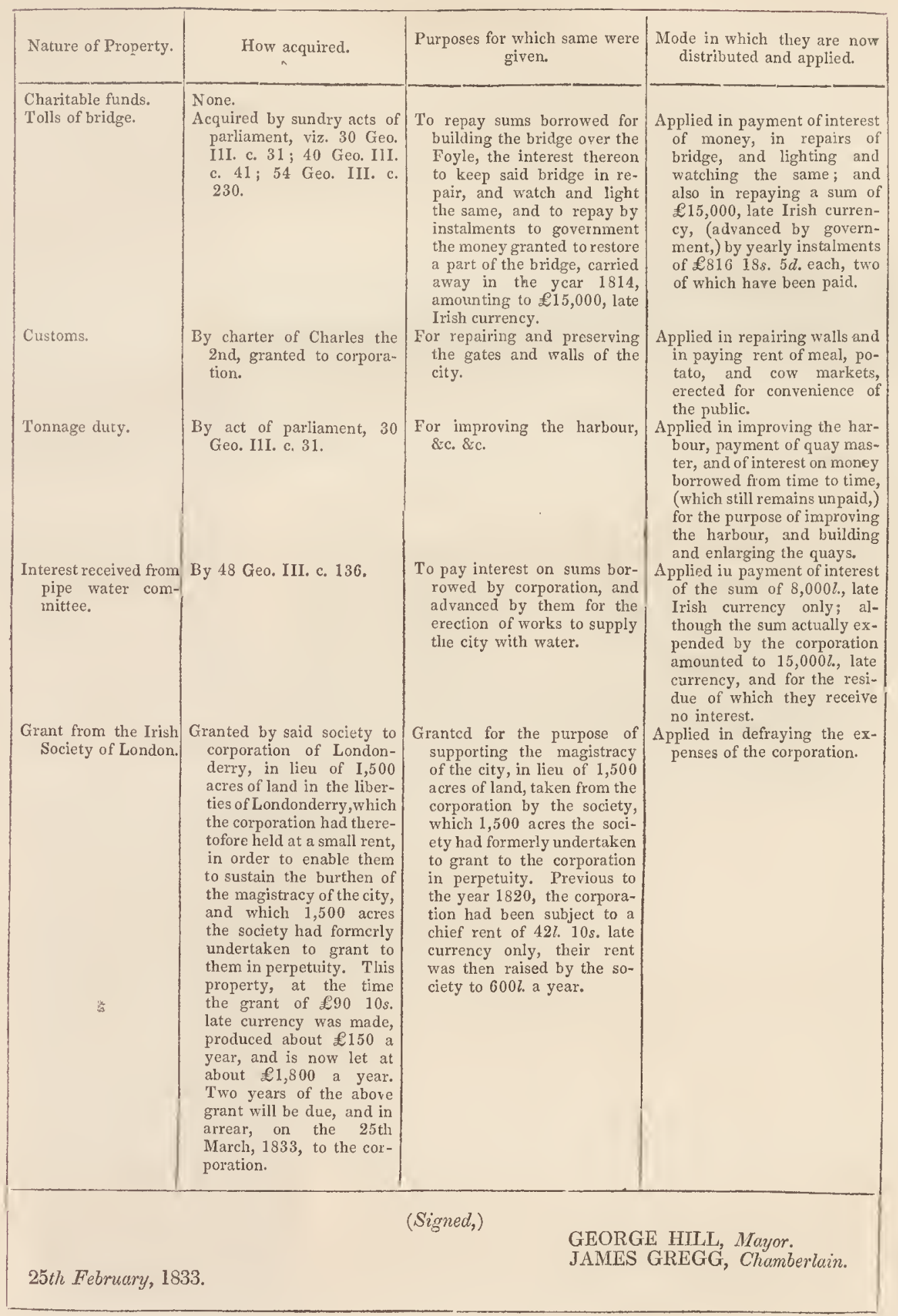




\section{MUNICIPALITY-}

Annual Expenses of the Londonderry Bridge for 1833, 1834, and up to the $19 \mathrm{th}$ of
June, 183.5.

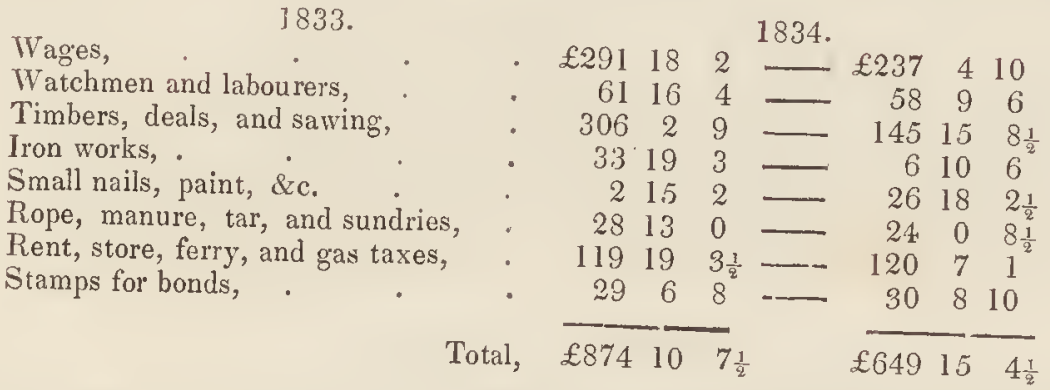
On the 19 th June, 1835 , the amount of the expenses from the 1 st of January was
$£ 2426 \mathrm{~s}$. $5 \mathrm{~d}$.

The law directs that watchmen be employed at night; and these watchmen are occasional labourers on the bridere.

The gas tax is $£ 7616$ s. Od. a year.

The following crossed the bridge on two days of June, 1834 :-

\begin{tabular}{|c|c|c|c|c|c|c|c|}
\hline & $\begin{array}{l}\text { Foot Pas- } \\
\text { sengers. }\end{array}$ & $\begin{array}{l}\text { Horse- } \\
\text { men. }\end{array}$ & $\begin{array}{c}\text { Car- } \\
\text { riages. }\end{array}$ & $\begin{array}{c}\text { Private } \\
\text { Cars. }\end{array}$ & $\begin{array}{l}\text { Post } \\
\text { Cars. }\end{array}$ & $\begin{array}{c}\text { Wheel } \\
\text { Cars. }\end{array}$ & Drays. \\
\hline $\begin{array}{l}\text { Monday the } 2 \text { nd, from } 8 \text { A. M. to } 9 \text { P. M. } \\
\text { Tuesday the } 3 \text { rd, from } 9 \text { A. M. to } 10 \text { P. M. }\end{array}$ & $\begin{array}{r}983 \\
1004\end{array}$ & $\begin{array}{r}113 \\
76\end{array}$ & $\begin{array}{l}49 \\
51\end{array}$ & $\begin{array}{l}82 \\
89\end{array}$ & $\begin{array}{l}31 \\
23\end{array}$ & $\begin{array}{r}13 \\
7\end{array}$ & $\begin{array}{l}147 \\
123\end{array}$ \\
\hline Totai for 2 Days. & 1987 & 189 & 100 & 171 & 54 & 20 & 270 \\
\hline
\end{tabular}

The following crossed it on two days of January 1835:-

\begin{tabular}{|c|c|c|c|c|c|c|c|}
\hline & $\begin{array}{c}\text { Foot Pas } \\
\text { sengers. }\end{array}$ & $\begin{array}{l}\text { Horse- } \\
\text { men. }\end{array}$ & $\begin{array}{c}\text { Car- } \\
\text { riages. }\end{array}$ & $\begin{array}{c}\text { Private } \\
\text { Cars. }\end{array}$ & $\begin{array}{l}\text { Post } \\
\text { Cars. }\end{array}$ & $\begin{array}{l}\text { Wheel } \\
\text { Cars. }\end{array}$ & Drays. \\
\hline $\begin{array}{l}\text { Tuesday the } 13 \text { th, from } 8 \text { A. M. to } 9 \text { P. M. } \\
\text { Monday the } 19 \text { th, from } 8 \text { A. M. to } 9 \text { P. M. }\end{array}$ & $\begin{array}{l}1240 \\
1075\end{array}$ & $\begin{array}{l}35 \\
13\end{array}$ & $\begin{array}{r}20 \\
6\end{array}$ & $\begin{array}{l}19 \\
10\end{array}$ & $\begin{array}{l}6 \\
4\end{array}$ & $\begin{array}{l}5 \\
6\end{array}$ & $\begin{array}{l}190 \\
162\end{array}$ \\
\hline Tотац for 2 Days. & 2315 & 48 & 26 & 29 & 10 & 11 & 352 \\
\hline
\end{tabular}

\section{PARLIAMENTARY REPRESENTATION.} Elecrion of MEMBERs.-From the extensive authority confelred on the Irish Society at
the plantation, it was to be expected that their influence would be paramount in the parliamentary representatives. And that their influence would be paramount in the election of century-the candidates nominated by the society to have been down to the middle of the last tion; for some time also after the by the society having been generally returned by the corporatheir electioneering services. From the abovermed they paid allowance to the burgesses for was a close borough.

From the enfiction

liament, which number was then reduced to the Union it returned two members to the Irish par-

The constituency is now vested in the one.

residing more than seven now vested in the $f 10$ householders, and resident freemen-no freemen the charter "citizens and inhabitants" centre of the city being competent to vote. The terms in 


\section{CITY OF LONDONDERRY.}

to the rights of freemen, which were rejected by the assessor, in 1830, when sixty-seven individuals, who had been sworn in before a bench of magistrates at Burnfoot (a place within the liberties), tendered their votes.

The following table exhibits the constituency for a series of years:-

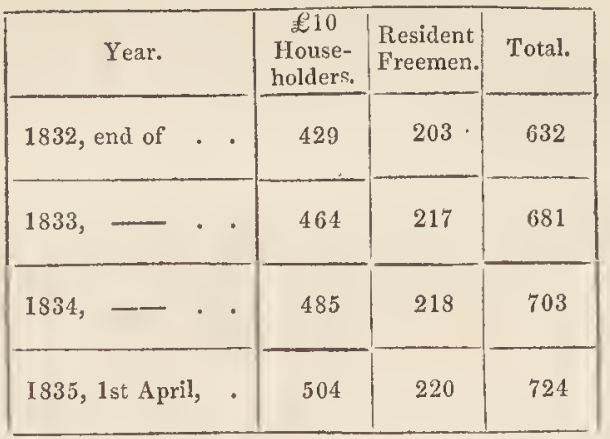

Sir George Fitzorerald Hill continued to represent the city for many years, until the dissolution of parliament, on the death of George the 4th. The representation was then contested by Sir Robert Alexander Ferguson, Bart., John Hart, Esq., and John Montgomery, Esq., and on the 17 th of August, 1830, Sir Robert Alexander Ferguson was returned.

This return was petitioned against, on the ground of the successful candidate having held the office of mayor, at the time of his election. The petition was granted, and another election ensued. On this occasion, the same candidate was again returned, on the 9th of A pril, 1831, after a contest with John Hart, Esq.

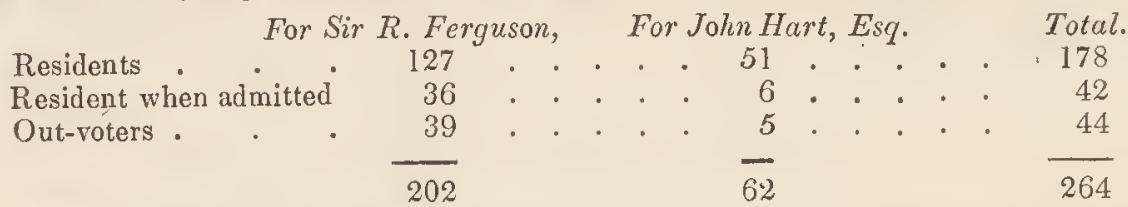

After the dissolution of parliament Sir R.A. Ferguson was again returned on the 12th of May, 1831, after a contest with Conolly Lecky, Esq.

For Sir R. A. Ferguson.

Residents

Resident when admitted

Out voters.

$\begin{array}{r}140 \\ 27 \\ 38 \\ \hline 205\end{array}$

For C. Lecky, Esq. . . . 42

$$
\begin{aligned}
& 7 \text {. . . } 182 \\
& \frac{1}{59} \cdot \cdot \cdot \frac{48}{264}
\end{aligned}
$$

The next election terminated on the 18 th of December, 1832, when Sir R. A. Ferguson was again returned after a contest with the Honorable George Robert Dawson.

The state of the poll was as follows:-

For Sir R. A. Ferguson

- Honorable G. R. Dawson

Rejected, Sir R. A Ferguson.

Ditto. Honorable G. R. Dawson

Of these $539,-176$ were freemen,

$$
\text { and } \frac{363}{539} \text { house holders. }
$$

The above election was petitioned against on the ground of bribery, but the petition was considered to be frivolous and vexatious.

On the 12th of January, 1835, Sir R. A. Ferguson was again returned without any opposition. 


\section{EDUCATION.}

\section{Section 2.-Education.}

Among the various modes of classification, which have been adopted in works devoted to this important subject, none is more simple than that which, being founded on the threefold condition of man, is divided into three distinct heads of instruction-physical, intellectual, and moral. In these pursuing through their various modifications in the city and parish under consideration, such: historical and other notices as are necessary will be given, but those details which are best expressed by numbers will be found in the subjoined table. It is right, however, to observe, before entering more fully on the subject, that imperfect and incongruous systems, eren in the instruction of the poor, must continue to prevail-especially at a distance from the metropolis-until some efficient model establishment shall have been formed, in which teachers may themselves be trained and disciplined, and an example provided for their guidance in the training of others.

\section{Sub-section 1.-Physical.}

When it is considered that, notwithstanding the great intercourse between these countries and the continent, many important branches of physical instruction, extensively practised there, have been generally neglected at home, it is by no means surprising that in a provincial city, such as Derry, they as yet form no regular part of the system of instruction, though at Gwyn's school the boys are exercised in military drilling, and it is intended to introduce gardening as soon as a sufficient extent of ground shall have been added to the establishment.

In dancing-which, properly considered, is a minor branch of physical education, and not a mere accomplishment, there are two resident masters, one of whom has adopted a very judicious system, combining calisthenics, the balancing of poles, \&c., with dancing, from a conviction that the true object of the art is to give flexibility to the body, and induce an easy, flowing gait, in place of the violent and unnatural cfforts of the opera dancer.

\section{Sub-section 2.-Intcllectual.}

In reference to intellectual instruction it will be found that the parish is provided with a variety of establishments, which, notwithstanding their various and important differences, may all be ranked under this head.

Keeping solely in view the nature of the instruction imparted, these establishments may be divided in to Classical and English schools. Of each description some are public, some privatethe former term comprising such as derive from some public institution the whole or part of their support, - the latter, such as are altogether dependent on the number of pupils.

\section{Public Schools.}

Crassical.-The Diocesan and Free Grammar School, or Foyle College, is the first in order of this class. On proceeding to notice this establishment, it may be advisable to glance at the old Free Grammar School which it has superseded.

In the reign of James the 1 st a piece of ground near the cathedral was granted by the governor and assistants of the new plantation of Ulster, as a site for a free grammar school. The building was of stone, one story and a half high, and provided with four dormant windows. The first story consisted of a school-room and hall, orer which were the lodging apartments. On a stone over the door was the following inscription:-

$$
\begin{aligned}
& \text { "MATHIAS SPRINGHAM AR... } \\
& \text { AD HONOREM DEI ET BONARUM } \\
& \text { LITTERARUM PROPAGATIONEM } \\
& \text { HANC SCHOLAM FUNDAVIT } \\
& \text { ANNO SALUTIS, 1617." }
\end{aligned}
$$

This school was endowed with funds by the Irish Society, and the corporation. The annual salary of the head master, who was bound to instruct fourteen poor scholars in the classics, was $£ 40$, and that of the usher 40 marks. A library, collected by Bishop Hopkins, was purchased by his successor, Bislop King, and bestowed upon the school. The succeeding bishops, and the inferior clergy, remunerated the master in his new capacity of librarian, and the school was hence termed diocesan. 


\section{CITY OF LONDONDERRY.}

The school has long been justly esteemer most respectable, and many who have filled high stations in life, have been educated at it. In the Report of the Commissioners of Education, in 1825, this school is stated to be "one of the best conducted and most useful schools in Ireland." It was removed to its present site in 1814, [see State as to Buildings], and an act of Parliament was obtained by which the dean and chapter were appointed trustees.

For the Iast few years, however, the number had gone on declining, especially in boarders, until at length there were none but day scholars, of whom 30 were educated by the Rev. Mr. Knox, then the master, as free scholars, being ten above the prescribed number, which had been already augmented to 20 by the new trustees.

A little more than a year ago $\mathrm{Mr}$. Knox retired, worn out by a faithful discharge of his arduous duties, continued during nearly 40 years, and the trustees having appointed the present master, exerted themselves to the utmost to restore the school to its former state of prosperity. In addition to 24 free day scholars, the school at present consists of 26 boarders, and 6 grown lads who study here, but attend examinations at college. The advantage of thus educating the children of the gentry within their own county is of equal importance to that of affording the higher means of instruction to those of the respectable town's-people. Appeals have been made to the generosity of those London companies who have withdrawn their subscriptions, and it is hoped that by their aid, and the liberality of the more wealthy gentry, something may be effected towards the permanent establishment, in Derry, of regular teachers of drawing, and of modern languages- the want of assistants, so essential in perfecting education being seriously felt, not merely in this school but in the city at large.

ENGLISII. - In these schools the education of pupils of the upper ranks frequently includes one or more of the modern languages, together with various accomplishments, such as music, drawing, dancing, and, in female schools, needle-work, in addition to the ordinary routine of a purely English course. In those intended for the humbler ranks the education is confined to reading and writing, with the addition of arithmetic for boys, and plain needle-work for girls, who are also taught some of the lower rules of arithmetic: in Gwyn's alone, the course is more comprehensive, and it is rendered still more so, by the use of books containing numerous extracts from works in natural history, or on other useful subjects. It is indeed surprising that in all schools for the poor, this easy method of rendering the acquisition of a knowledge of words, a step towards the real knowledge of things, is not adopted.

The public English schools are 10, of which 7 are in the city, or suburbs, and 3 in the country. The 7 civic schools consist of Gwyn's charitable institution, the parish school, the Presbyterian meeting-house school, the St. Columb's school, the London ladies' society's school, the gaol school, and the penitentiary school. The barrack school, from its migratory nature, cannot
be included.

Gwyn's Charitable Institution.-This school, the institution of which shall be more fully noticed under the head "Benevolence," was opened in 1833, pursuant to the will of Mr. John Gwyn, the founder. The system of intellectual instruction, as prescribed in the will, includes spelling, reading, writing, and arithmetic, with book-keeping, and navigation, under certain circumstances. In aldition to these English grammar, geography, \&c. are taught at the discretion of the trustees. The system followed embraces catachetical and mental calculation to a considerable extent-many of the children exhibiting great quickness in this most valuable practical application
of mathematics.

The Parish School.-The parish school is of ancient foundation, having originated in an act of the 28 th Henry the 8 th, hy which any person receiving spiritual promotion was bound by oath to establish within his district " a school to learn English, if any of the children of the parish should come to him to learn the same, taking for the keeping of the same school such convenient stipend or salary as in the said land was accustomably used to be taken." This act was confirmed by one passed in the 7th William the 3rd, "to the intent that no pretence may be made or used, that there are not sufficient number of schools in this realm to instruct and inform the youth thereof in the English language and otlier literature."

The male children are taught reading, writing, and arithmetic; the female, reading, writing, and sewing, with arithmetic, as far as proportion, inclusive. The expenses of apprentices, the repairs and fuel, are defrayed from an annual subscription of $£ 30$ from the Irish Society, $£ 10$ from the bishop, and $£ 2$ from the dean; if any surplus remain, after defraying these expenses, it is laid out on clothes for the poorer children.

The mastel receives a fixed annual salary of $£ 20$, to which $£ 10$ are added, provided the management and progress of the school be approved.

The master of this school has further been, a successful candidate for one of the $£ 10$ premiums, for the last four years, offered by the board of Erasmus Smith's fund in Dublin.

The salary of the mistress is arranged on the same principle-namely, $£ 14$ fixed-a gratuity of $£ 8$ granted on the inspector's report, and the chance of a premium of $£ 5$. By the rules of the 


\section{EDUCATION.}

board, each teacher must educate 20 pupils free of expense, and from the others they are entitled to reeeive $1 d$. per week, the usual rate they cost the parish; but, as is commonly the case in mixed arrangements of this kind, the payments are very irregular-and the total received by both teachers from this source cannot be estimated at more than $£ 5$, viz., male $£ 3$-female $£ 2$.

Presbyterian Meeting House School.-This establishment was preceded by the Presbyterian Blue School, which had existed above a century. It owed its namo to the uniform worn by the boys, which was blue coats with yellow collars. The number admitted was 12 . They were educated and clothed, after which they were apprenticed to trades; and these boys, with a precentor, formed the choir of the congregation. The school was supported by collections made at charity sermons.

The present school was established in 1820 , on a system altered from that of the old Blue School. The change originated in a suggestion made by the senior Presbyterian clergyman to the session and congregation, to abolish the uniform, and educate poor children of both sexes, and every sect. A subscription was forthwith opened for building a school-room, but the accomodation was afterwards considerably enlarged, to mcet the great demand for education. The total expense of these erections was $£ 450$.

A second suggestion of the same gentleman led to the separation of the sexes, and the appointment of a mistress over the girls. The ladies of the Presbyterian congregation undertook the expense of this additional department, and appointed a committee to superintend it. The boys are taught reading, writing, and arithmetic, the girls needle-work in additon. The Irish Society have increased their former annual subscription of $£ 12$ to $£ 30$, allotting $£ 20$ to the male school, and $£ 10$ to the female. The school requisites are defrayed from the voluntary subscriptions.

This school was for many years in connexion with the Kildare-street Society, until its parliamentary grant was withdrawn.

St. Columb's School.-The St. Columb's school was founded in 1813, under the auspices of the Roman Catholic bishop, and clergy. In consequence, however, of a disagreement between that prelate and one of his curates, the work was for some time suspended. In 1824 it was resumed, and in 1825 completed. The expesnes, including that of erecting a lofty inclosure, amounted to nearly $£ l, 000$.

This institution is now under the National Board of Education.

Gaol School.- In the gaol one of the turnkeys acts as inaster, and the matron as mistress, in instructing the male and female prisoners. Males are taught spelling, reading, and arithmetic daily, for an hour in summer, and half an hour in winter. In the female department, in which arithmetic is omitted, instruction is given for an hour, daily, throughout the year.

\section{Private Schools.}

CLASSICAL.-There are at present three private classical schools, two of which are boardingschools. These schools require no particular notice, in addition to the information contained in the subjoined table. This may, however, be the most convenient place to allude to a seminary of the abore descridtion, which has ceased to exist.

In 1806 a house in Bishop-street, without the Gate, was opened under the auspices of Dr. O'Donnell, the Roman Catholic bishop of Derry, for the education of young men intended for the priesthood. They all lived in common, kept a servant, purchased themselves the necessaries of life, and paid for their own teachers. It was closed about 1815, revived in 1821, and closed a second time in 1826. Some of the pupils used this as a preparatory school for Maynooth College; others completed their course at it, and were then ordained by their bishop. The average number of students was from 12 to 15 .

Englisir.-The Private English Schools are 29 in number, of which 25 are in the city or suburbs, and 4 in the country.

Several of them are highly respectable: they descend gradually to the humbler classes of society; and the infant school, which closes the chain of intellectual instruction, from its novelty claims a separate notice.

The Infant School (which those acquainted with the details of such institutions, will understand to be in a slight degree physical) was opened on the 7 th of January, 1835 . It is restricted to the children of the gentry. The terms are $\mathfrak{E} 4$ a year, paid quarterly in advance. It is open daily (Sundays excepted) for senior pupils from 10 to 1 , and for junior from 11 to 1 , and again from 2 to 3 . There is no play-ground annexed, but during the time of recreation, the pupils either remain in the school, walk on the walls, or are taken home by their parents. No holidays or vacation has been yet prescribed. Every parent is allowed to visit the school, and to introduce two friends. Should the institution succeed in the first year, it is in contemplation to erect a 


\section{CITY OF LONDONDERRY.}

suitable building, and to annex to it a play-ground. The number of children at present attending the school is 28 .

\section{Summary.}

On the whole it may be stated, under the head "intellectual instruction," that there are 46 teachers and 2027 scholars, of whom 1022 are under 10 years of age, 859 between 10 and 15 , and 146 above 15, forming nearly one-third of the population computed to be of thosc ages. From the natural reluctance felt by some of the proprietors of private schools to afford minute information, these numbers can only be given as an approximation; they are, however, believed to be very near the truth. The total expense may be estimated at $£ 3464$, but it will be seen by the annexed tables that the class of instruction afforded is so various, that no general average cost can fairly be drawn from these totals.

\section{Private Instruction.}

Another description of instruction remains, which is commonly resorted to by the higher members of society, and conducted either at the residence of the parents or teachers. The number of young persons, male and female, thus instructed, is small in Derry. For the lighter accomplishments, such as drawing, or the French and Italian languages, there are no resident masters, though the assistants in two respectable schools give occasional instruction. A practice prevails of professors in these branches visiting the city periodically from Dublin and Belfast.

\section{Auxiliaries.}

As auxiliaries to the intellectual branch of instruction it is proper to class libraries, museums, calinets, and collections of objects useful in science or in art. The only establishments of this nature that belong to Derry are as follows:-

1st. The Diocesan Library, already mentioned, which is rich in books of divinity, and is open to the clergy of the diocese, at all times which do not interferc with the business of the school. It is projected to add somc theological periodicals, to allow a sum for re-binding some of the ancient volumes, \&c., but the altered circumstances and uncertain incomes of most of the clergy have retarded the collection of funds.

2nd. The Public Library and News Room-or Library Association-was commenced in 1819, by subscription, and established in 1824 on its present footing, at which time a general meeting was held, and trustees appointed, in whom was vested by agreement the whole property of the institution, amounting at that time to $£ 15153 \mathrm{~s}$., to be applied to the purchase of books, \&c., at the discretion of a committee elected annually.

The shares are transferrible at the price of twenty guineas, but the candidate must be proposed, seconded, and balloted for.

There is a librarian, having apartments to the house, and a salary of thirty guineas a year.

The library at present consists of -

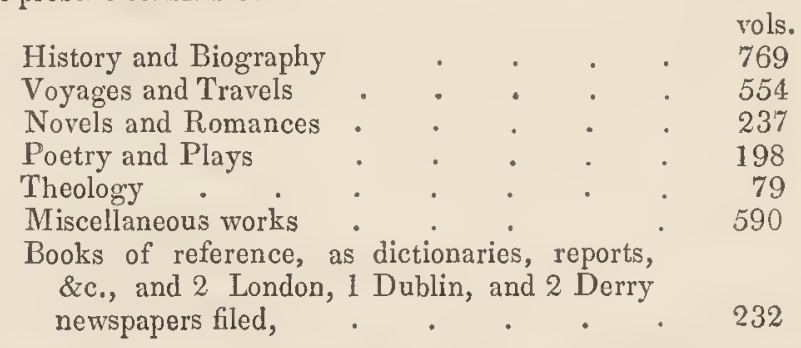

Twenty-four monthly or quarterly publications are taken, and the following newspapers:-

6 Daily, and 6 Weekly London.

6 Daily, and 2 Weekly Dublin.

2 Provincial English.

1 Edinburgh.

1 Glasgow.

3 Belfast.

1 Derry.

1 Limerick. 


\section{EDUCATION.}

Persons residing at a greater distance than two miles from Derry are admissible for one month, on the recommendation of a proprietor.

3rd. A Library connected with the Tract Society, supported by the clergy, various respectable tradesmen, and others, at a subscription of 10 s. a year.

4th. A Poor Library at the Fountain-street school-each subscriber of $2 s .8 d$. havino power to recommend readers, and bearing the responsibility of the books - consists of about 200 or 300 volumes, embracing voyages, travels, history, and religious subjects.

The Londonderry Literary Society must also be mentioned in connexion with this head. It was established on the 29th of August, 1834, from which time to the termination of their first session, there were 9 regular debates, and 10 lectures delivered. The present number of regular members is 30 , together with 3 honorary members. The society is increasing very rapidly.

The subjects on which the questions are chosen are principally history. The recess is of 3 months, and the meetings will be resumed on the Ist September, 1835.

In 1823 the North West Society established a monthly magazine in Derry, called after their name, which was given up in 1825. A newspaper was then substituted, called the "North West Farmer," which was, however, discontinued on the 1st July, 1826. A second series of the "Nortl West Society's Magazine" was then undertaken, but on the 1st of July, 1829, the publication ceased al together.

The city possesses two weekly newspapers of respectable character. The Londonderry Journal, established upwards of 60 years, appears on Tuesdays : in the year ending on the 5 th April, 1831 , it published 31,375 copies, which gives a weekly average of above 603 . The Londonderry Sentinel, established on the 19tl September, 1829, appears on Saturdays: in the same year it priblished 65,700 copies, which give a weekly average of above 1263 .

There is no account kept at the Post Office of the number of the newspapers transmitted through it, but it is supposed to be on the increase.

The following is a list of the periodical publications now circulating in the city, the reading rooms included :-

\begin{tabular}{|c|c|}
\hline & \\
\hline Orthodox Presbyterian, . & 50 \\
\hline Christian Freeman, & 300 \\
\hline Chambers' Edinburgh Journal, & 83 \\
\hline enny Journal, [monthly parts], & \\
\hline Ditto Magazine, & \\
\hline Saturday's Magazine, & \\
\hline sh Farmer's ditto, & \\
\hline itish Cyclopædia, [monthly parts] & \\
\hline Blackwood's Magazine, & \\
\hline Fashionable ditto, & \\
\hline hristian Gleaner, & \\
\hline ublin University Magazine, & \\
\hline ublin Christian Examiner, & \\
\hline enny Cyclopædia, & \\
\hline arterly Journal of Agriculture, & \\
\hline hnson's Medical, & \\
\hline ton's Bo & \\
\hline
\end{tabular}

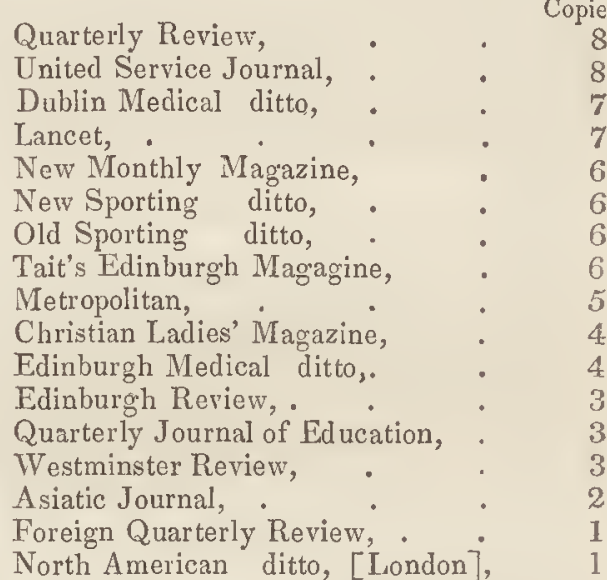

The following periodicals were sold at one of the bookselling establishments:-

\begin{tabular}{|c|c|c|c|c|c|c|}
\hline & & $\begin{array}{l}335 . \\
\text { 1st } \\
\text { ch.) }\end{array}$ & & & 32 & $\begin{array}{l}\text { In } 1835 . \\
\text { (Up to } 1 \text { st } \\
\text { March.) }\end{array}$ \\
\hline Cashionable Magazine, & .10 & 20 & New Monthly,. & . & & 4 \\
\hline lackwood's do., & .11 & 13 & Quarterly Revier, & $\cdot$ & . & \\
\hline Dublin University do. & 6 & 8 & Tait's Magazine, & . & - & \\
\hline Lardner's Cyclopædia, & 4 & 6 & Edinburgh Review, & . & . & \\
\hline New Sporting Magazine, & & 6 & Metropolitan, . & . & . & \\
\hline Old do. & . 2 & 6 & Westminster, . & . & . & \\
\hline Quarterly Journal of Agriculture, & 7 & 6 & Asiatic, & . & . & \\
\hline Dublin Christian Examiner, & & 5 & Edinburgh Medical & Tournal, & & \\
\hline Johnson's Medical, & & 5 & Foreign Quarterly I & leview, & & \\
\hline ited Service, & 5 & 5 & North American & & & \\
\hline
\end{tabular}

Practical Instruction.- Passing from the consideration of the branches of instruction now described, which may be classed under the head scholastic education (as even the apartment 


\section{CITY OF LONDONDERRY.}

in which the private tutor communicates instruction is, to all intents and purposes, a school), another and much neglected branch succeeds-practical instruction, or that which is to fit the boy for the duties of the man in that class of society in which circumstances may placc him: some are destined for a handicraft trade; of others the provincial city ceases to he the theatre of instruction, and their course is comparatively difficult to trace; but it has been ascertained that at present there are-

In the university of Dublin

In that of Belfast

In that of Maynooth

In the Military College of $\dot{\text { Sandihurst }}$

There are likewise 334 apprenticcs in Dcrry. Gwyn's Charitable Institution, from its nature and rules, peculiarly promotes the last class of practical instruction: 27 have been already apprenticed out of it.

The N.W. of Ireland Society, which was established in the year 1821, extended its operations in favour of practical instruction throughout the counties of Londonderry, Donegal, and Tyrone. It originated at a meeting of gentlemen residing in Derry, whose views were warmly seconded by a number of the nobility and gentry of the above counties.

The prime object of the society was to investigate the condition of the district, with a view to the development of its various resources; and thus attention was specially directed to the state of the fisheries, manufactures, agriculture, and cattlc breeding.

A school for the instruction of boys of the middle classes, in the agricultural knowledge necessary to fit them for farm stewards, was established in the neighhouring parish of Faughanvale with which it will be noticed in dctail.

The business, as well of the parent society as of its various branches, was conducted by a committce, who met quarterly in Derry, and whose proceedings were reported half-yearly to general mcetings of the society, which wcre convened in April and September. At these general meetings shews of cattle were held,- - specimens of agricultural produce and rural manufactures exhibited,-challenges issued for future competition, - and premiums awarded for past success. These last consisted, in the parent society, of silver medals, and challengeable silver cups-in the branch societies, of money and a magazine published by the parent society. Among the minor articles exbibited on such occasions were butter, cheese, flax, woollen cloth, and imitation Leghorn bonnets. No member of the parent society was admissible to pecuniary competition in any of the branches.

Prcmiums were also offered for the best statistical reports on the parishes of the three counties.

In the first year the number of the subscribcrs was 220 ; and in the second, when the society proceeded to offer premiums, they found that their funds amounted to $£ 9591 \mathrm{~s}$. $11 \frac{1}{2} d$. of which the portion allocated for premiums was $£ 609$.

During the first four or five years the society continued to increase in prosperity: it then became stationary for two or three, after which it began to decline. Its dissolution was occasioned by various causes. Some of the nembers died,-others neglected to pay in their subscriptions, - and others again withdrew in disgnst at not having obtained premiums. A few, however, kept together; until thcy felt the inefficiency of strenuous efforts, unsupported by numerical strength, or percuniary aid. The society, however, continues to exist in at least one of its branches (see Parish of Clondermot). The magazinc and newspapers published by this society have been noticed already.

The late Mechanics' Institute was organized early in 1829. At its first meeting, held on the 19th of March, it was resolved that a library of reference should be formed, lectures delivered, and a philosophical apparatus provided. The two former resolutions were carried into effect; however, the attcndance was bad from the outset: in 1830 it had decreased to three or four members, and in the July of that year the institute was dissolved, the library continuing in the hands of the ex-secretary. This was the only society existing in Derry for the encouragement of useful arts and sciences, (except so far as the N. W. society was subservient thereto), and its history may serve to corroborate what is generally admitted- that such institutions are suited for manufacturing districts alonc.

\section{Sub-section 3.-Moral}

Although from the nature of this branch of education it is impossible to adopt any distinct classification, similar to that in sub-section 2, there are still certain shades of differcnce incident to the state of religious opinion in the community.

The parisl, in its limited acceptation, is divided by the three curates of the Established Church, into three districts, to each of which one of them peculiarly derotes himself, visiting all the 


\section{EDUCATION.}

schools within it at least once a week. The Presbyterian and Catholic clergymen visit also, but not in the same systematic manner.

At Gwyn's Charitable Institution the business begins and ends with prayer. The pupils attend their several places of worship on Sunday, and also receive instruction during the week from their respective pastors. It is indeed provided in the founder's will that boys of all persuasions should be admissible, but that the teachers should be Protestants, or Protestant Dissenters; that Roman Catholics should be permitted to attend chapel on Sundays; and that, although no clergyman whatever should be allowed ingress without the permission of the trustees, unremitted attention should be paid to Christian instruction. At the gaol there are three chaplains. The Catholic worship is conducted from 9 to 10 o'clock the Protestant, from 11 to 12, and the Presbyterian, from 3 to 4 .

Bishop Barnard contributed to the moral instruction of the parish, by bequeathing $£ 50$ a year, charged on lands, for the support of a curate to the Chapel of Ease.

Bishop Knox also contributed very largely to the moral instruction of the parish, in founding or promoting various establishments which have been noticed elsewhere. In these laudable exertions he was warmly seconded by the influential part of the community, and he was equally ready to co.operate in such exertions as originated with others.

\section{Auxiliaries.}

The following institutions are instrumental in the circulation of moral and religious literature.

1st. The Religious Tract Depository, established about 1822, by the ladies of the Penny Society. It is assisted by the Protestant clergy, but it is nearly independent, owing to the discount allowed by the bookseller that supplies it.

2nd. A Religious, Moral, and Historical Society, instituted on the 1st of August, 1819, at the tract depository. A library, mentioned before, is attached to it, which consists of about 500 works, and one-half at least of the funds must be expended in publications purely religious. The affairs are managed by a committee, consisting of a treasurer, secretary, librarian, and 4 ordinary members of this committee : four constitute a quorum. The terms of admission are 10s, entrance money, and $10 s$. annual subscription; but any subseriber, who, after having paid for five years, may have become unable to pay any longer, is allowed to read gratuitously, should his claim be approved by the committee.

Sunday School Union.-The Sunday School Union was formed on the 28th of December, 1832. The objects are to establish and revive Sunday schools in the city and liberties, to promote zeal and good feeling among the members, to encourage well qualified teachers, to prevent a useless interchange of pupils, and to induce parents to send their children for instruction.

The 11 th rule provides against retaining in the society any person, "who is of exceptionable moral character, or who is professedly of Arian, or Socinian principles." The meetings are opened and closed with prayer. The union liave divided the liberties into six districts, each of which is placed under the control of one or two members.

The committee consists of a treasurer, a secretary, and 12 other members. At their meetings, which are quarterly, moral and religious questions are discussed.

The number of schools in TEMPLEMORE, at present in connexion with the union, is 16 , attended by 162 teachers. The number of pupils on the books is 1726 , and the average attendance 1100. The number of schools was until lately 25 , from which, however, 9 were withdrawn at a meeting held by the clergy and others, on the 13th of $A$ pril last [1835], and annexed to the Glendermot [Clondermot] School Union formed in 1819, and lately revived. 
CITY OF LONDONDERRY.

EDUCATION

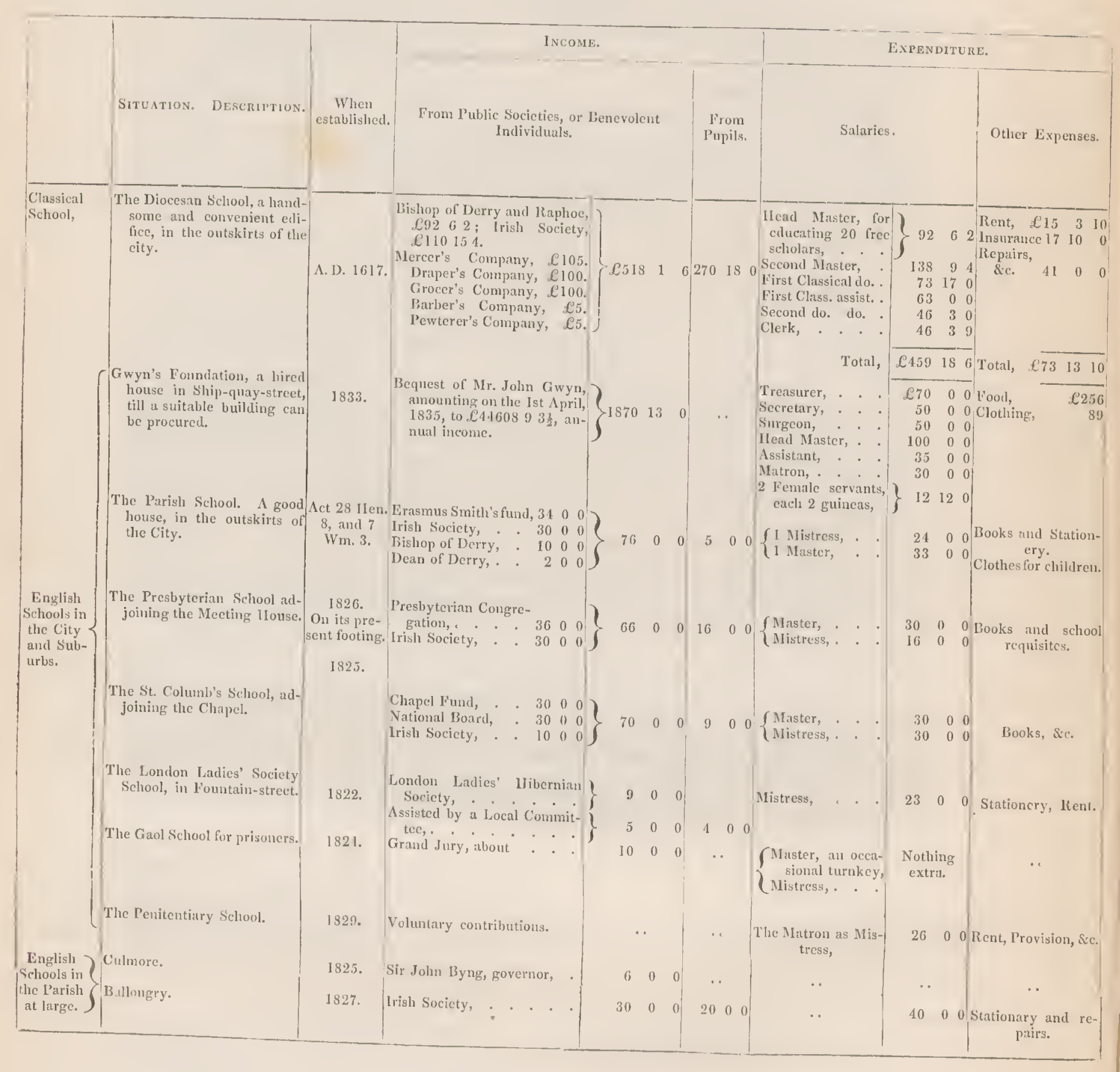

EDUCATION.

PUBLIC SCHOOLS

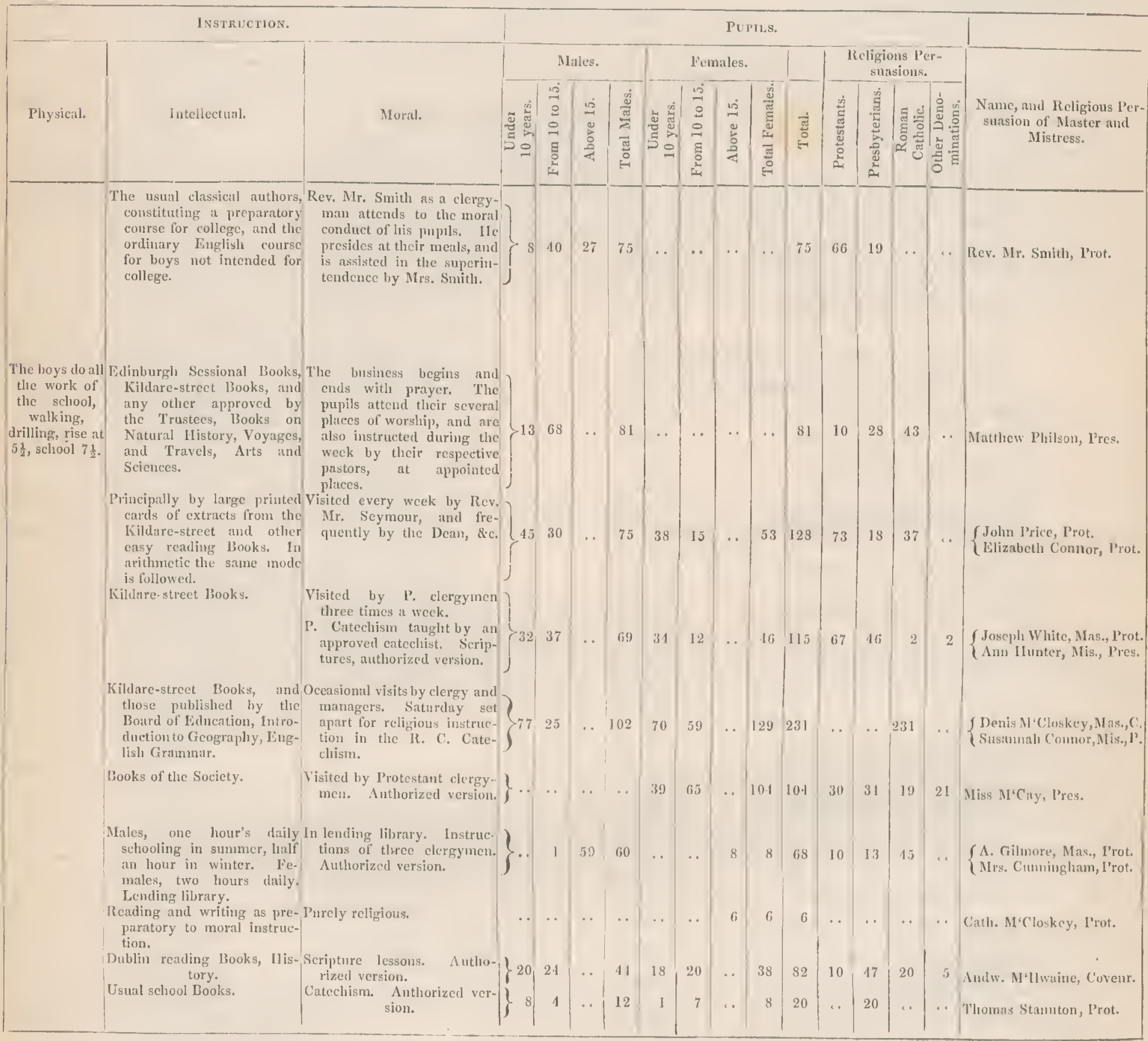


CITY OF LONDONDERRY.

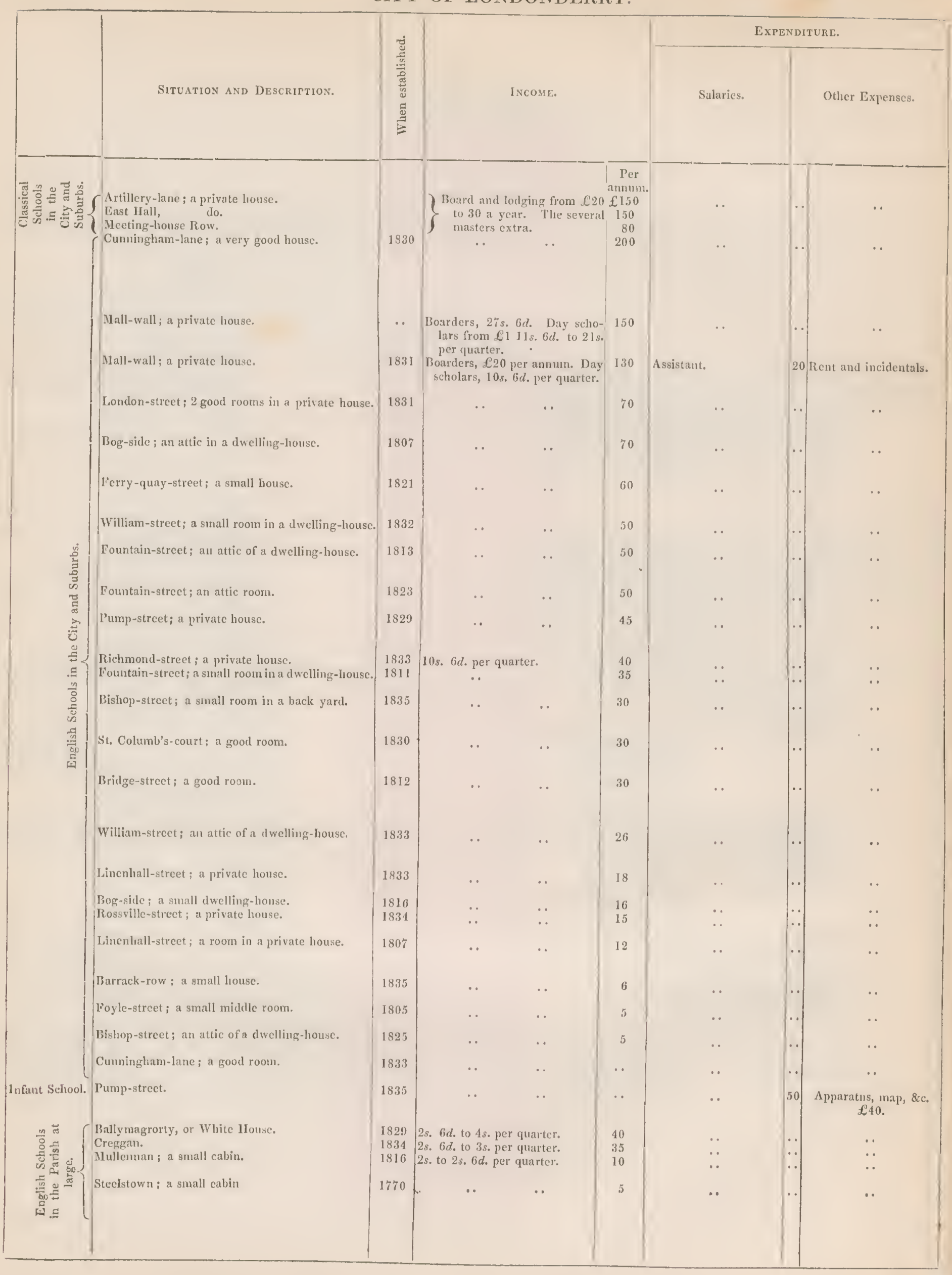

PRIVATE SCHOOLS

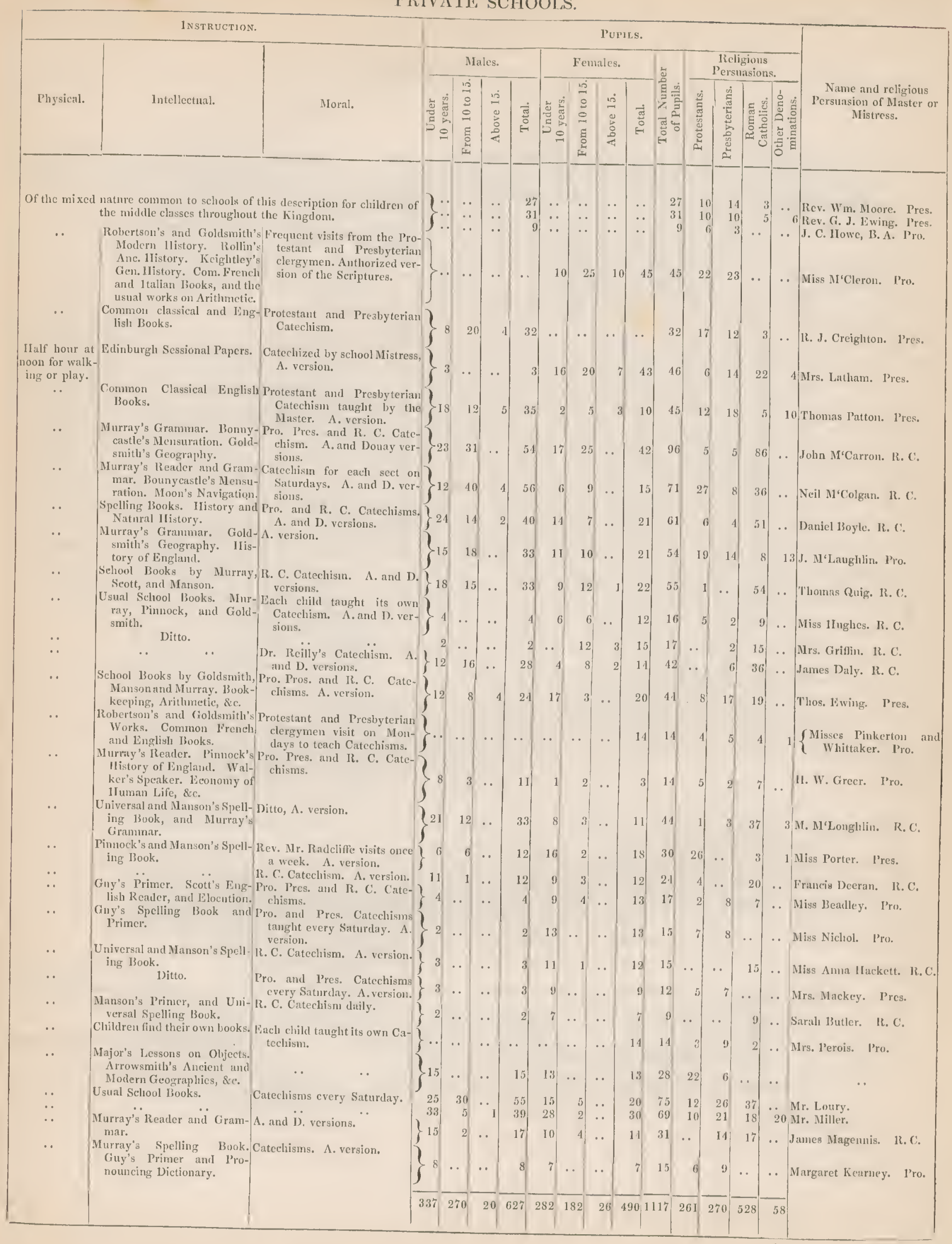


CITY OF LONDONDERRY.

There is in Derry a Depository of the Sunday School Society. And as intellectual Instruction lias been followed to the after-walks of Life, so may the head Moral Instruction appropriately close with the following Summary, compiled principally from the recent "Report of the Commissioners of Public Instruction."

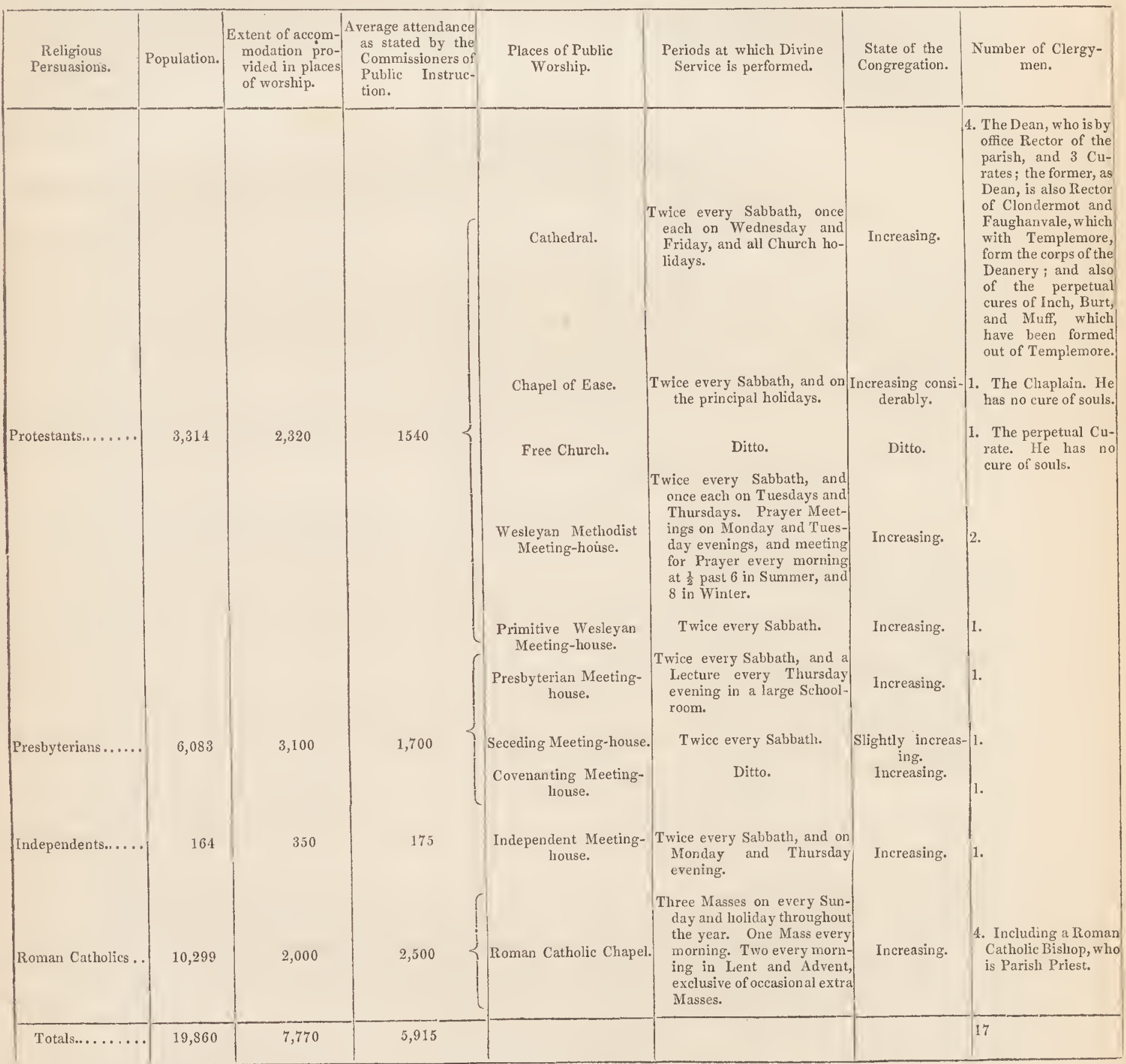




\section{BENEVOLENCE.}

\section{Section 3.-Benevolence.}

Under this head it is intended to reduce all such establishments, intended to alleviate the wants of man, whether moral or physical, as are supported by private or public bounty. And these establishments may be conveniently classed under three divisions, according as they are designed to remove ignorance, to relieve the indigent, or to alleviate the sufferings of disease.

\section{Sub-section 1.-Establishments for Instruction.}

In order to give a complete view of the quantity of instruction diffused over the parish, it was found necessary to incorporate with the pay schools, described under that head, those free schools, which, with equal propriety, enter as an element into the quantity of benevolence. And, in estimating to what extent education is advanced by the exercise of benevolence, it would not be sufficient to contrast the numbers of the free and pay schools. The result thus obtained would be fallacious, for the payment here, as in many other parts of Ireland, is frequently nominal; and, where it has been enjoined by the founders of the school, to induce or to gratify an honorable repugnance to gratuitous or charitable instruction, it is frequently evaded. This, however, is more the result of necessity than of inclination-the education of three or four children beino, even at the lowest rate, a considerable deduction from the limited wages of a common labourer, or cottier; and, it must be admitted that, though willing to receive instruction for their children as a free gift, they are, in general, equally ready to make great sacrifices to obtain it.

Twenty-four free scholars are educated at the Diocesan School; and there is one institution of so peculiar a description that it seems to require special notice under this head, as well as under. that of instruction.

Gwyn's Charitable Institution is named from the late Mr. John Gwyn, its founder, who died in 1829 . By a will dated the 16th of May, 1818, this benevolent individual left the bulk of his large property, amounting to above $£ 40,000$, as a provision for "as many male children of the poor or lowest class of society resident in, and belonging to the city of Londonderry, and the precincts around the same, as hereafter described, as the said funds will feed, clothe, and educate -orphans, or such children as have lost one of their parents, always to be preferred." "The precincts defined are the N. W. Liberties, with the village of Muff, in the county of Donegal, and a circuit of a mile round it. A well attested certificate of residence for three or five years is required from parents, a medical certificate, and any other recommendation which the trustees may desire. Provision is made for including the Waterside and its precincts, when the funds should allow of it, "not exceeding the extent of the liberties," and the district has already extended to the Waterside.

The management of the property is by the will vested in twenty-one trustees, consisting of the bishop of Derry for the time being, the two Presbyterian clergymen, and their successors, and eighteen merchants of the city. It is also provided in the will that a full meeting of the trustees shall be held quarterly, but that a committee of five shall sit every week to transact incidental business.

The school was openened in a hired house, formerly the City Hotel, but the erection of a new school-house, at the rear of the Infirmary, is in contemplation, intended to accommodate 200 pupils. Ten acres of ground, statute measire, have accordingly been purchased in perpetuity. For the present, however, the project is deferred, in the hope of obtaining the bishop's palace, should the ecclesiastical commissioners consent to its sale.

The estimates state the probable expense of the building at $£ 6,000$. The plan presents a front of 193 feet, broken in the centre by an Ionic tetrastyle portico, above whicl rises a cupola.

In a codicil, dated the 21 st of May, 1824, the testator expresses a wish that his bequest may be suffered to accumulate to $£ 50,000$ before the opening of the school; however, from the number of orphans left destitute by the cholera of 1832 , further delay was considered inexpedient, and the school was accordingly opened on the 1st of A pril, 1833.

Each pupil receives daily $90 z$ of oatmeal, 1 quart of buttermilk, 1 pint of sweetmilk, and 3lbs. of potatoes, with $\frac{1}{3}$ lb. of beef twice a wreek.

The pupils' relations are allowed to visit them monthly. They leave the institution at fifteen, and are clothed during their apprenticeship. 


\section{CITY OF LONDONDERRY.}

On the 1st of Mareh, 1834, the state of the bequest was as follows :-

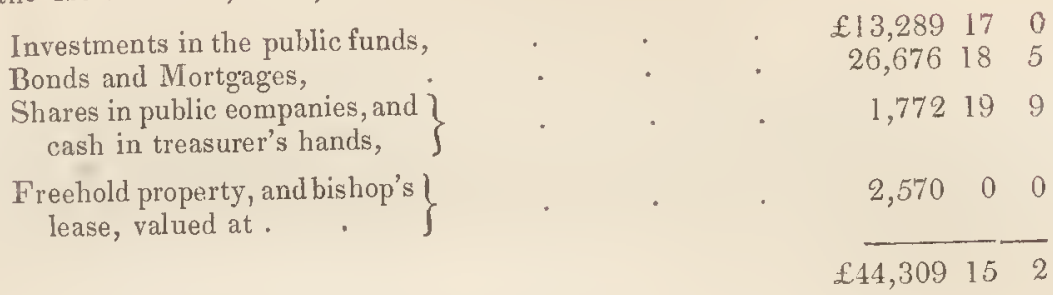

The income resulting from this capital was $£ 187013$ s. on the 1st of March, 1835 . On the 1 st of April, 1835, the funds were estimated at $£ 44,608$ s. $3 \frac{1}{2} d$.

\section{Sub-section 2.-Establishments for the Indigent.}

To aroid a too eomplicated classification it has been thought advisable to rank under this head not only such establishments as are intended for thc actual pauper, but such as contemplate

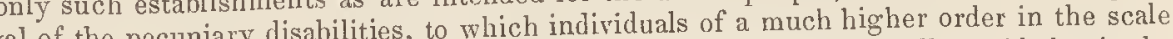
of society are exposed. With establishments of each description this city is well provided. At the head of them stands the Clergymen's Widows' Fund, next to which are the Savings' Bank and the Friendly Soeiety.

The following may more properly be termed "Establishments for the Indigent:"- the The Society with its branch the Flax Fund, the Poor Shop, the The Gaol also is made subservient to benevolent purpoor of the district. In addition to the following notiees, mueh information will be found in the annexed table.

The Clergymen's Widows' Fund originated in a voluntary subseription, to which most of Protcstant clergy of the diocese contributed, and which has accumulated to a sum, out of Protche houses rent-free. These whieh the widows are each paid $£ 35$ annually. The 5 senior widows have houses reste from the
houses, which eonstitute the Widow's $R$ ow, adjaeent to the cathedral, were built funds.

On the 19th of Oetober, 1830 , the state of the institution was as follows:-

Balanee of stock in hands:-viz.

Corporation securitie

Earl of Bristol's bond

Government securities

Balance on hands

\section{Total}

$$
\begin{array}{rll}
£ 3046 & 3 & 1 \\
923 & 1 & 6 \frac{1}{2} \\
2500 & 0 & 0
\end{array}
$$

$$
\begin{aligned}
& \begin{array}{rrr}
25469 & 4 & 7 \frac{1}{8} \\
196 & 7 & 6
\end{array} \\
& £ 6665 \quad 122
\end{aligned}
$$

On the diocese, then asselnblcd in visitation, agreed on a number of rules for the future government of the institution, among which were the following: - that a committee of nine benefieed clergymen-to meet quarterly, and of whom three should combined treasurer and secretary, who should give security to the amount of $£ 600$, and reccive a salary of $£ 35$, - that no investment should thenceforward be made exeept in the government securities, and that all sums otherwise the members on payment of $£ l$ per cent. annually, on their salarics,-and that, to meet the present exigeneies of incumbcnts, the 1 per cent. payable by them, should be rated aeeording to their nett ineomes aftcr the following deductions :-

1. Salary to curate or eurates.

2. Interest to board of first fruits.

3. Agents' fees.

4. Per-centage allowed to landlords on tithe payment.

5. Per-centage payable to ecclesiastical commissioners.

6. Rent of house, where no g'ebe-house is, not to exceed $£ 50$ a year.

7. Rent of house, if chargeable.

8 . Interest of money expended in building a glebe-house, and ineluded in eertifieate. 


\section{BENEVOLENCE.}

Savings Bank. - There is a savings bank at the mayor's private office, which is open from 7 to 8 on Saturday evenings.

\begin{tabular}{|c|c|c|c|c|}
\hline ACCOUNT. & 1832. & 1833. & 1834. & Remarks. \\
\hline 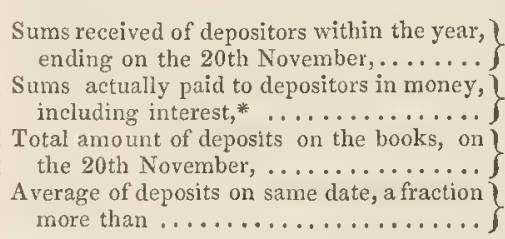 & $\begin{array}{rrr}\mathscr{e} . & s . & d . \\
2,419 & 4 & 11 \\
2,680 & 8 & 2 \\
11,257 & 13 & 5 \\
20 & 19 & 3 \frac{1}{4}\end{array}$ & $\begin{array}{rcc}\mathfrak{E} . & s . & d . \\
3,264 & 11 & 7 \\
2,866 & 13 & 2 \\
12,034 & 0 & 11 \\
21 & 15 & 2 \frac{3}{4}\end{array}$ & $\begin{array}{rrr}\mathscr{E} . & \text { s. } & d . \\
4,310 & 1 & 3 \\
3,315 & 4 & 2 \\
13,460 & 6 & 7 \\
22 & 1 & 3 \frac{3}{4}\end{array}$ & \multirow[t]{2}{*}{$\begin{array}{l}* \text { This increase } \\
\text { of disbursements } \\
\text { above deposits } \\
\text { was caused by } \\
\text { emigration, } \\
1832 \text {. }\end{array}$} \\
\hline $\left.\begin{array}{r}\text { Total number of depositors, whose accounts } \\
\text { were open on } 20 \text { th November,........ }\end{array}\right\}$ & 537 & 553 & 610 & \\
\hline
\end{tabular}

The following classification is for the year ending' on the 10th of March, 1827:-

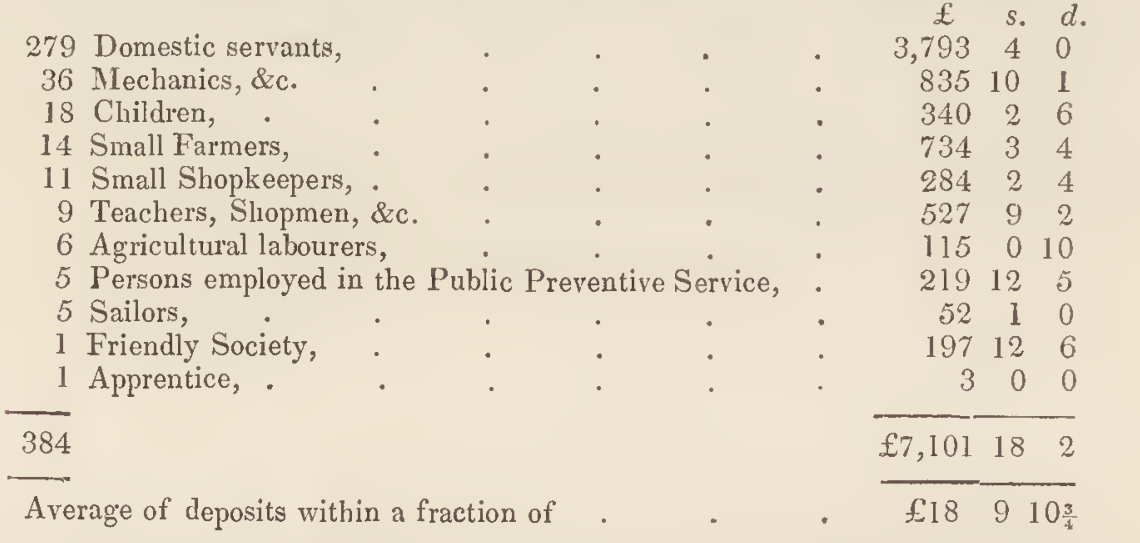

Charitable Loan. -The charitable loan was instituted by bishop Knox. Up to 1829, the corporation contributed 30 guineas a-year. The institution was without support from this period until 1833 , when a representation was made to the Irish Society, who granted $f 10$ a-year towards the annual expense of management. The donations not being sufficient for the current expenses of management; the capital is on the decrease. On the 31 st of July, 1835 , it amounted to $£ 423$.

Ladies' Penny Society. - The ladies' pcnny society derived its name from the original limitation of the subscriptions to $1 d$. a-week. They now vary generally from 5 s. to $£ 1$ a-year, but some are much higher.

In 1827 , the society received a bequest of $£ 30$, and a like sum from the Irish Society, which las been since continued annually. The average income from these resources, aided by a few occasional donations, is about $£ 200$ a-year. The management is vested in a patroness, a president, and a committee of ladies. The visitors, who inspect the habitations of the poor, are also ladies, and mostly distinct from the sitting committee. To each of the four city wards, three collectors are appointed, of whom two are gentlemen, and of these one, at least, is a clergyman.

The committec meet weekly to consider petitions, and receive the reports of the inspectors. In case of urgent distress the visitors grant immediate relief, and usually in kind.

Previously to 1831 , no Report was issued, but only a ycarly abstract of the finances. In the first Report the relief specified is food, (i.e. meal), clothing, and comforts. The visitors distribute at their discretion orders for $2 \frac{1}{2}$ lbs. of meal; however, the quantity distributcd seldom exceeds 500 pecks annually, in value about $£ 30$. Clothing is given out in October and November, on the recommendation of a subscriber. Being the only kind of relief originally contemplated, it is the chief source of expenditure. In 1830 above 1000 garments were issued. The comforts consist of soap, straw, bread, groceries, and turf. The first two have indeed become regular iterns 


\section{CITY OF LONDONDERRY.}

of expenditure; but the last three have been discontinued since 1821. Of straw beds above 470 were granted in 1830 , and of soap above $161 \mathrm{lbs}$.

The Flax Fund is a separate and important branch. Soon after the establishment of the Penny Society, it was suggested, that, in addition to relieving the poor, something might be done to awaken their industry, and the most obvious mode appeared to be the promotion of flax spinning. In 1817 a grant of $£ 10$ was made from the funds, and for sereral years the branch society prospered. In $1818,1820,1822,1829$, and 1831 , the funds were aided by collections at charity sermons, to the amount of $£ 178, £ 263$ (including a donation of $£ 100$ from the bishop), £131, $£ 141$, and $£ 141$ 6s. $3 d$. ln 1831 , indeed, they had been completely exhausted, from the want of purchasers for the yarn manufactured. The Irish Society subscribe $£ 20$ annually.

Security is required for the flax intrusted to the spinner, which is generally fiom 1 to 2 lbs . The yarn is weighed, and examined, and, if all be found right, the spinner is paid, and supplied with flax anew. The payment varies. From $1 s .4 d$. a spangle, the original allowance, it gradually fell to $10 d$., owing to the decline of the linen trade -the committee conforming, although reluctantly, to the depreciated market prices, to avoid the appearance of patronizing the interests of commerce, rather than those of benevolence. However, although a diligent spinner can scarcely earn $2 \frac{\mathrm{T}}{2} \mathrm{~d}$. a day, the applicants are too numerous to be constantly employed. The number of spinners is between 400 and 500 , and the average quantity of yarn manufactured annually, was found in 1830 to be about 7657 spangles.

The report published in the present year (1835) gives a favourable account of the funds. Their prosperity is chiefly due to an increase in the price of yarn, and a reduction in the quantity of flax issued. The report concludes with a tribute to the inemory of the late Hon. Mrs. William Knox, whose zeal for the interests of this institution, had continued unabated after her removal from Derry.

On the 1st of January, 1835, there was a balance of $£ 133 s .5 \frac{1}{2} d$. to the credit of the ladies' penny society, and of $£ 26619 \mathrm{~s} .4 \mathrm{~d}$. to the credit of the flax fund. On the 3rd of July, 1835, the subscriptions to the parent society amounted to $£ 17210 \mathrm{~s} .7 \mathrm{~d}$. 


\begin{tabular}{|c|c|}
\hline 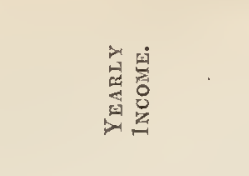 & 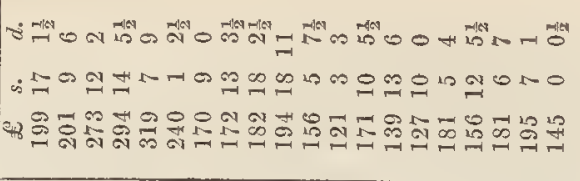 \\
\hline 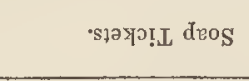 & 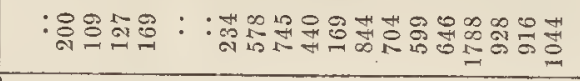 \\
\hline 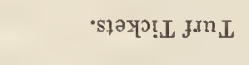 & 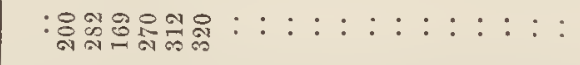 \\
\hline 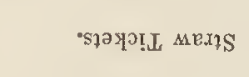 & 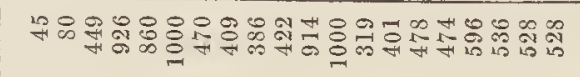 \\
\hline 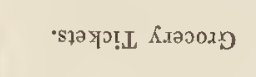 & 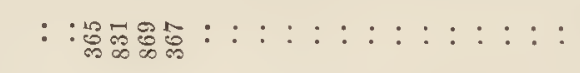 \\
\hline 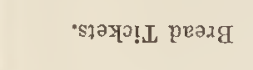 & ॠ아영 \\
\hline 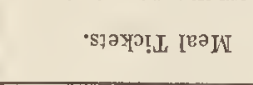 & 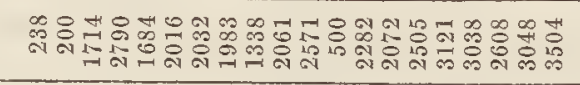 \\
\hline 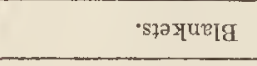 & $:::::::::: 2 \circ::::::::::$ : \\
\hline s.snu pəa & 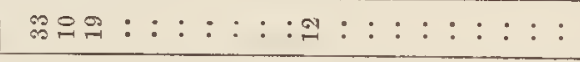 \\
\hline "s & 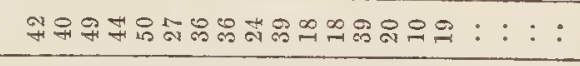 \\
\hline •ฮัв & 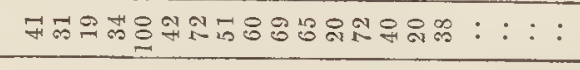 \\
\hline siborma & 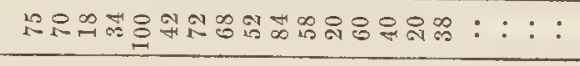 \\
\hline 'эy!पs & 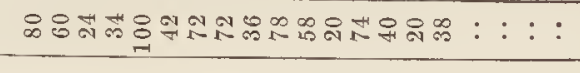 \\
\hline 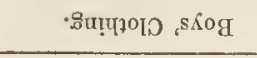 & $:::: \infty \mathbb{a}^{\infty}:::: \infty::::::::$ \\
\hline 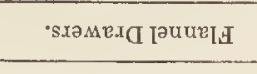 & : : : : : \\
\hline 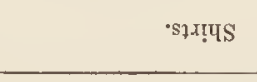 & 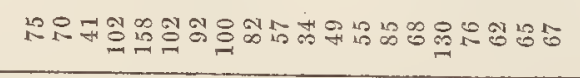 \\
\hline 'รәочS & $20::::::::::::::::::::$ \\
\hline 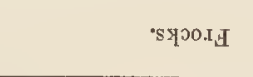 & 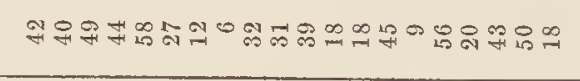 \\
\hline 'sdes & 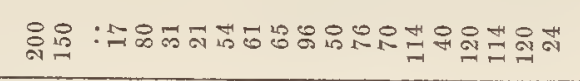 \\
\hline 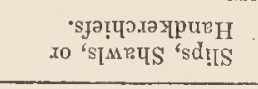 & $::::::::: \circ::::::: \infty 8$ \\
\hline 'suмоврәя & 걍: \\
\hline 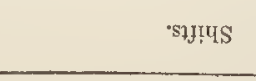 & 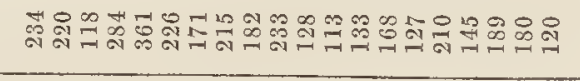 \\
\hline 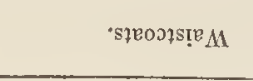 & 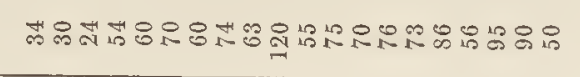 \\
\hline 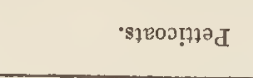 & 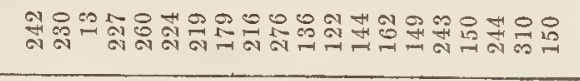 \\
\hline ·sumop & 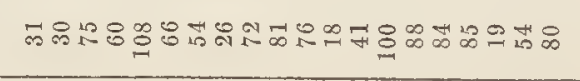 \\
\hline 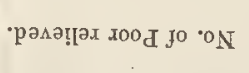 & 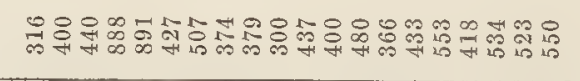 \\
\hline $\operatorname{sxea} \lambda$ & 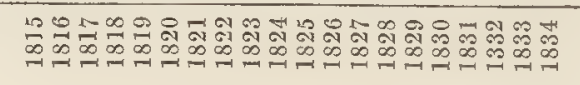 \\
\hline
\end{tabular}




\section{CITY OF LONDONDERRY.}

Poor Shop.-The poor shop was instituted in 1821. It is supported from subscriptions, which average from $£ 50$ to $£ 60$ annually. Its object is to provide all poor applicants with clothes and bedding at prime cost, on condition of their giving security, and paying for them weekly, at the rate of $1 d$. in the shilling. Shoes are sold every Tuesday, and other clothing every alternate Tuesday. Instalments are received every Friday from 11 till 2. The management is vested in a committee of ladies.

This institution has tended to promote habits of punctuality, honesty, industry, and independence. The expenses of management (including loss by defaulters, office rent, \&c.) being only from $£ 20$ to $£ 25$ annually; the capital is always on the increase, so that the mere interest will perhaps in time cover the expenses. When the security fails to cover a loss by default, the original capital becomes liable to it. The funds amount at present $(1835)$ to $£ 5442 \mathrm{~s}$. $2 \mathrm{~d}$.

The following articles have been disposed of in the years specified:-

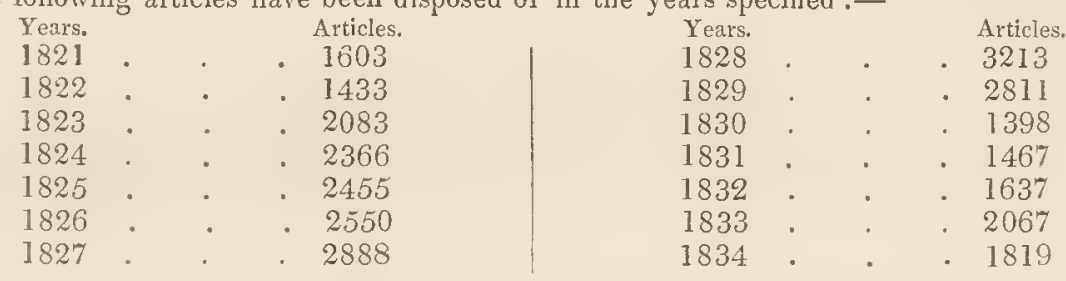

Detail for the last 3 Years.

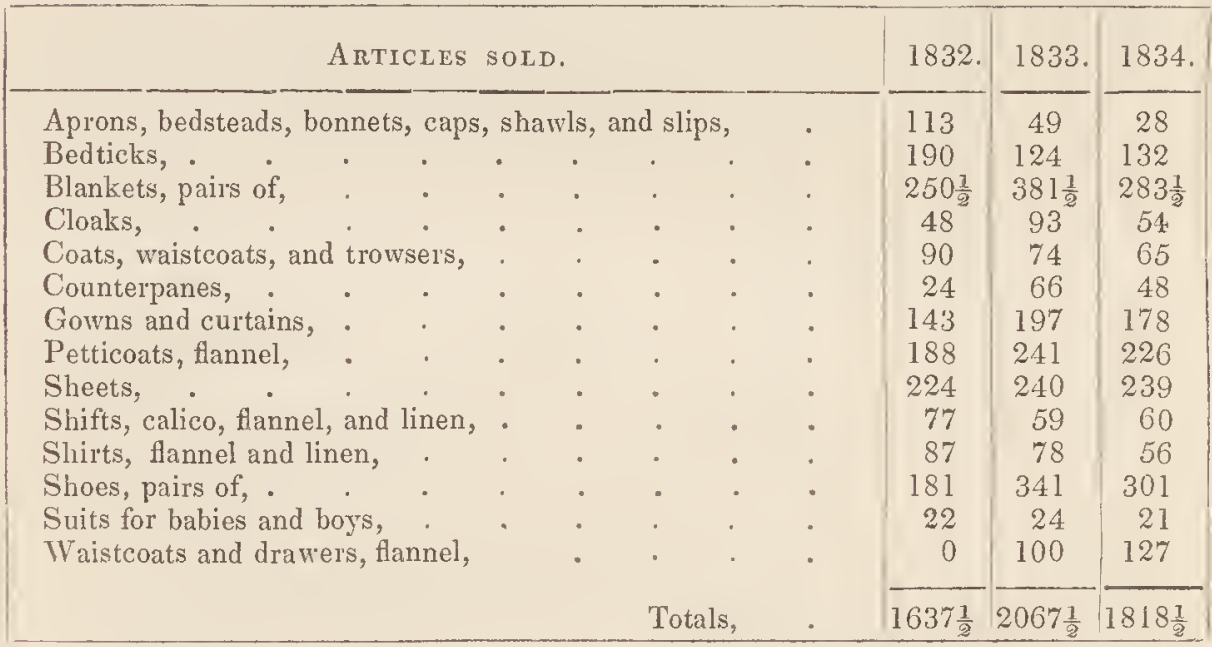

Mendicity Assaciation. - The mendicity association, or asylum, was instituted on the 13 th of May, 1825. It is supported from voluntary subscriptions, and governed by a committee, which varies in number, and is annually renewed. The original object was the employment and support of street beggars but relief is also extended to the labouring poor in seasons of distress. The diet consists chiefly of oatmeal, potatoes, and milk. In 1829-30, when oatmeal was dear, rice was used for dinner, and a $\frac{1}{2} \mathrm{cwt}$., which cost only $12 s .5 \mathrm{~d}$., slightly seasoned with molasses, ginger, and pepper, was found sufficient for 169 persons - allowing $2 \frac{1}{2} \mathrm{lbs}$. each to 123 adults, and $1 \frac{1}{2} \mathrm{lbs}$. each to 78 children.

In 1830-1 the committee were obliged for about three months to diminish the rations, to substitute Indian meal for oatmeal, and preserve rice for dinner on alternate days. In 1832-3, it became necessary to reduce the list of paupers, and diminish the rations by $1 \mathrm{oz}$. of meal, and $\frac{1}{9} 1 \mathrm{~b}$. of potatoes. Thus the daily expense of about $1 \frac{1}{2} d$. for each pauper, not only provided them with the necessaries of life, but procured for several of the older inmates the luxuries of snuff and tobacco.

The paupers are employed in spinning, and occasionally in net-making. It was intended that one-half of their earnings should be spent on clothing, the only gratuitous supply being donations of worn garments : such labours, however, as suited the aged and infirm, were found to bo but scantily productive. 


\section{BENEVOLENCE.}

In 1829-30, several paupers, both men and boys, were engaged by the corporation as scarengers; the manure was sold, and the wages, which at first amounted to $\mathfrak{E l}$ a week, were to be spent on clothing. Much disappointment, however, ensued. From the eighth Report of the association, published in 1833 , it appears that although they had been for three years satisfactorily fulfilling their part of the engagement, no payment had yet been made, notwithstanding repeated applications. The case was one of peculiar hardship, as, depending on their new resource, the committee had burthened the institution by an unusual increase of admissions. The debt of the corporation was then $£ 2115 \mathrm{~s}$. and the treasurer of the association was $£ 1751 \mathrm{~s}$. $6 \mathrm{~d}$. in advance. The sum of $\mathfrak{E} 50$ has since been paid on account, and the sweeping of the streets resumed.

The committee of this, as of many similar institutions throughout Ireland, have frequently had occasion to complain of a decrease not only in the number, but in the liberality of the subscribers, and yet the utility of such asylums, especially during the visitations of the cholera, has been fully substantiated. In one of their Reports the committee also advance, as permanent claims on public support and confidence, the economy observed in the management of the funds, and the vigilance employed in the examination of applicants. Beadles are appointed to apprehend beggars, who are committed to a bridewell, annexed to the establishment. There were formerly only two beadles, but in 1830-1 a third was added. In that year the number of arrests amounted to 286 ; in $1831-2$ to 168 ; in $1832-3$ to 184 ; and in $1833-4$ to 173 . The asylum is lighted with gas, the expense of which for 1831-2 was defrayed by the city member.

By the death of bishop Knox, in 1831, the institution lost not only its most munificent supporter, but its virtual founder. The idea of establishing it was originally suggested by two gentlemen to that prelate, who immediately embraced their views, and subsequently exerted himself to overcome the prejudice of their opponents.

In the winth and latest Report it is stated that the diminution in the number of panpers on the books is no evidence of the proportional decrease of pauperism, but arose rather from the necessity of removing nearly 40 individuals, who, under ordinary circumstances, would have been still entitled to assistance. A second measure of relief was the burrowing of $£ 100$ from the fund raised, in 1832, for the relief of cholera widows and orphans; for which sum the association is still responsible. And a third was a successful effort to recruit the funds of the association by applying to the Irish Society, who not only announced a present donation of $\mathfrak{L} 50$, but a future increase of their annual subscription of $\mathfrak{E} 10$ to $\mathfrak{L} 30$.

On the 4th of February, I835, the number on the books was as follows :-

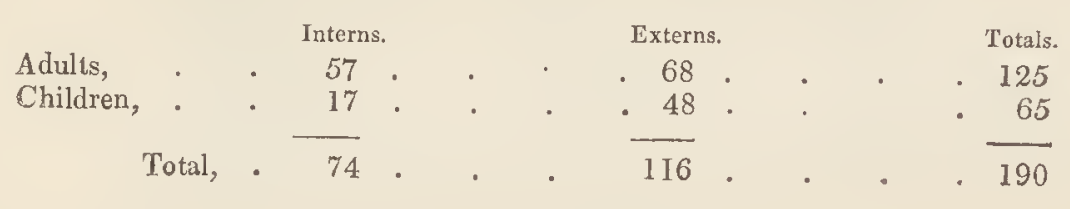




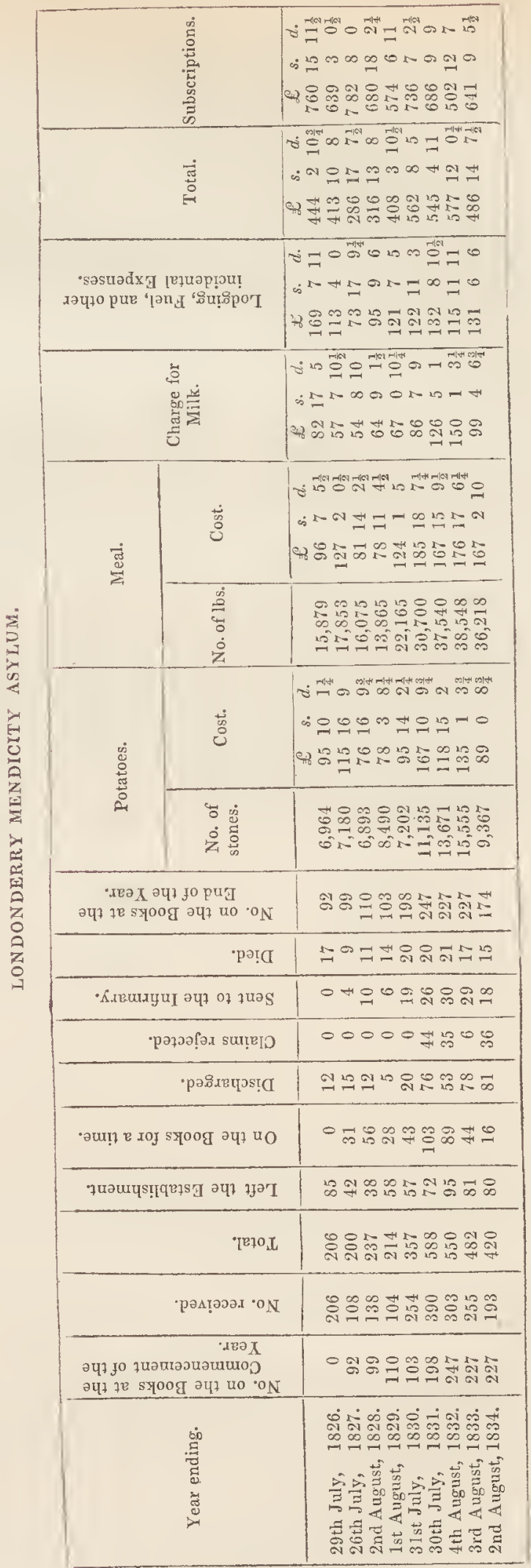




\section{BENEVOLFNCE.}

Penitentiary.-The Penitentiary, which was instituted on the 1st of May, 1829, is supported from subscriptions and donations. Its object is to afford temporary shelter to unfortunate females, with a view to their reformation, and the period of residence is limited to three years. The patrons, committee, and secretary, are ladies, and the present number of inmates is seven.

In the rules the inmates are reminded of their voluntary seclusion, and enjoined under certain penalties to conduct themselves discreetly, and, in particular, to avoid any allusion to the past irregularities of each other. No conversation is permitted after they have retired to rest, and no message can be conveyed but through the matron.

In 1834 the funds failed, owing to a decrease in the subscriptions. In the treasurer's account of that year, a small balance appears to its credit, which, howerer, scarcely exceeds half a year's rent, then due on the premises. 'Two of the inmates have since left the institution, with the approbation of the managers. Early in 1835 sewing was abandoned as an employment, and washing substituted, which it was hoped, would prove more beneficial, and produce $£ 40$ or $£ 50$ a-year. This plan, however, proved abortive, as appears from the Sixth Annual Report, published within the present y ear (1835), in which the cause of the failure is chiefly attributed to the inconvenient construction of the house. This Report also dwells at some length on the conduct of several inmates discharged from the Penitentiary, in terms which, notwithstanding a few disheartening exceptions, evince great general satisfaction. This Report, like one on the Ladies' Penny Society, before alluded to, contains a tribute to the memory of a benefactress, whose persevering bounty towards the institution, after she ceased to be locally connected with it, appears not to have terminated at her grave,-- for in the list of subscriptions, annexed to the Report, there is one of $£ 10$ from the "executors of the late Hon. Mrs. Knox."

Dr. The Londonderry Penitentiary in Account with William Haslett Treasurer. Cr.

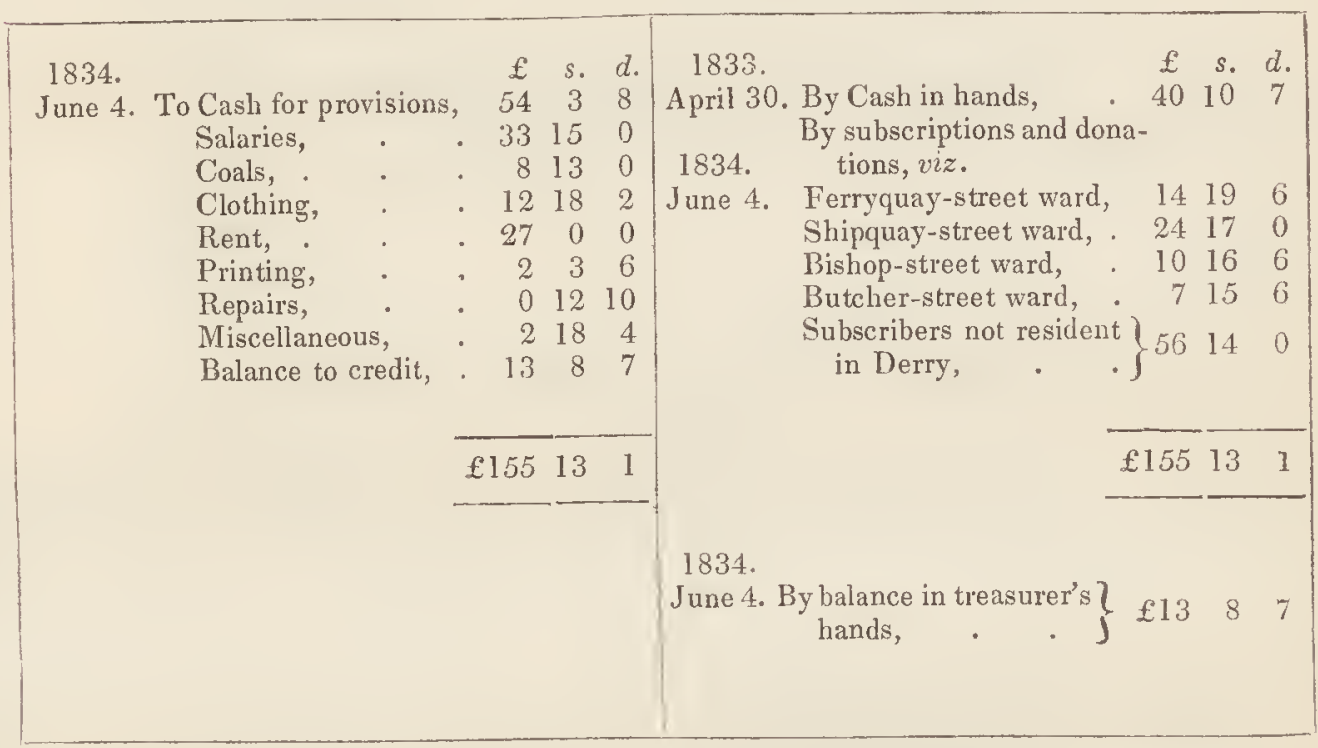

At the Gaol the prisoners receive one-third of their earnings. Several bequests have been also made, at different periods, for the relief of the poor and other purposes. - [See Table.] 
CITY OF LONDONDERRY.

ESTABHLSIMENTS FOR THE INDIGENT.

\begin{tabular}{|c|c|c|c|c|}
\hline \multirow[t]{2}{*}{ Naмk. } & \multirow[t]{2}{*}{ Olject. } & \multirow{2}{*}{ Management. } & \multirow{2}{*}{ Number relieved. } & FUNDs. \\
\hline & & & & From Pubtie Bodies. \\
\hline $\begin{array}{l}\text { Ten sclools are winlly or } \\
\text { partly supported by benc- } \\
\text { volence. }\end{array}$ & The removal of ignorance. & Suntry societies. & $\begin{array}{l}865 \text { pupils receiving instruc- } \\
\text { tion. }\end{array}$ & $\begin{array}{ccc}f & s . & d . \\
6.15 & 15 & 4\end{array}$ \\
\hline Clergynens' Widows' Fund. & $\begin{array}{l}\text { To relieve the wilows of eler- } \\
\text { gymen of the diocese. }\end{array}$ & $\begin{array}{l}\text { Committee of nine bencficed } \\
\text { elergymen. }\end{array}$ & 13 & \\
\hline Savings' Bank. & $\begin{array}{l}\text { To enalle the werking classes } \\
\text { to anasss she fruits of their } \\
\text { industry. }\end{array}$ & 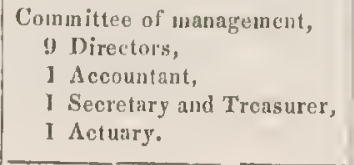 & $\begin{array}{l}610 \text { on the books, 20th No- } \\
\text { venmber, 1834. }\end{array}$ & $\begin{array}{l}\text { Interesst paid by government } \\
\text { on deposits. }\end{array}$ \\
\hline Charitable Loim. & 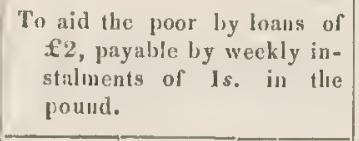 & $A$ conmittce of 18 . & $\begin{array}{l}\text { About } 400 \text { persons reeeive } \\
\text { x2 per anruun in loans. }\end{array}$ & 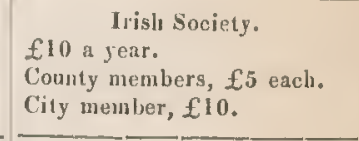 \\
\hline Ladies' Pcnny Society. & $\begin{array}{l}\text { To relieve sieks and indifent } \\
\text { roun-keperss, and the int- } \\
\text { dustrious poor. }\end{array}$ & $\begin{array}{l}\text { Patroness, president, and a } \\
\text { colunitittee of } 1+\text { ladies. }\end{array}$ & 550 in 1834. & $\begin{array}{l}\text { Bequest of } ₫ 30 \text { a year, and } \\
\text { lrish Society } £ 30 \text { a year. }\end{array}$ \\
\hline $\begin{array}{l}\text { Flax Fund (a branch of the } \\
\text { Ladies' 'Penny Society). }\end{array}$ & To cinploy the poor. & A lady. & 450 average per amum. & $\begin{array}{l}\text { Irish Society, } f_{20} \text { a year, } \\
\text { occasioul clurity sernons. }\end{array}$ \\
\hline Poor Shop. & $\begin{array}{l}\text { To sostl lolthes and bedding at } \\
\text { pritive coss. }\end{array}$ & Cormmittee of Iladies. & Unicertain. & \\
\hline Mendioity. & $\begin{array}{c}\text { To sopport street beggars and } \\
\text { the labonring poor. }\end{array}$ & Committee. & $\begin{array}{l}1990 \text { on the books, 4th Feb., } \\
1835 .\end{array}$ & Irish Society, $£ 30$ per annum. \\
\hline P'enitentiary. & 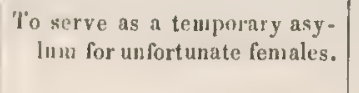 & $\begin{array}{l}\begin{array}{l}\text { Patroness, and a commuittee of } \\
\text { ladies. }\end{array} \\
\text { f }\end{array}$ & 7 & 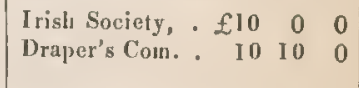 \\
\hline Gaol. & 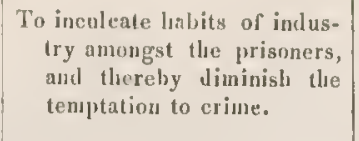 & Governor and other oflicers. & Fluctuating. & $\begin{array}{c}\text { Earnings of prisoners pur- } \\
\text { cliase materials and toots. }\end{array}$ \\
\hline Boquest. & $\begin{array}{l}\text { To relicve the poor of the } \\
\text { parisht. }\end{array}$ & Fall len into disuse. & Uncertain. & . \\
\hline Bequest. & 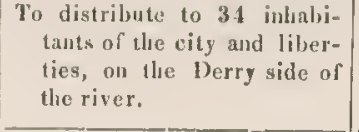 & $\begin{array}{l}\text { 1)ean and curates of Derry, } \\
\text { and exeeutors. }\end{array}$ & 34 & \\
\hline Bequest. & $\begin{array}{l}\text { To distrilibetame aung the proor } \\
\text { of the parisls. }\end{array}$ & | Cluurch-wardents. & 152 & \\
\hline
\end{tabular}

BENEVOLENCE.

ESTABLISIMENTS FOR TIIE INDIGENT

\begin{tabular}{|c|c|c|c|c|c|c|c|}
\hline \multirow{2}{*}{$\frac{\text { Fuvos. }}{\text { From Private Individuals. }}$} & \multicolumn{2}{|c|}{ 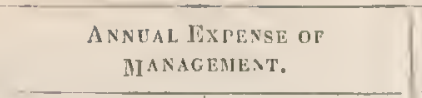 } & \multicolumn{4}{|c|}{ RRELEF A AFPRDED. } & \multirow{2}{*}{ When founded. } \\
\hline & IIouse Rent. & Saluries. & Diet. & Clolling. & Money. & Otherwise. & \\
\hline 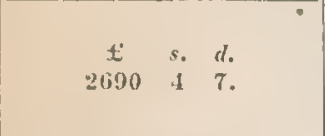 & $\begin{array}{c}\text { With other ex- } \\
\text { prenses, } £ \text { 6001. }\end{array}$ & 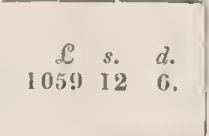 & 87 pupils dieted. & 87 pupils clothed. & 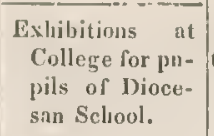 & 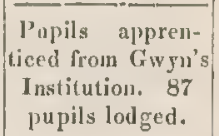 & At sundry periods. \\
\hline 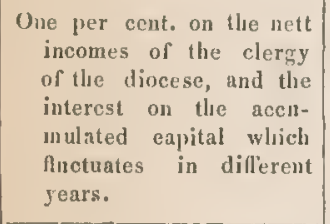 & & 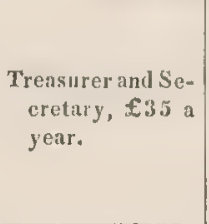 & $\cdots$ & $\cdots$ & $\begin{array}{c}\text { f35 a year to } \\
\text { each widow. }\end{array}$ & $\begin{array}{l}\text { Thes } 5 \text { chinor wi- } \\
\text { dows lave lousc } \\
\text { rent free. }\end{array}$ & 1729. \\
\hline 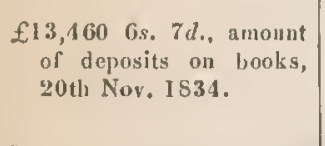 & & .. & . & $\cdots$ & $\begin{array}{l}\text { Sums drawn out } \\
\text { by depositors, in- } \\
\text { creased by come- } \\
\text { pound interest. }\end{array}$ & . & $\begin{array}{l}1816 . \\
\text { 19th Felruary. }\end{array}$ \\
\hline 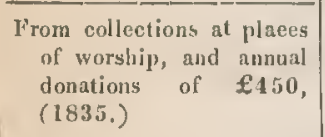 & Housc rent, $£ 1$. & $\begin{array}{l}\text { Onc clerk, } £ 20 \\
\text { Attendant, } £ £ 1\end{array}$ & & & $\begin{array}{l}\text { Loouns amounting } \\
\text { to abuout } f 800 \\
\text { per anulum. }\end{array}$ & & 1809. \\
\hline Donations, about $£ 140$. & $\mathcal{E}_{4} 10 \mathrm{~s}, \cap d \mathrm{~d}$ & .. & $\begin{array}{l}\text { Meal, } 500 \text { peeks, } \\
\text { (worth about } \begin{array}{c}\text { (wor } \\
\text { anmully) }) \text { \& bread } \\
\text { and groceries. }\end{array}\end{array}$ & $\begin{array}{c}\text { Various articles } \\
\text { of female dress. }\end{array}$ & & $\begin{array}{l}\text { Soan, , and straw, } \\
\text { aud turf. }\end{array}$ & 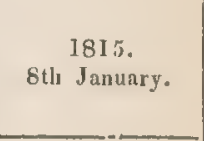 \\
\hline & $\mid \begin{array}{l}\mathcal{E}_{16} \quad 14 s .4 d ., \\
\text { (including other } \\
\text { expenses.) }\end{array}$ & $f 12 \quad 12 s .0 d$. & & & $\begin{array}{l}\text { 10d. a spangle } \\
\text { for yarn. }\end{array}$ & & $\cdots$ \\
\hline $\begin{array}{c}\text { Snbseriptions, about } £ 55, \\
\text { (average.) }\end{array}$ & 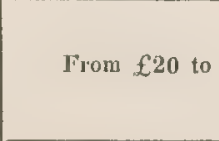 & f25 a year. & 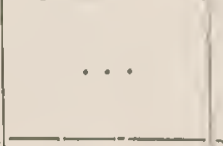 & 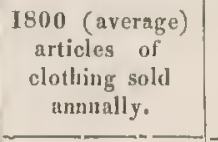 & & & I821. \\
\hline 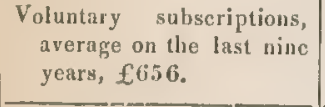 & & $\cdots$ & $\begin{array}{l}\text { Oatmeal, pota- } \\
\text { toes, milk, \& \&o. }\end{array}$ & $\begin{array}{c}\text { Donations of fome } \\
\text { garnents. }\end{array}$ & $\cdots$ & $\begin{array}{l}\text { Snurf and tobacoco } \\
\text { (to some). }\end{array}$ & $\begin{array}{l}1825 . \\
1311 \text { Mny. }\end{array}$ \\
\hline $\begin{array}{r}\text { Voluntary subscriptions and } \\
\text { donations, } £ 1079 s .22 .\end{array}$ & $£ 270 s, 0 d$. & $£ 3515 s .0 d$. & Inmates fed. & Innates clothed. & 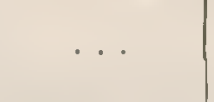 & . & $\begin{array}{l}1829 . \\
\text { Ist Mlay. }\end{array}$ \\
\hline $\begin{array}{c}\text { Earnings of prisoners pur- } \\
\text { chase materials and tools. }\end{array}$ & No separate & to expense. & Usual diet. & Usual clothing. & 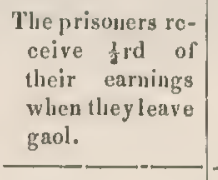 & . & $\begin{array}{l}1826 . \\
31 \text { st May. }\end{array}$ \\
\hline 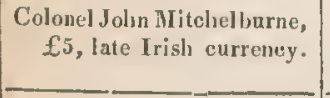 & - & $\cdots$ & .. & .. & $\mathscr{L} 5$ late currency. & $\cdots$ & $\begin{array}{l}\text { I721. } \\
\text { 12th July. }\end{array}$ \\
\hline $\begin{array}{l}\text { Alderman } \\
\text { Neter Stanles, } \\
\text { fur a year, latec Irish } \\
\text { surrency. }\end{array}$ & . & $\cdots$ & . . & . & $\begin{array}{l}£ 42 \text { late eurren- } \\
\text { ey. }\end{array}$ & . & $\begin{array}{l}\text { I826. } \\
\text { 6th November. }\end{array}$ \\
\hline $\begin{array}{l}\text { Miss Murgaret Evory, £20 } \\
\text { a year. }\end{array}$ & & - & $\cdots$ & $\cdots$ & $\{20$. & $\cdots$ & $\begin{array}{l}\text { 1831. } \\
\text { 5th February. }\end{array}$ \\
\hline
\end{tabular}




\section{CITY OF LONDONDERRY.}

Sub-section 3.-Establishments for Mental and Bodily Disease.

With this class of establishments also the city is amply provided. The Lunatic Asylum cars be only partially considered as appertaining to this parish, as its district embraces three counties. The Infirmary likewise is intended for the whole county, but the Dispensary is confined to the city and its liberties.

Lunatic Asylum.-The expense of erecting the Lunatic Asylum was advanced by government, and the three counties which constitute its district are bound to refund it by instalments. The expenses also of management are advanced from the same source, and repaid into the consolidated fund, by applotments levied on the three counties at the assizes, in proportion to the number of patients furnished by each.

The management is vested in a board of governors and directors, appointed by the Lord Lieutenant and Council, and selected from the nobility, clergy, and gentry of the district. The directors meet monthly, or oftener if necessary.

The general dietary is as follows:-

Breakfast -7 ounces of oatmeal, with $\frac{3}{3}$ quart of new milk.

Dinner, Sunday $-\frac{1}{2}$ lb. of beef, and $3 \frac{1}{2}$ lbs. of potatoes.

Monday, Wednesday, Friday, and Saturday -1 pint of buttermilk, and $3 \frac{1}{2} l b$. of potatoes.

Tuesday and Thursday, Ox-

Supper-5 ounces of oatmeal with $\frac{1}{3}$ quart of new milk.

No deviation from the above dietary is allowed, unless by an order from the physician.

Of the patients about 100 are constantly employed-the males in tailoring, shoemaking, carpentry, garden and field labour, weaving and winding, pumping, wasbing potatoes, \&c.the females in plain work, quilting, knitting, spinning, washing in the laundry, cleansing the house, \&c.

The state of the establishment reflects great credit on the board, as well as on the manager and matron. It has repeatedly elicited the approbation of the inspectors-general of prisons, in whose Report for 1833 it is stated, that "this provincial asylum maintains its rank amongst those alrearly established in Ireland, for neatness, good order, and economy, and manifests the success that has invariably followed the humane and wise treatment pursued."

The officers, with their annual salaries, are as follow :--

\begin{tabular}{|c|c|c|c|c|c|}
\hline Surgeon &.$£ 100$ & 0 & 10 assistant nurses (eacli) & $\mathfrak{L} 4$ & 4 \\
\hline Manager and matron* & 250 & 0 & 1 cook & 6 & 6 \\
\hline Clerk and store-keeper & 30 & 0 & 1 laundress & 6 & 6 \\
\hline Gardener & 15 & 0 & I assistant laundress & 4 & 4 \\
\hline 5 keepers (each) & 121 & 12 & 1 office store maid & 4 & 4 \\
\hline 5 nurses (each) & 6 & 6 & 1 hall porter & 10 & 0 \\
\hline
\end{tabular}

YEARLY EXPENSE.

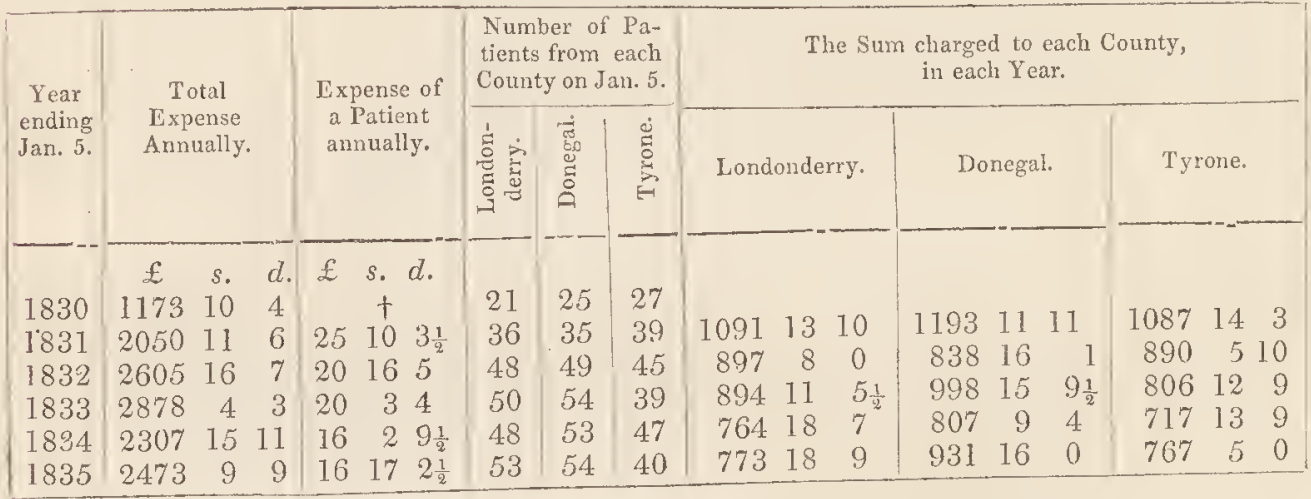

* Being a married couple they receive a joint salary.

$\dagger$ Notling was paid this year. The items of expense are included in that following. 


\section{BENEVOLENCE.}

RETURN OF PATIENTS.

\begin{tabular}{|c|c|c|c|c|c|c|c|}
\hline Year. & $\begin{array}{c}\text { No. of Pa- } \\
\text { tients on } \\
\text { the 5th Jan. }\end{array}$ & Admitted. & $\begin{array}{c}\text { Discharged } \\
\text { recovered. }\end{array}$ & $\begin{array}{c}\text { Discharged } \\
\text { relieved. }\end{array}$ & $\begin{array}{c}\text { Discharged } \\
\text { harmless and } \\
\text { incurable. }\end{array}$ & Died. & $\begin{array}{c}\text { Total } \\
\text { discharged } \\
\text { and died. }\end{array}$ \\
\cline { 1 - 2 } 1830 & 73 & 87 & 8 & 1 & 0 & 5 & 14 \\
1831 & 110 & 84 & 36 & 4 & 2 & 5 & 47 \\
1832 & 142 & 81 & 32 & 5 & 1 & 11 & 49 \\
1833 & 143 & 66 & 42 & 7 & 3 & 13 & 65 \\
1834 & 148 & 74 & 41 & 6 & 3 & 19 & 69 \\
1835 & 147 & 70 & 43 & 5 & 4 & 19 & 71 \\
\hline
\end{tabular}

Infirmary. - The funds arise from parliamentary grants, grand jury presentments, governors' subscriptions, and contingencies.

The number of beds is 120 .

Donors of 20 guineas become life governors or governesses, and the lowest qualification for an annual governor is 3 guineas. The number of life governors is 22, and of governesses 7: the number of alnual governors is $3 \mathbf{i}$, and of gorernesses 3 .

Average annual income for 5 years, ending on the 5 th of January, 1833 ,

Expenditure for do.

Number of patients for do.

$£ 1475 \quad 15 \quad 10 \frac{3}{2}$

$£ 14.56 \quad 10 \quad 0$

375

Total number of rations issued to patients, in the year ending. on the 5 th January, 1833 , .

Daily average number of patients, exclusively of paupers and lunatics,

Daily average cost for provisions and medicine for each patient,

Do. do. including every item of expenditure,

$4 \frac{1}{4} d$.

$9 \frac{1}{4} d$.

The actual number of lunatics and idiots on the 31 st of December 1833 was 12 , of which 2 were born idiots, 2 epileptic, 1 a curable maniac, and 7 incurable maniacs.

The patients are bound to adhere to the rules under penalty of expulsion. These prescribe strict subordination and decorum. No intercourse is allowed between the male and female wards, without the surgeon's permission, on whom also depend the privileges of going beyond the walls, and smoking in the wards. No ginme of chance is allowed, and convalescents are obliged to assist in nursetending, \&c.

The patients are expressly prohibited from conversing across the walls, resorting to the porter's lodge, or parting with any of their provisions; and visitors are similarly prohibited from introducing provisions, under pain of permanent exclusion.

The visiting days are Tuesday, Wednesday, and Saturday, from 11 to 12 , and a gorernor's order must be produced. The surgeon, however, and the house steward, have a discretionary power of admitting at all times visitors from remote districts.

This building was erected to replace an old foor-house, which, previously to 1806 , occupied the site of the present fish and regetable markets, but was deficient both in funds and accommodation.

The officers, with their anmal saluries, are as follows:-

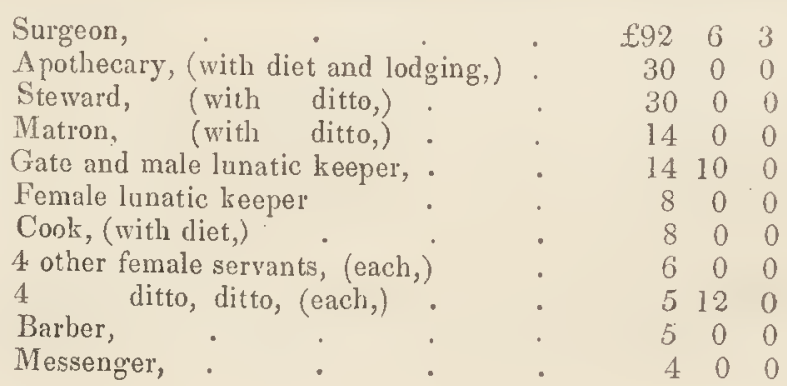




\section{CITY OF LONDONDERRY.}

\section{Patients admitted.}

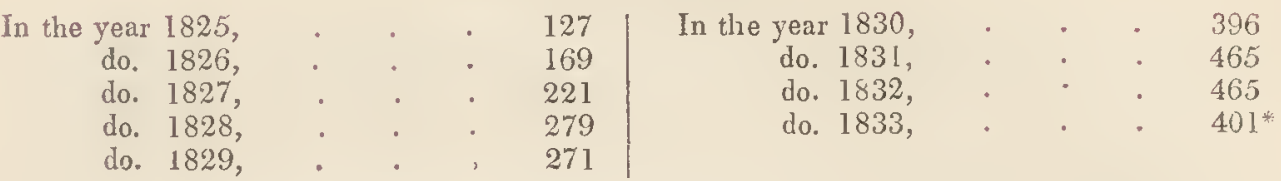

Cases admitted from 5th January 1832 to 5th January 1833.

\begin{tabular}{|c|c|}
\hline Amaurosis, & \\
\hline Cataract, & . \\
\hline Nebula, & - \\
\hline Ophthalmia & \\
\hline Fracture, & . \\
\hline Syphilis, & . \\
\hline Hydrocele, & - \\
\hline Ulcers, & - \\
\hline Tumour, & . \\
\hline Dyspepsia, & - \\
\hline Fever, & - \\
\hline Herpes, & - \\
\hline Ozoena, & - \\
\hline Scrofula, & \\
\hline Paralysis, & . \\
\hline Epilepsy, & - \\
\hline Asthma, & - \\
\hline Dropsy, & . \\
\hline Dysentery, & . \\
\hline Gangrene, & - \\
\hline Rheumatis & $m$, \\
\hline Lepra, & . \\
\hline Abscess, & - \\
\hline Psoas Absc & cess, \\
\hline $\begin{array}{l}\text { Pneumonia } \\
\text { Dislocation }\end{array}$ & \\
\hline Dislocation & \\
\hline
\end{tabular}

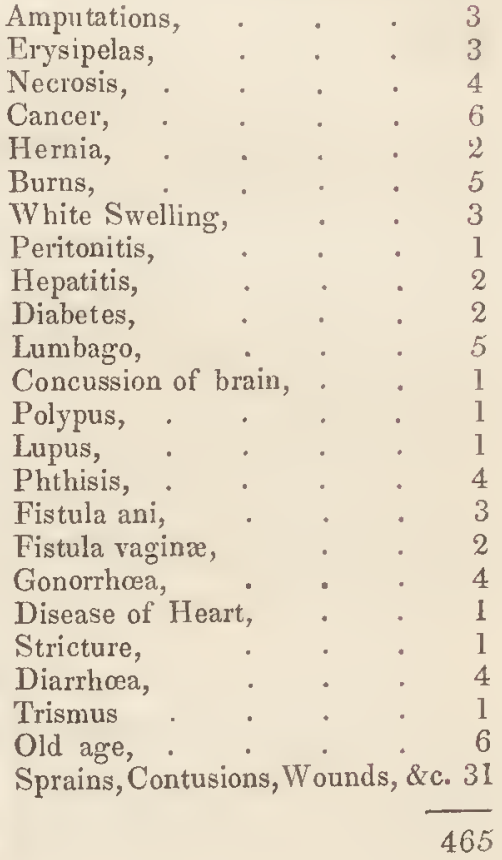

Patients. Remained in the house 6th January, 1833. $\begin{cases}\text { Hospital patients, } & 48 \\ \text { Lunatic patients, } & 11\end{cases}$

$-59$

Cured, . . . . . 331

Relieved, . . 45

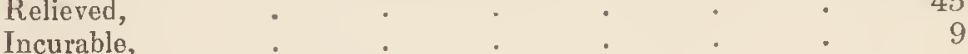

Died,

Remaining in the house 5th January, 1834,

$\frac{44}{449}$

Lunatics remaining in the house, 5th January, 1834 ,

11

Aged and infirm remaining in house, 5th January, 1834,

Total $\frac{10}{470}$

* The diminution in the number of cases reported was eaused by fever being less prevalent last year than formerly. 
BENEVOLENCE.

LIST OF DISEASES IN THE LONDONDERRY INFIRMARY, TOR 1834--35.

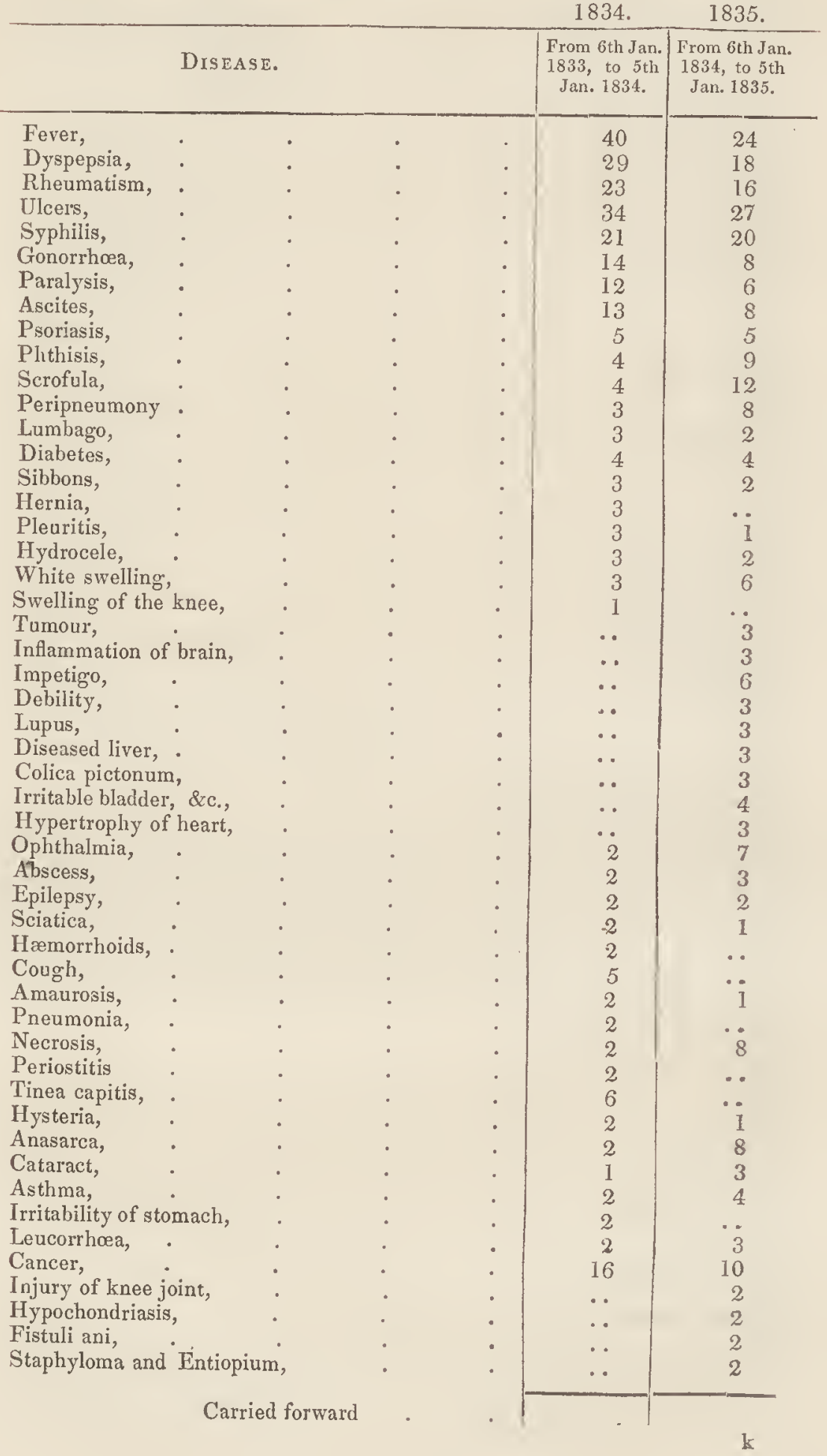


CITY OF LONDONDERRY.

List of Diseases continued.

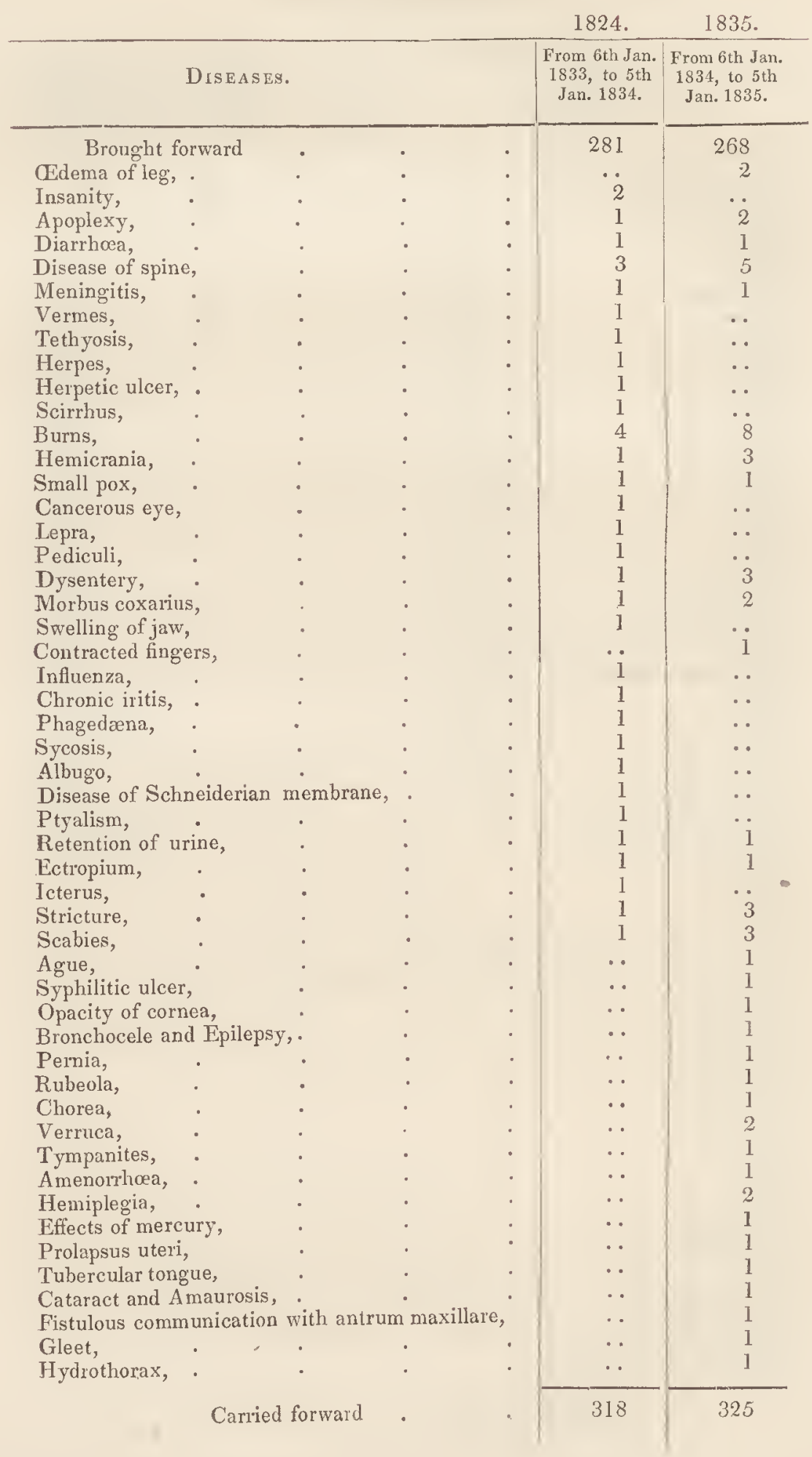




\section{BENEVOLENCE}

List of Diseases continued.

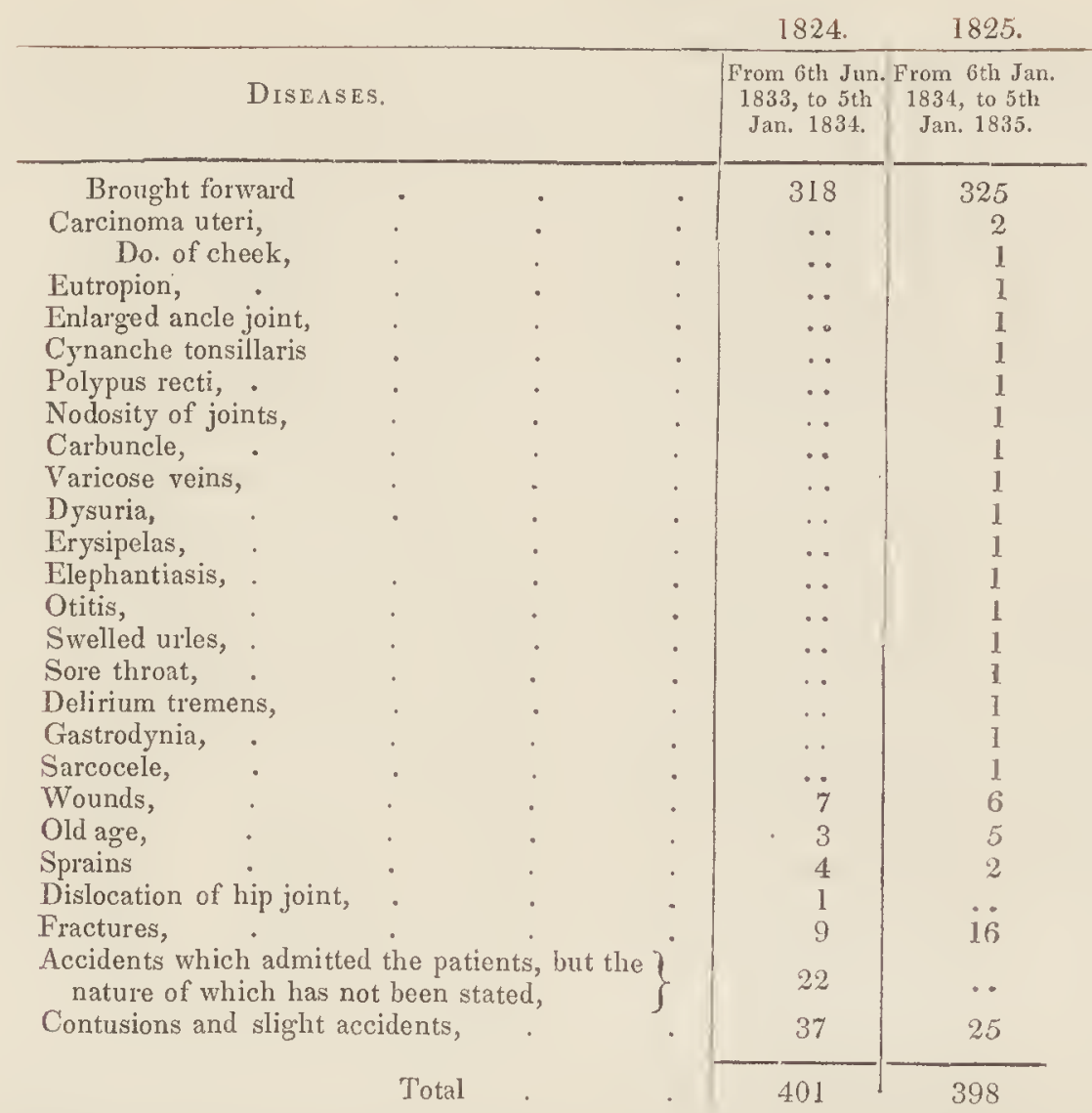

Dispensary. - The dispensary is rented at $£ 23 \mathrm{Is}$. $6 \mathrm{~d}$. a year. It was established in 1819 , by the late Bishop Knox and the inhabitants of the city, to which with its N.W. Liberties the district is confined.

It is supported from voluntary contributions, an annual grant of $£ 30$ from the Irish Society, and a county grant. The committee of management is appointed by the subscribers. The institution is open on Tuesdays, Thursdays, and Saturdays, from 11 to 2. 


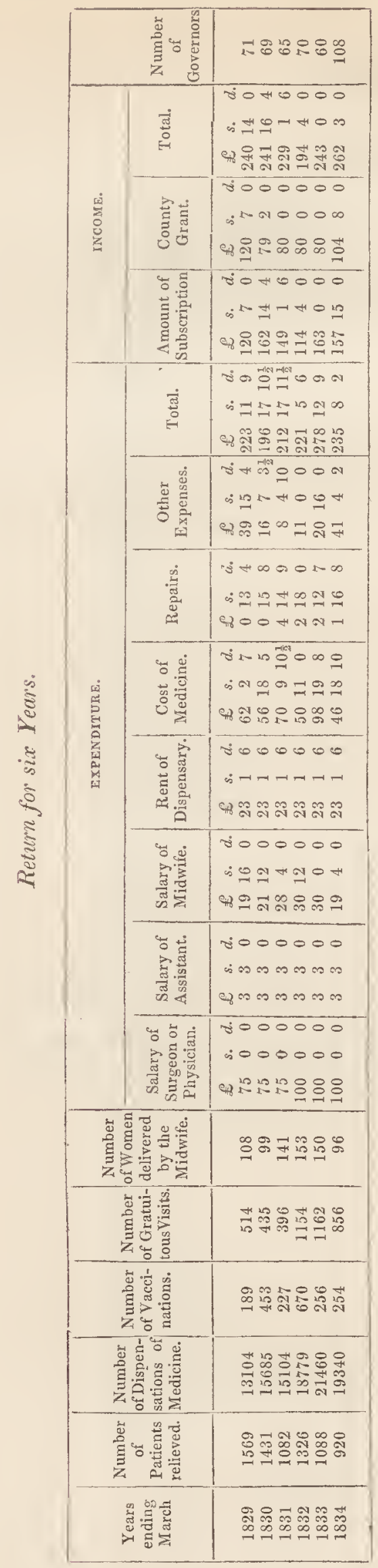

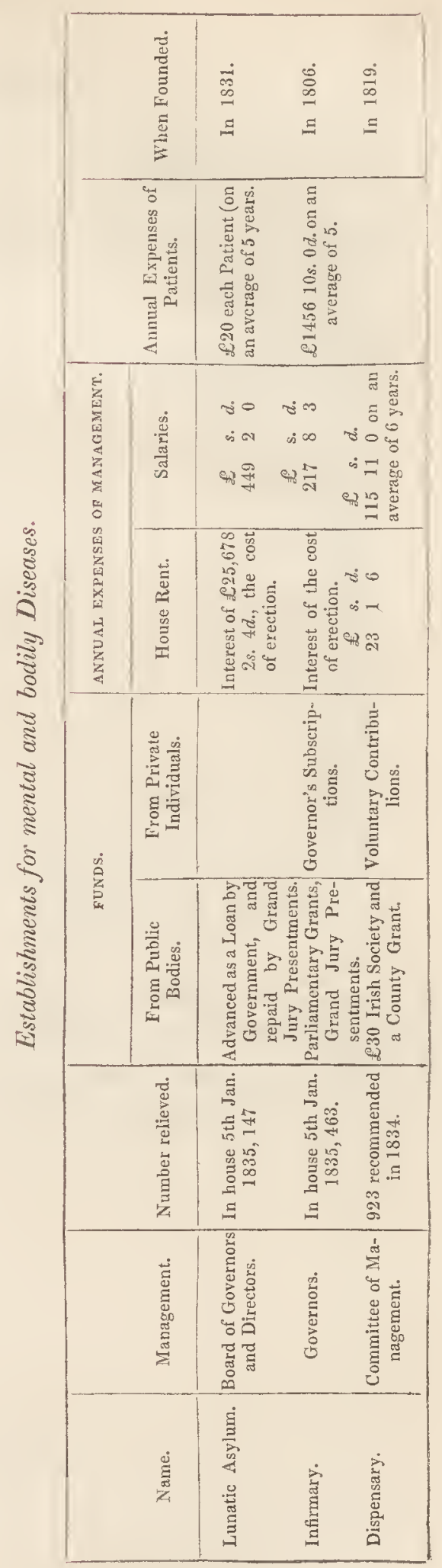




\section{JUSTICE.}

\section{Section 4.-Justice.}

Those, who have directed their attention to the philosophy of crime, are aware that of late years several ingenious attempts have been made, more especially by continental writers, to reduce the subject to a science. M. Quetelet, of Brussels, and M. Guerry, of Paris, liave taken the lead in these investigations; and--by tracing crime through the various motives and circumstances, which had led to or accompanied it-have given ground to hope that, when sufficient time and space have been afforded for the extension of such investigations, it may be practicable, by reaching the general causes of crime, to attain the first step towards its diminution and ultimate removal.

M. Quetelet infers, from the results of his inquiries, the possibility of calculating what number of murders, forgeries, \&c. will be committed in any given community, within any given time, with the same weapons, \&c. \&c.- and this with the same certainty as we can reckon on the accurrence of the number of marriages, births, deaths, \&c.- but adds:- "Je suis loin d"en conclure cependant que l'homme ne puisse rien pour son amélioration: je erois, comme je l'ai dit au commeneement de ce Mémoire, qu'il possède une force morale capable de modifier les lois qui le eoncernent; mais eette force n'agit que de la maniére la plus lente, de sorte que les eauses qui influent sur le système social ne peuvent subir aueune altération brusque."**

M. Guerry, likewise, has expended a great deal of ingenuity and research on this most interesting subject, and furnished a variety of curious tables, which have been laid before the British public by Mr. H. L. Bulwer, who expresses himself "greatly disposed to concur in the majority of M. Guerry's conclusions," adding, howerer:- "This disposition I own is not merely founded upon a faith inspired by the calculations I have submitted to the reader. I do not feel that faith in such calculations which many do. But in this instance the results which M. Guerry has given are those whicl the ordinary rules of nature and observation would teach me to believe." + These considerations disarm the subject of its terror; ; and enable us to enter calmly on the inquiry-how far natural, or general, causes may be modified by those circumstances, which it is in the power of a community to throw around them. Similar causes must, to a great extent, produce similar effects, while the human race continues to exist; but those causes are of two kinds-one general, or founded in nature, the other particular, or proceeding from the intervention of mankind : over the first, in the present state of knowledge of the natural history of man, it cannot be expected that any marked control can be exercised, and it is tlerefore on the second that reliance must be placed for that direction of the mental impulses, which shall lead rather to virtuous than to vicious resilts. It is demonstrated that mere intellectual instruction tends neither to diminish nor augment human depravity, "L'instruction," says M. Guerry, "est un instrument dont an peut faire bon ou mauvais usage. Celle qu' on va puiser dans nos écoles élémentaires, et qui consiste seulement à savoir, d'une manière assez imparfaite, lire, écrire, et ealeuler, ne peut suppléer au défaut d'éducation, et ne semble pas devoir exercer une grande influence sur la moralité. Nous pensons qu'elle ne rend ni plus dépravé ni meilleur. Nous aurions peine à comprendre comment il suffirait de former un homme à certaines opérations presque matérielles, pour lui donner aussitốt des mours régulières et développer en lui des sentimens d'honneur et de probité." + How, then, can so important a result as the improvement of human character be hoped for from the application of mental training alone, at least when exhibited in the mere rudiments of knowledge? rather, indeed, might an advancement in the aptitude to crime be expected to attend it; for intellectual knowledge alone is not sufficient to restrain the passions, though it may in some degree influence the mode of their direction. It is therefore to the combined influence of religious, moral, and intellectual instruction alone, that the amelioration of the human race may be safely committed. Had the researches of M. Quetelet been continued for forty years instead of four ("les QUATRE années qui ont préé́dé 1830"), or those of M. Guerry for sixty years instead of six ("les SIX années comprises de 1825 à 1830"), accompanied by the favourable circumstances here premised as essential to the improvement of mankind, there can be little doubt that the restilts developed would have been such as the warmest philanthropist could desire. Were such indecd not the case, loow gloomy would be the prospect of the future-combining the same tendercy to crime, with an increase of knowlerge to facilitate its perpetration! Happy is it that the favourable is also the reasonable view of the

* "Recherches sur le Penchant au Crime aux différens Ages. By A. Quetelet.

† "France, Social, Literary, Political." 2 vols. By H. L. BuLwer, Esq.

‡ "Essai sur la Statistique Morale de la France." By A. M. Guerri. 


\section{CITY OF LONDONDERRY.}

subject, and that the well-wisher of his fellow-creatures can go on labouring for their benefit, under the cheerful conviction, that, if well directed, his labours will not be in vain.

Preventive Justice. - In reference to this head it has been shown that instruction is at work in the district now under consideration. Among those who form the adult generation many are ignorant of even the elementary knowledge of reading and writing, nor does that ignorance appear to be compensated by the moral instruction they received in youth. With the rising generation, however, both these branches appear to be better attended to. It has been shewn that out of the whole population, of 19,860 individuals, there are above 2,000 children receiving instruction; and even the gaol itself, the proper theatre of retributive justice, is, in degree, also preventive of crime-its discipline being calculated to reform the criminal, and thus diminish the danger of a second incarceration, when the period of his imprisonment shall have elapsed. Did he also acquire a handicraft trade within its walls, as is usual in several of the American prisons, there is little doubt that the cells would become, in a great measure, tenantless, while the want of expert artisans, which is generally felt throughout Ireland, would be at Derry considerably obviated.

The next step in the progress of the present inquiry leads to the establishments, which the county supports for the prevention of crime. The benevolent institutions, so liberally patronized by a numerous resident gentry, and a respectable mercantile body, and which afford relief to so large a proportion of the community, may be at least supposed to remove many of the temptations to crime, and for its suppression there are the following courts [see Municipality], in addition to the usual array of a city magistracy and police, aided by those of the county, which shall be more particularly noticed in their proper place :-

1. The Assizes' Court, held twice a year.

2. The Sessions' Conrt, do.

3. The City Sessions' Court, held four times a year.

4. The Petty Sessions' Court, held every week, before 2 or more magistrates.

5. The Mayor's, or Recorder's Court, held every Monday.

6. The Court of Conscience, held every Week.

In this part of the subject it is necessary to observe that, in any attempt to give a comprehensive view of crime, debt must be inevitably mixed up with it, although, when unaccompanied by fraud, it implies more of imprudence, than of moral criminality. This must be taken into consideration in estimating the quantity of delinquency (a term sufficiently wide in its acceptation to include both classes, ) exhibited in the following tables, which have heen drawn up from various retirns, communicated through the courtesy of different officers, but which, notwithstanding much painstaking, it has been found impossible to reconcile in all their details. 


\begin{tabular}{|c|c|c|c|c|c|c|c|}
\hline 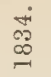 & $\mid \begin{array}{l}8 \\
8\end{array}$ & 离 & $\infty \infty:^{\infty}$ & $:{ }^{N \mathrm{~N}} \overrightarrow{\mathrm{G}}:$ & $\mathscr{C}$ & \% & \\
\hline 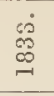 & $\Rightarrow$ 舟 & 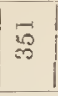 & $\infty 2$ & $::$ & कूष & $\mid \overrightarrow{65}$ & \\
\hline 怘 & 호요 & $\approx$ & $+:^{+\infty}$ & E & $\stackrel{\infty}{\infty}_{-\infty}^{\infty}::$ & $\vec{a}$ & \\
\hline$\dot{\vec{\infty}}$ & 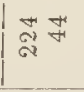 & $\mid$ & $:^{\infty}:=$ & $:: \stackrel{\infty}{\circ}$ & 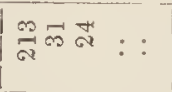 & \& & \\
\hline 突 & $\frac{\infty}{2}$ & $\left|\begin{array}{l}\infty \\
\hdashline \\
\hdashline\end{array}\right|$ & : & & 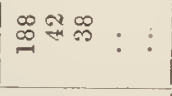 & $\mid \begin{array}{l}\infty \\
0 \\
-\infty\end{array}$ & \\
\hline 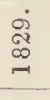 & 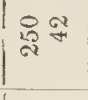 & : & $-:^{n}$ & $::^{10008}:$ & 용요 : : & बे & : \\
\hline$\underset{\tilde{\Phi}}{\stackrel{\dot{\Phi}}{\sim}}$ & 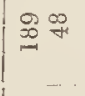 & aे & - & $::^{n} g_{-1}^{-1}$ & $\underset{\Psi}{\mathbb{1}}=\infty$ & 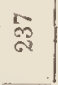 & : \\
\hline 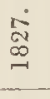 & $\mid \begin{array}{c}\infty \\
0 \\
\infty\end{array}$ & 学 & $: \infty a$ & $::{ }^{n}$ 웅 & |뮤: & $\stackrel{8}{\%}$ & \\
\hline 岕 & 象 & $\vec{\circ}$ & $:::^{\infty}$ & & 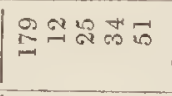 & $\vec{\circ}$ & ? \\
\hline 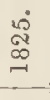 & $\prod_{\substack{\infty \\
\cdots \infty \\
\cdots \infty}}^{\infty}$ & $\left|\begin{array}{l}\pi \\
\cdots\end{array}\right|$ & $:^{\infty}:=$ & $\stackrel{2}{2}:$ & 㣽: & $\pi$ & \\
\hline 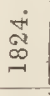 & 䓋只 & $\vec{m}$ & $::^{\infty} \stackrel{\infty}{-\infty}$ & $::^{\infty}$ & $\frac{\pi}{a} a=g$ & $\frac{\pi}{\infty}$ & : \\
\hline 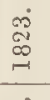 & $\infty$ & $\begin{array}{l}\infty \\
\infty \\
\infty\end{array}$ & $:::^{\oplus}$ & 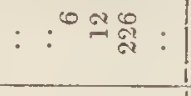 & 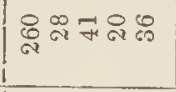 & 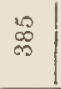 & : \\
\hline ๙ & 离高 & 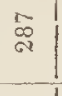 & $:^{\infty}:^{\infty}$ & $::^{20}$ & 10000207 & $\begin{array}{ll}\infty \\
\infty \\
a\end{array}$ & : \\
\hline$\stackrel{\overrightarrow{0}}{\stackrel{\infty}{\infty}}$ & Sa & $\vec{\sigma}$ & $:::^{\infty}$ & $:::^{c}$ & 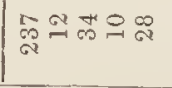 & $\vec{\sigma}$ & : \\
\hline 灾 & $\overbrace{\substack{\infty \\
\hdashline}}^{\infty}$ & 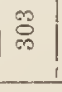 & $:::=$ & $::$ : 节 : & 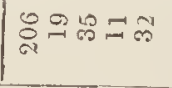 & $\stackrel{\circ}{\circ}$ & $\vdots$ \\
\hline 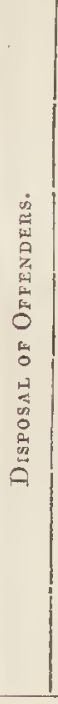 & 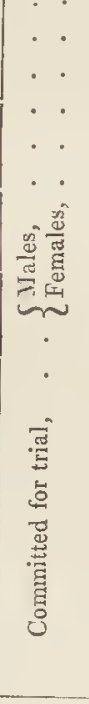 & 胥 & 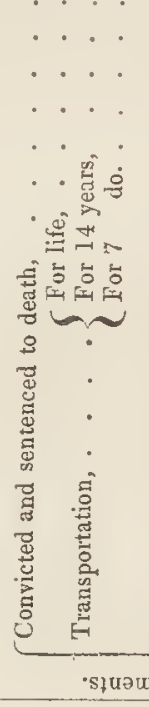 & 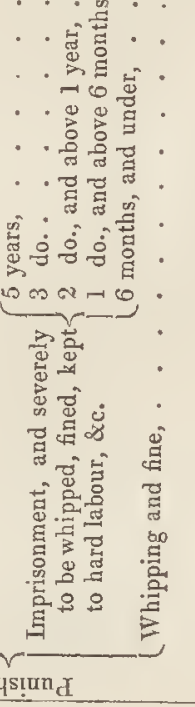 & 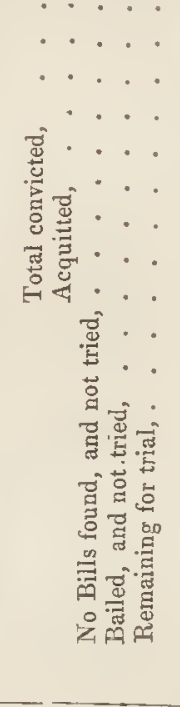 & 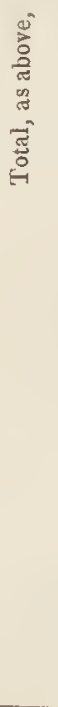 & $\begin{array}{l}: \\
\dot{0} \\
\dot{0}\end{array}$ \\
\hline
\end{tabular}




\section{CITY OF LONDONDERRY.}

PRISON REPORT.

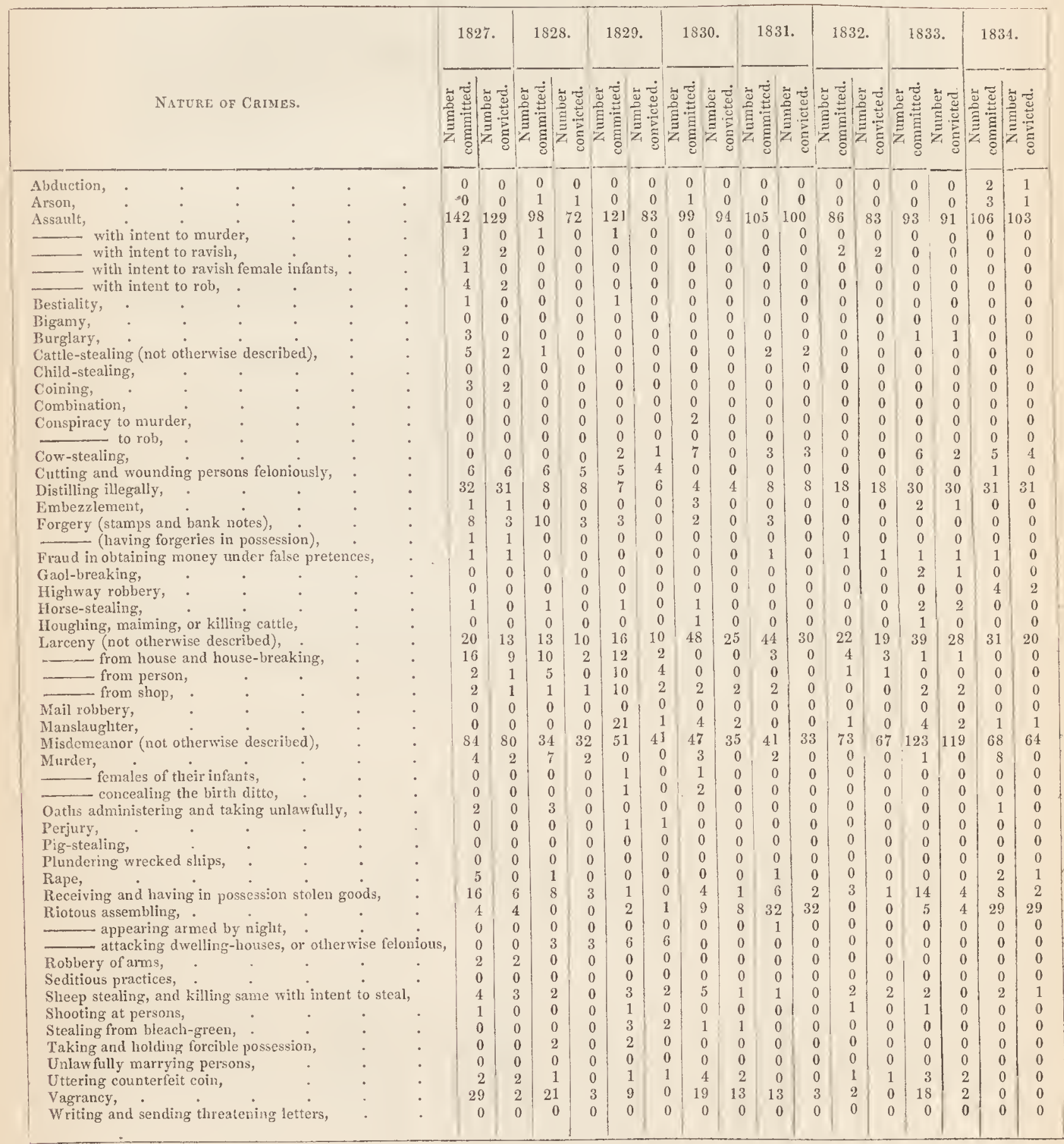




\section{JUSTICE.}

COURT OF PETTY SESSIONS.

Cases for six Years.

\begin{tabular}{|r|r|r|r|r|r|r|}
\hline & 1829. & 1830 & 1831 & 1832. & 1833. & 1834. \\
\hline Judgment passed, . & 53 & 6 & 9 & 37 & 79 & 78 \\
Dismissed, . . . & 3 & 0 & 0 & 3 & 1 & 16 \\
\hline Total, . . . & 56 & 6 & 9 & 40 & 80 & 94 \\
\hline
\end{tabular}

COURT OF CONSCIENCE.

Cases decreed and dismissed in eight years.

\begin{tabular}{|r|r|r|r|r|r|r|r|r|}
\hline & 1827. & 1828. & 1829. & 1830. & 1831 & 1832. & 1833. & 1834. \\
\hline Decreed, . . . & 648 & 671 & 694 & 767 & 743 & 612 & 586 & 729 \\
Dismissed, . . . & 83 & 64 & 62 & 71 & 52 & 47 & 43 & 39 \\
\hline Total, . . . & 731 & 735 & 756 & 838 & 795 & 659 & 629 & 768 \\
\hline
\end{tabular}

MAYOR'S OR RECORDER'S COURT.

Cases in four years.

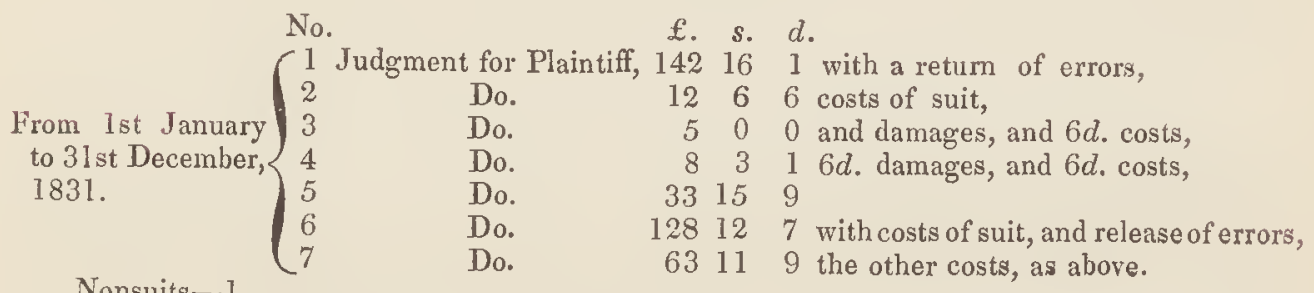

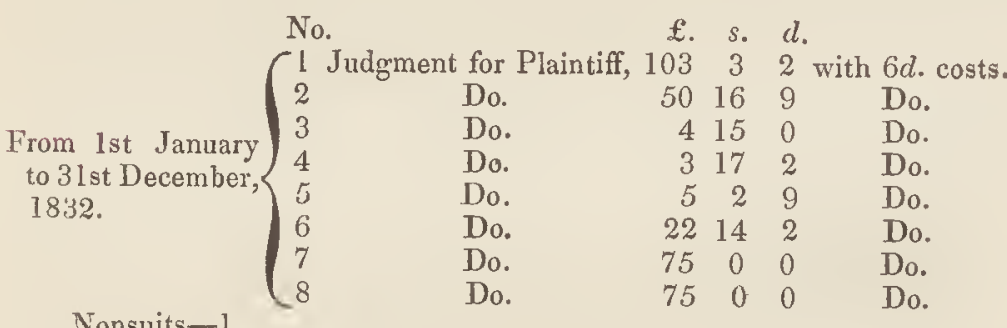

Nonsuits-1.

No.

f. s. $d$.

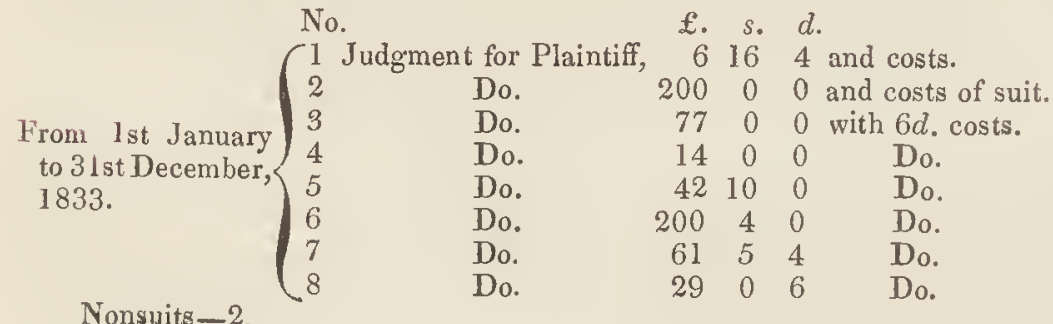




\section{CITY OF LONDONDERRY.}

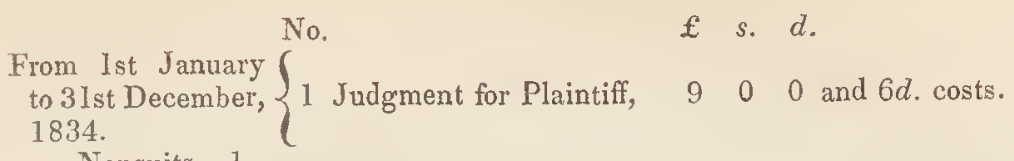

Nonsuits-1.

This great diminution in the number of cases arose from a recent law, by which a portion of the mayor's jurisdiction was transferred to the court of the assistant barrister.

Crime - In connection with this head, it is satisfactory to exhibit the following table for the year 1834 , resulting from the operation of the above courts, which, through the industry of Mr. Coningham, the clerk of the gaol, has been drawn up with some reference to the classification of crime adopted by M. Guerry. 


\begin{tabular}{|c|c|c|c|c|c|c|c|c|c|}
\hline \multirow{4}{*}{ 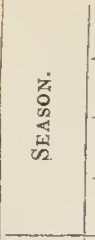 } & & •хәұџ!M & $:::-:: \infty:$ & se & 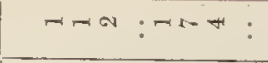 & $\stackrel{0}{-1}$ & $0 \times 5:$ : & $\approx$ & in \\
\hline & & -uxump & $: \neg:::$ ๙ $^{\circ}:$ & $\infty$ & $:::-1: \infty-\infty$ & $\approx$ & लविस : & $=$ & $\vec{b}$ \\
\hline & & 'xәтишй & $: \neg \neg:::_{\substack{\infty \\
1}}^{\infty}$ & $\vec{\infty}$ & $N \backsim N ー \infty \infty$ & 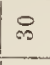 & $\Rightarrow \Phi$ : & $\infty$ & $\%$ \\
\hline & & 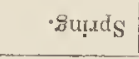 & $\infty::-: \infty$ & a & $::::-1++1$ & 0 & $\circ 0 \mathrm{~m}:$ & ה & 8 \\
\hline \multirow{5}{*}{ 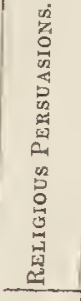 } & & & $::::::::$ & $:$ & $:::::::::$ & $:$ & $:::$ : : & : & : \\
\hline & & Аноия 7ON & $::::::_{\infty}-$ & 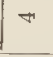 & : : : : : : : : & : & $::::$ & : & 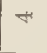 \\
\hline & son!lo & [tro uxwoy & ar : en: : : : & $R$ & 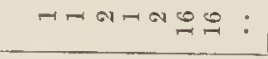 & is & $\stackrel{2}{2}$ ล & 8 & 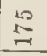 \\
\hline & & 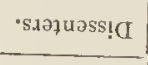 & Nमन: : : & 아 & 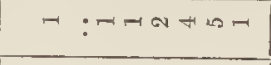 & $=$ & $\infty+\infty:$ & $\stackrel{\infty}{\sim}$ & $\stackrel{\infty}{+}$ \\
\hline & & 'squetsatoxd & : : : : : & $\mid \begin{array}{c}\infty \\
-1 \\
\end{array}$ & $\because ー A:-\infty \infty:$ & $\stackrel{\infty}{-\infty}$ & $\approx: \infty:$ & $\infty$ & H \\
\hline \multirow{4}{*}{ 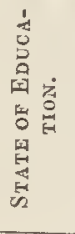 } & & 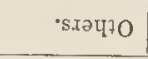 & $\neg: \neg \infty: ล 2:$ & $\infty$ & $:-:^{-\infty}:$ & $=$ & o : & $\stackrel{\infty}{=}$ & $\ddot{0}$ \\
\hline & pur $p$ & 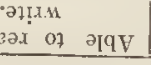 & : & 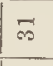 & $\neg$-a : $-\infty 0:$ & $\stackrel{\infty}{-}$ & os: & 22 & 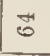 \\
\hline & & реа. 01 ә & $\neg:::: \pm ー$ & 1 & $7:-1,-100-1$ & $\stackrel{2}{2}$ & $\infty$ : & $\stackrel{\infty}{2}$ & 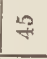 \\
\hline & & 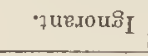 & $:-1::: x^{-1}:$ & $\infty$ & $\neg:-\neg \infty=\infty:$ & $\therefore$ & $0 \pm$ 용 & 5 & $\cong$ \\
\hline \multirow{6}{*}{$\frac{\sqrt{3}}{\mathrm{~d}}$} & & 0709 wox & $::::: 0:$ & 0 & $:::::$ ๙ & $\infty$ & $-7:$ & -1 & 10 \\
\hline & & 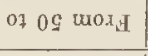 & $::::: \mathbb{T}^{-}:$ & $\pi$ & $:::::: \infty-:$ & $\infty$ & $\neg \nrightarrow::$ & 20 & $\cong$ \\
\hline & & of of woxd & |rन: : : : : : & $\approx$ & $::::$ : & $\infty$ & बत्म : & $\infty$ & $\mid \begin{array}{l}\infty \\
\infty \\
\infty\end{array}$ \\
\hline & & 0708 wor. & $::::: 0:$ & $\stackrel{0}{2}$ & 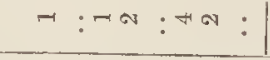 & i & $\infty \oslash \infty:$ & ज्ञ & $\neq$ \\
\hline & & 0706 wods & Iーーーの : & is & $:$ N $: \infty=$ & $\infty$ & $\stackrel{0}{\sim} \operatorname{si}^{\circ}:$ & $\%$ & $\stackrel{\oplus}{\mathscr{m}}$ \\
\hline & & of 0 [ woxd & $1^{\circ}::::=-$ & $=$ & a : : : - +o: & $\approx$ & no : : & i- & $\infty$ \\
\hline \multirow{6}{*}{ 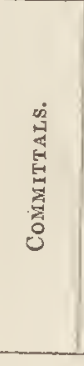 } & \multirow{2}{*}{ 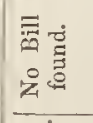 } & -sәртиан & $:::: r-1:$ & $\infty$ & $::^{-1}: \infty \mathrm{er}:$ : & 0 & $::-7:$ & $=$ & 0 \\
\hline & & - sәrent & $::::::-1-$ & $\infty$ & $:$ ( : : : : & 10 & $:::^{-1}$ & -1 & $\infty$ \\
\hline & \multirow{2}{*}{ 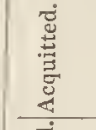 } & •sә̨еü II & $::::::::$ & $:$ & ๙ : : : न : : & + & $:::$ & : & 4 \\
\hline & & sarew & $\infty \sim:^{-1}:-$ & $=$ & $::$ : & 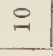 & $::$ & : & ส \\
\hline & \multirow{2}{*}{ 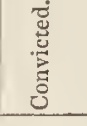 } & "รогриа & $::::::^{\infty}-$ & 10 & $::::$ - $\varrho^{\mathrm{N}}:$ & $\cong$ & - $-\infty:$ & $\infty$ & $\%$ \\
\hline & & 'sәएँ & $: \leadsto+: \infty 8:$ & 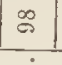 & 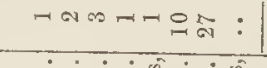 & 13 & 蛋品: : & 2 & $\frac{0}{\pi}$ \\
\hline & \multicolumn{2}{|l|}{ 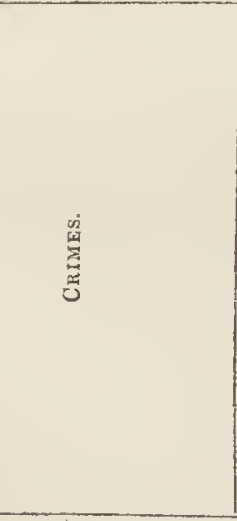 } & 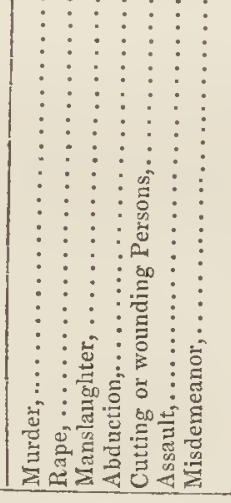 & 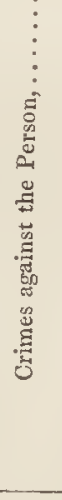 & 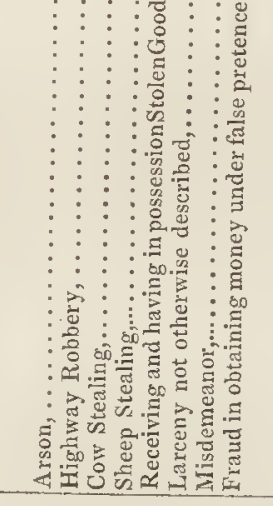 & 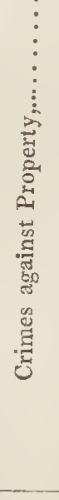 & 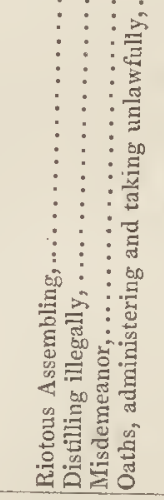 & 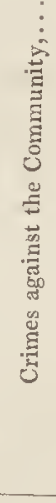 & 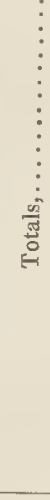 \\
\hline
\end{tabular}




\section{CITY OF LONDONDERRY.}

The above table, presenting merely a view of the crimes committed within the short space of one year, and the small compass of one county, is not capable of being satisfactorily submitted to the tests proposed by M.M. Quetelet and Guerry. It may be, however, interesting to make the application so far as it is practicable.

With regard to the three classes of Crimes-against the person, against property, and against the community-it appears, at first view, that a vast majority have been committed by persons between the ages of 20 and $30:$ this is in exact conformity with the principle of the above writers, who fix upon 25 as the maximum period of criminality in males, and towards 30 in females. On the other hand, the predominance of ignorant delinquency is against their results. It may be also ohserved-that the crimes against property are nearly a mean between those against the person, and against the community.

In reference to crimes against the person there are but few instances of conviction for heinous offence; nor is it to be inferred from the number of committals for murder that any such crimes really took place-such committals being notoriously common throughout Ireland, in cases wherein there is not the faintest colouring of malice prepense. The age too of six out of eight of those committerl-10 to 20 -diminishes the probability of its existence. The instances of assault, which are on the other hand very numerous, are probably the result of drunken squabbles, or party differences: those committed by males are twelve times as numerous as those by females. The influence of season is but slightly perceptible.

In reference to crimes against property the convictions for serious delinquency are more numerous. In all cases the offenders were males, - and the most heinous crime, arson, was committed by a youth under twenty. Larceny is divided equally between the sexes - but in misdemeanor, (a crime variable in its nature, and scarcely capable of definition,) the proportion of male criminals is to that of female as 13 to $\mathrm{I}$. Juvenile profigacy is here also remarkable-onefourth of the crimes having been committed by youths between the ages of 10 and 20. The preponderance of summer over the other seasons is also very great.

In reference to crimes against the community, with the exception of misdemeanor, the male convictions are to the female as 29 to 1 . The summer season here also appears the most prolific.

Retributive Justice. - This branch of the subject relates to the interior of the gaol, which, as will have appeared from its topographical description [see Section 2], is well calculated for the adoption of two great features of improvenent in prison discipline-classification, and inspection. The former, however, excepting the separation of the sexes, was abandoned on the 12 th of June in the present year (1835), strict silence having being found to answer the same purpose, to enforce which a turnkey is always present during meals and work. With regard to the latter, the exemplary assiduity, as well of the board of superintendence as of the officer's of the gaol, has called for the frequent approbation of the Inspectors General. In their Report, for example, of 1826, the following testimony occurs : - "On the whole, the gaol of Derry must be considered as of the first class in accommodation; and the discipline of the whole establishment bears the marks of that constant attention which is paid by the board of superintendence." The Report for 1831, in like manner, asserts that- "the unremitting" attention paid by the board of superintendence to this new gaol, has secured that regularity, cleanliness, and order, whicl must be manifest to every person visiting it." And again, in the Report for 1833 , it is stated, that"the prison exibits a system of discipline and good order, which leaves an inspector nothing to do but record his approbation for the information of government and the grand jury."

Much information on the subject of gaol discipline has been diffused by an excellent "Report of William Crawford, Esq., on the Penitentiaries of the United States, addressed to his Majesty's Principal Secretary of State for the Home Department," and from the work entitled "Du Systeme Pénitentiare aux Etats Unis et de son Application en France," by MM. G. de Beaumont and A. de Tocqueville: much more may also be expected from the pen of Dr. Julius, who was sent out to America some years since by the Prussian government, and that of $M$. Ducpétiaux, of Brussels, who lately visited this country. However, before the appearance of the interesting volume of MM. de Beaumont, and de Tocqueville, (which was first made known to the British public by an excellent article in the Foreign Quarterly Review, No. 23.), the discipline of the gaol under consideration was in a great degree modelled after that of the Auburn Penitentiary, in the state of New York. The most valuable features of the system there pursued are adopted here-solitude at night, and labour in common workshops by day, but with the observance of rigorous silence-while corporal punishment, as a means of enforcing such silence, is not resorted to, the Derry criminal being literally "unwhipped of justice." At this gaol, also, the prisoner receives one-third of his earnings, a regulation which exists in none of the American establishnients. By the act 7th Geo.4. c. 74, all pauper prisoners, that is, those supported at the public expense, are obliged to work, debtors included. The males are employed in carpentry, carrying and breaking stones for repairing the roads in the city and liberties, pulveriz- 


\section{JUSTICE.}

ing bones for manure, and whitewashing and cleansing the gaol-the females in spinning, knitting, sewing, washing, and cleansing the gaol. The males work 7 hours in summer, and 4 in winter; the females 7 in summer, and 5 in winter. There is no particular description of work for prisoners sentenced to hard labour; these, however, receive no part of their earnings.

The treadmill, although recommended by the Inspectors-General, has not been introduced; this is indeed fortunate, as the effect of labour enjoined as a punishment, and accompanied by no visible benefit either to the prisoner or to the community, can only induce in the criminal's mind an increase of his antipathy to work, rather than a growing desire to adopt it as the means of support; such punishment is only laborious idleness, and is here wisely superseded by work evidently directed to the advantage of the public - an advantage in which the prisoners share by receiving a portion of the profit.

The only punishment which has been found necessary, for enforcing the ordinary discipline of the gaol, is a change of diet, from milk to water at breakfast.

The cost of the male dress is for frieze about $£ 111$ s., and for fustian about $8 \mathrm{~s}, 6 \mathrm{~d}$.: that of a female dress is about $15 \mathrm{~s} .6 \mathrm{~d}$. The dietary consists of about $8 \mathrm{oz}$. of oatmeal made into stirabout, with 1 pint of newmilk, for breakfast; $4 \mathrm{lbs}$. of potatoes, with one pint of buttermilk, for dinner, and $2 \mathrm{oz}$. of oatmeal made into gruel for supper. From the 1st of October to the 1st of June, the weekly expense for each prisoner's diet is $1 s .4 d$., during the rest of the year, $2 s .6 \frac{1}{4} d$. $1 \mathrm{lb}$. of bread, with newmilk, being then substituted for dinner. The provisions are inspected by the chaplains. The surgeon visits twice a-week, and oftener, if necessary. In the hospital there are separate wards for the sexes. 


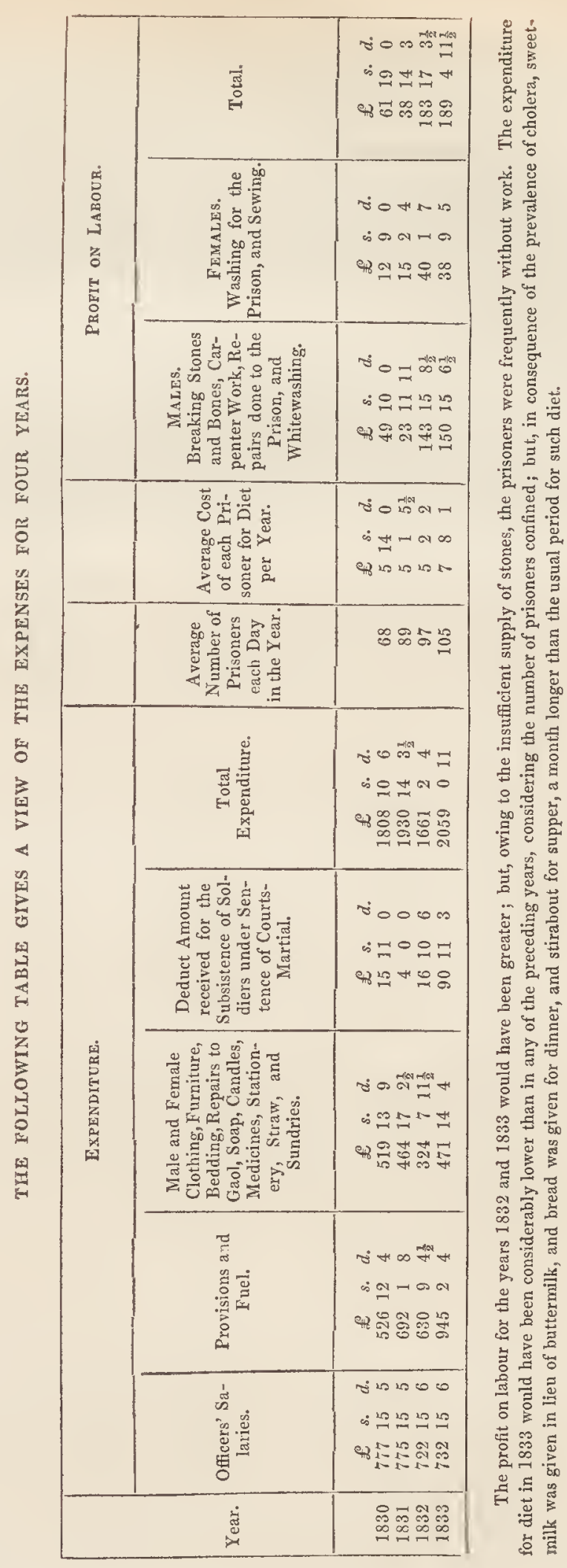




\section{COMMERCE.}

The classification, above alluded to as now obsolete, was as follows :-

\section{Males.}

Ist. Class.-Master debtors, i. e. those who maintained themselves.

2nd. do.-Pauper, do. i. e. those maintained by the public.

3rd. do.-Prisoners for trial at assizes.

4th. do.-Do. tried at do.

5th. do.-Do. for trial at sessions.

6 th. do.-Do. tried at do.

7 th. do. -Do. for fine or imprisonment.

8 th. do.-Do. for king's evidence.

9th. do. - Soldiers tried by court-martial.

10th. do.-Prisoners condemned to death.

11th. do.-Convicts under sentellce of transportation.

\section{Females.}

1st. Class. - Debtors, who maintained themselves.

2nd. do.-Do. maintained by the public.

The only classification observed with the female crown prisoners was that prostitutes were kept by themselves.

Prisoners, confined here before, are kept in strict seclusion.

From a report of committals for eight years - from 1827 to 1834 , both inclusive-it appears, that the greates number in gaol at one time, including debtors, ranged between 89 (in 1829 ,) and 153 (in 1833).

\section{The Officers and their Salaries are as follows:-}

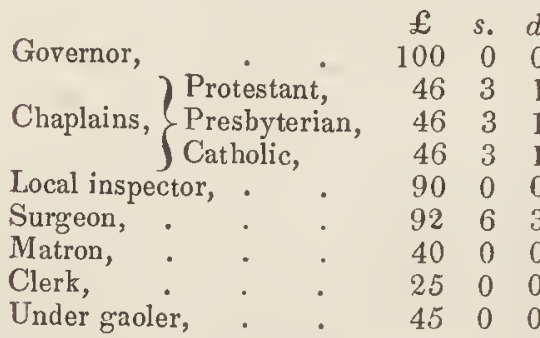

\begin{tabular}{|c|c|c|}
\hline Ist Turnkey, & & \\
\hline 2nd Do. & & \\
\hline 3rd Do. & & \\
\hline 4th Do. & & \\
\hline Hospital do. . & & \\
\hline Gemale do. . & & \\
\hline ospital nurse, & & \\
\hline arber, & & \\
\hline
\end{tabular}

In conclusion-it is gratifying to state that no execution has taken place in Derry since that of Acheson, for murder, in 1820 , several years before the present gaol was built; and it may be reasonably hoped that the modern improvements in both branches of justice will for a long period avert the occurrence of another. Upon the whole-when the strict order, the unvarying cleanliness, and the mild yet firm government, which characterize every department of this gaol, are considered, it will be seen that the system adopted rests on sound principles, and is steadily advancing towards that perfection of prison discipline, equally remote from the unwholesome lenity, which ofters a premium to crime, by pampering the indigent felon with physical comforts, unknown to him before he became such, - and from the overstrained severity, which, by the application of debilitating and degrading punishments, endanger the extinction of that dim ray of moral light, which may still linger within the bosom of tlie darkest criminal.

\section{Section 5.-Commerce.}

General Description of the Port.-Derry has now been viewed in all those varied lights, which the beauty of its natural position, the animated story of its early history, and the importance of its institutions, are peculiarly calculated to throw over a city, at once memorable for past scenes and impressive in its present aspect and condition. As the commercial emporium of an extensive and fertile district it has yet to be noticed, and its fitness to fulfil the relations which are connected with a sea-port will require little elucidation or proof. 


\section{CITY OF LONDONDERRY.}

The natural advantages of Derry as a port, were perhaps among the principal motives which led to its selection as the focus of king James's plantation of Ulster. When the north was first eonverted into "shire-ground," by Sir John Perrot, the county was called the county of Coleraine, and Derry had apparently no existence as a port; but the bar at the mouth of the river Bann soon led to a preference of the deeper and more extended waters of the Foyle.

The rocky coast of Donegal, on the W. of Lough Foyle, abounds with deep and often land-locked inlets, but the prevailing westerly winds render them difficult of access; on the E. the bold basaltic cliffs of Antrim are equally unfavourable, but the port of Derry affords ample water at the quays, with safe anchorage in all weather's.

It has been already stated, that the city lies about 19 miles above the entrance of the lough, the approach to which is made known by the light-house, on the island of lnnistrahull, and will be much facilitated by two others, now erecting on Ennishowen Head, which are intended to serve as guiding lights past the great Tun Bank. The mountains of Renyevenagh, opposite Ennishowen liead, is also a conspicuous landmark. Good charts and sailing directions have been published by the Admiralty, and at the entrance of the longh there is an establislıment of pilots, under the Ballast Board. 'The channel lies under the bold sliore of Ennishowen. Its breadth from Greencastle up to Redcastle (a distance of $6 \frac{1}{9}$ miles,) is about half a mile. It there widens a little, but speedily becomes more shallow, and continues so to Quigley's Point, a distance of $3 \frac{3}{4}$ milcs from Redcastle, where the fluctuations of depth are defined by a perch, placed at low-water mark, and graduated with a scale of feet in large aud legible characters. A succession of flats, consisting of mud and fine sand, extends from Redcastle to Culmore Point, where the lough narrows into a rirer. The channel is provide with buoys throughout. Those in the lough are neither sufficiently large, nor disposed in opposite pairs, to mark the width, as well as the direction of the cliannel. They form a single zig-zag chain, and are so far asunder that it is impossible to see half the distance between them in hazy weatlier, which, owing to the exhalations of the lough, is frequent. In the river the banks and shoals are well defined, both by the buoys, and by extensive salmon-weirs. Access to the lough is in stormy weather rendered difficult by an extensive shoal which lies without, and to the eastward of the entrance, and is variously called the Tons, the Tuns Shoal, and the great Ton Bank, from the Irish zonn, "wave." li extends in length 2 miles, and is and is bounded on one side by a line parallel to the Ennishowen coast-on the other by one curved towards the open sea. At each end there is a buoy-the outer one in 6 fathom water, and the inner, which is off Magilligan Point, in 4 fathom. The former is attached to a chain, capable of holding a ship of 400 tons; yet such is the violence of the sea that it seldom lasts more than two or three years. The expense of renewal is $£ 55$, and a further annual expense of about $£ 50$ is incurred in the restoration of the buoys, the destruction of which is sometimes imputed to the malice of the fishermen, who are charged with destroying them, as being an obstruction to their nets. In the finest weather there is generally a run on the shoal, and the attempt to cross it in a boat is always dangerous. Small vessels can sail into the lough by passing on the $\mathrm{S}$. of the shoal, and between it and Magilligan Point: this, howerer, is advisable for none but steamers, except under very favourable circumstances. There is a better ehannel on the northward, along the Ennishowen coast. A vessel would be speedily swallowed up in this quicksand, yet it does not appear to undergo any change of position, or figure-a nearly complete correspondence existing between a survey of it made by Mr. Murdock Mackenzie, nearly eighty years ago, and a recent one conducted under the Board of Admiralty by Captain Mudge, by whom the nautical information, contained in this Memoir, has been contributed. Three patches of the shoal become dry at low water during spring-tides. The continuance of this bank without sensible variation for so long a period, is extremely curious, and proves that the currents have in this instance acted witl great uniformity, depositing and removing the sandy detritus in nearly an equal proportion.

'There is ofod ancher abount $2 \frac{1}{2}$ miles above Greencastle, in from 6 to 7 fathom water. The anchorage is, however, by no means secure for small vessels, when the wind is southerly, as the tide, which at springs rins with great velocity, then occasions a short troublesome sea. By the application of steamers to tow shipping tllrough the lough the danger of its navigation is greatly diminished, and much time saved: by their aid also vessels drawing 19 feet of water have come up to the city, although the general limitation is 16 or 17 feet, unless under favourable circumstances of wind and tide.

At the entrance of the lough there is high water at the full and change of the moon at 6 г. 0 м., A.м., and the rise and fall are with spring-tides from 7 to 9 feet, and with neap-tides from 5 to 6 .

At Quigley's Point, the depth of water on the flats is with spring-tides from 16 to 20 , and from 12 to 13 feet, with neap-tides from 10 to 11 at high water, and from 5 to 6 at low water. At 


\section{COMMERCL.}

the quays of Derry there is high water at the full and change of the moon at 6 H. 30 M., A.M., and the rise and fall are with spring-tides from 7 to 9 feet, and with neap-tides from 5 to 6 .

The depth of water at the wharfs is from 12 to 14 feet at low water of neap-tides. The tide-way extends through the parish, and on to Lifford, the county town of Donegal. The velocity of the current is from 3 to 4 miles an hour in the narrowest part of the channel, and from 2 to 3 in the widest. The prevailing wind is S. W. - variation, $28^{\circ} \mathrm{W}$.

Lough Foyle. - Placed between the sea and the city, it has been shewn by the preceding notice of its entrance and channel, that the lough constitutes an essential element of the port. It is situated between the county of Londonderry on the E. and S., and the peninsula of Inishowen, in the county of Donegal, on the $W$., having nearly the form of a right angled triangle, and communicating with the sea at the northern extremity by a narrow strait about a mile wide, between Magilligan Point and Greencastle. The length of the lough is about 15 miles, and its greatest breadth about $10 \frac{1}{2}$. Generally shallow, its navigation is confined to the narrow channel, already described, which, following the windings of the Donegal coast, is bounded on the opposite side by sand banks, of which tlie most remarkable is Shell Island, so called, as being formed almost entirely of shells. By the continued accumulation of mud and sand brought down by the river, the land is gaining on the waters of the lough--large portions, popularly called the Slob, having
been effectually reclaimed.

Lough Swilly. - That the interests of the port would be greatly advanced by extending. it. influence to Lough Swilly and the country surrounding it cannot be doubted. With this riew a junction canal between Loughs Foyle and Swilly has often been contemplated, but in any consideration of the modes of effecting it, the curious fact must not be orerlooked, that in conSwilly, at the Burnfoot, which is separated from the Foyle by a neck of land about 3 miles broad, the rise and fatl at spring tides is 18 feet, that is, twice as great as at Derry, and the surface of the lakes rising therefore at high water to different levels. This circumstance may be thus accounted for. The great flood tide from the Atlantic, whose true course is from W. to E., rushes without impediment into Lough Swilly, but passes the narrow entrance of Lough Foyle. When it is half flood upon the shore, the stream flows back from Fair Head, and the island of Rathlin, (in the county of Antrim), and runs westward from half-flood to half-ebb upon the shore. This continues all the way from the above places to the mouth of Lough Foyle, which is supplied by the refuent tide, while the true tide, in the offing, is flowing and ebbing six hours each way.

\section{Port Regulations.}

The success of commercial speculation depends so much on the regularity and order with which they are conducted that, to ensure the prosperity of an extersive port, it is essential that arrangements should be made for promoting expedition and certainty in all its operations, for guarding as far as is practicable against accidents, and for facilitating repairs. A well matured. system, therefore, of pilots, quays, and docks, is of the highest importance-and the imposts for their support are at once reasonable and necessary.

Ballast Office.-A ballast office was established in 1790 , by act of parliament, and by a subsequent act remodelled in 1833. The port regulations are under the control of a committee of this establishment, which consists of the mayor for the time being, and seven other members, tliree of whom form a quorum. The two senior members go out by rotation annually. Candidates must be occupants of premises within three niles of the corporation hall, rated at $£ 30$ to the annual applotment of the police committee, and must also have been shareholders to the amount of $£ 250$ in shipping registered from the port, or have, in lieu of the latter qualification, imported or exported goods of the value of $£ 2000$, or paid in freight $£ 200$, during the year preceding the election. Electors must be occupants of premises similarly situated, and rated at $£ 10$, and must have also been shareholders of $£ 100$ during six months previous to the election, or have imported or exported within the year goods of the value of $£ 500$, or paid in freight $£ 50$.

Pilotage. - The strict discipline to which the pilots of this harbour have been latterly subjected, have rendered them efficient and well-behavecl. Intended candidates must learn how to work a vessel of any size and under any circumstances, by serving three years at sea, and then study the navigation of the lough and river, with the practice of sounding. Experienced mates of
E produce satisfactory are exempted from this preparation. They must also write a fair hand, and produce satisfactory certificates from their masters. A strict examination is held before the balvessels. Should the pilot-master, a branch pilot, and from two to four expert masters of only: for a greater draft they be favourable the candidates are licensed for 9 feet of water good securities, and enter into have to undergo a second examination. They have also to provide are always chosen from vessels, which good behaviour. The masters appointed to be examiners lification, in order that personal interest may at least as much water as is to fix the new pilot's qua. 


\section{CITY OF LONDONDERRY.}

conduct is kept by masters of ressels. Intoxication while on duty is punished by dismissal : for a similar offence while off duty, the penalty generally varies from $£ 2$ to $£ 3$; and the fines are expended in improving the harbour. All such cases of delinquency are investigated by the ballast committee : they are, however, of rare occurrence, not exceeding four or five in a year.

In consequence of various complaints the pilot regulations were revised in 1826 , and the sum of 5 per cent. allocated from the pilotage to remunerate the ballast master for collecting. Since that period the rates of pilotage have been occasionally revised. By an act, which obtained the royal assent on the $4 \mathrm{th}$ of $\mathrm{July}, 1832$, several preceding acts respecting pilotage and other matters were repealed. The right, however, of making by-laws was reserved for the ballast committee. On the 1st of December, 1832, the old by-laws were repealed. Among those now in force are the following, besides others specified in the annexed extract from the ballast office table :-

No pilot is allowed to accept of any gratuity beyond his legal demand - penalty $£ 1$.

The collector of the ballast-office committee is bound to withhold payment of the pilot's demand, until he shall have produced a certificate of his good conduct, to be accompanied by an entry in the pilot.book, specifying the draft of water-such entry to be made by the person in actual charge of the vessel: penalty for refusing to make such entry, or for making a false one [see Ballast-office Table], $£ 1$.

The pilot-master may grant leave of absence, not exceeding 30 days : and the pilots are prohibited, under pain of suspension, from absenting themselves without leave, or exceeding the period allowed, unless by special permission of the ballast committee.

Any pilot refusing or neglecting to attend the pilot-master's summons; or to take charge of any vessel, is liable to a penalty varying from $1 l$. to $2 l$.

Persons in charge of vessels are allowed to change their pilot, on submitting to the clerk of the ballast committee, or the pilot-master, the particulars of the acting pilot's deficiency.

No person in charge of a vessel is allowed to ride it by any buoy within the Foyle (save the warping buoys at the Crook)-penalty $2 l$.

The harbour master is empowered to assign the station of all vessels, and, in any case of opposition on the part of those in charge, he is reimbursed for all expenses arising out of such opposition, from the fines imposed on the vessel.

Number of pilots licensed in 1830-1831 (including 1 supernumerary), 27

Do. . . 1831-1832 . . . 29

Do. : $1832-1833$ (including 3 supernumeraries), 30

Number of apprentices licensed in 3 years, as above, . . . 10

Number of applicants, from 1826 to 1833 , who were refused licenses, 4

No pilots nor apprentices were deprived of their licenses during the 3 years, ending in 1833 , but there occurred long suspensions, and fines.

The following are the rates of pilotage, now $[1835]$ in force, with various regulations respecting pilotage, ballast, \&c., as given in the ballast office table:--

\section{BRITISI SHIPS OF EVLRY DESCRIPTION, OR STEAM BOATS.}

\section{Inwards.}

7 feet and under, to pay $14 . s$.

pay, at the rate of

Above 7 feet and under 8 to pay, at the rate of

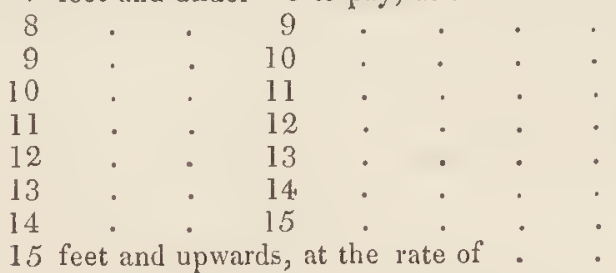$$
\left.\begin{array}{ll}
s . & d . \\
2 & 0 \\
2 & 2 \\
2 & 4 \\
2 & 8 \\
3 & 0 \\
3 & 4 \\
3 & 8 \\
4 & 0 \\
4 & 4
\end{array}\right\} \text { in prop proportion. }
$$

7 feet and under, to pay $10 s .6 d$

\section{Outwards.}

Above 7 feet and under 8 to pay, at the rate of

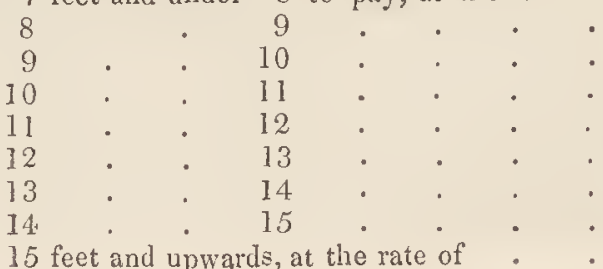

$\left.\begin{array}{cc}s . & d . \\ 1 & 6 \\ 1 & 9 \\ 2 & 0 \\ 2 & 3 \\ 2 & 6 \\ 2 & 9 \\ 3 & 0 \\ 3 & 3 \\ 3 & 6\end{array}\right\}$ in per foot,




\section{COMMERCE.}

ALIEN SHIPS OF EVERY DESCRIPTION, OR STEAM-BOATS.

\section{Inwards.}

7 feet and under, to pay $£$ I. Is.

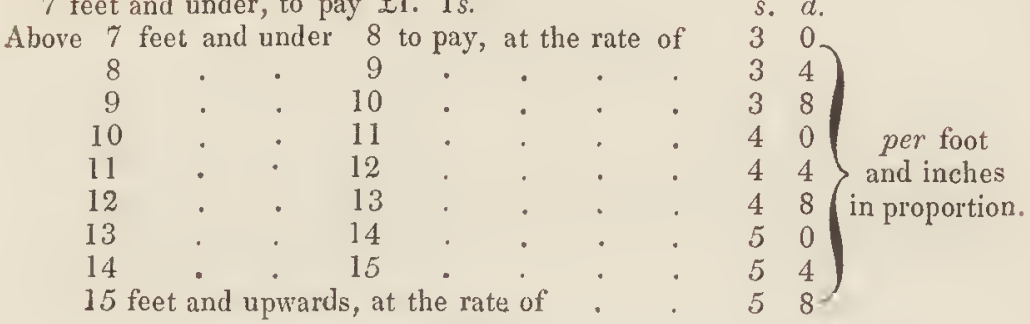

\section{Outwards.}

7 feet and under, to pay $17 \mathrm{~s} .6 \mathrm{~d}$.

Above 7 feet and under 8 to pay, at the rate of

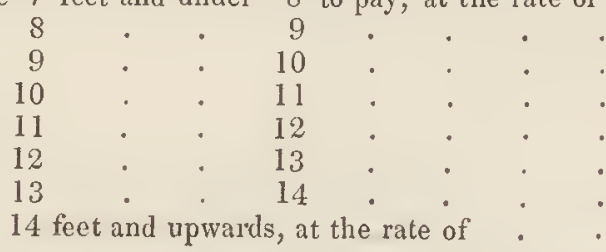

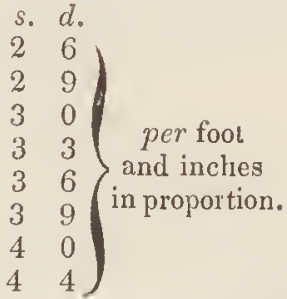

Vessels of 30 tons burthen per register, and under, pay $10 \mathrm{~s}$. inward pilotage, and $7 \mathrm{~s}$. outward pilotage if British. Wind-bound ressels pay half pilotage in, and half pilotage out, to or from Moville or Quigley's Point.

All vessels laden with bark, under 120 tons, pay $6 d$. per foot extra,-120 tons, and not exceeding 150 tons, 9 d. per foot extra, -151 tons, 1 s. per foot extra.

All British ships from foreign ports, or bound to foreign ports, or having on board half a cargo, or with passengers, pay $4 d$. per foot extra, in addition to the above charges.

Vessels which have cleared the lough, and by stress of weather are obliged to return, having. already paid the full amount of pilotage, pay but one-third in, and one-third out, of the amount of their outward pilotage, to be ascertained by the master's account from the collector.

Pilots detained on board vessels receive the sum of $2 s .6 d$. when the measurement of such vessels does not exceed 150 tons, and when such measurement exceeds 150 tons, the sum of 3s. 6d.per day, and if detained unnecessarily in Derry, the like amount.

Lighters or steam-boats employed in the river, discharging, or loading, or found within one mile of the public quays, exceeding 20 tons burthen, pay 10s. per annum; those under 20 tons 7s. $6 d$. per annum; open boats or cots 5 s. per annum, for a license.

Master pilots' licenses are, $1 \mathrm{~s}$.; pilots' licenses, $10 \mathrm{~s}$. per annum ; supernumeraries', $1 \mathrm{~s}$. ; old pilots', ls.

The following are the Rates of Ballast, to those who may require to be supplied by the ballast office-two-thirds of the amount to be paid on ordering, and the remainder immediately on delivery, to the superintendent, or person appointed by the committee to receive the same.

Gravel ballast supplied by the office, at $1 s .3 d$. per ton; sand, or sufficient ballast supplied by the office at $1 \mathrm{~s}$. per ton. Twenty-four hour's' notice to be given before ballast is required, after which period 30 tons must be delivered every twenty-four hours if demanded. Hours of demand from 10 A. M. to 3 P. M., (Sunday, Christmas-Day, Easter-Day, [accidentally recapitulated in the act], and Good-Friday excepted), to be supplied by cars at the public quays or lighters.

Neither shells nor stones fit for building, or paving, are considered ballast.

Fines for Infraction or Evasion of the Regulations, are as follows:-For giving a false draft of water, $£ 1$; for obstructing any pilot or other persons belonging to the ballast office, in the performance or execution of their duty, $£ 10$; for maliciously damaging the property of the ballast office, $£ 20$, and to make good the injury; for aroiding payment of duties, $£ 10$; for refusing in any vessel to take a pilot, $\mathfrak{E} 5$; for every 50 tons and treble pilotage. Receivers may enter ships, seize and distrain, and sell in five days after, if the duties are not satisfied. Further particulars are given in the by-law and act. Pilots are required to produce their regulations, with the pilot
laws, when required to do so by masters of vessels. 


\section{CITY OF LONDONDERRY.}

Tonnage, \&c.--The tonnage for every foreign ship, $5 \frac{1}{2} d$. per ton, British currency; for every ship belonging to Great Britain or Ireland, or the Plantations, trading from Foreign or British Plantations, $2 \frac{1}{2} l$. per ton; and those of thirty tons and under, $\frac{1}{2} d \cdot$ per ton British currency; if in ballast from a port in Ireland, free, as heretofore. Steam-boats pay the same rates as other vessels, according to trade and property.

Quayage.-In the old plan of Derry, dated 1625 , the only semblance of a quay is a short mole, built nearly on the site of the present ship quay.

Previously to 1832 the corporation alone possessed the right of having quays. They then lost their monopoly, and private ones were built. In November 1831 the corporation sold the interest of their quays to Mr. John A. Smyth, in whom their powers became consequently vested. Mr. Smyth adopted the former rates of quayage and port dues, and his quays are regulated as private property, with these provisions - that they are open to the public, and that all ships paying the stated charges, have a right to demand a berth. In default of payment the proprietor has recourse to the mayor. These quays are styled the Merchants' or Custom-House Quays. There are 21 sufferance, or private wharfs, or quays, including 2 at the Waterside, in CLOXDERNOT. At those of the Liverpool steam-boat yards none but the steamers have berths, and no quayage is charged-in consequence of an agreement made between the steam-boat company, and their agent, to whom these quays belong, and who receives remuneration for them. At the Scotch steam-boat yards the same quayage is charged as at Mr. Smyth's quays.

\section{Quayage Rates for Ships.}

Ashes, per barrel, per ton,

Beef, and pork, per barrel,

Bark, per ton,

Bottles, per groce,

Butter, per eight firkins,

Canes, or cane reeds, per 1000 .

Coals, per ton,

Earthenware, per crate,

- - per load,

Flax, per ton

Flaxseed, per hhd., . per barrel,

Grain, meal, and flour, imported,

Glass, per crate, or package

Hemp, per ton,

Dry hides, per ton, .

Raw, do, per 100 .

Hops, per pocket,

Iron, and lead, per ton

Lemons, and oranges, per box,

Linen, per bale,

Mahogany, per ton,

Pot ashes, per ton, s. $d$.

0 Salta ${ }_{3}$ s. $d$.

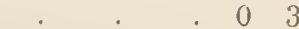

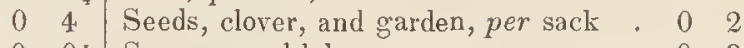

$0 \quad 0 \frac{1}{2}$ Sugar, per hhd., . . . . . 03

$\begin{array}{lllllll}0 & 4 & \text { Slates, and flags, per ton } & 0 & 3\end{array}$

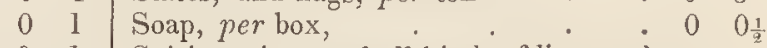

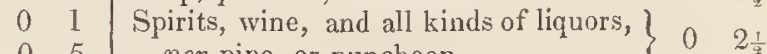

$\begin{array}{ll}0 & 5\end{array}$

$\begin{array}{ll}0 & 2\end{array}$

$\begin{array}{ll}0 & 2\end{array}$

$\begin{array}{ll}0 & 8\end{array}$

$0 \quad 5$

$\begin{array}{ll}0 & 1\end{array}$

$0 \quad 0 \frac{1}{2}$

$\begin{array}{ll}0 & 3\end{array}$

00

$0 \quad 0 \frac{1}{2}$

$0 \quad 5$

06

$\begin{array}{ll}0 & 9\end{array}$

$\begin{array}{ll}0 & 3\end{array}$

$\begin{array}{ll}0 & 3\end{array}$

00

03

$\begin{array}{ll}0 & 3\end{array}$

( 3 per pipe, or puncheon,

- per her per.

Tallow, per barrel,

Tallow, per cask,

Tobacco, per hhd.

Timber, per ton,

, under 20 feet, 10

Staves, pipe, . - above, $\begin{array}{lll}1 & 3 \\ 0 & 2\end{array}$

—-, hogshead, per 120, . . $01 \frac{1}{2}$

- - , barrel, . . . 0 I

Herrings, per barrel . . . $00 \frac{1}{0}$

Bale goods, in proportion to size, from ? $3 d$. to

Paving, or building stones, shells, ? bricks, slates, shipped as cargo per $\} \begin{array}{ll}0 & 2\end{array}$

ton,

Passenger ships $2 d$. per ton in register, in lieu of groods.

No brick, stones, sand, lime or manure can be landed on the Merchants'-quay, unless for immediate shipment on board vessels, after February.

All articles not particularly specified, to pay the same as other goods of the same weight and proportion.

No goods are allowed to remain longer than three days on the Merchants'-quay (if discharged by the revenue), save and except the following:-

Herrings-one half the cargo from first delivery, 6 days. - Slates coastwise or from Great Britain, from first delivery, 6 days.

Timber-20 tons, 6 days ; deals $1,000,6$ days ; staves $4,000,6$ days.

But in all cases when goods intearupt the discharge or loading of vessels, they are to be immediately removed by the owner or consignee, or be subject to a fine under $20 \mathrm{~s}$. per day, and the expense of removal by the quay-master-and when a longer period than is stated is necessary, 


\section{COMMERCE.}

all entry must be made in the receiver's office, who is authorized to extend the same, if he sees reasonable grounds for so doing.

No goods can be taken away until the quayage has been paid, and a receipt granted by the receiver, at tlie office.

\section{Quayage Rates for Boats.}

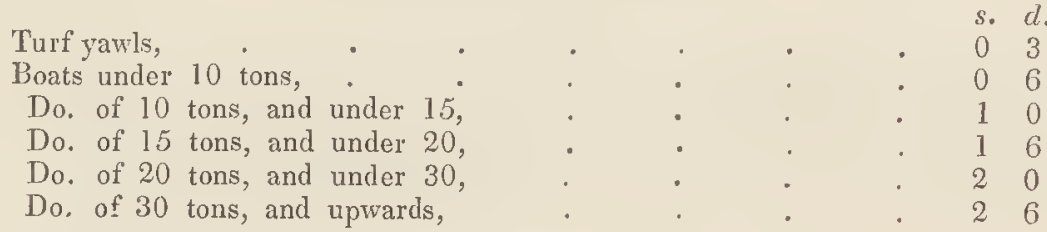

Any boat discharging, without having first paid the quayage, is subject to double quayage, the amount of which is determined by the regular tonnage of the boat. Any brick, stones, or sand, remaining on the quays more than one day, will be charged double quayage. No lime is permitted to be discharged on the quays, but must be put into carts out of the boat, and drawn away.

Port Dues.-By the authority of the 30th George the 3d, c. 31, the corporation collected the following port dues, which are only one-half of what they are entitled to by the act:- -

Coasters,

Colliers,

British vessels from foreign parts, per ton.

Patent Slip Dock.--Until about 5 years ago there was no accommodation for repairing vessels, except by laying them on the bank of the river, or excavating for them shallow docks or cuts in tlie sandy slob, a system, which, in spite of its difficulties, with so small a fall of tide, is still sometimes followed: most vessels, however, were sent to Liverpool, or the Clyde, when in need of repair. In 1830, Messrs. Pitt Skipton, and Co. undertook to construct a patent slip dock, where vessels of 300 tons register can now be hove out of the water, and repaired. The expense was
$£ 4000$.

In 183431 vessels of all sizes were repaired at the slip, and it is found to answer all the purposes of a dry dock.

Mr. Skipton's partner is Mr. Henderson-an experienced lieutenant in the navy: a first-rate foreman, and a gang of good shipwrights, are employed in the general yard attached to the establishment, from which a vessel of 180 tons register has recently been launched. It is a handsome vessel, built of Irish oak, and calculated to carry 259 tons.

For masts American pine is most approved, for spars Baltic, but American is generally used. Irish timber, chiefly oak, is procured from Walworth wood, Killymoon, Beach Hill, Learmont, \&c. Irish timber is more used than English.

Miscellaneous Observations. - The port is well supplied with naval stores from Belfast; but sails, \&c. are manufactured on the spot.

Small vessels, when outward bound, water at the wharfs, but large vessels at Moville, to ensure a light draft in crossing the flats which lie between Derry and that place.

The people of the neighbourhood engage readily in maritime pursuits.

Internal Trade.-The first impulse of the growth of a seaport must be given by the necessity of providing external markets for the increasing produce of well cultivated rural districts, or of extensive manufactories. Without the advantage of such sources of supply, the most favourable natural position must prove insufficient to advance a port to eminence; and the neglect of this consideration has often led to projects, which have only resulted in wasteful expenditure and useless establishments.

In Derry many of these advantages are found to exist in a very high degree; it is, in short, the natural port of export for the rural productions of a large space of fertile country, which extends far into the counties of Donegal and Tyrone, and is still the market for a considerable quantity of linen. Nor can there be a douht, that from the future improvement of internal communications, a new extension of external trade may be expected, and a general enlargement of all the commercial relations of the port. 


\section{CITY OF LONDONDERRY.}

The extent of internal supplies may be estimated by the quantities of the several leading articles sold in the markets :-

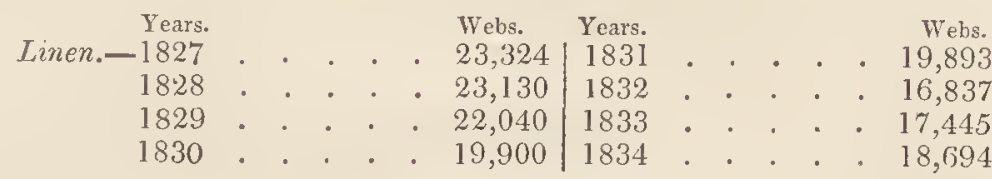

Butter.-Year ended 31 st December, 1819 . . . . . 14,020 firkins.

1820 . . . . 20,544

1821 . . . . 22,036

1822 . . . . 15,000

1823 . . . . . 15,686

$1824 \cdot$. . . 15,323

1825 . . . . 21,028

1826 . . . . 34,500

$1827 \div \quad \cdot \quad \cdot \quad \cdot \quad 52,640$

1828 . . . 48,759

$1829 \cdot$. . . 36,982

1830 . . . . 24,096

1831 . . . 26,576

$1832 \div . \quad \cdot \quad \cdot 39,821$

From the 1st Jan. 1833, up to the 2Ist Dec. . . . . . . 37,840

Weigh-house, 26th December, 1833.

From the time of the repeal of the butter act, originally passed in 1812 , this is but an in. perfect return of the quantity shipped from this port. The statement previous to that time, 1829 , may be taken as nearly correct.

R. TODD.

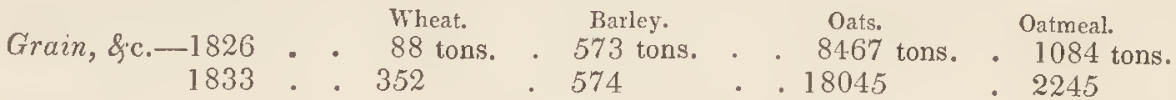

Flax.. 1833 . - . . . 800 tons. Yarn.-From Jan. 1, to Aug. 5, 1835, spun 1834 . . . . . 2000

1835 between Jan. I and Aug. 5.3000 in the neighbourhood, 150,000 spangles. And brought from Donegal and Tyrone, 100,000 .

But the rural trade most curious and novel is that of eggs, which has sprung up in consequence of the ready means of export afforded by the steam boats, and it is worthy of remark that notwithstanding the great exportation the price for home consumption has fallen. This trade, though only one of five jears' growth, has so much increased that iu the year 18332533 boxes were exported.

In summer the weekly exportation is about 100 tons, and in winter abont 20. About twothirds of the quantity are shipped for Liverpool, and the remainder for Glasgow. In England the chief consumption is at Liverpool and Manchester, in Scotland at Glasgow, - but, when the supply is very abundant, they are sent further into the interior. The eggs are chiefly used for food, and are bought and sold by the hundred. The supply fluctuates considerably, and with it the price. In summer they are about 2s. 6d. a hundred, but in March, April, and May, they are frequently lower. In autumn, and the early part of spring, the price rises to about $4 s .0 d$., and at Christmas sometimes to $7 s$. $0 d$. The average price throughout the year is $3 s .6 d$. The dealers do not consider themselves repaid, unless the eggs bring from $8 d$. to $10 d$. a hundred more in the British markets than in Derry. This is the average profit in summer, but in winter it fluctuates more, and rises to $1 s$. 2d. The eggs are brought from the same counties as the other provisions, and the market is every day supplied. They are packed in boxes, with alternate layers of straw, and conveyed in steam-boats. The boxes sent to Liverpool average in size 25 cubic feet,- those sent to Glasgow, 20. In the abundant season, the sum of $£ 2,000$ a week is often expended on eggs.

Steam-Mill.-The erection by Mr. Schoales of this mill in 1831, worked by an engine of 18 horse power, has greatly added to the quantity of meal manufactured, and even changed the import of that article into an export. In 1831553 tuns were imported, in 18342280 tons were 


\section{COMMERCE.}

exported: a part is also sold at the mill; the grain is procured in the markets of Derry, Strabane, and Castlefin. The success of Mr. Schoales has already given rise to a similar establishment erected by Mr. Leatham, and worked by an engine of 20 horse-power. The mill at Pennyburn is also a valuable auxiliary to the production of grain, which is further stimulated by the distillery at Pennyburn, and by the brewery and distillery in William-street. The smaller mills are too uncertain in the times of working, and too feeble in power to bear any comparison with those more
powerful establishments.

Foundery.-As exercising an influence, though indirect, over production, the foundery and copper works of Mr. David Craig deserve notice. They are extensive, supplying the whole N.W. of Ulster. Twenty-five men are annually employed, most of whom have served an apprenticeship of seven years-besides a carpenter and turner, who are occupied in making wooden models for the castings ordered. The copper is imported direct from $\mathrm{S}$. Wales, and the price varies from $11 \frac{1}{2} d$. to $13 \dot{d}$. a pound; the iron from Wales and Scotland, chiefly from Wales; bar iron
averages about $£ 7$ a ton, pig iron $£ 410 \mathrm{~s}$.

Coach Factory.-There are two, the principal belonging to Mr. Foy.

The Gas Factory, which was established in 1830 , at an expense of $£ 7000$, raised by shares of $£ 11$, adds to the resources of the port by increasing the demand for coal. The manufacture has been most carefully conducted, and from the purity of the gas it is now used even in the chambers of private houses. There are 5 workmen employed exclusive of the engineer, and the success of the undertaking is manifested by the rise of the price of shares, which are now
at $£ 15$.

Though now extinct, the following attempts to increase the wealth of the city should not be passed unnoticed.

The Sugar House was built in 1762 by the late Mr. Robert Alexander, in a lane off Foylestreet, still called Sugar-house Lane. From this period until 1790 it continued under the management of the original proprietor, who then disposed of it to a company of wine merchants, by whom the business was continued, under the firm of Hugh Young and Co. Previously to "the rebellion Mr. Y. emigrated to America, and the name of the firm was changed for that of Herman, Verdenhalm, and Co. When, in 1804, in consequence of the Berlin and Milan decrees, the sugar refiners of England and Scotland lost their continental markets, one-half of the protecting. duty of $10 \mathrm{~s}$. a cat., imposed on all refined sugars imported into Ireland, was taken off, and in 1807 the other lialf. From this period the business of the firm decreased perceptibly, and in 1809
it was finally abandoned.

The Glass House.-In 1820, Mr. Joseph Moore, who had been the principal shareholder in the sugar establishment for some time previously to its dissolution, and to whom the buildings then belonged, converted them into a glass louse. This business he conducted on a small scale, in connexion with his son; but, in 1825 , the determination of the government to place this manufacSwan River.
Swcise, led to its abandonment, and the younger partner subsequently emigrated to

Intcrnal Communication.-The river above the bridge is navigated by lighters, which bring down the agricultural produce of the country about Strabane, Lifford, and as far as Castlefin. They are also frequently loaded with bricks, and even with sand. The beds of gravel below Lifford, which formerly obstructed the navigation, have been removed, and the channel piled, so that the whole line to Castlefin is now open, and barges carrying 20 tons, with a draught of 2 feet of water, ply regularly along the line. The Moville steamer was originally intended for the same station, but drawing 4 feet of water, she could only pass the shallows at spring tides, and being so frequently delayed by the obstructions in the river, the plan was abandoned. In 1832 she was tried between steamer was for some, and occasionally went to Castlefin, towing barges the whole way. An iron steamer was for some time talked of, but has not hitherto been tried. The depth of water, however, is now sufficient, and it is probable that tle necessity of adding to the supplies for export, in order to keep pace with the increased means of sending them away by steam, will speedily induce a
renewal of this project.

\section{The Lighter charges are}

For Salt, coals, and iron, per ton, $£ 00$

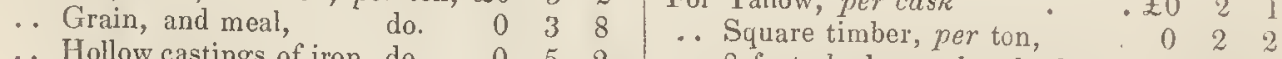

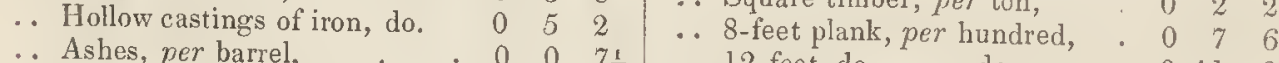

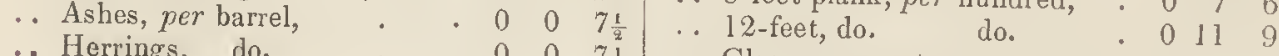

- Herrings, do. $\quad \begin{array}{llllllll}0 & 0 & 7 \frac{1}{2} & \text {. Glass, per crate, . } \quad ~ & 0 & 0 & 7\end{array}$

The roads are in general good, and carts are numerous, and easily procured for the purposes of transport. 


\section{CITY OF LONDONDERRY.}

External Trade. - The external trade depends principally on the rural production of the counery, and in that respect is supplementary to the internal trade, by conveying to the final market those articles, which, in the first instance, have been brought for sale to the home market. But it has also to bring within reach of the home eonsumer the return products of foreign industry, and in so doing, assumes the more general aspect of foreign commerce. In this latter point of view, the import trade may be considered under four different heads-1st, as conducted by foreign ships. 2nd, as conducted by British ships not belonging to the port of Derry, but making the voyage direct. $3 \mathrm{rd}$, as conducted by British ships, \&c. bit not making the voyage direct. 4 th, as conducted by ships of the port.

In the first, the arrivals of foreion ships are few, and consist of Norway and Dantzic ressels, laden with staves and timber, occasionally a Portugueze ship with salt and fruit, and ships of the United States, with small parcels of tobacco as a part cargo, their object being to take emigrants on the return voyage.

In the second, the trade is also small, and principally consists of barilla from Spain, sugar's and rrm from the West Indies, and wines from Spain and Portugal.

In the third, the trade is very considerable, the greater proportion of foreign commodities used in the city and county, coming indirectly or coastwise.

In the fourth, the trade is extremely small, consisting of timber from Canada and St. John's, and occasionally a carge of wine from Oporto, and combined with these is the import from Great Britain of all those numerous articles, the product of its manufacturing industry, which penetrate even into the humble cottage of the poorest peasant. Bark, salt, and many other useful substances are introduced in the same way.

Amongst the most interesting imports is that flax-seed, which has increased to such an extent, that it is estimated that the quantity imported this year would sow 30,000 acres.

$$
\begin{aligned}
& \text { In 1833, . . . } 8100 \text { hogsheads. } \\
& 1834, \quad . \quad . \quad . \quad 12024 \\
& 1835, . \quad . \quad . \quad 16600
\end{aligned}
$$

And this augmentation, after a decline to the small quantity of 3267 hogsheads in the year 1828 , is to be ascribed to the powerful stimulus afforded to its production, by the recent spinning: factories.

The coast trade is rapidly absorbing by the steam-ressels, though smacks to London and other ports, out of their immediate lines, are still in use.

The shipping of the port of Derry, in 1760 , consisted of 67 sail, from 30 to 350 tons.

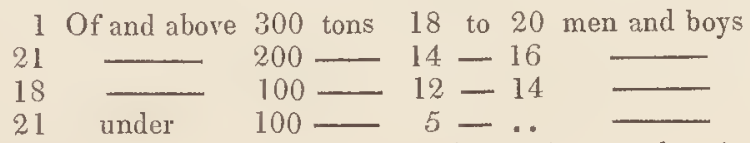

In 1776 about two-thirds of the above; the decline owing to that in the passenger trade, and in the import of flax-seed.

The following tables exhibit the present extent of shipping connected with the port of Derry :-

\begin{tabular}{|c|c|c|c|c|c|c|c|c|c|c|c|c|}
\hline \multicolumn{7}{|c|}{ FOREIGN. } & \multicolumn{6}{|c|}{ CoAstwise. } \\
\hline \multirow{2}{*}{ Date. } & \multicolumn{3}{|c|}{ Inwards. } & \multicolumn{3}{|c|}{ Outwards. } & \multicolumn{3}{|c|}{ Inwards. } & \multicolumn{3}{|c|}{ Outwards. } \\
\hline & No. & Tons. & Men. & No. & Tons. & Men. & No. & Tons. & Men. & No. & Tons. & Men. \\
\hline 1826 & 59 & 10,450 & 519 & 21 & 5559 & 273 & 422 & 32,632 & 2347 & 307 & 20,498 & 1684 \\
\hline 1827 & 59 & 9,961 & 514 & 24 & 6132 & 310 & 481 & 42,165 & 3402 & 393 & 34,233 & 3018 \\
\hline 1828 & 39 & 6,686 & 351 & 11 & 2553 & 128 & 628 & 50,243 & 4098 & 521 & 45,083 & 3741 \\
\hline 1829 & 48 & 7,537 & 412 & 14 & 3865 & 159 & 574 & 48,912 & 3763 & 508 & 43,347 & 3346 \\
\hline 1830 & 64 & 10,989 & 591 & 13 & 2689 & 144 & 612 & 51,088 & 3875 & 515 & 42,986 & 3354 \\
\hline 1831 & 37 & 6,286 & 326 & 10 & 1989 & 109 & 694 & 58,955 & 3458 & 547 & 44,351 & 3381 \\
\hline 1832 & 59 & 10,310 & 553 & 16 & 4321 & 219 & 637 & 62,032 & 4251 & 555 & 50,303 & 3510 \\
\hline 1833 & 57 & 11,294 & 572 & 22 & 6843 & 321 & 607 & 63,879 & 4343 & 540 & 52,952 & $390 \mathrm{I}$ \\
\hline 1834 & 57 & 10,406 & 561 & 16 & 4869 & 223 & 649 & 63,726 & 4502 & 646 & 62,502 & 4511 \\
\hline
\end{tabular}

An account of Vessels employed in the Foreign and Coasting Trade for eight Years, ending 5th January, 1835. 


\section{COMMERCE}

Of these, however, the following are Sieamers :-

\begin{tabular}{|c|c|c|c|}
\hline Date. & $\begin{array}{c}\text { No. of } \\
\text { Steam } \\
\text { Vessels. }\end{array}$ & Tonnage. & $\begin{array}{c}\text { No. of } \\
\text { Men. }\end{array}$ \\
\hline 1829 & 1 & 136 & 12 \\
1830 & 1 & 136 & 12 \\
1831 & 2 & 309 & 27 \\
1832 & 3 & 516 & 42 \\
1833 & 3 & 516 & 42 \\
1834 & 5 & 741 & 59 \\
\hline
\end{tabular}

The combined effect on the general interests of the city of all the modes of commercial intercourse which has been detailed, may to a certain extent be estimated by the amount of revenue and the post-office receipts.

\section{Custom-House.}

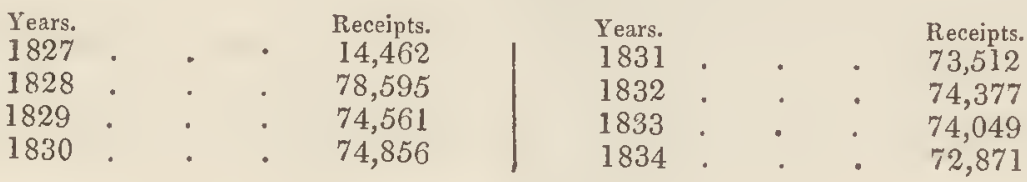

\section{Post-Office.}

The Post-Office was established in 1784.

Amount of Postage collected in the year ending 5th July, 1821, . $\quad 2,490 \quad 0 \quad 7$

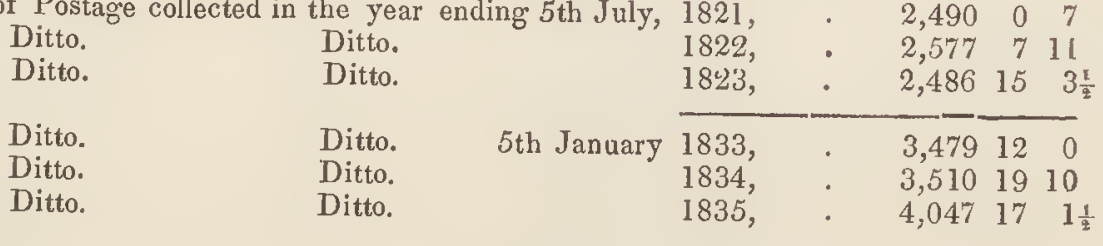

\section{Emigration.}

It has been incidentally mentioned that emigration attracts to this port a considerable portion of its foreign shipping, and it is impossible to stand on the quays of Derry in the early part of the year without experiencing some melancholy feeling at the sight of numbers who are thus leaving their native country, though probably with every chance of success and amelioration of condition.

The following are the numbers for a short series of years :-

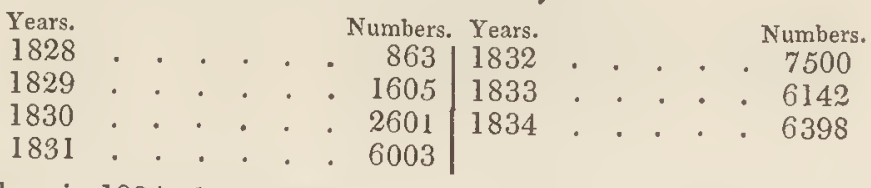

Of the numbers in 1834, there appears to have been-

$$
\begin{aligned}
& \text { To British America, . . . . } 3750 \\
& \text { To the United States, } \quad \cdot \quad \cdot \quad \cdot \quad \cdot \quad 2648
\end{aligned}
$$

Of these emigrating to British America-

589 were under 7 years of age.

341 were under 14 years of age.

2831 adults.

And of these last only 137 were above 40 years of age. 


\section{CITY OF LONDONDERRY.}

This classification has been obtained from the registry list at the custom-house. As the emigrants to the United States are not obliged to register with the same exactness similar information cannot be procured for them.

The great majority appears to be in the vigour and energy of youth, seeking a new field for exertion and success. If the number above 40 years of age had preponderated there would have been cause to fear that they were of broken fortunes, or had already failed in some career at home.

Five-sixths of the number are said to belong to the middle class of farmers, and it is their custom to convert into money all their moveable property: if $£ 10$ be aliowed for each, 50,000 would appear to be thus abstracted from this country.

\section{Section 6.-Population}

As a mere numerical question of increase or decrease, under peculiar circumstances of greater or less production, power, or means of subsistence, the statistics of population have acquired great interest from the exertions of Malthus, Sadler, \&c. ; but the want of a well digested and uniform system of registry for births, deaths, \&c., is so generally felt throughout the kingdoms, and especially in Ireland, that but little light can be thrown on it from matter connected with Derry. On the other hand, the term is here taken in a much wider sense than is usual, comprehending not only the number of the people, but several other considerations indicative of their tastes, or descriptive of their habits.

Number.-The aarliest notice on record of the number of the people of Derry, is that of Nicholas Pynnar, in 1618-19, who, in describing the city, sets down the population at 102 families.

The next is the muster-roll of Sir Thomas Phillips, dated 1622, in which he gives 110 as the number of men capable of bearing arms. The roll itself is too curious a document to be here omitted. 


\section{COMMERCE.}

A Muster taken by $\mathrm{S}^{\mathrm{r}}$. Thomas Phillips \& Richard Hadsor, Esq ${ }^{\text {t* }}$ his Maties. Commissioners, of all $\mathrm{y}^{\mathrm{e}}$ Inhabitants with theire Servants residing in $\mathrm{y}^{\mathrm{e}}$ County [rectius City] of Londonderry, $w^{\text {th }}$ theire sev ${ }^{\mathrm{ll}}$. Armes.

Mr. Mayor,
Mr. Wraye,
Mr. Wynslow,
Mr. Hugh Thompson
Mr. Russell,
Cliristopher Gifford,
William Cottismore,
Mr. Goodwin's man,
Mr. Steele,
Nicliolas Baily,
Walter Tuckey,
Edmond Glover,
John Frewen,
Mr. Brute Hamond,
Greorge Newton,
Greorge Downing,
William Haile,
Thomas Sherrington,
Robert Shawe,
Robert Flavell,
Thomas Craford,
George Hamond,
One of y Sherif's men,
The

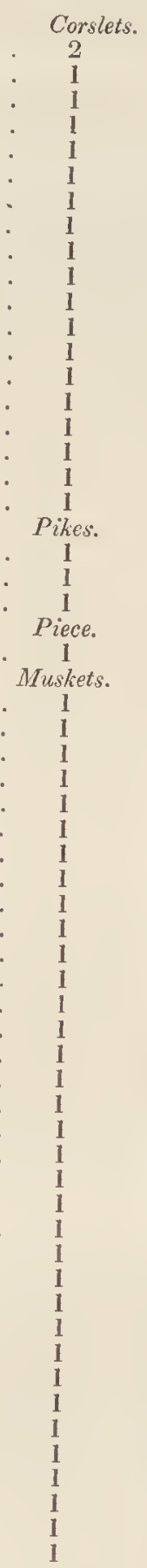

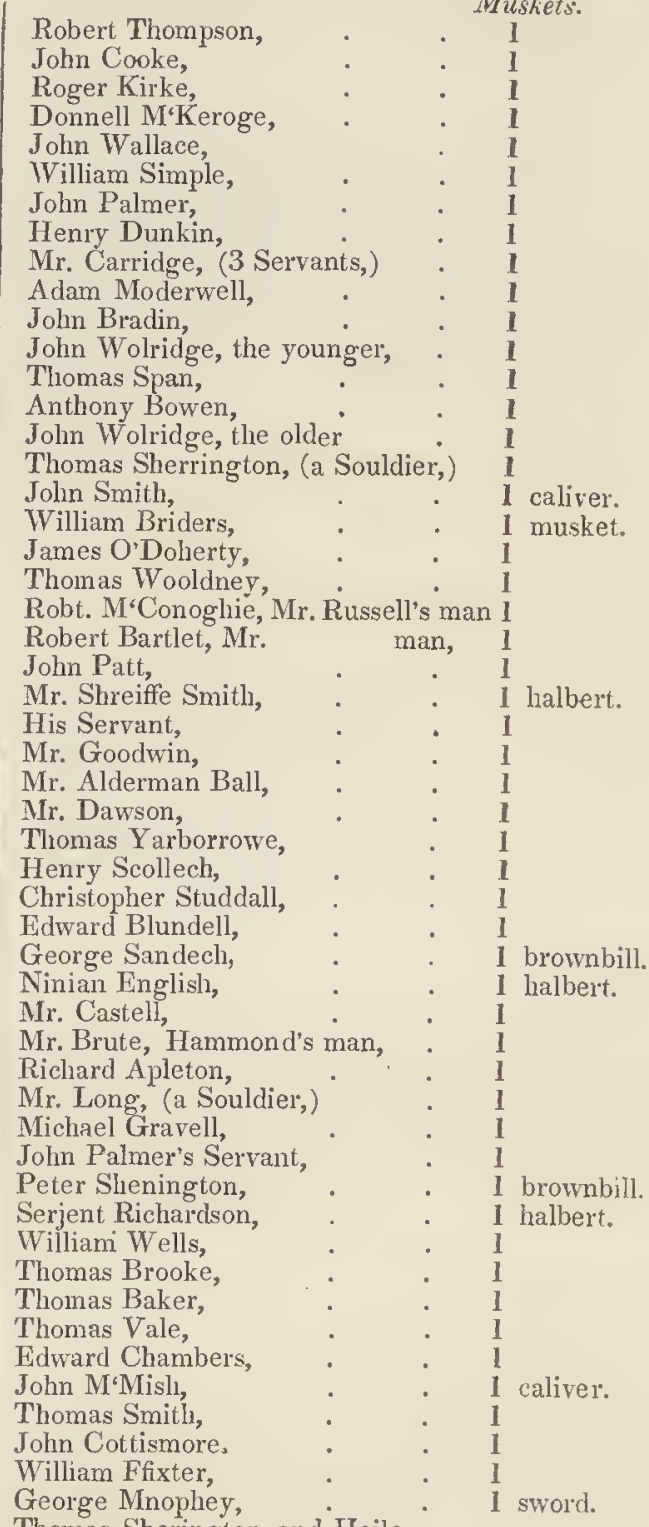




\section{CITY OF LONDONDERRY.}

In 1623, according to the same authority, there were 109 families in Derry, and in 1626 , the same number, whereof 5 were soldiers, the company in garrison there subject to be removed.

Archbishop King, in 1690, states the whole of the population of the parish, (including, of course, the Donegal part,) at about 700 .

Beaufort and Seward, in the same year, 1792, give the population at about 10,000, which is evidently too high a statement.

The earliest general census of Ireland was that of 1800 , in which Derry is omitted, "no "returns having been received from that city."

In 1814, it appears from a "Report of the Deputation of the Irish Society," that the population amounted, at that time, to 14,087 persons.

The first census which gives any registered returns is that compiled in 1821, by Mr. William Shaw Mason, which gives 9313 as the number of the inhabitants of the city.

The decennary census of 1831 is the next, which gives for the city 10,130 , or, including the suburbs, 19,620. The results of these official reports show that the estimate of Beaufort and Seward was too high.

The details of each decennary census are as follows:- 


\section{POPULATION.}

1821.

\begin{tabular}{|c|c|c|c|c|c|c|c|c|c|c|c|c|c|c|}
\hline \multirow{3}{*}{$\begin{array}{c}\text { Parishes, Towns, Villages, } \\
\text { or other } \\
\text { Dexominations. }\end{array}$} & \multicolumn{4}{|c|}{ Houses. } & \multicolumn{3}{|c|}{ Persons. } & \multicolumn{4}{|c|}{ Occupations. } & \multirow{2}{*}{\multicolumn{3}{|c|}{$\frac{\text { ScHools. }}{\text { Pupils. }}$}} \\
\hline & & & & & & & 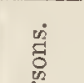 & & $\begin{array}{r}\text { No. of } \\
\text { persons }\end{array}$ & $\begin{array}{l}\text { No. ofall } \\
\text { other per- } \\
\text { sons }\end{array}$ & & & & \\
\hline & 离 & 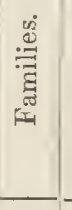 & 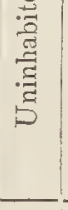 & | & 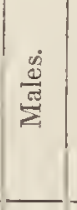 & 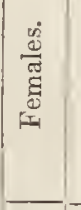 & $\sum_{\substack{\pi \\
0}}^{2}$ & $\begin{array}{l}\text { chiefly } \\
\text { employ- } \\
\text { ed in } \\
\text { agricul- } \\
\text { ture. }\end{array}$ & $\begin{array}{c}\text { employed } \\
\text { in trades, } \\
\text { manufac } \\
\text { tures, or } \\
\text { handi- } \\
\text { craft. }\end{array}$ & $\begin{array}{l}\text { and not } \\
\text { compris- } \\
\text { ed in the } \\
\text { two pre- } \\
\text { ceding } \\
\text { classes. }\end{array}$ & $\begin{array}{l}\text { Number } \\
\text { of per- } \\
\text { sons oc- } \\
\text { cupied. }\end{array}$ & 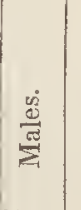 & 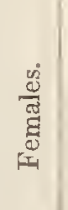 & 呇 \\
\hline \multirow[t]{2}{*}{$\begin{array}{l}\text { Parish of Templemore, (part of ) } \\
\text { Culmore, (Extra-parochial, ) } \\
\text { City of Londonderry, }\end{array}$} & $\begin{array}{r}1190 \\
130 \\
1252 \\
\end{array}$ & $\begin{array}{r}1290 \\
139 \\
1958 \\
\end{array}$ & $\begin{array}{r}41 \\
5 \\
77 \\
\end{array}$ & $\begin{array}{l}1 \\
1 \\
1\end{array}$ & $\begin{array}{r}3323 \\
301 \\
4507 \\
\end{array}$ & $\begin{array}{r}3674 \\
360 \\
4806 \\
\end{array}$ & $\begin{array}{r}6997 \\
661 \\
9313 \\
\end{array}$ & $\begin{array}{r}921 \\
81 \\
177\end{array}$ & $\begin{array}{r}1660 \\
180 \\
1204\end{array}$ & $\begin{array}{r}557 \\
47 \\
1359\end{array}$ & $\begin{array}{r}3138 \\
308 \\
2740\end{array}$ & $\begin{array}{r}252 \\
47 \\
719\end{array}$ & $\frac{55}{18}$ & $\begin{array}{r}307 \\
47 \\
737\end{array}$ \\
\hline & 2572 & 3387 & 123 & 38 & 81318 & 8840 I & 16971 & 1179 & 3044 & 1963 & 6186 & 1018 & 73 & 1091 \\
\hline
\end{tabular}

1831.

\begin{tabular}{|c|c|c|c|c|c|c|c|c|c|c|c|c|}
\hline \multirow[b]{2}{*}{ PARISH, ETC. } & \multirow{2}{*}{$\begin{array}{c}\text { Areas. } \\
\\
\text { Eng- } \\
\text { lish } \\
\text { Statute } \\
\text { Acres. }\end{array}$} & \multicolumn{4}{|c|}{ Houses. } & \multicolumn{3}{|c|}{ Occupations. } & \multicolumn{4}{|c|}{ Persons. } \\
\hline & & 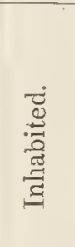 & 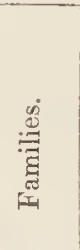 & 茎 & 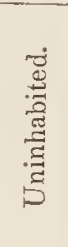 & $\begin{array}{l}\text { Families } \\
\text { chiefly } \\
\text { employ- } \\
\text { ed in } \\
\text { agricul- } \\
\text { ture. }\end{array}$ & $\begin{array}{c}\text { Families } \\
\text { chiefly } \\
\text { employed } \\
\text { in trade, } \\
\text { manufac- } \\
\text { tures, and } \\
\text { handi- } \\
\text { craft. }\end{array}$ & $\begin{array}{l}\text { All other } \\
\text { Families } \\
\text { not com- } \\
\text { prised in } \\
\text { the two } \\
\text { preced- } \\
\text { ing } \\
\text { classes. }\end{array}$ & 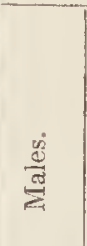 & 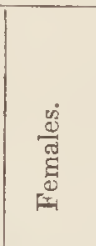 & 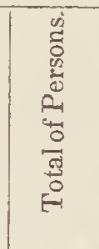 & 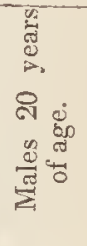 \\
\hline $\left.\begin{array}{l}\text { Parish of Templemore, } \\
\text { (part of,) City of Lon- } \\
\text { donderry.* }\end{array}\right\}$ & - & $\begin{array}{l}1530 \\
1292\end{array}$ & $\begin{array}{l}1727 \\
1972\end{array}$ & $\begin{array}{l}25 \\
20\end{array}$ & $\begin{array}{r}94 \\
113\end{array}$ & $\begin{array}{r}724 \\
34\end{array}$ & $\begin{array}{r}593 \\
1297\end{array}$ & $\begin{array}{l}410 \\
641\end{array}$ & $\begin{array}{l}4535 \\
4530\end{array}$ & $\begin{array}{l}4955 \\
5620\end{array}$ & $\begin{array}{r}9490 \\
10130\end{array}$ & $\begin{array}{l}2245 \\
2201\end{array}$ \\
\hline Total . & - & 2922 & 3699 & 45 & 207 & 758 & 1890 & $105 \mathrm{I}$ & 9065 & 10555 & 19620 & 4446 \\
\hline
\end{tabular}

* The city and suburbs together contain 19,620 inhabitants.

The latest Official Account of the Number of the Parishioners is contained in the following Abstract from the "First Report of the Commissioners of Pullic Instruction :" the Number of those in the City is not, however, given separately.

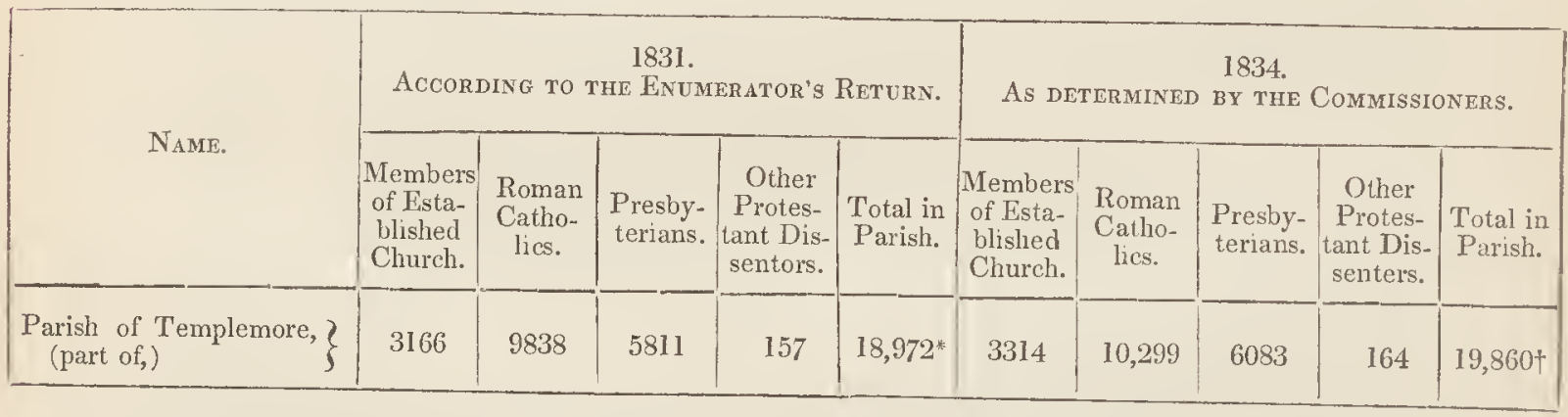

* Besides this number, there were included in the census of 1831, 655 persons, whose religion could not be ascertained; of these 105 were patients and servants in the infirmary, 151 patients and servants in the lunatic asylum, 76 prisoners in the gaol, I 18 the wives and families of the military at that time in the parish, and the remainder generally vagrants and casual
lodgers in the city. + By computation. 


\section{CITY OF LONDONDERRY.}

Race.-The next step after the above review of the number of the people at different periods, is the consideration of the different races, of which they have consisted, and at present consist. It appears that down to the occupation of Derry by Docwra in 1600 , the place was inhabited chiefly by that race of the native Irish, called Kinel-Owen, of whom the Mac-Loughlins, O'Deery's and O'Cairellans, were the most numerous and respectable families. The colony of' Docwra which supplanted them were wholly English; and that introduced at the plantation was nearly so, as appears from the muster-roll of the men of Derry, above cited, in which there occur only about three or four names of Scottish origin, and an equal number of Irish. Subsequently to that period there was a considerable infux of Scotch settlers, whose present descendants constitute the larger portion of the respectable citizens. The great bulk of the population are now, however, of the aboriginal rival Irish tribes, of the Kinel-Connell and KinelOwen, who commingled with the English and Scottish races, retain but little recollection of past feuds, and are rapidly approaching a state of harmonious amalgamation, through the happy influence of wise laws, and the arts of peace. On referring to the list of mayors and sheriffs, it is rather remarkable, that the respectable name of Babington does not occur-that family being among the earliest settlers, as is evident from tle plan of Docwra's city, in which "Babington's house" is the only private residence laid down in addition to the gorernor's.

Supply.- Having traced the number of the people, and their race down to the present day, it will here be necessary to advert to the means which the working classes in particular possess of supplying both their natural and artificial wants - so far as these have not been already treated of under the heads Education, Benevolence, Justice, \&c. Here a comparison between the prices of provisions and the wages of labour becomes particularly interesting, and the groundwork for such is very amply afforded by the subjoined extract from Porter's "Tables of the Revenue, Population, Commerce, \&c., of the United Kingdom and its Dependencies." 


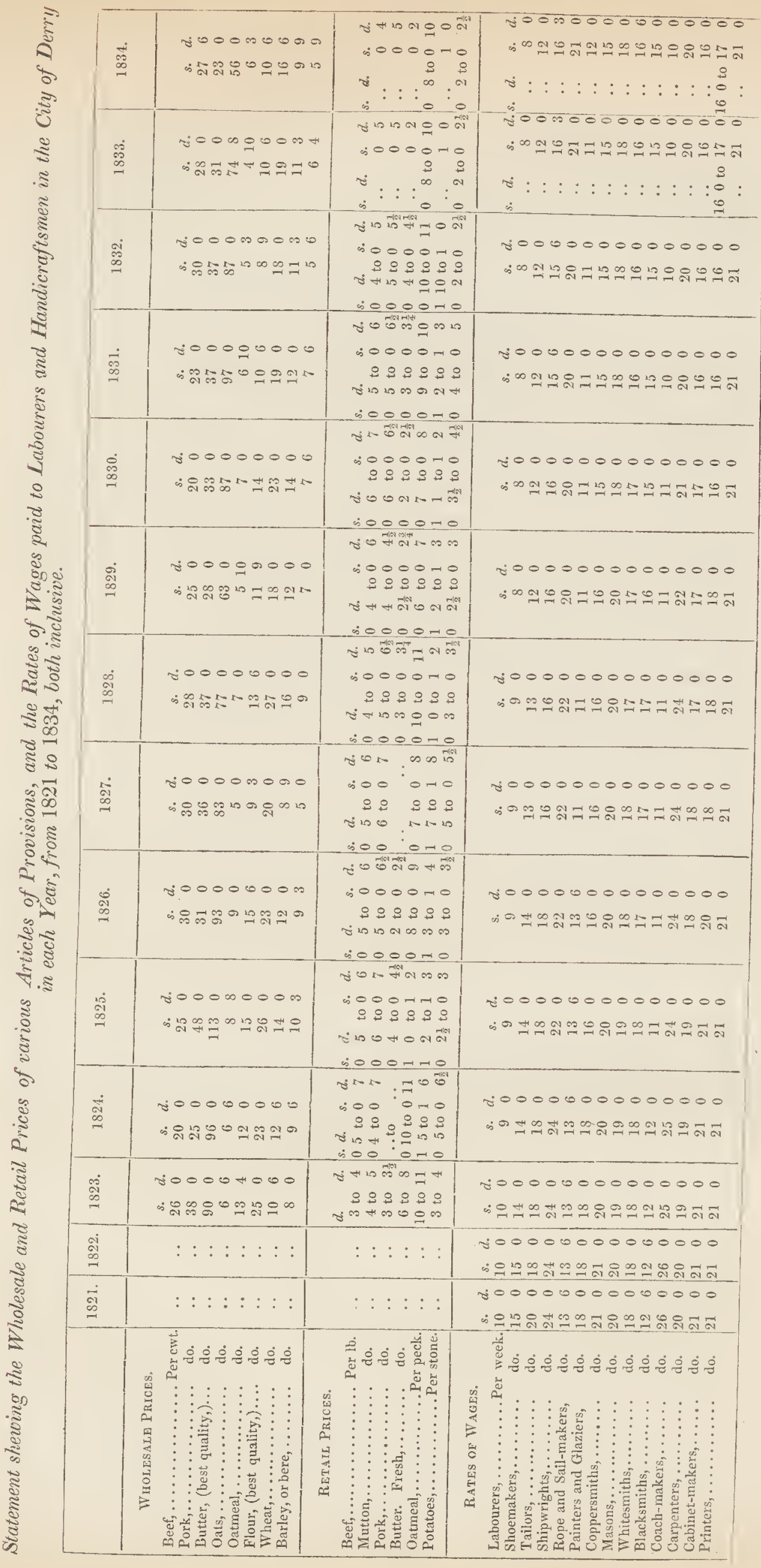




\section{CITY OF LONDONDERRY.}

This head also embraces the fairs and markets at which the usual articlcs are exposed for sale, such as horses, cattle, butchers' meat, hardware, and soft goods, farming implements, \&c. Customs are paid for the above only when they arc exposed for sale at their respective stations, and therefore commodities sold in the open street are not chargeable. The gencral supply of horses is about 250 , but about onc-third are of bad quality.

The city is in general well supplied from the counties of Londonderry, Donegal, Tyrone, Fermanagh, and Cavan. The supply of fish is frequently scanty, owing to the difficulty of encountering a rough sea in the indifferent boats employed. However, the market often abounds in turbot, soles, haddock, cod, and oysters. The turbot are taken near lnnistrahnll, and on Hempton's Bank, about 18 Irish miles N. of Inishowen Head. To the latter placc, however, the fishermen do not resort before March. The soles and haddock are taken in Lough Swilly and elsewhere; the cod mostly off the entrance of Lough Foyle; and the oysters in Lough Swilly, from the island of Inch up to Fort Stewart, and in Lough Foyle from Quigley's Point down to Greencastle.

For horses, which are but rarely exposed for sale, there is no separate market-place, but they are walked through the streets with a tape or ribbon round the neck.

The supply of meat and vegetables depends, of course, on the quantity of grazing and vegetable ground in the vicinity. A few gentlemen have grazing fields close to the city, but the majority of the inhabitants are obliged to stall-feed their cattle. Grazing for milch cows costs $£ 210$ s. for the six summer months. Good clorer is sold at from $£ 410$ s. to $£ 6$ an acre, and good meadow grass let at $£ 5$ an acre.

Ground for vegetable gardening, situated near the city, brings from $£ 4$ to $£ 6$ an acre - the tenantproviding manure, and generally from the stables in the city.

In connexion with the rates of labour, as given above in Porter's "Tablcs," some notice of the ordinary building materials, \&c. may be appropriately introduced.

A merican pine, which is mostly used in building ordinary houses, is sold at the average price of $£ 215$ s. a ton. Memel pine, bcing of superior quality, is preferred for important structures, in which it is used for roofing, joistino, door and window-casino, and ornamental work. It is imported from Prussia, and sold in the city at from $£ 410$ s. to $£ 55 s$. a ton, which is $£ 1$ a ton lowe than in 1832. American timber has also fallen proportionally. This deprcssion arises from the extent of the supply consequent on the great demand.

Stone is procured from Bogstown and Shantallow, 2 miles N. of the city-and from Glashagh and Creggan, on the W. The landlord is paid $1 d$. a load for trespass, and the stone sold at the building ground for $1 s$. $4 d$. a ton.

Bricks are procured from the neighbourhood of St. Johnstown, and cost from $14 \mathrm{~s}$. to $16 \mathrm{~s}$. a thousand at the building ground. Many proprietors of brick-kilns beside the Sooly, have lighters and carts for conveyance. When unprovided with such, they pay $3 s$. a thousand for water-carriage to the city, a distance of 8 miles. lime.

Lime is sold at kilns in the city, at $1 s .8 d$. a barrel for roche, and $1 s$. a barrel for slakect

Wclch Queen Ton Slates are those most in use. The supply is abundant, and the averagc price is $£ 217 s .6 d$. a ton. foot.

Flooring Flags are supplied from Prehen, distant 2 miles, and sold in the city at 2 d. a square

Conveyances. - The consideration next in order, after alluding to the supplies of the people's wants, secms to be the conveyance of them. This subject, however, in the majority of its bearings, immediately belongs to the Port, to which head the present notice, which is confined to an enumcration of public vehicles, must be deemed supplementary. This head necessarily implies some consideration of the artificial wants of the people, if recreation be indeed an element of that catagory. 


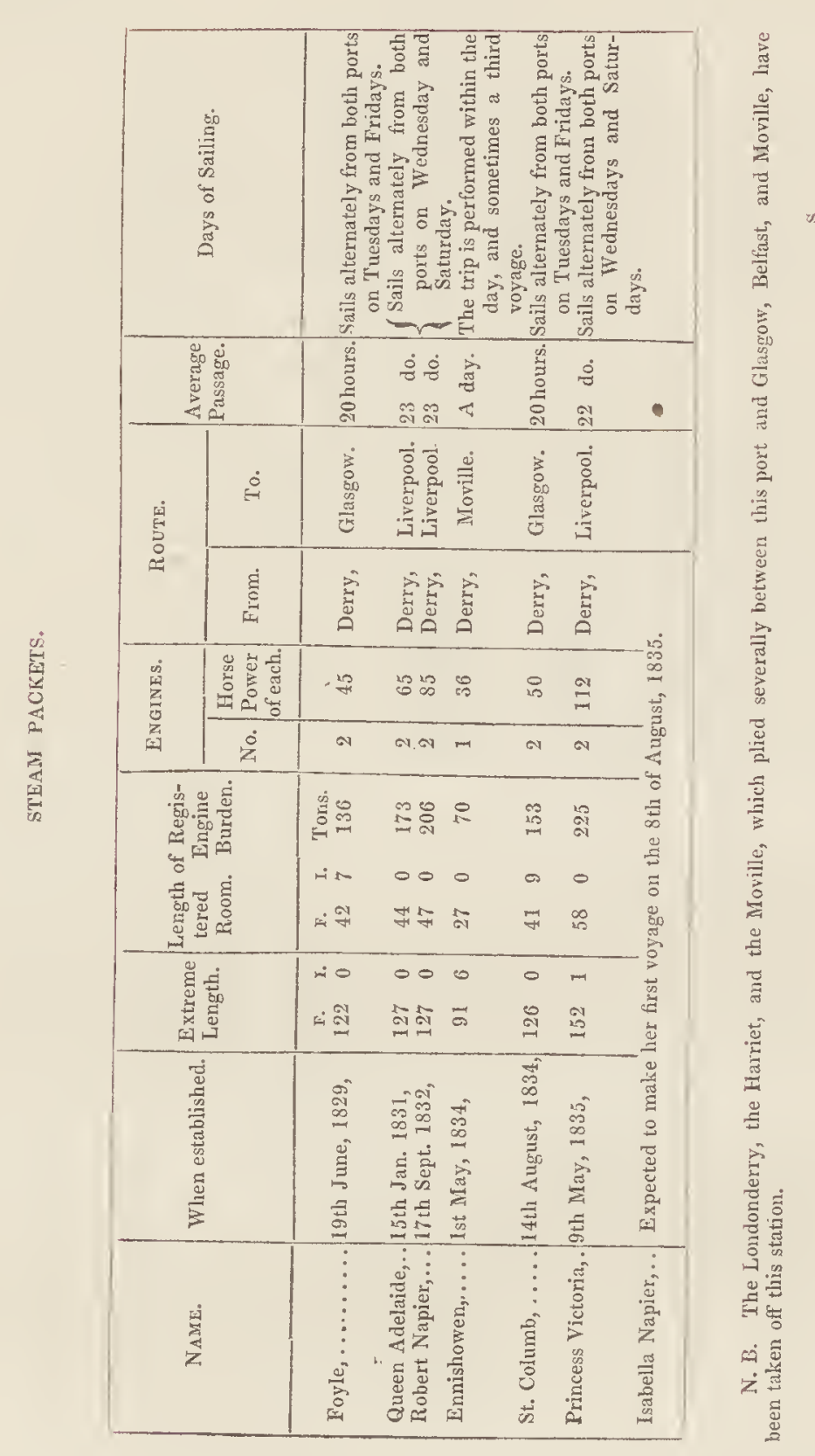




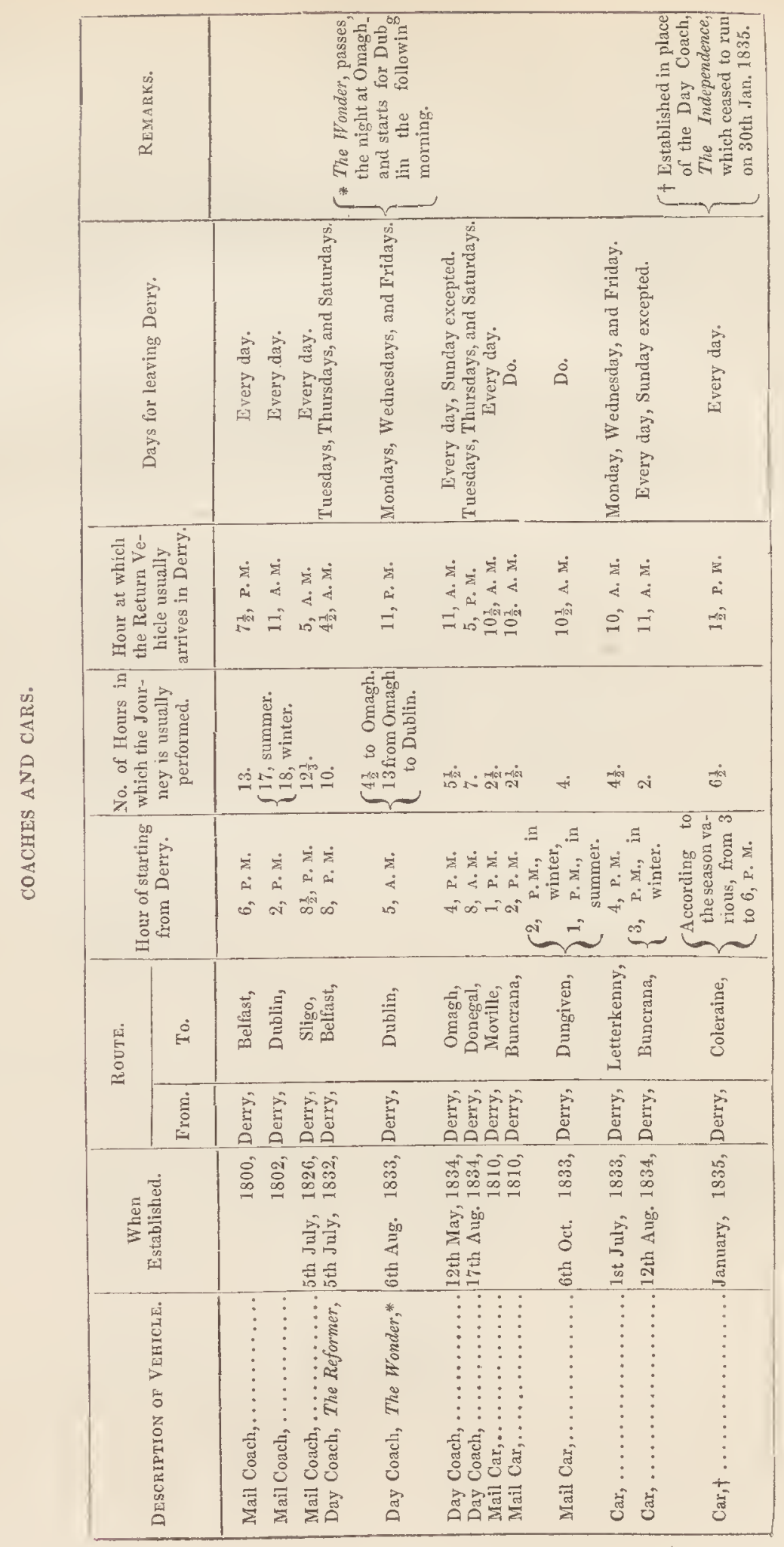




\section{POPULATION.}

Habits. The phrase habits of the people, taken in its most general sense, is applicable to the highest as well as to the lowest classes. It is abundantly manifest from the preceding parts of this memoir, that the tastes of the upper orders of the inhabitants of Derry, and its neighbourhood, are decidedly utilitarian. There is no place of public amusement, except the theatre, which is seldom open. The concerts also have been discontinued, which were formerly given at the King's Arms Hotel. Even the coerie has fallen into disuse, a name given to the assemblies of the nobility and gentry, which were under the control of a king and queen of the night.

In the general recreations of the community at large there is nothing remarkable or peculiar. There is, however, one observance which claims peculiar consideration. The shutting of the gates of Derry by the apprentice boys, on the 7 th of December, 1688, O. S., and the opening of the gates on the 12th of August following, have led to the observance of a curious ceremony, and to the establishment of various clubs.

So early as 3 in the morning parties of youths marched through the streets, preceded by military bands, playing, among other airs, that of "No Surrender," an air connected with the siege, and to which words have been adapted by Mr. Henry Morrison, a descendant of one of the Morrisons who fought at it. The motto also of "No SURRENDER" was displayed on a flag over the four principal gates before day-break. The effigy of Governor Lundy was likewise suspended from a gibbet, erected in the Diamond. The commencement of the ceremony was announced by the firing of a large cannon, while the bells of the cathedral also chimed some popular airs, connected with the siege. The red flag of the vircin city was hoisted, the vessels at the quays were gaily decorated, and a royal standard, with the date "1688" wrought in its centre, was planted formerly on the eastern end of the cathedral, but latterly on Walker's testimonial.

During the forenoon, crowds continued to pour into the city, and at noon several Orange lodges, adorned with standards and trappings, marched in to unite with the apprentice boys (a society so called,) in commemorating the day. After mustering at 1, they marched to the four gates in succession, and discharged volleys over then from the inside, according to the system of street-firing. After this they proceeded to the Diamond, discharged three volley's more, and gave three cheers for the king and constitution. The houses here were lined with people, and, amid shouts, music, and execrations, the effigy of Lundy was burned. The cereinony was concluded by an assembly of the gentry and apprentice boys in the corporation hall. Hither every man brought a glass, and a bottle filled with such beverage as he preferred; and this conviviality, which was hence termed the bottle and glass, was celebrated with music, singing, and public speaking: On several successive anniversaries, divine service was performed in different places of worship throughout the city.

Subsequently to the passing of an act of the $2 \& 3$ William 4 , c. 118 , by which such commemorations became illegal for five years, from the 16 th of August, 1832 , and from thence until the end of the then next sessions of parliament, the above observances were modified. At the last celebration in December, 1834, the ceremony began in the usual form. $A$ board inscribed "No Surrender" was affixed to each of the gates, the red flag. was hoisted on the eastern end of the cathedral, and a duplicate of it on WValker's testimonial. At 3 o'clock the effigy of Lundy was blown up amid shouts of "Down with the traitors," and "God save king William," but without music. There was no public display of badges, and the firing was limited to the discharge of six shots, from a 6 pounder, at the Testimonial, which began at $120^{\circ}$ clock. Until of late the ceremonies trere celebrated by persons of all religious denominations.

Clubs. - There are three clubs of Apprentice Boys at present. One of these consists chiefly of old men, and is itself of an old standing. Another, which was formed in October, 1824, is called the "No Surrender Club." It consists of 150 members, who subscribe 2s. a year. The business is conducted by a president, vice-president, two secretaries, two treasurers, and five other members, and the club assemble on the first Thursday of November, February, May, and August, and hold general meeting's on the 8th of December, and 12th of August.

The third is of more recent formation. It is called the "Death and Glory Club," and is composed principally of journeymen tradesmen. tivity.

There is also a club entitled the "Friendly Brothers," whose object is merely jovial fes-

Rural condition.-In this parish the consideration of the rural part is so completely absorbed by that of the city, that there can be no impropriety in introducing the present notice here. In Creggan the cottiers are rather comfortable, the proximity of the city allowing a fair chance of employment. In the direction of Lough Swilly also, that is from Pennyburn to Coshquin; the houses beside the road look pretty well, and the population are apparently comfortable. 


\section{CITY OF LONDONDERRY.}

Towards Ballyarnet, orchards and kitchen gardens are seen, with farms and fences of considerable extent, and in good condition.

The cottiers are miserably poor about Killea, Upper Creevagh, and Lower Creevagh, whicli are mountain townlands, much frequented on account of free turbary being granted with the cabins. Whole families are frequently met with, begging for seed potatoes to crop their patch of ground. In thesc townlands several of the farm houses are nearly as wretched as the cabins of the cottiers. Windows are frequently seen stopped up with stones, boards, or rubbish. The walls, which are built of rough stone, are not even plastered within or without, and the yards are quite filthy.

Fuel is scarce; hígh wages are paid for a "dark," that is, the day's labour of one man, working witl the spade in a bog, and sometimes assisted by others with wheelbarrows. In Killea, green sods are used, and the gleanings of cut-away bog. The city is partially supported with turf from Whitehouse or Ballymagrorty.

The Presbyterian population resemble their brethren in other parts of the country. Their character varies much from the Scotch, and seems to have been formed by the peculiar circumstances of colonization in a wild and unsettled country.

The oldest individuals appear to be about Killea.

Ancient Traditions and Observances.-Fires are lighted on St. John's Day only by a few poor Roman Catholic families. Stations are still performed at Doon's (correctly Adamnan's) well near Kilmacrennan, and at many others in the county of Donegal, although the practice has ever been denounced from the altar. Several of the miracles and traditions current throughout the parislı are immediately connected with the city.

Attached to the monastery of Derry was a large round tower, supposed to have been built by St. Colımblille, in whiclı was a silver bell provided by him. After his departure a plot was formed to steal this bell; upon which it rung spontaneously for three days; and, at the moment when the thieves arrived, it sprang forth and disappeared in a part of the Lecky property, since called the Blue Bell Hill.

The wells in Derry, popularly calied after St. Columb, although regarded in remote parts of Ireland as a specific for ocular complaints, are of small repute in the neighbourhond.

In Magazine-street, Derry, stands the Haunted House, called also the Bridge House, from a wooden bridge or arch, which, until lately, communicated between the hall door and the city wall. According to tradition, a young lady, an inmate of this house, suffered forcible abduction from the fairies, but reappeared to the proprietor, and requested him to undertake her rescue on the following night. He neglected to comply, and the tradition goes on to say that, on the morning after the appointed night, certain trees, which stood opposite to the house, were found stained with blood, and hung with pieces of human flesh. Strange voices were afterwards heard at night in the Bridge House. A female figure, also, in white attire, was seen issuing from a neighbouring cemetery, entering the house, returning to the place from whence she had come, and vanishing. This house remained long untenanted : but it is surmised that a party of smugglers, by whom the neighbourhood was infested, conld have explained its mysteries.

There is in Killec a heap of stones called "Jenny's Cairn," connected with the following catastrophe, which occurred about 1775. A young man named Ramsay, who was attached to one Jane Glendinning, understanding that on a certain day she would go to Derry, contrived to meet her on her return, and besought her to accompany him to a friend's house, and remain in it until he should have obtained her parents' consent to their union. His reiterated entreaties being. fruitless, he decoyed her to the spot now marked by the caim, where he murdered her. His fury however, soon yielded to horror. He lay beside the body until morning, and then carried it to the nearest house, where he made a confession and surrender. He was subsequently executed at Derry.

There is another cairn in the bed of a rivulet called the "Priest's Burn," from a tradition that a priest was killed on the spot.

The description of the city being now concluded, it is necessary to advert to the few remaining subjects of this section, distributed tbroughout the parisb at large.

Gentlemen's Seats.-On descending the Foyle from Derry, the first seat that occurs is The Farm, the property of Sir Robert Alexander Ferguson, Bart., the city member. Adjoining The Farm is Boom Hall, so called from a boom thrown here across the river in the time of the siege. It is the property of the Earl of Caledon, and the residence of the Bishop of Derry and Raphoe. Adjoining Boom Hall is Brook Hrall, formerly the residence of Sir George Fitzgerald Hill, Bart., the present Lieuteaant Governor of Trinidad, and now of Henry Barré Beresford, Esq. It is remarkable for the beauty of its grounds. Thorn Hill occurs next, the residence of Captain Simeon. The last in the line of villas is Ballynagard, the property of Captain Hart. 


\section{TOWNLANDS.}

Near The Farm is Belmont, once the residence of the late William Miller, Esq. Near Belmont is Troy Cottage, or Troyvale Cottage, the residence of Charles O'Doherty, Esq.

On ascending the Foyle from Derry the first seat that occurs is Foyle-hill, the residence of Mrs. Scott. It is situated one mile from the city, about 200 yards on the right of the Lifford road. On the same road, and a mile beyond Folye-hill, is Milton-lodge, the residence of Captain Henry Lecky.

To the above residences may be added the following, which, like the former are situated near the river. The localities given in italics, are those of townlands, the residences having no distinctive names:

\begin{tabular}{|c|c|c|c|c|}
\hline \multirow{2}{*}{\multicolumn{5}{|c|}{ Captain M'Nei }} \\
\hline & & & & Captain M'Neil. \\
\hline Greenham-house, & & - & & William C. M`Clintock, \\
\hline Mullennan, & & . & & Richard Harvcy, Esq. \\
\hline Culmore-point, & - & . & & Andrew $M^{\circ}$ Causland, Esq. \\
\hline $\begin{array}{l}\text { Bellevue, } \\
\text { Pennuburn. }\end{array}$ & & . & & Hans Riddall, Esq. \\
\hline $\begin{array}{l}\text { Pennyburn, } \\
\text { Do. }\end{array}$ & • & - & & William D. Smyth, Esq. \\
\hline Troy-house. & & : & & Tristrem Holliday, Esq. \\
\hline
\end{tabular}

The bishop's demesne also, although it contains no residence, deserves to be enumerated under the present head.

The cassino, (correctly casina,) was erected by the Earl of Bristol, Bishop of Derry. It is distinguished from the above residences by being nearly in the city, as it is situated in the suburbs close to a garden of the bishop. From its position on the slope of the hill, it commands a beautiful view of the river with the opposite bank. Although irregularly built it presents a handsome front, and the principal apartment is tastefully decorated with paintings in clear-obscure.

Manufactories. The only buildings of this description beyond the limits of the city, which require notice, are the mill and distillery at Pennyburn. The former is a windmill of considerable magnitude, possessing also the advantages of an undershot water wheel 12 feet in diameter. The latter is a very extensive range of building, but possesses no architectural features of importance. The most striking pecularity in its appcarance is the cooler, a long "chamber occupying the whole upper portion of the building, to which the air is admitted by a series of arched openings extending all around it, and supporting the roof. The chinney, as in all edifices of this description, is a striking object in the surrounding landscape, surmounting the trees with which the building is surrounded.

Communications. - Three main-roads diyerge from Derry, which lead severally to Greencastle, Lifford, and Letterkenny. The first runs for about $5 \frac{1}{2}$ miles through the parish, the second about $4 \frac{1}{2}$ miles, and third about $3 \frac{1}{2}$. The high road to Buncrana branches off from the Greencastle road at Pcnnyburn Mill, and runs for about $2 \frac{3}{4}$ miles through the parish in one level line. The Greencastle and Lifford roads lie along the edge of high-water mark-the former, so far as Pennyburn Mill ; the latter, so far as Foyle Hill. These roads are all in bad order : that leading to Greencastle is the best, but a part of it, which lies along the strand, is an incommodious paved causeway. The branch leading to Buncrana is in very bad order. The Letterkenny road is hilly and uneven; its direction also is capable of much improvement.

The cross-roads and bye-roads are sufficiently numerous; in the more improved districts they are broadest and least frequent.

The bridges in the rural part of the parish are small, and insignificant. Previously to the building of Dcrry Bridge, the communication with the opposite country (as has been elsewhere mentioned, was by a ferry. There is still one existing at Culmore.

\section{ANCIENT.}

\section{Section 1.-History and Antrquitres of tine Parisit.}

Townlands. - The most ancient name of the district in which the parish is situated was Már lre, (Moy-Iha), "the plain of lth," who, according to the Irish bardic histories, was the uncle of Milesius, the Spanish lrero. Moy-Iha was the level district lying between the Foyle and Swilly, and extending to the south so far as to include the Church of Donaghmore, which is always called Oomnać món Muíje líe in the Irish annals, calendars, and other historical documents. Moy-Iha appears to have been the territorial name of the district down to the 5 th century, when the country was partitioned among the sons of Niall of the Nine Hostages, and though it was then divided so as to form parts of two different territories, it still popularly retained its ancient 


\section{PARISH OF TEMPLEMORE.}

name. The northern part merged in the principality of Eoghan, (Owen), the son of king Niall, which as lying between the two arms of the sea, Lough Foyle and Lough Swilly, by which it was very nearly insulated-received the appellation of Inip $\epsilon_{0} \dot{\delta}$ com, (Inishowen), or Owen's Island. 'The southern part was allotted to Enda, or Enna, his brother', and hence received the name $\mathcal{Z}_{i n} \epsilon_{n o \alpha}$, or the land or country of Enda. This territory contained 30 quarters of land.

An Irish poem, a thousand years old, referred to by Colgan, shews that the posterity of Enda were deprived of their patrimony by the Kinel Connell and Kinel Owen at a very remote time; and though that ancient authority states that they recovered it in the 6th century, it appears certain from the whole stream of Irish history that they were sonn after again stript of their territory by the dominant power of the kings of Aileach of the race of Owen, by whom it was retained till the close of the 14th century. As long as the regal succession of the kings of Aileach was preserved, the territory of Moy Iha or Tir Enda, appears to have constituted the lordship of the R Moy Iha by the annalists, are also generally called heirs of Aileach, and, excepting when they were cut off prematurely, appear subscquently as kings. Previously to the twelfth century, Moy Iha appears to have been occupied by a branch of the Kinel-Owen called Clan Conor, of which the most distinguished families were the O'Cathans, O'Cairellans, O'Murrys, O'Kennedys, O'Corrans, O'Quins and O'Dugans. Most of them subsequently crossed the Foyle, and possessed themselves of territories in the present county of Derry, and their place in Moy Iha was occupied by the Kinel Moen, another branch of the Kinel Owen, of whom the. O'Gormlys and O'Loonys reere generally the chiefs. And these in turn were also driven across the Foyle by the Kinel Connell in the fifteenth century. In Inishowen, the principal families were the Mac Loughlins (of royal rank), O'Deerys, O'Deromys, O'Brollaghans and O'Brolys, who were also of the Kinel Owen, but after the destruction of the fortress of Aileach, these also became subject to the power of the Kinel Connell, though permitted to retain their lands, and O'Dogherty was placed in the lordship of the peninsula at the commencement of the fifteenth century.- (See Castle of Aileach.)

About half the parish of Templemore, or what is generally called the northern liberties of Londonderry, was comprised in Inishowen, before the formation of the county of Londonderry, as is evident from an inquisition taken at Derry in the scventh year of the reign of James I., from. which it appears that a jury composed of resident English and ancient Irish natives, of the principal septs of the district, "did upon their oaths find and present that the auntient and knowne meares of the countrey of Inishowen, alias O'Dogliertie's countrey, to the south and south-east, are and havc been, tyme out of mynde, as followeth, viz. from the part or braunch of Lough Swilly, on the weste and south-west parte of Birt, thorough the midst of a bog which extendeth to Lough Lappan, (O'Lappan's Lake,) from a well or spring upon Mullaghknockemona, and from the topp of that mountayne the meare extended thorough a small bog., which runneth alonge the top of the hill of Ardenemahill, and soe to the top of the hill of Knockenagh, upon the easte part of which hill ariseth the streame of Altbally M'Rowertie, which runneth a meare betweene Bally Mac Rowertie in Ennishowen, and parte of the landes of the Derry and Garrowgarle to the cawsy under Ellogh, and soe down thorough the bog to Logh Swilly, and from the foresaid cawsy the meare of Inishowen aforesaid is thorough the midst of the Bog to Lough Foile." The southern part of the parish was in Tir-Enda.

It appears from this inquisition and some others, that Sir John O'Dogherty was possessed of the townlands of Ballyarnett, Ballymagrorty, Coshquin, Culmore (then called Leharden), and Elaghmore, being a part of his principality of Inishowen, all which was upon a surrender confirmed to him by letters patent in the 30th year of the reign of Elizabeth. In the year' 1599, Sir John O'Dogherty, rebelled, and forfeited all Inishowen, but it was afterwards regranted to his son, Sir Cahir, as appears from an inquisition taken at Derry in the 7 th year of James the 1st, with the exception of the quarter of Ballyarnet, the half quarter of Leharden (now Culmore townland), and 300 acres allotted to the castle of Culmore. In the year I608 Sir Cahir also rebelled, and his letters patent, therefore, be. coming null and voide, his whole property was granted to Arthur Lord Chichester, of Belfast, by letters patent bearing date the 20th of November, in the 19th year of the reign of James the Ist. It appears from the same inquisitions, that Lord Chichester being thus seized, leased his possessions here to Faithful Fortescue, Knt., Arthur Usher, Tristram Berrisford, and Charles Points, and to their heirs. (Vide Inquisition, No. 1, Tempore Car. I.)

The townlands of Ballougry, Ballymagowan, Ballynagard, Ballynashallog, Creevagh, Killea, Mullennan, and Termonbacca, belonged to the abbey of St. Columbkille, at Derry.

The quarter of Craggin and Drumniurny and the half-quarter of Courneglogh, all which seem to be included in the present townlands of Creggan and Edenballymore, belonged to the bishop, and the townland of Ballynagalliagh, as its name imports, was a part of the property of the nunnery of Derry. (Vide Inquisition, 7 James I.) 


\section{TOWNLANDS.}

It has not been discovered to whom Shantallow belonged, as that name does not occur in the inquisitions ; the remaining townlands, Cloughglass, Pennyburn, Sheriff's Monntain, Springhill, and Springtown, are modern subdivisions of the more ancient denominations.

The ancient topography of the district, and the fluctuating fortunes of its dynasts, being thus pointed out, the next most important object of statistical research is the investigation of the orthography and etymology of the names of the townlands, into which the district is now divided.

Townlands, formerly called in Irish, bailee bo, (Anglicized balliboes, ) i. e. cow-towns, or grazing-towns; bailee bıazcic, (Anglicized ballybetaghs,) i. e. victuallers-towns, or farmerstowns, are now called barlze zalman, or townlands - to distinguish barle in this sense from borle, a village.

1. Ballougry: called Ballywirry, in the Ulster inquisitions, 1609; Ballywirry, a lias Ballyougry in the act of parliament, 4th Anne; and Ballougry, by Mr. Sampson. Ballywirry, its more ancient name, is most probably an Anglicizing of baile $u_{1}$ mhuineariciri, i. e. the town or townland of O'Murry, a family of the Kinel-owen, of whom Duald Mac Firbis speaks, under the head Men of Moy-Ithe-Lord Roden's copy (p. 127). Ballyougry, its "alias" and modern name means borle ugorme, i. e. Ugaire's town-Ugaire having been a man's name among the Picts, and ancient Irish, as appears from Mac Firbis (p. 241), and from the Annals of the Four Masters, in the year 1033. It may be here remarked, once for all, that the Irish word borle (which is generally Anglicized Bally, and sometimes contracted to Ball-where it enters into composition with a word beginning with a vowel) signifies a place, or locality, a village, a seat, a town, and a townland, which last is now its usual meaning. It is explained by inco, $\mathrm{i}$. e. a place or locality, in the Book of Lecan (fol. 164. p. b. col. $a$ ); translated oppidum by Archbishop Usher in his book on the Origin of British Cliurches (p. 861), and by his cotemporary Philip O'Sullevan Beare, a Spanish officer, in his History of the Irish Catholics (p. 159); villa, vicus, vel Burgum, by Colgan, in his Acta Sanctorum (p. 544, n. 2); and villa, pagus, vel villata, by Roderick O'Flaherty in his Ogygia (p. 24).

O'Brien, in his dictionary, remarks that this Celtic word, boulle, and the Latin, vallis, are originally the same, as the ancients always built their habitations in low, sheltered places, near rivers or rivulets." This, however, though ingenious, and the opinion of a man of sound learning, is scarcely tenable.

Dr. Villanueva, the author of Ibernia Phoniciana, throws the weight of his leanning in support of the opinion of Vallancey and others, that the names of many places in Ireland (even Ballycastle, in Antrim), are derived from Baal, the God of the Phonicians, and the supposed God of the ancient Irish; but this opinion is unsupported by a single solid argument, as no earlier authority than Keating has been yet adduced to prove that Baal was ever known in Ireland, and, even if there had, it is not at all likely that so many places would have been named after him. The truth seems to be, the the Irish words, bail, or baile, a village, ball, a spot, and balla, a wall, are referrible to the same parent source with the Latin villa, vallum, ballium, and the German and English wall.

It appears from an inqusition taken at Derry in 1609, that Eallywirry was then in the occupation of John Howton.

2. Ballyarnet, called Ballyarnell in the printed copy of the Ulster Inquisitions; but arnell is doubtless a misprint for arnett, committed by the decypherer of the original MS. and a mistake which it was very diffcult for a person unacquainted with the present name to aroid. The etymology of the latter part of this compound is uncertain, nor can it, perhaps, ever be ascertained, as the Irish language has totally disappeared from the district. It may, indeed, be remarked, that etymology is very uncertain, and, in fact, useless, unless when it elucidates or is elucidated by topography or history. The great topographer Colgan, a native of this very district of Moy-Iha, has frequently expressed this opinion, though almost all his followers in this path have wandered into the wildest regions of conjecture.

3. Ballymagowan: called baile na $\delta$-canánac by the Four Masters (A. D. 1537); Ballyqam in the lnquisitions, by mistake for Ballygan, or Ballygann; and Ballygan, alias Ballygowan, in the act of Parliament, 4th Anne. On Sampson's map it is spelled Ballynagowan. Ballymagowan is now, however, become the established name. It signifies Canon's town, and the townland doubtlessly belonged to the canons of Derry. If the correct name could be restored it slould be Anglicized Ballynaganon. In 1609, it was in the possession of George Norman. In the Down survey the Northern part of this townland is marked as "many small parcels of land belong unto the city of Derry."

4. Ballymagrorty: called by Colgan Baile-meg-rabhartaich; in the Inquisitions Ballym ${ }^{c}$. Rowertie, and Ballymacrewortie; in the Down survey Ballymagorty, but by mistake or ignorance. The signification is unquestionably the town of Mac Raverty, now Magrorty-a family of the Kinel-owen. slosely connected with the early ecclesiastical history of Derry 


\section{PARISH OF TEMPLEMORE.}

Colgan says that there was a monastery anciently in this townland, the ruins of which were scarcely visible in his time [I647] (Tr. Thau. p. 495, col. I.) Another branch of the Mac Ravertys, who were the keepers of the Caah of St. Columbkille, which has been described by Sir William Betham in his Antiquarian Researches (vol. 1.) gave name to Baile Meg-Rabhartaich, in the barony of Tirhugh.

5. Ballynayalliagh: called Ballynecalliagh, and Ballygalliagh, in the Inquisitions, and Ballynagalliagh by Sampson. The meaning is unquestionably boule na $\delta$-calleac, the town of the nuns, as it appears from the inquisition already referred to, that the jurors did, "upon their oaths say and present that there was a nunnery on the south side of the saide cittie, in the Island of Derry, with a small garden or plot of ground, called Garnegalliagh, zanó no $\delta$ cailleaci, the garden of the nuns, "and a quarter of land called Ballygalliagh, to the said nunnery belonging, and that the half quarter of land called Rosnagalliagh, lying on O'Kane's side, was parcell of the possessions of the said nunnery." Caileac is the Irish word to express an old woman who has borne no children, and also a nun. Cormac, Archbishop of Cashel, in the tenth century, derives it from the verb cail, to keep, and says that it was a name for an old woman who keeps the house. Callecic, when it signifies a nun, is derived from caille, a veil or cover, q. d. the veiled: this rests on the authority of a very old Life of Saint Bridget. This townland has been in the possession of the Donegal family since 1620, but how it was acquired does not appear from the Inquisitions.

6. Ballynagard, called Ballenegarde, Ballinnegord, and Ballynagardie, in the Ulster Inquisitions; Ballynagard on Sampson's map; and Ballymagard in his memoir; the latter has also by corruption become the popular name. The signification is doubtlessly baile no zanoa, the town of the guard or garrison: thus Stranagarl, the name of a townland in DESERTMARTIN, is known to have its origin from a guard-house, a part of one wall of which still remains. This townland was, in 1609, in the possession of "Captain Henry Harte," whose heir still retains it.

7. Ballynashallog: called in the Inquisitions Gortneshalyg, and Corneshaglagh, and on Sampson's map Ballynashannagh. The name is evidently boile no pealz, the town of the chaces or hunting, a name synonymous with Huntingdon in England. Gortneshalyg, written Corneshalgagh in all probability by a mistake of the transcriber of the original roll (7 Jac. I.) is $\delta$ one na real , the field of hunting. The word $\delta^{\circ}$. Te is now understood in the north of Ireland to signify a glebe, but this meaning is not recognized by any Irish writers; Keating used the word to signify a tilled field, and O'Sullevan Beare translates it simply ager, and Colgan prodium. It is sometimes written zop $\overline{\text {, }}$, and traceable to the same parent language with the English garden, and the German garten.

8. Cloughglass this name does not appear in the Inquisitions. In the Down survey the townland immediately to the north of Edenballymore, and evidently occupying the situation of this is called Knocktall. Cloughglass, in Irish cloc $\delta$ lar, means green stone. Its ancient proprietor has not been discovered, it is probably a modern subdivison of some more extensive denomination.

9. Coshquin, called in the Inquisitions Costquoyne, and Coskeyne. The orthography would at first sight appear obscure ; but to a person acquainted with the general nomenclature of Ireland it will not appear inexplicable. A barony in the county of Waterford bears the name of Cor burioe, Coslıbride, i. e. along the Bride, from its stretching along the banks of a river of that name, and another barony in the county of Limerick has derived the appellation of Coshma, in Irish Cor maize, from its lying along the river Maig. We find also in the county of Antrim the names of Cushindun and Cushindall, derived from two rivers anciently, but not at present, called Dun and Dall. Now it seems bighly probable that the stream that flows by this townland into Lough Swilly was anciently called cooin, or the beautiful, (amona, Colgan), and that the townland received the appellation of corr coome, from its situation on its banks. coom would be a very appropriate Irish name for a stream, as such appellations are constantly given to them ; for example finn, white, or bright; glan, and its diminutive glanog, clean; dubh, black; finglass, the brighlit-green, \&c. Sampson explains Cosquin as rabbit's-foot; but the Irish word which signifies rabbit is not quin, but coinin.

I0. Creevagh, (upper and lower), called in the Inquisitions Crivagh and Crevagh, and in the act of Parliament, 4th Anne, Creevagh. It is an Anglicizing of the Irish word Cnaubac, which literally means bushy, but which is constantly used in a topographical sense to signify bushy or shrubby land.

This townland was a portion of the possessions of the abbey of Derry, but in I609, it was in the occupation of Denis U'Dery, who was probably the Erenach. This family, called in Irish O'Oaizne, which is now Anglicized Deery, was a distinguished branch of the Kinel-Owen, and for many centuries hereditary Erenachs of half the church lands of the monastery of Derry.

11. Creggan: called Craggin in the Inquisitions, and Craggabell in the Down Surreysheet 5 of Londonderry. Cpeazón means rocky ground. 


\section{TOWNLANDS.}

It is stated in the Down Survey, that the half of Craggabell belonged to the church of Derry.

12. Culmore: The fort is called by Philip O'Sullevan Beare, Cuil more: and the place is called by the Four Masters an cuil, mop ; in the lnquisitions the fort is called Coolemore, and the townland on which it stands, Letarden; it is called Coolemore, Coolmore, Culmore, alias Cross in the Charter of Londonderry. Philip O'Sullevan Beare, in his Account of the Rebellion [motus] of Sir Cahir O'Dogherty, translates Cuil more by angulus magnus, which is the true meaning, and descriptive of the locality. The two Irish words-cül and cúl-are sometimes confounded by Irish topographers; they are however two distinct words-cull signifying. a back or retired place, and cúll, a corner or angle. Cưl excipann, (now Culfeighterin), the name of the north-eastern corner of the county of Antrim, affords another corroboration of the real meaning of this word. Leharden the "alias" name of this townland, signifies lear apoan, the half hill, by which is meant gently sloping hill.

13. Edenballymore. This townland does not appear in the Inquisitions. In the Down Survey it is called Edenballimore and Edenballynore. The name is evidently Euoan baile mop, which means the large townland on the brow or face of the hill. Euocon boule is Brae-facetown, and the adjective mon, large, was generally postlixed to the name of Irish townlands, when a denomination, originally one, was subdivided into a larger and smaller portion. To the former the adjective mon, large, was postfixed, and to the latter beaz, small. Though this is the prevalent usage throughout Ireland, there is no Edenbally Beg to be found in this neighbourhood.

The Irish word Eoan is translated Frons by Cormac, Archbishop of Cashel, and generally signifies the human forehead, but when used topographically it signifies the brow of a hill ; generally, but not always, the sonthern or sunny side, and the opposite of cul, the back or northern side of a hill. Keating defines the meaning of this word completely when he informs us that the River Barrow springs from the Eden or brow of Slieve Bloom: Ir follur zup ab o heuoan pléibe oblaoma oon leı̇ rọn o’fápar beapba.

Lluyd observes that bron, the breast, lhygad an eye, geneu, the mouth, and braich, an arm, enter into the names of some mountains in Wales. In Ireland likewise places are fornd which take their names from a comparison with almost every member of the human frame.

It appears from the Down Survey, which was finished in 1657, that 224 acres of this townland were held under lease by Captain Alexander Staples, and 12 acres of the south-eastern corner of it "a controversie." It seems to be included in the bishop's lands called Craggin, Drumniurney, and Courneglogh, which lay on the northern side of the bog, near the island of Derry. (See Inquisition 7 th James I.)

14. Elaghmore: called in the most ancient Irish MSS. indifferently Gileać and Oileać, both which are pronounced elagh, according to the Ulster mode of pronouncing the diphthong a 1 and $\mathrm{ol}$, when short. In the Ulster Inquisitions, the $l$ is doubled, to render the short sound of the $c$ certain. A full explanation of this name will be found in the account of Grianan Aileach, and that of the O'Dogherty Castle which stands in this townland.

The adjective món, large, is postixed to the name of this townland, to distinguisl 1 it from the smaller tornland of Elagh beg. which lies to the west of it, outside the boundary of the county.

5. Killea : called Killeigh in an inquisition taken at Derry, in the 45th Elizabeth; Kellegh in an inquisition of the $7 \mathrm{tl}$ James the 1st; Killeigh, alias Killeagh, in an act of parliament of the 4 th Anne; and Keelagh, by Sampson. The name must be an Anglicising either of Cull Cuar; grey churcli, or Colll 乙ıa , grey wood, but it cannot be ascertained which, as the aboriginal language is no longer spoken in the district. Countless names of places in Ireland begin and end with the adjective, liaci, arey, especially names of mountains, rocks, and barren hilly Iands.

The inquisition of the 7th James I. found it in the occupation of Francis White.

18. MIullennan: called in the Inquisition of the 7th James I. Mullennan; in the act of parliament of the 4th Anne, Mollenam (by mistake for Mollenan), and by Sampson Mollenan.

The meaning of this name is, in all probability, if not certainly, Mulleann Enna, Enna or Anna's mill-Enna, or Annadh, as being. a male proper name, having been current in Ireland down to the 16th century, and in particular, the name of the chief from whom was derived TirEnna, the name of the ancient territory in which this townland lay. That there were several mills in Ireland a little before the introduction of Christianity is proved by several genuine fragments of Irish history still remaining. It appears from Cormac's Glossary - a very valuable fragment of ancient lrish literature - that before the erection of mills in Ireland, the lrish chiefs had female slaves, called cumals wlio ground their corn with querns. "Cumal, .l. cumola .. ben bir

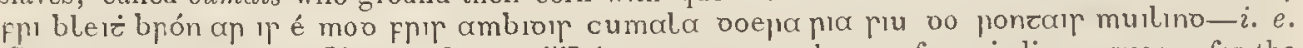
Cumal, quasi Cu-mola [i.e. mola, a mill] i. e. a woman, who was for grinding a quern; for the cumals were enslaved before mills were made." In the same work, the etymology of mulleann, a mill, is attempted to be accounted for by mo-a-all, $i$. e. greater its stones, "because," adds the 


\section{PARISH OF TEMPLEMORE.}

etymologist, "its stones are larger than those of the quern; or from mol-onn, $i . e$. the shaft and the stone, because these are the two things ealled the mill, and from mel-lin, i. e. mel, to grind, and $\operatorname{lnn}$, the pond, " because it grinds by means of the pond." These derivations are obviously visionary, but they are curious, as evidenees of the existence of watermills in lreland, previously to the year 908, when the author of the Glossary was killed. In the same Glossary mention is made of cozao .1. aıpnem frir a melaiżep epna " a mill stone by which barley is ground."

Cuan O'Lochain, chief poet and lawgiver of Ireland, whose death is recorded in the Annals of Tighearnach, at the year 1024, states in his poem on the ruins then existing at Tarah - that the monareh Cormac, the son of Art, had a beautiful Cumal [Bond-maid,] by name Ciarnad, who was obliged to grind a eertain quantity every day with a quern; but that the king, observing her beauty, took her into his house, and sent across the sea for a millwright (zuz roen mulllino zop mop zuıno), who constructed a mill on the stream of Nith, which flows from the fountain of Neamhnach to the N. E. of Tarah. This lrish custom of women grinding at the quern, will bring to the recollection of the reader the words of Job, (chap. 31, v. 10.) Tighearnach, under the year 65l, records that the two sons of Blamae, the son of Hugh Slaine, monarch of Ireland, were killed in Muillenn Maeloran in a fray which took place between them and the Miller Maeloran.

Several other mills also are mentioned in various fragments of lrish history, such as St Feehin's mill at Fore in Meath ; St. Kiaran's at Clonmacnoise, St. Lucherin's, \&c. ; and it is recorded in the annals of the Four Masters, that the celebrated upright stone in east Meath ealled lic culbe fell in 998, and that Malachy, king of Ireland, made fonr mill stones of it.

There are also still preserved among the MSS. of Trinity College, (class E. ta) \% 3, No. 5, ) some ancient Irish laws relating to the regulation of mills.

Seeing then that there is every reason to believe that there were several milis in Ireland at a very aneient period, it is rational to eonelude that this townland derived its name from an ancient mill, as the locality is adapted for one, and as the ruins of a modern mill are still existing in it, and that the real meaning is Enna's Mill, or perhaps the Mill of Tir-Enna, the territory in which it lay.

It appears from the Inquisition of the 7 th James 1., that this townland was then in the oceupation of John Woods.

17. Pennyburn.-This townland does not oecur in the Inquisitions, nor in the charter of Derry. It must have been a name imposed by the English eolony, as it is not of lrish origin. In the Teutonic dialects, according to Richard Verstegan, burn or bourne, signifies a stream. It lias been added by the Seotch settlers to the names of several small rivers in the north of 1 reland, s Burndale, the modern name of the eelebrated river in Donegal ealled Dailia, in the lives of Columbkille and Oaoul by the Four Masters.

18. Shantallow: this townland does not neeur in the Inquisitions or any other aneient document hitherto discovered. The meaning of the name is evidently Sean zalam, old land ; but why it originally received such an appellation, would be now difficult to ascertain. Perhaps land a long time tilled might be so calied, in contradistinction to land lately reclaimed.

19. Sheriff's Mountain. This townland, whieh does not appear in the Inquisitions, appears to be a sub-denomination of some other townland; most probably of Ballymagrorty.

20. Springhill. This townland does not appear in the Inquisitions, and appears, also, to be a sub-denomination of Ballymagrorty.

21. Springtown. This townland, whieh does not appear in the Inquisitions, must be a sub-denomination of Ballymagrorty or Shantallow.

22. Termonbacca. Called in the Inquisition of the 45th Elizabeth, Termonbackagh; in that of the 7th James I., Termonbaccoe; in the aet of parliament of the 4th Anne, Termonbacco; and by Sampson ineorrectly Tirmonbacca.

The meaning is evidently Teapmann bacaib, i. e. the termon of the eripple.

Usher translates tearmann by the Latin asylum, and thinks that the Irish borrowed this word, as well as many others, from the Latin terminus, beeause sueh privileged places were coin monly designated by special marks and bounds. Termons indeed, (he adds) were free land, but free from all claim of temporal lords, not of the church, being truly territoria ecclesiastica. Some have thought that Termon was the same as terra monachorum, or, in French terre moine, the land of monks. But this derivation is not tenable, nor is it derived from terra immunis, free land; although it is true that termons were sometimes îree from tribute, they were not so always, for Red IIugh O'Donnell compelled the termon of Derry to render him 18 beeves a year in time of war, and the termon of Kilmacrenan, 24 methers of butter, and 24 methers of meal, once every quarter of a year.

There is a curious tract anong the Lambeth MSS. written about the year 1605, which gives a very ingenious explanation of this word; as it has not been published, the following extraet will be novel, as well as interesting :- "The tenents of the chureh lands, are called Eir- 


\section{TOWNLANDS}

enaci, Corbani, or Termoners, and are all for the most part, schollers, and speake latin and anciently the chiefe tenents were the determiners of all civill questions and controversies among their

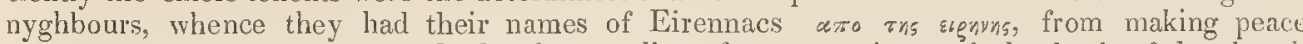
or of termoners, a terminandis, litibus from ending of controversies, and the lands of the church being anciently sanctuary lands within which no man was followed further by the pursuer in those tymes were thence also called Termons, a termino, because there ended the persuite. Theise telients were first placed in those lands by the bishops and the possession thereof contynued unto them by new grants from the succeeding bishops, after the death of every Eirenagh, \&c. Neyther was it lawful for the sonne of any Eirenagl, \&c. to meddle with the lands his father possessed till the byshop made him a grant of the Eirenacy. And yf the Eirenagh, his sonne, came not within a certayne tyme lymited to receave his graunt, the byshop might give the land to another, whereof I have seen som presidents, [precedents.] And if the bishop did see the sonne or next kynnesman that demanded the Eirenacy, to be unhable, in regard of his poverty, or otherwise, insufficient to performe the dueties of that place, the bishop gave the land to another whom he woulc chuse, whereof I have also seen some presidents [precedents.] The bishops altered the rents of these lands, accordingly as they were disposed to take more or lesse rejection from their tenents. These lands dich never paye rent, nor any other duetye, or acknowledgement unto any other person, but onely to the bishop, untill the rebellion of Shane O'Neell, who for the mayntenance of his rebellion, ymposed and exacted cuttings, out of the church lands, as well as the temporall, the byshops being not then hable to resist hin, nor redresse the wrong, otherwyse than by petition, to the deputye and councell, wch they did after the war ended; the temporall lords contynuing the sayd oppression of the church begon by Shane O'Neell, and obtayned an act of councell, against all the temporall lords that oppressed the church, whereby they were adiudged to restore unto the church ten for one, and this act, made by Sil Henry Sidney when he was deputye, and the counsell then was contynued in severell deputies' tymes successively."

These notices are curious, as illustrating the state of the termons in the time of the writer, and his derivations are very ingenions; but he is in error respecting their ancient history, and the meaning of the word. Erenachs were first appointed by abbots-not by bishops-and in the ecclesiastical stile, the word terminus as well as finis (both which also mean end or boundary) signifies a district or territory. - See Ducange at "Terminus." The truth seems to be, that the Irish word zeapmann, which is now used by the peasantry to signify refuge or protection, was originally borrowed, as Usher says, from the Latin terminus, which was used by ecclesiastical writers to signify church land, - that, when these lands were afterwards consecrated and erected into sanctuaries, the word terminus was taken to imply a sanctuary, - -and that, as termons were among the ancient Irish places of retreat from danger, the word came in later times to signify asylum, shelter, refuge, or protection. It appears from an act of parliament of the 4th Anne, that the termon of Derry was popularlycalled "the fifteen hundred acres," and that it comprised this townland of Termonbacea, as well as Mullennan, Ballygonan, Ballougry, Creevagh, and Fillea.

Why this townland, in particular, has retained the appellation termon, and received the additional epithet of bacca, or of the cripple, it would be now vain to conjecture, as after careful research no historical elucidation has been discovered. This was in the possession of Sir Thomas Phillips in 1609. (See County History and the inquisitions.)

23. Whitehousc. This is a part of the ancient denomination of Ballymagrorty, of which we have spoken above. The name Whitehouse is said to have been derived from an old English habitation, the ruins of which still remain. 


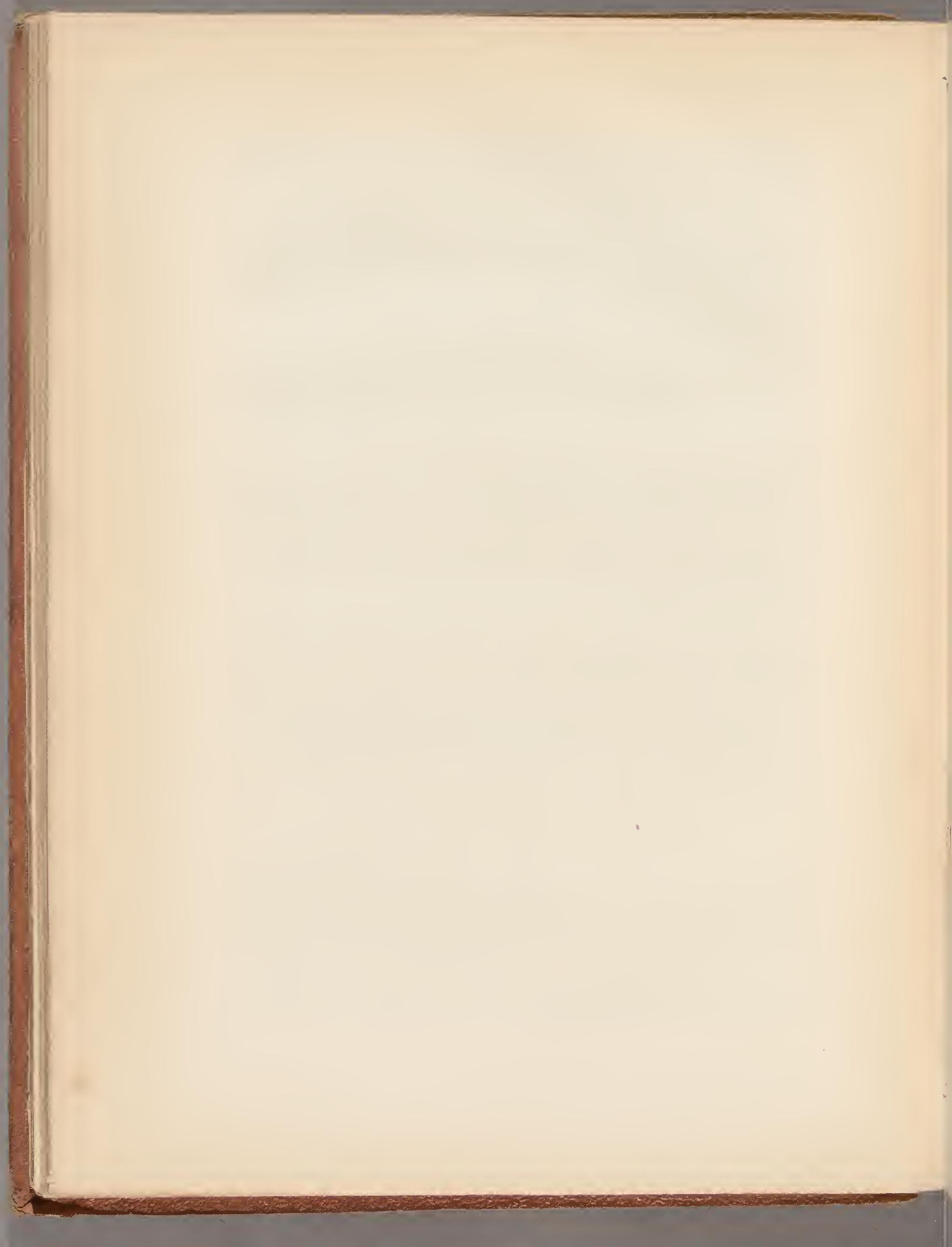





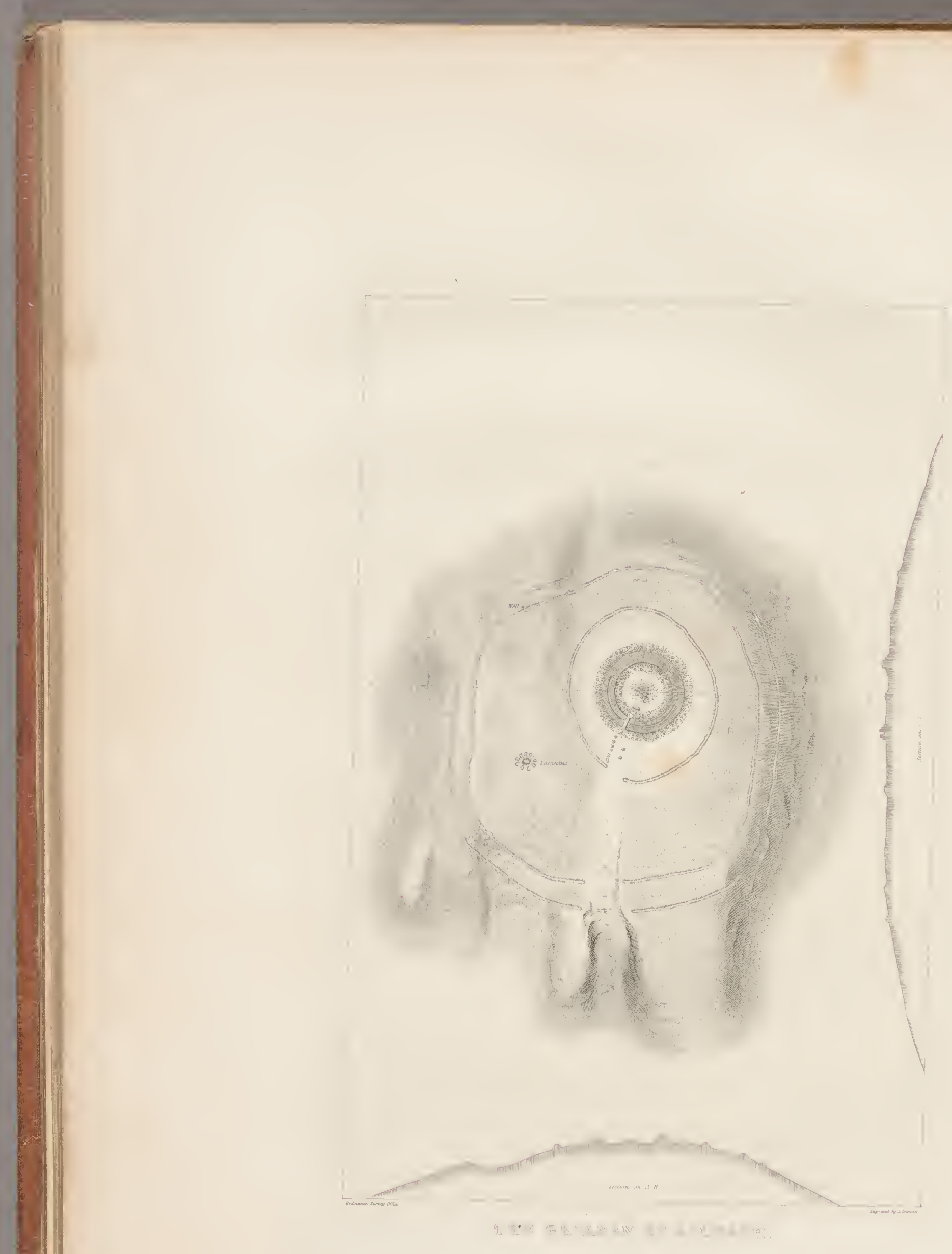




\section{PAGAN ANTIQUITIES.}

Section 2.-Antiquities.-PAGAN.

1. Sepulchral.-Therc are but fow vestiges of Pagan sepulchral remains in the parish. The summit of Holywcll Hill is occupied by the remains of a cairn, about 40 feet in diameter. In the centrc there is a small pit, 3 feet square, and 5 decp. It is formed by four large stones, and had doubtless a covering laid on them originally, as is usual in all snch scpulchral chests, or Fistraens, as they are called, in England and Walcs. The rock of the mountain forms the bottom of the sepulchre, which is called the IIoly Well, from a small pool of rain water being gencrally found in it, which is popularly supposed to be possessed of miraculous healing
virtues.

In Ballymagrorty, about 10 pcrches from Mr. Dogherty's house, therc is a small cromleac, the table-stone of which is about 4 fect by 3 , but it is at present nearly concealed by earth
thrown over it.

2. Military-Of this class the principal remain within the parish is a rath or earthen fort, situted in Ballynagard, on the westcrn shore of the river Foyle. It is of an oval form, measuring 60 yards from $E$. to $W$, and 73 from N. to $S$. ; and is nearly surrounded by a ditch, and a parapet of earth. This parapet is 6 feet high on the $W$, but near the river it disappears; and as the river and a natural bank of carth, 12 feet high, is a protection in that qnarter, it is probable that none ever existed there. The parapet is now covered with large trecs, and underwood. The original entrance is on the western side : two other points of ingress, near the river, appear
to have been formed for agricultural purposes.

The Grianan of Ely, or Grianan of Aileach, one of the most ancient, and historically intcresting monuments remaining in Ireland, though situated within the county of Donegal, is so contiguous to this parish, in which a townland (Elagfmore) still retains its name; and is besides so intimately connected with the history of the district, that it may not be improper in this place to give some account of it.

This remarkable fortress has been already noticed by Colonel Blacker, in a pamphlet addressed to Dr. Knox, the late Lord Bishop of Derry, but that talented gentleman being but insufficiently acquainted with the charactcristic peculiarities of the ancient Irish Cyclopean works, and still less with the cxisting historical notices appertaining to this particular one, has left unnoticed some of its most striking architectural features, and mistakcn altogether the purpose of its erection. Colonel Blacker is, however, entitled to high praise, as well for the purtrouble which he took in ascertaining the form and measurements of this venerable ruin, as for the patriotic zeal which prompted him to make his researches known. If such practical explorers of Irish antiquitics were morc numerons, our ancient monuments would be held in far higher estimation by the learned than they have becn hitherto.

The Grianan of Aileach is situated in the county of Donegal, about a mile from the boundary of that of Derry, on the summit of a small mountain, 802 fect high, to which it has given its name. This mountain rises from the southern shore of Lough Swilly, immediately in the rear of the island of Inch, from which it is separated by a channel, which at low water. is passablc. The ascent for about a mile is tolerably gradual; but within a few hundred feet of the top, it assumes a more precipitous character, and it terminates in a circular apex, which commands one of the most cxtensive and bcautiful varied panoramic prospects to be found in Ireland. A broad ancient road, between two ledges of natural rock, leads to the summit of the hill, from its base on the eastern or Derry side. By reference to the accompanying plan, it will be seen that, following this road, threc concentric ramparts must be passed in order to arrive at the caisiol, or keep, of the fortress, and judging from what is observable in other ancient Irish regal monuments-Emania, for example-there is reason to believe that the whole lill was originally inclosed by another rampart, of which, owing to the progress of cultivation, no traces are now distinctly visible. The truth of this conjecture will be very strongly corroborated by historical evidences, to be adduced presently. These cxternal ramparts, which are all in a state of great dilapidation, appear to have been formed of earth, mixed with uncemented stones. They are of an irregular circular outline, consequent upon steps. Btar inclosure, and asccnd above each other in successive steps. Between the third, or innermost, rampart and the cashel, the road diminishes cona wall on each side, of whiverges slightly to the right; and this approach was strengthened by 


\section{CITY OF LONDONDERRY.}

The cashel, though in a more perfect statc than the external ramparts, is still a mere ruin. "To the casual observer," Colonel Blacker remarks, "the first appearance of this edifice is that of a truncated cairn of extraordinary dimensions; but, on a closer inspcetion, particularly since the clearing away of fallen stones, \&c., it will be found a building constructed with every attention to masonic regularity, both in design and workmanship." It is, in fact, a circular wall, inclosing an area of 77 fect 6 inches in diameter, and in its present state about 6 feet in height, and varying in breadth from 15 fcct to 11 feet 6 inches, or averaging above 13 feet. Of its original height it is not easy to form a very accuratc conjecture, but, from the quantity of fallen stones which form a glacis on cither side, about 13 feet in breadth, it may be concluded to have been at least twice, or possibly three times, its present altitude. At the height of about 5 feet from the base, on the interior face of the wall, the thickness is diminished about 2 fect 6 inches, by a terracc, the ascent to which was by stair cases, or flights of seven steps, 18 inches wide, situated at each sidc of, but at uncqual distances from, the entrance gateway. It is probable that there are similar ascents to this terrace in othcr parts of the wall, as is usual in forts of this description throughout Ircland, but now concealed bcneath the mass of fallcn stones; and that there was originally a succession of three or four such terraces ascending to the top or platform of the wall. On each side of the entrance gateway there are galleries within the thickness of the wall, extending in length to nearly one-half of its entire circuit, and terminating nearly at its northern and southern points. These galleries are 4 feet 9 inches high, and have sloping sides, bcing 2 fect 1 inch wide at bottom, and 1 foot 9 inches at top; they are covered by large stones laid horizontally. The galleries do not, however, communicate with the gatcway, and to that on the N. no communicating passage, or entrance, has been discovered; but the other has, at its southcrn extrcmity, an entrance from the area, 1 foot 6 inches wide, and 1 foot 10 inches high, bcing barcly sufficient to admit a boy. In this gallery, and ncar its northcrn termination, there is a small oblong square recess, 2 feet 9 inches high. There is but one gateway to the interior area of the caisiol. It is but 4 feet wide at its base, and appears to have been not more than 6 feet high.

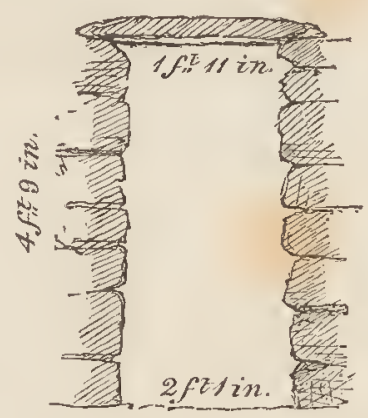

The sides of this passage, like those alrcady noticed, were inclined, and covered by large flags, laid horizontally: one of the lintels, which is 6 feet long, and 1 foot 3 inches thick, remains within the area, and others of inferior magnitude lie about the entrance.

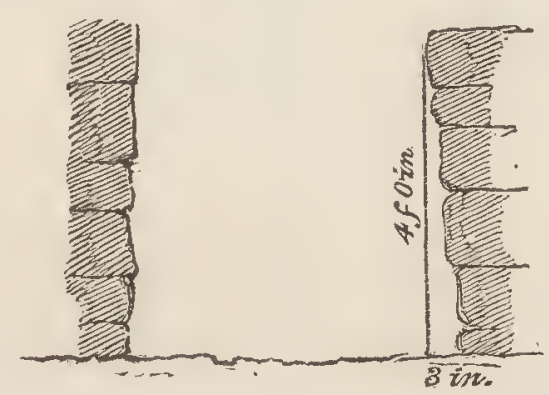



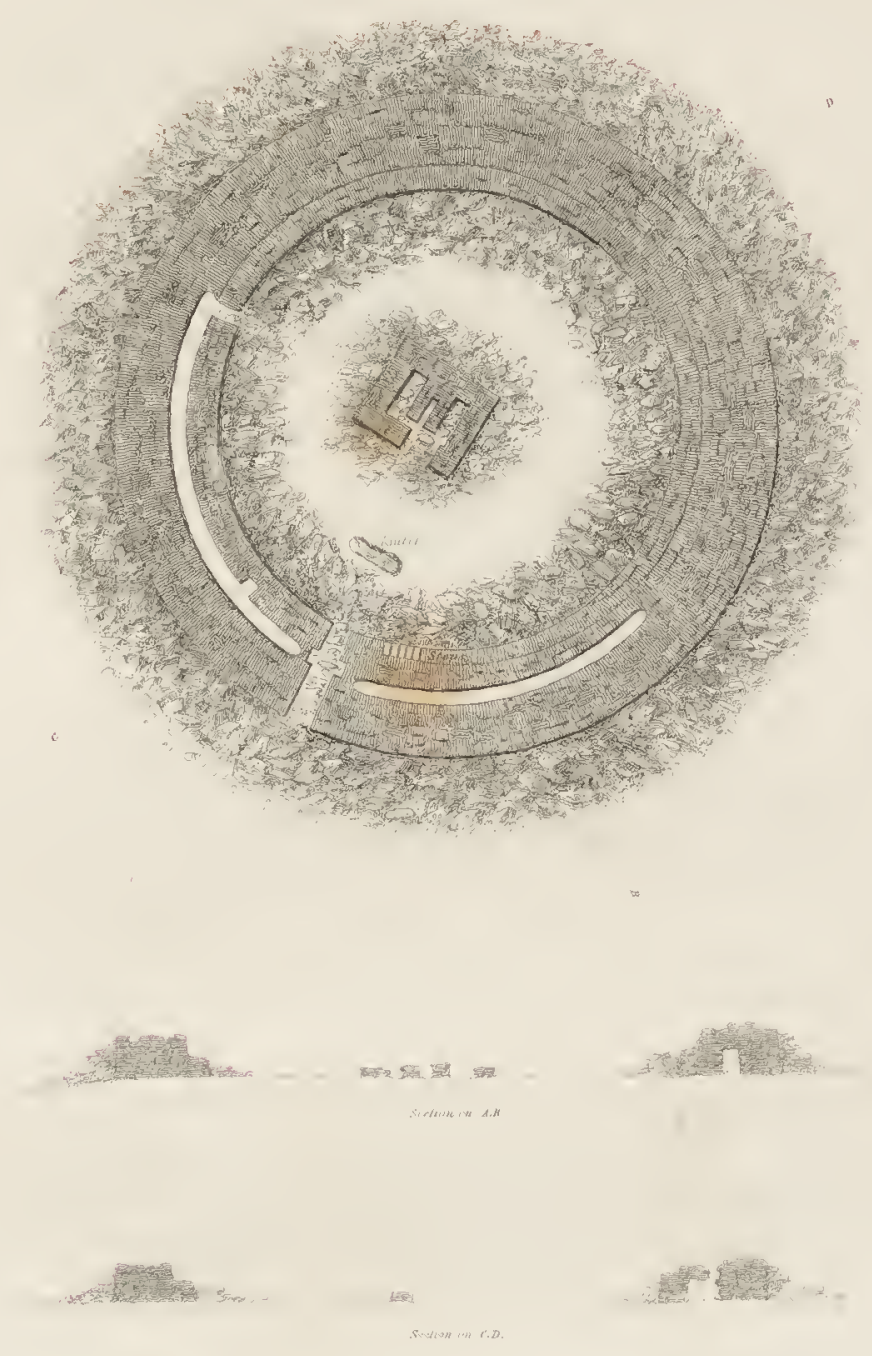

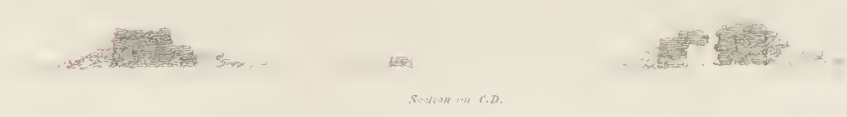




\section{PAGAN ANTIQUITIES.}

A sketch of this gateway is annexed, as it would appear in its original state. On each

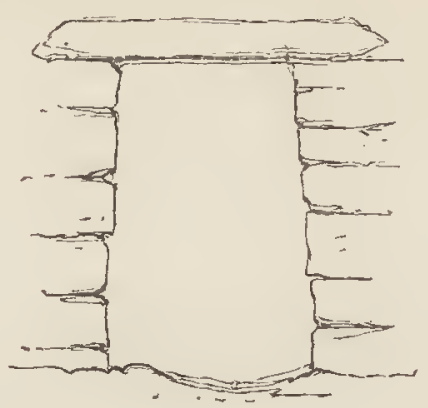

side of thc entrance passage there is a niche-or, as masons would express it, a double reveal-the purpose of which must be left to conjceture.

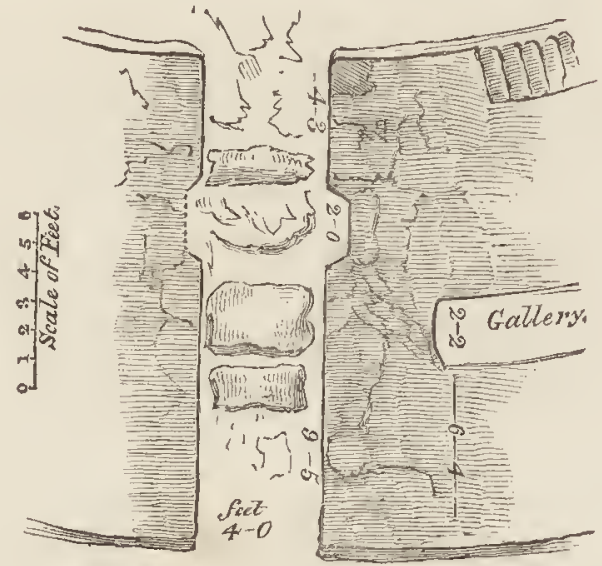

The circular apex contains within the outermost inelosure about $5 \frac{1}{2}$ acres, within the second about 4, within the third about 1 , and within the cashel about $\frac{1}{4}$. The masonry of this great work is exactly similar to that of many other Irish caisiols, or cahirs. The stones, which are of the common grey schist of the district, are of polygonal forms, adjusted to fit cach other, and wholly uncementcd. It is quite evident that they have bcen in many parts squared with the hammer, but not chiseled, as Colonel Blacker supposed. This is most apparcnt in the angles, \&c., of the entrance passage; but in the exterior faee of the building the stones are much more rounded, or worn, at the cdges, and indicate, from their state of decay, a very remote antiquity.

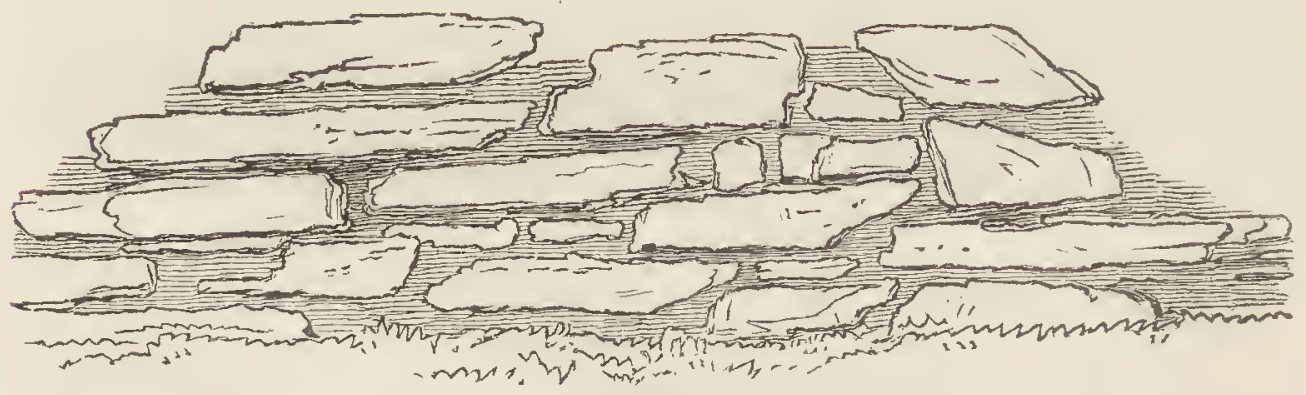

In the centrc of the area of the cashcl there arc remains of a small oblong building, measuring 16 feet 6 inches by 14 feet 3 inches. The walls, which are 2 feet thick, and, at 


\section{CITY OF LONDONDERRY.}

present not more than 2 feet high, are without mortar. The antiquity of this building is, however, extremely doubtful, as its angular form indicates a much more recent age than the works by which it is inclosed and the probability is that it was erectcd for a chapel during the severe administration of the penal laws, to which purpose it was certainly appropriated, until about forty years since, when a chapel was erected at Burt. Thcre are no other vestiges of habitations, either within the cashel or its external ramparts. Between the third and fourth walls there is a spring well, which, when discovercd a few years back, was covered with a large stone; and betwcen the second and third walls there is a small mound, having around it a circle of ten large stones, laid horizontally, and converging to a centre. This mound was recently opened, but nothing was discovered in it that would throw light on the purpose of its erection. The space inclosed by the outer rampart is 5 acres.

If a more minute and detailed account of this interesting ruin has been gone into than its apparent importance would seem to warrant, the necessity for this will be manifest when it shall be shown-that the Grianan of Ely was one of the most remarkablc and important works of its kind ever erceted by the ancient Irish,_-and the palace of the northern Irish kings from the earliest period of historic tradition down to the close of the 12 th ccntury-and that, consequently, such careful examination of its vestiges as should afford a clear idea of its original form, structure, and extent, would give the most accurate and conclusive evidence, now attainable, of the exact amount of skill in the art of building possessed by the ancient Irish

It has, indeed, bcen supposed by Col. Blacker, that this curious remain of antiquity was erected as a Temple of the Sun-a conjecture which he rests on the etymology of its name Grianan, which as he states, does literally mean "the place of the Sun" "or" appertaining to the Sun." But ctymology is at best but a very uncertain foundation for historical lyypothesis; and the habit so generally indulged in by Irish Antiquaries of drawing positive con. clusions from etynological conjectures has donc more to retard than advance the knowledge of the history and antiquities of the comntry.

That the word Grianan was ever applied to denotc a temple of the sun, or a temple of any kind, no authority has been adduced, or found; but there are abundant evidences that it was constantly used in a figurative sense, to signify a distinguished residence, or a royal palace. It is thus explained by O'Reilly, "Znıanón, a summer-house, a walk, arched or covered over on a hill for a commodious prospect, A RorAL SEAT." O'Brien, an earlicr and better authority, also explains it as a "royal seat;" and gives as an illustration the name of the very palace in question-Zrıanán Oı and $\mathrm{M}^{\circ}$ Firbis, without explaining the word, use it to express a royal habitation. "Lachtna Kenedei Patris successor tres annos, a quo Grianan Lachtna apud Creigleith." Thus also Keating. The third louse which was at Tara, was called Grianan na n-ingean, [Zrianán naninjean,] where the queens of the provincial kings used to sit. Colgan also observes, that places were called Grianans from the beauty of their situation, and renders it Terra Solaris and Solarium; and Cormac Mac Cuillenal, a writer of the 9th century, and superior as an authority to all the preceding, uses the words in a similar sense in his Etymological Glossary, in explanation of the word Teamhair, now Tara.

"Teamhair, corrupted from the Greck $\Theta \tilde{\varepsilon} \tilde{\omega} \varepsilon \tilde{\omega}$, , conspicio, Teamhuir, thcn, every place where there is held a meeting of the learned, both in the plain and in the house, unde dicitur, TEA M-

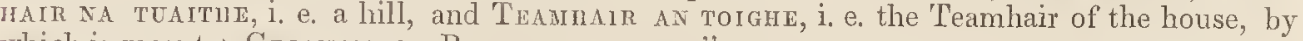
which is meant $\Lambda$ Grinian, or Patace on a imll."

That the learned king and archbishop of Munstcr, in his derivation of this and other Irish words from the Greek, was not lcd by the ignis fature of etymology as far into the region of fanciful conjecture as any of his modern followers in this uncertain science, it is by no means insinuated. But that the word Grianan, though often topographically applied to merely beautiful localities-_" loca amoenissima," as Colgan phrascs it, was also generally uscd to signify a palace, or distinguished residence, in such beautiful and sunny situation, may be considered certain from the authorities now given, to which, if further evidences were necessary, numerous examples could be added from the ancicnt Irish poems, and romantic tales, of which the following rann, (or quatrain), quoted by the Four Masters in their Annals, at the year 1088, may serve as an instance.

Cażalán an ćnábiaı́ cóip

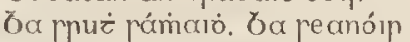

Fop neam ir in J̄pranán żlé

¿uió hi féil Ciapáin Sarźre.

Cathalan, of true piety.

Was tranquil, sage, and senior:

He passed to Heaven-to the bright palace [Grianan]

On the festival of Kieran of Saiger." 


\section{PAGAN ANTIQUITIES.}

But even though it were allowed that the word Grianan was sometimes applied to a temple of the sun, the Irish authorities will abundantly prove that this-the Grianan of Aileaeh-was not of that deseription. In all the Irish histories the palace of the northern Irish kings is designated by the name Aileach simple, or aceompanied with the epithets Grianan, Aileaeh-neid, Aileach Frigreann, and its situation is statcd to have been on a lofty hill in the immediate vicinity of Derry. This name of Aileach is still preserved in two adjaeent townlands ealled Elagh-more and Elagh-beg, or the great and little Elagh, and in the former there is a ruined castlc eallcd Aileach, built by the O'Doghertys, and whieh has bcen supposed by antiquaries to be the remains, or at lcast ereeted on the site of the aneient palaee. But the arehiteetural eharaeter of the ruins of this eastle leave no doubt of its eomparatively modern age, and its situation will notadmit of the assumption that it occupies the site of the Grianan of Aileaeh : in the immediate vicinity of these townlands there is an aneient fortress, the identity of whieh with that of the kings is proved no less by its concordant arehiteeture and loftiness of situation-like Tara and other distinguished Irish palaees-than by its still retaining the very name, with its peculiarly eharacteristic epithct Grianan prefixed, whiels is applied to it by the Irish annalists in their final notice of its destruetion, a name whieh no other aneient Irish monument is found to retain

All doubt of the identity of Grianan fort and the aneient palace is, however, removed by a deseription of the royal fortress, preserved in the Dinnseanchus, an Irish topographieal work of very high antiquity, if not, as Dr. $\mathrm{O}^{\prime}$ Conor states, the earliest treatise of the kind whieh any
eountry now possesses.

This work treats of the origin of the names of the most historieally distinguished plaees in Ireland, as forts, earns, mountains, rivers, lakes, \&c. ; and though, like the legends of the saints, it is almost wholly of a fabulous charaeter, its evidenees in regard to historie and geographic faets, are no less cntitled to respect. The lives of the saints have been received as authority by the learncd of Europe, "and rightly," as Pinkerton justly observes, "for there eould be no possible temptation to fietion in these artieles; but, on the eontrary, every indueement to preserve these grand features exaetly, in order to eolour their ridieulous tales." So in the Dinnseanehus, the places mentioned must have had a real, and the persons conneeted with them at least a traditional existcnce, or its legends eould have had no interest at the period of their eompilation.

With these prefatory remarks, the following poem from that aneient work, explaining the origin of the various names of Aileaeh, is given in a literal and unabridged form, in preference to any seleetion merely of its valuable parts; as it is only by plaeing the whole before the reader, that its worth as a historical record can be truly estimatcd, or that suspieion of unfairness be prevented, which the mutilation or suppression of any portion of an aneient doeument is almost sure to ereate. The parts worthy of attention, either as illustrating the monument under eonsideration, or illustrating aneient manners and eustoms, are however printed in italies.

Oileach Fpropeano faich na piz pizoa in oomain

Oun a poizir roir fo znearaib zpe choic claoab

Cnoc ap up chooal in oazoa oeanz a reoźa.

1 roa a thiz ceape a chpecha zepc a clocha

Cairlen up-apo Ailech Frisneno paich in oe zírp

Oun ina rcailzech ap rcolaib aeilzech emin

Inao aibino Oilech nzabnan jlar a chpaeba

Foo ca fuain* in $\mathrm{O} a \delta$ oa ouana aoba aeda.

Ino ir imoaib oinojenchur ana Orlio

Ro lepechan leazh in oomain zech bia thizib

Oileach Fridreann, seat of the kings royal of the world;

Dun, through which ran roads under heroes, through five ramparts;

HiLL, on which slept the Dagda; red its flowers,

Many its houses, just its plunders, searee its stones.

LOFTY CAISLEN, is Ailech Frigrenn, fort of the good man,

Dun, the shelter of heroes, NOBLE LIME HOUSE;

Delightful plaee is OILEeH GaBRAN, green its bushes,

Sod, where placed the Dagda, the resting mound of Aedh.

In it many are the aeeounts of the wealth of Oileeh,

$A$ house of its houses would improve half the world

* Fua in is an ancient form of cuın, he placed. See quotation from the Life of St. Bridget, under the word Cailleach, in O'Brien's Dictionary. 


\section{CITY OH' LONDONDERRY.}

Cach fazh o fpich ainm ap Oileach cona failze.

Iza puno ina reao chuinozro feap ca farobe.

Eocharo ollazhour noinoraro E pinn uile

Ro bo lezi naleach muigi opech in ouine

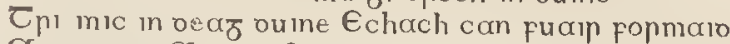

Clenzur ir Ceo ir Ceprmaro na caencomnaic

Coinnzeno mao Faizheamain Fenoich oeaparb oomam

Oclach o Eachaio oo uaip oebaio pe fuaip noomuin,

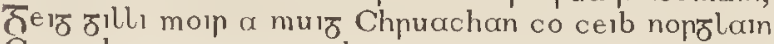

Co naib naibriz co nuche nanparo co nipe nonmaip.

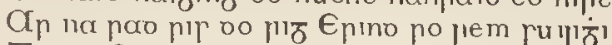

Zanic Coinnceano o chpuach Orgli co zuaith Cuipbi

Ceachna baingel fa bean Coinncino in chuipp champenz.

Nocop balli ouni ian noilino uile a n $\epsilon_{\text {pino. }}$

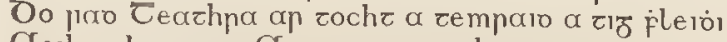

Qeib a harp op Geo zen cop orbi perm

Oo chuaro Coinnceno opir a fepaino zen bolc lerp e

Oo chan Zearhna zen zhaem opure, Oeo oa eire.

Ir ano pin oo pigne Coiprono in cleach fuileach

Juin in mic no mill $\alpha$ eneach ino can fuineach

Oo chuaio Eochaio oiapnaro choinncino 1 cpich n-u maill

Co pur zimainc epeolinm nuainz a curl cumanz

Conrebaipe cach cpochthap Coiprzeno ceann na femnea

Ma oo pinor uaill na uabap a zlua zlezel

Nocho benaim ap a Oazo man a oeapiap

Aninach oipipnach olizeo nio imolecrzan.

Ni oleazap aınım ip enech a mic manma

Ni hearobeapar o bpeith neamoa operch in Oazoa

Eaeh cause, from which Oileeh reeeived its name with its Kings

Is here related, the treasure-house of men and arms.

Eoehy Ollahir divided all Ireland,

(Greyer than the grey mist was the aspeet of the man)-

(Among) his sons who never felt envy -

Aengus, Aedh, and Kermad of tranquillity.

Corgeann, son of Fahoon, hero of the men of the world,

A youth, who on Eoehy brought disturbanee and afflietion,

A mighty seion of Moy-Croghan [Connaught] with hair golden fine,

With eheerfulness of mind, with breast of hero, with strength of nine.

At the desire of the king of Ireland, who invited him,

Corgeann eame from Cruach Oigli [Croagh Patriek] to Tuath Tuirbhi :

Teathra the white-fair was the wife of Corgeann, [she] of the fair, slender figure:

No fairer person sinee the deluge lived in Erin.

On eoming to Temur in the banquet-house, Teathra

Plaeed on Aedh her whole attention, though she had before refused him:

Went Corgeann to see his lands, although it grieved him-

And loved Teathra, in a fit of passion, Aedh-in his absenee.

Then did Corgeann, the sanguine sapling,

Slay the man without delay, who had his trust (enech) violated,

Went Eoehy then to seek for Corgeann, in the land of Umhall,

And drove him aeross Linm. Vuang into a narrow eorner.

So that all exelaimed-_" Be Corgeann, head of heroes, hanged,

If e'er [before] his bright eheek aeted pride or haughtiness."

"We shall not do so," quoth the Dagda, as it is said,

In lawful hospitality the law is not to be enforced.*

Must not be enforeed in name [honor] and hospitality, oh sons of my soul!

The Dagda's face shall never swerve from the heavenly sentence:

* The bard here puts a passage of the Oneata Neımio (celestial judgments) or Brehan law, into the mouth of the Dagda. 


\section{PAGAN ANTIQUITIES.}

Ache bio amain ap a muin in mac po muaiz

No co razba cloch bur cliubaio ma chomaip.

Cuiprheap in mac ap muin Choipnoino Cnuic na Caeivean

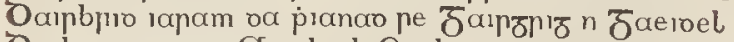

Oo himancear Ceo la h Eochaio in aipm azmaıp

Nocho puc juz peme a Zemparo eine amlaro

O cnuc Thempa zuap zuba in fep foppin femnich

Nor puc leip co paich neio napaio in nzeic zlezil

Ro zob Coinnzeno zap clap meoon moiz reanaio

Oo prace co pino, moch in paizen, fino Loch Feball.

Febal mac looam lam zlezel zuala na boc

Rolar aon loch zap in leanab cloch a chomar

Or chonoainc Corplreno cloch Febail pur fez nome

Nor puc le ir na uinoeam uipe culleam eine

Ro inolr co oepb oon Oazou cen dellm nuabain

Sin in cloch a muiz a milich uchorl uabain

Q oubaine co oeapb in Oazad co nopeich noibain

Caipm na zizıb bio on Ciliz aımm an maı.

bio Aileach biap ap in mbailipea oon banba

Sech cach cnoc map chnoc zarzeampa ap opas in Oazoa

Ro zhore Coippeno fan clorch zpuim no bpip a cpior

Ni bo charı a chup na laizl oo bun bilı

Oepin zaipcheap Gilech Ceoa na neach pine

Ir Giléc Cornnceno Cpuaichı boipbrhenn birhı

ap pin zuczha na oa oeiżin pe oan cpizhip

Zapban ir Michenn co h Eochaio Finocell prichıp.

Con zebaine pu paizh oo oenam mun opem remienz

Comaro hi paiz na neng nalaıno buo fepn o Epino

a oebaine piu Nero mac Inoar a naignio oolliz

Nocho neapnoair veazlluaz oomain Eap mon Oilich.

But he shall earry on his baek the son he has slain

Until he find a stone fit for his tomb.

The son is plaecd on the back of Corgeann, of Knock Taeidean,

For punishment by the ficree king of the Gaels :

Was [thus] conveyed Aedh by Eochy of valiant arms

(Never before brought king from Temur sueh a burden).

From hill of Temur-eause of woe upon the hero !

To the fort of Neid, the brave and beauteous seion,

[Then] passed Corgeann through the middle of the plain of Shanny,

And soon reaehed the promontory of the bright Lakie of Febhal.

Of Febhal, the son of Lodan, the fair-handed, soft-shouldered

Child, o'er whom the lake had rolled the stone of his grave.

When Corgeann saw the stone of Febhal he soon seized it,

And carried it with him tho' a heavy load.

Ie told the Dagda truly without boasting-

"There is the stone outside, O restrainer of pride!"

The Dagda said, with countenanee of protection- " Truly,

The houses and the place shall takc name from this stone."

"Aileaeh shall be the name of this town of Banba [Ireland]

"Beyond every hill likc the hill of great 'Temur," said Dagda's Druid,-

Under the heavy stone sunk Corgcann-his heart broke-

And was, with due respeet, interred at the foot of an aged tree.

Thence is called Aileach of Aedh, of wind swift horses,

And Aileach Corgeann, he of the bold eternal peat.**

Hereupon were brought the two good men, in art expert-

Garvan, and Miehenn-to the hoary, grave Eoehy:

And he told these mild slender peoplc to erect a fort,

That should be a fort of beauteous eireles-the best in Erin-

And said to them Ncid Mae Indai, of severe mind,

"Let not the great hosts of the world ereet a fort like Aileach."

* Alluding to the famous peak now called Cruach Patrick, where Corgeann is said to have resided. 


\section{CITY OF LONDONDERRY.}

Ro $\delta^{a b}$ Zapban znımach az raipr raz rnaıe

Ro gob imćeallzana aro zimcell zaioı

Cainilc oenam oaingin Oilich $\delta^{e}$ p bopo raezhnach

Mullach zhizi na ngiall nzabzhech no ico aelcloch.

Carnic Nero mac Inoai a n Oilech an ainm lebain

Ir puc leir in mnar mbuilich no ba 1 mbpezaib

Nocho nucaro I zech nailich nech man neamain

Oilech Nero o Nero mac lnoa ainm in bale

Sul zucao aip in zainin arle aipmca faiple

Oilech friopenn fuilleo n anma fuain na oeazaio.

Nocho chuinehep i ceno nallich zeno ach Cemain

Oo puache Fmopiu co flaizh n Glban an fiule na zlom

Ni zaparo op veapr an oeiz meio ceno oz amlar

Fuboain ainm aıpopiz alban in eich opemain

Oo charao cnanngaio i n gonasb bia laim lebain.

Inzen con piz nuc o piznaib ir o nomnaib.

Oo uain fpirplu zpe alb nanbail cainiu chomparo

Oileach ainm ingine Uboain oa lean caimfin

Na pin uazeiconur buaio in zpao in $\delta$ aeioil

Co $n$ oeacharo leip oo lap chino zipı $\alpha$ zıр nutao.

Roizpem neman im apal choimling cpuao

Ro chuinoich Uboain a ingen zpe aich feapnoa.

No no lorpcfear leach na banba fa zheach zempa.

O oubaipr pir Eochaio Oomlen co nopeich parloin.

Hach bepao co bpar a ingin zpia farh amluio

Ro zob in ceno cumainci in niz pin niz Cempa.

Ro chumbieh aip oun in Oazoa no mup Mearoba

Proceeded active Garvan to work with art, and chip [the stones]

He placed circular ramparts around the house,

And finished

The top of the housc of the querulous hostages closed limestone.*

Came Neid Mae Indai to Oileaeh of broad arms (weapons)

And brought with him the beauteous woman who was in Bregia,

Never was brought into the house of Aileach one like Neman. +

Oileach $\mathcal{N}$ eid, from Neid Mac Indai, was the name of the town,

Before the other name was given that armory of watehing:

Aileach Frigreann the other name it reeeived afterwards :

Bove Aileaeh strong no other is placed but Temur.

Passed Frigriu to the ehief of Alba of the very fine hair,

The illustrious of good judgment [literati] do not mention a young artisan like him.

Fubdaire was the name of the monareh of Alba, of the furious steed

Who hurled spears into wounds with his huge arm.

A daughter had this king, who bore [the palm] from queens and famous women,

Whose agreeable eonversation Frigriu got by eourteous glanees:

Oileaeh was the name of Ubdaire's daughter ; she followed the mild man,

Being subdued by the love of the Gaedel

So that she passed with him from the middle of Kintire [Cantire] into the land

And they passed some

Demanded Ubdaire his daughether in a diffieult elopement:

0. that he would burs daughter with manly rage,

To him said Eoehy Dowe half of Banba around the house of Temur.

That he never wollain, with the fine eountenanee,

That he never would regain his daughter by sueh threats.

Sought the artifieer the proteetion of that king-that king of Temur,

And asked of him the Dun of Dagda, or the Mur $\ddagger$ of Meva.

* That is :- "limestone closed," \&c. according to the English order of the words.

In all the genealogies of the Tuatha de Dananns Neman is set down as one of the two wives of Neid, the
f Indai. son of Indai.

$\ddagger$ The Mur of Meva, i. e. the palace of Croghan, in Connaught, which was erected by the famous Queen Mab, who yet lives in the memory of the peasantry as an enchantress. 


\section{PAGAN ANTIQUITIES.}

Caemain a piz ap a pizu pe piz Femin

Chainech thazaio in zobain Oilech o Oilich

Aprin zucao Oilech o Oilich pech cach nimoaio

Oon chair zlezil co nonuaio pa zloin co nuaill nibnaio.

Oepin gainzhen Oilech frizneni fpich a bunao.

Ir o Oilech in Oazoa ar cac inaro aoba Ulao

Flaiehir Epino inoirzep linn ir na lebpaib

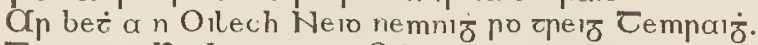

Eaniz pi fail co fuain Oiliz an uain alaio.

Con bi mazain Cholla cpioi onoma an oomain

a re reinnep ruezain $E_{\text {peno Ollech Frineno }}$

molaro ir mo na molbam oo ni oizenem.

Oa ficio bliarain ace bliarain bece oo pimar

¿nim zlas zlemep oo zeizeao le pil mac milear

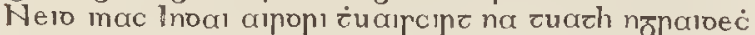

Ceio pep colach cap тpeizeao obac ap Ailech.

Nor piza oen ainm $a \mathrm{~h}$ Oilech ofine Croaim

Acur Eochaio ainm cach ém fin ne zalıım nzabaio

Eachaio ollarhain an ceio feap oo coipc oozpaing

Eochaio eozozac oo fuain inzpeim fa cpuaio comlainn

Eocharo Opziac Eocharo Feroleach reap na claroeam

Ri puc a beziaro co bunari $\epsilon_{\text {ocharo }}$ Q $_{1}$ im

Eochaio buarac Eocharo map oo mapbao cezhna

Eochaio Ooimlen fino oluiz fnomeha im oluiz noebża.

Eochaio muiomearoin mac Ciopis Inop renaid

Muin an muinen in ouine ap nap muio a noeabaio

Mac oon fin rin Niall oo neape an ooman oluizcheach

Sa mazain mop mineanz maifrec Cáıezen Cpuizhnech

Clanoa po Neill nionaio Oilich na napm naromap

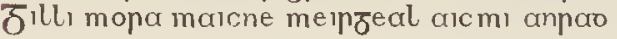

"Protect me, O King, against the rage of this king

Who has eome against thee,- and give Oileach to Oileach."

Then was given Aileach to Oileaeh, bcfore every place,

To the bright fair one with the splendid cheek, with the stately pride.

Hence the name of Aileach Frigreann is given to her lands,

And to the fort of Dagda, distinguished above every residenec in Uladh

The govcrnment of Ireland-it is told to us in books-

On being placed in Aileach Neid, abandoned Temur.

Came the king of Fail, and found Aileaeh one solitary time,

So that she became the mother of the Collas who figured in the world:

The oldest of the labours [works] of Erin is Oileach Frireann-

It deserves morc praise than I will here confer.

Twicc twenty ycars but one-exaet the computation-

Was this finc work erccted before it came to Mile's sons [sons of Milesius]:

Ncid Mac India, high king of the north, country of flocks,

Was the first brave man who placed his seat at Aileach.

Ninc kings of one name in Aileach, of Adam's racc:

Eochy the name of each-a dreaded sound!

Eochy Ollathair the first-he, who quelled disturbance;

Eochy Eadgothach, who rceeived persecution-he of the hard battle;

Eochy Opthach: Eochy Feileach, man of swords:

Eochy Airev, who established his right;

Eochy Buadhach [the victorions] Eochy mor, who slaughtered cattlc;

Eochy Dowlain, the fair, well proved in the contests thick.

Eochy Moyvaine, son of the monareh of Inehenny,

A sea in his offspring-he against whom the battle ne'er was turned,

Son to this man was Niall, who obtained great sway in the world,

His grcat, fair, slender, proud mother was Carina, the Pict.

The descendants of great Niall, kings of Oileach, of valiant arms,

Huge youths of white fingers, heroic tribe- 


\section{CITY OF LONDONDERRY.}

Eozan mae Neill co riepe milea⿱ o meı leınım Opeach oa zizearo moeam einiz fino fep Feabail. Ineaçrio inzen piz monaiz mazain Eozain

Co naig Neupro co pun zpein fin co luo leomain

Cinel Eozaın uarli finoa fine zemna

Meoip pa noabap fainne imea ailli inepla.

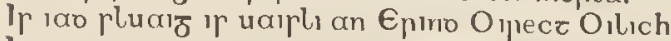
Ir ido ir fenn fa mao feocin żoip ca ziסוb

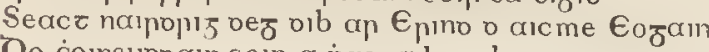
Oo correlrooar caip a raezall boib a n-oeonar

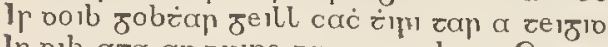
Ir oוb aza an ouine oizaıno ullı ap $\epsilon_{\text {pino }}$ Cuaparo eolać oo innir oa cać fiazain

Oinnjeancur Oibiz in uabain volliz o:amain

Oapreallur ope ć oearo oear ne beabaı znear na żizıb

Ir é fa haınopi an oomaın znım na znaıbib

On zan fpiz az loc aobal febail aroan Oiliz

Seachemozaro ap re ceouib bliarain blao no cianu

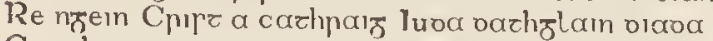

Cearhnacaro ap ceo ap cuis milı or na muizib Se bliana piu nann na comain żall im żizib Cun zabao az mop riuaz monarz ópouan Oilrz

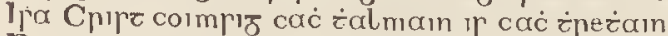
Rı zan ia an noainı fo oażab aill eazorl.

Eogan, the son of Niall, with strength of a hero from the size of a child, Countenanee, in whiel shone hospitality-fair man of Foyle.

Ineaehtfee, daughter of King Monaeh, was mother of Eogan-

He with the valour of royal Neid, * with the resolution of a hero, with the strength of a lion,

The Kinel-owen, nobles fair, tribe of Temur',

On whose fingers are rings, beautiful, loose,

The noblest host in Erin is the meeting of Oileach

They are the best and most honourable at their houses:

Seventeen monarehs of them [ruled] over Erin, of Eogan's raee,-

They defended their right against foreigners.

By them are reeeived the hostages of eaeh eountry, over whieh they pass,

Of them is the man who is the Defender of all Ireland:

Cuarad, the learned told to eaeh witness

The Dinnseanchus of Aileaeh of pride-difficult, obscure.

Dareylus of the ruddy faee, expert in the battle, of strong houses,

Was monareh of the world, aetive in his dignities-

When was found at spaeious Lough Foyle, the eause of Aileaeh,

Seventy years on six hundred-a famed remote period-

Before the birtl of Clurist in the Jewish eity, fair, pious;

Forty, one hundred, and five [two?] thousand from the eruptions,

Six years before the separation of the Comars with the houses,

Until assumed the great host of Monaeh, the superiority of Oileaeh.

Jesus Christ proteet each land and eaeh sea.

O King of the fair-eoloured land of our people, I implore thee.

It appears from Irish listory, that the nine kings mentioned in this poem as having pre ceded Owen, who flourished in the 5tli eentury, did not sueeed one another, but that several intervened between them. 'The periods at whieh they flourished are thus set down in O'Flaherty's eorreeted Irislı Chronology :-

1. Eochy Ollatmair, or the Dagda, eommeneed his reign A. M. 2804, and governed the Tuatha de Dananns 80 years, the same number as Aiod, of the tribe of Benjamin, governed the Hebrews.

2. Eochy Eadoothacir. He was the fourth in deseent from Looee, the son of Ith, the unele of Milesius : he eommeneed his reign A. M. 3041, and ruled 4 years.

* Neid was the Mars of the Pagan Irish.

+ That is:-the stone from which the name was given. 


\section{PAGAN ANTIQUITIES.}

3. Eociry Opthach. He was also of the racc of Looee, and commenced his reign A. M. 3432. Forty-one monarchs intervened between these two.

4. Eoch F Feidhleacir. He commenced his reign A. M. 3922, and ruled 12 years.

5. Eochy Alremi. He commenced his reign A. M. 3934, and ruled 10 years.

6. Eоch Y Buninach, or the victorious, appears to be another name for Eochy Gunat, who governed Ulster 13 years, and commenced his reign as monarch of Ireland A. D. 27\%, and
died the year after.

7. Eociry Mon does not appear among the monarchs of Ireland, but is found among the list of the kings of Uister, in the book of Lecan, as Eochy, the son of Lugh, who was the
son of Ross.

8. Eocuy Dowlain was the son of Cairbry Liffecar, monarch of Ireland. The bard calls this monarch king of Temur, which means monarch of Ireland; but it does not appear. from Irish history that he ever attained to that eminence, though it is probable that he was king of Ulster. He was the brother of Fiacha Sraivtinne, who was monarch of Ireland for thirty years, and was killed by his nephews, the three Collas, the sons of Eochy Dowlain, in the battle of Dubcumber, in 322. Collas Uais, who succeeded his uncle as monarch of Ireland, was deposed after a reign of 4 years, and fled to Scotland.

9. Eochy MoYvain mounted the throne of Ireland in 358. He was the grandson of Fiacha Sraivtinne, and as the poem states, father to the celebrated Niall Naoigiallach, or of the nine hostages. Carina, the mother of Niall, is called the Pict in the poem, but the Saxon woman by Tighearnach, and the books of Lecan and Ballymote, in the account of the illustrious women of Ireland.

If any reliance can be placed on Irish chronology, it will be seen that the antiquity of this building would be very great indeed, no less than upwards of a thousand years before the Christian era; and it is curious that the old poet, in making Eochy Ollathair, or the Dagda, synchronize with the Assyrian monarch Darcylus, exactly agrees with this chronology of O'Flaherty-the period assigned to that king by Usher being before Christ 1053. As it is stated, however, by Tighearnach, the accurate annalist of Clonmacnoise, in the 11th century, that "all the records of the Scots before the time of Kimbaoth are uncertain," that is to say, in the year 305 before Christ, this chronology must be regarded as the work of later times, and treated accordingly.

Passing, however, over this statement, and whatever clse may be fabulous or doubtful in the legends in this poem, there is obviously much still remaining that may be regarded as historic truth, and as evidences of the very remote antiquity assigned by distant traditions to the work to which it relates. The accuracy of the description of the ancient palace is fully verified by its existing ruins, and there appears no reason to doubt that the names of its builders, Garvan, Michan, and Frigriu, are real names, preserved by tradition. Without entering on the very difficult question respecting the claim of the Irish to the use of letters before their conversion to Christianity, it appears certain from this poem, that the ancient traditions of the eountry were committed to writing at least at a very early period after that cvent; for the writer, who, it is certain, from internal evidences, must have written in or before the 11 th century, refers to Cuarad an Eolach, or learned man of an earlier, and as it would appear, a distant age as his authority. The names of Garbhan and Frigriu are found in many other ancient Irish authorities as the builders of Aileach, and the latter is ealled Frigriu, the son of Ruibi Ruadh, who was the son of Didiul, and is stated to have been one of the Fomorians, or African mariners, celebrated for their skill in building with stone. The celebrated Irish antiquary, Duald $\mathrm{M}^{\prime}$ Tirbis, in combating the assertion of modern antiquaries, that the Irish were acquainted with stone buildings before the arrival of the Danes and English, quotes as evidence of the fact an ancient poem, written in or before the 10th century, by Donmell the son of Flanagan,
in which these two persons are named as the builders of Aileach.

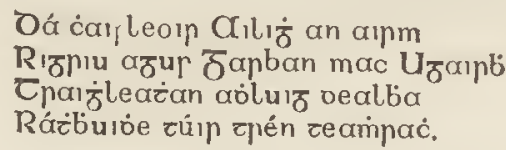

The two cashelors of Aileach of the army,

Rigriu and Garvan, son of Ugarv,

Traighleahan [Troylane] who split figures;

The rathbluide [rath-builder] of the strong tower of Temur.

And from this verse it will also be seen, that the ancient Irish had distinct terms to denote builders with stone and earth, and that a true distinction was made between the cashel, or stone 


\section{CITY OF LONDONDERRY.}

fortress of Aileach, and the rath or earthen one of Temur, as the existing remains in both places sufficiently testify.

A fact of greater importance, established by this pocm, is that its erection was not attributed to that dubious racc, the Milesians, whose reality has been impugned by Innes, Pinkerton, and Thomas Moore; but to the Tuatha De Dananns, a Scythic or Gothic people, whose historic existence is acknowledged by all those writers to stand on a more solid basis: and it is a remarkable circumstance shewn in Mr. Petrie's Prize Essay on Ancicnt Irish Military Remains, (1834,) that all the Cyclopean monuments, whether military or scpulchral, are ascribed by the Irish historians either to these Dananns, or their kindred race the Firbolg, or Belgæ. The uniformity pervading all thesc Danann and Belgic monuments in Ireland, has been proved in that cssay, as well as their perfect similarity, not only with the stone remains of the Picts in that cssay, as well as their perfect similar Wiltshirc, Devonshirc, and Cornwall; but also with thosc monuments in Bclgium, Grecce, Italy, and the islands of the Mediterranean, known among antiquaries by the term Cyclopean.

"To say who the Cyclopeans originally were," Mr. Petrie observes, "is beyond the scope of the present inquiry. It is one which the most learned mon have found difficult to answer, and which it would bc presumptuous in the writer to attempt to determinc. There is, however, such a singular agrcement between the accounts given by classical writers, of the builders of those remarkable rcmains in Grecce, and those prescrved by our native chroniclers of the buildcrs of the uncemented stone works in Ircland, England, and Scotland, as should not be passed unnoticed."

"Pliny," observes Mr. Dodwcll (vol. ii. 'p. 218), "says that according to Aristotle, towers were invented by the Cyclopeans, and according to Theophrastus, by the Tirynthii. The Scholiast of Statius prctends that every thing that was remarkable for its great size, was said to have bcen formed by the Cyclopeans. The great difficulty, however, is to ascertain said to have bcen formed by the Cyclopeans. The great diffculty, however, is to ascertain who the cyclopcans were, in wopes that it be fully refrain from entering into a long discussion upon systcm, (M. Pctit Radcl,) whose work, which investigatcd by the learned promoter of this systcm, (M. Pctit Radcl, ) whose work, which is earnestly expected, will, no doubt, throw new light upon this recondite and long neglected part of primitivc history; it suffices, at prescnt, to observe, that Strabo had as confuscd ideas about the Cyclopeans 18 centuries ago, as we have at present; he says that they were seven in number, and come from Lycia. The scholiast of Euripides, however, maintains that they werc a Thracian nation, so named from onc of their kings, and that they were the best they werc a Thracian nation, so named from military fortifications, and to have diffused their architectural knowlcd e through Greece, and many parts of Italy, Sicily, and Spain. These architure countries were colonized by the Pelasgi of Greecc, who the the Cyclopeans were the Pclasgians, who scttled at a very remote pcriod in the Peloponnesus, for it is generally allowed that they were strangers and not autochthonesian."

Ihre was convinced that the Pclasgi were Scythæ, and Pinkerton has (apparently) proved it "Historic Truth"- that the Pelasgi, or Hellenes, or Greeks, nere Scythians of Thraee. (Dis. on the Scythians, Part I. cap. iv.)

The Firbolg, under which name is included the Dammonii and Galenii, according to the books of Lecan, Ballymote, and all the other ancient Irish authorities, wcre of the Greeks of Scythia, and came hither from Thrace. The Piets and Belgic Britains were of the same race, and also came from Thrace.

The Tuatha De Dananns werc also Scythians of Greece, but are said to have come from Beotia, thence to the north of Europe, to Scotland, and lastly to Ireland, (Book of Lecan, folio). This colony, as wcll as the Firbolg, are represented as superior in their knowledge of the arts of civilized life to the Gael (Celtæ) or Milesians, their supposed successors. Whether the accounts of these races be wholly Bardic forgeries, or whether they may not have, in their chief facts, a traditional origin in truth, howevcr subscqucntly blended with fable, I in their chief facts, a traditional origin for himself, but I cannot hclp observing, that they seem shall leave the readcr to detcrmine for himself, but I cannot help observing, that Greece, Italy, wonderfully bornc out by the similitude between the Cyclopean nescribed.

and the islands of the Mcditerranean, and those which I have now described.

I have already spoken of the curious agreement between the monumental remains of the Damnonii in Devonshire and Cornwall, and those of the Damnonii or Firbolg in Ireland. The eastern, or Phœnician, origin of the former is strongly insisted on by the learned antiquary Mr. King, in his Monumenta Antique, in support of which, the most striking evidencc appears to be that drawn from a comparison of the form of the Median city of Ecevidence a related by Herodotus, with that of the ancicnt British castle of Launceston, in batana, as related by Herodotus, with that of the ancicnt British castle rcmarkablc as that Cornwall: the similarity pointed out is indeed strilsing, yet it is not so remarkablc as inaswhich will be found between the eastern city magnitude, and is built with lime cement, a cir. much as that the Cornish castle is of inferior magnitude, 


\section{PAGAN ANTIQUITIES.}

"The Medes being obcdient to him, Dejoees, in all thesc matters; he (Dejoces) built walls both great and strong, these whieh are now ealled Eebatana, each one in eircuit surrounding the other, and each wall so artfully constructed, that the one surpassed in height the other only by its battlements ( $\pi \rho^{\circ}$ peo $\left.\chi^{8 \omega \sigma}\right)$ : the very nature of the enelosed area aided this mode of construetion, it being on a high pointed hill, so that sueh a design might be well executcd, and still more did the pains bestowed cffect it.

"'Thus far" (says Mr. Petrie) " the'dcscription would apply equally to Dun Aengus; and in the details whieh follow the differenees are only sueh as point out the superior magnificence of the Median palaee to the Dun or Cahir of the Hibcrno-Belgic ehief.

"All the surrounding walls being in number seven, within the last was (were) the royal apartments and treasurcs; the grcatest of the walls answers (somewhat) to the greatest circuit of the walls of Athens; (this eireuit was inferior to that of the hill of Aileaeh); and of the first (or outcrmost) surrounding wall, the battlemcuts are white. But of the seeond, they are black. fifth of a reddirh sunding wall, they arc all Phœenician purplc. Of the fourth blue. Of the colours artifieially prepared and so of all the rest; all around the battlements are adorned with

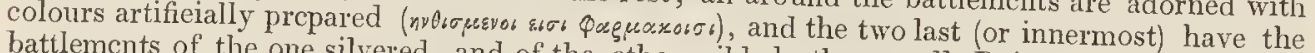
bither gilded; these walls Dejoces construeted for limself, and for enclosing the dwellings of those who belonged to him; but as to the rest of the people, hc ordered them to inhabit around the wall (or suburbs ;) and when all was built, DeKing, but that all bustablished this ordinanee, that no onc should enter into the palaee to the seen of no one.

"Allowance,"

point of magnitude between one of, "must unquestionably bc made for the vast difference in turcs in the east, where arts first the first and most sumptuous patterns of those kind of strueremote island of the more distant imitations of them in a description of Eebatana in Media, exeept Britain was. But yet, surcly in reading Herodotus's richly ornamented exana in Media, exeept mcrely as far as relates to the gilding and silvcring, and instca upon a grander scale." (Momumentast reading the deseription of Launeeston castlc, extended

These reale." (Monumenta. Antiqua, vol, 3.)

of Aileach, and the arc equally applieable to the Belgie fort of Dun Aengus, and the Danan one of chance, and affords a strong poth instances is such as eould hardly have been the rcsult origin. torieal poems, as well as in the lives of saints, Aileach preserved in the authentie annals, and hisof the kings of the nathe seat siderably anteeedent to the ino southern, from a period con.

In the tripartite life of St. Patriek of Christianity down to the close of the 12th century. Evin in the 6th century, Ailcach is spoken of as said to have been originally written by St. bcfore St. Patrick's time; and is spoken of as the remotely ancient seat of the Irish kings appears from internal time; and an historical poem, preserved in the book of Lecan-which gives a list of its forty-four to have been unquestionably composed in the 11 th centuryFith Eoghan the son of Niall in the The substanee of this poem will be found in in 1061, in whose reign the pocm was eomposcd. account of the revenues and we found in the introductory eounty history, as well as an subsidies paid to theies and rights paid to those lings from the subjcct territories, and the The paid to their petty dynasts, for thcir serviees in war, \&c.

The following notiees appear in the various Irish annals:-

A. D. 674. Aileach Frigreann was plundered by Finsneachta, the son of Donchadh (king of Ircland)

937. Aileach Frigreann was plundered by the Dancs.

1101. Mortagh O'Bricn, king of Munster, at the hear.

sory, Meath, and Connaught, marehed with a a the head of the forces of Lcinster, Osprocceded into Inishoweu, whieh he plunded (Ballyshannon), and fortresses revenge of the destruetion and demolition of and demolished the Grianan of Aileach, in some time before (1088) and demolition of Ceanneora [Kincora] by Donnell Mae Loughlin of the demolished building for Aileaeh to Limerick a stone

This is the last notiee for evcry saek of provisions whieh they had with them.

Annals, and it appears never aileach, as a residenee of the kings, to be found in the Irish rorthe king of the Kinel-Owen or the kings of the southern Hy Niall did for some time the name of Aileach as their title, as was rcmoved to Inis-Eanaigh in the deserted Temur or Tara-but their palaec to be their residence after the parish of Urney, in Tyrone, whieh probably continucd distinction of Aileach, like that of Emania, was regarded as an epoch in Irish history. In 


\section{CITY OF LONDONDERRY.}

1589, when Red Hugh O'Donnell plundered Thomond, the territory of the O'Briens, who were then leagued with Queen Elizabeth, Mac Brody their chief poet and historian, as the Four Masters record in their annals, wrote that it was in revenge of the destruction of Aileach by Mortagh O'Brien that God, in consequence of the curse of Columbkille upon his race, permitted Thomond to be so dreadfully devastated.

It will have been seen that the preceding notices of Aileach have been drawn entirely from Irish authorities, but it should also be stated, that there are strong grounds for believing that its existence as a royal seat or town was, as might naturally be expected, not unknown to Ptolemy, the Greek geographer of the second century, in whose map of Ireland it appears to be marked under the appropriate classical name of Regia, and situated on the west of his river Argita, which scems to be a translation of the Irish word Fin, the name of the principal or parent stream of Lough Foyle. It is not a solid objection to this supposition, that the situation of Ptolemy's Regia is not laid down with perfect accuracy. In a map which must have been drawn entirely from the reports of merchants or mariners, no exact position in localities should be expected, and certainly is found in no one instance. We should, perhaps, rather wonder at Ptolemy's general accuracy, when we consider that all the maps of Ireland, from the time of Norden and Jobson, in the reign of Elizabeth, down to the survey by Sir William Petty, often misname, and sometimes lay down, remarkable places altogether out of their proper localities : and it is a remarkable fact, that even in our own times the situation of Aileach is marked, by two of the most distinguished Irish scholars and topographers, Charles $\mathrm{O}^{\circ} \mathrm{Conor}$ and Haliday - as far from the actual locality of the palace as Ptolemy places his Regia.

It may, perhaps, be further objected that-though Ware, and most other antiquarics and geographers of the 17 th century, concurred in the opinion that the Argita of Ptolemy was the Fin, or river of Lough Foyle, and his Vidua, Lough Swilly, Camden-on the contrary, conjectured the Argita to have been the Swilly, and the Vidua the Crodagh, a small river in Donegal-and that this conjecture is corroborated by the map of Richard of Cirencester-said to be drawn from ancient authorities in the 14th century-which was unknown to Camden, having been but recently discovered. To this objection it may be replied, that the authority of Camden alone should be held as of little consideration in this inquiry, as his conjectures respecting the locality of Ptolemy's names in Ireland are in most instances erroneous, and that to concur with him on this occasion, we should also give assent to the supposition of the Rev. Charles O'Conor and others, that the Logia of Ptolemy is Lough Foyle, though it seems beyond question to be the Lagan, which is called Locha by the ancient Irish, and Logan by the early English writers. Neither does the authority of Richard add any great weight to Camden's conjectrire, though the difficulty is lessened by that writer, who throws into his map, between the Argita and Logia, as if they had been omitted by Ptolemy, not only the Banna or Bann, but also the Foyle, to which he gives the very suspicious name of Derabhona, or river of Derry. For, in the first place, it may be remarked, that his authority has been lately impugned, and in the second, that--even allowing his work to be genuinc, as Stukely and Pinkerton believed-it would still be as the latter observes, the height of absurdity to set his authority against that of Ptolemy when he differs from him. Be this, however, as it may, it is worthy of remark, that Richard, in transferring the Argita of Ptolemy to Lough Swilly, and inserting the Derabhona in its place, marks a city, which, though without a name, is evidently the Regia of Ptolemy in the exact situation of Aileach-namely, between the Derabhona, or Derry river, and the Argita, which is his Lough Swilly.

In conclusion-if the Regia of Ptolemy be considered, from the preceding evidences, as the Aileach Neid of Irish history, a point of great importance will be gained towards the general elucidation of the map of Ireland by that ancient geographer: may it not be added, that no other conjecture will combine so many plausible and concurrent evidences of probxbility in its favour? 


\section{PAGAN ANTIQUITIES.}

\section{St. Columb's Stone.}

Next to the Grianan of Aileach, the most remarkable remain of antiquity connected with this parish, is that ealled St. Columb's Stone, situated in the garden of Bellmont on the Fahan road, about a mile fiom Derry. It is marked on the map of the siege made by Neville, and reengraved for this memoir. This stone, which is of granite, exhibits the seulptured impression of two feet, right and left, of the length of ten inches eaeh, and is otherwise unmarked with the chisel. Its general form and measurements will appear from the annexed wood-cut.

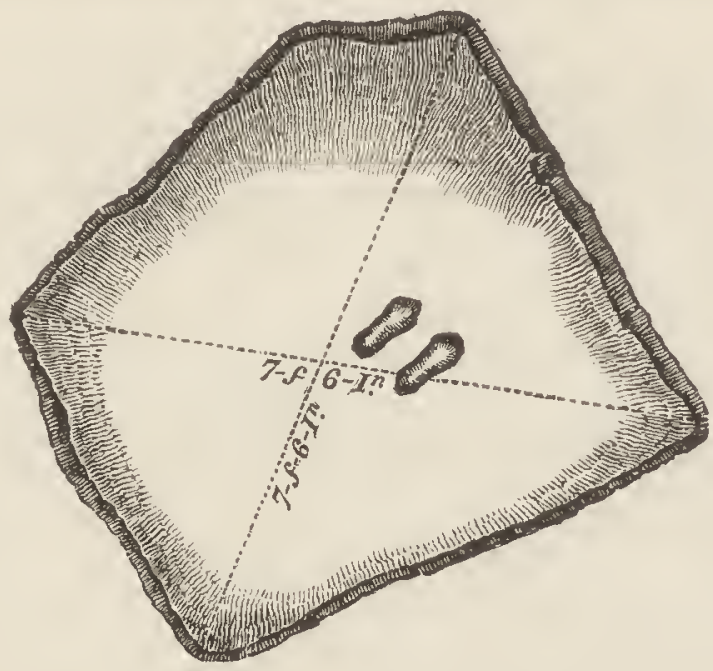

Though this monument is held in great veneration, there is no tradition connccted with its origin worthy of notice. It appears, however, to have been one of the inauguration stones of the ancient Irish kings, or chiefs. That stones of this kind, as well as rude stone ehairs, were used in the several distinct territories, appears not only from the existence of several to this day but also from the testimony of the poet Spenser, who thus spcaks of them in his interesting "Views on the State of Ireland." "Thcy used to place him that shall be their eaptain upon a stone always reserved for that purpose, and placed eommonly upon a hill, in some of which I have seen formcd an engraven foot, whieh they say was the measure of their first cap tain's foot, whereon he standing reeeives an oath to preserve all the ancient former eustoms in violable, and to deliver up the suecession peaeeably to his 'Tanist, and then hath a wand delivered unto him, by some whose proper offiee that is."

It is not, perhaps improbable, that this stone may be the identical one appropriatcd to the inauguration of the kings of Aileaeh, from a period even anteeedent to the establishment of Christianity in the country. That a stone conseerated to this purpose aneiently existed at Aileach, appear's from a passage in the tripartite life of St. Patrick, in which it is thus expressly
mentioned.

"The man of God accompanied Prince Eoghan to his palace, which he then held in the most aneient and eelebrated seat of the kings, called Aileaeh, and which the holy bishop eonsccrated by his blessing, promising that from the seed of Eoghan many kings and princes of Ireland should spring; and as a pledge of which he left there a certain stone, blessed by him, upon whieh the promised kings and princes would bc ordained." ('Triad. Thaum. p. 145.)

That such a stone, therefore, existed at Aileach, is unquestionable, and there is little reason to believe that it was ever destroyed, bccause with the Irish it would have been held sacred, and the English had no power in the country till the eommencement of the 17 th century, at which time it is recorded as a memorable fact, that they broke down the crowning stone of the O'Neill's at Tully $\mathrm{Og}$, and if they had destroyed any other crowning stones, we should not be without historic notice of the cireumstance. No stone of the kind is, however, now to be found at Aileach, which was deserted in the 12th century, - and it is not improbable that its ancient inauguration stone may have been removed to a more convenient site in the vieinity of Derry, for the use of the O'Doghertys, its more recent local chiefs, and be so used till the extinction of their independent existence. Against this eonjeeture, the traditional name of the monument should weigh but little, as the stone might have been, and very probar it has been the constant habit of the Irish people, when their local history was lost, to connect 


\section{CITY OF LONDONDERRY.}

their aneient remains with the name of the most popular, or patron saint of the district. 'Thus we find that the devastation of Thomond, by Red Hugh O'Donnell, at the close of the 16th century, was popularly supposed to be the effeet, not of St. Patriek's, but of St. Columb's curse, in revenge of the destruction of Aileaeh by the O'Briens, fire eenturies before.

There is also an artifieial mount twenty-five feet square, and raised about four fecs from the ground. It is called St. Columb's mount, and was probably the platform on which the stone formerly stood.

\section{Section 2.-Aitiquities.-Christian.}

Ecclesiastical.-The old Church of Killea or Killeagh, ("Grey Churcte"), whieh gives name to a townland, and was formerly one of the five chapels of ease of Tcmplemore, has not been used for divine service sinee the Reformation, and the foundations only now remain. It was of an oblong form, 60 feet by 30 ; the grave-yard, which is still used by the peasantry of the vieinity, is surrounded by an exeellent stone wall 7 feet high, whieh appears to be of equal antiquity with the ruined cliurel, there is an aneient gateway, now built upon the north-eastern side, 5 feet 6 inehes wide, and 5 feet 7 inehes high. The graveyard eontains no inseriptions worthy of notiee.

The Churcte of Culmore, or properly Cuilmorc (the great angle), though a ruin, is of no great age, having been built, as we learn from Arehbishop King's visitation book, before the late troubles, and burned by King James's army, since whieh it has never been repaired. It was obviously intended for the use of the Protestant garrison of the fort. This cluureh whieh was of no mean strueture, consisted of a nave and transept in the form of a eross, with a square steeple at its W. end. Its extreme length was 54 feet, and its breadth in the transepts 46. - With the exeeption of the W. end, the walls are still entire. Aeeording to tradition the hody of the Freneh general De Rosen was interred liere, as well as that of the person who killed him-but tradition is most generally a blundering chronieler, and in this instanee erred, at least in the name,-for De Rosen was not killed, but the Freneh general Momon fell at Pennyburn, and was very probably interred here. It is also said, that divine serviee was performed only twiee in the ellureh previously to its destruetion.

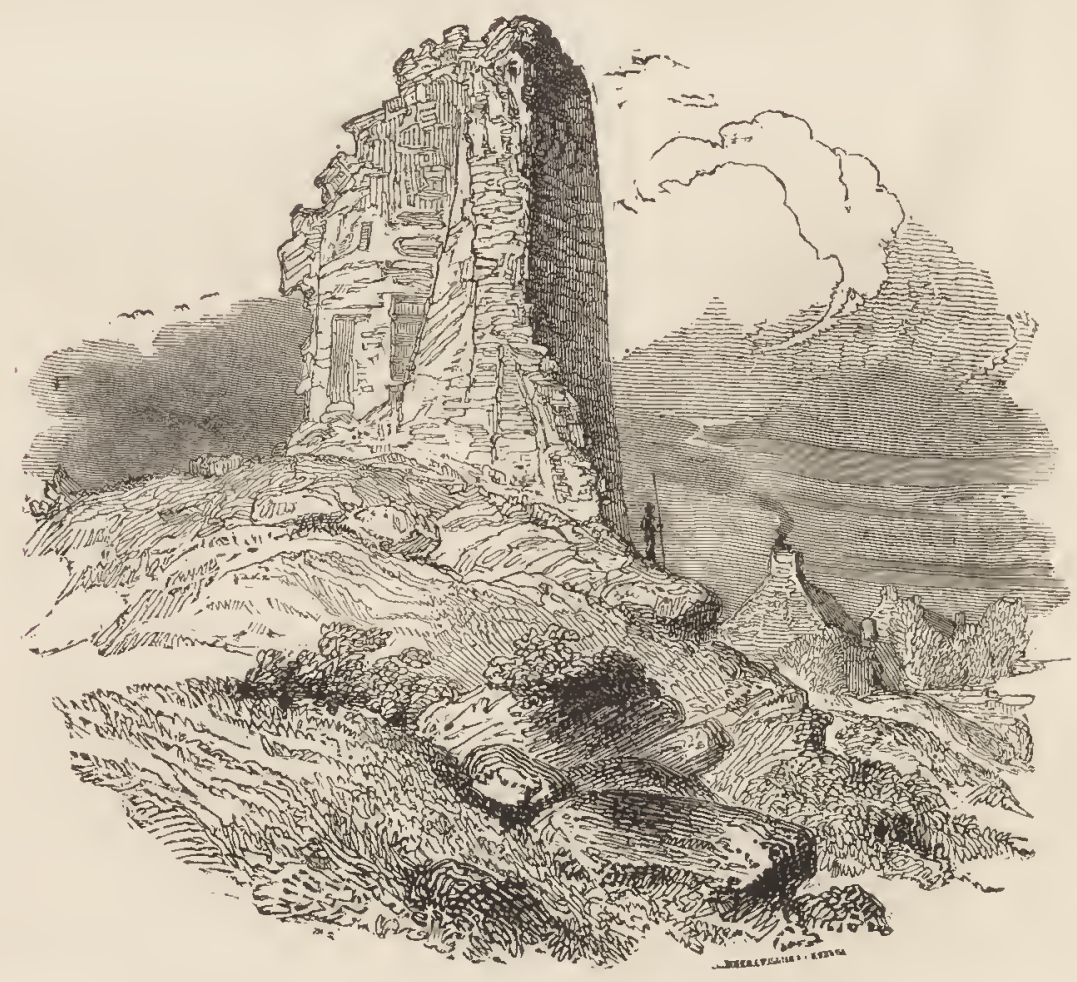

Military. The eastle of Aileaeh, or Elagh, though at present but an insignifieant ruil, claims attention, as retaining the name of the aneient fortress of the northern kings already no- 


\section{CHRISTIAN ANTIQUITILS.}

ticed, and with which it has in consequence been latterly confounded. In what manner this name was originally so transferred; whether given by its founder in remembrance of the more illustrious regal residence, or as more probable, merely bestowed in consequence of its situation within the district still called Aileach, it is fruitless now to conjecture, and is a question now of little moment. This castle is situated on the verge of the parish, in the townland of Elaghmore, on a gentle but commanding eminence, 248 feet above the level of the sea, (sheet 13;) and is about 2 miles distant from the more ancient fortress. Neither the date of its erection, nor the name of its founder are preserved in the Irish annals, but tradition assigns the erection of it, as well as the neighbouring castles of Burt and Inch, to the O'Doghertys; and their exactsimilarity in form and style shews them to be of the same age, and designed for a common objectwhich was obviously the defence of the peninsula of Inishowen.

From an examination of the castles of Burt and Inch, which are still in a tolerably perfect state, we find that each consisted of a lofty square keep, with semicircular towers projecting from two of the angles, and strengthened by an outward ballium; and of these castles, that of Burt was, according to O'Sullevan, and the inquisitions, O'Dogherty's chief fortress of Inishowen. Of Aileach, a portion of one of the semicircular towers only now remains, the chief portion having been used as building materials in the adjacent village. The form and style of these castles indicate their erection in the 15 th century, and history furnishes a strong though indirect evidence of their origin in that age. It is certain that the peninsula of Inishowen was anciently, as its name indicates, and has been historically shown, the original territory of the Kinel Owen, and that after the O'Neills, the chief family of this race had forced their way by conquest into the more southern territories called after them Tir Eoghain, or Tirone. This original district formed a portion of the territory of the $\mathrm{O}^{\circ} \mathrm{Gormly}$ 's, chiefs of the Kenel Moen a branch of the same stock. After the fall of the monarcliy in the 12th century, however, the increasing power of the Kinel Comnell cnabled them, after much contention, to add this district to their ancient possessions, and place the O'Doghertys, a distinguished family of that race, over it as tributary chiefs. And though we have no very cxact account of the circumstances connected with its occupation by this family, the Irish anmals afford such evidences as are sufficient to show that it must have been about the commeneement of the 15th century: for it is at this period that we find them for the first time add the title of Lord of Inishowen, to that of their more ancient patrimony. This will appear from the following extracts from the annals of the Four Masters.

1342. Donnell, O'Dogherty, chief of Ardmiodhair and the cantred of Tir Enda, a man abounding in hospitality and valour, died.

1359. John O'Dogherty, chief of Ardmiodhair, was killed at Ballyshanny, (Ballyshannon.)

1407. Owen O'Dogherty, hcir to the chieftainship of Ardmiodhair, dicd.

1413. Conor O'Dogherty, chief of Ardmiodhair, and Lord of INIsHowen, a man full of generosity and general hospitality to the poor and the needy, died.

This is the first notice which occurs in these annals, of the ODoghertys as Lords of Inishowen, and henceforward, they appear to have held it as tributary lords, sometimes under O'Neill, but usually under O'Donnell, till it was confiscated in the 17 th century.

It appears certain, therefore, that the castles of Aileach, Burt, and Inch, were not crected previous to the 15 th century, nor is it likely that they were built at a more recent period, as they were then indispensably necessary to the security of the territory, the possession of which was contested fiercely and witl great loss of life, by O'Neill and O'Donnell, the rival chiefs of the great races of Kinel Owen and Kinel Connell, till the commencement of the following century, when $\mathrm{O}^{\circ} \mathrm{Neill}$ was obliged to make a formal surrender of his right to it. According to the Four Masters, in 1512, O'Neill was forced to obtain peace from O'Donnell, by a formal renunciation " of every claim which had been disputed between their ancestors, of the rents of the territories of Kinel Moen, Knishowen, and all Fermanagh;" and in 1514, after mutual preparations for annother combat, ONeill was induced a second time to surrender his claims to these territories, on which occasion the annalists state, " he gave nev charters, (capraca nuab) to O'Donnell, together with a confirmation ot the old ones of Kinel Moen, Inishowen, and Fcrmanagh." During these contests, as we lear'n from Irish MSS., as well as Sir H. Dockwra's "Narration," the O'Dogherty was obliged to pay chief rent to the party uppermost. The rent exacted by O'Neill was sixty milcl cows each May day. That paid to the O'Donnell was sixty beeves and sixty milch cows each May day; and they were bound to send sixty horsemell and 120 foot soldiers to the field, and cntertain his Bonnaghts or hired auxiliaries, be they cver so numerous, for the space of nine nights. The Eric or mulct, paid by the territory for killing a man, was 168 cows. In the time of Red Hugh O'Donnell, the chief rent for Inishowen was increased to sixty beeves three times a year, or 180 annually.-
(Original Irish MS.)

During the existence of the monarclyy, as appears from the book of rights, Inishowen ranked among the five free territories, but its chiefs were obliged to wait on the king in all public assemblies, and also to aid him with his forces ill time of war. The gifts which the 


\section{CITY OF LONDONDERRY.}

Ting of Aileach bestowed on the Prince of Inishowen, when he had occasion for his services were, 7 slaves, 7 women, 7 swords, and 7 goblets.-(Leabhar Lecain, folio 188 , et serzen.)

It will be seen in the introduetory history, that Sir Henry Doewkra, previous to his oeeupation of Derry, and immediately after his landing at Culmore on the 16 th May, 1600, took the Castle of Aileaeh, whieh "Sir John O'Dogherty had reeently abandoned, and begun to pull down," and garrisoned it with Captain Ellis Floude and his company of 150 men. And also that this garrison was attaeked by the O Dogherty's on the 28th June following, on whielı occasion Sir H. Doekwra and Sir John Chamberlain, with 40 horse and 500 foot, liastened to the assistanee of the besieged, and in the pursuit of the Irish whiell followed, the former had his horse shot dead under him, and the latter lost his life.

On the deatl of Sir John O'Dogherty, in December following the Castle of Aileach was restored to his son Sir Cahir, who though not yet arrired at manhood, was appointed chief of his eountry by Doekwra, in opposition to his unele Felim, appointed by O Donnell, and after having in return rendered the most sigual and important serviees to the government, in eight years after, in revenge as it appears of a personal insult, he rashly entered into that unfortunate rebellion, whieh deprived himself of life, and his race of property.

The Forts of Culmore and Dunnalong.-The forts of Culmore and Dunnalong, so distinguished in the history of Ireland during the 17th century, from their eonnexion with Derry, as "the fortresses of Lough Foyle," present in their existing state but little to interest, exeept what is derived from the recolleetion of their former celebrity. Their original plans will be seen from the annexed outlines, copied from original drawings in the MS, chamber of Trinity College. Of Dunnalong, whieh was originally the more important of the two, seareely a trace is now diseoverable, but its early importanee is still indicated by the eontinuance of its fairs on the 1st January, lst August, and 8th November. It is situated immediately outside the southern boundary of the parish, in the eounty Tyrone.-(See History).

The fort of Culmore has not been oceupied as a military station for the last 100 years, but it still preserves to some extent its original form and eharaeter. The barraek, and also the parapet wall which surrounded the tower, have both disappeared, but the earthen rampart and ditch, which extending aeross the tongue of land defended the fort on the land side still exist, and have bcen partly planted by Anderson $\mathrm{M}^{\circ}$ Causland, Esq. whose father, Abraham, sared the tower from ruin by a temporary repair at his own expense in 1785 , until General Hart, soon after his appointment to the governorship of the fort, about the year 1824 , repaired it in a permanent manner. This tower is reetangular, and measures $25 \frac{1}{2}$ by 24 feet, the walls are 6 feet thick, and eonsist of three floors or stories.

The origin of this fortaliee has not been aseertained, but it was probably erected by the $0^{\circ}$ Dogherty's in the 16th eentury. It was in the possession of the erown so early as 1556 , as appears from the following grant of Mary.-Patent Sept. 12, 1556.3 et 4, f. R. 3 .

"Richard Bethel and) Hereby they had a grant of the offices of Constables of Cragfergus

William Piers, gent. and of the works and Customs of the Town and Keeper of the $\int$ Castle, Lordship and Town of Culmore, with all the lands and Hereditaments belonging to Culmore. And for the better custody of the Castle of Cragfergus is granted to them the command or rule of twelve Harqueboshers, five Archers, one Porter and two Bombardiers; and for the better eustody of Culmore five Harqueboshers and five Archers with all usual fees and $8 d$. stcrling a day for eaeh Harquebosher, $6 d$. for each Archer, $8 d$. for the Porter, and $8 d$. for eaeh Bombardier, they pay into the Exchequer the rent of $£ 8$ Irish yearly, out of the said works and customs of Cragfergus."-(Liber Hibernia).

During the Tyrone rebellions and the reign of Elizabeth, Culmore must have been abandoned by the English, and was probably destroyed by Sir John O'Dogherty; but it must liave fallen into their possession, as Sir Henry Docwra, when he landed there in 1600 , only found "the butt end of the old broken eastle," around whieh he raised " a forte such as might be capable to lodge 200 men in." Having completed the works in six days, he left in it a garrison of 600 men, under the eommand of Captain Launcellott Atford. At the termination of the war this garrison was gradually redueed, so that in April, 1602, it amounted to only 100 , and in 1603 , to no more than 20 men, who were under the command of Captain Henry Har't. This Captain Hart, who is the aneestor of the present respectable family of Ballynagard and Doe Castle, "was appointed" by privy seal (Whitehall, Mareh 31, 1604) and by patent (Dublin, May 30, 1605) during pleasure (3 James I.-12 pars et R. 8) "to the custody of Culmore, in consideration of the great eharges and labours he had taken in the building and fortifying of the Castle or Fort, with a grant of the buildings and appurtenances thereof, 300 aeres of land adjoining thereto, and the fishing thereof during pleasure.'

At the breaking out of the rebellion of Sir Cahir O'Dogherty, in 1608, the fort of Culmore was gained by treaehery, Sir Cahir, having invited Captain Hart to a conference at Burneranagh, (Bunerana,) made him his prisoner, and obtained the keys of the fort, as the condition of his liberation. The fort eontained at this period 12 pieces of ordnance, and also 2000 books belonging to the bishop of Derry. For the latter, as O'Sullivan states, the bishop offered 100 pounds 

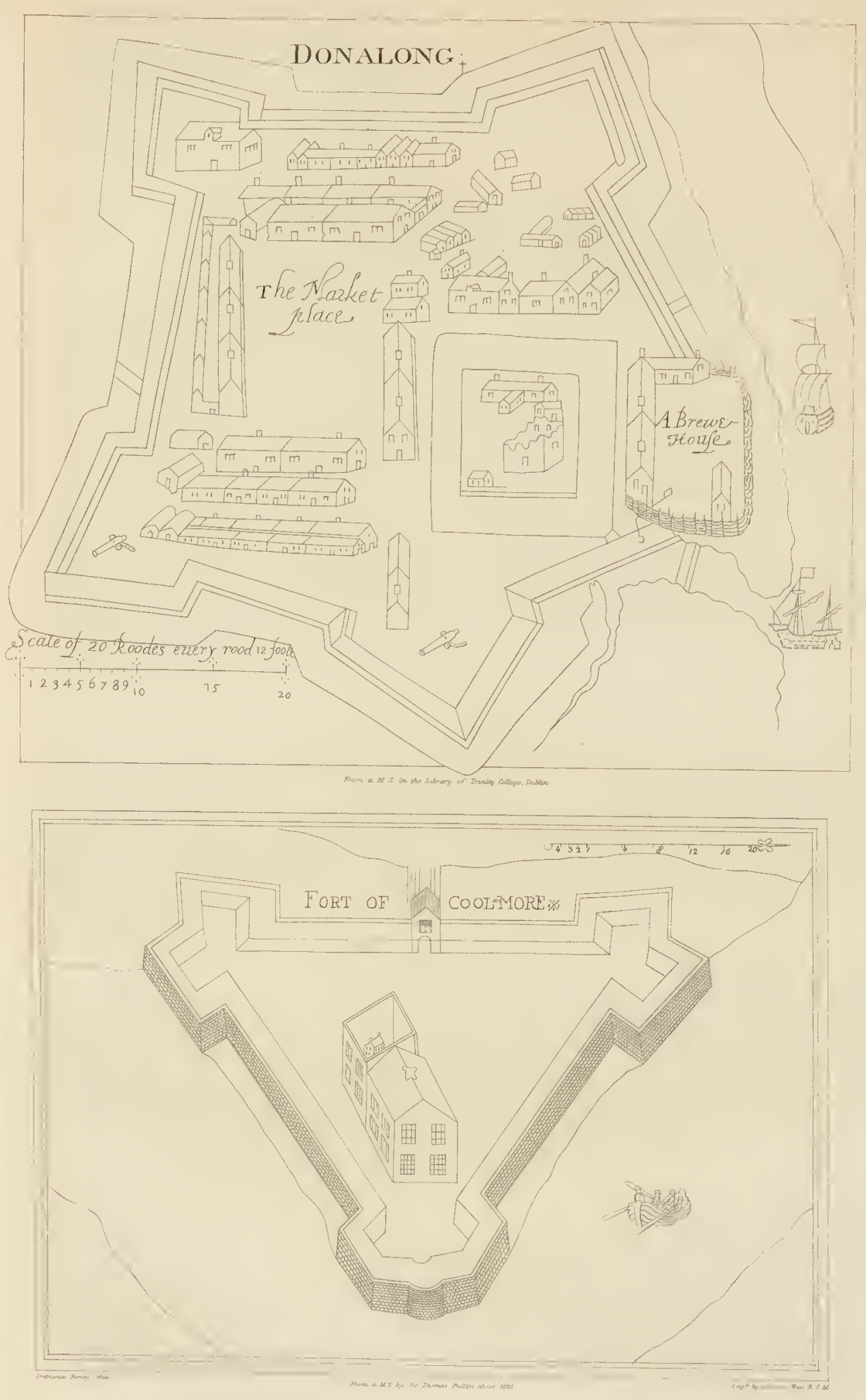


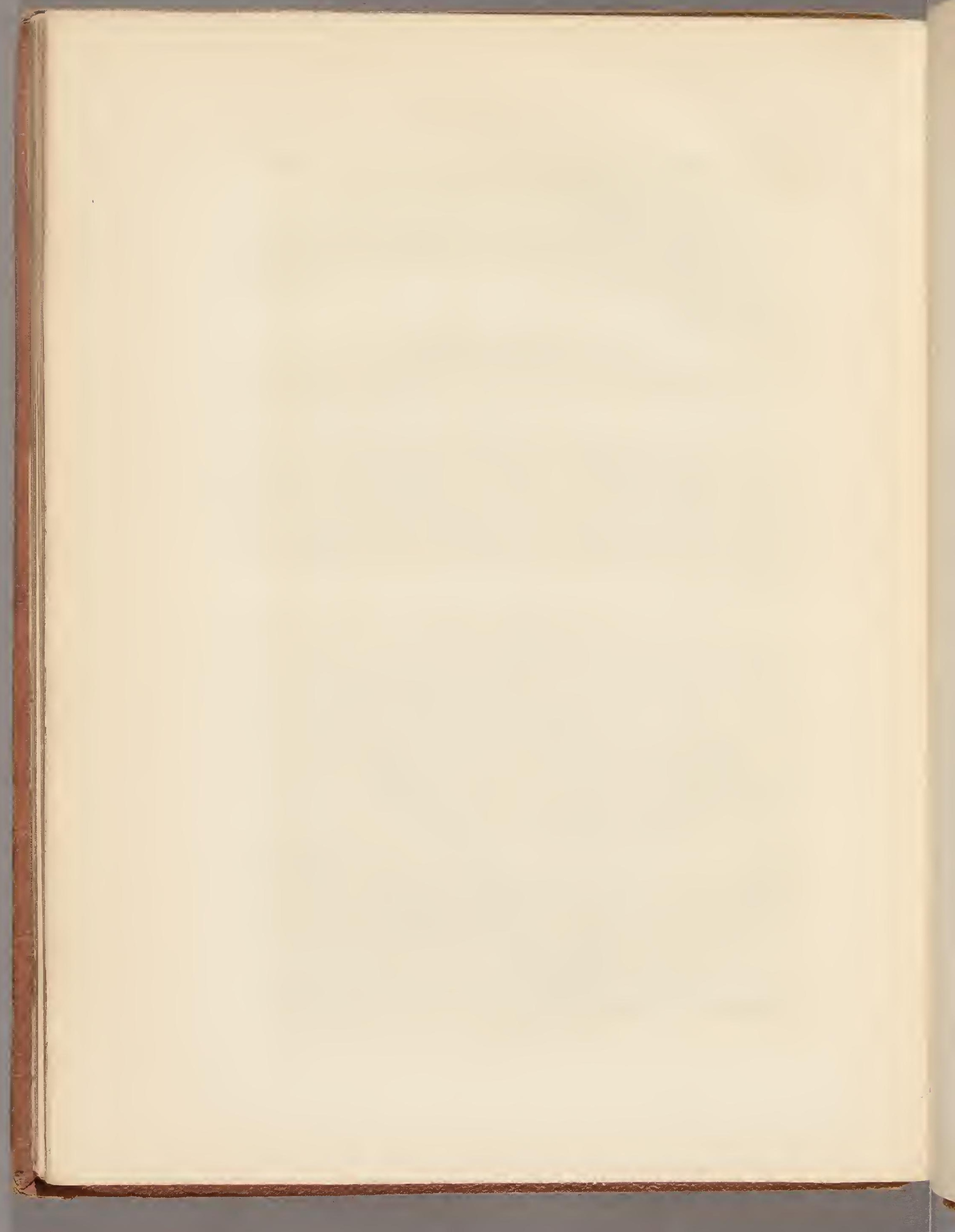




\section{CHRISTIAN ANTIQUITIES.}

weight of silver to Felimy Mae Devitt, who had been plaeed in eommand of the garrison by ODogherty: it was, however, refused, and shortly after, when the fort was besieged by Sir Riehard Vineuel, Mae Devitt eommitted the books to the flames in sight of the besiegers, and then took flight himself with his followers in two vessels, eonveying with him a part of the eannon, and easting the remainder into tle sea,

At the plantation, whieh followed in 1609 , it was an artiele of the agreement with the London eorporation, that "the eity should have the eastle of Culmore, and the land thereunto, in feefarm, they maintaining a suffieient ward of officers therein." In 1618, Thomas Raven was employed for two years, for measuring and setting out the fortifieations at Derry and Culmore; and it is probable, that the present tower was ereeted at this period, as it does not agree in situation with that marked in the plan.

From this period down to the present, a regular sueeession of governors has been kept up, thongh, as a military station, Culmore has been disused for more than a eentury. Indeed, even so early as 1625 , the default of the Londoners in not keeping a proper ward in it, ae. eording to their agreement, were made one of the artieles of eomplaint against them, as the eommissioners reported they had apparently violated their engagement. At this time the fort eiently manned an piees of ordnanee, and the eorporation were direeted to have them suffiswer to the artieles and charter. The eorporation, lowever, inade an swer to the king, that they had not broken their eovenant, "for they have ever had, (the ent ward there, aud now in those times of danger, they have inereased number of the wardel's aeeording to the direetion of the Lord Blayney."

A new eommission having been issued in 1628 , to inquire into the defaults of the Irish eorporation, they were instrueted to inquire "whether the City of Derry should have the Castle of Culmore and the lands thereunto belonging in fee farm, they maintaining a suffieient ward and offieer therein, whether is there any suel ward there maintained, and in what manner hath it been maintained, by how many men, and how furnished." To these inquiries the eommissioners made answer:- $"$ "we find that not the City of Londonderry but the City of London should have the Castle of Culmore, and 300 aeres laid thereto in fee farm, and we also find that a eontraet was made between the said Londoners and Captain John Baker, deeeased, who lleld the plaee till Miehaelmas, 1626; until his death, whieh was about Christmas following, he had from the Londoners an a d until his death, whieh was about Christfor the more keeping of the said fort. and sine $10 \mathrm{men}$, at $6 d_{\text {. per }}$ diem, a piee, of the said Fort and Castle, with

To the Fortand money, and land." and and gunners" - the eommissioners replied: - "that how the Castle of Cnlmore hath bin guarded witl warders we have shewed in our answer to the 7th artiele, among whom we do not find so mueh as one gunner: as for ordnanee and the other provisions, we find these partieulars: (viz.) 2 demi-eulverings, 4 saeras, 2 minions, 2 faleons, all of iron, and none of them 1l morms, ladles, and spunges, 24 Muskets, 16 bandoliers, barrells of eorne 15 musket moulds, 3 sows of lead, 100 wt. of lead in musket bullets, 19 barrells of eorne powder, 3 halberts, 15 old swords unservieeable, 15 wormes, 14 seourers grnne pole 18 lifton shot, 120 rouls of mateh, 6 pikes gynne, 2 ropes, 1 bloekhead, 1 groass, 1 hogshead of beef 12 barrels of wheat, 100 peeks of oatmeal, and 10 peeks of oatmeal Plillips's

The subsequent history of Culmore is thus stated in the history of the Irish Soeiety :of Cul November.-A report was made by the Committee as to the original establishment letters patent, whereby they stated, that his late Majesty King Charles the Seeond, by his letters patent, bearing date 10 th day of April, in the fourteenth year of his reign, granted to the soelety of the governor and assistants, London, of the new plantation in UIster, within Donegal, and all the and to their sueeessors the eastle and fort of Culmore, in the County of eastle and fort, then lands eontaining, by estimation, three hundred aeres, with the said be assigned, with the or then late oeeupied or used, or to the same belonging or assigned, or to they found that the appurtenanees to the said eastle and fort eonveniently adjoining; and sors, did eovat the said soeiety, by the said letters patent, for themselves and their sueeesthe said eastle and fort, a erown to keep and maintain, at their own eosts and eharges, in the said eastle and fort, a ward of so many men well and suffieiently armed, and expert having surrendered, neeessary for the defenee thereof: they further found that the said soeiety the said former letters patent, his surrender, to the erown, eertain eustoms to them granted by the 19th day of May, in the sevententhesty, was pleased by his letters patent, bearing date to release the May, in the seventeenth year of his reign, in eonsequenee of the said surrender, said soeiety, over and above the part of the soeicty; and to deelare that for the future the the yearly sum of garrison therein, an said eastle and fort, towards maintaining a garrison therein, and providing them with arms and ammunition: and also with the said three 


\title{
CITY OH LONDONDERRY.
}

hundred acres of land, and the profits thereof: so that upon the whole state of the case, it appeared that the legal estate of and in the said three hundred acres of land was properly vested in the society, in trust, for the governor of the said castle, and fort for the time being. The sum of $£ 200$ is still paid half yearly by the society to the governor of the fort.

Previously to the memorable siege of Derry, a strong garrison was placed in Culmore, under the governor William Adair, of Ballymena, Esq. The ordnance consisted of four falcon, and four rabonette of brass, and three minon, two demiculverine, four sacker-minion and two falcon of iron. Its governor (garrison?) did not, however, acquire an equal distinction by its defence as that of Derry. A body of the enemy consisting of 400 foot, with the cavalry regiment of Tirconnell and the dragoons of Dungan, under the command of Momont, Hamilton, Pusignan, and the Duke of Berwick, having chosen their quarters near the fort, "the commander," says Berwick, "surrendered at once," (on the 23rd of April, 1689,) " though we had not the means of taking it."

The following are the articles of capitulation, copied from the original in king James's papers, from the Sonthwell MSS, now in the library of the Royal Irish Academy -

"Capitulation between the Hon ${ }^{\text {ble }}$. Richard Hamilton, Lieu". General of his Majesty's forces in Ulster, on one parte, and William Adair, of the town of Ballymenoch, now Governor of the castle of Coolmore on the other parte, the $23^{\text {rd }}$ day of April, 1689.

" 1. Imprimis, that his Majestie's subjects at present at Kilmore, slrall by his most sacred Majestie's gracious and free pardon, enjoy their lives, religion, estates, goods and chattels whatsoever, whereon they find them, and command all his Majestie's officers, civil, military, and otherwise, to be aiding and assisting to them for the recovery of the same. And that his Majesty shall, upon application, order the said several pardon or pardons to be issued without any expense or charge.

"2. That the said officers and soldiers, and the said garrison on their submission, shall depart the said garrison, with all their goods and chattels, to their several abodes or dwellings from garrison to garrison; and on demand receive passes to transport themselves beyond sea, without imposition of others, together with full enjoyment, as formerly, of all their estates, goods, and chattels whatsoever, with a full and general pardon of all offences whatsoever, committed since their taking up of arms.

" 3. That the said officers and soldiers in Kilmore, shall be allowed to carry out their swords, and that the officers shall be allowed to have their own horses and mares, pistols, each of them a gin for their own pleasure, behaving themselves as becometh his Majestie's loyal subjects.

"4. And if the gentlemen oflicers and soldiers of the city of Londonderry, and other his Majestie's subjects in the province of Ulster, in the kingdom of Ireland, will accept of the like faror of his sacred Majestie's most gracious and free pardon, that they may enjoy the same if they accept of it within three days after the date of these presents, and surrender up of the said garrison, and have full freedom and liberty after the said three days, as they can most conveniently take away their goods and chattels, excepting their serviceable horses and arms, which are in like manıer to be surrendered up for lis Majestie's service.

"5. That the great gate of the castle of Kilmore, shall immediately be surrendred up to his grace the Duke of Berwick, to put such guard thereupon as he shall thinke fitt, all the soldiers of the said garrison, having before carried their fire-arms into such room of the said castle as shall be most convenient, where they are to be kept under lock and key, which said key, as also the keys of all the ammunition and powder, shall be delivered up to his grace the Duke of Berwick, at his arrival at the gate.

\author{
"WiLitaMr ADArr. \\ "Ricinard Jolinston. \\ "Benjumix Aparre,"
}

Governors of Culmore Fort:-Sir Arthur Chichester (afterwards Lord Chichester) was the first governor after the plantation. He was appointed by privy seal, (June 30, 1609); and by patent, (Oct. 25, 1609), for life, "with all the lands and hereditaments thereto belonging, and the charge and command of the warders, with the several pairs and entertainments already, or hereafter to be established for each warder, the fee of $4 s .8 d$. English, making $5 s$. $4 d$. Silver harpes, current in Ireland by the day, for a constable; and $2 s$. $6 d$. English, inaking $3 s, 4 d$.

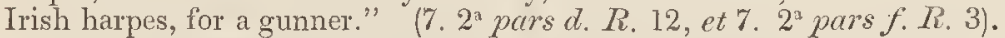

Captain John Baker held the place till Michaelmas 1626 , or thereabouts, only for the stipend of £52. per annum, and the 300 acres valued at $£ 30$ per annum, until his death, which was about christmas following. He had from the Londoners an addition of $10 \mathrm{men}$, at $6 d$. per diem, a piece, for the more keeping of the said fort; and since that time,-

"Captain John Bingham hath charge of the said fort and castle, with the same allowance of men and moncy." (Phillips's MS. anno 1628.) 


\section{CHRISTIAN ANTIQUITIES.}

Samuel Robert Stewart; Privy Seal, Westminster, April 11, 1638-Patent, 1638-Life. -(14 Charles $1.7^{\text {a }}$ pars d. R. 1.)

John Gorges, Esq.-Captain, Commander, and Governor-Patent, Dec. 3, 1670,-Behr. - (22 Charles 2. $2^{\text {a }}$ pars d. R. 49.)

Col. Wm. Cecill,--vice Gorges,_-Privy Scal, Whitehall, Feb. 2, 1673, Patent, Dublin, March 9, 1673,-Pleasure.-(26. $2^{2}$ pars f. R. 12.)

Col. Wm. Cccill, former patent revoked,-Patent, Nov. 16,1680,-Pleasure.-(32. 1a pars f. R. 36.)

Gcorge Phillips, Esq. Cecill surrcndered 29th,_-Patent, Junc 30, 1681,_Pleasure._33. 1 pars $f . R .37,38$.)

Capt. Mathew Bridges,-vicc Phillips,-Patent, Sept. 13, 1684-Pleasure.-(36. $2^{2}$ pars f. R. 54 .)

William Adair, Esq. of Ballymena, was governor in 1688-89; after which period there was no garrison kept up, and the fort was allowed to fall to ruin.

Colonel Mitchelburne, solicited the Irish Society in March, 1690, "to recommend him to his majesty, as governor of Culmorc fort, which thing the society took into consideration; and finding in the charter that they were obliged only to maintain such a garrison in the said fort as should be thought necessary by their majesties; and, considering that the said fort was then quite demolished, and not capable of any garrison, the society were of opinion that in regard there was no fortc, there could be no occasion for a governor, and therefore, no obligation on the society to pay any stipend or salary."-(Hist. Irish Society.)

Sir Charles Fielding was appointed governor, by his majesty, 6th of May, 1691 ; and a warrant was made out by the socicty, for payment of $£ 50$ to him.- $I b$.

1692 - 7th April. The society ordered the salary to bc paid, and the acres to be enjoyed the governors of Culmore fort in future.- $I b$.

Of the succeeding governors noaccount has been obtained.

General Appearance and Scenery. The general character of the parish is that of a rich well cultivated country. As much interest attaches to the neighbourhood of the river, whose broad and placid waters, with the long line of its light wooden bridge, combining with the battlemented walls and buildings of the town, the numerous demesnes and ornamented villas spread along its shores, and with the distant view of Lough Foyle and the mountains of Inishowen and Benevena, form a succession of landscapes possessing no ordinary share of beauty and picturesque effect. The city itself, with its towering spire, seated on a commanding and nearly insulated hill-its merchant vessels thronging the port-the steamers arriving from or starting on their voyages, with numerous small boats of fishermen and othersand all the activity and bustle which attends its present state of commercial prosperity, associated with the recollections which history supplies of its trials past, is the great central object of this interesting and beautiful district. 


\section{SECTION III.}

\section{SOCIAL ECONOMY.}

MosT of the matter eonneeted with this division of the subjeet has naturally arranged itself in the deseription of the city under the several heads-Municipality, Education, Benevolcnce, Justicc, Commerce, and Population.

\section{PRODUCTIVE ECONOMY.}

A eonsideration of the means by whieh the produetive powers of nature are ealled into benefieial aetion, and rendercd subservient to the wants of mankind, is not only useful as tending towards the amendment of imperfeet systems, but also as lcading to such a knowledge of the eomparative values of raw and manufaetured articles, as must materially assist the finaneier in predieating what effeets are likely to follow those imposts, which are laid upon produetion in any of its stages.

To secure the full advantage of this investigation, it is neeessary to kecp eonstantly in view the important prineiple, that applieation of extcrnal power to produetion, whether it be exhibited in mere manual labour, aided by implements of husbandry, or in the more eomexhibited in me the same thing. And fund sther the term manufactory implies not a work distinet from primary productions, but one either auxiliary or supplementary to it, so that the manufaeture of woollen goods is but of the agrieultural system being supplcmentary to the breeding of sheep. the still a part of the agrieultural system, being supplanfare of cotton goods to that of eot manufaeture of linen to the cor manner as the operations of the eorn mill are supplementary to the growth ton, in the same manner a the remove those of oats, barley, and wheat, a prineiple sound in itself, and caleulated to remate of the relative seurities and prejudiees whieh at present perplex the importanee of agrieulture and manufaetures, which he has

distinct things, and not as they really are, parts of the same.

The simplieity which results from the applieation of the prineiple, here laid down, does not terminate with manufaetures; it may be pursued even into trades, whieh are thus allocated to their respeetive heads of productions. The bakcr follows the miller, as the miller sueeeds the farmer. The shoe-maker, the tanner. The tanner in like manner the farmer; and if the system be pursued to its full cxtent, the ordinary shopkeeper beeomes auxiliary also to production, and may be classed among some one or other of the trades of distribution. This is the system adopted in the aecompanying tables of productive economy. In the first, a eondensed view is miven of the mode of distribution of the land, its aspcets, qualities, and general advantages, as exhibited in eaeh townland; and it may be here added that the soils, resulting from the deeom. extition of one class of rocks only, possess mueh uniformity both of appearance and quality. position of ond a dicter stony, sandy, and meagre ; but they generally eonsist of light, productive elays, or loams; becoming in the very low grounds stiffer, but never to an injurious degree.

Manures are readily attainable, being in part stable dung, either resulting from the home keep of eattlc, or bought in Derry. Lime burned in the city, the stone having been brought keep prish, and shells proeured at Shcll Island, in Lough Foyle. Kelp, purchased in Derry, is also oeeasionally used, and bog earth forms part of a very valuable

The aspect and elimate are on the whole favourable, and the appearanee of mueh of the parish is such as to hold out every promise of sueess to the farmer.

The seeond table embraees the subject of cultivation-shewing the various erops, the order in whieh they are usually eultivated, the times of seeding and of harvest, and the amount of erops. Some improvement in farming may be dcdueed from the statements it amount of erops. Som soil being 


\section{PRODUCTIVE ECONOMY.}

considered too light and the climate too cold for its growth, has gained a footing in the parish, and is advancing in estimation. Green crops are also occasionally adopted.

The natural meadows, which are few, have been described in the botanical notice of the parish. Pasture is limited and forced.

Artificial Botany, \&c. Forced or sown meadows are far from general; when for cutting the first year, they are sown with perennial rye-grass and red clover, 1 bushel of grass seed and $12 \mathrm{lbs}$. of clover being generally sown on each Cunningham acre.

When intended for grazing, white grass and white clover are sown, 4 bushels of the white grass seed and 6lbs. of clover seed being allowed for each acre.

It may be here remarked, that the grasses known by the name of white grass, which includes holcus mollis and lanatus, are the most general, if not the only grasses sown on ground laid out for pasture, which is certainly more owing to custom than to their merits as superior grasses, for although they produce a considerable crop on light, sandy, and even more in damp, boggy ground, they are rather disliked by cattle, particularly by horses, as is remarked by Mr. Sinclair, (Hortus. Gram. Wobumensis, page 164), who recommends that hay made of these grasses should be sprinkled with salt, cattle preferring such grasses as have either a sub-acid or a saline taste.

Nurseries constitute another branch of production, and from their increase it may be hoped that many parts of the parish will, at a future day, be ornamented by plantations.

That on the townland of Ballymagowan, is the largest and longest established; it contains an extensive collection of forest and fruit trees, with a few American plants, and flowering shrubs; there is one small glass-house, which contains a collection of geraniums, and other tender exotics. The forest trees consist of oak, ash, elm, birch, sycamore, beecl, alder, horse chesnut, Spanish chesnit, with spruce, silver, balm of gilead, larch, and Scotch firs, all of which are sold at from 13 to 15 shillings a thousand, after being two years transplanted from the seed-bed; in all, three years old. The fruit trees are sold at about 6 d. each; (i.e. pear's and apples; ) and among the apples, the kind called the may-bloom (probably the Irish codlin) is in most demand. Peach and plum trees are sold according to their quality and age. The grounds are but ronghly kept, and the superior branches of nursery business indifferently attended to.

That belonging to Mr. Hart on the townland of Shantallow is next in size, and contains a large collection of forest trees, which are sold at the same prices as above: there is also a small collection of flowering shrubs; the grounds are very rudely kept.

Reid's mursery, on the townland of Termonbacca, is the smallest and latest established besides a large collection of forest and fruit trees, it contains many flowering shrubs and flower roots, which are well cultivated. The forest and fruit trees are sold at the same price as at the other nurseries, the ground is neatly kept.

Besides the trees sold at the nurseries, it is customary for the nurserymen to send in trees to Derry on the market days, which are generally sold by the farmers, when the largest, or those, which experienced planters would reject, generally find the readiest market. Some of those are brought from the neighbourhood of Strabane in the county Tyrone.

The sale of thorn quicks, constitutes a considerable portion of the nursery trade; they are generally sold when two years old, one year from seed, and one transplanted from the seed bed, and sell at from $3 s .6 d$. to $4 s$, a thousand. When at that age, they are used for what is termed ditch fencing, i. e. throwing up a ditch and laying the young quicks on their sides, in the face of it; others are sold when two and three years transplanted, which sell at from $10 s$. to $15 s$. a thousand, and are only used for planting on the level ground without any ditch. With the exception of thorns, the nurserymen seldom raise their own seedlings; they mostly import them from Scotland, where the nursery price is, (taking one year with another) for the different kinds of hard wood, from three to four shillings a thousand; spruce and silver firs, from $2 s .6 d$. to $4 s$. a thousand; scotch and larch firs, from $1 s .3 d$. to $1 s .9 d$. a thousand; and such seedlings, when no agreement with the Scotch nurserymen has been made to free their charges to Derry, will cost in expenses of carriage, $\& c$. from Edinburgh to Derry, from $7 d$. to $9 d$. a thousand. It is the general practice, when a considerable quantity of different kinds of trees are ordered, to give all kinds, without exception, at the above stated prices, but when single thousands of good oaks, or Spanish chesnuts are ordered, they are charged higher rates, the oaks generally at from $17 s$. to $18 s$.; the Spanish chesnuts from one guinea to twenty-five shillings.

Most of the wood in this parish seems to have been planted rather with a view to ornament than to profit. The most common trees along the banks of the river Foyle, to the S. W. of Derry are beech, elm, sycamore, with some fine thriving asl in Termonbacca. Along the river side, to the N. E., are seen some good old specimens of Scotch and larch fir, and on the demesnes of Brook-hall, and Boom-Hall, are also some good oak, elm, and sycamore.

In general, little spirit prevails among the inhabitants of this parish either for collecting the choicer flowers, or ornamenting their dwellings, although within the last few years a greater taste has been shown, and some few of the gentry have at considerable trouble and expense ob- 


\section{PARISH OF TEMPLEMORE.}

tained extensive collections. That at the lodge belonging to Mr. Gilmour, is the best, and consists of carnations, Dahlias, and auriculas, which are cultivated with great care. Although the soil and climate seem favourable to the growth of a number of the more hardy exotic plants, few have been introduccd, except at Brook-hall and the palace. At the former, they grow with surprising Iuxuriance, several species of the beautiful north Amcrican genus, rhododendron fof which there is a large quantity, flourishing and seeding as if in their native climate. Some of those shrubs have attained the height of 15 and 20 fect in the woods; and the seeds dropping from them vegetate in abundance, and afford plenty of young plants annually, a circumstance of which the neighbouring nurscry-men sometimes avail themselves, by lifting quantities of the young plants in March, which they plant out in beds, and soon have fit for market. There are also several species of American oaks planted in the demesne, which are thriving well. The scarlet oak, and the cork tree willow, are becoming good trees, as is the liquid amber tree. Several other species of American trees are also thriving. Mr. Moore of Mullennan, has during the last few years madc much cxertion to introduce exotic flowcring shrubs, of which he has now a considcrable collection: plants of south America, New Holland and China, have, with a little care, withstood the cold of several winters even in an exposed sitnation. In the parish generally there is little change from the common kinds of forest trees, though the American plane trees planted in the ground of the frec school, are thriving, and already appear to good effect.

Cattle.-Have been little improved; it is indeed a received opinion, that in the small farms, in which the grazing cannot be much attended to, the common Irish breed is best suited to the indiffcrent food it obtains. Shcep are few in number, and hogs by no means so numerous as in other parts of Ireland, the high price which potatoes command in the Derry market, and the comparative low price of stock, rendering the feeding of pigs unprofitable.

Poultry have been very numcrous under the influcnce of the egg trade, and bee-hives prove also a sourcc of production.

In the two next Tables the amonut of labour, either simple as of man, or compound as in machines is exhibited; and the effects they produce can he readily estimated. Great subdivision of the land adds to the quantity of labour required for its tillage, by precluding that perfect system of management, whicl would induce cconomy of time and labour. The families also of small farmers arc in fact labouring, and thus add to the gross amount, considerations which must be kept in view in the examination of the Tables. By compound power in the grain mills alone, a force equivalcnt to the constant work of about $400 \mathrm{men}$, is added to the productive cnergy of the parish.

Ballynagalliagh, Ballyarnet, and Elaghmore, bclong to the Marquess of Donegal; Coshquin and Ballymagrorty to Lord Templemore; Creggan, and the most of Edenballymore are church lands; Ballynagard, (as already stated), belongs to Captain Hart; Culmore is the property of the governor for the time being, and pays neither tithes nor county cess ; the re maining denominations are hcld under the Irish Society.

The farms vary in size from 4 to 100 acres. The rent of the best land is from $£ 2$ to $£ 2$ $10 s$ an acre ; of second ratc, from $f 1$ to $f 110 s$; and some brings no more than from $5 s$, to 10s. This spccification does not include the town parks, many of which let very high. There is also a considerable number of cottiers.

Fishing.-The right of fishing the river. Foyle, so far up as Lifford, is vested in the Irish Society, by the charter of Londonderry, granted by James the Ist on the 29th of March, 1613; but at present the Marquis of Abercorn and the Earl of Erne, hold fisheries below that town. The bishop formerly excrcised a right to some small fishings, and also to a tithe of the whole, which led to disputes between the Irish Society and the sec of Derry; these wcre, however, settled by the 3rd and 4 th of queen Anne, the bishop renouncing his right to the fishing, \&c. and accepting a compensation of $£ 250$ a year. The original right was vested in the ancient mo* nastery of Derry, on the suppression of which, the see claimed it as its successor.

The Salmon Fishery of the Foyle is one of the most extensive in the county. The number of men employed is 120 ; exclusive of 120 water-keepcrs. The quantity of fish taken in 1835 , up to the 1 st August, was in weight 90 tons, $15 \mathrm{cwt} .1$ qr. 21 lbs. Or in number 35,473. There are twelve stake nets, and scven boats. The salmon is shipped principally to Liverpool, 25,742 , or 66 tons, of the above quantity having been shipped to that port. Some is also sent to Glasgow, and some pickled for the London market. The quantity consumed in the lower market of Derry is variable, it may be estimated at about one-fifth of the export to Liverpool, and the price averages about $4 d$. to $5 d$. per $1 b$. In the three preceding years, the quantities of fish taken were-

$\begin{array}{rrrrrr} & & \text { Tons. } & \text { Cwt. } & \text { Qr. } & \text { Lbs. } \\ \text { In } 1832, & 180 & 13 & 3 & 8 \\ 1833, & 130 & 15 & 2 & 11 \\ 1834 & 135 & 15 & 3 & 4\end{array}$


PRODUCTIVE ECONOMY.

$V$ aluation.-The only remaining subject of importance, is the valuation founded upon the Ordnance Survey - a copy of which is annexed.

\begin{tabular}{|c|c|c|c|c|c|c|c|c|c|c|c|c|}
\hline \multirow[t]{2}{*}{ Townlands. } & \multicolumn{3}{|c|}{ Quantity. } & \multicolumn{3}{|c|}{$\begin{array}{l}\text { Annual Value } \\
\text { of Land. }\end{array}$} & \multicolumn{3}{|c|}{$\begin{array}{l}\text { Annual Value } \\
\text { of IIouses, } \\
\text { deducting } \frac{1}{3} \text { rd. }\end{array}$} & \multicolumn{3}{|c|}{ Total. } \\
\hline & $\begin{array}{c}\text { A. } \\
664\end{array}$ & $\begin{array}{c}\text { R. } \\
2\end{array}$ & $\begin{aligned} P . & \\
20 & \end{aligned}$ & $\begin{array}{l}\mathcal{E} \\
447\end{array}$ & $\begin{array}{l}s . \\
18\end{array}$ & $\begin{array}{l}d . \\
0\end{array}$ & $\begin{array}{l}E^{\prime} \\
61\end{array}$ & $s$. & $\begin{array}{r}d . \\
0\end{array}$ & $\begin{array}{c}\mathfrak{L}^{\mathfrak{y}} \\
509\end{array}$ & $\begin{array}{l}\text { s. } \\
16\end{array}$ & d. \\
\hline Ballyarnet .............. & 603 & 2 & 27 & 349 & 18 & 0 & $\begin{array}{l}61 \\
62\end{array}$ & 9 & 0 & 412 & 7 & 0 \\
\hline Ballymagowan.......... & 381 & 3 & 3 & 391 & 0 & 0 & 69 & 2 & 0 & 460 & 2 & $\begin{array}{l}0 \\
0\end{array}$ \\
\hline Ballymagrorty ........... & 648 & 3 & 21 & 470 & 0 & 0 & 37 & 18 & 0 & 507 & 18 & $\begin{array}{l}0 \\
0\end{array}$ \\
\hline Ballynagalliagh ........ & 647 & 0 & 37 & 313 & 4 & 0 & 45 & 4 & 0 & 358 & 8 & 0 \\
\hline Ballynagard............ & 424 & 3 & 22 & 251 & 2 & 0 & 60 & 17 & 0 & 311 & 19 & 0 \\
\hline Ballynashallog.......... & 523 & 0 & 18 & 592 & $1 \overline{1}$ & 0 & 204 & 18 & 0 & 797 & $\begin{array}{r}19 \\
9\end{array}$ & 0 \\
\hline Cloughglass ............ & 87 & 0 & 13 & 111 & 10 & 0 & & .. & & 111 & $\begin{array}{r}9 \\
10\end{array}$ & 0 \\
\hline Coshquin .............. & 833 & 1 & 31 & 414 & 9 & 0 & 66 & $\ddot{10}$ & 0 & 480 & $\begin{array}{l}10 \\
19\end{array}$ & 0 \\
\hline Creevagh, Lower.......... & 351 & 2 & 23 & 173 & 19 & 0 & 6 & 15 & 0 & 180 & $\begin{array}{l}19 \\
14\end{array}$ & 0 \\
\hline Creevagh, Upper......... & 371 & 3 & 30 & 182 & 16 & 0 & 7 & 8 & 0 & 190 & $\begin{array}{r}34 \\
4\end{array}$ & 0 \\
\hline Creggan .............. & 342 & 3 & 36 & 246 & 4 & 0 & 7 & 2 & 0 & 253 & & 0 \\
\hline Culmore ............. & 708 & 1 & 12 & 384 & 0 & 0 & 75 & 10 & 0 & 459 & $\begin{array}{r}6 \\
10\end{array}$ & 0 \\
\hline Edenballymore ........ & 534 & 3 & 10 & 635 & 4 & 0 & 2007 & 15 & 0 & 2642 & $\begin{array}{l}10 \\
19\end{array}$ & 0 \\
\hline Elaghmore...$\ldots \ldots \ldots$ & 512 & 0 & 34 & 259 & 6 & 0 & 34 & 2 & 0 & 293 & $\begin{array}{r}19 \\
8\end{array}$ & 0 \\
\hline Killea ............. & 380 & 2 & 13 & 176 & 5 & 0 & 14 & 2 & 0 & 190 & & 0 \\
\hline Londonderry Suburbs..... & 197 & 1 & 21 & 226 & 15 & 0 & 15049 & 8 & 0 & 15276 & $\begin{array}{l}7 \\
3\end{array}$ & 0 \\
\hline Mullennan ............ & 829 & 3 & 18 & 511 & 5 & 0 & 65 & 8 & 0 & 576 & 13 & $\begin{array}{l}0 \\
0\end{array}$ \\
\hline Pennyburn ............ & 123 & 0 & 19 & 174 & 12 & 0 & 152 & 2 & 0 & 326 & 14 & 0 \\
\hline Shantallow $\ldots \ldots \ldots \ldots$ & 1178 & 0 & 27 & 907 & 0 & 0 & 191 & 17 & 0 & 1098 & 17 & 0 \\
\hline Sherif's Mountain ........ & 408 & 1 & 38 & 155 & 2 & 0 & 5 & 14 & 0 & 160 & 16 & 0 \\
\hline Spring-hill $\ldots \ldots \ldots \ldots$.... & 55 & I & 25 & 45 & 13 & 0 & & .. & & 45 & 13 & 0 \\
\hline Springtown ............ & 227 & 2 & 34 & 227 & 14 & 0 & 23 & 16 & 0 & 251 & 10 & 0 \\
\hline Termonbacca ........... & 464 & 0 & 3 & 417 & 16 & 0 & 72 & 7 & 0 & 490 & 3 & 0 \\
\hline \multirow{2}{*}{ Bally magror ty orWhite-house } & 1072 & 0 & 1 & 297 & 11 & 0 & 31 & 5 & 0 & 328 & 16 & 0 \\
\hline & 12573 & 1 & 16 & 8362 & 14 & 0 & 18352 & 7 & 0 & 26716 & 1 & 0 \\
\hline Exemptions. & 42 & 0 & 32 & 49 & 11 & 0 & 2651 & 7 & 0 & 2700 & 18 & 0 \\
\hline
\end{tabular}

Signed,

Richand Grffeith, $\left\{\begin{array}{c}\text { Commissioner of Valuation } \\ \text { in Co.Londonderry. }\end{array}\right.$

$\left.\begin{array}{l}\text { Rorert A. Ferguson, } \\ \text { Robert Bateson, } \\ \text { W. H. Ash, } \\ \text { W. H. Holmes. }\end{array}\right\} \begin{gathered}\text { Members of the Comimitte of Rerision } \\ \text { for the said County. }\end{gathered}$

County Court-house, Londonder: 17 th September, 1834. 


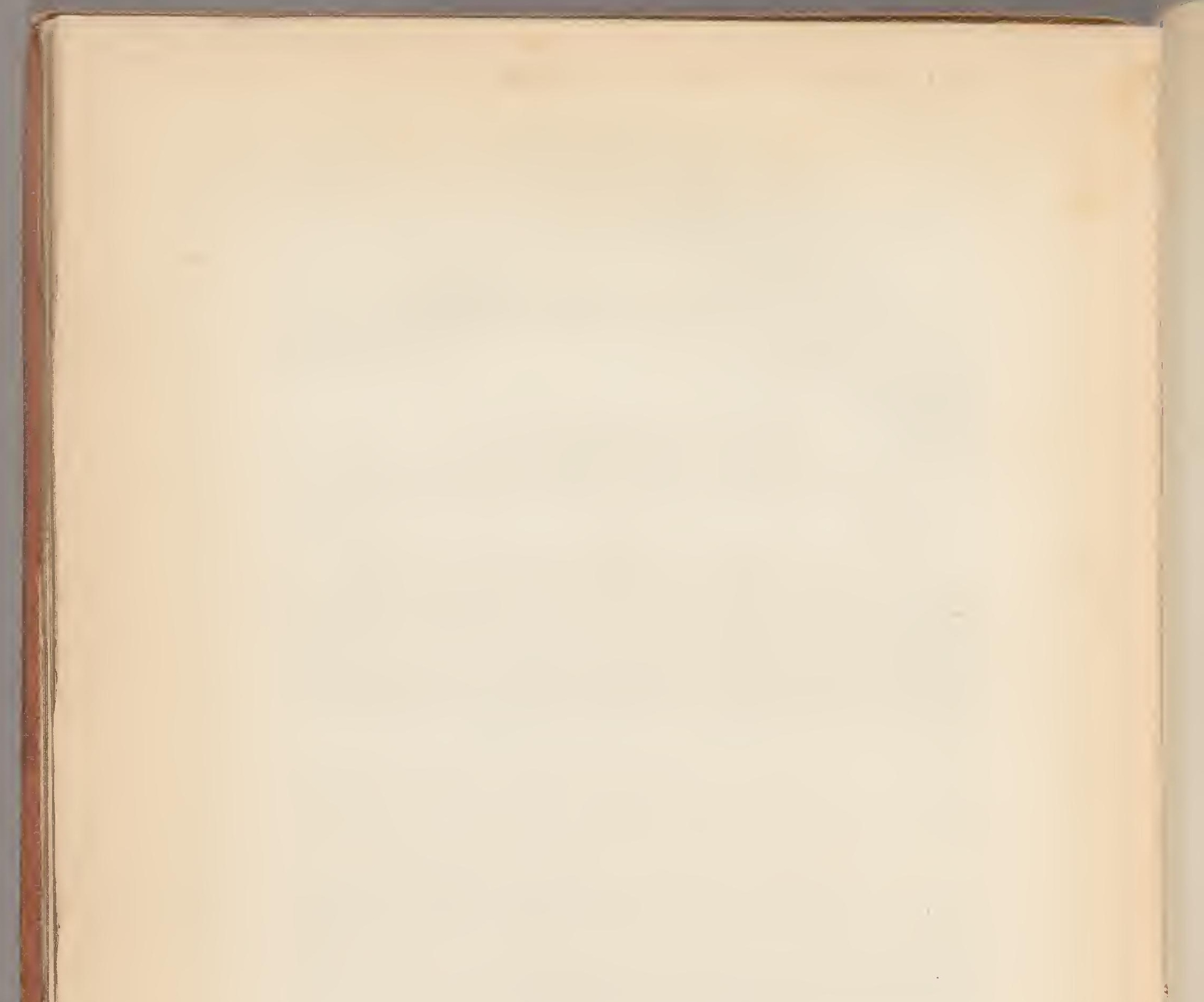




\begin{tabular}{|c|c|c|c|c|c|c|c|c|c|c|c|c|c|c|c|c|c|c|c|c|c|c|c|}
\hline \multirow[b]{2}{*}{ TOWNLAND. } & \multirow{2}{*}{ 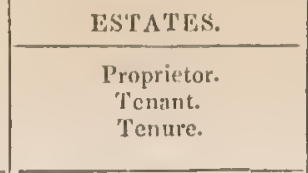 } & \multirow[b]{2}{*}{ Acreage. } & \multicolumn{3}{|c|}{ ASPECT. } & \multicolumn{3}{|c|}{ LIVWELI. } & \multirow{2}{*}{ 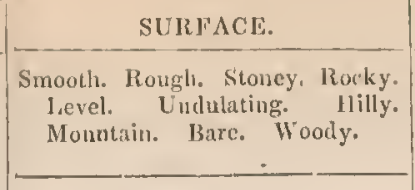 } & \multirow{2}{*}{ 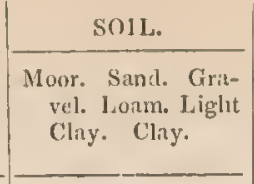 } & \multirow[b]{2}{*}{ SUB-SOIL. } & \multirow[b]{2}{*}{ 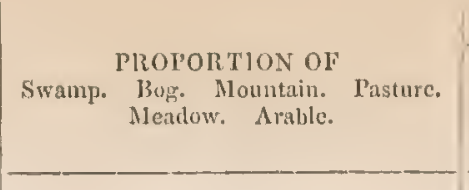 } & \multicolumn{4}{|c|}{ SUIPPLY OF WATER. } & \multicolumn{4}{|c|}{ PARMS. } & & \multirow{2}{*}{$\frac{\text { COMMULNICATIONs. }}{\text { Kind and Quality. }}$} & \multirow{2}{*}{ 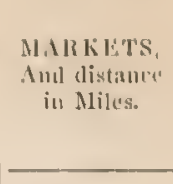 } \\
\hline & & & \begin{tabular}{|l|} 
\\
竎 \\
\end{tabular} & $\left|\begin{array}{|l}\text { Exposed to } \\
\text { - Winds. }\end{array}\right|$ & $\begin{array}{l}\text { Sluetter fiom } \\
\text { - Winds. }\end{array}$ & 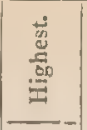 & 旁 & 荬 & & & & & 离 & 总 & 悉 & 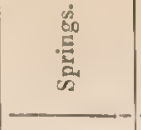 & 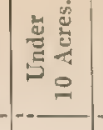 & : & . & & & & \\
\hline s. & ka. & 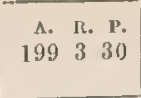 & L. & $\mid$ & 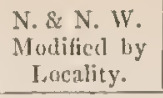 & $\begin{array}{l}\text { 登ect } \\
119\end{array}$ & $\begin{array}{l}\text { Ficel- } \\
\text { Foyle. }\end{array}$ & ${ }_{50}^{\text {Fect. }}$ & Smootl. Hill. & clay. & Gravel. 1rock. & II & Foyle. & & & 7 or 8 & & .. & .. & & & l'oyle, and principind Rowal. & \\
\hline LLVARNET. & 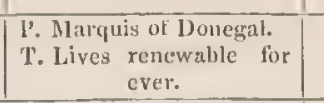 & 603227 & \begin{tabular}{|c|c} 
neiry \\
as \\
s.
\end{tabular} & $\begin{array}{l}\text { N. F. F. } \\
\text { S. W. }\end{array}$ & $\begin{array}{l}\text { N.W. W.at S.E. } \\
\text { corner. } \\
\end{array}$ & 290 & 100 & 160 & Snoothl. Summit, rooky. Bare. & 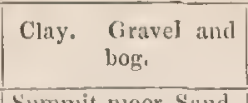 & Rock. & 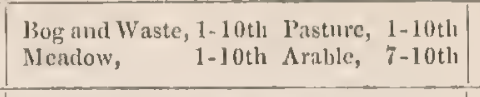 & & 1 & 1 & 4 or 5 & ${ }^{2}$ & 1 & 1 & ${ }^{3}$ & 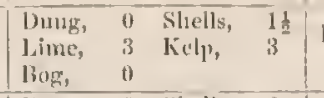 & 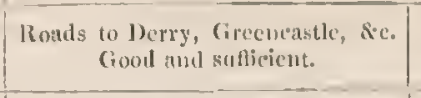 & Derry, 3 \\
\hline 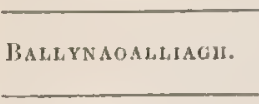 & 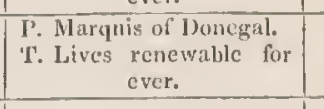 & 647037 & $\mathrm{ss}$ & S. to N. E. & v. w. & 259 & 36 & 140 & 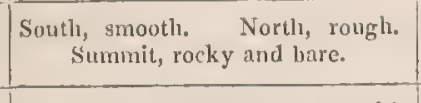 & 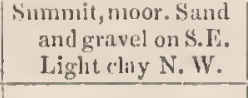 & 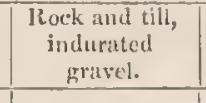 & 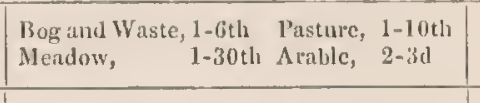 & & 2 & & 6 to 8 & & ${ }^{2}$ & 5 & ${ }^{4}$ & 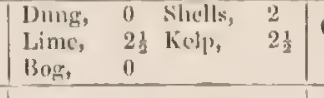 & 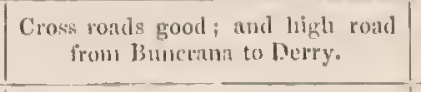 & Pery, 21 \\
\hline ALLYYNOARD. & 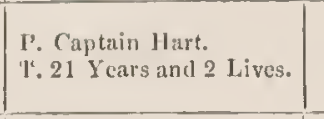 & 124322 & 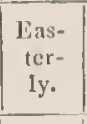 & 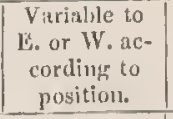 & 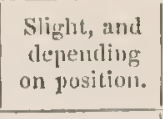 & $\mid 161$ & $\begin{array}{l}\left.\mid \begin{array}{l}\text { Foyle } \\
\text { water. }\end{array}\right] \\
\text { wat }\end{array}$ & 100 & 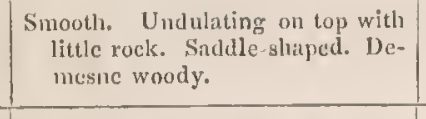 & $\begin{array}{l}\text { Gravel. Light clay. } \\
\text { Chlyy. }\end{array}$ & \begin{tabular}{|l} 
Hock, \\
rijit.
\end{tabular} & 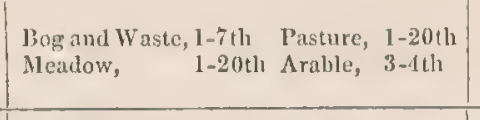 & Foyle, & 1 & 1 & 3 or mo & 3 & ${ }^{6}$ & 2 & & 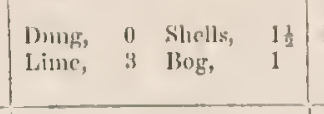 & 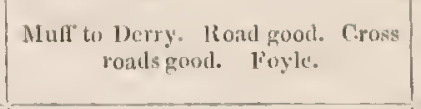 & Dern \\
\hline 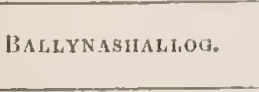 & $\begin{array}{l}\text { Pr. 1risil Society. } \\
\text { re. } 21 \text { ycars. }\end{array}$ & 523018 & 1. & E. & w. & 145 & Hoyle, & 100 & Smooth. Undulating. Woody. & Cliy. Boggy. Loan. & 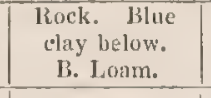 & 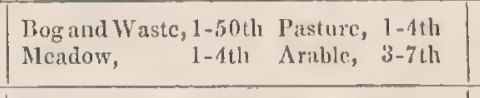 & \begin{tabular}{|l|l|} 
royle. \\
\end{tabular} & ${ }^{2}$ & .. & Pew. & & .. & ${ }^{1}$ & 3 & 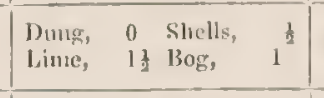 & Nunf to Derry. Raua good. Foyste. & Derry, 11 \\
\hline ALLYKA Gow AS. & \begin{tabular}{|l} 
Pr. Irisl Society \\
r. 21 Years and 1 Lifie.
\end{tabular} & 38133 & 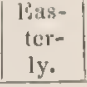 & s. \& E. & w. \& N. & 400 & $\begin{array}{l}28 \\
\text { Foyle. }\end{array}$ & 200 & Smooth. Wundulating. Wrilly. & \begin{tabular}{|l|} 
Moory. Ligitu clay. \\
Clay,
\end{tabular} & Rrock. Gravel. & 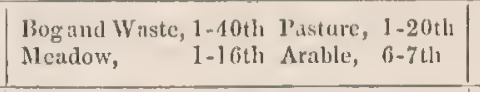 & Foyle. & $\mathrm{I}$ & .. & Many. & 15 & 1 & 1 & 1 & 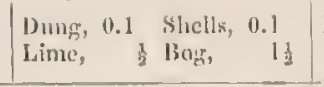 & 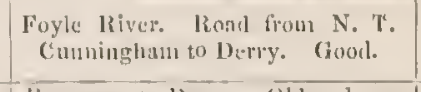 & Derry from, \\
\hline 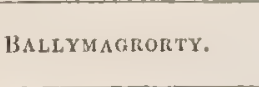 & $\begin{array}{l}\text { pr. 1risis Sociecty. } \\
\text { r: } 21 \text { Ycans. }\end{array}$ & $6+8321$ & $\left|\begin{array}{l}\text { Nore- } \\
\text { there- } \\
\text { yy. }\end{array}\right|$ & \begin{tabular}{|l|l|l|l} 
& Northerly. \\
\end{tabular} & titherly. & 450 & 66 & 200 & 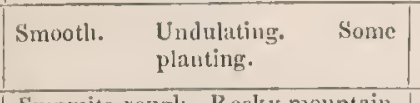 & \begin{tabular}{|l|} 
Loam. Lighth elay. \\
Clayy
\end{tabular} & 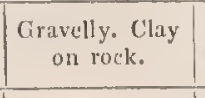 & 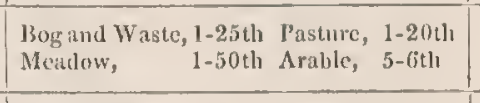 & $\ddot{*}$ & 4 & " & Many. & 8 & 11 & 6 &.. & 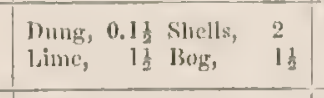 & 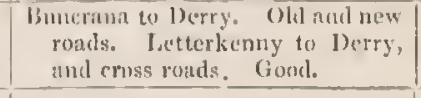 & Dery, 1! \\
\hline 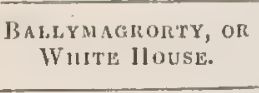 & $\left|\begin{array}{|c|}\mid \text { r. Lorf: Templemore. } \\
\text { T. } 4 \text { Years and } 3 \text { Livives. }\end{array}\right|$ & 107201 & $\mid \begin{array}{l}\text { Nor- } \\
\text { ther- } \\
\text { ly. }\end{array}$ & $\mid \begin{array}{l}\text { ienerally } \\
\text { cxpposed. }\end{array}$ & 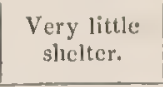 & 860 & ${ }^{50}$ & 250 & 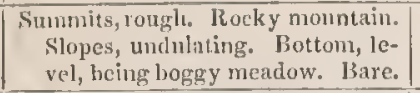 & \begin{tabular}{|l}
$\begin{array}{c}\text { Moor. Loam. Light } \\
\text { Clay. Clay. }\end{array}$ \\
\end{tabular} & Rook. & 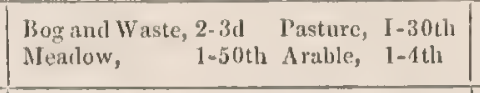 & .. & ${ }^{2}$ & .• & Many. & 3 & 9 & 5 & 1 & 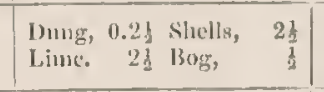 & 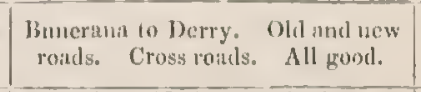 & 1)ery, 2 \\
\hline ILLovenr. & 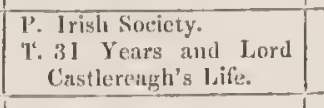 & 67030 & \begin{tabular}{|l|}
5 \\
8 \\
\end{tabular} & \begin{tabular}{|l|}
$\begin{array}{c}\text { Gencrally } \\
\text { exposed. }\end{array}$ \\
\end{tabular} & 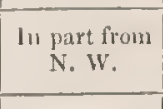 & 32,5 & Foyle. & 180 & 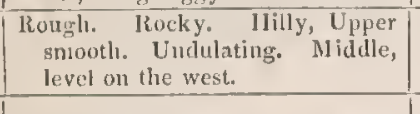 & 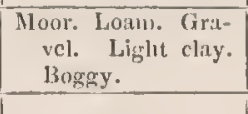 & 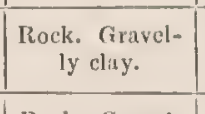 & 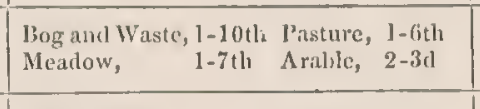 & Foyle. & 1 & .. & Nany. & 4 & 2 & ${ }^{5}$ & ${ }^{2}$ & 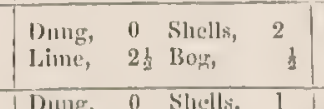 & 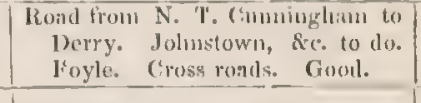 & , 24 to \\
\hline tovarior & \begin{tabular}{|l} 
P. Prish Society. \\
r. \\
ז. 21 Years.
\end{tabular} & 87013 & N. & \begin{tabular}{|l|l} 
Northerly. \\
\end{tabular} & Somulterty. & $|135|$ & 50 & ${ }_{80}$ & Smooth. Undulliting. Some treces. & Clay. & 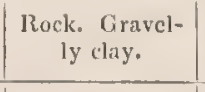 & 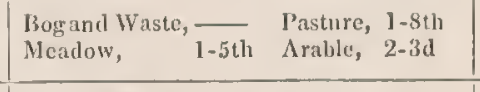 & $\cdot \cdot$ & 1 or 2 & .. & rew. & ." & . & .. & 1 & 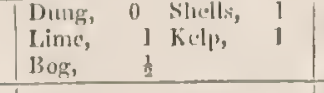 & 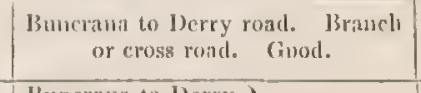 & 1)ert \\
\hline strovis. & 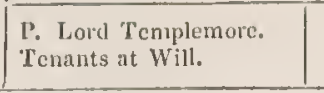 & 833131 & v.r. & \begin{tabular}{|l|l|} 
Northerly. \\
\end{tabular} & Sontthery. & 700 & 32 & $\begin{array}{l}150 \\
100 \\
350 \\
350\end{array}$ & 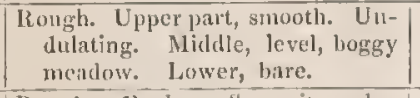 & 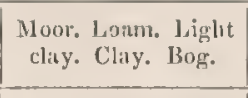 & Rock. Gravel. & 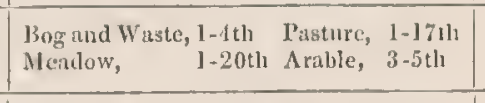 & $\cdot \cdot$ & ${ }^{2}$ & $\cdot \cdot$ & Many. & 1 & .* & 16 & .. & 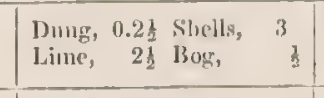 & 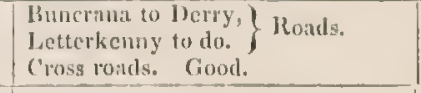 & Derry, \\
\hline 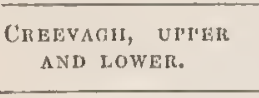 & 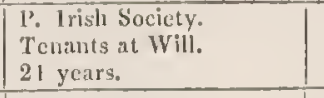 & 1.3 & s. & 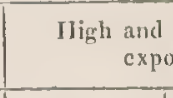 & $\begin{array}{l}\text { generally } \\
\text { seld }\end{array}$ & 615 & 140 & \begin{tabular}{|l|l}
490 \\
nearly.
\end{tabular} & 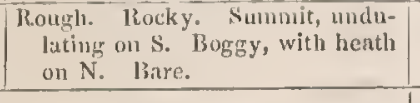 & $\begin{array}{l}\text { Moor. Loanu, clay. } \\
\text { Hoge: }\end{array}$ & 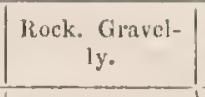 & 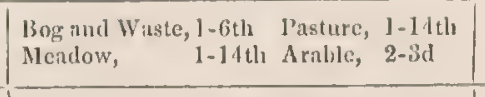 & .. & .. & .. & Many. & $\circ$ & 3 & ${ }^{6}$ & 4 & 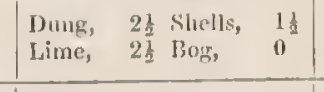 & Letterkentyy rand, and cross road. & erry, \\
\hline nвво м.s. & \begin{tabular}{|l} 
P. Rishlop of Ilerry. \\
r. 21 Years.
\end{tabular} & 31 & N. & \begin{tabular}{|l|l|} 
Nortlerly \\
\end{tabular} & $\begin{array}{c}\text { Partly S. but } \\
\text { hight. }\end{array}$ & 161 & 110 & 300 & \begin{tabular}{|l} 
Roughl. Undulating. Bare. \\
\end{tabular} & \begin{tabular}{|l} 
Loamm, Irighit clay. \\
chlay,
\end{tabular} & \begin{tabular}{|l} 
Rock. Gravel \\
over it.
\end{tabular} \mid & 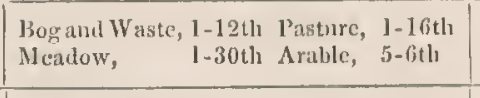 &. & ${ }^{2}$ &. & \begin{tabular}{|l|} 
Several. \\
\end{tabular} & 1 & 1 &. & 3 & 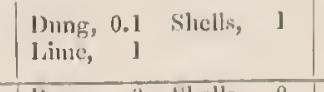 & 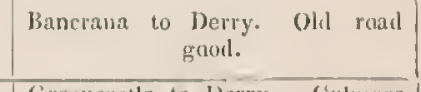 & Dern \\
\hline ULmonr. & 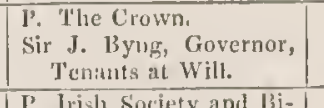 & 7 & E. & E. & $\mathrm{w}$ & 184 & \begin{tabular}{|l|} 
Foylc. \\
\end{tabular} & 80 & \begin{tabular}{|c|c|}
$\mid$ Smooth. Undulating, and some \\
level. \\
barece.
\end{tabular} & 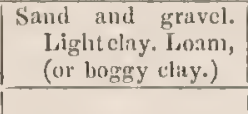 & $\mid \begin{array}{c}\mid \begin{array}{c}\text { ciravel. Clay, } \\
\text { and rock. }\end{array} \\
\mid\end{array}$ & 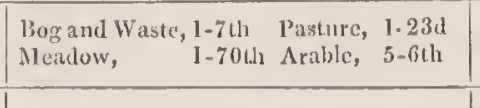 & Fayle. & 1 & Foyle. & $\begin{array}{l}\text { Several } \\
\text { sumall. }\end{array}$ & 31 & 6 & 6 &.. & 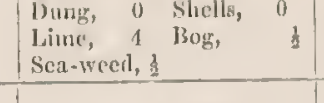 & 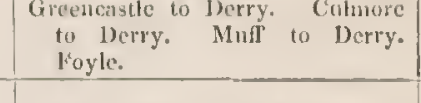 & Derry \\
\hline FDE:NBAI & 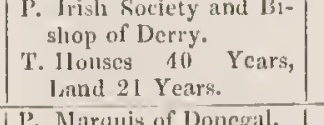 & 567133 & N. & ritherly. & 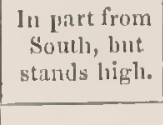 & 378 & Foyle. & 200 & 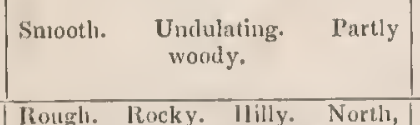 & Boggy, Loam, Clay. & 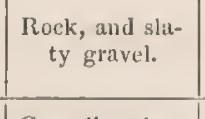 & \begin{tabular}{|l|l|} 
Pasture, \\
Arralle,
\end{tabular} & Foyle. & 2 & $\begin{array}{l}\text { Mill } \\
\text { lond. }\end{array}$ & Several. & 25 & 1 & .. & 1 & $\begin{array}{l}\text { Dung, } \\
\text { lime, }\end{array}$ & $\begin{array}{l}\text { Foyle. Various aud } \\
\text { aul } W .\end{array}$ & 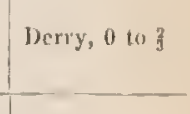 \\
\hline Eтаонмоге. & 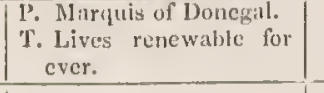 & 512034 & \begin{tabular}{|l|l} 
S. . E. \\
Muel \\
\end{tabular} & 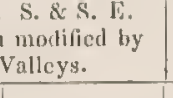 & N. w. & 354 & 32 & 150 & 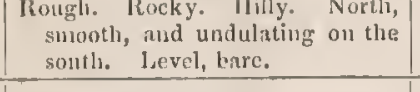 & 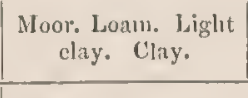 & 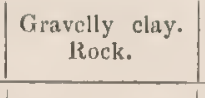 & 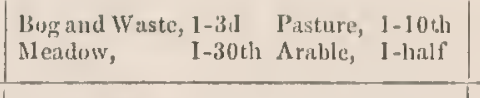 & & ${ }^{3}$ & & Several. & 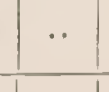 & ' & 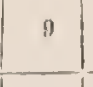 & 1 & 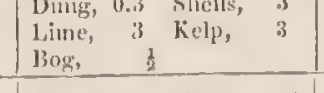 & 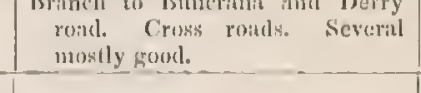 & Derry \\
\hline Kй.а. & \begin{tabular}{|l} 
P. Irisll Society. \\
renants at Will.
\end{tabular} & 381133 & w. & Westerly. & terely. & 527 & 100 & 250 & 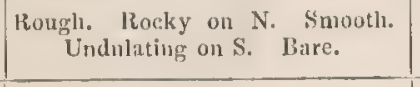 & $\begin{array}{c}\text { Moor, Gravel. Lightit } \\
\text { elay. Clay. }\end{array}$ & $\begin{array}{l}\text { Gravel, } \\
\text { rocks. }\end{array}$ & 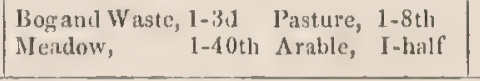 & & 1 & 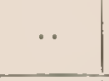 & Several. & 1 & 1 & 5 & 2 & 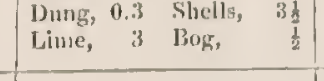 & 1.ecterkennyy to Derry roals. & Derry, 3 \\
\hline War. & 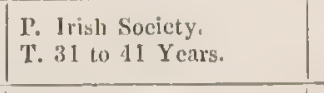 & 8293 I8 & s. & S. \& \&. E. & 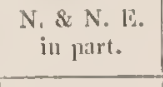 & 243 & Foyle. & 100 & 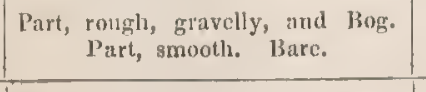 & $\begin{array}{l}\text { Cravel. Broggy. } \\
\text { Loam. CGliy. }\end{array}$ & 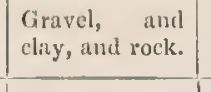 & 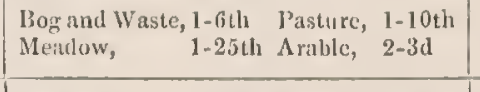 & Foylce. & ${ }^{3}$ & & ny. & 9 & $i$ & ${ }^{6}$ & 5 & 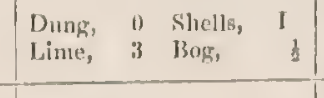 & 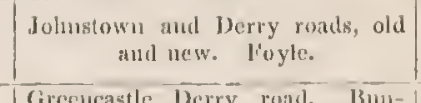 & Derry, 3 \\
\hline Pensybunan. & \begin{tabular}{|l|} 
T. Irisis Socicty. \\
T. 21 Years.
\end{tabular} & 123019 & N. E. & W. \& E. & $\begin{array}{c}\text { N. } \& \text { s. } \\
\text { lying low. }\end{array}$ & & \begin{tabular}{|l|l|l|l} 
& Foyle. \\
\end{tabular} & .. & 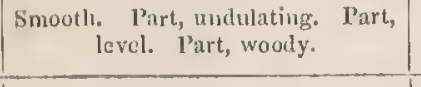 & 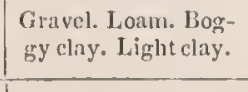 & $\begin{array}{c}\text { Gravel, any } \\
\text { cllyy. }\end{array} \mid$ & 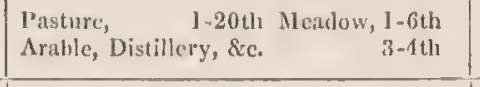 & . & 1 & & Pew, & 1 & ." & I & 1 & Dmug, & 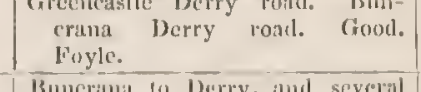 & Dery, I \\
\hline MANTALLOW. & \begin{tabular}{|l|} 
P. Irisl Socicty. \\
T. 31 Yenrs.
\end{tabular} & 1178027 & w. & \begin{tabular}{|l|l} 
| Westerly. \\
\end{tabular} & \begin{tabular}{|l} 
S. \&. S. . . . . \\
in parth \\
\end{tabular} & 281 & \begin{tabular}{|l|l} 
Foyle. & \\
\end{tabular} & 1,50 & Smooth. Unulutiting. Woody. & $\begin{array}{c}\text { Craveclly clay and } \\
\text { laan, and bog. }\end{array}$ & \begin{tabular}{|c|c|c|}
$\begin{array}{c}\text { Cravelly } \\
\text { and rock. }\end{array}$ & caly, \\
\end{tabular} & 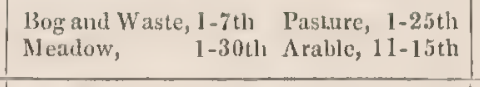 & Foyle. & ${ }^{2}$ & & Many. & 34 & 9 & ${ }^{6}$ & & $\mid \begin{array}{ll}\text { Dumug, } \\
\text { Lime, }\end{array}$ & 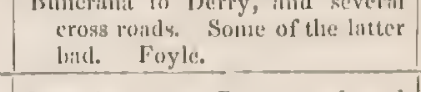 & Derry, 2 \\
\hline 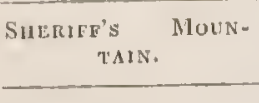 & \begin{tabular}{|l} 
P. Irist Socicty. \\
Tevenants nt will
\end{tabular} & 408138 & N. & N. w. & s. & 593 & 320 & 100 & 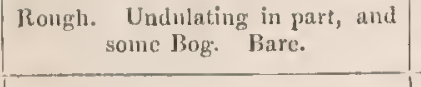 & Moor. Lighth chy. & 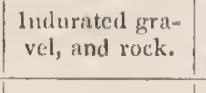 & 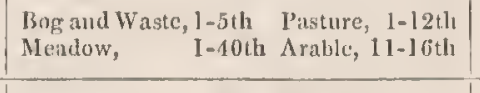 & & 1 & & Scevral. & 7 & 4 & 6 & & 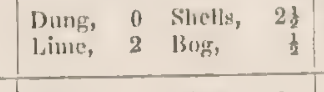 & 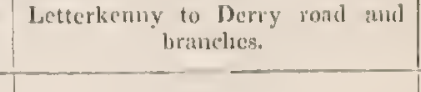 & , 2 \\
\hline Srrano llu.... & 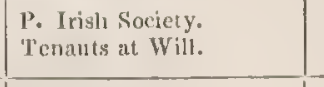 & 25 & s. & \begin{tabular}{|l|l} 
Southerly. \\
\end{tabular} & w. & 522 & 110 & 150 & Undulating. Bare. & Light clly, & Rock. & 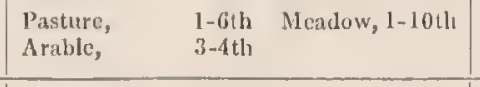 & & 1 & & Several. & 3 & ${ }^{2}$ & ." & r & 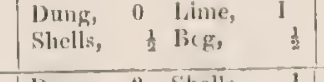 & russ road band. & riry, 11 \\
\hline SFraino Tow. & \begin{tabular}{|l} 
1.: Irisl Sodicty. \\
1.: 21 Ycaus.
\end{tabular} & ${ }^{34}$ & N.E. & \begin{tabular}{|l|l|} 
& Northerly. \\
\end{tabular} & s. & 200 & 57 & 90 & \begin{tabular}{|l} 
Sumooth. Undudlating. I \\
Barate.
\end{tabular} & Some Gravel. Clay. & $\begin{array}{l}\text { Gravelly clay, } \\
\text { and rock. }\end{array}$ & 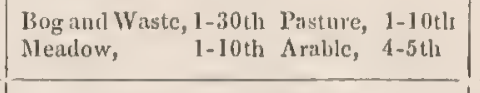 & & 3 & & Few. & I & " & .. & 2 & 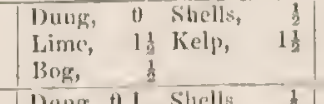 & 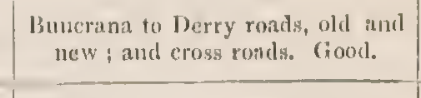 & rry 13 \\
\hline 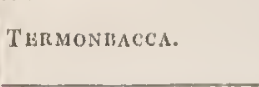 & 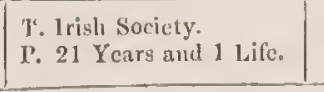 & ${ }^{16}$ & s. E. & s. \& E. E. & $\begin{array}{l}\text { exposed, a } \\
\text { exidge. } \\
\text { rist }\end{array}$ & 422 & Foyle. & 220 & 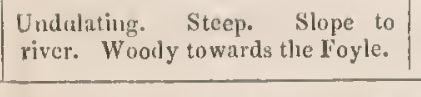 & elay and dlay. & Rock. & 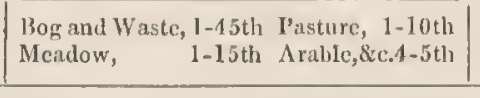 & \begin{tabular}{|l} 
Foyle. \\
\end{tabular} & 2 & & Bany. & 12 & &.. & 2 & 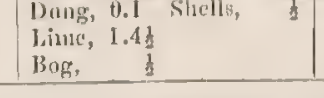 & 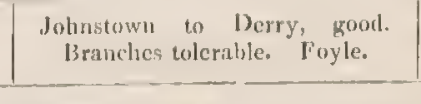 & Derry, 1 \\
\hline
\end{tabular}

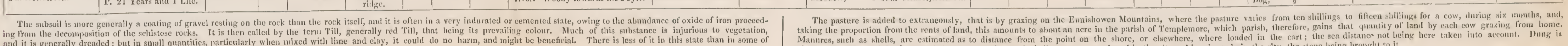

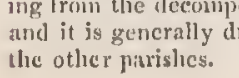


PRODUCTIVE ECONOMY.-RURAL

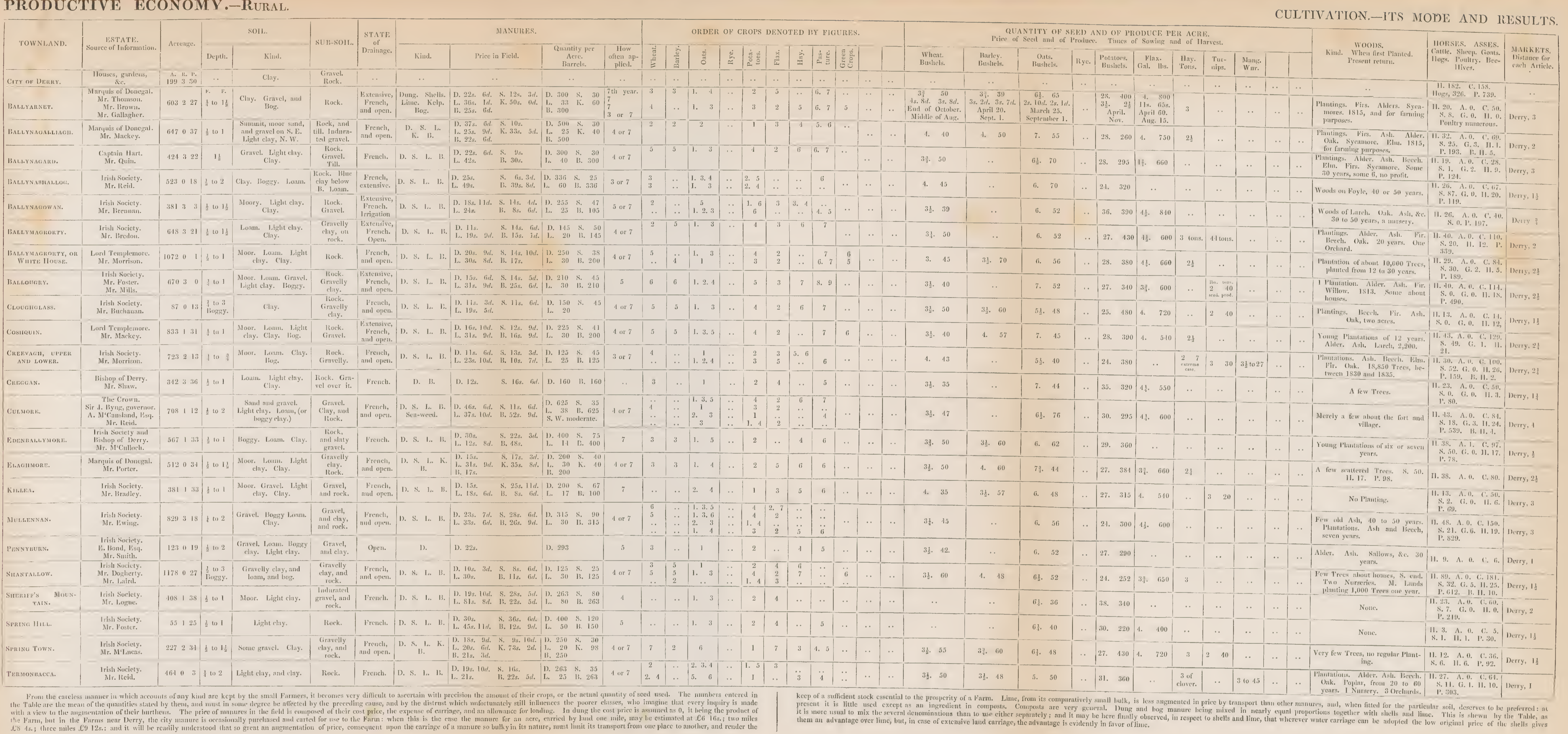



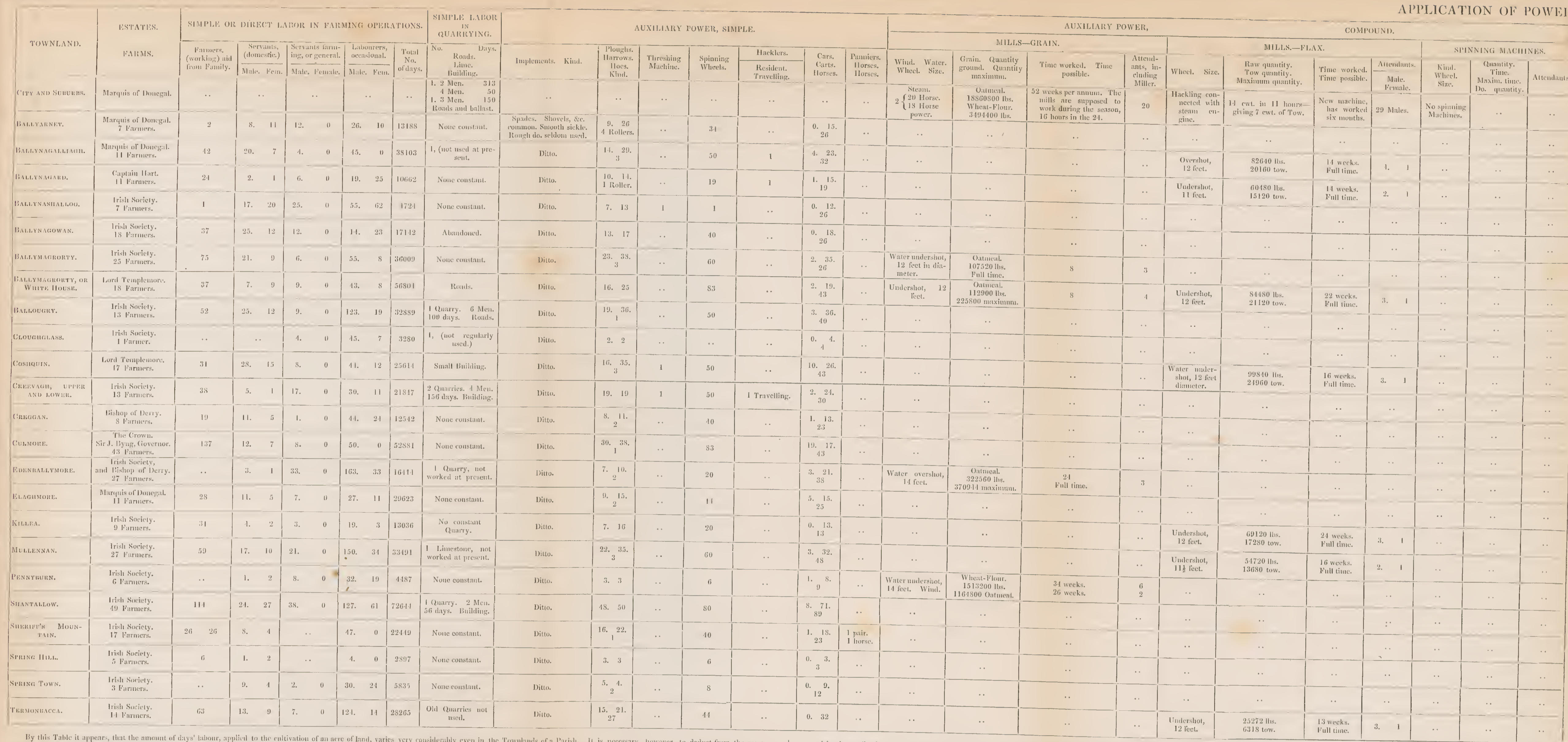

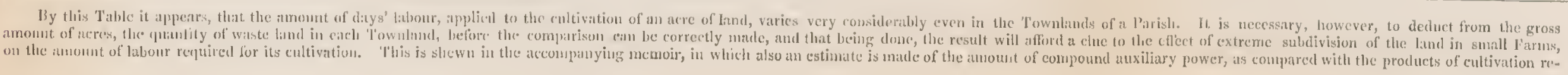


PRODUCTIVE ECONOMY _RURAL

MANUFACTURES AND MANUFACTURING PROCESSES-APPLICATION OF POWER.

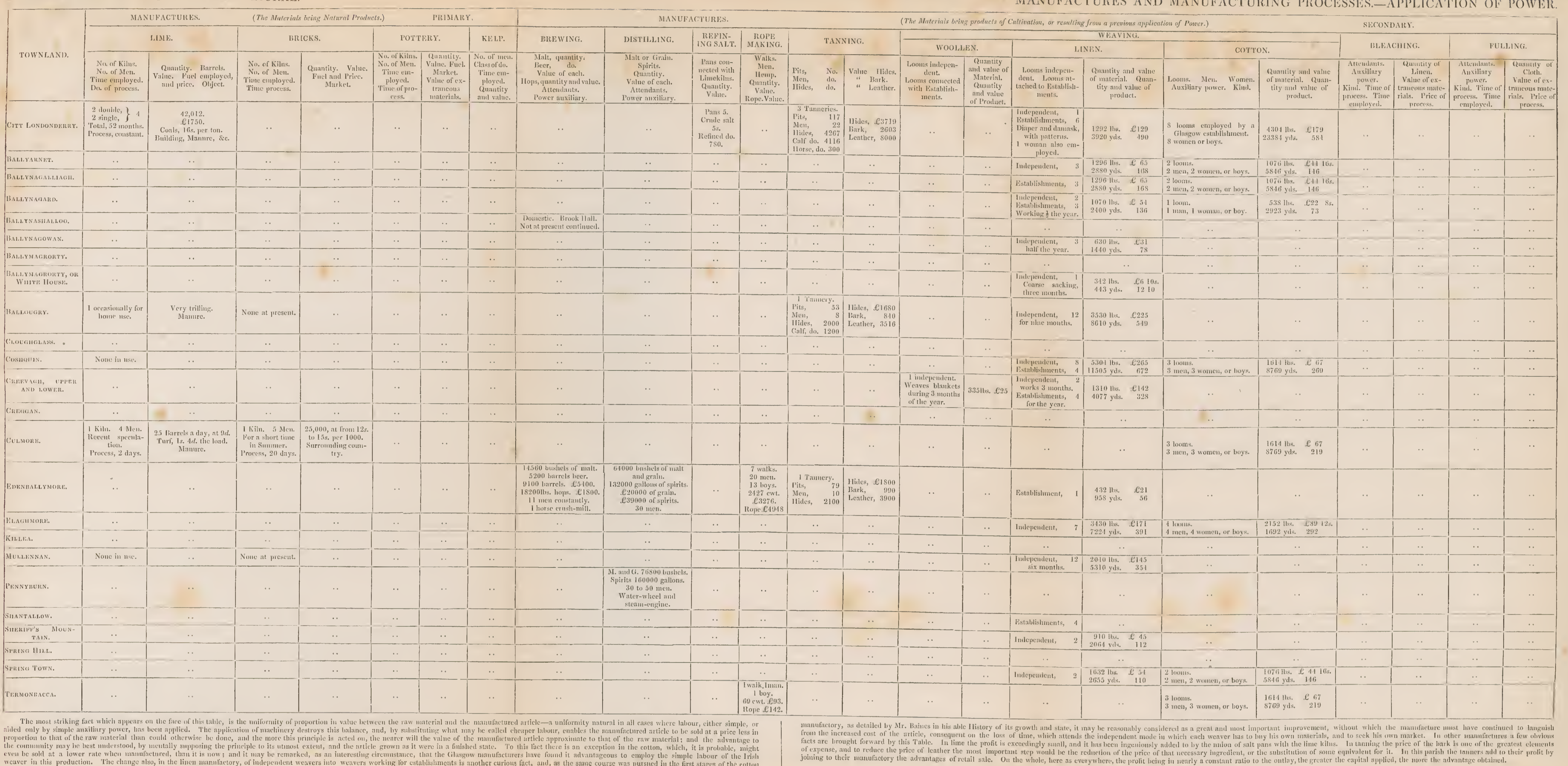

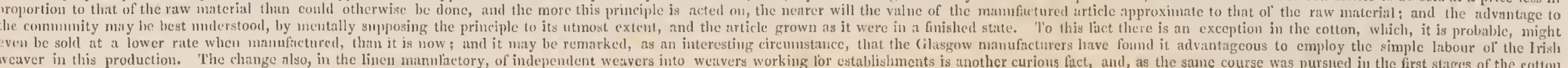


PRODUCTIVE RCONOMY.

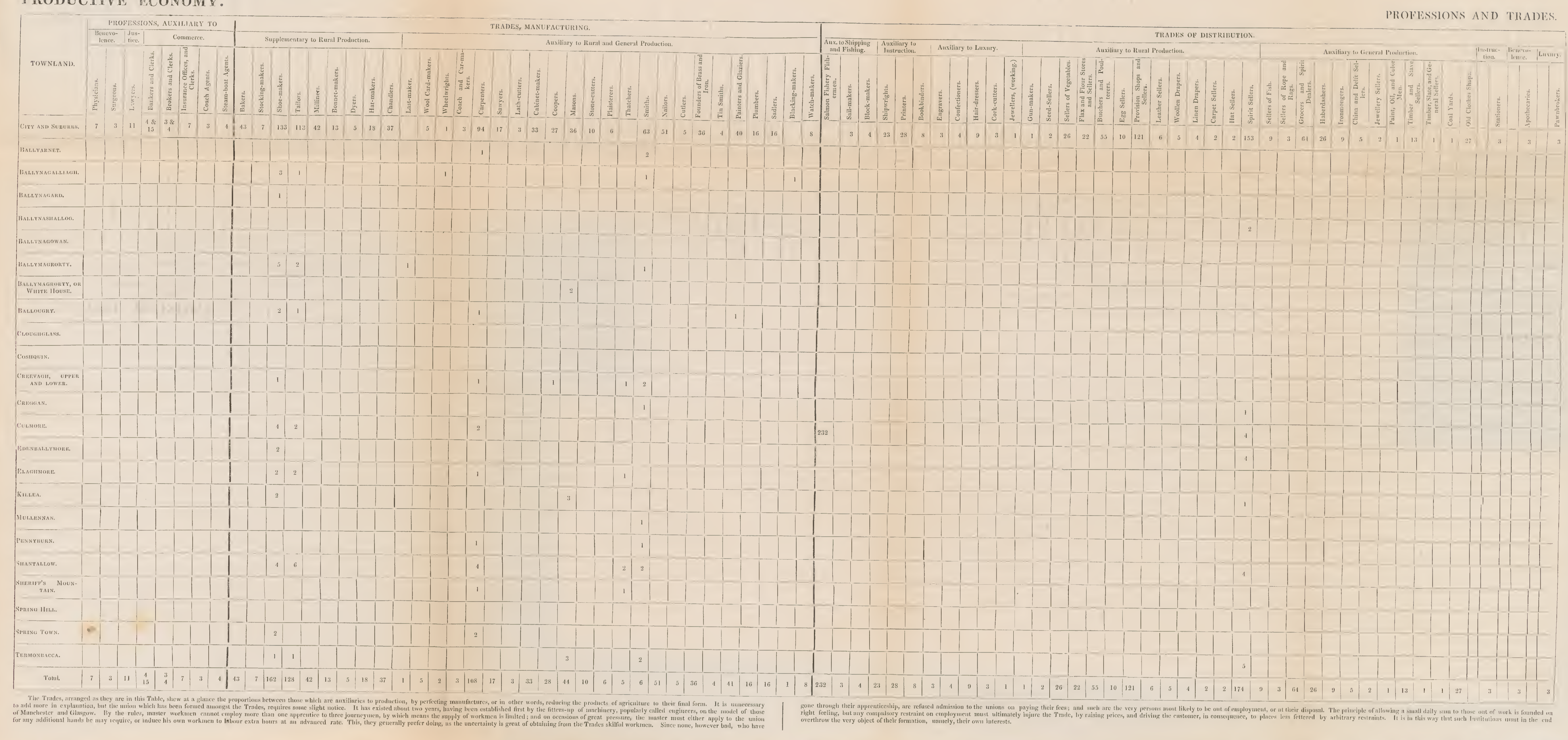





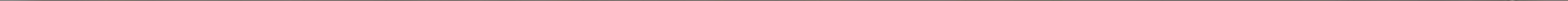


